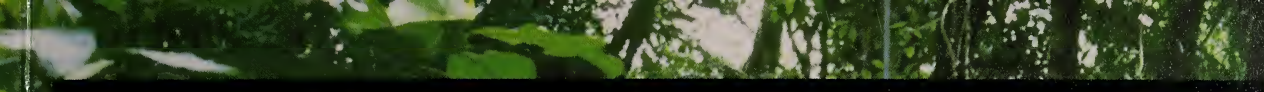

\title{
Stanley Heckadon-Moreno
}
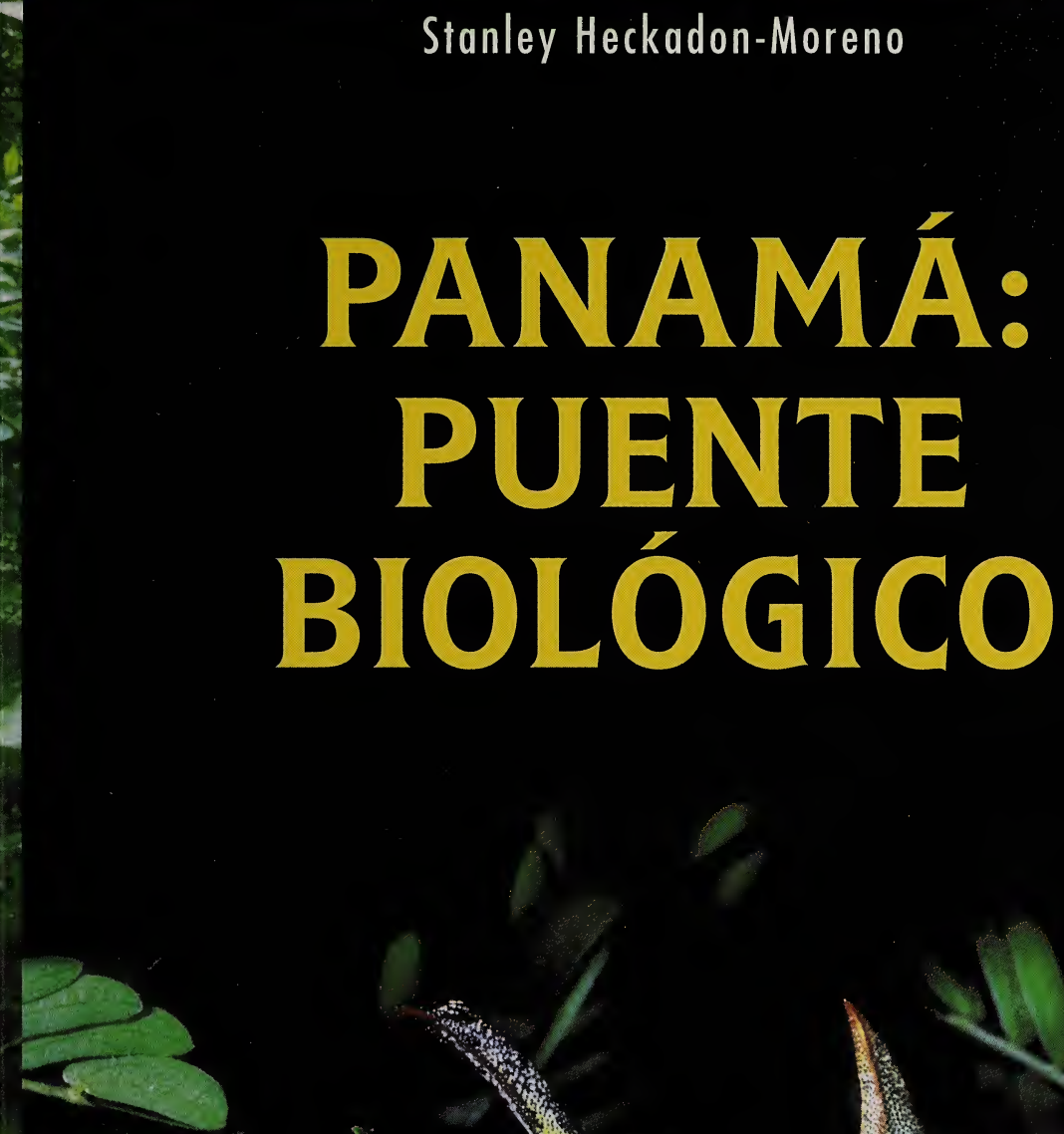

its

(6.

Ho.

(8)

16:

$4=$

A.

is

$\therefore$.

(3)

te:

5

$\%$

5

a

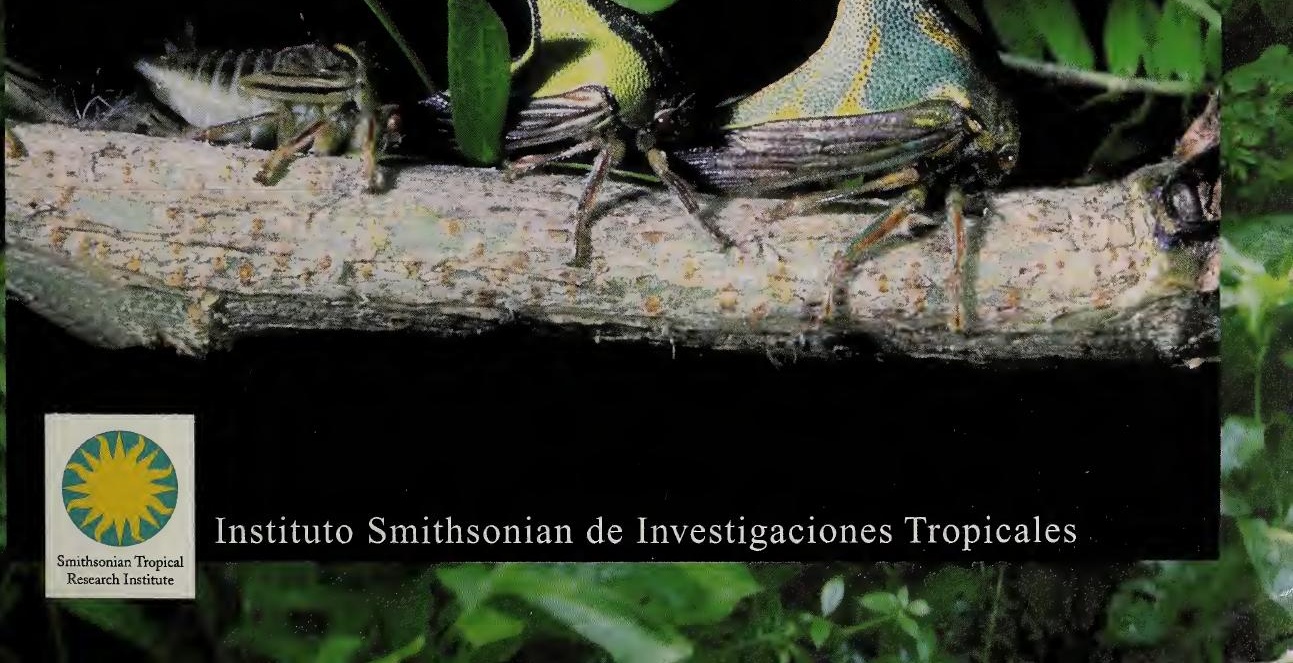




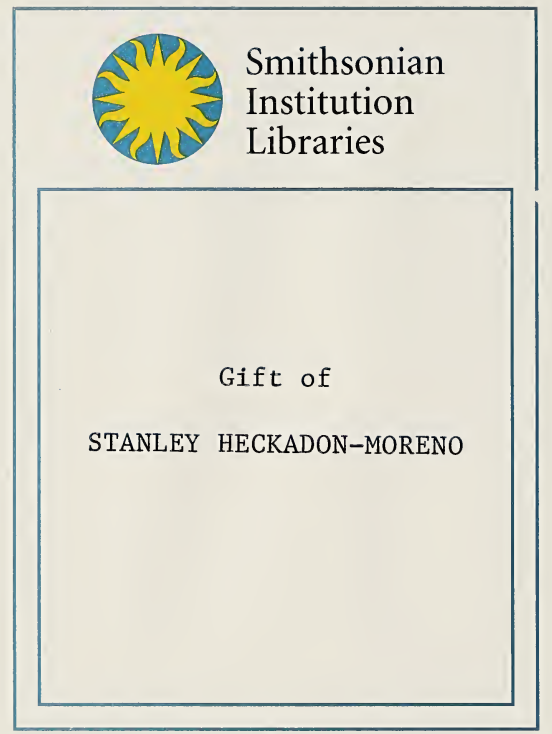




\section{PANAMÁ: PUENTE BIOLÓgICO}


Foto de la portada:

Tres ejemplares de Umbonia crassicornis (Homóptera: Membracidae), posadas sobre una rama. Los individuos adultos de este pequeño insecto, conocido comúnmente como "saltamatas", tienen una proyección cuticular que les hacen parecer espinas de la planta. A la ninfa de la Umbonia (más pequeña, a la izquierda), todavía no le ha crecido la "espina", ni tampoco las alas. La boca de los saltamatas es un tubo delgado, con el cual penetran el tallo de las plantas para chupar la savia. Estos insectos producen ruidos con los que se comunican, ya sea para el cortejo de apareamiento, o para que las ninfas pidan ayuda cuando se acerca algún depredador. Aunque estos ruidos están dentro del rango auditivo de los humanos, sólo podemos oírlos con ayuda de amplificación. Foto: M.Guerra. 
To The Smithso miana Collec tion STauley
Parminam 12003
Feb the 80 th annivernay I STRI Stanley Heckadon-Moreno

\section{PANAMA: PUENTE BIOLÓGICO}

Las Charlas Smithsonian del Mes: 1996-1999

Panamá, 2001 
574.5

H355 Heckadon-Moreno, Stanley

Panamá: Puente Biológico

Panamá: Instituto Smithsonian de Investigaciones Tropicales, 2001 260p. ; il. ; $25 \mathrm{~cm}$.

ISBN 9962-614-01-5

1. PANAMA

2. ECOLOGIA TROPICAL

3. BIOLOGIA TROPICAL

I. Título.

Edición: María Eugenia Mann

Diseño: Ricardo Ledezma Bradley

Foto de la portada: Marcos Guerra (STRI)

Ilustraciones de portadillas de capítulos: Melva Olmos

Instituto Smithsonian de Investigaciones Tropicales

Apartado 2072

Balboa, Ancón, República de Panamá

Central de teléfono: (507) 227-6022 / (507) 212-8000

Fax central: (507) 212-8146

e-mail: heckados@tivoli.si.edu

Impreso por Imprelibros, S.A.

Impreso en Colombia - Printed in Colombia 


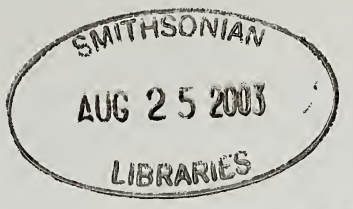

A la memoria del Dr. Monte Lloyd

(1927-2000)

Quisiera dedicar esta obra a un personaje inolvidable, mi recién desaparecido amigo, el Dr. Monte Lloyd. Este gran biólogo de campo fue un apasionado de Panamá y de sus selvas con sus incontables formas de vida, incluyendo aquellas que más le fascinaba estudiar, las cigarras. Quizo el destino que este profesor de biología de la Universidad de Chicago tuviese un papel importante, aunque poco conocido, en la decisión del gobierno de Panamá de establecer, a orillas del canal, el Parque Nacional Soberanía, un hito en la historia ambiental panameña del siglo XX.

Alto, desgarbado, brillante, sencillo, visionario, gran conversador. Su mente generaba cantidades prodigiosas de ideas y cuando una le acribillaba, sus ojos brillaban y agitaba los brazos asemejando a Don Quijote, pronto a arremeter molinos. Con el mismo gusto que las proponía, se complacía en demolerlas con una sonrisa picaresca.

Nació Monte el 6 de julio de 1927 en Omaha, Nebraska. Obtuvo su licenciatura en 1952 en la Universidad de California en Los Angeles (UCLA). En 1957, la Universidad de Chicago le otorga el doctorado en zoología. Entre 1962 y 1967 es profesor de biología en UCLA. A partir de 1968 se incorpora a la Universidad de Chicago como profesor de biología y ecología, hasta jubilarse en 1992. Uno de sus cursos, Hábitats y Organismos, era legendario por el número de estudiantes que atraía. Producto de sus continuos estudios de campo, publicó mas de cuarenta artículos en las revistas científicas más prestigosas. Era una autoridad mundial en las cigarras. Nunca olvidaré sus chispeantes conversaciones sobre temas como los cantos y comportamientos de los "totorrones" de Panamá.

El espíritu de las selvas le atrajo una y otra vez al Istmo durante sus vacaciones académicas de Chicago. En Panamá, su base de operaciones era el STRI y Barro Colorado. Cuando estaba en la capital, se alojaba en un modesto hotel cerca a la vieja 4 de julio, en cuarto sin aire acondicionado, ni abanico. Gustaba de los patacones de plátano acompañados de cerveza negra.

Con el correr de los años y al recorrer esta tierra estudiándola, la habia visto cambiar y ponerse vieja, maltratada. Sus imponentes selvas transformadas en potreros.

Nos conocimos a inicios de la década de 1970 cuando Monte comenzaba a preocuparse por las causas humanas tras el avance de la deforestación. Yo, recién egresado de antropología, trabajaba en la otrora Dirección General de Planificación Económica y Social de la Presidencia de la República y me iniciaba en estudiar a los campesinos que, en busca de mejores oportunidades, colonizaban las selvas, para encontrar alli, aun mayor pobreza. 
Desde el inicio nos unió una gran amistad. Paulatinamente, compartimos inquietudes, incluyendo la noción de que el futuro de las selvas istmeñas estaba indisolublemente unido a la búsqueda de alternativas que además de protegerlas, generasen mejores oportunidades para la gente.

Durante la década de 1970, el tema medular de política exterior panameña fueron los tratados del Canal con Estados Unidos. Cuando Monte llegaba, solía preguntarme: "Stanley, qué va a hacer Panamá con los bosques del Canal?". Su futuro era incierto, habia corrientes de pensamiento que sostenian que estas selvas debian ceder paso al progreso. Las riberas del Canal, decían, deberán asemejarse al río Rin: fábricas, astilleros y complejos petroquímicos a ambas orillas y miles de trabajadores. Eso necesitaba un país pobre.

Monte, contrariamente, con entusiasmo profético señalaba el brillante porvenir que aguardaría a Panamá en base a su diversidad biológica. Planteaba algo que a muchos sonaba a herejía: que bien protegidos, estudiados y manejados, estos bosques generarían más empleos e ingresos que la vieja vía interoceánica. Veía, entre otras cosas, numerosos cruceros atracar y bajarse legiones de amantes de las plantas y animales tropicales. Y claro está, ¿qué lugar más accesible y diverso en especies que Panamá?.

Para entonces, el país llevaba varios años bajo el mando de los militares. En el Cuartel Central se tomaban las grandes decisiones. Era preciso llegar al jefe de la Guardia Nacional, ferviente promotor de las políticas llamadas la "Conquista del Atlántico" y la "Conquista del Darién", esto es, la sustitución de bosques por potreros. Gracias a Lizia Z. Lu, fue posible arreglar para que Monte y un grupo de la Asociación Panameña de Antropología-Francisco Herrera, Sonia Martinelli de Heckadon y Aníbal Pastor-acompañasen al general Omar Torrijos en un vuelo en helicóptero sobre el Canal. Monte no hablaba bien el español, ni el general el inglés. Mas tal fue el entusiasmo y la convicción con que el viejo profesor de cigarras expuso su visión, que al bajarse de la nave el general era otro convencido que el futuro de Panamá y su Canal, tambien pasaba por la protección de sus selvas.

Poco después, en 1980, siendo presidente el Dr. Aristides Royo, se crea el Parque Nacional Soberanía con las primeras 20,000 hectáreas de selvas revertidas a Panamá, gracias a los tratados Torrijos-Carter. Muchas argumentaciones elaboradas por el Dr. Lloyd para justificar la creación de Soberanía, fueron útiles para luego sustentar el establecimiento de otras áreas protegidas.

Fundamental sería la decisión del presidente Eric A. del Valle, en 1985, de establecer el Parque Nacional Chagres resguardando 130,000 hectáreas en las cabeceras del río que más agua aporta al Canal: el Chagres. También se añadieron el Parque Natural Metopolitano en ciudad de Panamá y el Parque recreativo de Lago Gatún, en Colón. En 1993, en el mandato del presidente Guillermo Endara, la Asamblea Legislativa estableció el Parque Nacional Camino de Cruces, con los bosques de las bases de Albrook y Clayton. Así se consolidó el corredor selvático qué, paralelo al Canal, cruza el Istmo desde el Pacifico hasta el Caribe. Al finalizar el año 2000, están llegando los primeros cruceros con aquellos amantes de la naturaleza tropical que Monte había previsto. 


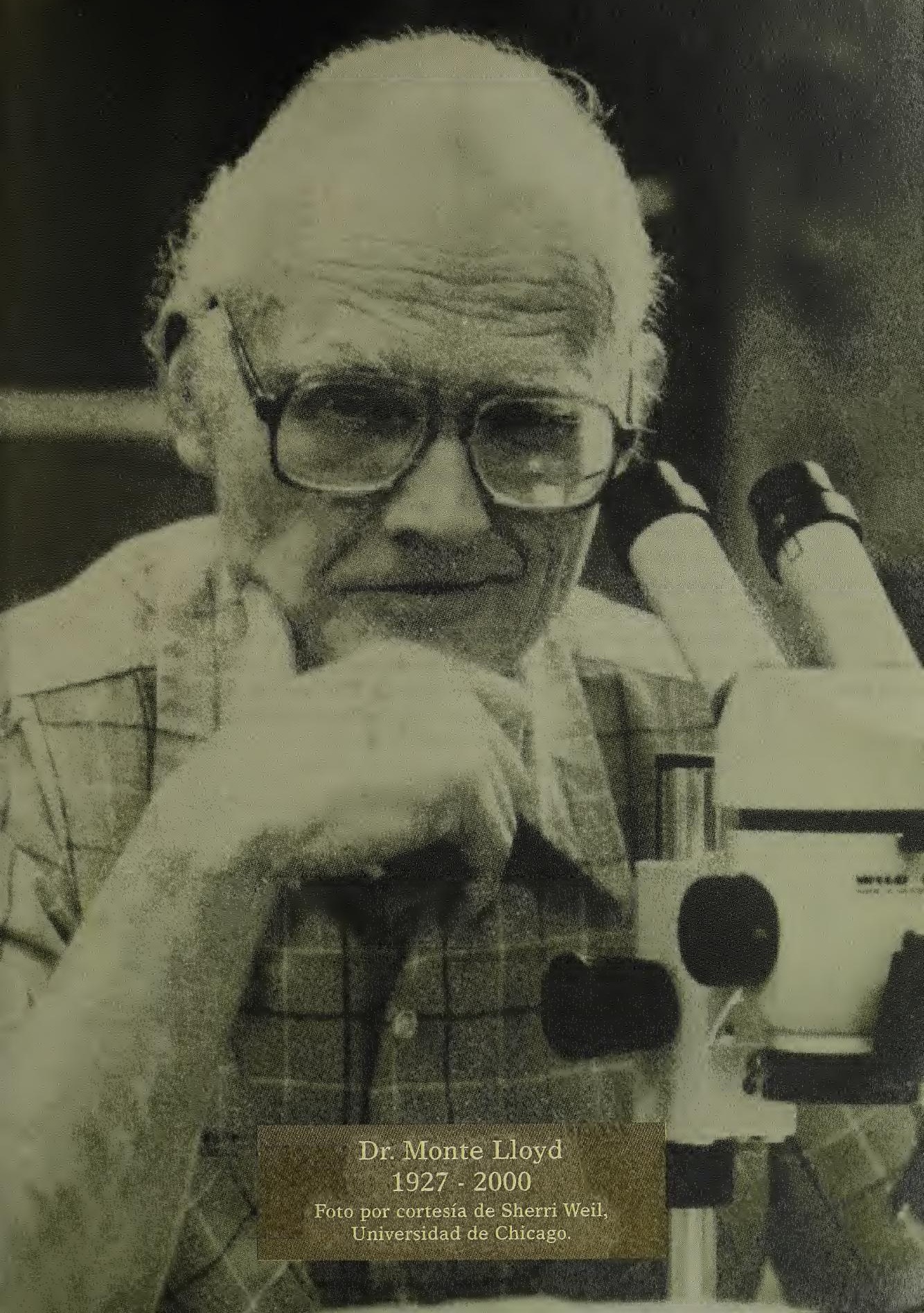


Los tesoros de la naturaleza panameña se apreciarán y conservarán mejor cuando se brinde a la sociedad una educación básica sobre las ciencias. Sólo el estudio y debido mantenimiento de los recursos naturales garantizará que las futuras generaciones gocen de ellos. Elektra Noreste participa en la formación de jóvenes científicos mediante las Becas Elektra, establecidas en conjunto con el Instituto Smithsonian de Investigaciones Tropicales. Estas becas dan oportunidad a estudiantes calificados, de realizar proyectos de investigación en ciencias marinas en la costa de Colón, desde el Laboratorio Marino de Isla Galeta, en la entrada Caribe del canal. Por tanto, es motivo de gran satisfacción apoyar la obra "Panamá: Puente Biológico", como muestra de nuestro compromiso con la comunidad a la cual servimos. Este libro retrata algunas de las especies animales y vegetales más características de los bosques y aguas panameñas, descritas por los especialistas que las estudian a diario. Exhortamos a los lectores de todas las edades a introducirse en este texto, ameno y enriquecedor, compartiendo nuestro entusiasmo por el descubrimiento de la naturaleza istmeña.

Aura Ferrer

Directora de Comunicaciones Corporativas

Elektra Noreste 
Refinería Panamá, empresa Texaco que suple al mundo de energía, se siente orgullosa y altamente complacida de haber tenido la distinción de contribuir a la publicación de esta obra sobre la historia natural de Panamá. No dudamos que el lector encontrará en sus páginas verdaderos tesoros de conocimientos sobre la riquísima diversidad de plantas y animales que habitan las selvas y mares de Panamá, país tropical cuyo nombre indígena significa abundacia de peces. Guardan nuestros océanos y selvas incontable número de especies, de formas de vida sobre las cuales poco conocemos y que constituyen toda una verdadera maravilla de este mundo, nuestro hogar, que llamamos Tierra. A los científicos del Instituto Smithsonian de Investigaciones Tropicales, cuya tesonera y silenciosa labor ha hecho posible esta obra, nuestra admiración y elogios. Gracias por permitirnos apoyarlos.

Ricardo Morales

Gerente de Planta

Refinería Panamá, S.A. 
Nos place apoyar esta nueva publicación del Instituto Smithsonian de Investigaciones Tropicales. El libro "Panamá: Puente Biológico" está dirigido a estudiantes y profesionales, a amantes de la naturaleza y a los científicos; al lector panameño y al extranjero deseosos de conocer la riqueza natural de nuestro país. La valiosísima información aportada por los estudiosos del STRI nos permitirá comprender mejor y conservar el mundo tropical que nos rodea, en el que vivimos y del cual poco sabemos. La Fundación Filantrópica Fidanque apoya la realización de esfuerzos de tal calidad y nobleza y se complace en compartirlos con la comunidad, aspirando a que contribuyan al enriquecimiento de su cultura. Es sobremanera placentero mencionar que merced a fondos otorgados por nuestra fundación, le fué posible al patronato del Parque Natural Metropolitano construir el Salón las Oropéndolas, en el cual durante cuatro años se realizaron las Charlas Smithsonian del Mes. Esta sala se ha convertido en un sitio de encuentro para la ciencia y cultura de esta, nuestra ciudad capital.

Stanley Fidanque

Presidente

Fundación Filantrópica Fidanque

Don Stanley Fidanque falleció en octubre del 2001. Paz al alma de este amigo de la ciencia y la cultura. 
Es un orgullo para nuestra empresa sentirnos parte, con nuestro humilde apoyo, de la magnífica labor que el STRI lleva a cabo en Panamá, y en particular con la publicación de "Panamá: Puente Biológico". Esta obra pone a disposición de un creciente número de personas preocupadas por la ecología, el valioso contenido de las investigaciones realizadas por los dedicados estudiosos del Smithsonian y presentadas al público de la capital durante las Charlas Smithsonian del Mes entre 1996 y 1999. Petroterminal de Panamá, S. A. empresa comprometida con el medio ambiente durante sus más de veinte años de trayectoria empresarial, celebra la iniciativa del Instituto Smithsonian en compartir el producto de sus investigaciones con la comunidad gracias a publicaciones como este libro que de seguro será de sumo interés, para la comunidad científica y estudiantil de nuestro país y el mundo, sino también para todos los que, como nosotros, somos cada día más conscientes del medio ambiente en que vivimos y sus limitaciones.

Luis A. Roquebert V.

Gerente General

Petroterminal de Panamá, S. A. 
Durante casi un siglo, el Instituto Smithsonian ha tenido el privilegio de estudiar la historia natural de Panamá. Los resultados de estas investigaciones siempre han estado disponibles a la comunidad científica a traves de las revistas profesionales de la ciencia. Asimismo, gracias a conferencias presentadas en eventos científicos.

Recientemente, los nuevos medios electrónicos, como la internet, permiten a cualquier persona alrededor del mundo acceso instantáneo a enormes cantidades de datos. Los científicos del STRI hacen pleno uso de estos medios ofreciendo datos sobre precipitación, fenómenos oceanográficos, cambios demográficos en los bosques de la Isla de Barro Colorado o las secuencias de ADN en peces, aves, erizos y corales. Nuestros investigadores, estudiantes y visitantes, publican anualmente casi trescientos artículos científicos. Creo que hacemos un trabajo razonable en comunicarnos con nuestros colegas científicos en todo el mundo.

Los métodos para divulgar los frutos de nuestro trabajo -datos y descubrimientos y su significado- a quienes toman las decisiones políticas y económicas que afectan el ambiente, están definidos con menor claridad.

Al presentar su historia, el STRI ha hecho uso efectivo de la televisión. La BBC, ABC, CNN, National Geographic, Discovery Channel, Oxford Scientific Films y otros, han producido muchos documentales que llegan a vastas audiencias. Publicamos libros para el público y los especialistas. Con regularidad enviamos a los diarios comunicados sobre nuestros hallazgos en lenguage no científico. Asimismo, preparamos exhibiciones con información sobre Panamá y nuestro trabajo. Por ejemplo, "Partiendo la Cortina Verde", elaborada en 1990, y la cual ha viajado a veinte países; "Nuestros Arrecifes, Unidos por el Caribe" confeccionada para el Octavo Simposio de Arrecifes de Coral y exhibida en Washington DC, Miami, Panamá, Puerto Rico, Jamaica, la República Dominicana y Brasil. 
Una manera excelente de presentar información sobre nuestro trabajo y su importancia es experimentando de primera mano las maravillas de la diversidad biológica de nuestros océanos y bosques. Desde sus inicios en 1923, Barro Colorado ha sido visitada regularmente por personas acompañadas por su primer naturalista, James Zetek. La tradición que él iniciase continúa con las 3000 personas que en el año 2000 visitaron la isla.

En 1990 establecimos, con apoyo de la Fundación Smithsonian de Panamá, un centro educativo en Isla Culebra que ofrece información sobre la riqueza marina de Panamá. Hoy, sus exhibiciones han sido visitadas por más de 275,000 personas.

A pesar de toda la divulgación hecha por el creciente número de organizaciones no gubernamentales ambientales, la televisión, los diarios y otros medios, nuestra sociedad aún permanece pobremente informada sobre los tesoros del Istmo, cómo se relacionan con los de la región y los del planeta y cuán importante es conservarlos y conocer su valor.

Estoy sumamente agradecido a los miembros del Patronato del Parque Natural Metropolitano por haber facilitado un foro para que nuestros científicos pudiesen presentar sus trabajos y contestar preguntas directamente, ayudándonos a desmitificar las maravillas de la naturaleza. Aplaudo la labor del Dr. Stanley Heckadon-Moreno, en organizar estas charlas y luego presentarlas en este excelente volumen, para que quienes no pudieron asistir a las Charlas del Mes, entre 1996-1999, puedan fortalecer su interés por las maravillas de la vida en el Istmo. Aspiro a que esta serie continúe y me siento contento de haber estado presente al inicio de lo que confío será una larga tradición.

\section{Ira Rubinoff}

Director

Instituto Smithsonian de Investigaciones Tropicales 

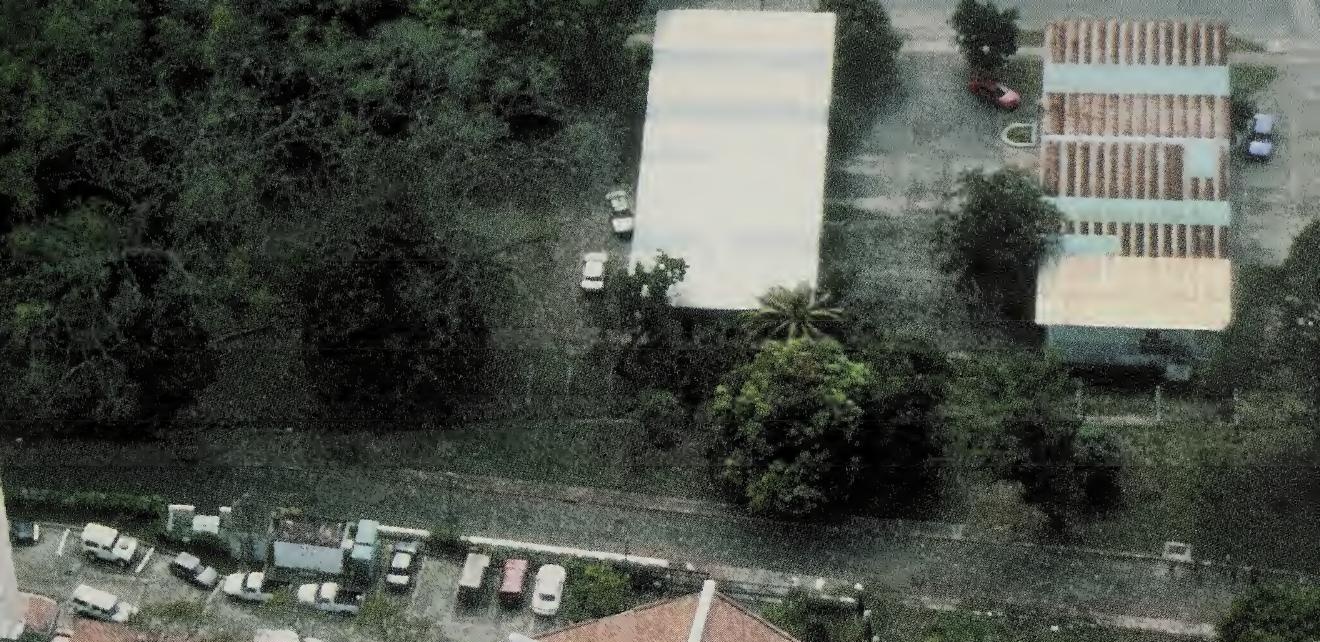

$x-2-2=0$. sent?
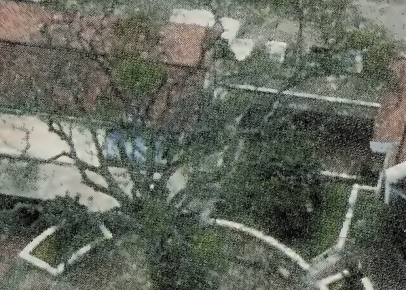

(x)

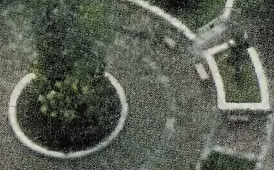

4
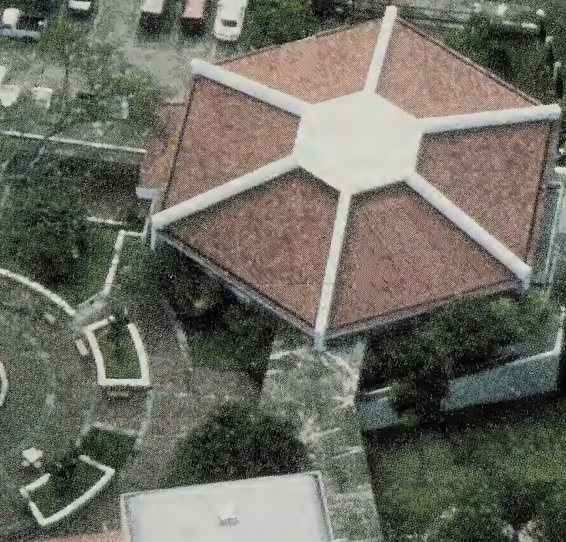

Complejo Earl S. Tupper, sede de los laboratorios

principales, la biblioteca y centro de conferencias del

Smithsonian Tropical Research Institute, ubicado en el

sitio que otrora ocupara el famoso Hotel Tívoli, durante

la construcción del Canal de Panamá.

(x)-

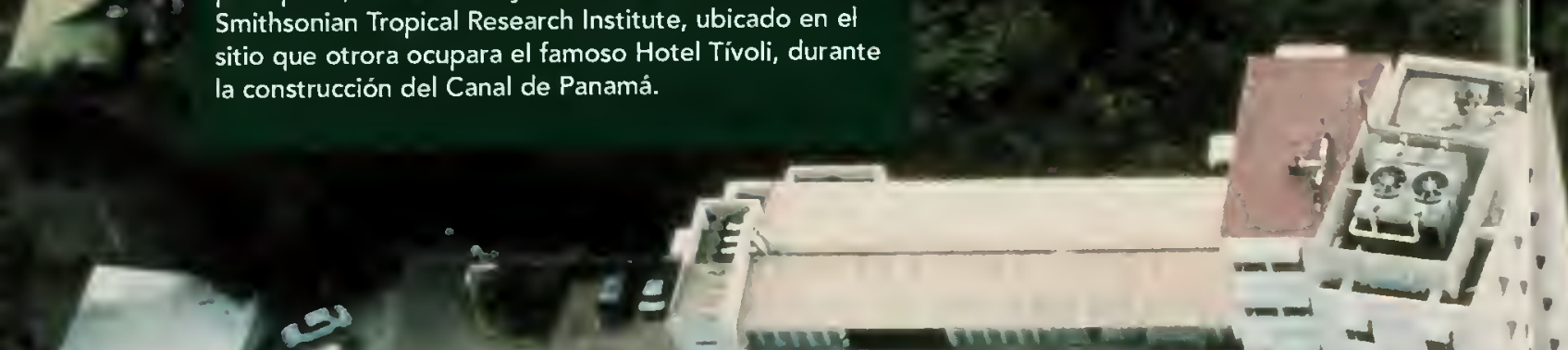

To:

(x)

$\frac{16}{8}$

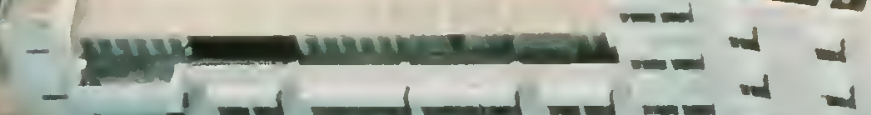

$-2$

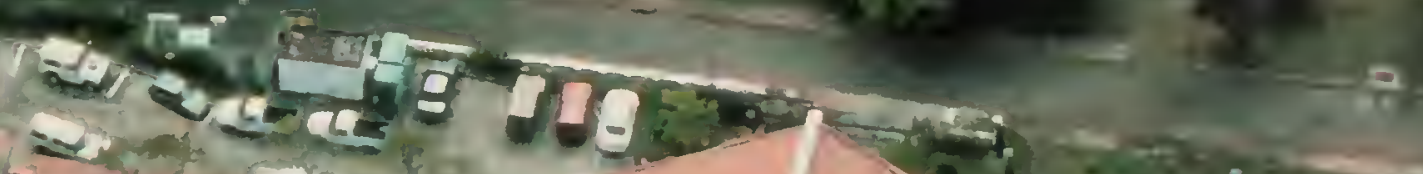

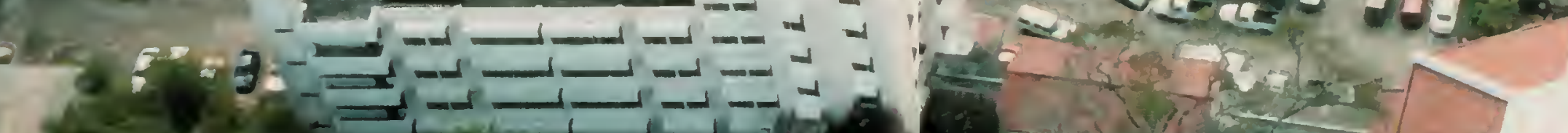
89.

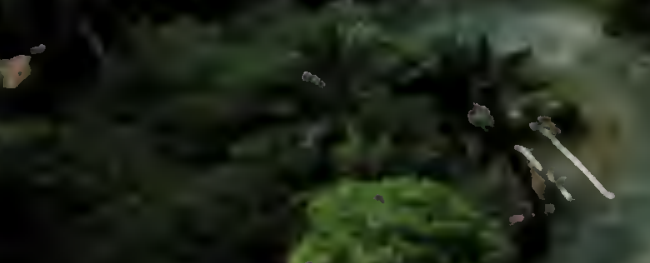

$+8$
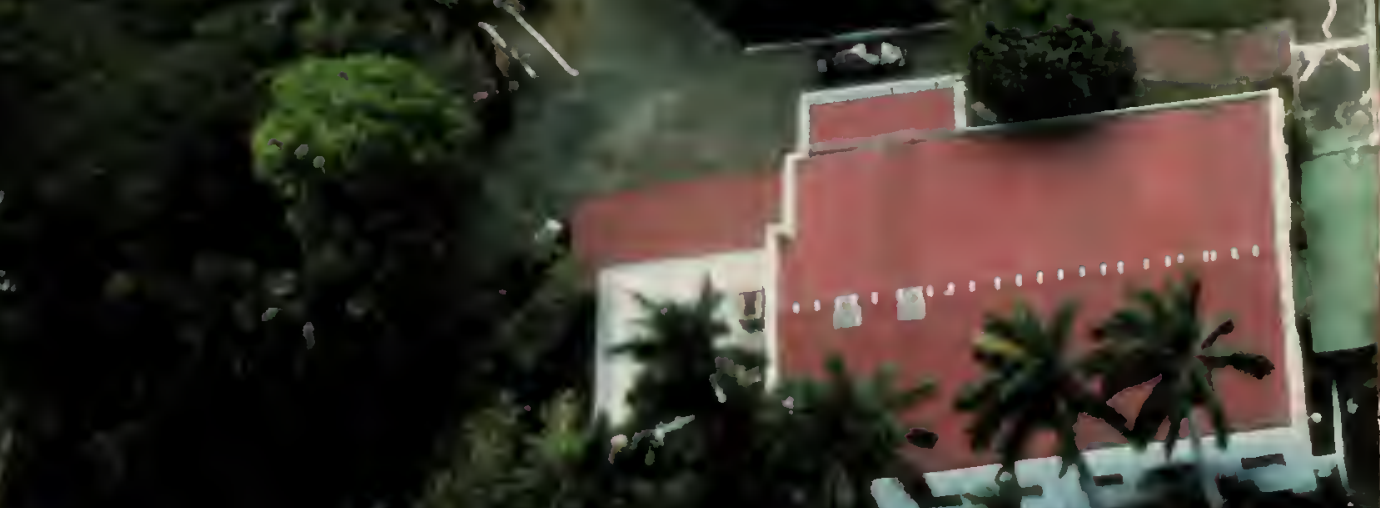

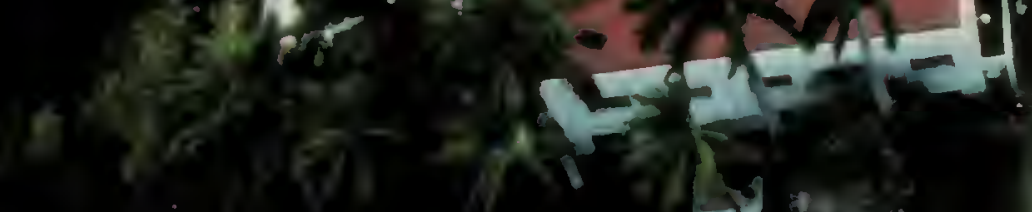

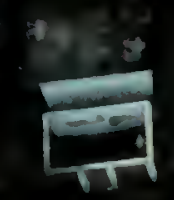

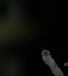

(5)

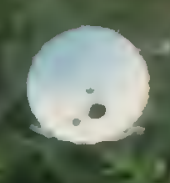

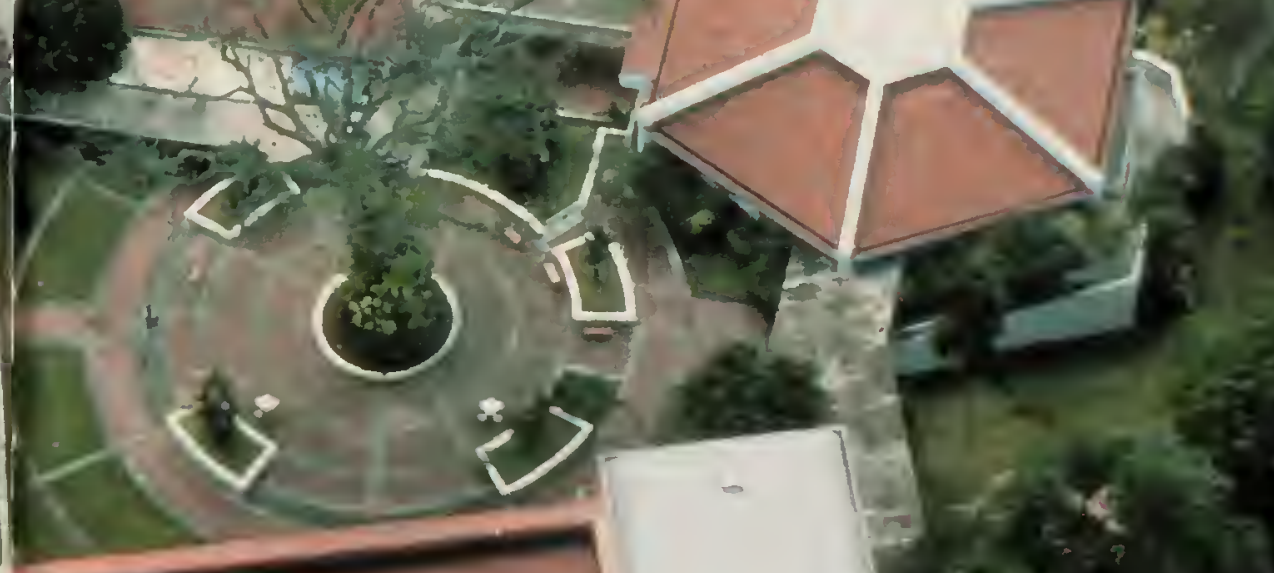

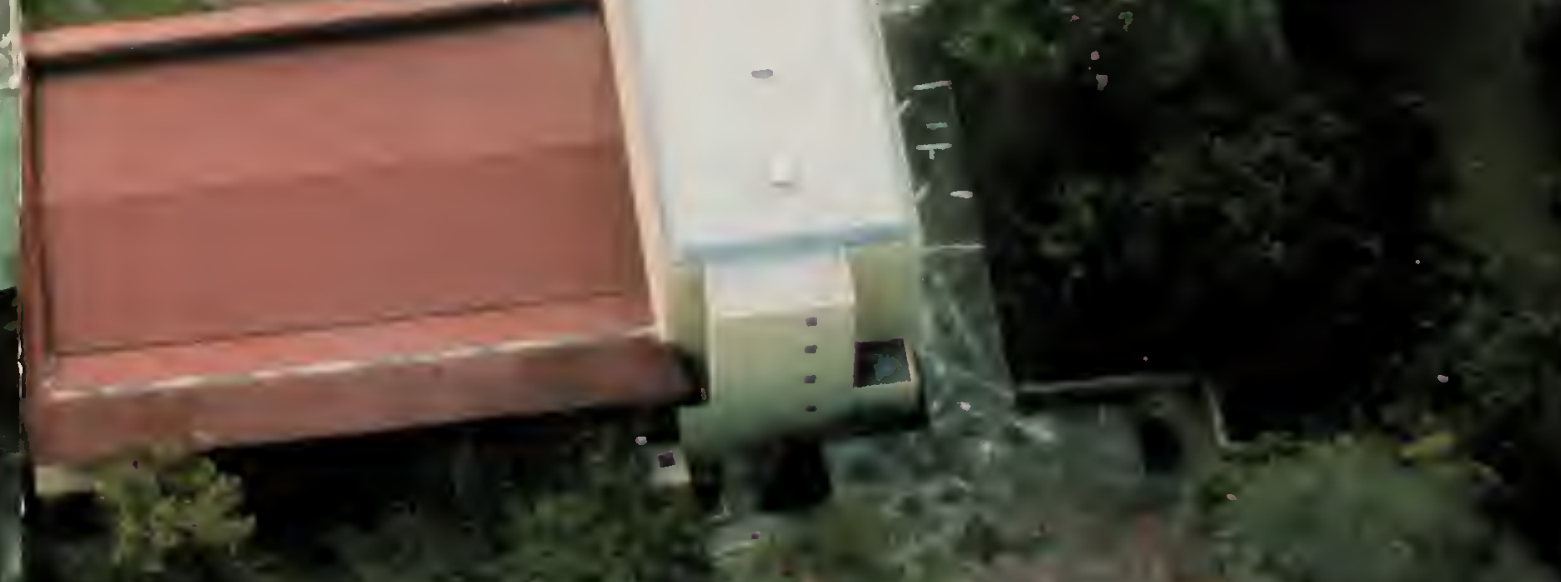

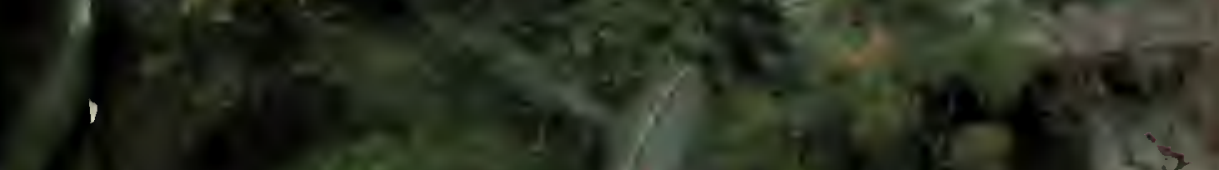
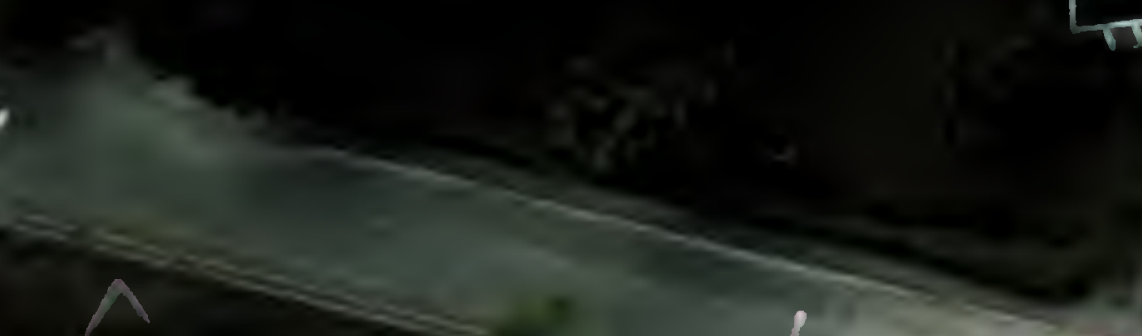
Realizar por cuatro años un ciclo de conferencias por científicos dirigidas a la comunidad no científica, para luego editarlas y publicarlas en esta obra, ha sido una aventura intelectual larga y ardua. Sólo el entusiasmo, el talento y colaboración de muchas personas e instituciones, amigos de la ciencia y la cultura, la ha hecho posible. Hacia ellos mi más profundo agradecimiento.

En primer lugar, a la comunidad científica del STRI, hombres y mujeres de diversas disciplinas y nacionalidades, motivados por el afán de entender los misterios de la naturaleza tropical. De su tiempo dieron generosamente, para preparar las charlas y luego los manuscritos. Las doctoras Mireya Correa, Noris Salazar-Allen y Nélida Gómez me dedicaron tiempo valioso a revisar la introducción.

Por diversas razones, algunas conferencias, partes integrales al éxito de estas charlas, no pudieron incluirse en este libro. Sin embargo, me es obligante reconocer los aportes del Dr. Martin Wikelsi, de la Universidad de Princeton; Gabriela Etchelecu, del Laboratorio Marino de Naos; Argelis Ruíz, del Centro de Exhibiciones Marinas de Isla Culebra; y a Alejandro Hernández y el cuerpo de guardabosques de la Isla de Barro Colorado.

Dentro del STRI, fueron fuentes constantes de apoyo Elena Guardia de Lombardo y Mónica Alvarado. Asimismo, María Luz Calderón, Reinaldo Urriola, Jaime Flórez, Marcos Guerra y Celideth de León. Indispensable fue la contribución de Lina González, del laboratorio de imágenes digitales, quien dedicó incontables horas a procesar las ilustraciones que embellecen esta obra. Así mismo, a los doctores Harry Barnes, Vijay Aswani y Aurelio Virgo. También a Xenia Guerra, Steve Paton, Mirna Samaniego, María Arrocha, Erika Garibaldo, Ernesto Peña, María Leone, Marlene López y Georgina de Alba. Lisa Barnett, de la oficina del STRI en la sede del Instituto Smithsonian, en Washington DC, fue tenaz colaboradora en la búsqueda de fondos para que esta obra saliese a la luz. Al Dr. Refugio Rochin por la contribución del Latino Fund, nuestra gratitud.

Me place reconocer la entusiasta colaboración del personal del Parque Natural Metropolitano en divulgar las charlas y por su cálida hospitalidad hacia los científicos y la audiencia: Daniel Holness, Juan Guerra, Jenny Echevarría, Rita Spadafora, Mariano Santos, Edmundo Benítez, Aristides Montilla, Sixto Mequizama y Daniel Núñez. Al Patronato del Parque Metropolitano, especialmente a Dorothy Wilson, Esther Adsett, Tomás Vázquez y a mi viejo amigo, el profesor Francisco Herrera, quien en varias ocasiones me sustituyó como presentador de las charlas. 
Este libro sólo ha sido posible merced a los talentos y motivación de dos profesionales panameños de los más altísimos quilates: María Eugenia Mann y Ricardo Ledezma Bradley. Ellos se ocuparon de la edición y diagramación y de mumerosísimos detalles críticos. ¡Muchísimas gracias! También agradecemos al profesor Rodolfo A. de Gracia por sus revisiones gramaticales a los manuscritos.

A nuestros donantes, cuya generosidad ha permitido que este libro salga a la luz y cuyos mensajes encontrará el lector en las páginas iniciales: Elektra Noreste, Refinería Panamá, Fundación Fidanque, Ali Reza-Mobil y Petroterminal de Panamá. Debo resaltar a otros dos mecenas: el doctor David Cofrin, de Tampa, Florida, miembro de los Smithsonian Associates, cuyo aporte fue clave en un período crítico de la gestación de esta obra. A John Moses, del Sheraton Grand Park Hotel, patrocinador de las Charlas del Mes para 1999.

Los medios de comunicación siempre fueron generosos en permitirnos invitar al público a las Charlas. Indispensables roles desempeñaron los diarios el Panamá América y La Prensa, así como los canales de televisión Telemetro y RPC, TVN, TVOnce, TV5 y la emisora RPC Radio.

A nuestra leal audiencia, que por cuatro años nos acompañó el último miércoles de cada mes en el salón Las Oropéndolas del Parque Natural Metropolitano: niños, jóvenes y adultos; estudiantes, maestros, profesores, operadores y guías de turismo, hoteleros, profesionales, indígenas y diplomáticos, ambientalistas, jubilados y funcionarios públicos. Su motivación e interés fue nuestro mayor estímulo y premio.

La libertad intelectual que caracteriza a STRI, gracias a su director Ira Rubinoff, fueron claves en facilitarme el tiempo e independencia para acometer empresas intelectuales como las "Charlas del Mes".

Al personal de Imprelibros de Cali, Colombia, por el esmero y calidad de esta impresión. Muy en especial a Fernando Orozco quien nos acompañase desde un inicio y atendió sinnúmero de detalles.

En los seis años transcurridos desde el inicio de estas conferencias hasta la publicación de este libro, mi fuente vital de apoyo moral y comprensión fueron mi esposa Sonia y nuestros hijos, Diego y Mónica. Por su inagotable paciencia y comprensión muchas, no, muchísimas gracias.

Stanley Heckadon-Moreno

Tivoli, Ancón

Ciudad de Panamá 
En mayo de 1996, el Instituto Smithsonian de Investigaciones Tropicales (STRI) y el Patronato del Parque Natural Metropolitano de ciudad de Panamá, iniciamos un ciclo de conferencias al cual titulamos La Charla Smithsonian del Mes. Sirvió de ocasión la celebración de un doble acontecimiento científico: los $\mathbf{1 5 0}$ años de la fundación del Instituto Smithsonian en Washington, Estados Unidos, institución dedicada al avance del conocimiento humano, y los 50 años del establecimiento del STRI en Panamá.

El programa original era modesto: seis charlas en el último semestre de 1996. Sin embargo, gracias al interés de la audiencia y de los científicos, el programa se extendió a cuatro años, hasta noviembre de 1999. Se realizaron cuarenta conferencias a las que asistieron casi cuatro mil personas. Los temas surgieron según la disponibilidad de los investigadores y las sugerencias del público, quien también propuso se hiciese un libro de estas presentaciones.

Fue el espíritu de estas charlas promover un espacio de diálogo entre los naturalistas y la comunidad; una oportunidad para que los investigadores compartiesen sus hallazgos, y motivar así un mayor interés por la naturaleza tropical y las ciencias. Asimismo, para que los investigadores captasen los conocimientos e inquietudes de la ciudadanía.

A estas conversaciones con la comunidad, los científicos acudían usualmente acompañados de sus colaboradores, pues la ciencia funciona hoy en base a equipos internacionales e interdiciplinarios, y no el esfuerzo del investigador solitario de antaño. Con lenguaje sencillo y claro, apoyándose en bellas diapositivas, grabaciones de sonidos de animales, muestras de sus equipos de campo y laboratorio, los naturalistas maravillaron a la gente con la riqueza de plantas y animales del país. Nos asombraron con el altísimo número de especies conocidas, cuya cifra seguramente aumentará al explorarse áreas poco estudiadas de la vertiente caribe y el Darién, y de la misma manera nos mostraron un sinfín de detalles desconocidos sobre los colores, tamaños, mutaciones, hábitos alimentarios y los papeles que estas especies desempeñan en el complejo proceso de equilibrio de la naturaleza tropical.

Cada presentación era seguida de un animado período de preguntas y respuestas y comentarios sobre las últimas novedades científicas de Panamá. Al final de cada velada, era grato ver a la audiencia rodear a los investigadores para conocerlos personalmente y hacerles mas preguntas.

Sirvió de espléndido marco a estas jornadas el Parque Natural Metropolitano, un bello rincón selvático de la ciudad capital de 320 hectáreas de bosques secos del pacífico, que otrora fuera parte de la antigua Zona del Canal y que hoy es un área protegida única. Este parque es la primera experiencia panameña en co-manejo de un área silvestre protegida, siendo administrada por un patronato. Algo novedoso para un país que trata de romper con una pesada tradición de centralismo administrativo de casi quinientos años. EI STRI fue invitado por el Ministerio de Desarrollo Agropecuario, en 1985, a ser parte del patronato del parque, junto a la Alcaldía de la ciudad de Panamá, quien lo preside, la Autoridad Nacional del Ambiente, la Autoridad de la Región Interoceánica, la Asociación para la Investigación y Propagación de Especies Panameñas, la Sociedad Audubon de Panamá, las Asociaciones Cívicas Unidas y el Club Soroptimista Internacional de Panamá. 
Stanley Heckadon-Moreno.

\section{Capítulo 1. Geología, Peces y Prehistoria}

En la historia geológica, Panamá ha cambiado el mundo.

Anthony Coates.

Los moluscos y la historia natural de Panamá. Helena Fortunato.

Peces de agua dulce de Panamá. E. Bermingham, V. Aswani, A.

Castillo, R. González.

Arrecifes y peces de la costa pacífica panameña: una región biológica única. Ross Robertson.

La pesca en estuarios panameños: una visión histórica y

cultural desde la Bahía de Parita. Richard Cooke.

Cuidando a los ancestros: rasgos mortuorios precolombinos

en cerro Juan Díaz, Los Santos. Richard Cooke.

Introducción a la historia de la isla Barro Colorado. Elizabeth King.

\section{Capítulo 2. El mundo de las plantas}

Diversidad en la flora de Panamá. Mireya Correa.

Plantas pequeñas en lo más alto del bosque tropical.

José Luis Andrade.

Los briofitas o musgos de los bosques nubosos.

Noris Salazar-Allen.

El consumo de agua en los árboles del Parque Natural

Metropolitano. José Luis Andrade.

Bosques de la Cuenca del Canal de Panamá. Salomón Aguilar.

¿Cómo se defienden las plantas de sus enemigos? Nélida Gómez.

Las plantas tropicales y el aumento del dióxido de carbono en la atmósfera. Klaus Winter.

El fenómeno del Niño y los bosques de la Isla de Barro Colorado. Joseph Wright. 


\section{Capítulo 3. El pequeño gran mundo de los insectos}

Las orugas de Panamá. Annette Aiello.

¿Por qué hay más de 10,000 especies de escarabajos en Panamá?

Donald Windsor.

Las abejas africanas y el café en Panamá. David Roubik.

El fascinante mundo de los higuerones y sus avispas polinizadoras.

Allen Herre.

El gusano barrenador en Panamá. John Welch y Danel Hale.

\section{Capítulo 4. El mundo de los animales terrestres.}

Los anfibios del área central de Panamá. Roberto Ibañez.

Las serpientes de Panamá. César Jaramillo y Frank Solís.

Biología y conservación de los loros, pericos y guacamayos de Panamá. Jessica Eberhard.

El águila harpía y su conservación en Panamá. Karla Aparicio.

Mito y realidad asombrosa de los murciélagos. Wibke Thies.

\section{Capítulo 5. La búsqueda de alternativas.}

La búsqueda de medicamentos en el bosque tropical panameño.

Todd Capson.

La artesanía de la tagua y el cocobolo en las comunidades Wounaan y Emberá de Darién.

Julia Velázquez-Runk y James Dalling.

Manejo sostenible de los cativales del Darién.

Thomas Kursar y Bil Grauel.

La pesca y el deterioro de los arrecifes en el Caribe y Panamá.

Gabriel Jácome.

Cantidad y calidad de agua en la Cuenca del Canal de Panamá.

Martín Mitre.

El impacto del turismo en los bosques y arrecifes panameños.

Marco Díaz.

El desarrollo sostenible en la reserva biológica y comarca Kuna de Wargandi, Darién. Heraclio López y Sarah Dalle.

Experiencias de educación ambiental en Kuna Yala. Jorge Ventocilla y Valerio Núñez. 


\section{PASADO, PRESENTE Y FUTURO DEL PUENTE BIOLÓGICO}

\section{Stanley Heckadon-Moreno}

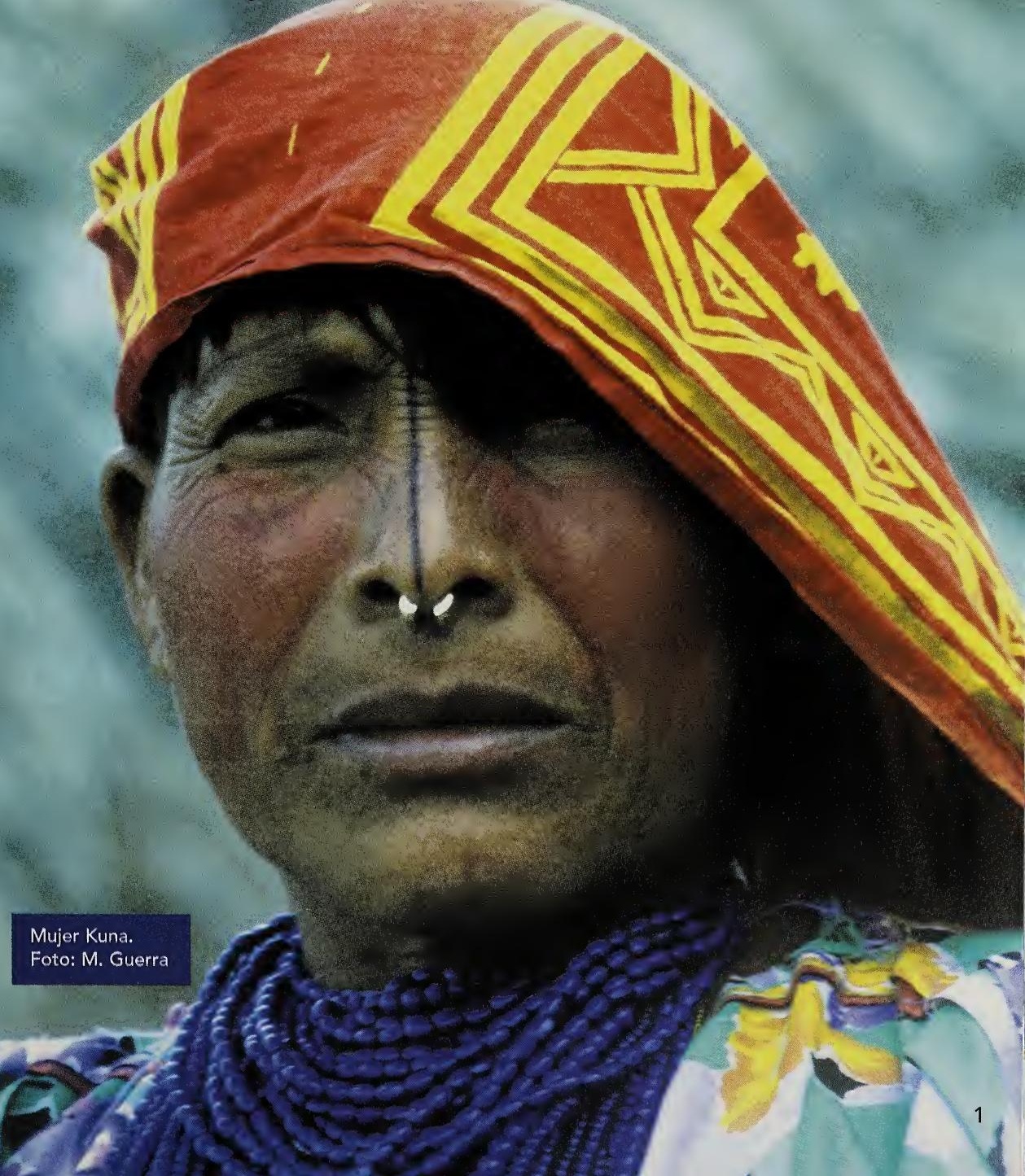




\section{$A R \mid B E$}
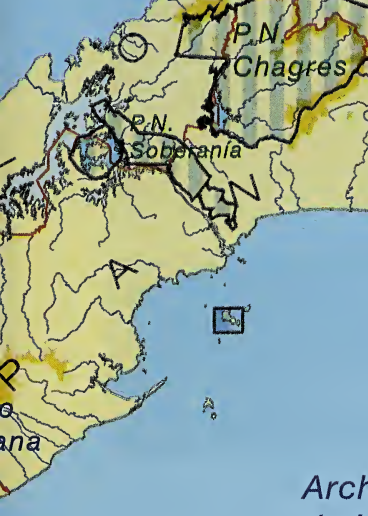

जi
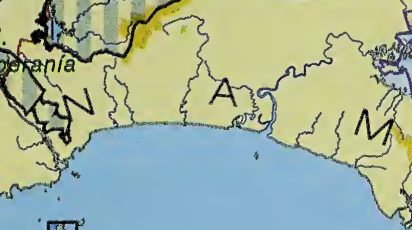

四

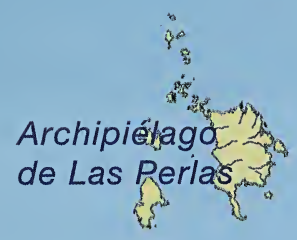

A C I F I C O

ESCALA $1: 1,700,000$

$\begin{array}{lllll}18 & 0 & 18 & 36 & 54 \mathrm{KMS} .\end{array}$ 



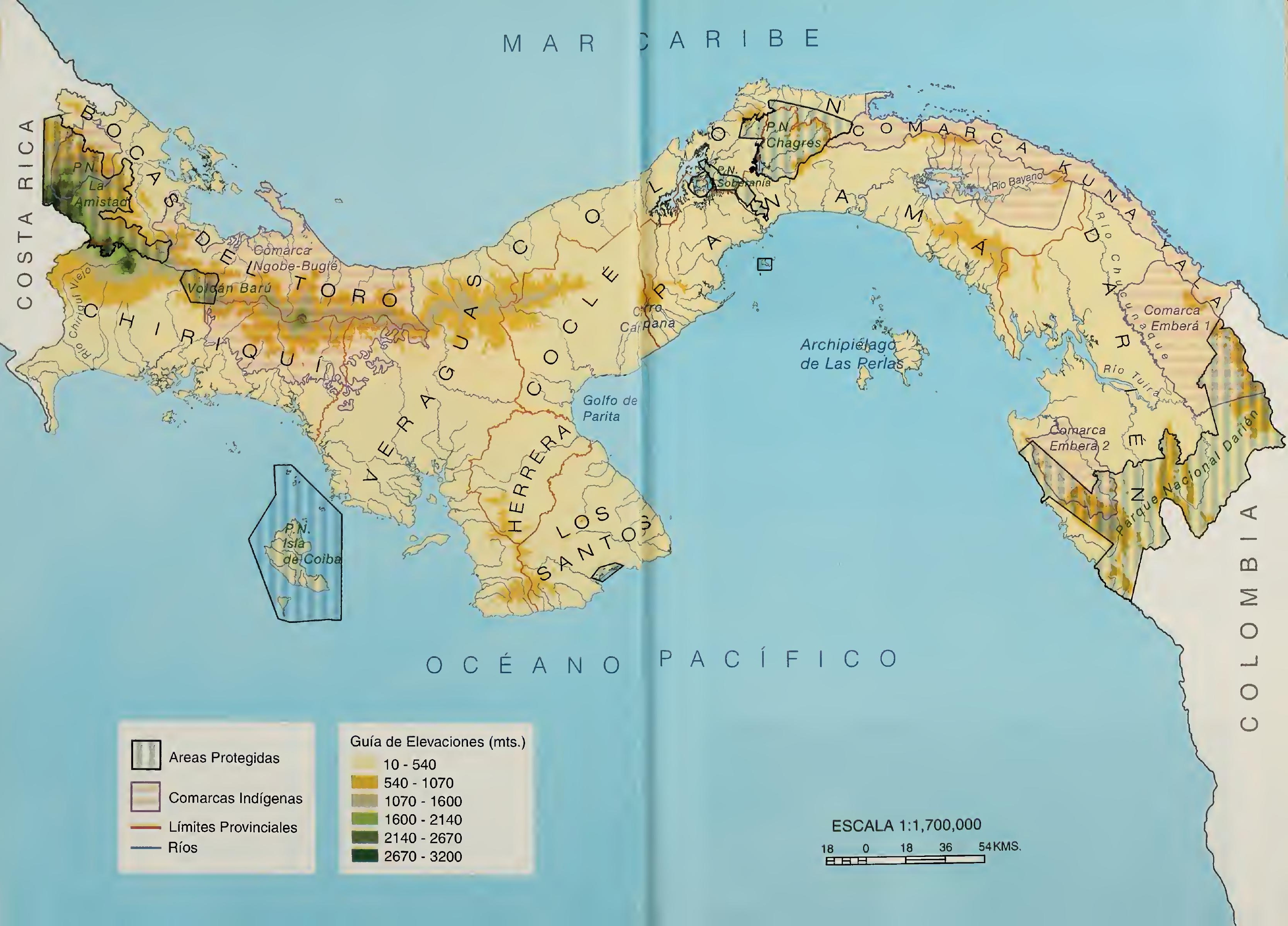


El Canal y el Puente de las Américas. símbolos del Panamá conocido como "Puente del Comercio". Foto: M. Guerra.

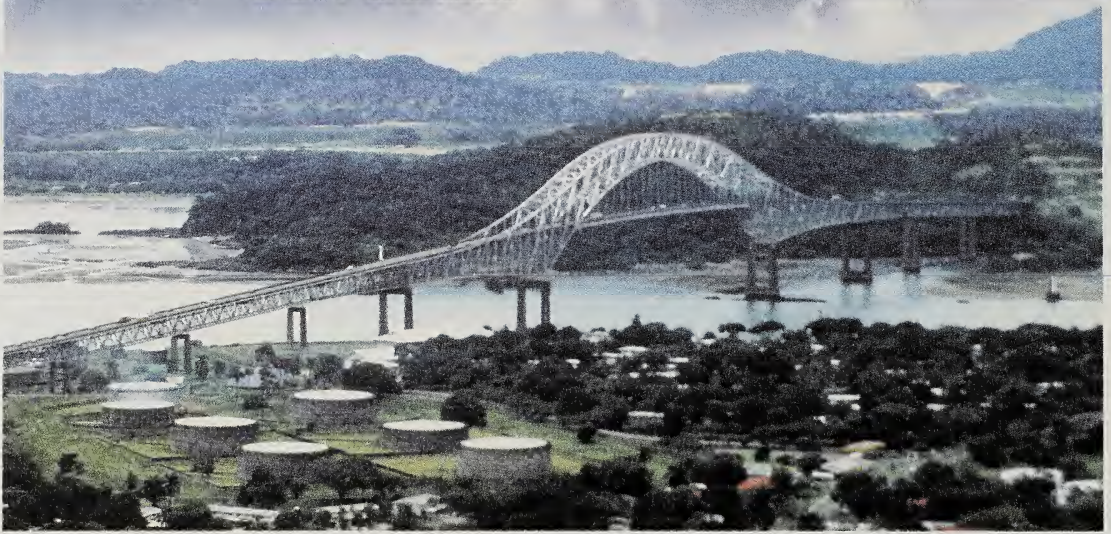

A Panamá usualmente se le conoce como el puente del comercio internacional. Mas esta función es reciente, de los últimos quinientos años, luego del descubrimiento de América y el establecimiento de la ruta del tránsito entre el Pací. fico y el Atlántico a través de este Istmo, la parte mas angosta de las Américas. Los vaivenes del tránsito, el movimiento de mercancias y pasajeros de una mar a la otra y las obras para facilitarlo, explican en buena medida la formación y evolución social y económica del país. Son estas actividades económicas, vinculadas a la posición geo. gráfica y el Canal, las más dinámicas y las que mayores ingresos producen.

Pero existen otros acontecimientos, más remotos, desconocidos y épicos. Ellos hablan de un archipiélago volcánico que se trans- forma en Istmo y que al unir a dos grandes continentes, sirve de puente para el intercambio de sus plantas y animales. Esta es la historia natural del puente biológico de América. De aquí que esta angosta faja de tierra lluviosa tropical, hoy llamada Panamá, de apenas $75,500 \mathrm{~km}^{2}$, posee una asombrosa riqueza biológica.

Esta obra recoge treinta y tres de las cuarenta charlas presentadas, entre 1996 y 1999, por investigadores del Instituto Smithsonian de Investigaciones Tropicales (STRI) en el Parque Natural Metropolitano de ciudad de Panamá. Aquí aparecen no en el orden en que fueron expuestas, sino agrupadas en cinco grandes temas. Al mismo tiempo, ellas representan sólo una fracción de la amplia gama de estudios que realizan los científicos del STRI.

Anthony Coates, con camisa de cuadros, explica a la audiencia los origenes del istmo, durante su presentación en el ciclo de las Charlas Smithsonian del Mes.

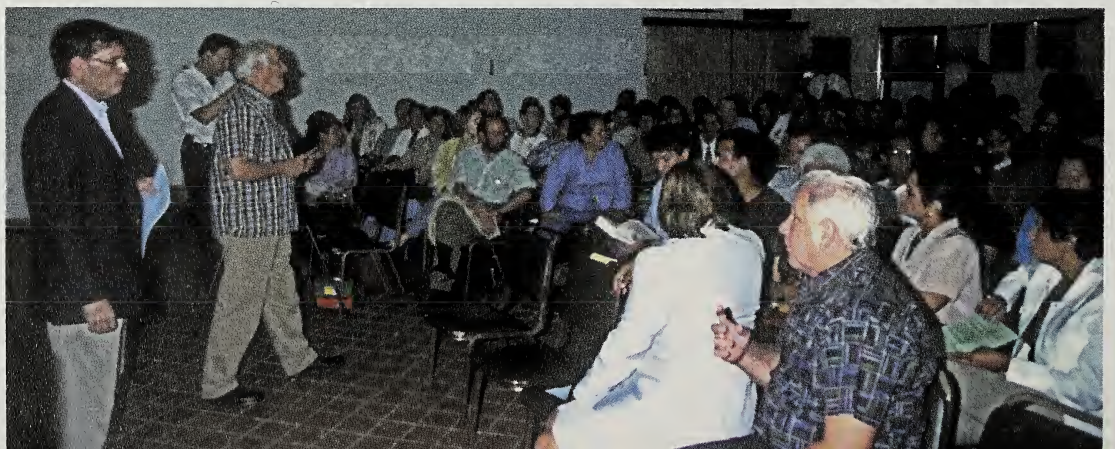




\section{Capítulo 1. Geología, Peces y Prehistoria}

Este capítulo abarca millones de años. Desde el nacimiento del Istmo, hasta la llegada de sus primeros pobladores humanos, nueve mil años antes de Cristo. Tempranamente se asientan del lado pacífico, dedicándose a la pesca y a la agricultura. Paulatinamente, se multiplican y van cambiando el paisaje del puente de tierra.

En el interesante artículo En la historia geológica, Panamá ha cambiado el mundo Anthony Coates, geólogo, reseña el modelo que ha revolucionado nuestra concepción del funcionamiento del planeta. Esta teoría, de las "placas tectónicas", visualiza su superficie dividida en fragmentos, placas, cuyos lentos desplazamientos hacen surgir y desaparecer continentes, montañas, volcanes, mares y trincheras oceánicas. Así se formó hace cien millones de años América Central, y tres millones de años atrás, Panamá. Además de facilitar el intercambio de la flora y fauna, el puente de tierra trae otros cambios dramáticos: separa las aguas de los océanos y origina grandes corrientes marinas.

Cuenta el país con casi 4000 kilómetros de costas, entre ambos mares y sus numerosas islas, costas donde abundan las conchas y caracoles, es decir los moluscos. $\mathrm{Su}$ estudio, la malacología, se ha profundizado poco en nuestro medio. Helena Fortunato, investigadora portuguesa, nos habla en Los moluscos y la historia natural de Panamá de las 50,000 especies de moluscos del país, tanto fósiles como contemporáneos. Describe sus tres grandes grupos -gasterópodos, bivalbos y cefalópodos- y cómo conchas y caracoles son como una ventana al pasado, que deja saber si hace millones de años el mar era más frío o tibio, más profundo o seco y qué animales y plantas com- partían con los moluscos estas aguas.

Se dice que Panamá, un vocablo originario de los indígenas Cueva que habitaban el Istmo al llegar los españoles, significa abundancia de peces. Por ser tierra lluviosa, numerosos ríos cruzan sus dos vertientes. En Peces de agua dulce de Panamá, Eldredge Bermingham -investigador estadounidensey sus colaboradores bosquejan cuándo, cómo y de dónde llegaron las centenares de especies que poblaron sus numerosos sistemas hidrográficos, así como las cinco regiones en que se divide esta fauna de peces.

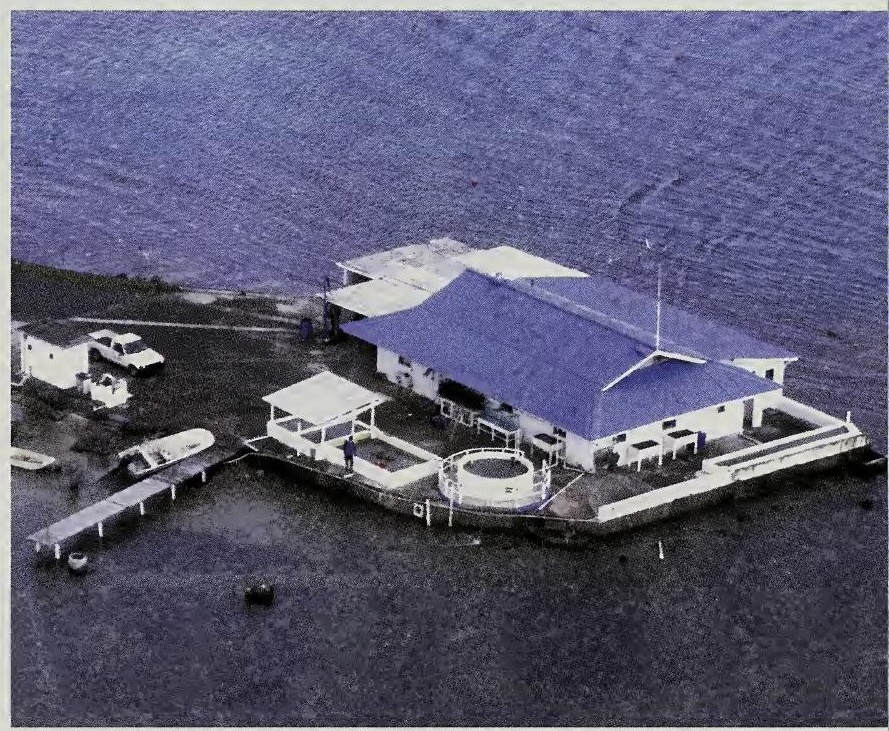

El laboratorio marino del STRI en Isla Galeta, Colón. Foto: M. Guerra

El artículo del biólogo australiano Ross Robertson, Arrecifes y peces de la costa pacífica panameña: una región biológica única, compara la diversidad de corales y peces que habita el Caribe y el Pacífico. Aunque en Panamá ambos mares están cercanos, difieren mucho en la presencia de arrecifes coralinos. En el Caribe abundan, no así en la costa tropical del Pacífico que abarca desde Baja California a las islas Galápagos. La Corriente de El Niño, masa de agua caliente que surge cerca a Asia y Oceanía, extendiéndose gradualmente hasta chocar con la costa de América del Sur, es el factor natu- 
En Diversidad en la Flora de Panamá, Mireya Correa, profesora de la Universidad de Panamá e investigadora del STRI, resalta al país como uno de los veinticinco más ricos en plantas en el mundo, con sus trece ecosistemas que tienen numerosas plantas endémicas, únicas a estos hábitats. Describe los grandes grupos o familias de plantas -las angiospermas o plantas con flores, las gimnospermas, a la cual pertenecen los pinos; los helechos o pteridofitas y los musgos o briofitas- y luego enfoca a aquellas con flores. Son ellas las más abundantes y estudiadas existiendo 10,400 especies para el país, $17 \%$ de ellas endémicas o nativas.

Finalmente recapitula las tres grandes etapas de los estudios botánicos en Panamá: la dominada por los europeos, de 1700 a 1914; luego la de 1914 a 1957, con una mayoría de investigadores norteamericanos entre quienes destaca Paul C. Standley, autor de La Flora de la Isla de Barro Colorado y Flora de la Zona del Canal de Panamá. Y por último la etapa presente, con más presencia de botánicos latinoamericanos y panameños. Descolla el aporte del Missouri Botanical Garden, cuyas expediciones, iniciadas en la década de 1930, recorren el Istmo y culminan en 1980 con la publicación de la monumental Flora de Panama.

De sus estudios en Panamá, el botánico mexicano Jose Luis Andrade nos deja dos trabajos. Plantas pequeñas en lo más alto del bosque tropical explica la biología y ecología de las epífitas, plantitas que crecen sobre otras plantas, frecuentemente en la copa de los árboles y que desempeñan muchísimas funciones en el bosque. Por vivir en lo alto ellas deben tolerar sequías, soles ardientes, vientos fuertes y la escasez de nutrientes. Las epífitas son muy diversas, e incluyen a las bromelias, que dan su aspecto distintivo a las selvas tropicales de América, así como también las delicadas orquídeas.

El agua es el elixir de la vida. Su ciclo, su constante movimiento entre la atmósfera, el suelo y los árboles, es poco comprendido. En El consumo de agua en los árboles del Parque Natural Metropolitano, Andrade condensa los resultados de estudios en Panamá por universidades de Estados Unidos y La- tinoamérica. Ello, para responder a diversas preguntas: ¿cómo hacen los árboles del bosque tropical para extraer agua del suelo y elevarla hasta sus hojas? ¿Cuánta agua consume un árbol en una hora, en un día soleado o nublado? ¿Cuánto vapor de agua liberan sus hojas a la atmósfera?

Las briofitas o musgos de los bosques nubosos de Noris Salazar-Allen, docente universitaria e investigadora del STRI, nos habla de
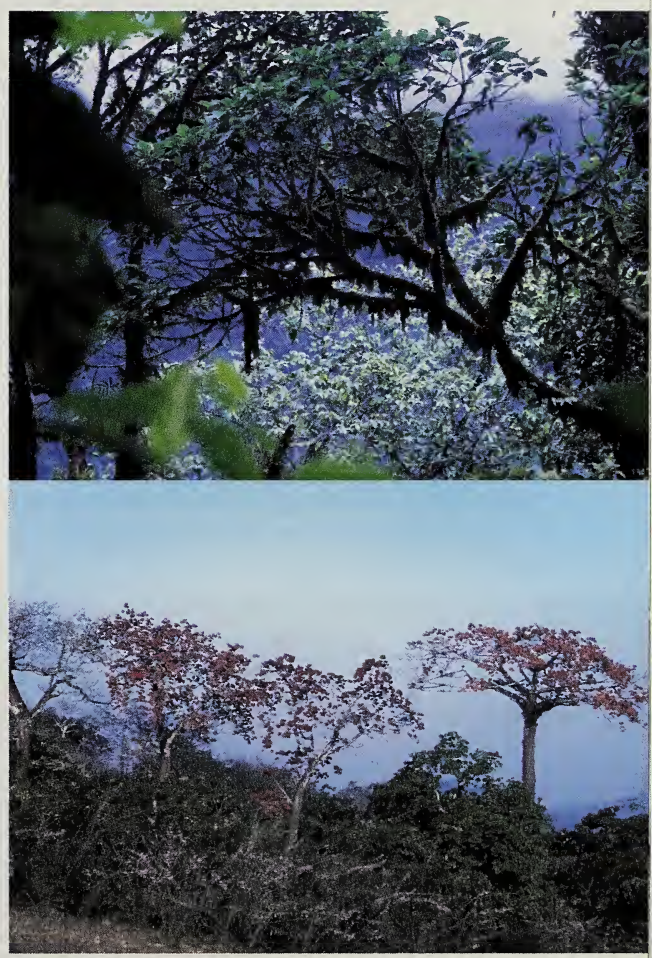

En la foto de arriba, vegetación típica de los bosques nubosos de Panamá. Abajo: Arboles de cuipo del Parque Metropolitano, florecidos. Fotos: M. Guerra.

estas plantas originadas hace cuatrocientos millones de años. Crecen en sitios húmedos, preferiblemente en los bosques nubosos de las montañas del trópico, y aunque pequeñas y humildes, son claves para el equilibrio natural. Indican la humedad y presencia de contaminantes en la atmósfera. Son pione- 
La revolución industrial nos hizo adictos al consumo de combustibles fósiles, carbón y petróleo, lo que ha estado elevando los niveles del dióxido de carbono en la atmósfera. Panamá inició el siglo $\mathrm{XX}$ sin vehículos a motor. Hoy, el parque nacional de carros y camiones, sobrepasa los cuatrocientos mil. La mayor presencia del carbono se agrava a medida que convertimos más bosques en zonas agrícolas y ganaderas. Sostienen algunos climatólogos que al aumentar el carbono se trastocarán los patrones de lluvias y tormentas, las temperaturas terrestres y oceánicas y los niveles de sus aguas.

Klaus Winter, investigador alemán, en Las plantas tropicales y el aumento del dióxido de carbono en la atmósfera resume estudios pioneros en Barro Colorado y el Parque Natural Metropolitano. Señalan éstos que el acrecentamiento del dióxido de carbono podría aumentar hasta en un $50 \%$ la biomasa de las plantas tropicales. Asimismo, podría inhibir el consumo de agua de las plantas y reducir el volumen de vapor que sus hojas inyectan a la atmósfera.

Un fenómeno que trastorna el clima del trópico es la Corriente de El Niño, que trae a Panamá sequías devastadoras para la agricultura y para el funcionamiento del canal. El artículo El fenómeno del Niño y los Bosques de Panamá, del científico canadiense Joseph Wright, describe sus efectos sobre la flora y fauna de Barro Colorado. También revisa las consecuencias de La Niña, fenómeno similar que usualmente acompaña al primero. Aquí se resumen cincuenta años de observaciones de las delicadas interacciones entre el clima, el mar, las lluvias, los bosques y los animales silvestres.

Para entender los fenómenos de la naturaleza, es esencial contar con datos climatológicos a largo plazo. Los registros llevados en Barro Colorado desde 1923, permiten estudiar los efectos que El Niño ha tenido en nuestro país, en cada una de las diecisiete veces en que se ha presentado desde 1923 a la fecha. Uno de estos efectos es que las sequías producidas por El Niño aumentan la producción de frutas y semillas del bosque, creando tiempos de bonanza para los animales que las comen. Pero, cuando a El Niño le sigue La Niña, causando días nublados y lluviosos en la estación seca, la producción de frutas decae suscitando grandes hambrunas y mortandad entre los animales silvestres.

Capítulo 3. El pequeño gran mundo de los insectos

Del millón de formas de vida conocidas del planeta unas 700,000 son insectos, en su mayoría tropicales. Entre los más numerosos y llamativos están las mariposas. Panamá tiene mas de 16,000 especies. Annette Aiello, en Las orugas de Panamá muestra cómo estos insectos, antes de ser mariposas, pasan la mayor parte de sus vidas como orugas. Describe sus formas, colores, tamaños, estilos de vida, defensas y comportamientos. Cómo cada especie tiende a alimentarse de un tipo de planta. Algunas hacen viviendas, siempre usando seda, que para las orugas, es tan importante como para las arañas.

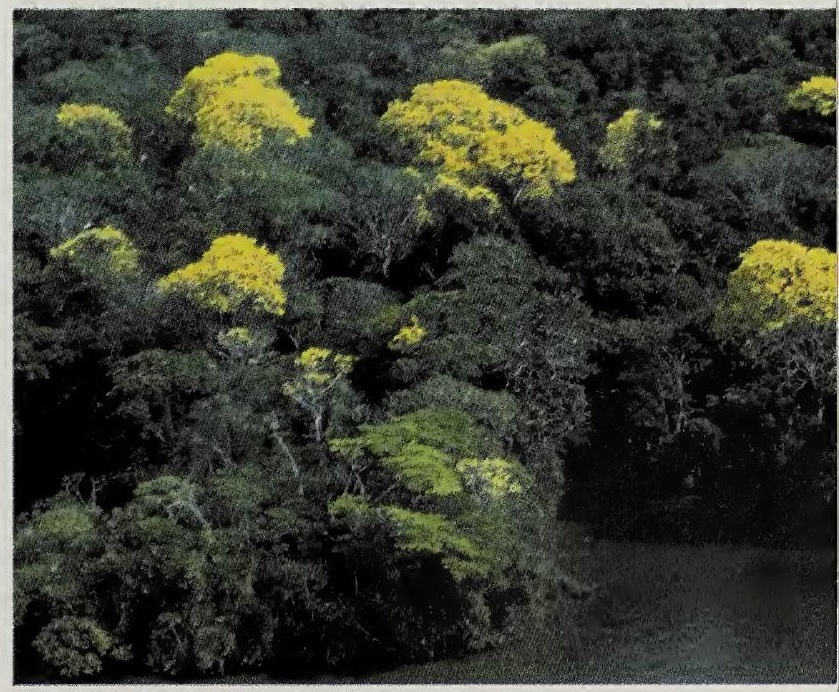

Arboles de guayacán en floración, en la Isla Barro Colorado. Foto: M. Guerra. 
Tres cuartas partes de los insectos pertenecen a la familia de los escarabajos, llamados científicamente coleópteros. Donald Windsor en ¿Por qué hay $\mathbf{1 0 , 0 0 0}$ tipos de escarabajos en Panamá? analiza el universo de los insectos más diversos y comunes de las selvas. Se concentra en aquellos que comen plantas y cómo esta dieta vegetal ha podido promover su diversificación.

A algunas plantas las poliniza el viento. Pero la mayoría sólo se reproduce gracias a insectos y animales. Casi el $90 \%$ de las plantas con flores, se extinguirian si ellos no transportasen su polen. Se estima que las abejas polinizan unas 40,000 especies de plantas, incluyendo $70 \%$ de los cultivos mas importantes para la humanidad.

Uno de estos cultivos es un árbol de origen africano bien adaptado a la América tropical que desde el siglo XIX se convirtió en el mayor cultivo de exportación de muchos países: el café. En Panamá, el epicentro cafetalero son las tierras altas de origen volcánico de Chiriquí. Las abejas africanas y el café en Panamá, de David Roubik, detalla aspectos ignorados de la relación entre la producción de los cafetales y los insectos

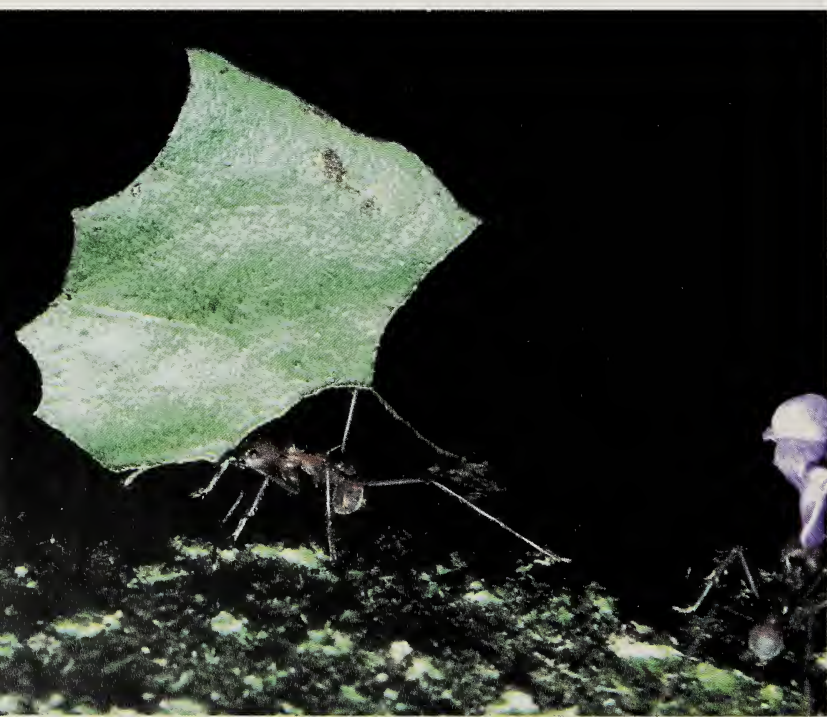

Hormigas acarreando material vegetal hasta el interior de sus nidos. Foto: M. Guerra. que visitan sus flores. Sobretodo, uno que es nativo del Africa, recién llegado a Panamá vía Brasil: la abeja africana.

Uno de los árboles mas importantes de la selva es el higuerón, cuyos frutos o higos alimentan a muchas aves y animales. Allen Herre en El fascinante mundo de los higuerones y sus avispas polinizadoras, muestra una de las interdependencias más singulares e importantes del bosque, que une indisolublemente a estos grandes árboles y las pequeñas avispitas que los polinizan. Hay muchas especies de higerones, pero cada una sólo puede ser polinizada por una especie de avispa.

En su clásica novela Doña Barbara, Rómulo Gallegos deja testimonio del brutal tributo pagado por hombres y reses en los llanos venezolanos, a uno de los insectos mas voraces del trópico, el gusano barrenador. "El ganado grande -dice amargamente el viejo llanero Melesio- me lo arrasó el gusano". Ataca este insecto a los animales de sangre caliente. Comienza con una formidable mosca que pone centenares de huevos, dentro o cerca de las heridas de un animal. En pocas horas éstos se convirten en gusanos y de no tratarse la infestación, sea en animal o en el hombre, este se muere en poco tiempo. Luego de vivir por pocos días en la herida, los gusanos caen y se entierran para transformarse en moscas adultas.

El gusano barrenador en Panamá, de John Welch y Danel Hale, recapitula los esfuerzos de un vasto proyecto internacional para entender la biología y ecología de esta mosca con el fin de erradicarla. Se combinan investigaciones básicas y aplicadas, con una inversión de más de 35 millones de dólares. Sus beneficios anuales, según se elimina la mosca, representa más de 23 billones de dólares anuales a las economías de Estados Unidos, México y Centro América. Para Panamá, sus réditos son de 29 millones de dólares. 
Capítulo 4. El mundo de los animales terrestres

Panamá es rico en anfibios. Cuenta con unas ciento setenta y cinco especies de estos animales que pasan parte de sus vidas en el agua y parte en tierra. Vasta es nuestra ignorancia sobre los sapos, ranas y salamandras.

La mayoría de las especies ni siquiera ha ameritado nombres comunes. Los anfibios del área central de Panamá, de Roberto Ibáñez, recoge tres años de investigaciones del componente de vertebrados del Proyecto de Monitoreo de la Cuenca del Canal. Los anfibios sirven de indicadores sobre la salud del ambiente. Ibáñez describe las especies que más abundan y las más raras. Asimismo, sus sitios preferidos para habitar y sus dietas, siendo muchos grandes comedores de insectos. También, sus formas de aparearse, cantos amorosos y los cuidos que los padres dan a sus crías.

Reza un dicho popular "culebra vista, culebra muerta". Frank Solís y César Jaramillo en Las serpientes de Panamá, presentan a los animales considerados por los panameños como más feos, repugnantes y peligrosos. Tiene el istmo ciento veintisiete especies, veintiuna de ellas venenosas, incluyendo a las marinas del Golfo de Panamá. Unas habitan en el agua, otras en tierra, en los árboles y otras pasan enterradas. Ellas son de importancia al equilibrio natural y eliminarlas tiene un costo, tal como la actual sobrepoblación de roedores que facilita la propagación de enfermedades peligrosas como el hanta virus.

Jessica Eberhard nos deleita con Biología y conservación de los loros, pericos y guacamayos de Panamá, animales amados por sus bellos plumajes, sociabilidad y bulliciosidad. Son vegetarianos y monógamos, que gustan de anidar en huecos de los árboles. Desafortunadamente, muchas especies están amenazadas por la deforestación y la captura de sus pichones para venderlos como mascotas.

Karla Aparicio nos ofreció dos conferencias. La primera, sobre las aves del Parque $\mathrm{Na}$ cional Chagres. La segunda, conjuntamente con el indígena emberá Euriato Valdespino, El aguila harpía y su conservación en Panamá. Esta especie, una de las águilas más grandes del mundo, es el ave nacional de Panamá y aparece en su moneda y escudo de armas. Casi nada sabemos de ella. Aparicio describe las primeras investigaciones hechas en Darién desde 1992. Luego, los estudios iniciados desde 1997 en la Cuenca del Canal, despues que indigenas emberás detectasen un nido de harpías. Reseña los esfuerzos para que las comunidades, campe. sinas e indigenas, que viven en el Parque Nacional Chagres participen en estudiar y proteger esta especie.

Wibke Thies investigadora alemana, en Mito y realidad asombrosa de los murciélagos, nos presenta a uno de los animales más incomprendidos pero útiles. Ellos son los mamíferos mas abundantes de los trópicos, eficientes diseminadores de semillas de los

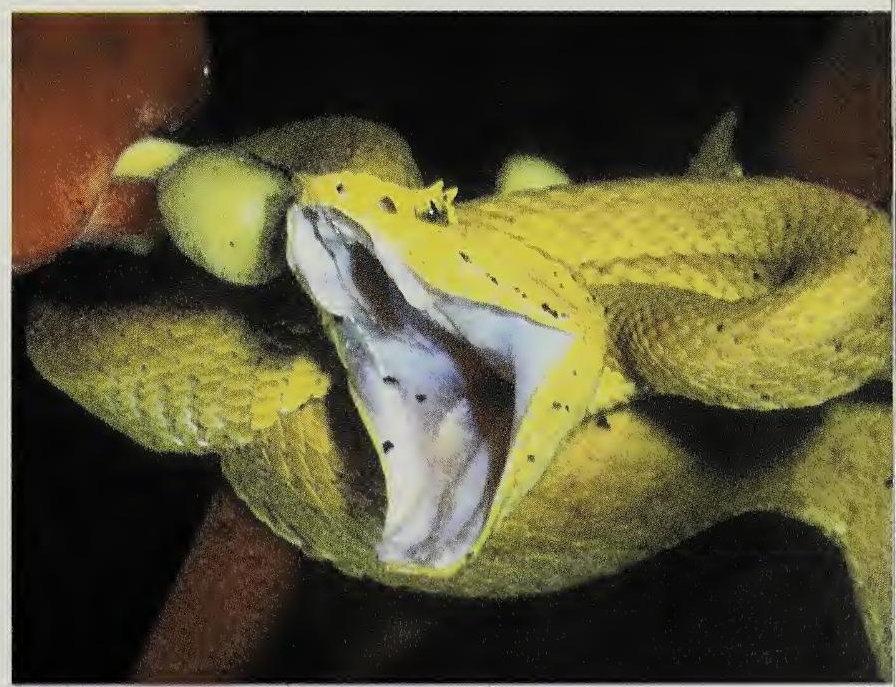

Serpiente Bothriechis Schlegelli, conocida comúnmente como "serpiente de pestañas" o serpiente "oropel". Foto: M. Guerra. 
árboles y grandes eliminadores de insectos. Siendo nocturnos, su vida nos parece misteriosa y sus beneficios permacecen ocultos.

\section{Capítulo 5. La búsqueda de alternativas}

El siglo XX trajo una revolución demográfica debido a grandes avances en la salud pública, educación y las condiciones de vida. Gracias a sus esfuerzos, Panamá tiene uno de los mejores índices de desarrollo humano en la América Latina. A principios del siglo su población era de unos 250,000 habitantes. El censo del 2000 reporta 2,815,000. En una centuria, su población ha aumentado once veces. La expectativa de vida se ha duplicado. Los nacidos en el 2000 pueden aspirar a vivir 74 años. A principios de siglo sólo un panameño en cada diez sabía leer; hoy nueve de cada diez lo hacen.

La economía creció significativamente. Para el año 2000 el producto interno bruto superaba los 7 billones de dólares. Paradójicamente, este crecimiento social y económico, según las Naciones Unidas, ha sido "parcialmente exitoso, pero, también particular mente excluyente". Un millón de personas, $37 \%$ de su población total, es pobre. Ello se agrava en las zonas rurales campesinas y peor aún entre las comunidades indígenas. La deuda externa alcanza cifras astronómicas que algunos consideran impagable.
Acompaña a este desarrollo excluyente un deterioro sin precedentes de la naturaleza. Por doquier abundan las señas del deterioro ambiental. En 1910, el naturalista suizo Henri Pittier comentaba que tres cuartas partes del Istmo tenía una extensa carpeta selvática. La otra cuarta parte eran las sabanas naturales y bosques secos del pacífico. Quizás $5 \%$ del territorio había sido descumbrado por el hombre. En el siglo XX deforestamos casi 4 millones de hectáreas, $80 \%$ de ellas luego del año 1950. Para el 2000 quedan unos 3 millones de hectáreas en bosques, en su mayoría dentro de los parques nacionales o en los territorios de las comunidades indígenas. Fl avance de la frontera agropecuaria a costa de los bosques se estima, conservadoramente, en 40,000 hectáreas anuales. Los suelos erosionados suman más de dos millones de hectáreas, a lo que debe añadirse la creciente y preocupante contaminación de las aguas.

Los escritos que siguen son estudios en busca de conciliar el desarrollo económico con la conservación y el manejo sostenible de la naturaleza tropical.

Todd Capson en La búsqueda de medicinas en el bosque tropical panameño, esboza un complejo proyecto entre el Instituto Conmemorativo Gorgas, la Universidad de Panamá y el STRI, con fondos del National Institute of Health de los Estados Unidos, que estudia plantas tropicales que pudiesen tener compuestos con potencial para curar males de la humanidad. Uno de los indicadores de selección, llamados criterios ecológicos, consiste en observar si una planta resiste a los insectos. Ello puede indicarnos la posible presencia de sustancias químicas beneficiosas.

Los dos artículos que siguen son resultado de estudios hechos en Darién por investigadores del STRI y la ANAM, con apoyo de la Organización Internacional de Maderas Tropicales (OIMT). Tuve la satisfacción de ser parte del equipo que formuló este proyecto, con-
Indígenas emberá del Darién, moliendo caña en un trapiche de palo. Foto: M. Guerra. 
juntamente con James Dalling y Thomas Kursar. Luego, negociar exitosamente su financiación en Yokohama, Japón, en 1995.

Urgen alternativas para que las comunidades rurales mejoren sus ingresos y participen en proteger la naturaleza. Una vía es extrayendo de los bosques productos no maderables. A diferencia de la madera, las fibras, semillas, gomas, ceras y frutos, pueden obtenerse de la selva sin dañarla.

Julia Velázquez-Runk y James Dalling en, La artesanía de la tagua y el cocobolo en las comunidades Wounaan y Emberá de Darién, describen cómo estos indígenas del este de Panamá extraen productos no maderables para hacer artesanías para el mercado. Destacan las tallas del corozo de la palma de tagua y la madera del cocobolo. Esbozan la historia natural de ambas especies, su ecología y cómo garantizar su uso sostenido.

Un ecosistema de poca biodiversidad, pero altísima productividad forestal son los cativales del Darién, bosques casi puros del árbol cativo, especie llamada científicamente Prioria copaifera. Los cativales, que ocupan terrenos anegados por mareas e inundaciones, proveen casi el $90 \%$ de la materia prima para fabricar el plywood. Poco se sabía sobre esta especie forestal, intensamente explotada, o casi sobrexplotada desde la década de 1960.

Thomas Kursar y William Grauel comparten en Manejo sostenible de los cativales del Darién, los resultados preliminares de su estudio sobre la ecología y biología de los cativa les. Incluye información sobre la regeneración de las semillas bajo sequías e inundaciones, el crecimiento de la especie en diversos suelos e intensidades de luz. Muchos aspectos del plan para manejar los cativales serán útiles para otras especies de árboles maderables de $\mathrm{Pa}$ namá, las cuales son muchísimas, pero sobre las cuales conocemos poco.

Gabriel Jácome, en La pesca y el deterioro de los arrecifes en el Caribe y Panamá, analiza el deterioro de los arrecifes del Caribe panameño. Describe las funciones y beneficios de los arrecifes y luego los métodos de pesca que deterioran los corales y extinguen a muchas especies que los habitan. Además, sugiere medidas para proteger estos ecosistemas marinos.

Una función vital de la naturaleza es filtrar el agua. Al llover, las raíces de las plantas, los microorganismos del suelo, las capas de rocas, piedras y arena, operan como una eficiente red de filtros. Gradualmente, estamos reduciendo la capacidad de la naturaleza de purificar el agua. Se estima que unos cinco millones de personas mueren anualmente en el mundo por tomar aguas contaminadas.

En Panamá, son pocos los estudios sobre la calidad de las aguas. Martín Mitre, en Cantidad y Calidad del Agua en la Cuenca del Canal de Panamá, presenta los hallazgos del componente de aguas del Proyecto de Monitoreo de la Cuenca del Canal. Se concentra en los procesos que afectan la cantidad y sobre todo su calidad. Todos los indices muestran una preocupante contaminación de las aguas, sobretodo en el eje de la carretera Transístmica, el área mas industrializada y urbanizada. La mejor calidad del agua está en las cabeceras de los ríos, en las zonas

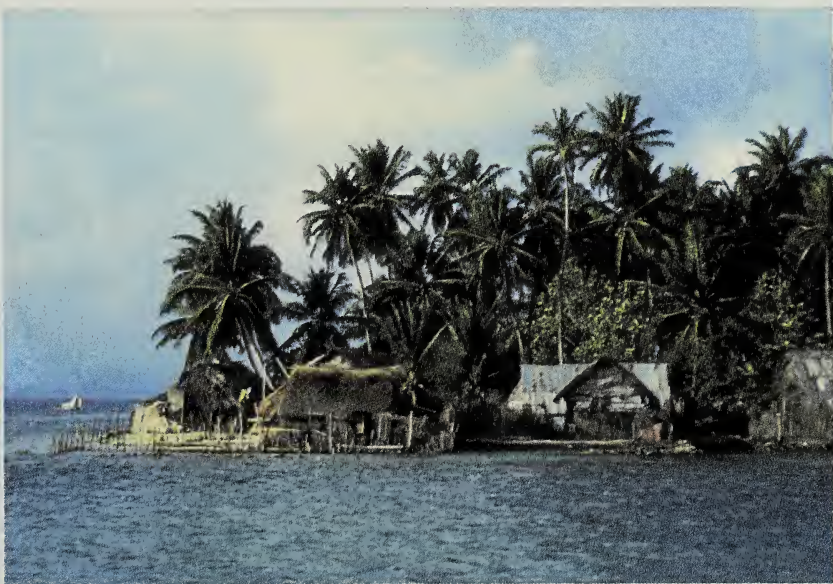

Una de las islas del archipiélago de San Blas, en la Comarca indigena de Kuna Yala. Foto: M. Guerra. 
boscosas protegidas. Detener y reducir la contaminación de las aguas emerge como uno de los mayores desafíos ambientales de Panamá en el siglo XXI.

El turismo es una de las actividades que más ingresos genera a nivel mundial, más de 440 billones anuales según el Banco Mundial. En años recientes cobra auge el ecoturismo, observar la naturaleza. Ello favorece a países con gran diversidad biológica como Panamá. Bien manejado, el turismo naturalista podría generar tantos ingresos como el Canal.

Marco Díaz, en El impacto del turismo en los bosques y arrecifes panameños describe algunos efectos negativos del incipiente turismo naturalista sobre bosques y arrecifes. Señala la poca infraestrucura dentro de las áreas protegidas y su sobreutilización por grupos muy grandes de visitantes. Describe las prácticas negativas de los botes que visitan los arrecifes de isla Iguana y Bocas del Toro. Recomienda prácticas sensatas para mantener la belleza de los bosques y los corales para no matar, como reza el dicho "la gallina de los huevos de oro".

El desarrollo sostenible en la Reserva Biológica y Comarca Kuna de Wargandi, Darién de Heraclio López y Sarah Dalle trae datos novedosos sobre uno de los pueblos y regiones menos conocidos de Panamá, los kunas del alto río Chucunaque. Bosquejan la historia y ecología de la región, la riqueza cultural de este pueblo, sus usos y costumbres, lengua, cantos e identidad y la íntima relación de la religión y filosfía kuna con el bosque. Incluye un trabajo pionero de etnoecología sobre la soska, palma esencial para construir viviendas, en busca de maneras de evitar su extinción.

Finalmente, Jorge Ventocilla y Valerio Núñez en Experiencias de educación ambiental en Kuna Yala narran cómo una investigación de campo en la década de 1980, sobre la cacería de subistencia entre los $\mathrm{Ku}$ nas de Cangandi, sirvió para establecer paulatinamente un proceso de aprendizaje y educación ambiental con la comunidad. Proceso que generó libros de colorear, concursos de dibujo, talleres de arte infatil y culmina en la publicación de la obra El espíritu de la tierra: plantas y animales en la vida del pueblo Kuna.

\section{Unas últimas consideraciones}

Al concluir el siglo XX y tocar a su fin el período de intensa presencia de Estados Unidos en Panamá, cabe resaltar dos grandes legados institucionales: uno, la Autoridad

Laboratorio marino del STRI en isla Naos, en la entrada pacífica del Canal de Panamá.

Foto: M. Guerra.

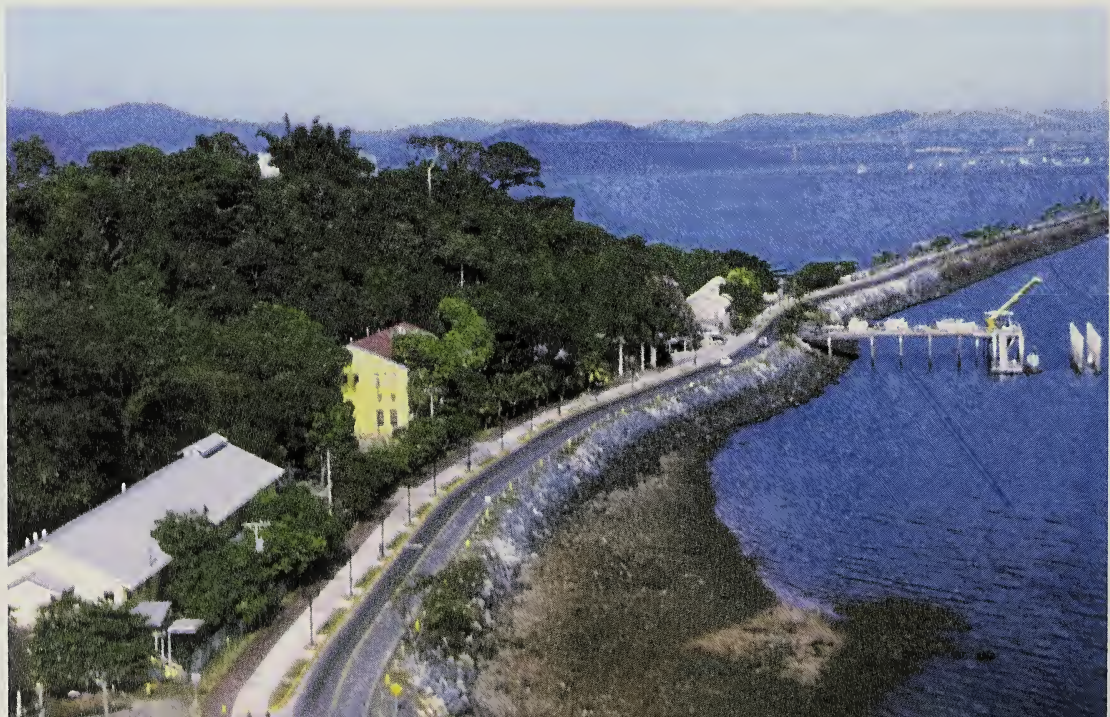


del Canal de Panamá, institución moderna y eficiente que maneja la vía interoceánica, descendiente directa de la vieja Isthmian Canal Comission que construyese el canal. La otra, el Instituto Smithsonian de Investigaciones Tropicales, centro científico avanzado.

El trabajo de tres generaciones de investigadores del STRI, constituye un aporte único al conocimiento sobre las plantas y animales del puente biológico de América. Hacia estos dedicados estudiosos de la naturaleza, hijos espirituales de una larga tradición iniciada en la vieja estación de Barro Colorado, guarda el país una impagable deuda de gratitud. El tesonero y silencioso trabajo de estos dedicados hombres y mujeres, de tantas disciplinas y nacionalidades, nos ayudan a entender mejor cómo un país físicamente pequeño como Panamá pueder ser, biológicamente, uno de los más ricos del mundo.

Una preocupación que comparten todos los investigadores es la acelerada destrucción de los hábitats del país y sus especies. El futuro de este patrimonio nacional y universal, dependerá de las decisiones y acciones de la especie más exitosa y dañina del planeta: el hombre.
En el siglo XXI estudiar, utilizar sabiamente y resguardar este legado biológico es un reto medular de Panamá, tanto como mejorar las condiciones de vida de sus habitantes. Ello exigirá, entre otras medidas, fortalecer la ciencia y la tecnología. Esta tarea exigirá cambios profundos en el sistema académico que, tradicionalmente, ha enfatizado las carreras vinculadas a la función del Istmo como puente del comercio. Promover las ciencias implicará también, ampliar el acceso al mundo de las computadoras y un mayor dominio de lenguas extranjeras, sobretodo el inglés. Cuando los naturalistas del Instituto Smithsonian realizaron el reconocimiento biológico de Panamá, en plena construcción del canal en 1910-1912, el latín era la lengua de las ciencias. Hoy es el inglés. Quienes no lo hablan, quedan marginados de la revolución del conocimiento.

Dos han sido las aspiraciones de las "Charlas Smithsonian del Mes" y de esta obra: una, ayudar a reducir la distancia entre las ciencias y la comunidad. La otra, promover entre la ciudadanía una mayor comprensión y admiración por las maravillas de la naturaleza tropical del Istmo, el ser custodios de su buen uso y conservación en este nuevo milenio.

El Museo del Canal Interoceánico, edificio de la izquierda, y el Palacio Municipal en la Plaza de la Catedral del Casco Viejo de la Ciudad de Panamá. Foto: M. Guerra.

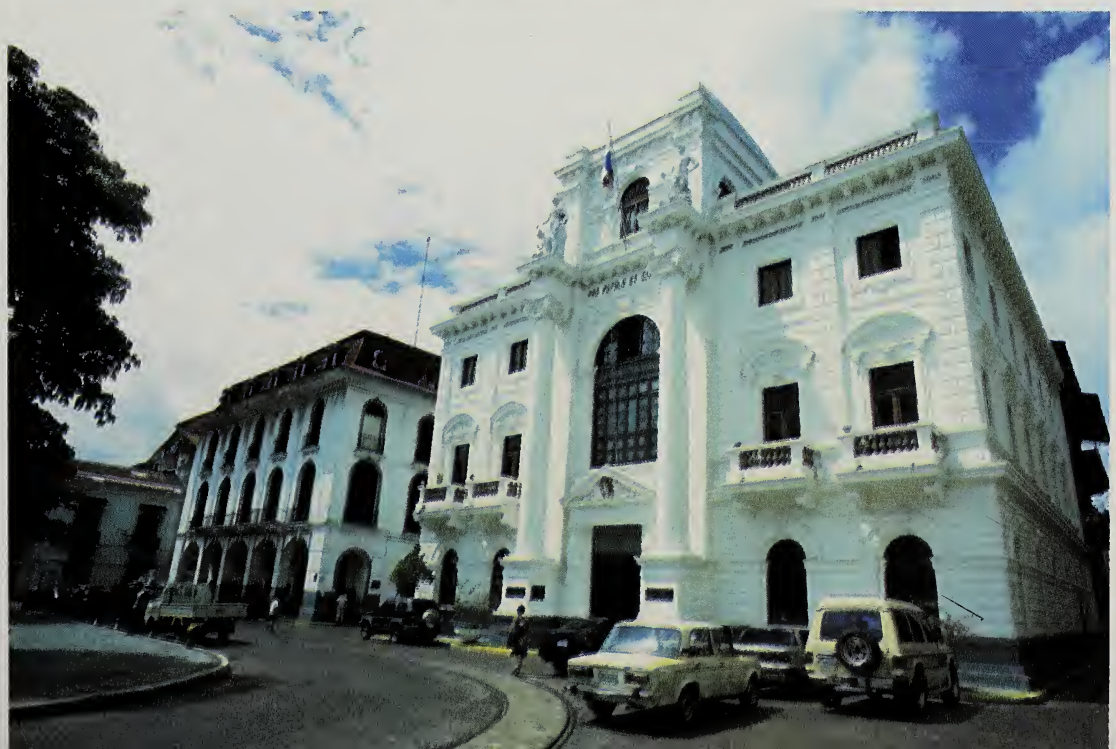


-2. Una de las edificaciones del STRI en Punta Culebra, a la entrada del Canal de Panamá, dedicadas a la educación marina. Foto: M. Guerra. 


\section{CAPITULO 1}

\section{GEOLOGÍA, \\ PECES Y \\ PREHISTORIA}

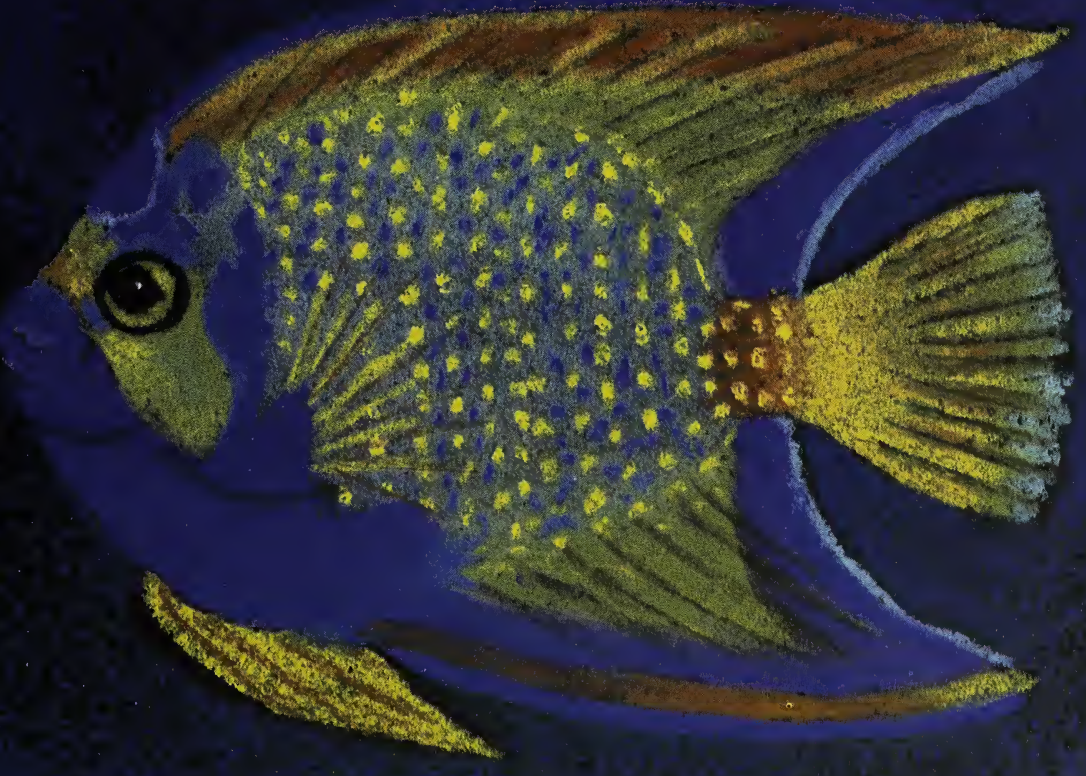

Ilustración: Melva Olmos 


\section{En la Historia Geológica, Panamá ha Cambiado el Mundo}

\section{Anthony Coates}

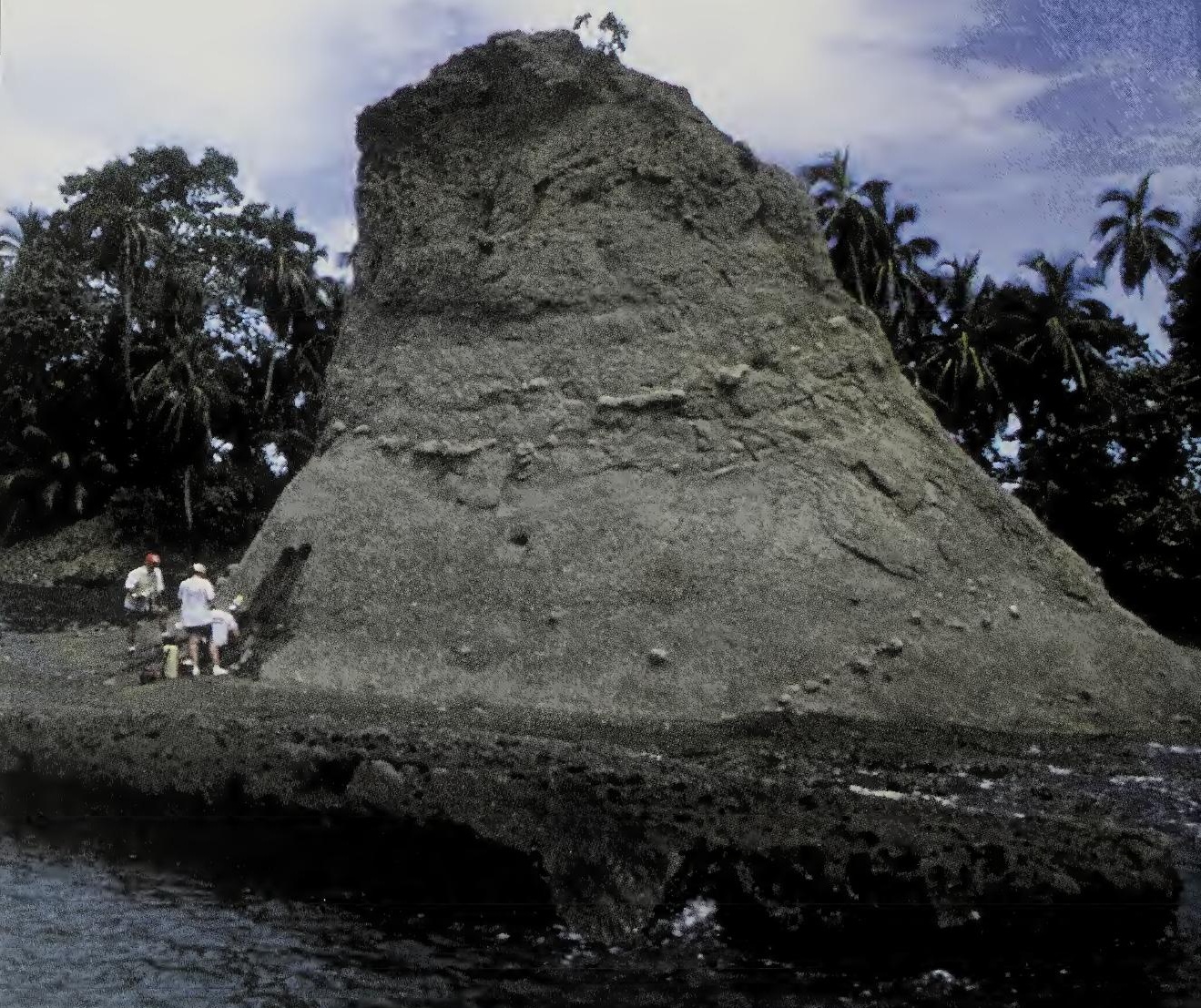


$\mathrm{L}$ a tierra tiene aproximadamente 4.7 billones de años de antigüedad. Tenemos evidencia de que la vida en la tierra existe hace casi 4 billones de años. Es importante comprender esta escala de tiempo, pues significa que procesos muy lentos -aparentemente insignificantes para el promedio de vida humana- pueden producir cambios dramáticos en el planeta.

Los geólogos estudiamos las transformaciones que sufre la tierra midiéndolas a través de esta escala. Por ejemplo, sabemos que cada vez que ocurre un terremoto, la tierra se mueve. En 1991, parte de la costa caribeña de Costa Rica se elevó 1.60 metros, a raíz de un temblor. Arrecifes coralinos se elevaron sobre el nivel del mar, cambiando la forma de la costa, añadiendo así más tierra firme a Costa Rica y produciéndo un cambio en su geografía. Si calculamos que la tierra se eleva un metro cada vez que ocurre un terremoto y conocemos la frecuencia con que estos suceden, podremos estimar que en unos pocos millones de años el proceso puede crear montañas tan altas como los Andes.

Vamos a hablar ahora sobre tres temas:

Cómo funciona la tierra mecánicamente como un sistema global, con sus capas internas y sus movimientos producidos por el calor.

Cómo a través del tiempo geológico este proceso mecánico produce cambios fundamentales en la superficie de la tierra.

Por qué el surgimiento del istmo de Panamá fue el evento más importante en la historia geológica del mundo después de la extinción de los dinosaurios hace 60 millones de años.

Movimiento y crecimiento de las capas tectónicas

La tierra es como una cebolla con varias capas concéntricas; el núcleo es la capa más densa, envuelta por una capa llamada manto, más liviana, y que se encuentra en estado semi-líquido viscoso causado por el calor. La única parte de la tierra que es sólida es la capa externa, denominada cor- teza. El calor del interior de la tierra se produce por la lenta desintegración de elementos radioactivos como el uranio, de tal modo que la tierra parece una central nuclear que libera energía continuamente, en forma de calor. Algunas regiones son más calientes que otras, y se puede decir que el manto está hirviendo lentamente.

Los movimientos causados por las temperaturas hirvientes de las capas internas hacen que la corteza se fracture; de esta fractura resultan los fragmentos llamados placas tectónicas, que también se mueven, mientras que otras se separan, chocándose entre sí. (El término tectónico alude a las fuerzas internas de la tierra que dan forma a los continentes, las depresiones de los océanos, las cordilleras, las zonas de terremotos y otras características de su superficie.)

Estas placas se mueven entre tres y doce centímetros por año, y en las zonas donde las placas chocan se producen terremotos y erupciones volcánicas. A través del tiempo geológico estos movimientos también crean

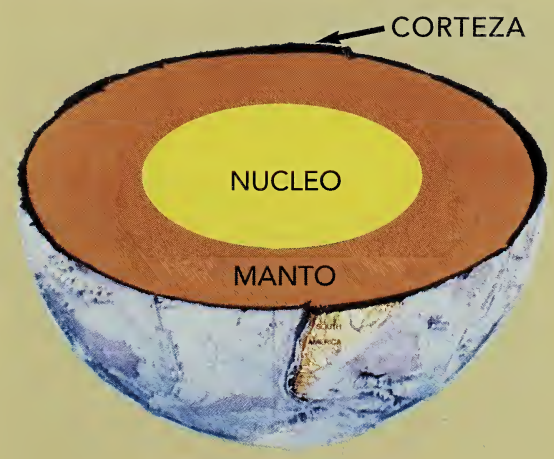

En el centro de la Tierra está el núcleo, rodeado por una capa de magma llamada manto, sobre la cual flota una delgada capa sólida llamada corteza, que forma la superficie externa de la Tierra. El núcleo se encuentra a una profundidad de $2,900 \mathrm{kms}$. y su temperatura oscila entre 2,600 y 2,300 grados centígrados; el manto está a una profundidad de $100 \mathrm{kms}$. y su temperatura varía entre 2,300 y 1,100 grados centígrados. La corteza va desde la superficie hasta los $100 \mathrm{kms}$. de profundidad. 

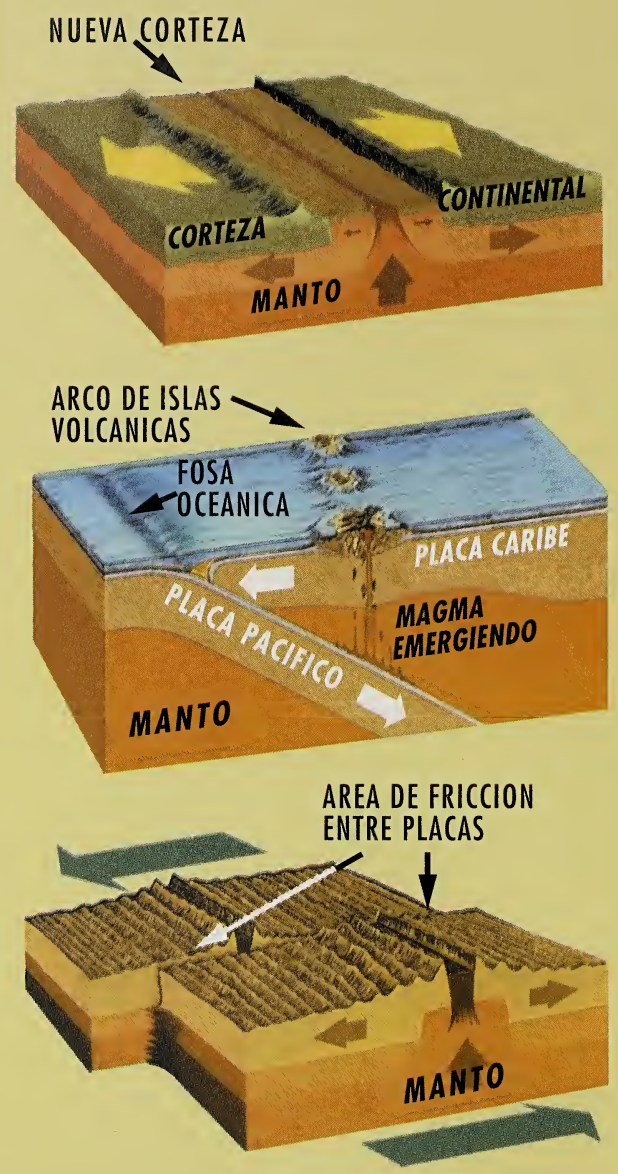

Los tres tipos de interacción entre las placas tectónicas:

Arriba, en una cordillera meso-oceánica, el magma que fluye desde el manto se enfría y se convierte en nueva corteza, desplazando y separando la corteza existente.

Al centro, en una zona de subducción, una placa se hunde bajo la otra y se sumerge en el magma, derritiéndose. El nuevo magma se eleva y sale a la superficie formando volcanes. Así debió lucir Panamá hace seis millones de años, en la zona de subducción que le dió origen.

Abajo, en una falla de transformación, dos placas tectónicas se deslizan una contra otra, produciendo con la fricción fuertes temblores. las cadenas montañosas y las fosas oceánicas más profundas.

\section{Continentes y océanos}

Existe una gran diferencia geológica entre los continentes y los océanos, además de que unos están constituídos por tierra y otros por agua; los océanos son las zonas de la corteza más nuevas y por lo tanto más delgadas. Bajo los océanos se encuentra una zona de ruptura, por donde emerge constantemente nuevo magma (la parte líquida del manto, roca derretida), creando de esta manera una fila de volcanes submarinos. Estas son las zonas de ruptura conocidas como cordilleras meso-oceánicas, por encontrarse en medio de los océanos. Cuando este proceso tiene lugar debajo de una placa continental, el continente se parte en dos y nuevos continentes comienzan a separarse, formándose entre ellos un océano. A través del tiempo el océano va creciendo a una tasa de tres a doce centímetros por año y así los dos continentes se van separando más y más.

Cuando dos placas se chocan, una pasa debajo de la otra, creando una zona de terremotos muy severos. La placa se sumerge hasta 20 kilómetros de profundidad, tras lo cual comienza a derretirse; la parte más liviana y volátil ejerce presión hacia arriba, atravesando la placa superior, y esta emerge en la superficie, formando los volcanes más impredecibles y violentos. Este tipo de juntura de placas se conoce como zona de subducción. Estas zonas son muy importantes en términos económicos, ya que los líquidos del magma son ricos en metales preciosos como oro, plata, platino, estaño y cobre. Una típica zona de subducción es la del Océano Pacífico en el Ecuador. Allí la colisión entre dos placas ha presionado y engrosado la placa continental de Sur América formando la cordillera de los Andes, a la par que ha forzado la placa oceánica hacia abajo, creando una profunda fosa marina.

En zonas de subducción la placa oceánica siempre se hunde y desaparece; nunca llega a tener más de 200 millones de años. Pero la parte continental de la placa, que es más liviana, no puede hundirse, por el 
contrario, recibe más material y crece. Debido a esto llega a alcanzar una mayor antigüedad.

Otra forma de crecimiento de la placa continental ocurre cuando se añaden trozos de placas oceánicas a las que se llama terrenos exóticos. Un ejemplo típico se encuentra en Costa Rica y Panamá. Hace millones de años existía una serie de volcanes, similar a las actuales islas de Hawaii, dispersas sobre la Placa Cocos en el Pacífico. Al desplazarse la Placa Cocos hacia la Placa Caribe, los volcanes, uno a uno, llegaron hasta la zona de subducción localizada cerca de las costas de Costa Rica y Panamá. Estos grandes volcanes oceánicos no se hundieron en la zona de subducción y quedaron adheridos a la placa superior; ellos son hoy las penínsulas de Nicoya y Osa en Costa Rica y las de Burica y Azuero en Panamá. Estos trozos de la placa Cocos se originaron en latitudes muy distantes de los dos países y por esta razón se les llama terrenos exóticos.

Cuando dos placas oceánicas se encuentran en una zona de subducción, una se sumerge y se derrite bajo la otra. En estos casos la juntura se manifiesta como un arco de volcanes, tal como fue Panamá hace 6 millones de años.

El tercer tipo de juntura entre dos placas es conocido como Falla de Transformación. En este caso, las dos placas se deslizan una contra la otra. La fricción produce terremotos severos, pero como ninguna de las dos placas se hunde o se eleva no se forman ni montañas ni volcanes. La Falla de San Andrés, sobre la que se ubica la ciudad de San Francisco, en los EE.UU., es la más famosa de este tipo de junturas.

\section{La evolución geológica de Centroamérica.}

Si de esta manera funciona la tierra como un sistema, cabe suponer que en el pasado los continentes y los océanos, los volcanes y las montañas deben haber estado situados en lugares distintos a los que conocemos hoy.

Hace 170 millones de años, los continentes estaban unidos en forma de un "supercon-

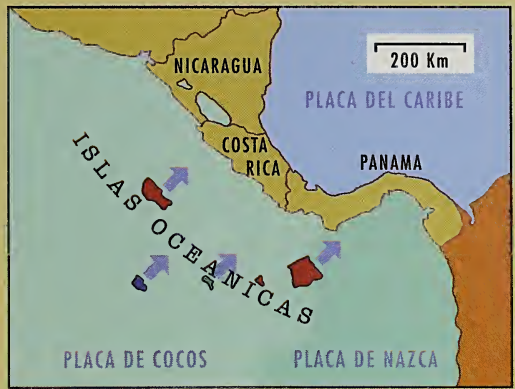

Varias islas que se formaron en la placa del Pacífico se fueron moviendo lentamente en dirección de la placa del Caribe.

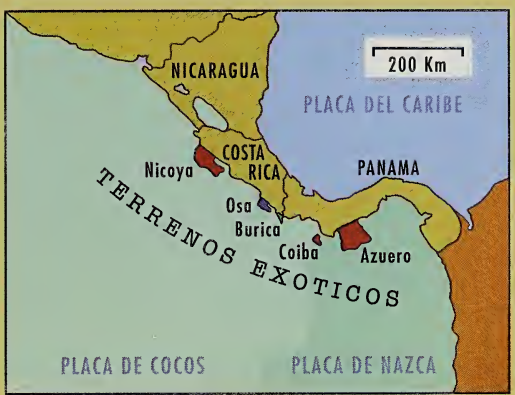

Al avanzar, las islas toparon con América Central, quedando adheridas al territorio en forma de penínsulas, puntas e islas.

tinente" que los geólogos denominan Pangea. Treinta millones de años más tarde, hace $\mathbf{1 4 0}$ millones de años, se formó una cordillera meso-oceánica que separó Norteamérica de Africa y Sur América, iniciándose al mismo tiempo la formación del Océano Atlántico norte. Para entonces Sur América y Africa aún se encontraban unidas. En la región de México, un terreno exótico da lugar a la formación de Guatemala, Honduras y Nicaragua.

Hace 80 millones de años el Océano Atlántico completó su formación, con la cordillera meso-oceánica y sus fallas de transformación incluidas. Entre el Océano Pacífico y las placas de Norte y Sur América, se encuentra una zona de subducción muy activa, pero entre ambos continentes, en la región de América Central y del futuro $\mathrm{Ca}$ ribe, existía corteza oceánica de ambos lados, y un arco volcánico dentro de la zona. 
Caribe hace contacto con la Placa Nazca; debido a que ambas placas se mueven en la misma dirección y a la misma velocidad, no tenemos formaciones volcánicas ni terremotos severos.

Hace 15 millones de años Panamá surgió como un archipiélago; hace 8 millones de años, este archipiélago se extendió hasta Sur América; 4 millones de años más tarde el istmo ya había emergido y solamente existian tres corredores marinos entre el Océano Pacífico y el Mar Caribe. Creemos que el istmo de Panamá separó el océano del mar hace tan solo 3 millones de años.

\section{Consecuencias del surgimiento del istmo}

Las consecuencias de este evento fueron dramáticas. En ese momento miles de animales cruzaron el istmo desde el sur hacia el norte y viceversa. El encuentro de la fauna de dos mundos que habían estado separados por millones de años fue un acontecimiento ecológicamente fascinante. Por ejemplo, el ave Titanis, un impresionante predador de 4 metros de altura, migró desde el sur del continente hacia los estados de Texas y la Florida en los EE.UU., acompañada por un armadillo gigante. También desde el sur cruzaron un oso perezoso gigante -de 6 metros de altura- junto con muchas otras especies exóticas. A pesar de que muchas especies del sur llegaron a Norteamérica, sólo tres existen hoy en día: la zarigüeya, los erizos y los armadillos. Muchas especies provenientes del norte se multiplicaron en América del Sur, cambiando notablemente la fauna del continente. Entre estos cabe mencionar animales como los felinos, venados, osos y tapires, y también otras especies ahora extintas, como los mastodontes, caballos y elefantes.

Los cambios causados por el surgimiento del istmo centroamericano en los océanos han sido aún más notables, afectando el clima del mundo.

Antes del surgimiento del istmo, la fuerte corriente ecuatorial del Atlántico fluía a través del Caribe, directamente al Pacífico. Al levantarse el istmo de Panamá esta corriente giró hacia el norte, convirtién-

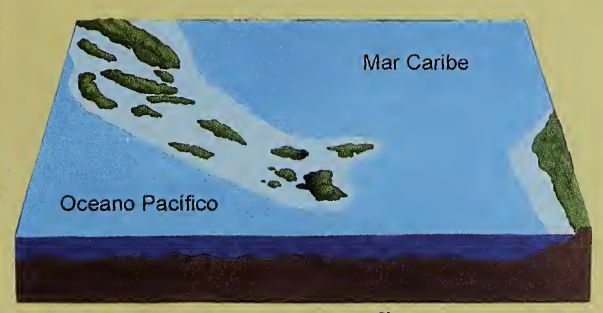

\section{MILLONES DE AÑOS ATRAS}

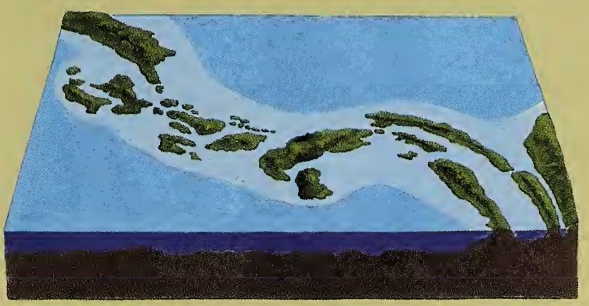

8 MILLONES DE AÑOS ATRAS

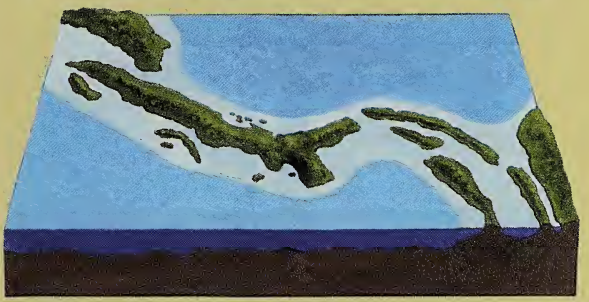

4 MILLONES DE AÑOS ATRAS

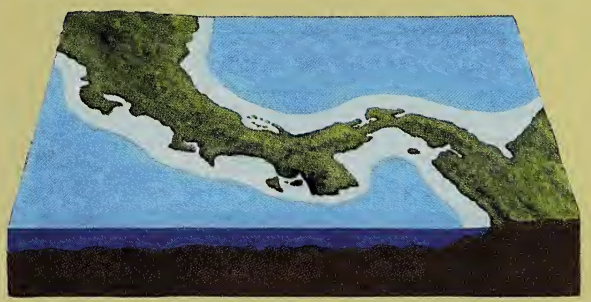

3 MILLONES DE AÑOS ATRAS

Antes del surgimiento del istmo, un estrecho de mar separaba a América del Norte y del Sur. Los territorios de América Central y el istmo de Panamá se formaron a partir de un archipiélago de islas de origen volcánico. A medida que los volcanes iban vertiendo más cantidades de lava y ceniza, las islas se iban fundiendo unas con otras, hasta formar un faja de tierra en forma de istmo. 


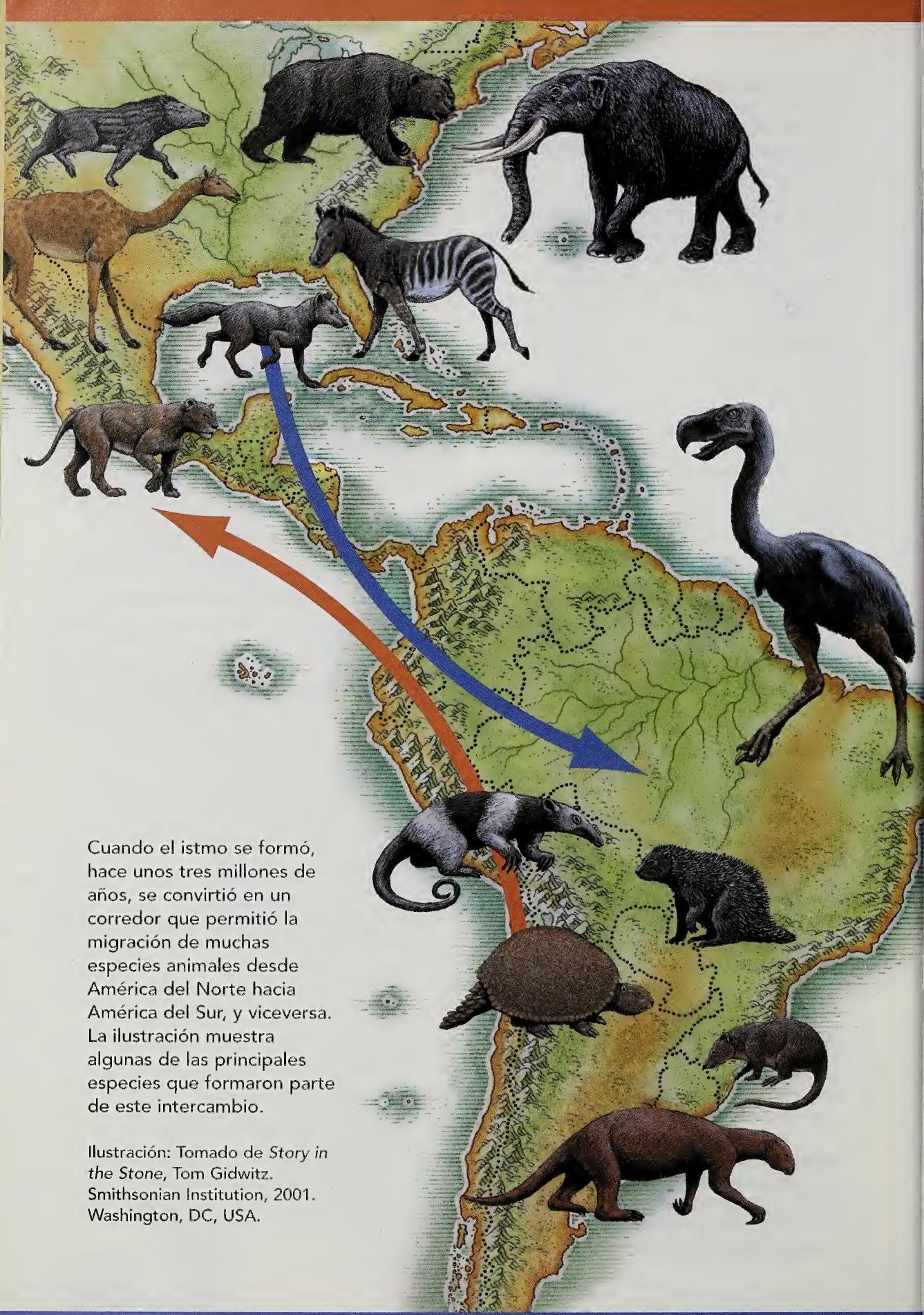


dose en lo que hoy conocemos como la Corriente del Golfo de Méjico. Esta corriente lleva agua caliente de los trópicos hasta las latitudes árticas. Sin las aguas calientes de la Corriente del Golfo, los puertos de Europa estarían congelados durante el invierno; de esta manera el levantamiento del istmo cambió totalmente el ambiente y la historia humana de Europa. Adicionalmente, la Corriente del Golfo proporcionó mayor humedad atmosférica, que al transformarse en nieve, dio lugar a los glaciares de las Edades Glaciares en los últimos dos millones de años.

El surgimiento del istmo ha cambiado las características de los océanos: el Caribe se convirtió en un mar cerrado, con poco movimiento de mareas y pobre en nutrientes. Como consecuencia el agua se volvió más caliente y salada, ideal para la formación de arrecifes coralinos. El Pacífico ha cambiado de manera más compleja; es más frío, menos salado, contiene muchos más nutrientes y pocos arrecifes coralinos.

En el Pacífico el surgimiento del istmo ha creado dos tipos de océanos, en relación a la circulación global de los vientos. Durante la estación lluviosa chocan dos grandes frentes de viento, produciendo lo que se conoce como zona de convergencia tropical (ZCT), es decir, cuando ambas masas de aire se encuentran, el aire asciende y se enfría, produciendo lluvias torrenciales pero muy poco viento.
En la estación seca la zona de convergencia tropical se mueve hacia el sur y toda América Central se encuentra bajo los efectos de fuertes vientos Alisios.

En las zonas más bajas del istmo los vientos Alisios desplazan el agua caliente de la superficie, causando que el agua fría del fondo, rica en nutrientes, ascienda a la superficie; a este fenómeno se le llama afloramiento y es muy notable en el Golfo de Panamá.

Las zonas de afloramiento de aguas frías son muy ricas cerca de la superficie del mar. Gracias a la energía del sol, estos nutrientes se convierten en una enorme cantidad de microplantas, que son una importantísima fuente de alimentación, y constituyen la base de una cadena alimenticia excepcionalmente rica. Por ello Panamá tiene hoy en día una vasta cantidad de peces, mariscos y aves marinas.

Hemos visto cómo el origen geológico de Panamá ha sido un fenómeno vinculado a cambios lentos pero inexorables; cómo estos eventos geológicos han causado cambios extraordinarios en los océanos y en el clima mundial; cómo estos cambios han tenido importantes efectos en la vida marina $\mathrm{y}$ terrestre, y en la vida humana.

Espero haberlos convencido de que la historia geológica de Panamá ha tenido un profundo impacto en nuestro mundo.
En las zonas de afloramiento, las aguas frías ascienden a la superficie, trayendo abundantes nutrientes del fondo del mar. Estas sustancias nutritivas son alimento importante para las microplantas, que constituyen la base de una cadena alimenticia excepcionalmente rica, que incluye una vasta cantidad de peces, mariscos y aves marinas.
Suroeste

Noreste

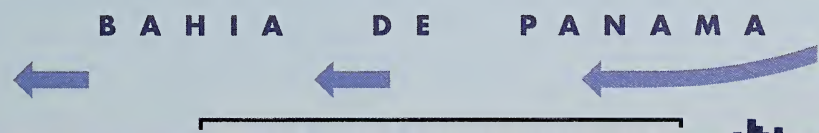

Nivel del mar ZONA DE AFLORAMIENTO CIUDAD $D E$ PANAMA
AGUAS DEL FONDO

DEL MAR RICAS EN NUTRIENTES EN NUTRIENTES 


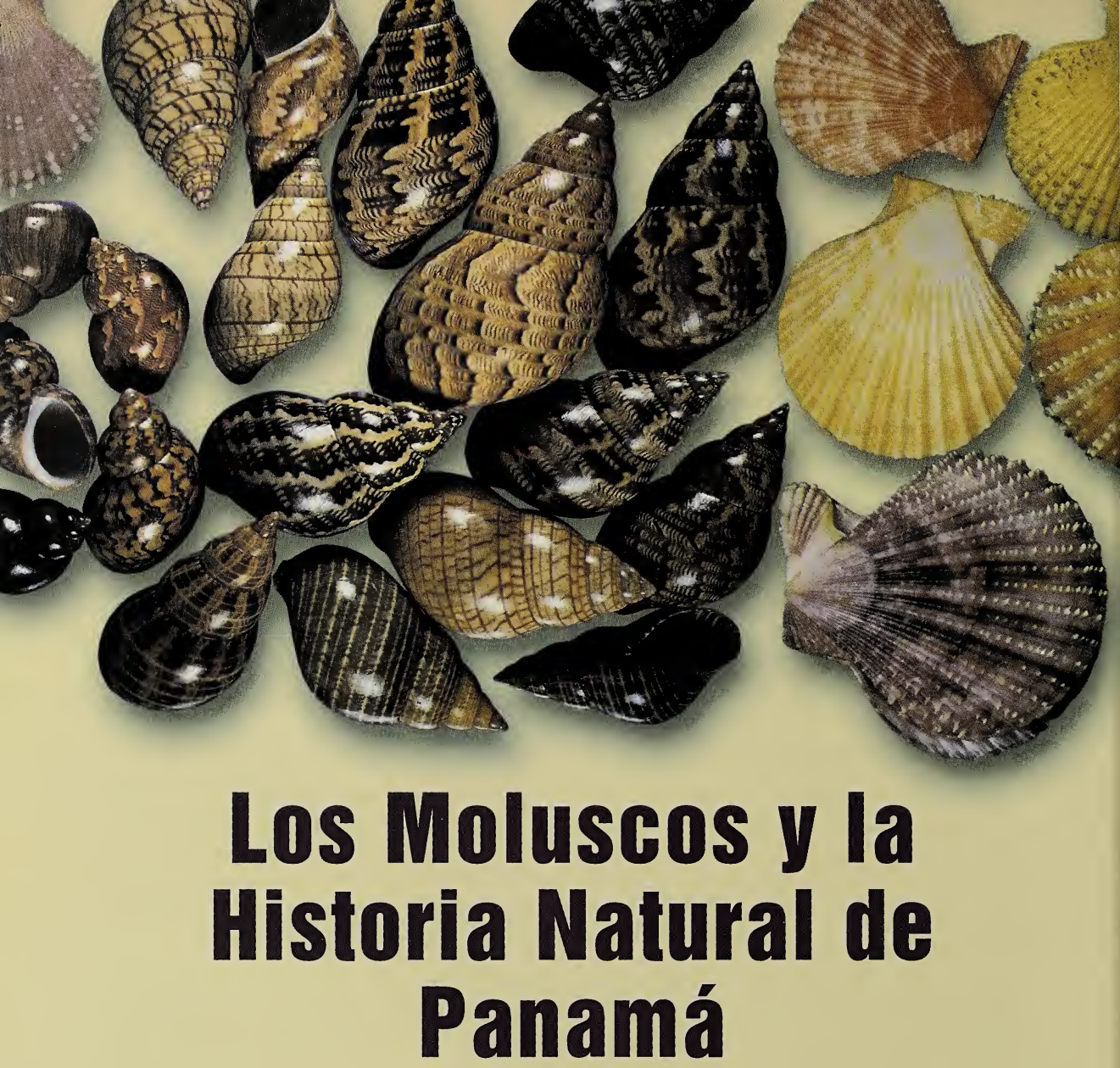

\section{Helena Fortunato}

¿Sabía usted que las conchas marinas pueden hablarnos de cómo era la Tierra hace millones de años? Ellas nos cuentan si el mar era cálido o frío, profundo o más seco, y qué animales y plantas vivían en sus aguas. En Panamá las conchas nos ayudan a reconstruir la historia natural del istmo.

Después de los insectos, los moluscos son los animales con mayor número de especies. Sus formas, colores y diseños son casi inimitables en la naturaleza. Aquí vemos ejemplos de caracoles y conchas. $A$ veces los colores avisan que el animal es venenoso, pero en realidad desconocemos el porque de tanto derroche de colores. 
$\mathrm{L}$ as conchas son regalos del mar. Todos las hemos colectado algún día y "oído el mar" dentro de ellas. Cautivados por su belleza e infinita variedad encontramos valiosas colecciones atesoradas en museos y en manos privadas. Muchas culturas las han utilizado como moneda, ornamentos, objetos de cultos religiosos y en ceremonias fúnebres. En las tumbas de los indígenas de Panamá y la América pre-colombina, es común encontrar collares de conchas, especialmente de la especie espondilus rosado (Spondylus americanus).

Después de los insectos los moluscos son los animales más comunes del planeta. Se han descrito más de 500,000 especies, fósiles y contemporáneas, de las cuales 100,000 viven en los mares del trópico. Para Panamá se conocen al menos unas 50,000 especies marinas y terrestres. Estas cifras, según dicen los malacólogos o estudiosos de los moluscos, seguramente aumentarán a medida que se realicen más inventarios biológicos.

No hay caos en esta asombrosa diversidad de los moluscos. Hasta los elementos que en ellos se repiten tienen su función. Nuestro sentido estético es atraído por la regularidad de un objeto que gradualmente aumenta de tamaño sin cambiar su forma, tal como la espiral de los caracoles. Los antiguos griegos la consideraban la forma más perfecta en el universo, llamándola "la proporción dorada”. ¡Para los an- tiguos naturalistas tan insuperable y hermosa regularidad sólo era atribuible al poder divino!

La mayoría de las investigaciones malacológicas en Panamá se han concentrado en moluscos fósiles que vivieron millones de años atrás. La razón principal para ello es que las excavaciones del Canal a principios del siglo $\mathrm{XX}$ revelaron una formación geológica llamada Gatún, extremadamente rica en esqueletos de moluscos que hace unos $\mathbf{1 0}$ millones de años habitaron los mares de lo que hoy es el Istmo de Panamá. Este hallazgo atrajo a famosos estudiosos del Instituto Smithsonian tales como Woodring y A. Olsson.

Los moluscos nos hablan del pasado de la Tierra, pues existen desde hace más de 300 millones de años, habiéndose adaptado, sobrevivido y diversificado mejor y durante más tiempo que la mayoría de los otros animales. Su historia permite documentar los posibles cambios que ha sufrido nuestro planeta. Y en Panamá utilizamos los moluscos para conocer mejor la historia natural del Istmo.

\section{Los tres grandes grupos de moluscos}

Los moluscos se dividen en tres grandes grupos, según su tipo de concha. Aquí se mencionan en orden de abundancia y diversidad. El primer grupo es el de los gasterópodos, cuyo nombre significa "estómago en el pie” (del griego gaster, estómago,

Artefactos de concha rosada hechos por indígenas pre-colombinos que habitaron en el Golfo de Parita, en el Pacífico. Los objetos, de un gran valor simbólico, prueban que existían relaciones entre las comunidades de ambas costas, pues la concha rosada es nativa al Caribe.
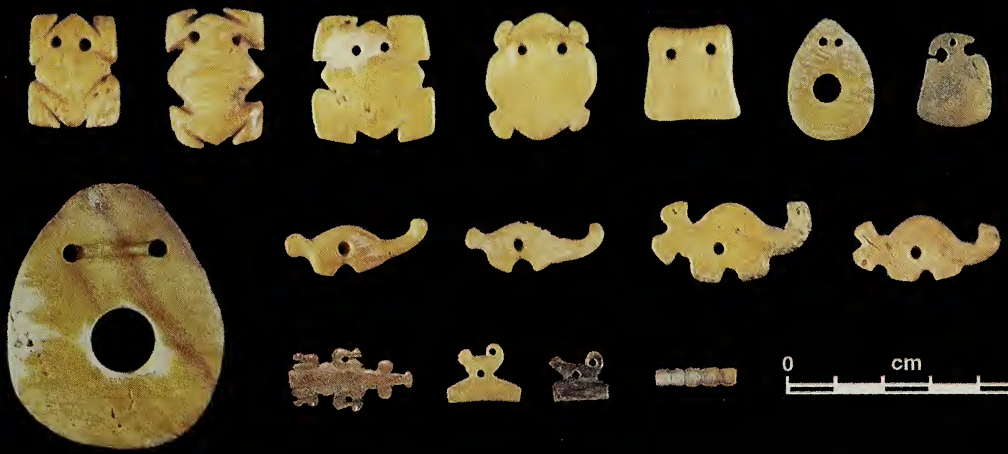
y podos, pie), compuestos por una sola concha; a este grupo pertenece la cambombia o cambute. El segundo grupo, los bivalvos, incluye a aquellas especies con dos conchas simétricas, como las almejas y mejillones. El tercer grupo es el de los cefalópodos, nombre que quiere decir "cerebro en el pie",(del griego kephale, cabeza, y podos, pie), que carecen de concha, como es el caso de los pulpos y calamares.
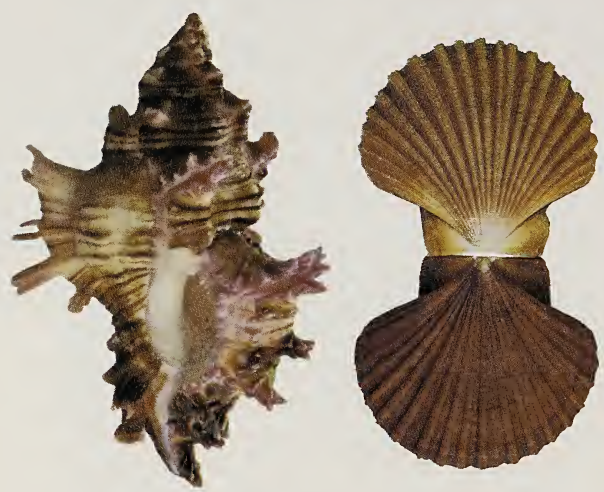

Un caracol y un bivalvo o concha. Los caracoles tienen una concha simétrica, mientras que los bivalvos, más primitivos, tienen dos tapas simétricas.

Tanta atención damos a la concha que olvidamos el animal que vive dentro de ella, y cuya anatomía es tan variada como la parte externa que admiramos. Su mayor característica es que la piel forma un manto o pliegue asemejando una bolsa que envuelve al animal por arriba y los costados. Este manto es el que forma la concha o esqueleto externo, segregando carbonato de calcio.

En la parte de abajo -o ventral- de su cuerpo, el caracol tiene un músculo duro llamado pie, que sale del manto y que usa para apoyarse y moverse. En la parte de- lantera tiene la boca y dos tentáculos con ojos. Dentro de la boca está la rádula, una larga banda de tejido muscular, o lengua, con dientes que usa para raspar o desgarrar el alimento. La lengua de algunos moluscos puede perforar la concha de sus presas.

Además de las diferencias externas, estos tres grupos también difieren en sus órganos internos. En la mayoría de los gasterópodos, el cuerpo está torcido y sus órganos son impares, contando con sólo una gónada, un riñón y una agalla. En el caso de las conchas, éstas carecen de cabeza, tentáculos y ojos, pero cuentan con órganos especializados como las papilas, sensibles a las sustancias químicas disueltas en el agua, así como pigmentos que responden a la luz. Estos órganos les permiten "sentir" $\mathrm{y}$ "ver" el ambiente que los rodea.

Los cefalópodos son el grupo con menor número de especies y el menos conocido; a él pertenecen lo pulpos y calamares, en torno a los cuales se han tejido leyendas terribles, dándoles una fama inmerecida de monstruos que salen de los abismos para atacar al hombre y las embarcaciones. Sin embargo, la realidad es otra: son criaturas muy inteligentes, con gran capacidad de aprendizaje. Usan sus tentáculos para manipular objetos; cambian de color, lo cual les sirve de camuflaje para escapar de sus enemigos; realizan danzas para cortejar a su pareja. Son los únicos moluscos que pueden moverse velozmente, propulsándose con chorros de agua. Poseen una cabeza y un cerebro relativamente grande y ojos desarrollados con excelente visión.

\section{Ecología y adaptación}

La mayoría de los moluscos habitan en los mares, pero son comunes en tierra, ríos, lagos y hasta en los charcos que quedan después de llover. La diferencia básica es que
Los pulpos y calamares perdieron su concha, pero han desarrollado mecanismos de defensa como el camuflage, los chorros de tinta y la velocidad.

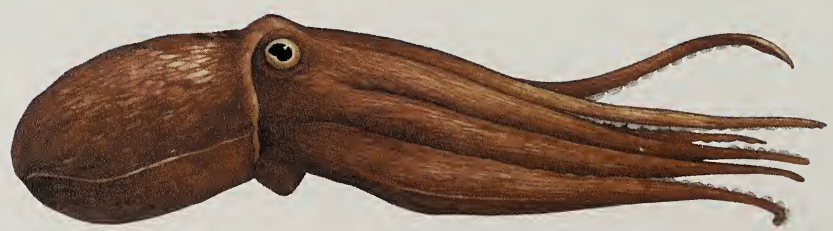




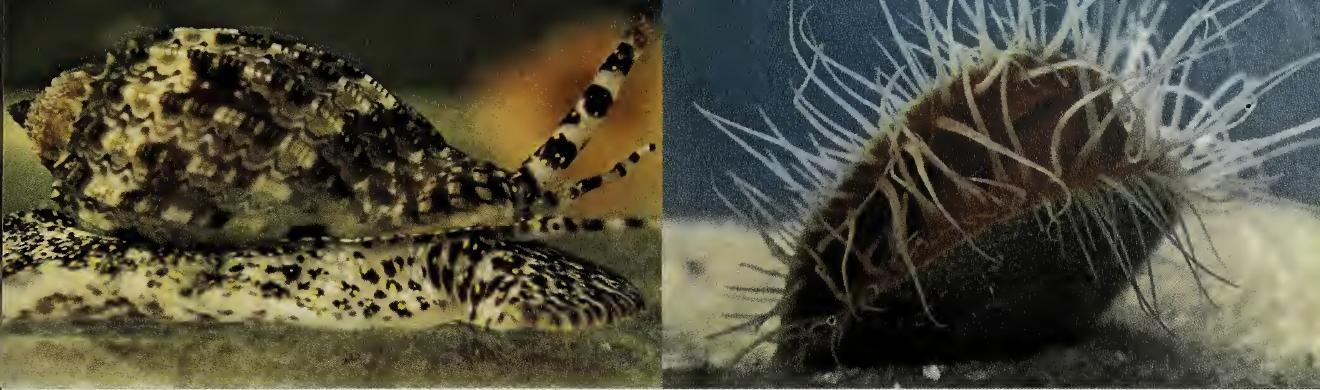

A la izquierda un caracol con su pie para movilizarse. Sobre la cabeza, tentáculos con ojos bien desarrollados. El animai dentro de esta concha que tanto admiramos, es su verdadero dueño.

A la derecha vemos una concha rojiza con pequeños tentáculos. Las conchas carecen de cabeza y ojos pero poseen sentidos táctiles y químicos muy desarrollados.

los del mar tienen agallas para respirar y los de tierra, pulmones.

Estos animales, numerosos y diversos, viven en todo tipo de regiones, desde las árticas hasta los trópicos. Muchos son costeros, habitando playas arenosas, rocosas y lodosas. En la marea baja quedan expuestos al aire y al sol. Otros habitan los abismos oceánicos, a más de 3,000 metros de profundidad.

Las distintas y hermosas formas y colores de los moluscos son producto de sus adaptaciones a diversos ambientes. Así, la concha Crepidula, conocida en español como "sombrerito chino", se especializó en vivir pegada a las rocas. Los caracoles muricidos o "pulludos" tienen una bella ornamentación que les sirve para protegerse. Otras especies han desarrollado "dientes" para perforar las conchas de los moluscos de los cuales se alimentan. Hay características de los moluscos que aparentan carecer de función, como los colores de las conchas que viven en el fango o los caracoles dorados de aguas profundas, cuyos colores jamás serán vistos. Posiblemente estos llamativos colores sirven para liberar venenos y toxinas, advirtiendo a sus enemigos que el caracol es venenoso.

Cuando un caracol habita los mares tropicales, ricos en calcio, desarrolla una concha fuerte y gruesa; si vive en las rocas, tiene protuberancias que le ayudan a estabilizarse boca abajo, a pesar del oleaje del mar. Al mismo tiempo, los ornamentos de su concha pueden servirle de defensa, y hacerlo más resistente a los enemigos.
Muchos organismos marinos, como las anémonas, corales y algas, usan las conchas de moluscos vivos o muertos como sitios para crecer. Ambos se benefician de esta relación. El animal huésped sirve de camuflaje al caracol y éste a su vez le ofrece una morada estable donde vivir.

\section{Reproducción y desarrollo}

Los moluscos se reproducen por medio de huevos. Unos ponen dos o tres, otros más de cien mil huevecillos. En su mayoría las especies marinas los depositan en lugares húmedos como rocas, arenas, algas y hasta en otras conchas. Las especies terrestres los colocan en la hojarasca y en plantas acuáticas y algunas especies mantienen los huevos dentro de su cuerpo.

Cuando los huevecillos se rompen se observan dos tipos de desarrollo, el indirecto y el directo. En el indirecto, las larvas con velo salen del huevo, nadando en el plancton marino y alimentándose de él. Las corrientes marinas las arrastran grandes distancias hasta que encuentran un sitio adecuado en donde se establecen, crecen y se transforman en adultos. En el proceso directo, el animal sale del huevo como una copia exacta en miniatura de sus padres.

\section{Una ventana al pasado del Istmo}

Hace apenas unos 10 años, se pensaba que Panamá había surgido del fondo de los mares rápida y recientemente, en una sola etapa. Hoy, gracias a los estudios de los fósiles de moluscos, corales y otros organismos marinos en las costas del Pacífico y 
de los árboles contando sus anillos. Por ejemplo, en las conchas de las almejas estos "anillos de crecimiento" indican la productividad del mar. Si durante su vida un animal tiene abundante alimento, crece rápidamente y sus anillos son anchos. Al contrario, si dispone de poca comida o si las temperaturas del mar bajan drásticamente, el animal deposita poco calcio en su concha y sus anillos son más delgados. Recordemos que el molusco construye su concha con el calcio disuelto en el agua marina y al bajar la temperatura, disminuye el calcio presente.

\section{Bocas del Toro como zona de refugio}

Aunque el Caribe se considera bajo en nutrientes, recientes hallazgos indican que las aguas de Bocas del Toro son una excepción, sirviendo como zona de refugio para especies que requieren aguas más ricas.

Un instrumento importante para la investigación del pasado y presente de los mares que rodean el Istmo, es el navío oceanográfico "Urraca" del STRI. Esta moderna embarcación permite realizar inventarios biológicos del fondo marino. Uno de los resultados más inesperados es el hallazgo en Bocas del Toro de especies de conchas consideradas extintas para el Caribe. Asimismo, la alta productividad de las aguas ha permitido que algunas especies recientes, mantengan las grandes dimensiones que tenían sus ancestros hace millones de años.

El estudioso de los moluscos está motivado por la curiosidad y el deseo de conocer cómo son y cómo viven estos seres, sin pensar mucho en las aplicaciones prácticas de este conocimiento. No obstante, el entender mejor las fascinantes historias de estos animales nos permite comprender mejor el pasado y quizás vislumbrar el futuro de nuestro planeta.

\footnotetext{
El R/ Urracá, barco de investigación oceanográfica del STRI, es único en la América Central. Fué construido en 1986 en Cowes, isla de Wight, Inglaterra. Es atendido por cinco tripulantes y puede acomodar hasta nueve científicos. Mide 96 pies de largo y 22 de ancho. En su cubierta de trabajo de popa tiene una grúa, cuyo cable permite hacer investigaciones casi hasta 1000 metros de profundidad. Cuenta con laboratorio, cuarto oscuro, compresores y botes de emergencia, así como un ROV (Remote Operated Vehicle), un minisubmarino no tripulado, capaz de tomar fotos hasta 400 pies de profundidad.
} 


\section{Peges de Agua Duloe de Panamá}

Eldredge Bermingham, Vijay Aswani, Ascanio Castillo y Rigoberto González

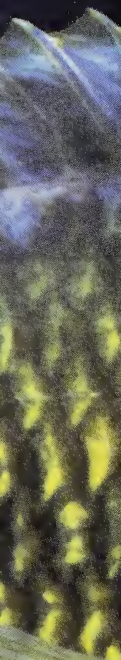


$\mathrm{E}$ n los últimos 6 millones de años ha ocurrido un extenso intercambio de plantas y animales de Norte y Sudamérica, usando como puente de tierra el istmo de Panamá. Este extraordinario fenómeno, llamado el Gran Intercambio Biológico de las Américas, es importante para entender la distribución actual, o la biogeografía de las especies del Nuevo Mundo.

La migración de los mamíferos de un continente a otro ha sido relativamente fácil, porque son animales de sangre caliente y esto les facilita poblar regiones con diferentes climas. Los estudios más célebres, instructivos y detallados sobre el intercambio de la fauna del Nuevo Mundo se han concentrado en los mamíferos, cuyo registro fósil también es mejor. Para los peces, emigrar de los trópicos hacia las zonas templadas y viceversa, ha sido más difícil, porque tienen sangre fría y los cam bios en la temperatura del agua pueden constituir una barrera formidable.

Para entender cómo, cuándo y dónde migraron los peces debemos estudiar su distribución en el tiempo y el espacio desde hace millones de años hasta el presente. Los pocos estudios realizados sobre su distribución indican, básicamente, que este intercambio ha sido en una dirección, de la América del Sur hacia Centro América. Ello es así porque el Amazonas, con más de 5000 especies conocidas, tiene la fauna de peces de agua dulce más rica del mundo. Panamá tiene 200, el mayor número de especies en América Central.

\section{Los ríos como vías de colonización}

Para migrar de una región a otra, los peces de agua dulce usan como vías las cuencas hidrográficas de los ríos. Las historias de las relaciones entre las distintas redes de ríos puede descifrarse estudiando la historia geológica y de los ríos. Combinar la historia de los paisajes y de las especies que los habitan puede ayudarnos a explicar las diferencias en la diversidad de especies entre las regiones. $\mathrm{El}$ análisis biogeográfico de la historia de los peces de agua dulce nos permite entender mejor la evolución geológica y de las especies del Istmo de $\mathrm{Pa}$ namá. Así, ríos que antes pertenecían a una sola red hidrográfica pueden quedar separados al surgir montañas, tal como sugiere la evidencia en el Valle de Antón.

Para muchas especies, la migración es un proceso lento y complicado. No todas pueden viajar o colonizar una región a la misma velocidad. Muchas especies sudamericanas no han llegado a Panamá, habiéndose quedado en el camino. Otras han arribado, pero no han continuado su viaje al norte, aunque algunas llegaron hasta Centroamérica. Panamá es pobre en cuanto a su fauna de peces amazónicos, pero es más rico que los otros países centroamericanos.

Los peces periféricos como la "guabina" Gobiomorus, ilustrada aquí, suelen pasar parte de su vida en agua dulce y la otra en agua salada. En Panamá existe una especie de guabina en el Pacífico y otra en el Caribe, siendo la especie caribeña la que alcanza un tamaño mayor. A ambas especies les gusta vivir en los fondos arenosos o pedregosos de los ríos y quebradas, donde permanecen casi inmóviles y mimetizadas, acechando a sus presas. Se alimentan principalmente de crustáceos y peces, así como insectos acuáticos y terrestres. Su carne posee un excelente sabor y calidad por lo que es muy apreciada. 

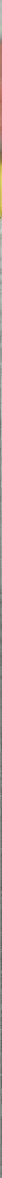

CUADRO 1

\begin{tabular}{|c|c|c|c|c|c|c|c|c|c|c|}
\hline $\begin{array}{l}\text { Peces de } \\
\text { la División } \\
\text { Primaria } \\
\text { ORDEN }\end{array}$ & 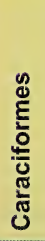 & 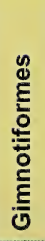 & 孪 & $\begin{array}{l}\overline{\mathbb{I}} \\
\text { 。 }\end{array}$ & $\begin{array}{l}\text { Peces de } \\
\text { la División } \\
\text { Secundaria }\end{array}$ & 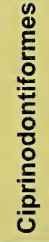 & 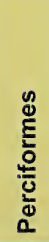 & 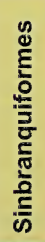 & $\begin{array}{l}\text { त्ञ } \\
\text { 잉 }\end{array}$ & $\begin{array}{l}\frac{\bar{J}}{\circ} \\
\frac{5}{\pi} \\
\frac{5}{0}\end{array}$ \\
\hline $\mathrm{CHOCO}$ & 81 & 6 & 60 & 147 & & 9 & 7 & 1 & 17 & 164 \\
\hline BAHIA & 30 & 5 & 27 & 62 & & 18 & 7 & 1 & 26 & 88 \\
\hline CHAGRES & 18 & 1 & 13 & 32 & & 7 & 4 & 1 & 12 & 44 \\
\hline CHIRIQUI & 17 & 2 & 8 & 27 & & 15 & 7 & 1 & 23 & 50 \\
\hline SAN BLAS & 14 & 1 & 11 & 26 & & 5 & 4 & 1 & 10 & 36 \\
\hline BOCAS & 9 & 2 & 3 & 14 & & 12 & 12 & 1 & 25 & 39 \\
\hline CR-ATL & 9 & 2 & 3 & 14 & & 16 & 15 & 1 & 32 & 46 \\
\hline CR-PAC & 8 & 2 & 3 & 13 & & 14 & 10 & 1 & 25 & 38 \\
\hline
\end{tabular}




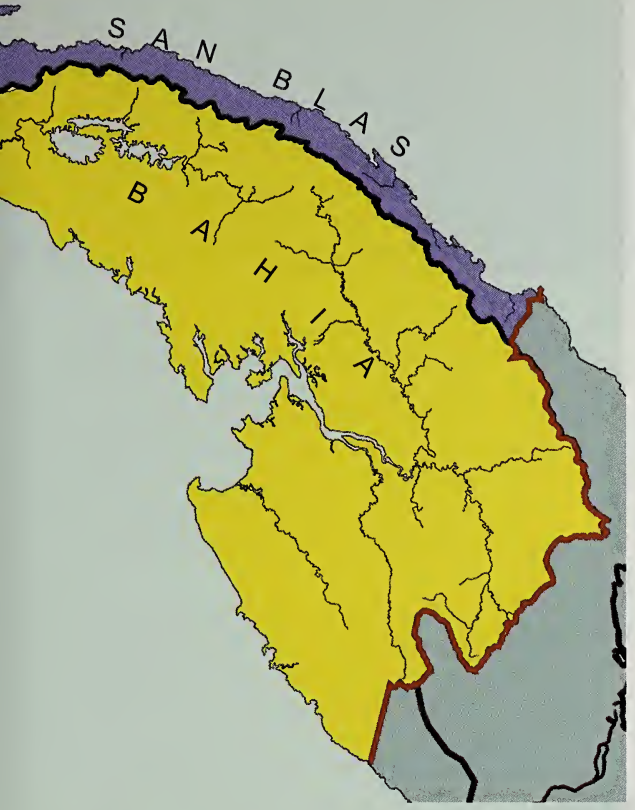

Izquierda: En la gráfica se compara el número de especies pertenecientes a los órdenes o grupos (caraciformes, silurformes, gimnotiformes y otros), en las cinco regiones biogeográficas de Panamá.

Cuadro 1: número de especies de peces de agua dulce (primarios y secundarios) de las principales regiones biogeográficas de Panamá, la región del Chocó (Colombia) y las zonas caribeñas (CR-ATL) y Pacífica (CR-PAC) de Costa Rica. Se observa la superioridad numérica del Chocó sobre las demás regiones del Istmo Centroamericano.

Cuadro 2: número total de especies primarias y secundarias presentes en Colombia y Costa Rica, en comparación con Panamá. Aquí se observa claramente el dominio numérico del elemento sudamericano, representado por Colombia, y la disminución en el número de especies a medida que se avanza hacia la América Central.

\section{CUADRO 2}

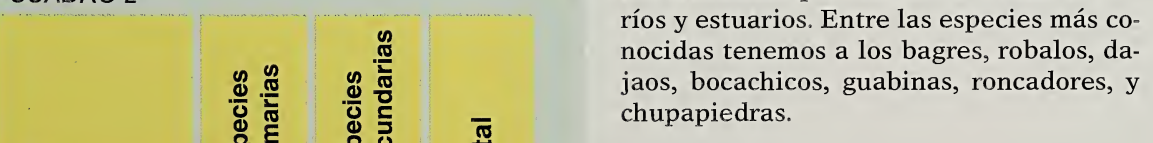

\section{Ríos y embalses}

Por ser un país tropical y lluvioso, Panamá posee muchísimos ríos y quebradas. Pero 

debido a su geografía angosta y precipitada, estos ríos son cortos y con bastante gradiente o declive. Los mayores sistemas hidrográficos, el Tuira-Chucunaque y Bayano, están en la región oriental cerca de la frontera con Colombia y América del Sur.

A diferencia de Nicaragua y Guatemala, que tienen grandes lagos y lagunas, muchas de origen volcánico, Panamá sólo cuenta con dos pequeñas lagunas naturales, una en el Volcán de Chiriquí y otra en La Yeguada, viejo volcán ubicado en las montañas de Veraguas.

En el siglo XX el hombre ha cambiado sustancialmente el paisaje istmeño. La construcción del canal y varias hidroeléctricas han creado numerosos embalses, entre los que destacan los lagos Gatún $\left(450 \mathrm{~km}^{2}\right)$, Alhajuela $\left(45 \mathrm{~km}^{2}\right)$ y Bayano $\left(350 \mathrm{~km}^{2}\right)$.
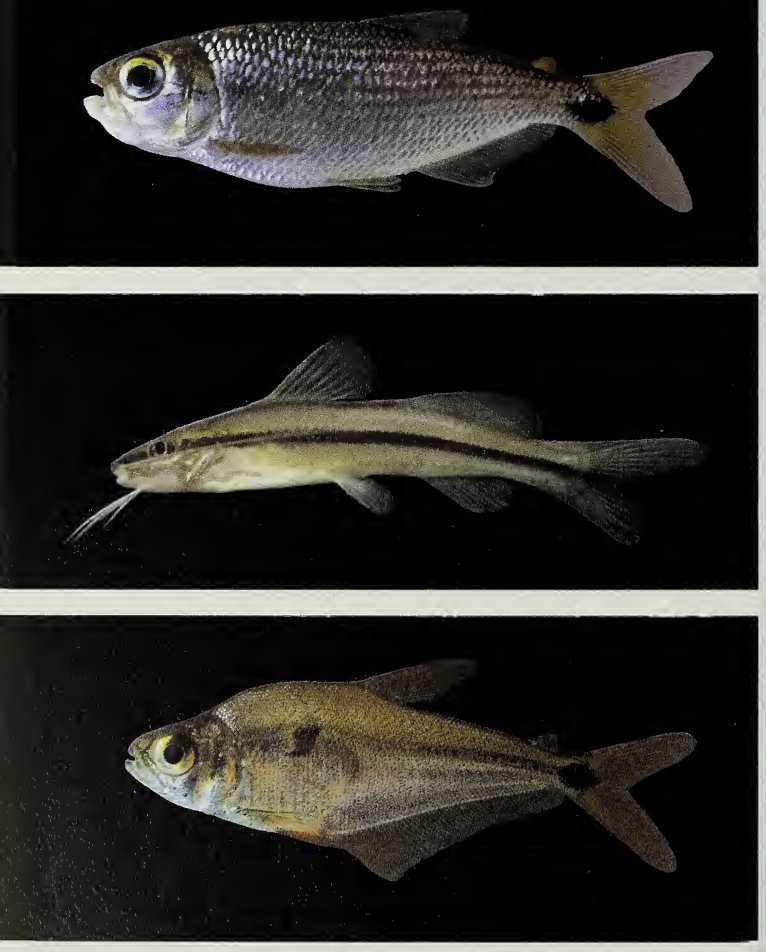

Izquierda, arriba: El género Brycon es otro representante del grupo de los caraciformes. Conocidos comúnmente como "sábalos" o "sábalos pipones", habitan ríos, quebradas y reservorios de aguas transparentes en ambas vertientes del Istmo panameño. Su alimentación es omnivora, con preferencia de insectos terrestres, acuáticos y materia vegetal. Se ha comprobado que desempeñan un papel en la dispersión de semillas de plantas como el Ficus. Muchas especies de sábalos poseen importancia económica y alimenticia para los pobladores de los ríos y embalses panameños.

Izquierda, centro: Los siluriformes, conformados por los peces gatos acorazados y aquellos desnudos o carentes de escamas, representan el segundo mayor grupo entre los peces primarios. El Pimelodella es un bagrecito que suele encontrarse en grupos o solitario, en los fondos arenosos o pedregosos de arroyos cristalinos. Entre las características distintivas de este barbudo están las bandas negras que corren en sus costados y las glándulas venenosas en la base de las aletas pectorales, las cuales pueden causar heridas dolorosas. Contrario a lo que se pensaba, los datos genéticos indican que en Panamá existe más de una especie en este género.

Izquierda, abajo: Los caraciformes representan unos de los tres grupos principales de peces primarios en el Neotrópico. Por lo general son peces pequeños y plateados localmente conocidos como "sardinas". La sardina ilustrada aquí pertenece al género Roeboides, la cual se alimenta de escamas de otros peces. Se piensa que el Roeboides colonizó América Central mucho antes que se completara el puente terrestre de Panamá, pero los datos genéticos sugieren que este pez arribó a Centro América inmediatamente después que el corredor terrestre se completara, hace 3 millones de años. 
En estos embalses viven especies nativas como pejeperros, robalos y sábalos. También se han propagado especies exóticas, introducidas recientemente, como el sargento, tilapia y colosoma, que son muy populares entre pescadores y consumidores.

\section{Genealogías y migraciones}

Para determinar la historia de los peces de agua dulce de Panamá que han participado en el gran intercambio de las especies americanas utilizamos nuevos métodos genéticos. Conceptualmente, estos asemejan a los usados para establecer un árbol genealógico familiar, salvo que los árboles de relaciones que intentamos establecer para las especies de peces, en vez de abarcar cientos de años, como en las genealogías de familias humanas, se extienden millones de años en el pasado.

También debemos prestar suma atención a la distribución de cada especie, por ejemplo, si es abundante en todo el país o sólo en Darién, Veraguas o Chiriquí. Para los peces de Panamá empleamos marcadores genéticos, como la secuencia del $A D N$, a fin de determinar las relaciones entre las especies. Ello nos permite encon. trar nuevas especies que, debido a la semejanza existente entre ellas, son difíciles de diferenciar por su cuerpo. No obstante, pueden distinguirse por medio de sus genes. Un ejemplo de esto es el caso de Pimelodella chagresi, un barbudo colectado en todo el país, salvo en Bocas del Toro, el cual se pensaba era una sola especie. Sin embargo, los métodos genéticos permitieron precisar que en realidad se trata de diez especies diferentes. Una vez que se ha identificado estos diez distintos linajes de Pimelodella, su distribución geográfica y las relaciones entre estos linajes nos permite analizar cómo este pez se ha dispersado por el país. Esto se ha hecho con todos los peces que hemos estudiado.
Los gimnotiformes, representados aqui por el Brachypopomus, son el tercer mayor grupo en la división primaria de peces neotropicales. Estos gỉmnotiformes, comúnmente conocidos como "cabuyas", son de hábitos nocturnos, y poseen órganos especializados que producen un campo eléctrico que les permite localizar sus presas y parejas. En este grupo se incluye la anguila eléctrica del Amazonas, capaz de generar descargas eléctricas que pueden inmovilizar a un hombre.

Cada especie cuenta un relato algo distinto sobre la historia ictiológica de Panamá. Sin embargo, tomados en conjunto, ofrecen una narrativa coherente para entender la biodiversidad de los peces del Istmo.

\section{Cuándo y cómo llegaron los peces a los ríos}

Los ríos son un marco excelente para esta historia biogeográfica, pues ellos son los equivalentes terrestres de las islas oceánicas, tales como las Galápagos de Darwin, que han tenido un gran papel en nuestra comprensión del surgimiento y evolución de las especies.

Por ello, nuestro estudio de la distribución de los peces a lo largo de los ríos de Panamá nos permite describir el proceso de colonización y cómo ha influido en las diferencias entre las regiones y la formación de nuevas especies.

Nuestros estudios muestran, por ejemplo, que muchos ríos de Panamá fueron colonizados en un período de corto tiempo, poco después del surgimiento del Istmo, hace unos tres millones de años. Asimismo, que hubo al menos tres distintas oleadas migratorias de peces, que fueron la fuente de poblamiento al noroeste de Colombia, esto es, la región del Chocó. 
Con cada oleada colonizadora la escala de dispersión geográfica de los linajes se hizo progresivamente más limitada. Así, muchos peces de la primera ola atravesaron Panamá hasta Costa Rica y en ciertos casos llegaron hasta Chiapas, México. La mayoría de los de la segunda migración, luego de recorrer parte de Panamá, no llegaron a Costa Rica. Finalmente, la mayoría de los peces de la tercera ola sólo se encuentran al este de Panamá y en los ríos que desaguan a la Bahía de Panamá. Éstos diversos patrones de poblamiento son atribuibles a los cambios continuos en la geografía panameña, con su formación de montañas y el consiguiente aumento en el aislamiento de las cuencas hidrográficas.

La formación de montañas y el aumento de su tamaño reduce las probabilidades de que los peces puedan moverse de un sistema de drenaje a otro.
Una conclusión importante de nuestros estudios sobre la genética de los peces de agua dulce, es que la formación de una comunidad de peces en una red hidrográfica es un proceso complejo. Para entenderlo hay que estudiar las relaciones ecológicas entre las distintas especies del río y la historia de la migración de cada especie. Para entender cómo se forma una comunidad de peces y cómo se mantiene en el tiempo, se requiere de una visión histórica. Al considerar la ecología de un río debemos tomar en cuenta no sólo los procesos locales, sino también los que se han dado en toda la región. También sugieren nuestros resultados que las comunidades de peces de agua dulce que han habitado los ríos de Panamá no son sistemas locales, con un equilibrio cerrado, sino más bien de sistemas abiertos, dinámicos, sujetos a episodios de invasión como también de extinción de especies.

El Aequidens, pez cíclido conocido popularmente como "chogorro", pertenece a la división secundaria de peces de agua dulce, capaces de dispersarse en condiciones de alguna salinidad. En comparación con los peces primarios, la distribución geográfica de los peces secundarios no refleja tan fielmente el desarrollo geográfico del paisaje panameño. El chogorro es el cíclido más abundante en Panamá, y con excepción de Bocas del Toro, se le encuentra en todos los ríos del país. Otros peces de la familia Cichlidae, son muy populares en los acuarios de agua dulce.

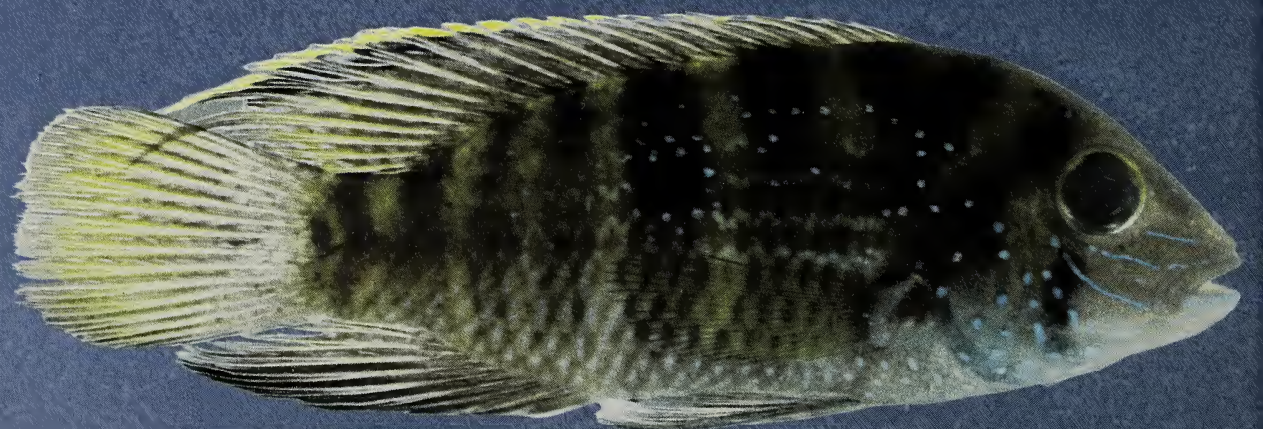




\section{Arrecifes y peces de la costa pacífica}

panameña: una región biológica
única

Ross Robertson

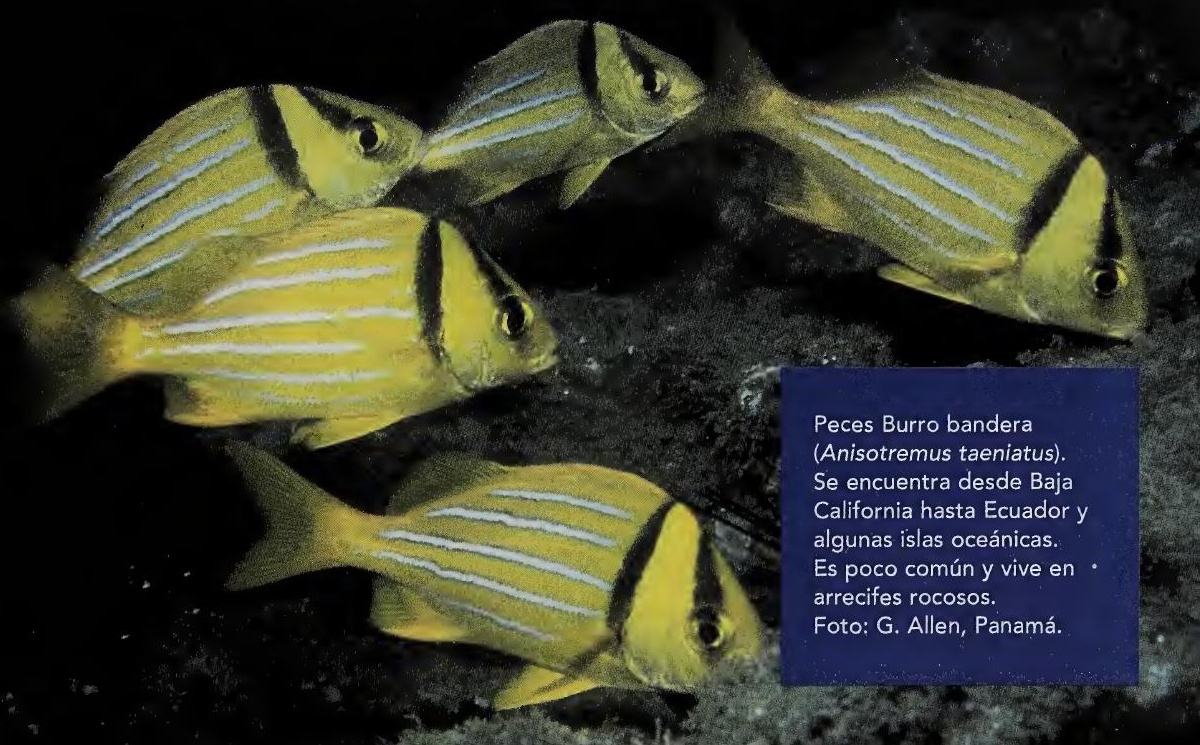




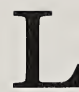

os arrecifes de coral son ecosistemas marinos que proveen habitats para muchísimas plantas y animales. Por su gran biodiversidad frecuentemente se les compara con las selvas tropicales. Al observar la gran variedad de peces que viven $\mathrm{y}$ se alimentan de los corales, las personas piensan que esta multiplicidad está íntimamente unida o depende de la existencia de los arrecifes que construyen los corales. Dicho de otra forma, que arrecifes y peces han evolucionado conjuntamente.

Debido a que los arrecifes coralinos han existido por casi doscientos millones de años y que los grupos de peces modernos evolucionaron bastante después, pareciera sensato asumir que la existencia de estos peces depende íntimamente de los corales. Un ejemplo es el grupo compuesto por los brillantes peces mariposa, muchos de los cuales sólo se alimentan del coral vivo.

El propósito de la investigación sobre la cual se basa este artículo es preguntarnos si, en efecto, la existencia de los peces considerados como típicos de los arrecifes coralinos realmente depende de estos ecosistemas y si ambos han evolucionado armónicamente.
Para ello utilizaremos la composición de la fauna de peces de arrecifes, contrastando la variedad de familias de peces entre dos grandes regiones marinas. Una, abundante en arrecifes de coral, la otra, predominante con arrecifes rocosos. Compararemos a las familias más comunes, esto es, aquellos grupos de especies que guardan mucha cercanía entre sí y que representan a los peces del arrecife de coral. Entre estos grupos están los peces mariposa, los peces loro, meros y damiselas.

Para que nuestra comparación sea válida debemos seleccionar cuidadosamente las áreas a cotejarse. Para no sesgar los resultados, contrastaremos áreas cuyas historias evolucionarias no sean tan diferentes, sujetas a toda una gama de procesos a lo largo de grandes períodos de tiempo y que hayan podido alterar la estructura de sus faunas permitiendo, por ejemplo, que ciertas familias de peces se hubiesen extinguido, mientras que otras florecieron y

Cardumen de pargos azules dorados (Lutjanus viridis). Se les encuentra desde Baja California y el Golfo de California hasta Ecuador, las islas Galápagos y otras islas oceánicas. Vive en arrecifes rocosos o de coral. Foto: G. Allen, Islas Galápagos.

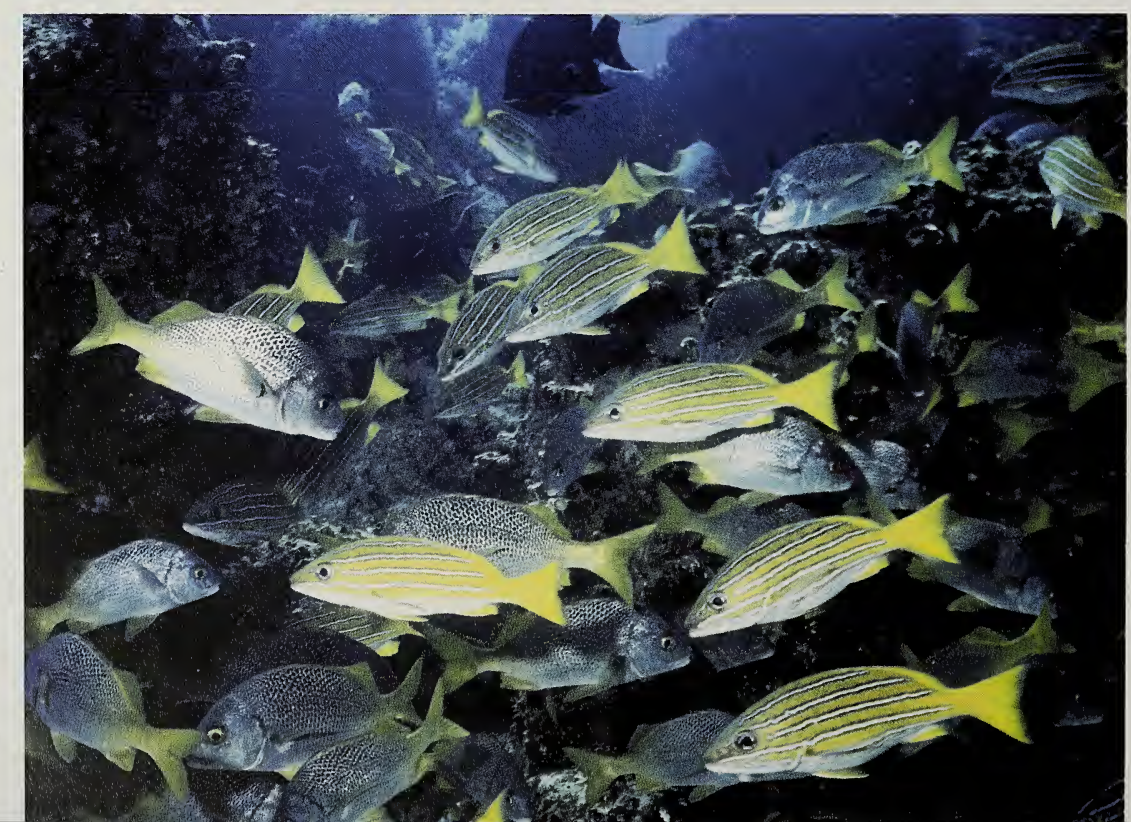


produjeron muchas especies. Lo ideal sería comparar dos regiones que hasta hace poco compartían una historia común, y cuyas faunas comenzaron después a evolucionar por separado.

De hecho, en el mundo sólo es posible encontrar dos grandes regiones marinas que pueden equipararse y que en el pasado geológico reciente fueron lanzadas en trayectorias evolucionarias muy distintas: son las costas del istmo centroamericano.

\section{Arrecifes coralinos y rocosos}

En los mares tropicales la mayoría de los arrecifes han sido formados por corales, animalitos microscópicos semejantes a una anémona, que con la ayuda de plantas simbióticas, forman un esqueleto que gradualmente va construyendo la gran estructura del arrecife. Este lento crecimiento orgánico es el que construye la estructura física completa del arrecife coralino, el habitat que luego es ocupado por los peces. Aunque en los trópicos son raras las áreas que no tienen arrecifes coralinos, en la costa pacífica de Panamá y Centroamérica son muy escasos.

En contraste con los arrecifes coralinos, los arrecifes rocosos tienen como base una roca recubierta por una capa delgada de organismos como plantas, esponjas y colonias aisladas de corales. Además de ser raros, han aparentado ser biológicamente menos interesantes, por lo que son poco visitados incluso por los estudiosos de arrecifes de coral.

Veamos ahora por qué nuestra costa pacífica es tan pobre en arrecifes de coral.

\section{El surgimiento del istmo y los arrecifes}

El surgimiento del Istmo de Centroamérica, hace sólo 3 millones de años, separó dos grandes regiones marinas que solían estar unidas: el Caribe y la costa pacífica de América llamada por los científicos marinos el Pacífico Oriental Tropical. Se extiende esta última desde el Golfo de California hasta el norte de Perú e incluye la costa de tierra firme e islas alejadas como las de Revillagigedos, de México, la Isla
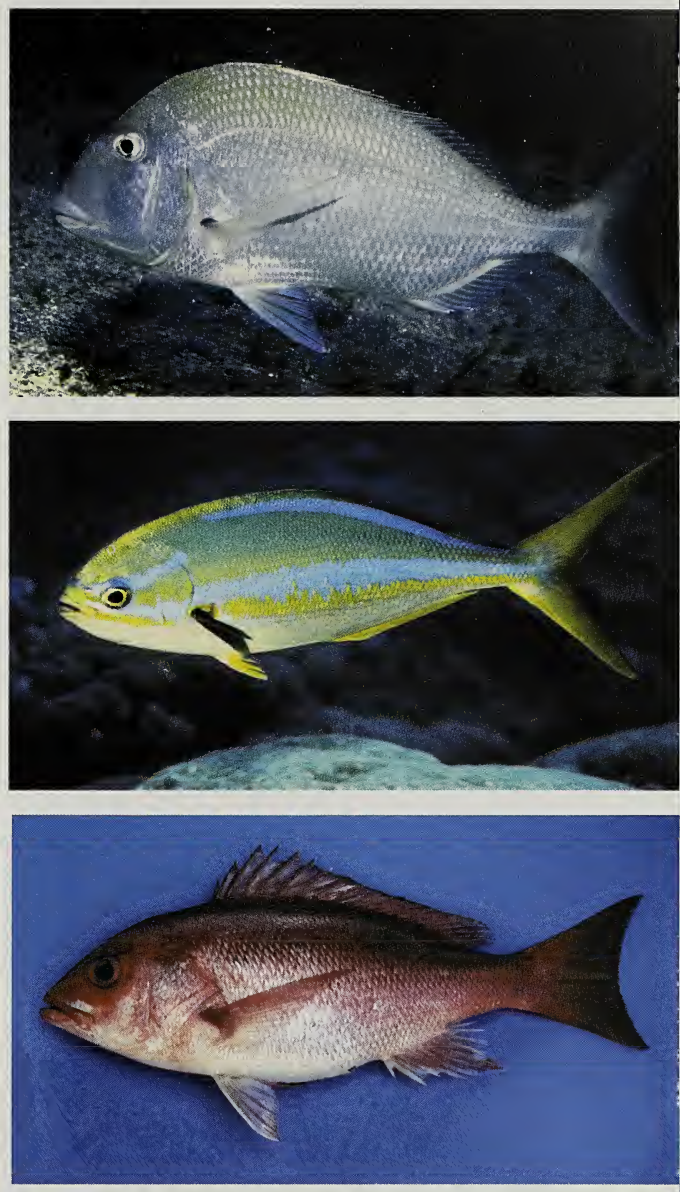

Arriba: Pargo chaveco (Calamus brachysomus). Habita el Pacífico desde Baja California hasta Perú. Regularmente se observa en aguas claras, sobre fondos planos arenosos. Foto: G. Allen, México.

Al centro: Chopa salema (Sectator ocyurus). Se encuentra desde Baja California hasta Perú y en las islas oceánicas, así como en varios sitios del Pacifico central.

Foto: G. Allen, Isla de Clipperton.

Abajo: Pargo de seda (Lutjanus peru). Se distribuye desde el Golfo de California hasta Perú y la isla de Malpelo. Vive en aguas abiertas, hasta 90 metros de profundidad. Foto: D. R. Robertson, Panamá. 

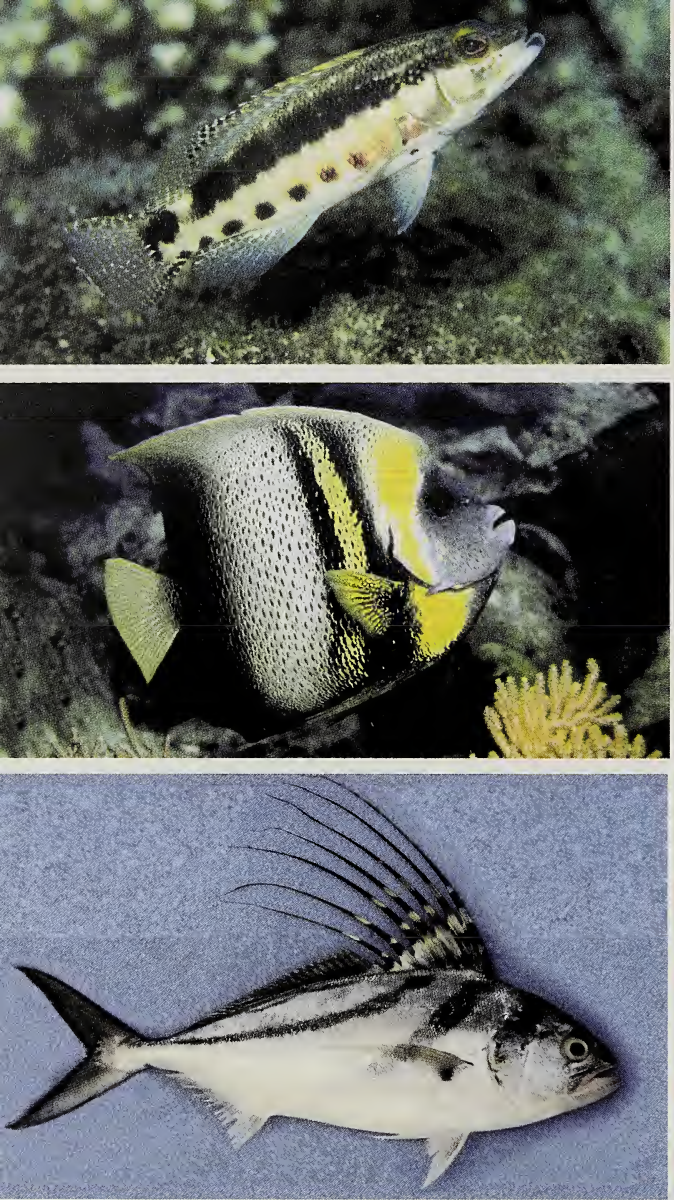

Serrano rayado (Serranus psittacinus).

Lo encontramos desde el Golfo de California hasta Perú y las islas Galápagos. Vive en pequeños parches de arrecife o en afloramientos rocosos en áreas de arena y piedra, entre 2 y 60 metros de profundidad. Foto: R. Steene, Panamá.

Ángel de Cortes (Pomacanthus zonipectus). Distribuído desde el Golfo de California a Perú, incluye las Galápagos y otras islas oceánicas. Vive solitario o en parejas en arrecifes rocosos. Foto: G. Allen, México.

Peje gallo (Nematistius pectoralis). Especie distribuída desde el Golfo de California hasta Perú, las islas Galápagos y la isla de Malpelo. Habita en costas arenosas y ocasionalmente en esteros; es una especie favorita para la pesca deportiva. Foto: D. R. Robertson, Panamá. del Coco, de Costa Rica, y las Galápagos de Ecuador.

Toda la costa pacífica tropical de nuestra región es casi única para los trópicos, pues cuenta con muchas costas rocosas y poquísimos arrecifes coralinos. A lo largo de este vasto litoral apenas existen 25 kilómetros cuadrados de arrecifes coralinos. $\mathrm{Su}$ mayor y único atolón coralino es la islita de Clipperton, de 4 kilómetros cuadrados, ubicada a 2700 kilómetros al oeste de $\mathrm{Pa}$ namá. En tierra firme el mayor arrecife tiene 1 kilómetro cuadrado y está en isla Coiba, Golfo de Chiriquí, Panamá. De hecho, Panamá tiene los arrecifes mejor desarrollados de la costa continental del Pacífico Oriental Tropical.

\section{El Niño y los corales}

Mientras el Caribe abunda en arrecifes coralinos, con miles de kilómetros cuadrados, ellos escasean en la cercana costa pacífica. Esta carestía obedece al enorme estrés que con regularidad sufren los corales dado a los fuertes cambios ambientales y el calentamiento del agua que trae la Corriente de El Niño. Este evento, que ocurre a intervalos de 4 a 9 años, provoca gran mortalidad entre los corales, impidiendo el surgimiento de extensas formaciones coralinas. La mayoría de los arrecifes coralinos de nuestro lado pacífico dejó de existir hace mucho tiempo, luego del surgimiento del istmo.

En las aguas tropicales de nuestra región pacífica encontramos 41 especies de corales. Sólo la cuarta parte de estas especies son endémicas, las otras tres cuartas partes son inmigrantes o descendientes de inmigrantes provenientes del pacífico central, desde islas como Hawai y la Polinesia Francesa. Sólo $7.3 \%$ de las especies de corales de nuestras aguas pacíficas pueden trazar sus ancestros a individuos que estaban aquí antes de que surgiese Centroamérica.

Aunque en años recientes los arrecifes del Caribe y de todo el mundo están siendo sometidos a mayor estrés dado el creciente calentamiento del mar, esta presión no ha 
impedido la formación de miles de kilómetros cuadrados de arrecifes coralinos en el Caribe.

\section{La diversidad de especies}

Por mucho tiempo se pensó que el Caribe tenía 20\% más especies de peces que el Pacífico. Esta diferencia se atribuía a que este último contaba con pocos arrecifes. Pero en realidad, tal disparidad obedecía a que los biólogos marinos, al dedicar más atención a estudiar el Caribe, habían encontrado más especies en este último.

A lo largo de la última década del siglo $\mathrm{XX}$, sin embargo, los peces del Pacífico se estudiaron más, y se descubrieron y describieron muchas especies nuevas. Ello ha reducido considerablemente la diferencia en cuanto a la riqueza de ambas faunas. Actualmente conocemos 450 especies para el Caribe y 420 para el Pacífico. Desigualdad mínima que seguramente se reducirá según más se investiguen los peces del Pacífico.

La abundancia de especies que dependen del coral

Un análisis de las dietas de los peces de arrecife coralinos de nuestra costa pacífica, me permite estimar que menos del $1 \%$ de sus peces depende directamente de los corales. Es decir, de peces que se alimentan de los corales o viven en ellos. Aunque este número es muy bajo, resulta que algo similar ocurre en el Caribe; sólo el $2 \%$ de sus peces pertenecen a tal categoría. Por

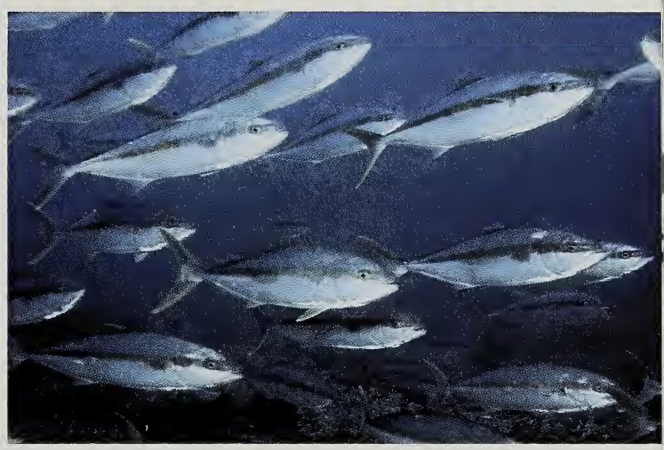

Hojarán amarillo (Seriola lalandi). Es una especie circuntropical pelágica. Crece hasta 1.5 metros. Foto: M. Chamberlain, México.

Morena joya (Muraena lentiginosa). Especie que se encuentra desde el Golfo de California hasta Perú, incluyendo las Galápagos y otras islas oceánicas.

Foto: R. Steene, Panamá.

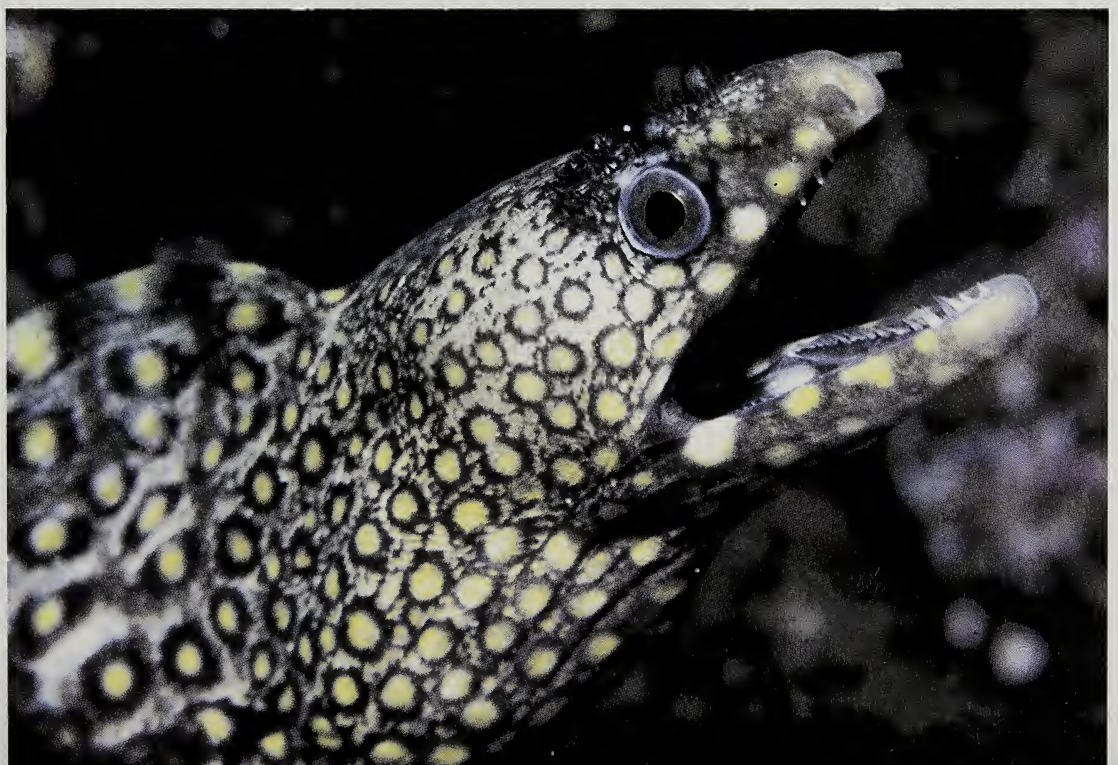




\section{La pesca en estuarios panameños: una visión}

histórica y cultural desde la Bahía de Parita

Richard Cooke

El pescado ha sido, por milenios, un alimento primario para la gente de este istmo angosto, bañado por dos océanos y atravesado por centenares de ríos y quebradas. Sin embargo, con el paso del tiempo los gustos han cambiado.

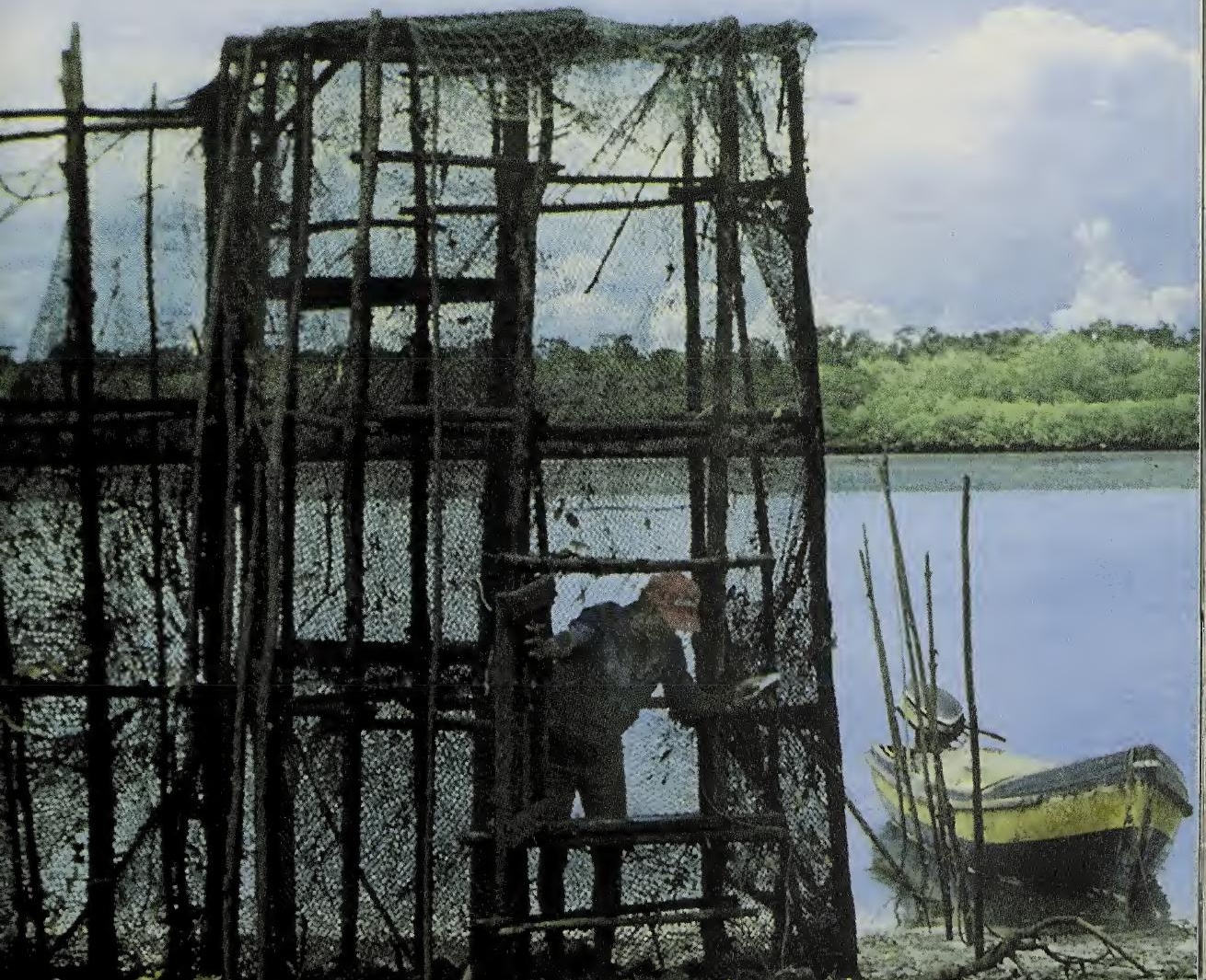




\section{Precios y prejuicios}

Un día en que acudía al viejo mercado de mariscos de la ciudad de Panamá, en busca de esqueletos de peces para añadir a mi colección de referencia, la cual se usa para identificar huesos hallados en excavaciones arqueológicas, presencié la siguiente situación.

Un pescador que no gusta de los científicos porque "manosean el pesca'o y no compran na' ", exhibía sobre su mostrador de azulejos blancos, un berrugate (Lobotes surinamensis). Pasaba por allí un ama de casa con dos empleaditas, vestidas con trajecitos de cuadros. Buscaban corvina para hacer ceviche.

- ¿Hay corvina? -le pregunta al pescador.

- No doña, no hay -le contesta él- pero este berrugate es buenísimo pa' hacer ceviche, mejor que la corvina y más barato; para usted, 60 centavos la libra.

- iAy, no! -exclama la señora- qué pescado más feo, me da asco.

Las tres damas siguieron campantes bastante salpicadas de escamas. Mientras la doña le daba la vuelta al mercado buscando corvina, el pescador agarró el menospreciado berrugate y, más rápido que ligero, lo fileteó, sincronizando su faena con el retorno del ama de casa ya bastante disgustada.

- Tiene mucha suerte, doña -le dice éste- le consegui estos filetes de corvina, fresquecitos.
- iAy, muchas gracias, señor! ¿Y a cómo la libra?

- Para usted, doña, do' dola'.

Los panameños urbanos con ingresos medianos o altos comen una pequeñísima proporción de las especies de peces que se obtienen en aguas de la costa del Pacífico. Existen según los gustos de la gente, tres categorías. Las especies más "ranqueadas" son las corvinas (Cynoscion), los pargos (Lutjanus), los robalos (Centropomus), los meros (Serranidae) y la guabina (Nebris occidentalis). Parece que la blancura y lo insípido de su carne son los factores que más influyen en esta preferencia. Este "pescado de primera" es el que más a menudo aparece en los menús de los restaurantes que se creen elegantes.

En las especies de segunda categoría encontramos a peces de carne oscura, tales como la cojinúa (Caranx caballus) y la sierra (Scomberomorus sierra), que no obstante, tienen muy buena acogida en los puestos callejeros de pescado frito y en los restaurantes populares, conjuntamente con los cazones (tiburones juveniles).

La tercera categoría encierra una inmensa variedad de especies consignadas con ignominia a la "revoltura", las cuales se venden a menos de 50 centavos por libra y son compradas principalmente por personas de ingresos modestos. Paradójicamente, muchas son "pri-

\section{Especies preferidas de los estuarios de la Bahía de Parita. (2000 d.C.)}

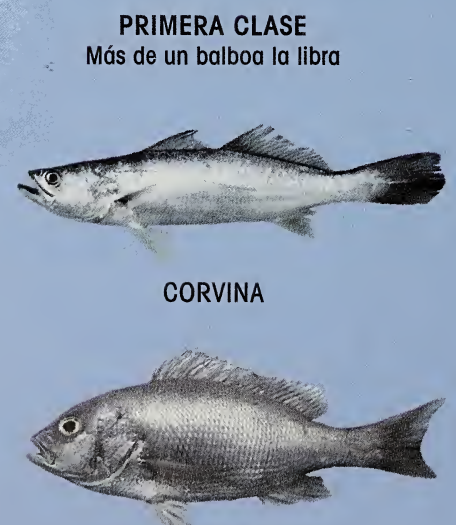

PARGO

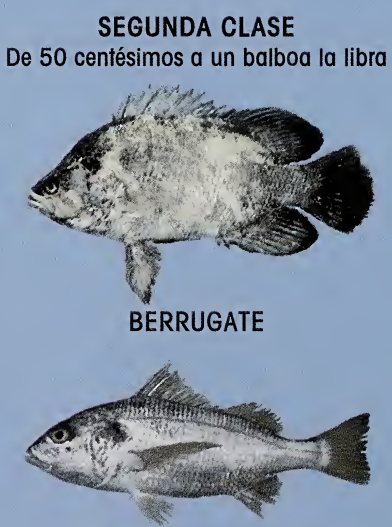

"PARGO BLANCO"
TERCERA CLASE ("revoltura") Menos de 50 centésimos la libra
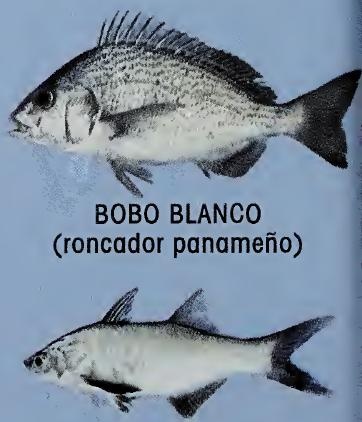

ÑAO-ÑAO 
mas hermanas" de la corvina y la guabina, ya que también pertenecen a la familia Sciaenidae: por ello, en sabor y consistencia su carne es muy parecida a la de aquellas.

Nuestro amigo el pescador demostró que, si el aspecto físico de un pescado de segunda o tercera categoría se modifica, despellejándolo y fileteándolo, se puede vender a precios más altos a personas que tienen ideas predeterminadas sobre lo que es digno de consumo o no.

Por último, están las especies de peces que los pescadores ni siquiera llevan a puerto por no considerarlos comestibles. En esta categoría se incluye la "arenga" (Opisthonema libertate), un pequeño pez que por nadar en cardúmenes grandísimos es importante como carnada y en la industria de harina de pescado. Como veremos a continuación, las poblaciones precolombinas de la Bahía de Parita no la despreciaban como alimento.

\section{La época precolombina: ¿pesca sin prejuicios?}

Es natural que en un istmo angosto, bañado por dos mares, el pescado haya sido siempre un elemento primordial de la dieta. La teoría más verosímil sobre el origen etimológico de Panamá sostiene que esta palabra significaba "abundancia de peces" en el idioma cueva, el cual se hablaba al momento del contacto español desde Chame hasta el Darién oriental. "Había más pescado que agua", exclamó el capitán español Gaspar de Espinosa, cuando en sólo dos horas sus soldados pescaron dos mil arrobas $(50,000 \mathrm{lbs}$.) en territorio del cacique cueva Tabore, a orillas de la Bahía de Chame.

En la época precolombina el pescado fue no sólo abundante, sino también un alimento de jerarquía. Según los cronistas del siglo XVI, a los capitanes españoles se les regalaba un trío de manjares cuando trataban con los líderes indígenas: venado, iguanas y pescado. La arqueología de investigación lo ha confirmado, al señalar que en sitios precolombinos cercanos a la Bahía de Parita, la mayoría de los huesos hallados en basureros pertenecen a este trío dietético.
El consumidor panameño actual suele preferir el pescado de acuerdo a su apariencia y al color de su carne. Son preferidas especies que tienen escamas y carne blanca que "no huele a marisco". No obstante, las especies de carne más oscura, grasosa y "mariscosa", como la sierra y cojinúa, son populares en los puestos de venta de pescado frito. En la época pre- colombina, había menos prejuicios. Los indígenas consumían grandes cantidades de especies que actualmente son descartadas como alimento para los humanos, como arengas, machetes, cocochas y pejesapos. Fotos: Ross Robertson, Gerald Allen.

\section{Especies preferidas de los estuarios de la Bahía de Parita. (5000 a.C. al 1515 d.C.)}

CONSUMIDOS ACTUALMENTE (PARA SOPAS)

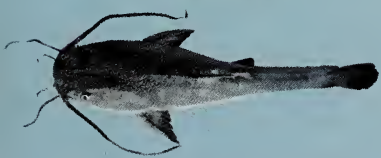

BAGRE GRIS

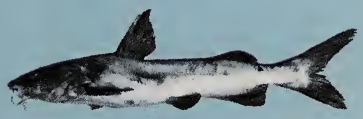

HOY DESCARTADOS COMO NO VENDIBLES

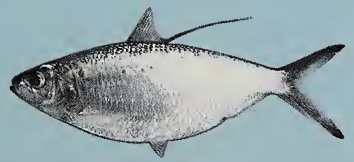

ARENGA

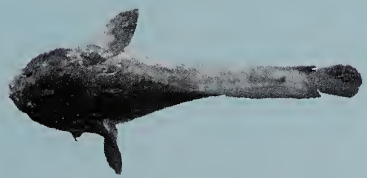

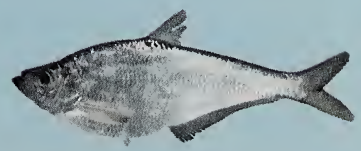

MACHETE

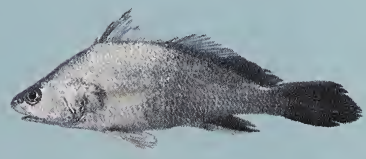


Las bahías de Chame y Parita son ecosistemas formados por estuarios, cuya gran carga de sedimentos acarreados por los ríos, junto con un amplio rango de mareas, han formado extensos fangales y una inmensa variedad de habitats; estos albergan gran cantidad y variedad de peces y otros organismos acuáticos. Por ser fácilmente accesibles desde tierra firme y por tener un sinfín de acequias y esteros, son lugares donde la pesca puede ser muy efectiva con métodos sencillos. Cualquier tipo de barrera que aproveche la subida y bajada de las mareas es capaz de atrapar buenas cantidades de pescado, mientras que las muchas charcas que se forman con cada marea baja acogen muchas presas, que pueden ser envenenadas o atrapadas con canastas y hasta con las manos.

Otro factor positivo es el efecto de las mareas sobre los peces que viven dentro de los cursos bajos de los ríos. En Panamá, la fauna de agua dulce es bastante pobre en especies; pocas alcanzan un buen tamaño. La mayoría de los peces que se capturan en la zona de influencia de las mareas en los rios es, por consiguiente, de origen marino. Demostramos este hecho por una investigación efectuada junto con Gonzalo Tapia en el río Santa María en 1992. 1993. Recurriendo a trasmallos, palangres, cañas de pescar y nasas empleadas en cuatro estaciones de colecta, capturamos 38 especies de peces marinos a $0,8 \mathrm{kms}$. de la desembocadura, 27 especies a 7 kms., 6 especies a 12 kms. y 4 especies a $20 \mathrm{kms}$.

El hecho de que muchos peces marinos suban por los ríos no significa que los indígenas precolombinos que vivían a cierta distancia de la costa, hayan desdeñado especies de agua dulce. Muestras de huesos de peces recogidos en

Desde 8000 años antes de Cristo, la Bahía de Parita fue una de las zonas más pobladas del "Gran Coclé", debido a la gran abundancia de mariscos de sus estuarios y ríos, y a la fertilidad de sus suelos agrícolas. Actualmente los pescadores artesanales siguen abasteciendo de pescado a la región, aunque las malas prácticas amenazan con extinguir esta milenaria industria. Se supone que los indigenas precolombinos usaban "atajos" de palos y redes colocados en bocanas y esteros para atrapar peces, camarones y tortugas marinas, cuya carne seca y salada era enviada a asentamientos en el interior de Azuero, Veraguas y Coclé (ver en el mapa el detalle destacado con la palabra "Trampa").

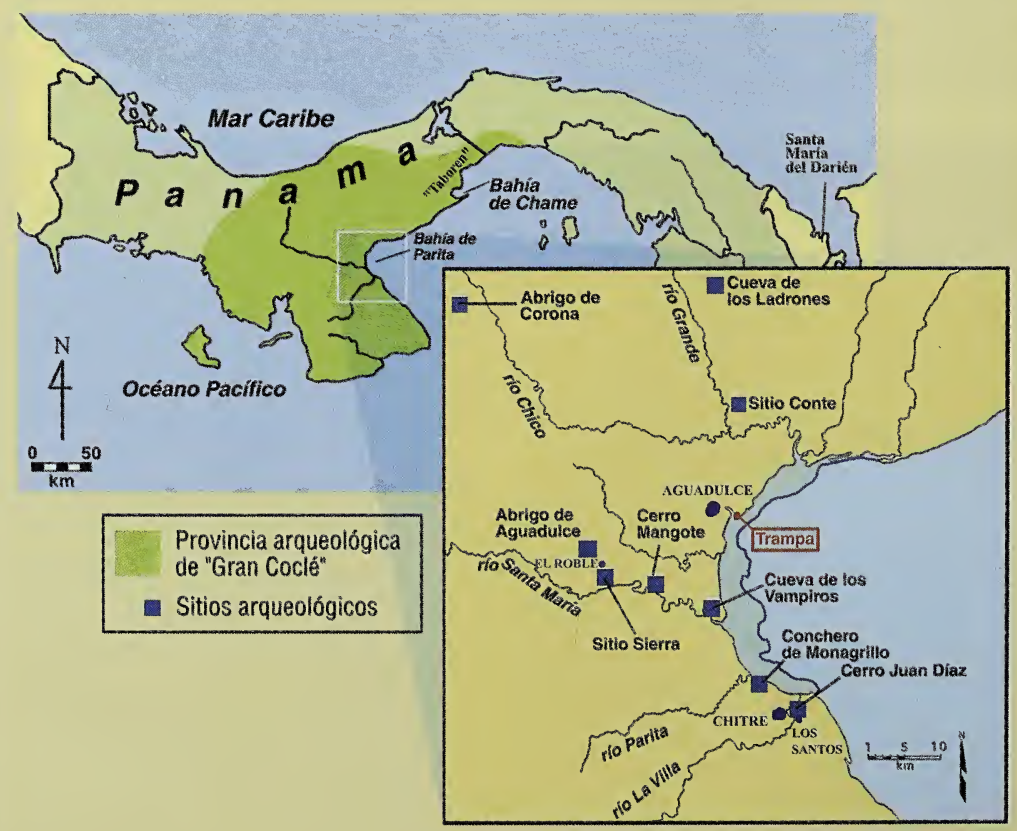




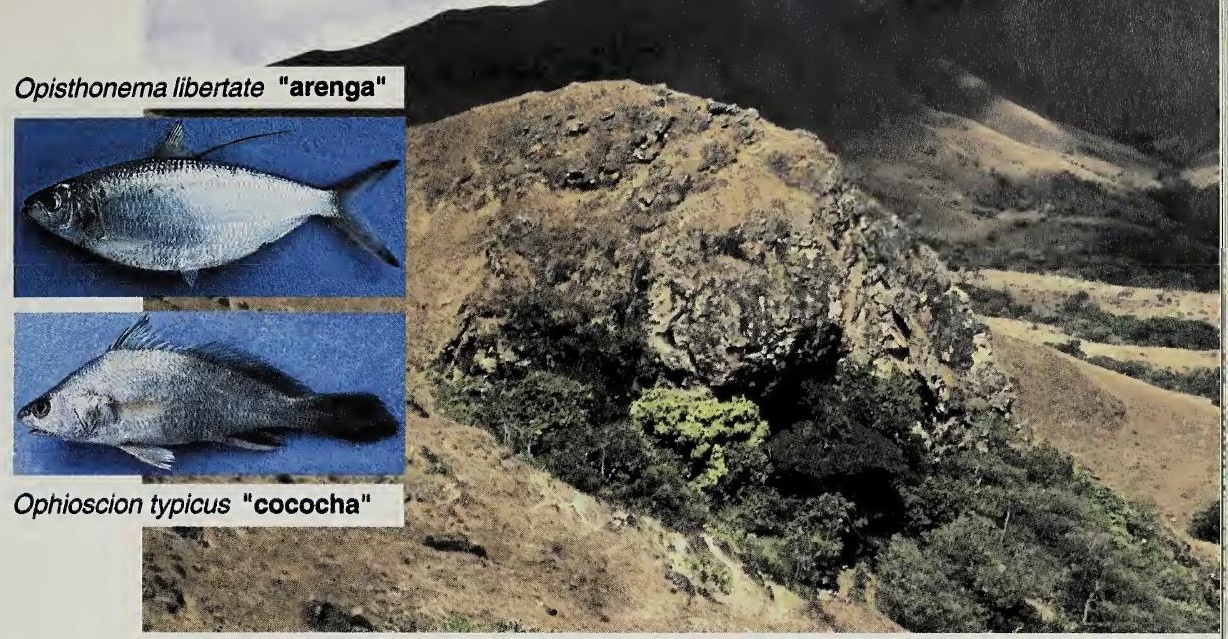

abrigos rocosos, habitados por los antiguos pobladores de las estribaciones de las montañas de Coclé y Veraguas, confirman el consumo de barbudos (Rhamdia, Parauchenipterus amblops) chupapiedras (Hypostomus panamensis, Sturisoma panamense), sardina manada (Cyphocharax magdalenae), aguja de río (Ctenolucius hujeta), pejeperro (Hoplias sp.), chogorro (Aequidens coeruleopunctatus), macana (Sternopygus dariensis) y morena (Synbranchus marmoratus).

En estos sitios vivían pequeños grupos de horticultores transeúntes entre aproximadamente el 8000 y 1000 antes de Cristo. Durante el siguiente milenio, la población precolombina de esta zona aumentó rápidamente, y comenzó a congregarse en aldeas localizadas en los cursos bajos de los ríos más grandes. De estas, una de las poblaciones estudiadas de manera más completa es Sitio Sierra, cerca de El Roble de Aguadulce, cuya fundación remonta al 300 a.C. Su ubicación entre 12 y 14 kms. de la costa de la Bahía de Parita privilegió por un lado, el cultivo de maíz, yuca y zapallos en los profundos suelos aluviales y por otro, el aprovechamiento de los recursos de la costa y del río. A esta distancia del mar el río Santa María corre dulce, lo que hace comprensible que según las investigaciones arqueofaunísticas, los peces de agua dulce hayan representado el $30 \%$ del pescado que consumían los aldeanos, siendo la especie más abundante el torito $(P$. amblops), un barbudo que apenas alcanza tan sólo 60 gramos de peso, y que además posee espinas pectorales muy ponzoñosas.

Los peces marinos que los habitantes de Sitio
Aunque distaba $20 \mathrm{~km}$ de la costa, los habitantes de la cueva de los Ladrones, en Cerro Guacamayo, Coclé, consumían pescados marinos del Pacífico, como "arengas" y "cocochas". Se supone que este pescado era salado y secado al sol y luego comerciado tierra adentro.

Foto: Junius B. Bird.

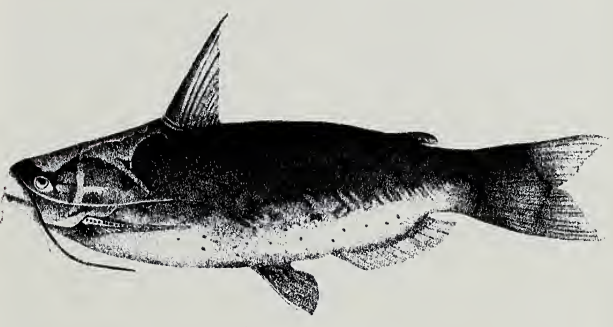

El Torito (Parauchenipterus -o Trachycorystesamblops), pez de agua dulce muy apreciado por los indígenas precolombinos.

Dibujo: Arcadio Rodaniche.

Sierra consumían habitualmente abundan en manglares, bocanas y en partes del río donde entra la marea, como bagres y cominates (Selenaspis dowii, Arius spp.) robalos (Centropomus spp.), y otras especies que se concentran en corrientes de agua clara en la periferia de los estuarios. En efecto, el $50 \%$ del pescado marino consumido por esta aldea, entre el $300 \mathrm{y} \mathrm{el}$ 600 d.C., comprendió tres especies marinas que entran a los estuarios en corrientes de agua clara: la arenga, la catarnica (Selene peruviana) y el ñao-ñao (Orthopristis chalceus), un 
colombinos. En realidad, muy poco se sabía acerca del comportamiento de los peces en las aguas turbias de la Bahía de Parita, por lo que el trabajo cuantitativo y taxonómico realizado ha probado ser de gran utilidad ictiológica y antropológica.

El atajo fue construido por el Sr. Pablo Aguilar en la salida del estero Palo Blanco, cerca del puerto de Aguadulce, donde la salinidad osciló entre 20 y $34 \%$. Este consistió en tres componentes: (1) el "vaquero", una barrera semicircular de 2 metros de alto, la cual se extendió desde el borde de un manglar Rhizophora, abarcando una distancia de 160 metros hacia el canal principal del estero; (2) el "salón", el cual se valía de la pared del "vaquero" y de otra pared más corta para conducir el pescado a través de una abertura de un metro de ancho hacia una cámara en forma de "V"; y (3) el "chiquero", una cámara hexagonal a la cual el pescado entraba a través de una ranura de sólo $15 \mathrm{cms}$., por una puerta en el sector norte. Las paredes del atajo fueron construidas con palos verticales y horizontales y luego cubiertas con redes comerciales que los barcos camaroneros le regalaron al $\mathrm{Sr}$. Aguilar. Los palos verticales, de 3 a $5 \mathrm{cms}$. de grueso, estaban colocados a intervalos de 50 cms.; las redes en el "vaquero" semicircular tenían mallas de $9 \mathrm{cms}$. y las del "salón" y el "chiquero", de $3 \mathrm{cms}$.

Entre diciembre de 1991 y octubre de 1993 se hicieron colectas, que proporcionaron 9,114 peces, que fueron casi todos identificados, medidos y pesados. La mayor parte de estos especímenes comprendió diez especies de congos (Ariidae), jureles (Carangidae), cocochas (Sciaenidae), anchovetas (Engraulidae) y arenquillas (Pristigasteridae) cuyo peso promedio por especie fue de 20 gms. (Chloroscombrus orqueta) hasta 160 gms. (Ariopsis seemanni). El congo prieto (A. seemanni) fue la especie que más se capturó en el atajo, en el $78 \%$ de las colectas. De vez en cuando, entraron depredadores bastante grandes, incluyendo un mero de $19 \mathrm{kgs}$. y varias corvinas boquiamarillas de 10 a $13 \mathrm{kgs}$. Se supone que las tortugas negras (Chelonia agassizi) que se atraparon, las cuales pesaron de 50 a $125 \mathrm{kgs.}$., subieron al estero a comer peces y medusas.

Los resultados de esta investigación mostraron que casi el $90 \%$ de las especies de peces marinos encontradas en los sitios arqueológicos de la Bahía de Parita pueden capturarse hoy en trampas de barrera erigidas sobre fangales próximos a manglares. También indican que la familia de peces marinos más pescada en tiempos precolombinos (Ariidae, los peces gato marinos), fue la más abundante en el atajo. Algunos peces que probaron ser hiperabundantes actualmente, como el congo cabeciseco (Cathorops hypophthalmus) y una cococha (Stellifer zestocarus), no son los representantes más frecuentes de sus respectivas familias en las muestras de huesos arqueológicos. Otros, como el congo prieto (Ariopsis seemani) y la horqueta (Chloroscombrus orqueta), demostraron ser tan abundantes en el atajo, como en los sitios arqueológicos.

Tres especies marinas que solían ser muy populares en los tiempos precolombinos, la arenga, la catarnica y el ñao-ñao, cayeron muy esporádicamente en el atajo. Pero otra investigación realizada por $\mathrm{D}^{\prime} \mathrm{Croz}$ y otros, con una trampa de barrera en Veracruz, cerca de la ciu-

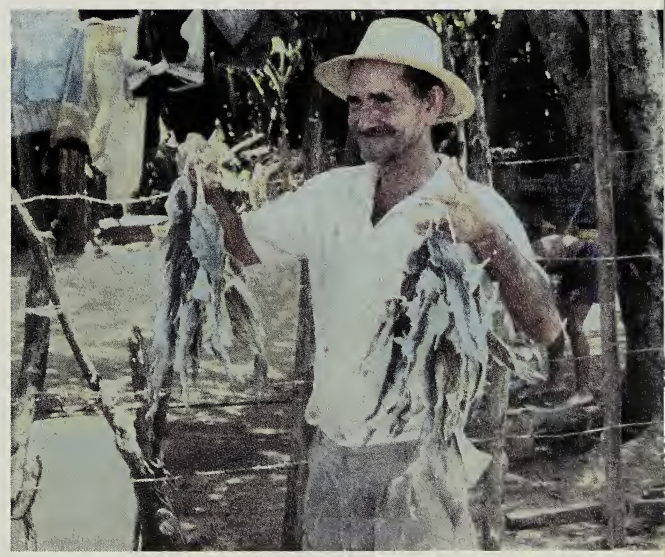

La práctica de ahumar, salar y disecar pescado marino para comerciarlo remonta al 5000 a.C. En esta foto, el Sr. Francisco Villarreal sostiene "amarras" de "congos" recién salidos de un tanque de salmuera (los "congos" son pequeñas especies de peces gato de los géneros Ariopsis y Cathorops). Las "amarras" serán secadas al sol por varios días antes de venderse por 40 - 50 centavos a compradores que las revenderán en pueblos del interior de Azuero y Veraguas. Foto: R. Cooke. 
dad de Panamá, en un fondo de arena y fango, reportó una gran cantidad de catarnicas, por lo que se sospecha que con atajos construidos sobre bancos de arena, o en las playas que bordean el estuario, se atraparían cardúmenes de estas tres especies que suelen buscar corrientes de agua clara.

\section{Panamá: crisol de comidas interesantes}

Es lógico que el pescado haya sido por mile nios un alimento primario para la gente de este istmo angosto, bañado por dos océanos y atravesado por centenares de ríos y quebradas. Investigaciones hechas en huesos de la fauna antigua muestran, que a partir del año 6000 antes de Cristo, los indígenas que residían cerca de la Bahía de Parita aprovechaban de manera eficiente los recursos de este estuario prolífico. Una vez capturado, el pescado se salaba, secaba y distribuía a comunidades más alejadas de la costa.

Al parecer, los habitantes precolombinos tenían pocos prejuicios en relación a los alimentos. Algunas especies de peces marinos, hoy descartadas por casi toda la población panameña, eran entonces consumidas regularmente, en tanto que otras especies actualmente consideradas de pobre calidad, tenían aceptación general.
En la actualidad, millones de peces son atrapados en redes cerca del litoral del Pacífico por los barcos camaroneros y los trasmalladeros, y luego... ¡tirados al mar! Mientras tanto, los pescadores artesanales se quejan de que las especies de primera corvinas, robalos y pargos- están desapareciendo.

Lograr que una población humana agregue nuevos alimentos a su dieta es tarea difícil. Una solución pragmática es vender berrugate por corvina. Otra es vender filetes de barbudo azul (B.p.) como "corvinata" o de "cabezón" (Pomadasys panamensis) como "pargo blanco". Hay que recordar que la fruta kiwi tenía poca aceptación entre los consumidores cuando se le llamaba "grosellero silvestre de la China" (Chinese gooseberry).

A la larga sería más beneficioso para la conservación y el aprovechamiento racional de los recursos pesqueros darle publicidad a dos conceptos: primero, que es sano y divertido probar platos nuevos, y segundo, que lo feo no quita lo sabroso. Quién hubiera pensado hace treinta años que uno de los peces más grotescos de los océanos -el "monkfish" o "bocón" (Lophioidei)- se convertiría en plato predilecto de los gourmets del mundo. Algún día, tal vez, un restaurante de la ciudad brindará "filetes de pejesapo a la brasa".

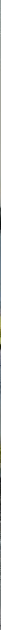




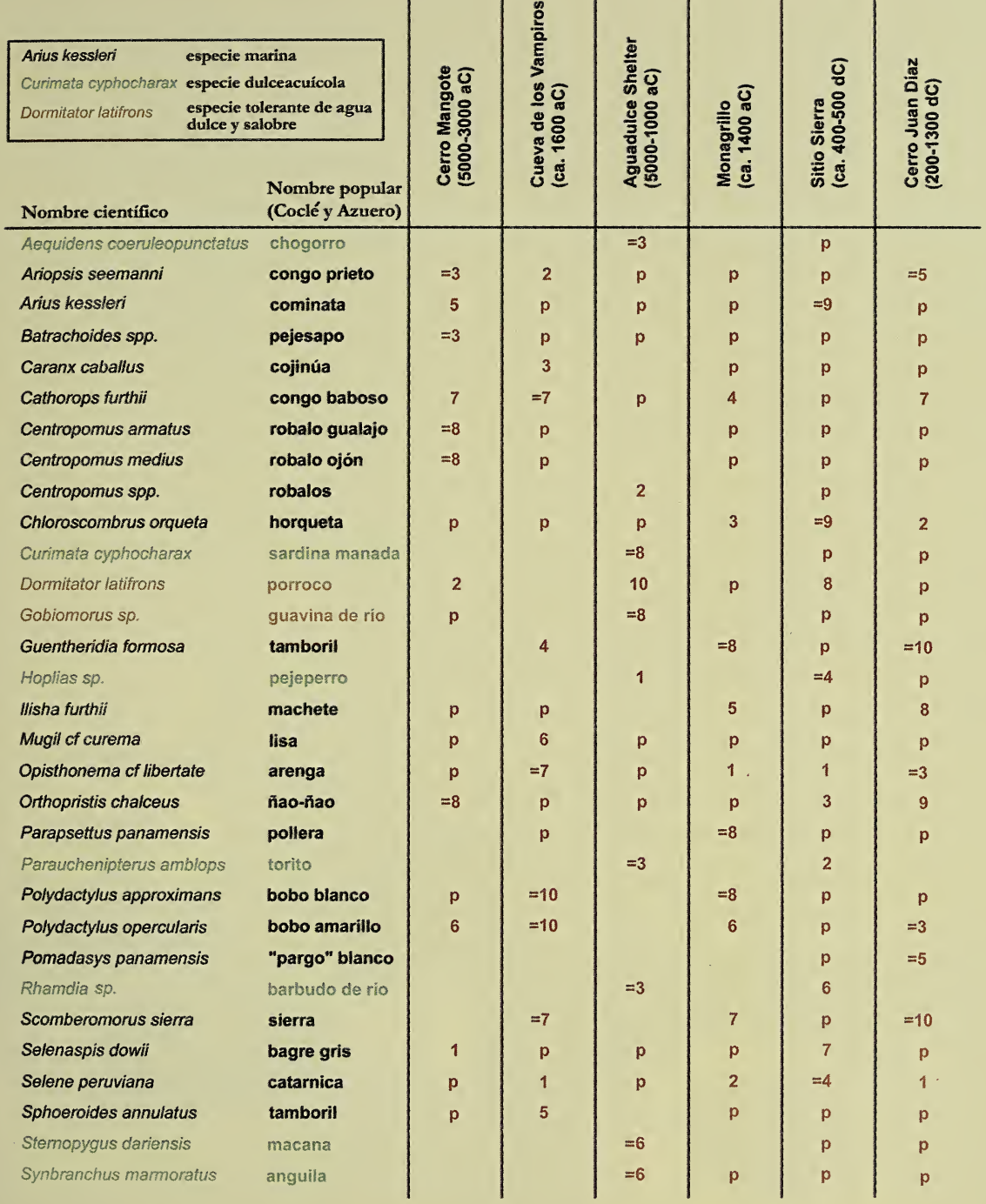

Este cuadro resume información proporcionada por seis sitios, que abarcan desde el 5000 a.C. hasta el 1300 a.C.

$\mathrm{R}=$ rango por orden de abundancia, de las diez especies de pescados más frecuentes en cada muestra de huesos.

El "bagre gris" fue la especie más apreciada en Cerro Mangote, la "catarnica" en la Cueva de los Vampiros y Cerro Juan Díaz, el "pejeperro" en el Abrigo de Aguadulce y la "arenga" en el conchero de Monagrillo y Sitio Sierra.

$p=$ presente en la muestra en pequeñas cantidades. 
Cuidando a los ancestios:

Rasgos mottuow

otecolombinos

en cento Juan Diaz,

Los Santos

Richard Cooke

A 30 kilómetros de Sitio Conte, en la costa sur de la Bahía de Parita y a orillas del río La Villa, se encuentra cerro Juan Díaz, un sitio arqueológico que atesora 1800 años de historia.

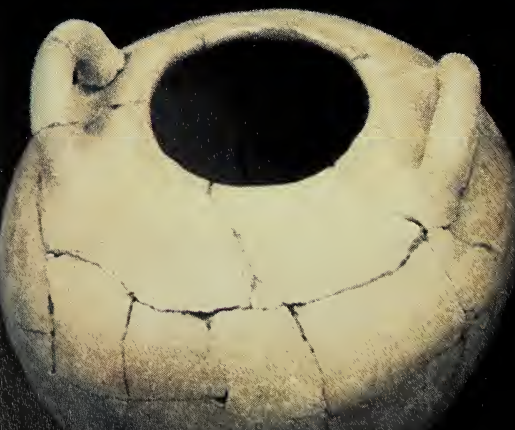




\section{La muerte inoportuna del cacique Antatará}

En el año 1516, el capitán español Gaspar de Espinosa salió de Santa María La Antigua a la cabeza de un pequeño grupo de soldados, cruzó la serranía hasta las llanuras del Pacífico y luego marchó hacia "poniente", sometiendo, atormentando y ajusticiando a caciques recalcitrantes. El móvil de esta incursión era castigar a Antatará, conocido también como París, un guerrero renombrado que el año anterior había "desbaratado" las huestes de Gonzalo de Badajoz, quitándoles el oro con el que esperaban conseguir prebendas de regreso a Darién. Después de una recia batalla en las sabanas, Antatará se replegó al “despeñadero áspero de un cerro". Aunque sus guerreros fueron diezmados por los arcabuces y espadas de los españoles, el cacique escapó. Irónicamente, el sanguinario Espinosa nunca disfrutó el apresamiento de su rival indígena, porque cuando volvió a verlo no lo encontró con vida, sino disecado, envuelto en mantas pintadas y ataviado con muchas piezas de oro: tenía en la cabeza un yelmo, al cuello cuatro o cinco collares "hechos a la manera de gorjal", en los brazos y piernas "armaduras hechas como cañones" y en la espalda muchas "patenas". La mujer que yacía a los pies del cacique y otras que estaban a la cabeza de este, también vestían alhajas de oro. Otros envoltorios contenían los restos mortales de dos caciques engalanados con joyas, aunque no "tan rica ni tan apuestamente", los que según Espinosa "habían sido y sucedido después de Antatará y habían muerto."

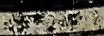

Descubrimientos hechos en sitios arqueológicos en la misma región de Panamá confirman las observaciones españolas del siglo XVI. En el cementerio precolombino de Sitio Conte, cuyas tumbas abarcan desde el año 750 hasta el 950 después de Cristo (d.C.), se encontraron más de 1000 objetos de oro. Sin embargo, tan sólo las sepulturas complejas y opulentas contenían la misma categoría de alhajas

Arriba: Vasija polícroma del estilo "Macaracas" del Gran Coclé (850-1000 d.C.) hallada en el "rasgo 4" de la operación 4. Foto: R. Cooke.

Abajo, izquierda: Los habitantes de Cerro Juan Díaz tenían diferentes formas de preparar a sus muertos, como se evidencia en la tumba 1 de la operación 4 . Una urna funeraria tapada con otra vasija contenía los restos de un infante recién nacido.

Derecha: Restos de una mujer adulta enterrada de modo "primario" y en posición flexionada, además de los huesos desordenados de tres infantes y seis adultos, incluyendo una ofrenda de cuatro cráneos. Fotos: M. Guerra, izq., R. Cooke, der.
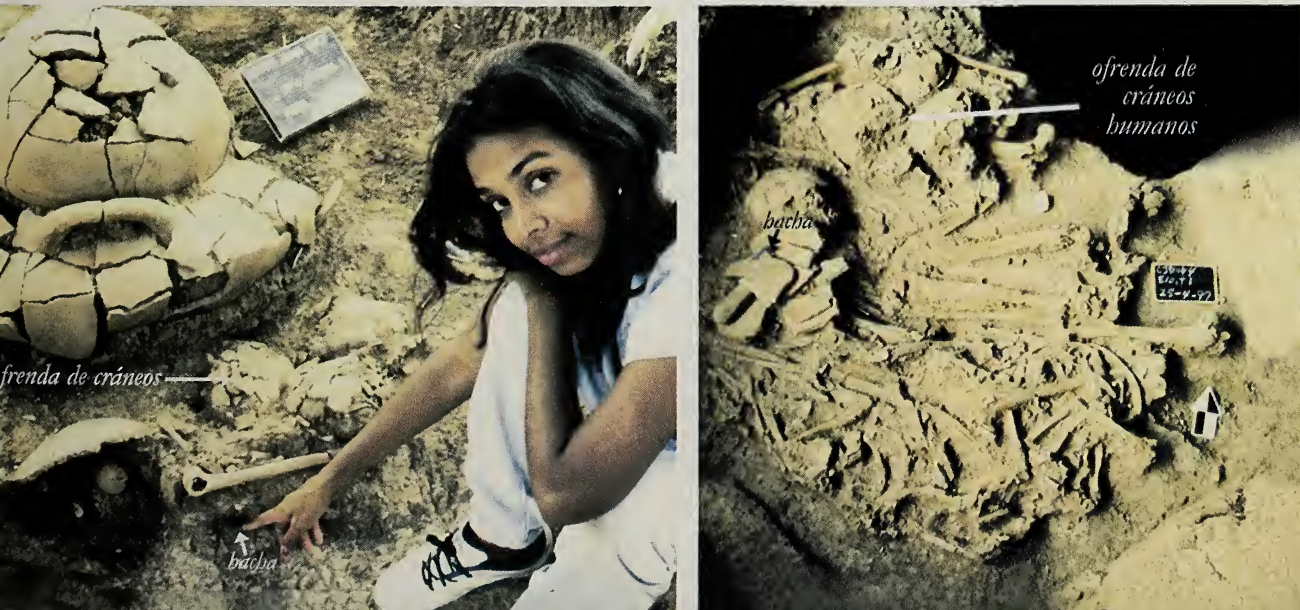


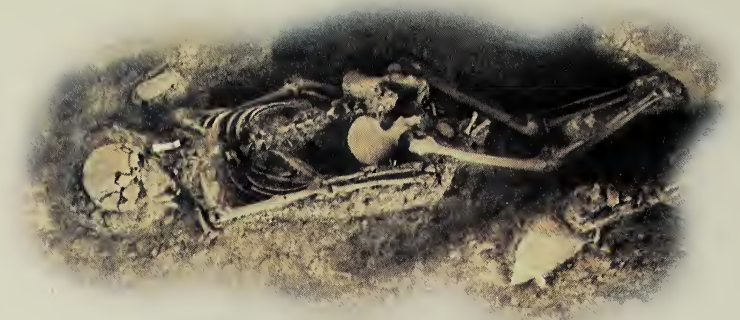

Izquierda: Enterramientos primarios encontrados en las excavaciones de la Operación 4 de Cerro Juan Díaz.

Página opuesta: Las excavaciones en cerro Juan Díaz comenzaron en 1992 cuando la Dirección de Patrimonio Histórico del INAC solicitó a Richard Cooke que organizara un proyecto de investigación a fin de detener la huaquería. Los arqueólogos del proyecto han realizado ocho operaciones en campo. La mayor parte de las sepulturas se hallaron en una plataforma de tierra en el lado sur del cerro.

que Espinosa observó en el cuerpo de Antatará: yelmos, discos, brazaletes, polainas y cintas. En Sitio Conte el $94 \%$ de los 93 esqueletos humanos cuya edad los antropólogos físicos pudieron calcular, eran adultos. De ellos, el $80 \%$ masculinos y el $20 \%$ femeninos. Las personas más importantes en cuatro sepulturas de inusitado esplendor eran hombres, dos de ellos de avanzada edad. No se hallaron restos de niños o bebés.

Los caciques panameños que se opusieron a los españoles en la época de Espinosa y Pedrarias se ataviaban con piezas de oro cuando salían a guerrear. En el enfrentamiento entre Espinosa y Antatará, un "capitán" indígena acudió a ayudar al cacique "armado" con muchos discos y puñetes puestos sobre una gruesa chaqueta de algodón. En una escaramuza posterior en Veraguas, el cacique Pocoa anduvo delante de "500 guerreros" con un gran disco de oro en el pecho y lanzas en ambas manos porque, según Fernández de Oviedo, era "costumbre en aquellas partes que los caciques y hombres principales traigan en la batalla alguna joya de oro en los pechos o en la cabeza o en los brazos para ser señalados y conocidos entre los suyos y aún entre sus enemigos."
Los arqueólogos no han encontrado, en ningún sitio de la provincia arqueológica llamada "Gran Coclé", restos mortales de niños o mujeres tan "apuesta y ricamente" ataviados como los "hombres alfa" de Sitio Conte, lo que sugiere que en la sociedad precolombina de esta región de Panamá, el status social y la riqueza no se heredaban, sino que se alcanzaban o ganaban por méritos propios. Los caciques de mayor habilidad (o suerte) lograban atesorar en vida impresionantes cantidades de artículos suntuosos. (Algunos comentarios hechos por cronistas españoles del siglo XVI sugieren que cuando un guerrero mataba o capturaba a un enemigo, se quedaba con todos los atavíos de este y sus familiares).

Si Sitio Conte era la necrópolis de los guerreros y sus mujeres, ¿dónde enterraban los indígenas precolombinos a sus niños y adolescentes, y a los miembros comunes y corrientes de sus comunidades?

\section{Rituales mortuorios en cerro Juan Díaz}

A 30 kilómetros de Sitio Conte, en la costa sur de la Bahía de Parita y a orillas del río La Villa, se encuentra cerro Juan Díaz (ver 
ga (aleación de oro y cobre) martillada con espirales divergentes. ¿Otro chamán o curandero? Es posible, aunque para confirmarlo sería necesario ampliar la muestra de entierros de esta época (500-750 d.C). Se puede encontrar más información sobre estas sepulturas y sus artes mortuorias en el portal o "página web" del Proyecto Arqueológico Cerro Juan Díaz: www.geocities.com/CollegePark/Residence/3863, y en el portal del Instituto Smithsonian (STRI).

\section{Segunda fase de entierros $(750-1000 \mathrm{dC})$}

En la excavación de la Operación 4, al extremo opuesto de la plataforma, a cargo del arqueólogo japonés Koichi Udagawa, se descubrió otro grupo de entierros que, según fechamientos radiocarbónicos y el estilo de la cerámica pintada enterrada, abarcan aproximadamente del 750 al 1000 d.C. Esto quiere decir que son más o menos coetáneos con el cementerio de Sitio Conte. En otros aspectos son muy diferentes. El ajuar funerario de los 160 individuos hallados en esta excavación es escaso y sencillo: uno que otro collar con pequeñas cuentas de concha, piedra y oro, herramientas de hueso, hachas, vasijas monocromas y pintadas y ofrendas de alimentos, como pescado y moluscos. En términos estrictamente materiales, se podría afirmar que estos entierros correspondían a "gente pobre".

Desde un punto de vista conceptual, sin embargo, la organización espacial de este emplazamiento mortuorio y la diversidad de los tratamientos fúnebres aluden a un mundo espiritual bastante complejo. Se pusie- ron en evidencia cinco clases de sepulturas variables en tamaño, forma, profundidad, modo de enterramiento y clase de ofrendas. Las más simples y superficiales contenían esqueletos extendidos, rara vez acompañados de ofrendas. Otras tumbas, como mencionamos, eran sumamente complejas. El denominado Rasgo 4 fue la sepultura de mayor envergadura, cantidad y variedad de enterramientos, incluyendo los restos de un gran sahumerio realizado en el ensanchado piso de la fosa, a 4 metros de profundidad (la urna funeraria polícroma que se muestra en la página 39, hacía parte de este ritual).

Aparte del enterramiento primario extendido, característico de esta segunda fase, todas las formas de disponer los cuerpos de la etapa temprana se repitieron. Osarios apilados en el fondo de las fosas fueron muy comunes, así como el arrimar cráneos (hasta en grupos de cuatro) a los últimos ocupantes de la fosa, tal vez como símbolo de afiliación familiar. Los entierros en envoltorios contuvieron únicamente los restos de niños menores de 9 años o de adultos mayores de 40 años. En el "Rasgo 4", Koichi Udagawa identificó 42 eventos deposicionales relacionados con el entierro de al menos 29 individuos. La posición de las inhumaciones primarias y sencillas arregladas alrededor del borde de esta bóveda sugiere que se mantuvo abierta bastante tiempo, tal vez protegida por una enramada. Es verosímil que haya sido propiedad de un grupo específico, como una familia extendida o un linaje. Cada entierro nuevo perturbaba los anteriores, cuyos esqueletos eran recogidos y arrimados contra las paredes de la tumba.

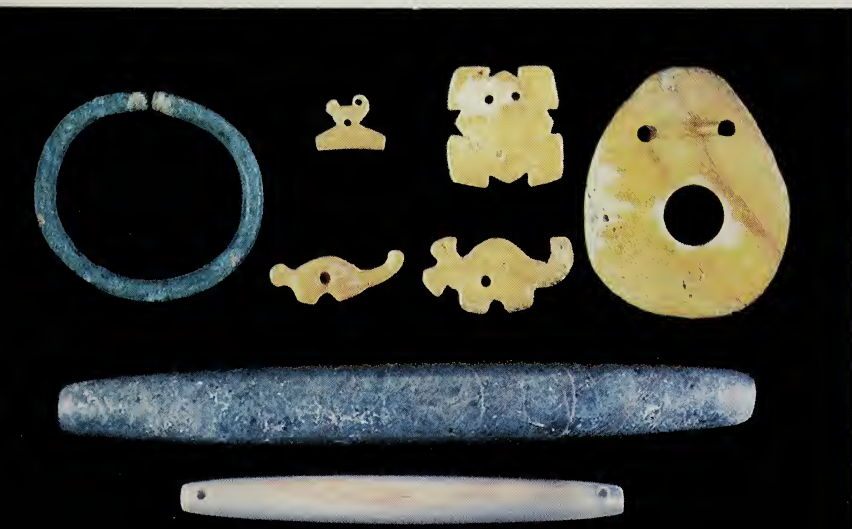

En la tumba 16 de la operación 3, los adornos de mayor valor se encontraron junto a un hombre adulto: una argolla de cobre, cuentas de conchas "Spondylus" en forma de animales y dos barras de piedra pulida. La argolla de cobre mide $5 \mathrm{cms}$ de diámetro y la barra de piedra más grande, $25 \mathrm{cms}$.

Foto: R. Cooke. 
En resumidas cuentas, el número y la calidad de los objetos imperecederos que se depositaron en las tumbas de los tres emplazamientos de cerro Juan Díaz son, desde un punto de vista materialista y estético, inferiores a los que acompañaron a los "hombres alfa" de Sitio Conte. Aquí no se encontraron los yelmos, brazaletes, gorjales y pu-

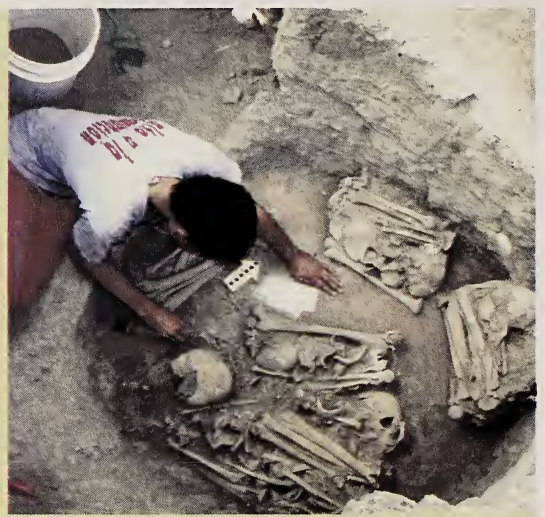

El arqueólogo Luis Alberto Sánchez limpia entierros "secundarios" depositados en una fosa clilíndrica. Esta sepultura (tumba 2, operación 3) fue utilizada tres veces para enterrar a unas 25 personas adultas y adolescentes. Foto: A. Badilla.

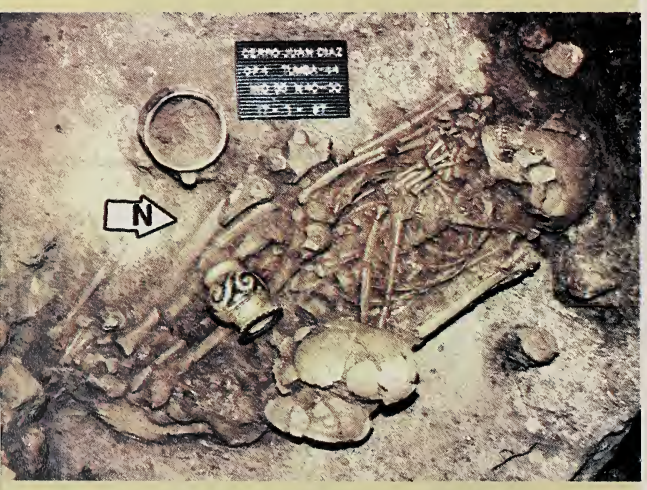

Esta mujer de 40 a 45 años de edad fue enterrada en posición flexionada y de modo "primario" junto con una vasija modelada y dos policromadas. Este entierro (tumba 44, operación 4) data del 750 al 950 d.C. Foto: K. Udagawa. ñetes de oro, ni los colmillos de cachalote esculpidos, que simbolizaban el "poder ganado". Aún así, tanto la organización del espacio de los entierros, como el empleo coetáneo de muchas formas de arreglar y enterrar a los cadáveres, indica que no sólo la gente pudiente en el "Gran Coclé" precolombino cuidaba de sus ancestros. La evidencia obtenida en cerro Juan Díaz señala que ciertos artefactos y ciertos modos de emplazar a los cadáveres no aluden al rango social, sino al oficio del difunto o a su edad. Pensamos que algunos objetos hallados en los entierros más antiguos podrían haber sido usados por un chamán o curandero. Todas las urnas funerarias en el cerro contuvieron restos de infantes o niños. El "Rasgo 4", la sepultura más profunda de la plataforma, reportó a las personas de mayor edad en el cementerio: dos adultos mayores de 50 años y una mujer de más de 60 años.

\section{Salud, nutrición y la inusitada deformación de un cráneo (750-1000 dC)}

Los esqueletos humanos representan una mina de información, no sólo sobre las costumbres culturales de una población antigua, sino también su salud y nutrición. En la muestra obtenida de la Operación 4, Clau* dia Díaz identificó un achatamiento anormal de la parte superior del cráneo en dos mujeres, una de edad estimada entre 20 a 24 años y otra de 45 a 50 años. La similitud de la anormalidad en ambos individuos sugiere una costumbre de alterar el cráneo por medio de una compresión vertical (cuando el individuo era joven y los huesos aún no se habían fusionado). Hasta la fecha han sido los únicos casos arqueológicos documentados en Panamá y hasta donde sabemos en la Baja América Central.

Aproximadamente el $94 \%$ de la población adulta sufría de caries, mientras que en menores proporciones padecían de cálculos dentales, abscesos, periodontitis e hipoplasias. A veces estas dolencias condujeron a la pérdida de varias piezas dentales. El caso más extremo fue el de una mujer de 20 a 24 años, que al morir había perdido casi todos sus dientes. Posiblemente algunos abscesos conllevaron mortales infecciones bacteriales. Las hipoplasias -interrupciones del esmalte dental durante el desarrollo de los 
dientes permanentes- están relacionadas a un estrés metabólico sistemático por desnutrición, enfermedad o fiebre; están presentes en un $9 \%$ de la muestra de esqueletos. Se registraron diez casos de osteoartritis, incluido un caso de anquilosis (fusión de los huesos de dos dedos) en un hombre de 35 a 40 años. Una mujer de 20 a 24 años presentó síntomas de osteomielitis y siete individuos de periostitis, una afección menos grave que aquella.

Si bien la población del segundo cementerio de cerro Juan Díaz presenta un alto índice de mortalidad infantil, este no es fuera de lo común entre las poblaciones agrícolas precolombinas. Aunque hay evidencia de estrés nutricional, la frecuencia de infecciones en los huesos es baja. También lo es la incidencia de los traumas resultantes de los conflictos bélicos. Algunos se preguntarán por los supuestos guerreros ricos de Sitio Conte, que peleaban ataviados con prendas de oro. Desafortunadamente, los arqueólogos que excavaron este lugar en los años ' 30 y ' 40 no recogieron los restos óseos, por lo que habría que aguardar otra excavación en el sitio o en otro similar, para verificar la existencia de heridas de guerra.

Un extraño ritual y una posible casa mortuoria

En algunos sitios arqueológicos de la provincia arqueológica del "Gran Coclé", como Finca Calderón, Herrera, se han encontrado grandes cantidades de muelas humanas perforadas por la raíz, lo que alude a su uso en la confección de collares. Resulta interesante, por ende, que las únicas ofrendas observadas en el tercer emplazamiento funerario en cerro Juan Díaz, hayan consistido en huesos maxilares y mandíbulas humanas, cuyos dientes habían sido extraídos post mortem.

Cuando estas mandíbulas y huesos maxilares humanos fueron depositados como ofrenda ritual, ya se les habian extraído las piezas dentales, que fueron usadas posiblemente para hacer collares. Las cortadas visibles en algunas mandíbulas sugieren que cuando se prepararon para la ofrenda, los tejidos blandos no estaban completamente descompuestos. Foto: R. Cooke.
CRANEO FEMENINO DEFORMADO

CRANEO FEMENINO NORMAL
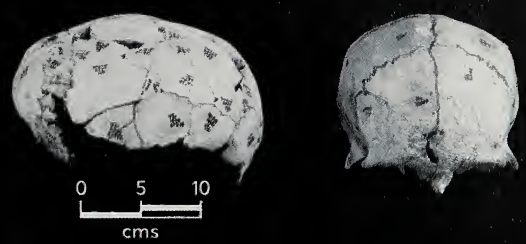

$\mathrm{cms}$

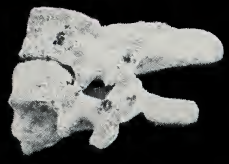

OSTEOARTRITIS

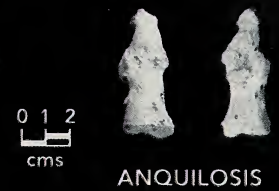

OSTEOMIELITIS
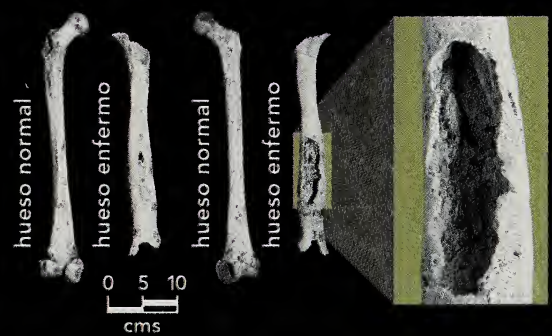

Los huesos humanos hallados en tres tumbas en Cerro Juan Díaz, dan información sobre la salud de sus habitantes. También nos hablan de algunas prácticas culturales como las deformaciones de cráneos.

Investigación y foto: Claudia Díaz.

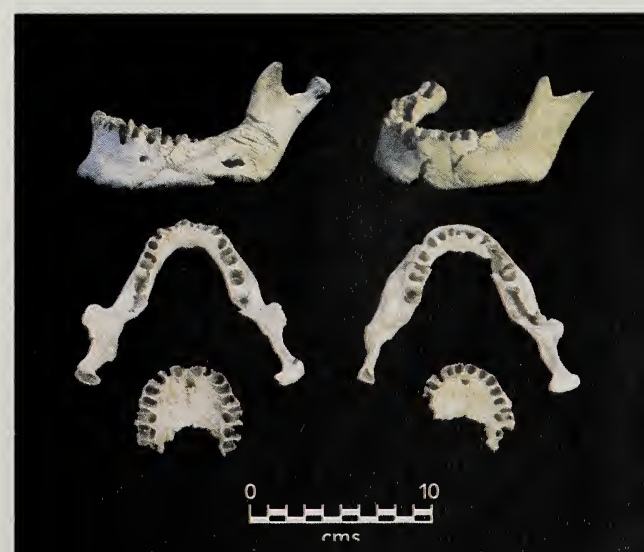




\section{HORNOS Y TUMBAS CERRO JUAN DíAZ}

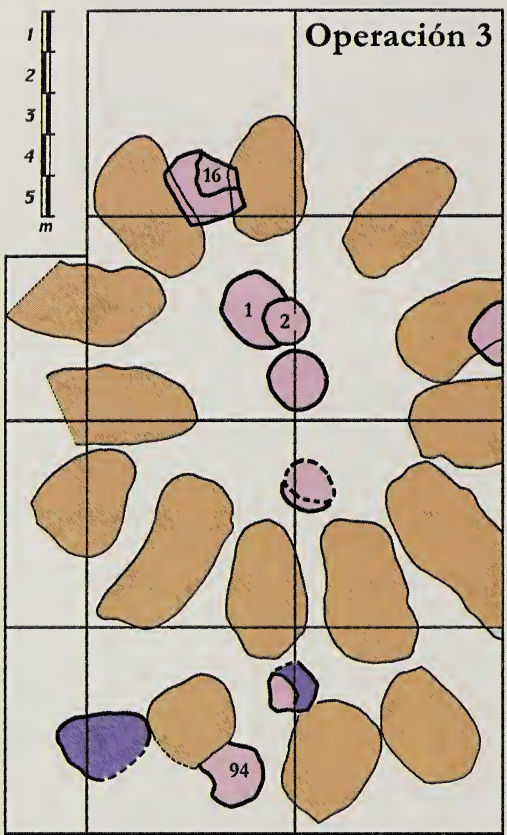

hornos

\section{tumbas debajo de hornos}

tumbas sobre hornos

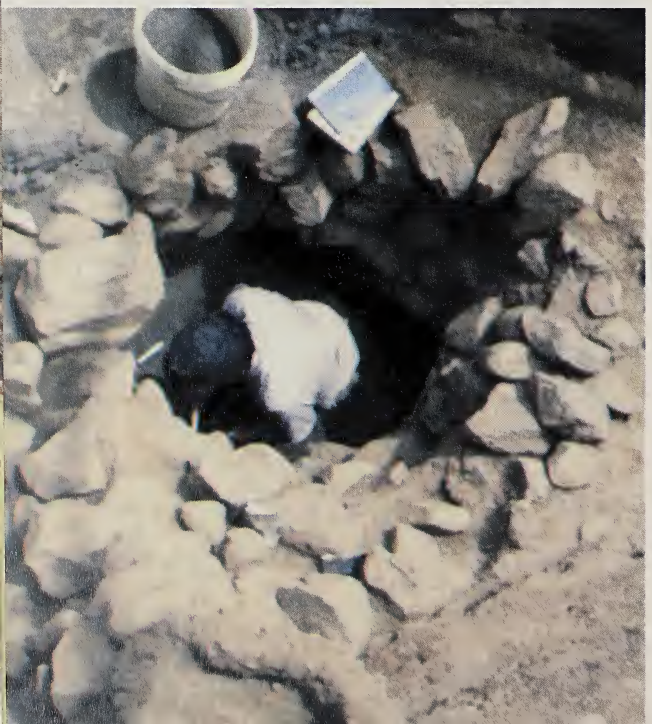

Estos fueron descubiertos por el arqueólogo kuna Aguilardo Pérez y estudiantes de la Universidad de Londres en la Operación 31, dentro de ollas monocromas, pertenecientes a 28 vasijas colocadas sobre un piso de arcilla. Dos ollas están ilustradas en la portada de este ensayo.

Adyacente a este hallazgo hay un pequeño montículo rocoso, que según una minuciosa excavación realizada por Claudia Espejel y Diana Carvajal, fue acomodado por indígenas en el siglo XIV d.C. para erigir una estructura redonda de unos 15 metros de diámetro, cuyos postes centrales se quemaron. Su piso de arcilla apermasada también estuvo sujeta al calor. La escasez de restos de comida (y otros desechos que son característicos de las viviendas), además del hallazgo de dientes y fragmentos de huesos empotrados en el piso, sugieren que esta estructura pudo haber sido una casa mortuoria del tipo que, de acuerdo a las crónicas españolas, albergaba cadáveres de ancestros "embalsamados".

El "lío luengo" que cubría los restos mortales de Antatará reposaba según Gaspar de Espinosa en semejante casa mortuoria. Se dijo al principio que el barranco en el extremo noroeste del cerro pudo haber sido el "despeñadero áspero" donde Antatará trató de repeler a los españoles. Este cacique tenía dos "asientos", el "viejo y el nuevo". Detalles topográficos registrados en las crónicas sugieren que el "asiento viejo" quedaba cerca del sitio arqueológico Finca Calderón a orillas del río Parita, donde se descubrió, en los años ' 50 , una especie de plazuela rodeada de montículos funerarios. Es posible que por su tamaño y ubicación cerro Juan Díaz hubiera sido el "asiento nuevo", incluso el mismo lugar donde Espinosa interrumpió los funerales de su rival fallecido.

Los entierros más antiguos en la plataforma se encontraron debajo de un arreglo circular de estructuras revestidas con piedras angulares las cuales posiblemente fungían como hornos para disecar a los muertos. Foto: Luis Sánchez. 


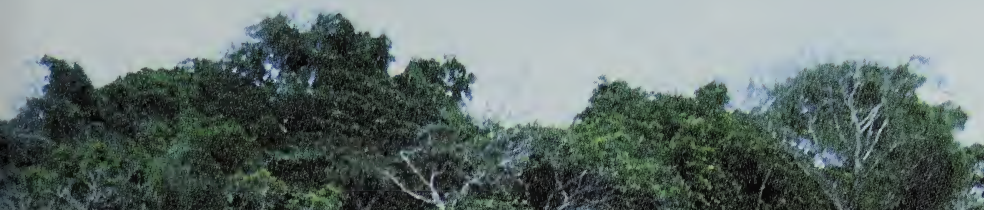

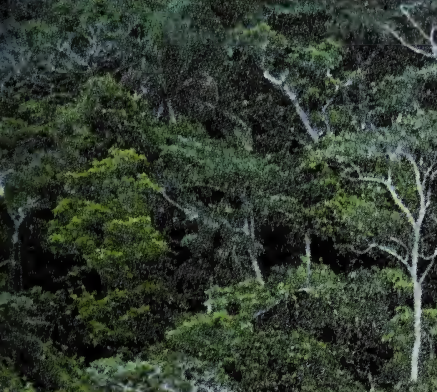

3.

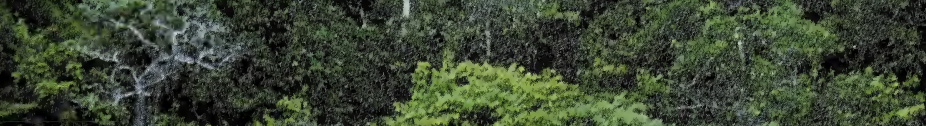

S.

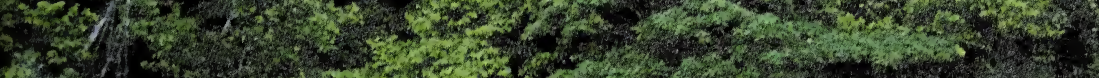
C.8.

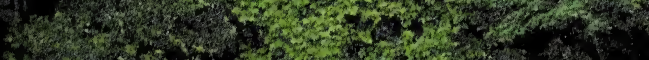

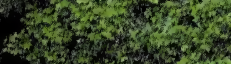

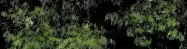

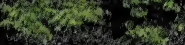

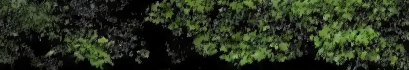

\section{Introduccion a la historia ic la isla \\ Bamo Colorado \\ Elizabeth King}


$\mathbf{P}$ ara muchas personas la isla Barro Colorado es un lugar casi mítico, debido a su ubicación no muy accesible en el lago Gatún, y también por su importancia histórica y científica como centro de estudios de biología tropical.

La isla es también casi un mito entre los científicos, ya que por muchos años, una gran cantidad de la información que se obtuvo sobre el bosque tropical del Nuevo Mundo procedía de los estudios hechos en este lugar de Panamá.

A pesar de que la Isla Barro Colorado goza del reconocimiento internacional, la divulgación sobre las investigaciones que allí se realizan ha sido mucho menor. Con esta presentación me gustaría invitarles a conocer un poco de la historia de la isla.

Voy a tratar tres temas: las personas que hicieron posible su existencia y los eventos históricos que influyeron en el desarrollo del centro de investigaciones en Barro Colorado; segundo, los cambios en las ins-

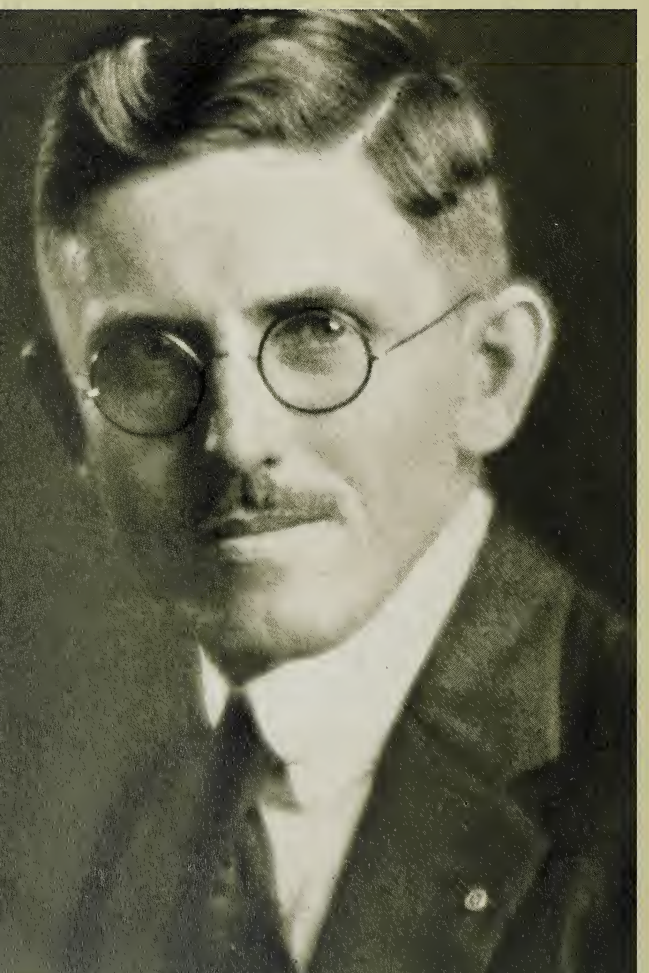

talaciones y el tipo de estudios sobre el bosque tropical efectuados en los 50 años del Instituto Smithsonian, custodio de la isla; y tercero, algunos de los principales proyectos que se llevan a cabo hoy en día.

\section{Fundación del centro de investigaciones}

Esta historia empieza con los grupos de científicos que llegaron a Panamá para combatir la fiebre amarilla y la malaria. Uno de ellos decidió quedarse, al enamorarse del país y de la riqueza natural que aquí encontró.

En 1911 el joven James Zetek viajó desde el estado de Illinois, Estados Unidos, para formar parte de un equipo que erradicaría el mosquito Anófeles de la Zona del Canal. Su trabajo como entomólogo fue estudiar la ecología de los mosquitos: entender su hábitat, su reproducción, los efectos del clima en su población, etc. En una charla que ofreció en 1938 en la Universidad de Panamá, habló de los eventos que lo trajeron a esta zona: "En Cuba, como una lejana voz en el desierto, se oía al insigne médico cubano, Doctor Carlos J. Finlay, decir que la fiebre amarilla se debía a un mosquito doméstico, y que por medio de la picada de estos mosquitos él había transmitido la enfermedad. Nadie le creía, nadie más que su buen y fiel amigo el Doctor Claudio Delgado. La prueba positiva vino con las investigaciones clásicas de los médicos del ejército de los EE.UU., Walter Reed, A. Agramonte, Jesse W. Lazear y James Carroll, asociados con algunos cubanos. El General Gorgas, entonces solamente Mayor, tenía fe en las palabras de Finlay y se comprometió en la lucha contra la fiebre amarilla basándose en la teoría de este cubano. En febrero de 1901 comenzó la batalla que lo llevaría a la fama. ¡En septiembre del mismo año no hubo más casos de esta enfermedad!

James Zetek llegó a Panamá en 1911 a estudiar los mosquitos. Su búsqueda para encontrar un sitio permanente para la investigación, hizo posible el establecimiento de la estación biológica en la Isla de Barro Colorado, en 1923.

Foto: Archivos del STRI. 
"Los americanos tuvieron éxito en la construcción del Canal principalmente porque la fiebre amarilla y la malaria habían dejado de ser un enemigo. Nadie sobresale más claramente en el horizonte que Gorgas. En la Zona, en las ciudades de Colón, Panamá, en la isla Taboga y Portobelo, él puso en práctica sus conocimientos adquiridos en Cuba y logró librar esta región de la enfermedad."

Una parte crucial de la construcción del Canal de Panamá fue la contención del río Chagres, y la inundación del área que pasaría a ser el lago Gatún. Una colina de 171 metros sobre el nivel del mar se fue separando lentamente de tierra firme, por las aguas crecientes del nuevo lago. Este proceso tomó años, de 1910 a 1914, y la colina se convirtió en la isla Barro Colorado. Con el propósito de preservar un área de esta zona para investigaciones científicas, James Zetek hizo una petición especial al General Jay J. Morrow, entonces Gobernador de la Zona del Canal, quien decretó que la isla fuera un santuario biológico, el 17 de abril de 1923; la institución que se transformaría en el Smithsonian custodiaría Barro Colorado para llevar a cabo estudios científicos y la formación del laboratorio de biología tropical.

¿Quiénes fueron los compañeros de Zetek que hicieron funcionar la estación en los primeros años de trabajo? Un grupo de personas de recursos de los Estados Unidos con interés en explorar y conocer el trópico, y los científicos que se beneficiaron del interés de aquellos.

Merece mención especial el Dr. Thomas Barbour, del Museo de Zoología Comparada de la Universidad de Harvard, por apoyar las investigaciones en Panamá, y por sus recolecciones extensivas de mamíferos, aves y reptiles, así como por sus valiosas publicaciones sobre éstos. Fue reconocido como una autoridad en reptiles y batráceos de los trópicos de América.

David Fairchild llegó a ser uno de los principales recolectores de plantas del mundo. En 1905 el General Gorgas invitó a Fairchild a establecer un jardín de plantas de los trópicos, sobre todo frutales, en Pana- má. En 1922 Fairchild estableció los jardines botánicos del Summit, que son hoy día un parque bajo administración del municipio de la Ciudad de Panamá. A él debemos también muchas de las palmeras y otras plantas que todavía crecen en la ciudad de Panamá. Fairchild apoyó los esfuerzos para establecer la estación científica en la isla Barro Colorado, y convenció a su amigo y mentor, Barbour-Lathrop, de financiar muchos de los gastos de los primeros años. E1 Doctor Frank Chapman, una autoridad mundial en pájaros, y jefe del Departamento de Aves del American Museum of National History de Nueva York, llegó a la isla con sus ayudantes, Potter y Jacques,

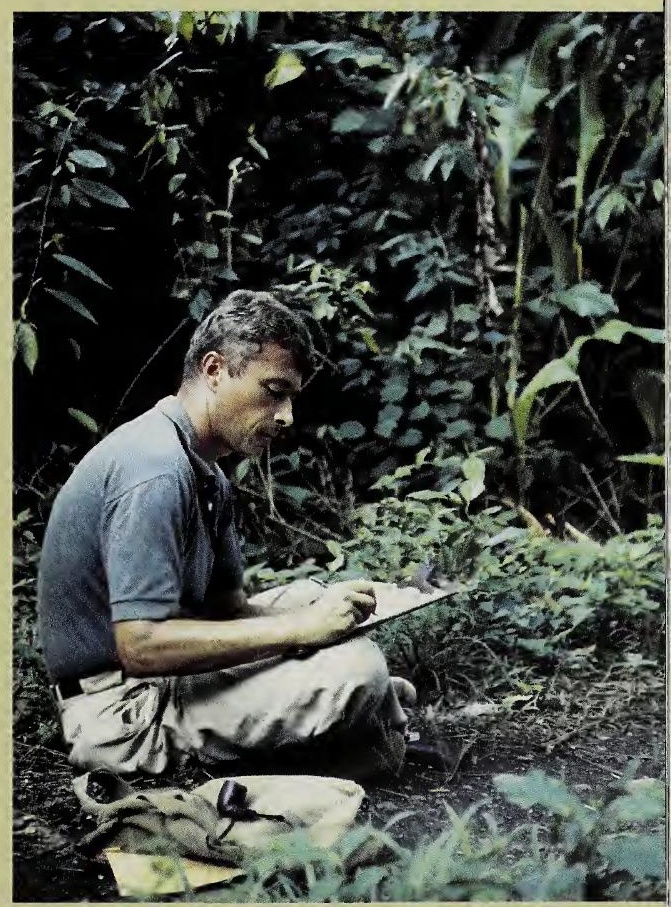

Martin Moynihan toma notas de una tropa de monos arañas (Saimiris) en Puerto Armuelles, 1967. Su clara visión del Istmo de Panamá como campo para comprobar ideas sobre la evolución, se transformó en una petición para establecer el Instituto Smithsonian de Investigaciones Tropicales en 1966. Foto: M. Hladik. 
en busca de material de historia natural para llevarlo a Nueva York y construir allí, en una gran sala, un rincón típico de la selva tropical panameña, representativa de Centro América. Chapman fue uno de los primeros en estudiar el comportamiento de aves en su entorno; construyó una casa en la isla, la cual visitó cada verano durante muchos años, y escribió varios libros populares sobre sus experiencias en Panamá. También fue uno de los primeros en usar una técnica de cámara con flash automático para "atrapar" en fotografías a los animales del bosque en la noche.

La estación de investigación de campo establecida por el Dr. Zetek sobrevivió la Primera Guerra Mundial y la Gran Depresión; a pesar de las estrecheces económicas, y para gran mérito, su fundador logró inaugurar los laboratorios en 1924, iniciar la primera clasificación de especies de plantas de la isla en 1930, y fundar el herbario en 1932.

Durante los años de 1924 a 1940 , la estación fue mantenida económicamente por el Instituto de Investigación en la América Tropical, aunque precariamente, pues los costos de traer investigadores eran muy altos y por la falta de interés sobre la biología tropical de la época. Algunos amigos filantrópicos de Barro Colorado, como Thomas Barbour y Allison Armour, siempre completaban la falta de fondos con sus contribuciones.

En los años de la Segunda Guerra Mundial, el Dr. Zetek concibió soluciones creativas para mantener la estación: dando giras y charlas a los soldados que transitaban por la zona, informándolos sobre las aves, los insectos y las serpientes venenosas de Panamá, la prevención contra garrapatas y coloradillas, contra la malaria y los mosquitos y el pie de atleta (Epidermomicosis). También realizando pruebas de materiales industriales para conocer su capacidad de resistencia a las condiciones del clima tropical.

En 1946 el Instituto Smithsonian es nombrado custodio de la Estación Biológica del Canal de Panamá. El 17 de abril de 1948, el laboratorio de la isla celebró su vigésimo quinto aniversario. Se distribuyó una estampilla conmemorativa de 10 centavos ilustrada con el perfil de la isla, dentro del cual se encontraba un gatosolo, "el mamífero más versátil e inteligente de la isla."

\section{Más infraestructura}

Zetek se retira en 1956 y Martin Moynihan es nombrado naturalista residente de la isla, y su director en 1957. Las investigaciones se centraron entonces en la biología evolutiva de las especies locales, en especial el comportamiento de los animales en su hábitat. El Dr. Moynihan continuó en Panamá sus propios estudios sobre el comportamiento social y la comunicación de las aves, los monos del Nuevo Mundo y el calamar. Moynihan reconoció la importancia de Panamá como puente biológico y barrera recién formada entre el Atlántico y el Pacífico. Tenía mucho interés en este sitio geográfico por sus implicaciones en la evolución de organismos; por ello logró establecer estaciones de investigación en las costas del Caribe y del Pacífico y unirlas junto con isla Barro Colorado como una sola entidad. Durante su gestión como director (1957-1973), el personal creció, y las facilidades para la investigación se consolidaron en el Instituto Smithsonian de Investigaciones Tropicales en 1966.

Fue este director quien tuvo la idea de establecer un núcleo de científicos que residiese permanentemente en Panamá. E1 primer grupo que se nombró estudió el comportamiento y ecología de los animales, incluyendo los monos aulladores y arañas, el apareamiento y captura de arañas tejedoras, la selección sexual de las ranas túngara, las iguanas, las poblaciones de ratones y el vuelo de las mariposas.

En 1965 se inicia el programa de becas del Smithsonian. Los programas educativos más importantes son las becas pre y post doctorales para biólogos profesionales, aunque el Instituto cuenta también con programas de becas de asistencia por tres meses y una variedad de cursos en temas especializados; la mayoría de los visitantes de Barro Colorado adquieren experiencia en los trópicos y su ecología. 
El año 1971 marca el inicio del programa de monitoreo ambiental (ESP), para empezar a relacionar los factores metereológicos y ambientales con el comportamiento de los organismos tropicales: por ejemplo, ¿por qué florecen los árboles en ciertos períodos del año? Cuando ciertos árboles no dan fruto, ¿qué les a pasa los animales que dependen de ellos para sobrevivir? ¿Se pueden detectar ciertos patrones del clima que determinan el funcionamiento del bosque, como el fenómeno de la Corriente de El Niño?

Durante los años 1960 muchos científicos de renombre visitaron la isla, invitados por el Dr. Moynihan. Si en los primeros cuarenta años el trabajo realizado fue descriptivo, identificando las especies que había en el bosque, y luego se pasó al estudio del comportamiento y la evolución de las especies, en los 1960 se estudió la influencia del ambiente en los ciclos de vida de los organismos. El segundo director transformó la remota estación de campo en un centro para la biología tropical de renombre internacional.

El Doctor Ira Rubinoff ha sido el director de STRI desde 1974 hasta hoy. En 1978, por medio de la Convención del Hemisferio Occidental para la Protección de la Naturaleza de 1941, el Dr. Rubinoff logra que las penínsulas colindantes de la isla se entreguen a la protección y el cuidado de STRI. El complejo pasa a llamarse Monumento Natural Barro Colorado.

El gobierno de Panamá establece en 1980 la reserva Parque Nacional Soberanía, en el área de tierra firme adyacente a la isla; en este mismo año la antigua Guardia Na-

Ira Rubinoff (cuarto de izquierda a derecha), director actual del STRI, sirve de anfitrión al Secretario del Interior de los Estados Unidos, Bruce Babbit (con binoculares), durante un tour al Monumento Natural de Barro Colorado, 1994. Les acompañan los científicos del STRI, Dr. Allen Herre y el Dr. Joe Wright y un guardaparques del MNBC. El Dr. Rubinoff negoció la continuación de la presencia del STRI en Panamá luego del año 2000 y es responsable de la construcción de lo último en instalaciones científicas para investigaciones de biología terrestre y marina en el Istmo.

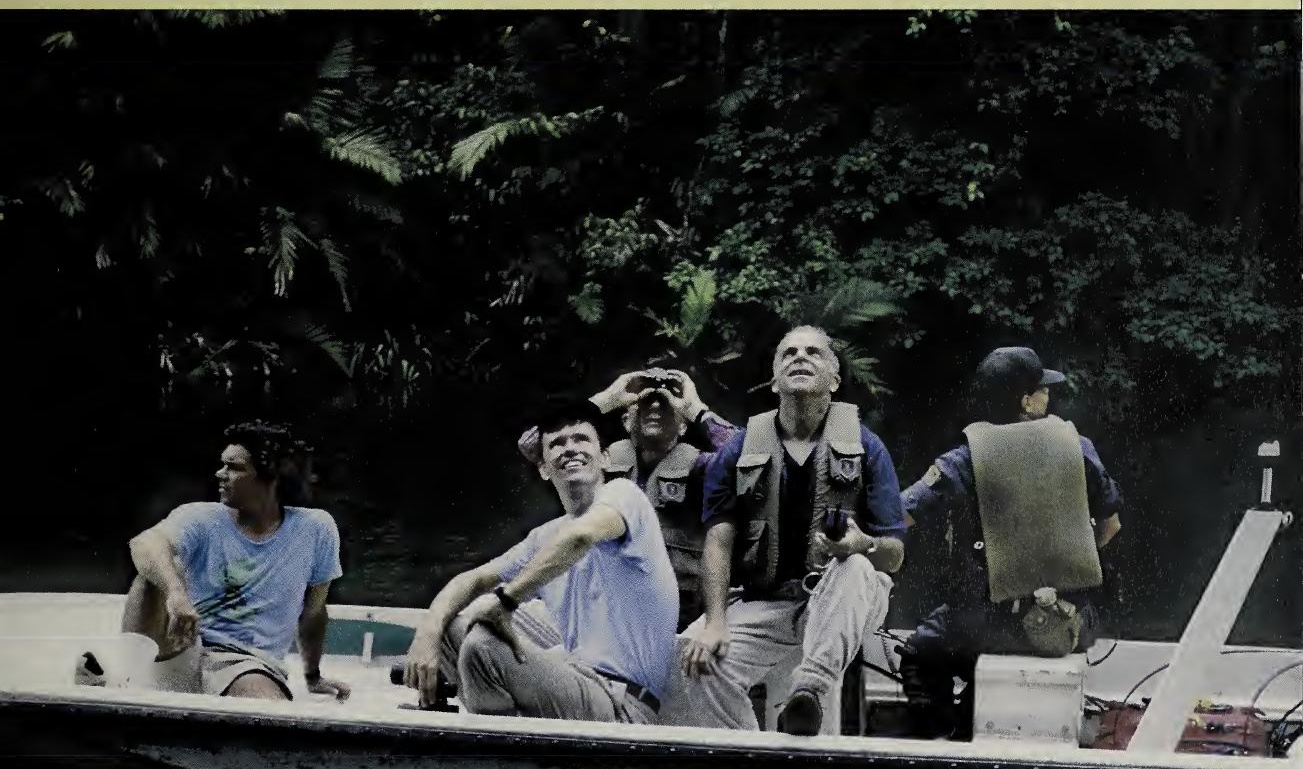


cional de Panamá inicia el patrullaje conjunto con los guardabosques del Monumento Natural Barro Colorado.

Muchas personas ayudaron en el diseño y construcción de los senderos naturales de la isla. La primera guía de senderos, Un día en la isla Barro Colorado, fue escrita por Marina Wong y Jorge Ventocilla en 1986. Esta guía fue patrocinada parcialmente por una donación del Comité de Mujeres del Instituto Smithsonian. Ese año se reemplaza el servicio de tren a Frijoles por el servicio diario de lancha a Gamboa. En 1990 se construyen nuevos dormitorios y el salón comedor.

\section{La importancia actual de Barro Colorado}

Los científicos que trabajaron en las primeras instalaciones de la isla, no hubieran podido imaginar la importancia de la que goza hoy en día, como centro de estudios para la biología tropical. El personal internacional de STRI se compone actualmente de más de 30 científicos permanentes, que realizan investigaciones en los trópicos del Nuevo y Viejo Mundo. Otros investigadores visitan el Instituto, con sede principal en Ancón, Ciudad de Panamá, en búsqueda de mayor conocimiento sobre la biología del dosel del bosque, la ecología de las plantas y la ecología marina, el comportamiento de los animales, la genética de los organismos tropicales y la conservación del ambiente, entre otros campos.

E1 Dr. Rubinoff ha modernizado las facilidades del Instituto durante su gestión, construyendo edificios y estableciendo relaciones cordiales entre la entidad y el gobierno panameño. Desde 1985 se le concedió a STRI el estatus de Misión Internacional; además, se le garantizó el uso ininterrumpido de sus facilidades en este país anfitrión hasta el año 2020 (período renovable), incluyendo, como es de esperarse, la isla Barro Colorado.

En los 15 kilómetros cuadrados que comprenden la isla, se encuentran más variedades de plantas de las que existen en todo el continente europeo; esta y otras riquezas más mantienen el interés de los estudiosos que la visitan año tras año. Setenta y siete años después de su fundación, es el área de bosque tropical con la más larga historia de investigación científica en el mundo. Barro Colorado es, y siempre será, la semilla que dio vida al Instituto Smithsonian de Investigaciones Tropicales.

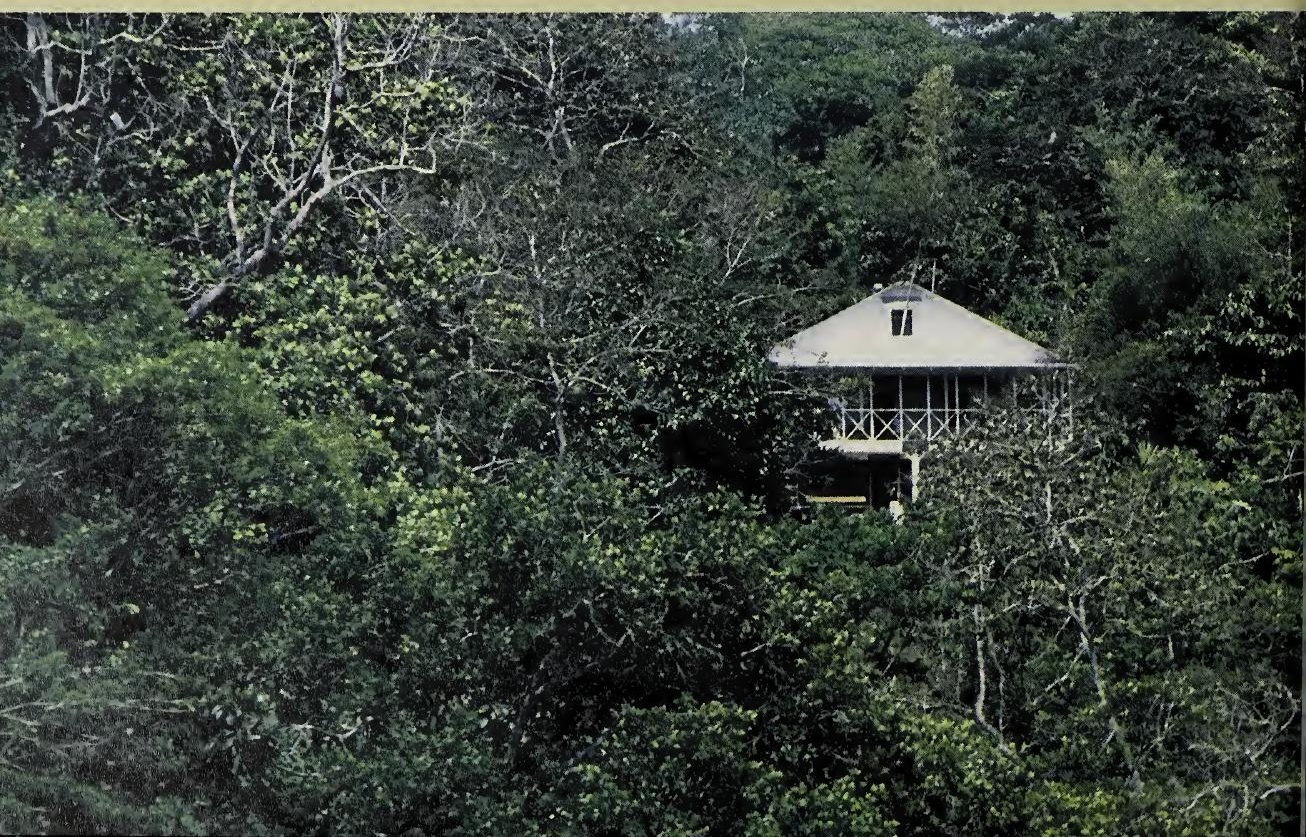




\section{CAPITULO 2}

\section{EL MUNDO \\ DE LAS \\ PLANTAS}

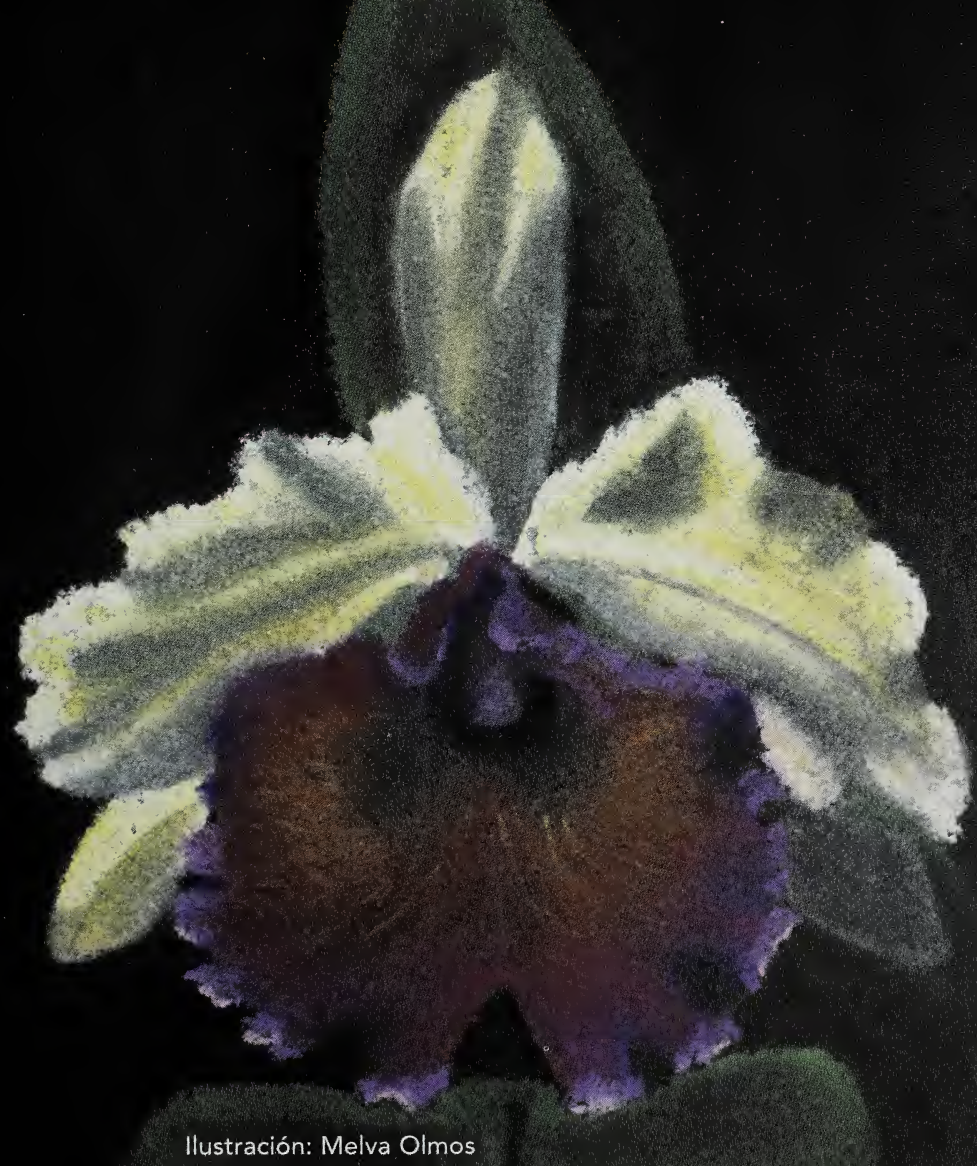


El género Podocarpus es la única conífera nativa de Panamá. Son plantas vasculares que producen semillas, pero carecen de flores y frutos. Foto: M. Correa.

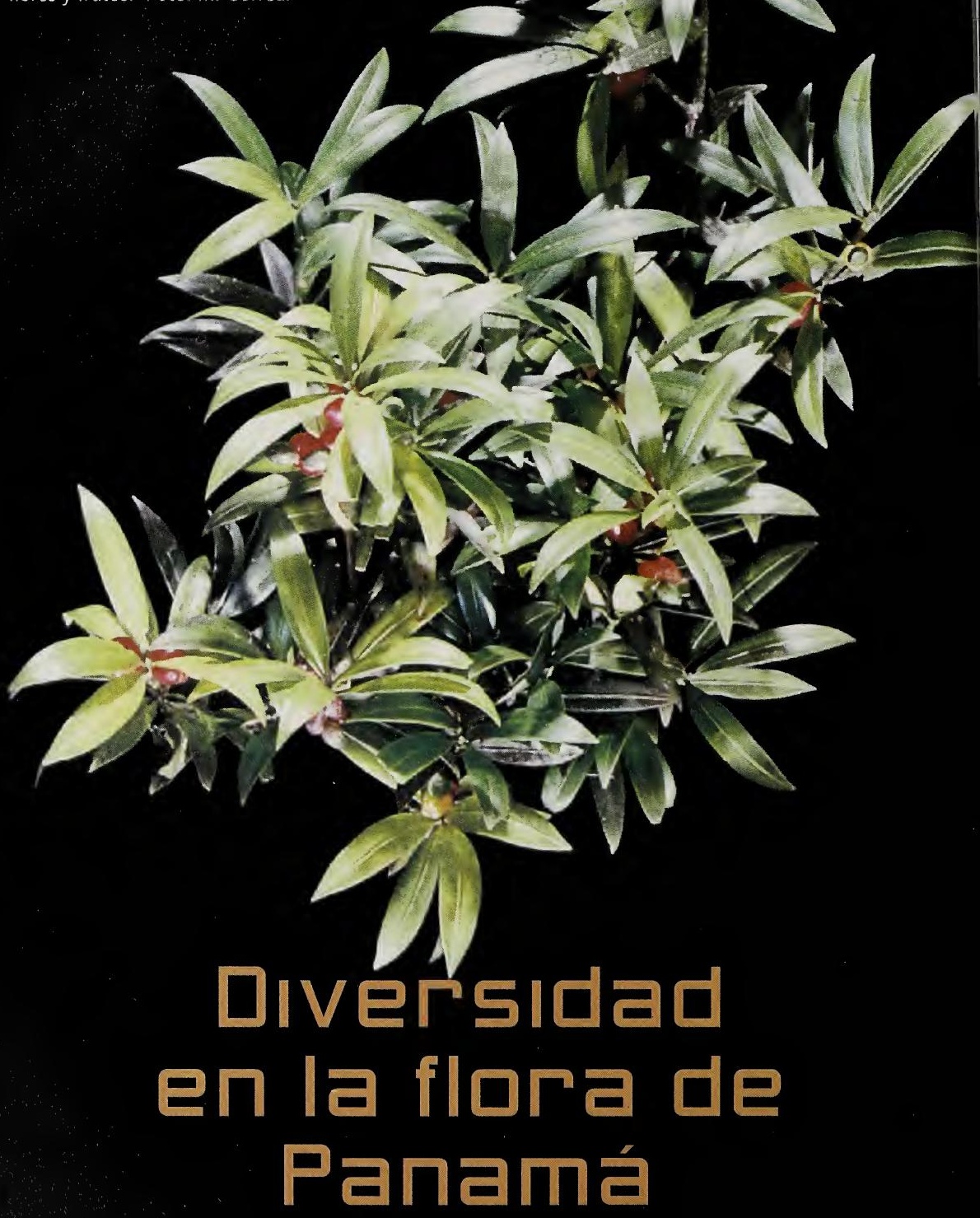


A pesar de que Panamá es un país pequeño de 75,517 kilómetros cuadrados, su flora es una de las más ricas del mundo. Esta diversidad tiene varias causas: una de ellas se remonta a más de tres millones de años, cuando el istmo surge del fondo marino y se convierte en un puente terrestre a través del cual emigran las especies entre Norte y Suramérica. Asimismo, su forma alargada y angosta, que asemeja una letra " $\mathrm{s}$ " acostada entre el Pacífico, el Caribe y las masas continentales americanas, permite el establecimiento de doce zonas de vida. Estas zonas difieren en sus tipos de suelo, patrones de lluvia, sistemas de ríos, elevaciones y temperaturas.

Otros factores físicos también contribuyen a su alta diversidad de plantas. Los océanos que rodean el istmo tienen un papel clave en su clima y la riqueza de su flora. Su litoral es extenso, compuesto por 1,287 kilómetros de costas en el caribe y 1,700 kilómetros en el pacífico. También existen 1,518 is las, islotes y cayos, destacándose Coiba, de 493 kilómetros cuadrados, la mayor isla del pacífico mesoamericano. Finalmente está la relación entre la altitud y la temperatura. Aunque la mayor parte del istmo está a nivel del mar, en su cordillera central encontramos elevaciones de 3,475 metros en el Volcán Barú y 3,335 en Cerro Fábrega.

La Aphelandra campanensis con su color rojo atrayente es polinizada por colibries. Foto: M. Correa.

\section{El número y la densidad de especies}

Las causas de la diversidad biológica son complejas. Para entenderla debe tomarse en cuenta la variación genética, los distintos ecosistemas y el número de especies. El criterio más usado para comparar la biodiversidad, entre regiones o países, es el número total de especies. Se estima que la flora de Panamá se compone de cerca de 10,000 especies de las cuales unas 1,500 (el 14.0\%) son endémicas, es decir que no se han encontrado en otra parte del mundo. En base al número total de especies, Panamá ocupa el puesto 19 a nivel mundial y es el cuarto entre los países de Norte y Centro América, sólo superada en orden descendente por Estados Unidos, México y Costa Rica.

No obstante, una escala más realista de la diversidad es la densidad de especies por kilómetro cuadrado, esto es, la relación entre el tamaño del país y su número de especies. El cuadro 2 ilustra la densidad de plantas con flores de Panamá, comparada con países cuyos territorios son mucho más extensos. Bajo este parámetro, como se muestra, la densidad de especies de Panamá es 41 veces mayor que la de China, 21 veces la de Brasil y 4 veces la de Colombia.

\section{Las plantas vasculares}

Tradicionalmente, los botánicos han dividido las plantas en dos grandes grupos: las vasculares y las no vasculares. Las vasculares cuentan con un tejido interno especial

\section{Cuadro 1}

Estimado del número de especies de plantas en el mundo, en el neotrópico y en Panamá

\begin{tabular}{|lrrr|}
\hline \multicolumn{1}{|c}{ Plantas } & Mundo & Neotrópico & Panamá \\
\hline Angiospermas & 250,000 & 90,000 & 8,000 \\
\hline Gimnospermas & 500 & 180 & 15 \\
\hline Helechos y afines & 15,000 & 4,000 & 935 \\
\hline Briofitas & 13,000 & 5,000 & 800 \\
\hline Totales & 278,500 & 99,180 & 10,233 \\
\hline
\end{tabular}

En el cuadro 1 no se incluyen líquenes, algas, ni hongos, ya que hoy estos organismos no se consideran parte del reino vegetal. Como el país carece de especialistas en hongos y algas, desconocemos el número de especies y su distribución en Panamá. 
Cuadro 2

La densidad de plantas con flores en varios países (especies por kilómetro cuadrado)

\begin{tabular}{|lrcc|}
\hline \multicolumn{1}{|c}{ País } & $\begin{array}{c}\text { Superficie } \\
\left.\text { (en } \mathrm{km}^{2}\right)\end{array}$ & $\begin{array}{c}\text { Número de } \\
\text { especies } \\
\text { (estimado) }\end{array}$ & $\begin{array}{c}\text { Densidad } \\
\text { (especies por } \\
\text { en } \mathrm{km}^{2} \text { ) }\end{array}$ \\
\hline China & $9,596,961$ & 27,100 & 0.003 \\
\hline Estados Unidos & $9,372,614$ & 18,956 & 0.002 \\
\hline Brasil & $8,511,996$ & 50,000 & 0.006 \\
\hline Colombia & $1,141,748$ & 45,000 & 0.039 \\
\hline Panamá & 75,517 & 8,483 & 0.112 \\
\hline Costa Rica & 51,100 & 11,000 & 0.215 \\
\hline
\end{tabular}

Económicamente, las angiospermas son las plantas más importantes para la humanidad, produciendo la mayoría de nuestros alimentos, como los cereales, frijoles, vegetales, condimentos y frutas comestibles. Muchísimas sirven como fuente de medicinas, como la quinina, ipecacuana, cortisona, digitalina y la morfina. También son angiospermas centenares de especies de árboles maderables como la caoba, maría, roble y cedro. A otras les extraemos productos industriales como caucho, carbón, balata, acei-

para conducir el agua absorbida por sus raíces y las substancias alimenticias elaborada por sus hojas mediante la fotosíntesis.

Entre las vasculares, el grupo con más especies es el de las angiospermas (del griego angio: cubierta y sperma: semilla), plantas que producen flores, frutos y semillas. Ellas son las más exitosas del reino vegetal, habiéndose adaptado a los hábitat más diversos, desde las tierras bajas a las montañas, en sitios muy húmedos o en lugares inhóspitos como los polos y desiertos. Pueden ser terrestres o acuáticas. Otras son epífitas, que usan a otras plantas como soportes. También abarca este grupo a las parásitas que se alimentan de las plantas que les dan hospedaje.

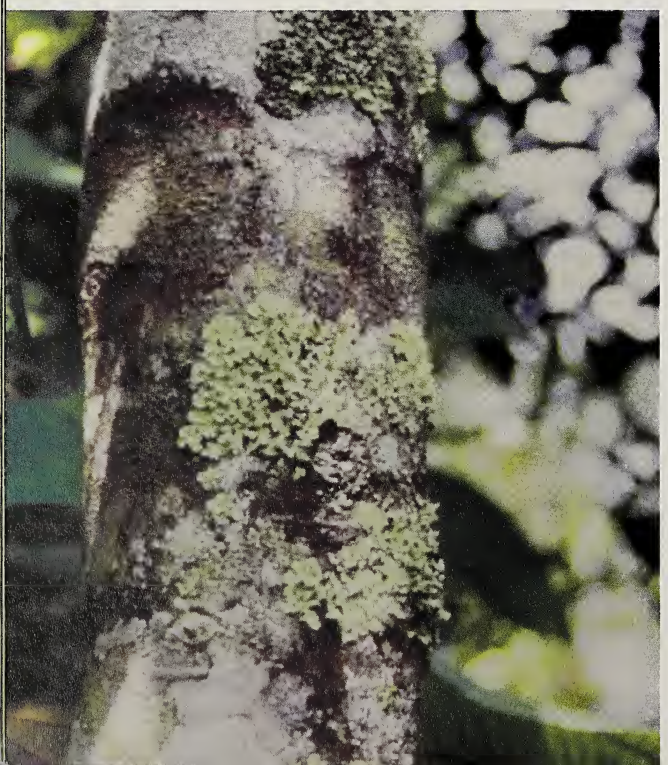

tes y taninos para curtir pieles y colorantes.

De las plantas conocidas para Panamá, el $82 \%$ (unas 8,483 especies) son plantas con flores. Las provincias con más especies son: Panamá con 3,414 ; Chiriquí con 3,258 ; Coclé con 2,318 y Darién con 2,303. Las provincias con menos especies son Herrera con 456 y Los Santos con 567. La Comarca de San Blas o Kuna Yala tiene 1,143 especies de angiospermas (cuadro 3 ).

Dos factores afectan los datos sobre la distribución provincial de las angiospermas: el número de expediciones botánicas realizadas y la cobertura boscosa de cada provincia. El mayor número de colectas botánicas se ha hecho en Panamá, Chiriquí y Darién, que son las provincias con más especies. Igualmente, Darién y Panamá tienen la mayor cobertura boscosa.

Chiriquí ha sido objeto de innumerables colectas botánicas, debido a su variado paisaje que incluye las mayores elevaciones de $\mathrm{Pa}$ namá, y por contar con hábitat muy especiales, como los bosques premontanos.

Las provincias de Herrera y Los Santos en la Península de Azuero, que tienen menos bosques y los cuales son los más degradados, han recibido escasa atención de los botánicos. Por ello es sumamente importante proteger el Parque Nacional Cerro Hoya y las

Los líquenes están formados por una comunidad de organismos constituida por algas y hongos. Se aprecian líquenes costrosos sobre la corteza del árbol. Foto: M. Correa. 
Cuadro 3

Reservas Forestales de El Montuoso y La Tronosa, donde están las últimas selvas de ambas provincias.

En el cuadro 4 se distribuyen las plantas de Panamá de acuerdo a sus formas biológicas, es decir, según su porte o aparencia externa.

\section{Gimnospermas}

También son plantas vasculares las gimnospermas, (del griego gimno:descubierto $\mathrm{y}$ sperma: semilla, que tienen semillas pero carecen de flores y frutos. Sólo se conocen 15 especies nativas a Panamá, pertenecientes a tres distintos géneros (Gnetum, Zamia y Podocarpus). Según Stevenson (1993), en Panamá, el género Zamia posee la mayor diversidad morfológica y número de especies por área que ninguna otra región de los trópicos americanos. El género Podocarpus cuenta con tres especies, incluyendo el único "pino" o conífera panameña. Usualmente se les encuentra en bosques húmedos de altura, aunque se han registrado especies en las islas de Coiba, Escudo de Veraguas y Bastimentos, y en cerro Campana.

Panamá cuenta con un gran número de especies exóticas de gimnospermas, siendo las más comunes el pino caribea centro americano y la araucaria suramericana.

\section{Los helechos}

Finalmente, pertenecen a las plantas vasculares los helechos cuya antigüedad data de hace más de 300 millones de años. Tienen tejido conductor pero carecen de semillas, flores y frutos. Panamá cuenta con unas 935 especies, principalmente en bosques nubosos. La mayoría prefiere sitios húmedos y su diversidad aumenta con la altitud.

Los helechos de Panamá guardan estrecha relación con los de Colombia y Costa Rica. Entre los helechos panameños encontramos

La planta Lepidopilon, es un musgo o briofita que se encuentra sobre troncos en descomposición. Algunos musgos forman almohadillas que retienen la humedad y sirven de sustrato para que germinen semillas y como hogar para animales pequeños. Foto: M. Correa.
Estimado de especies y de endémicas de angiospermas registradas en cada provincia de la República de Panamá

\begin{tabular}{|c|c|c|}
\hline Provincia & $\begin{array}{l}\text { Número de } \\
\text { especies }\end{array}$ & $\begin{array}{l}\text { Número de } \\
\text { endémicas }\end{array}$ \\
\hline Bocas del Toro & 1,840 & 152 \\
\hline Coclé & 2,318 & 286 \\
\hline Colón & 1,687 & 185 \\
\hline Chiriquí & 3,258 & 358 \\
\hline Darién & 2,303 & 243 \\
\hline Herrera & 456 & 6 \\
\hline Los Santos & 567 & 16 \\
\hline Panamá & 3,414 & 413 \\
\hline San Blas & 1,143 & 134 \\
\hline Veraguas & 1,558 & 193 \\
\hline
\end{tabular}

Cuadro 4

Estimado del número y porcentaje de especies de la flora de Panamá representadas en cada hábito y formas de crecimiento
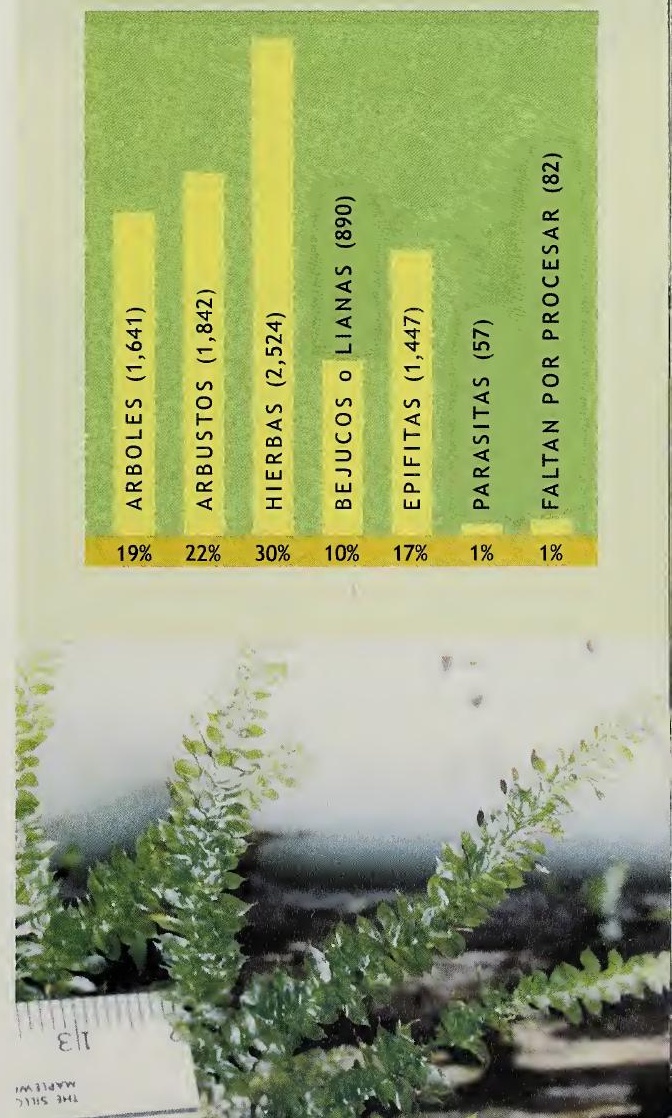


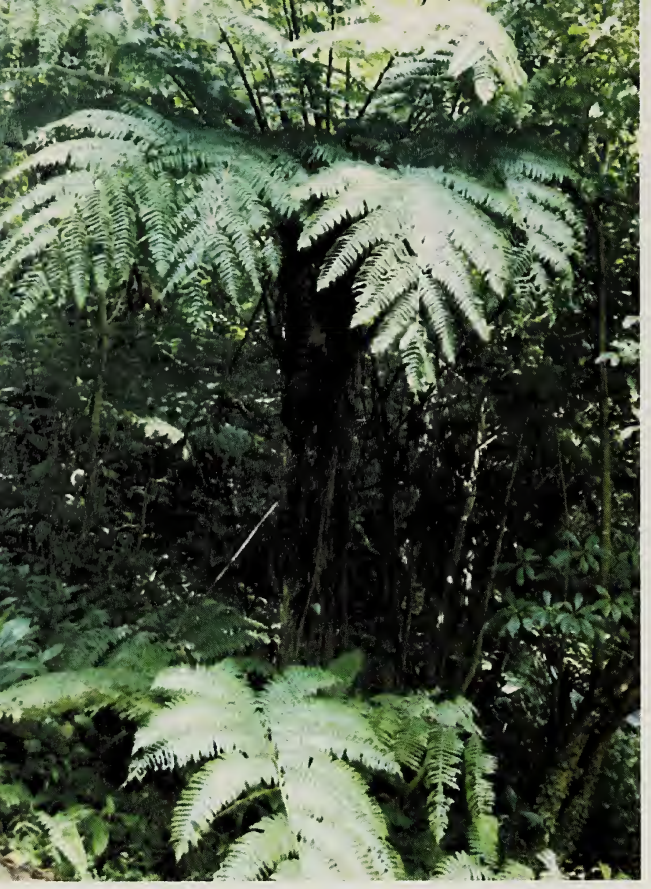

El helecho arbóreo Alsophila cuspidata es una planta vascular que no produce semillas, flores ni frutos. Su origen es muy antiguo, por lo que su conservación es de suma importancia. Foto: M. Correa.

especies originarias de Norte y Sur América así como de las islas del Caribe. También hay especies que sólo se encuentran en zonas montañosas específicas como el Volcán Barú, Fortuna, cerro Campana y cerro Jefe. Algunas especies típicas a estas montañas son los helechos arbóreos, plantas consideradas reliquias de un pasado remoto. Sus raíces y tallos se utilizan como sustrato para

\section{Cuadro 5}

Períodos de las exploraciones botánicas en Panamá.

\begin{tabular}{|c|c|c|}
\hline Períodos & Procedencia & Botánicos \\
\hline $1700-1914$ & Europa & Wallace, Seemann, Billberg... \\
\hline $1915-1957$ & Norteamérica & Standley, Steyermark, Allen... \\
\hline $1958-1981$ & $\begin{array}{l}\text { Norteamérica } \\
\text { y Panamá }\end{array}$ & $\begin{array}{l}\text { Gentry, Mori, Dressler, Carrasquilla, } \\
\text { Correa, Escobar, Taylor, Salazar... }\end{array}$ \\
\hline $1982-2000$ & $\begin{array}{l}\text { Diversas } \\
\text { nacionalidades }\end{array}$ & $\begin{array}{l}\text { Foster, Almeda, Maas, Velayos, } \\
\text { Castroviejo, también otros } \\
\text { panameños... }\end{array}$ \\
\hline
\end{tabular}

cultivar orquídeas, una práctica que los pone en peligro de extinción.

\section{Las plantas no vasculares}

A las plantas sin tejido vascular se les llama briofitas. Ellas absorben el agua a través de todo su cuerpo. Son más abundantes en los bosques húmedos, a más de 500 metros de altitud, en sitios con baja temperatura y luz moderada. Este grupo se divide en musgos, hepáticas y antocerotes.

Hasta hace poco no existía un especialista panameño en briofitas. Actualmente, gracias a los estudios de la Dra. Noris Salazar Allen, entendemos mejor el número y distribución de estas plantas.

Quizás nunca sabremos cuán rica en plantas es Panamá. Lo que sí sabemos es que contínuamente aumenta el número de especies registradas. Ejemplo de ello es el caso de las plantas con flores. De los países centroamericanos, Panamá es el único que cuenta con un estudio amplio, realizado a lo largo de muchos años, que ha intentado describir a todas estas plantas. Esta monumental obra, llamada Flora de Panamá, se inició en 1943 bajo la coordinación del Missouri Botanical Garden de Saint Louis. Al concluirse este esfuerzo científico, en 1980, se habían registrado 5,314 especies distribuidas en 192 familias y según D’Arcy (1987) el número de especies era de 7,345 pertenecientes a 195 familias. Para el año 2001, después de que se exploraron regiones poco estudiadas, su número aumentó a 8,483 especies y 213 familias de plantas (cuadro 6).

Cuando en 1949 se completó el estudio de las orquídeas de Panamá, describiendo todas las especies conocidas hasta entonces, su número era de 469. Actualmente el número de especies llega a 1,073 , casi tres veces mayor. Seguramente en el futuro se descubrirán nuevas especies que aumentarán el número total de plantas panameñas. 
Otra razón por la cual probablemente nunca conoceremos en su totalidad nuestra riqueza botánica, es la deforestación de los bosques, que se destruyen a razón de unas 50,000 hectáreas anuales. Para el año 2005 apenas le quedará al país un $35 \%$ de su cobertura boscosa, extinguiéndose para siempre innumerables especies de plantas y animales.

\section{Importancia de la conservación}

Se estima que a inicios del siglo XXI Panamá cuenta con cerca del $30 \%$ de su territorio cubierto con bosques, en donde se concentra la mayor diversidad de plantas. Se estima que el $28 \%$ de estos bosques están dentro del Sistema de Áreas Protegidas. Tanto en las áreas protegidas como en las que no están, la diversidad de la flora y fauna se encuentra en peligro de desaparecer.

La presión humana sobre el bosque ha aumentado en las últimas décadas. En el futuro hasta las áreas protegidas serán afectadas, lo que hace impostergable dar más protección a las áreas silvestres establecidas, así como incorporar ecosistemas de alta biodiversidad que hoy están desprotegidos tales como Cerro Tute en Veraguas, el Chorogo y los humedales del Golfo de Chiriquí, en la provincia de Chiriquí; la isla Escudo de Veraguas y las lagunas de río Caña, en Bocas del Toro; el Archipiélago de Las Perlas, la

Literatura citada.

Correa, A., M. D., Foster, R. \& Galdames, C. 2001. Flora de Panamá: Base de Datos. Herbarios de la Universidad de Panamá y del Instituto Smithsonian de Investigaciones Tropicales.

D'Arcy, W. G. 1987. Flora of Panamá. Checklist and Index. Monograph Syst. Bot. Missouri Bot. Gard. $17 \& 18$.

Stevenson, D. W. 1993. The Zamiaceae in Panama with comments on phytogeography and species relationships. Brittonia 45: 1-16.

Woodson, Jr., R. E., Schery, R. W. et al. 1943-1980. Flora of Panama. Annals of the Missouri Botanical Garden.
Cuadro 6

Variación en el número de familias y especies de plantas, 1980,1987 y 2001.

\begin{tabular}{|crrrr|} 
& $\begin{array}{r}\text { Woodson et al. } \\
(1943-1980)\end{array}$ & $\begin{array}{r}\text { D'Arcy } \\
(1987)\end{array}$ & $\begin{array}{r}\text { Correa et al. } \\
(2001)\end{array}$ \\
\hline Familias & 192 & 195 & 213 \\
\hline Especies & 5,314 & 7,345 & 8,483 \\
\hline
\end{tabular}

Serranía del Majé en la provincia de Panamá y la Punta de Garachiné, en Darién.

Así, en efecto, nuestro país podrá mantener, para beneficio de las presentes y futuras generaciones, la extraordinaria diversidad de flora con que contamos.

Conservar la flora de la cual dependemos para nuestra existencia es vital para el futuro de nuestra especie en el planeta y, definitivamente, es tarea de todos los grupos que componen nuestra sociedad y, por supuesto, una responsabilidad prioritaria e ineludible del estado.

El género Columnea es una planta epífita común en nuestros bosques, sobre todo en los bosques nubosos. Son plantas vasculares que producen semillas, flores y frutos.

Foto: M. Correa.

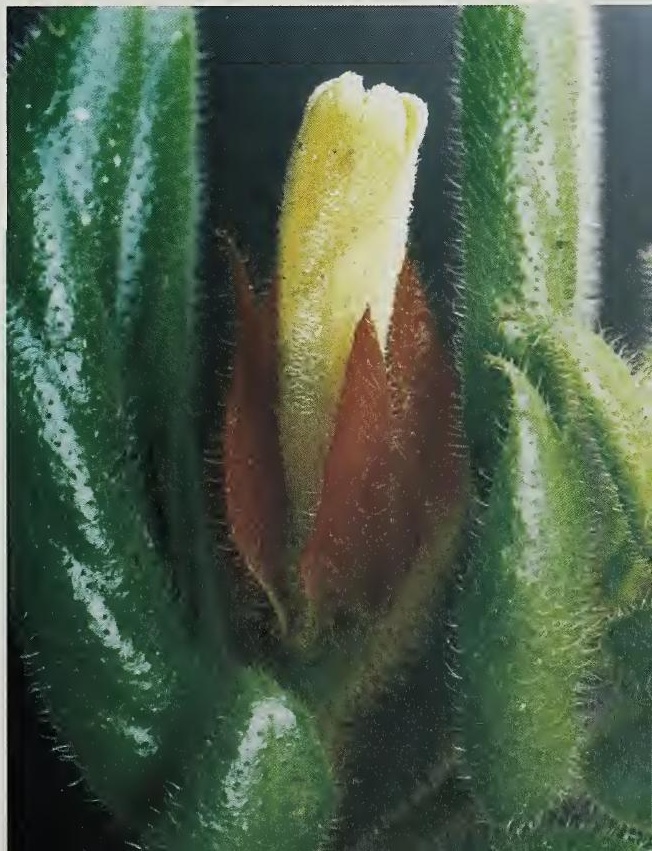




\section{Plantas pequeñas en lo más alto del bosque tropical}

\section{José Luis Andrade}

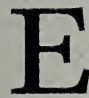

1 bosque tropical tiene cuatro capas de vegetación, una de las cuales crece sobre los troncos, ramas, e incluso encima de las hojas de árboles y arbustos; estas plantas reciben el nombre de epífitas, del griego epi, que significa sobre, y fito, que quiere decir planta: esto es, que crece o vive sobre las plantas. Frecuentemente sus flores son las más hermosas del bosque. Es común la creencia que ellas se alimentan de las plantas que las hospedan y que son parásitas; en verdad no lo son, ya que al igual que otras plantas, toman sus alimentos del ambiente. Cuando vemos los muros de las casas abandonadas o los alambres eléctricos en las ciudades, observamos que en ellos también existen estas plantitas, muchas de las cuales son del mismo tipo de las que crecen sobre los árboles.

La orquídea Caularthron bilarnellatum en un árbol de anona en Barro Colorado. Esta planta muestra los tallos carnosos, llamados seudobulbos, característicos a muchas orquídeas. En esta planta, los seudobulbos son huecos y frecuentemente los habitan hormigas.

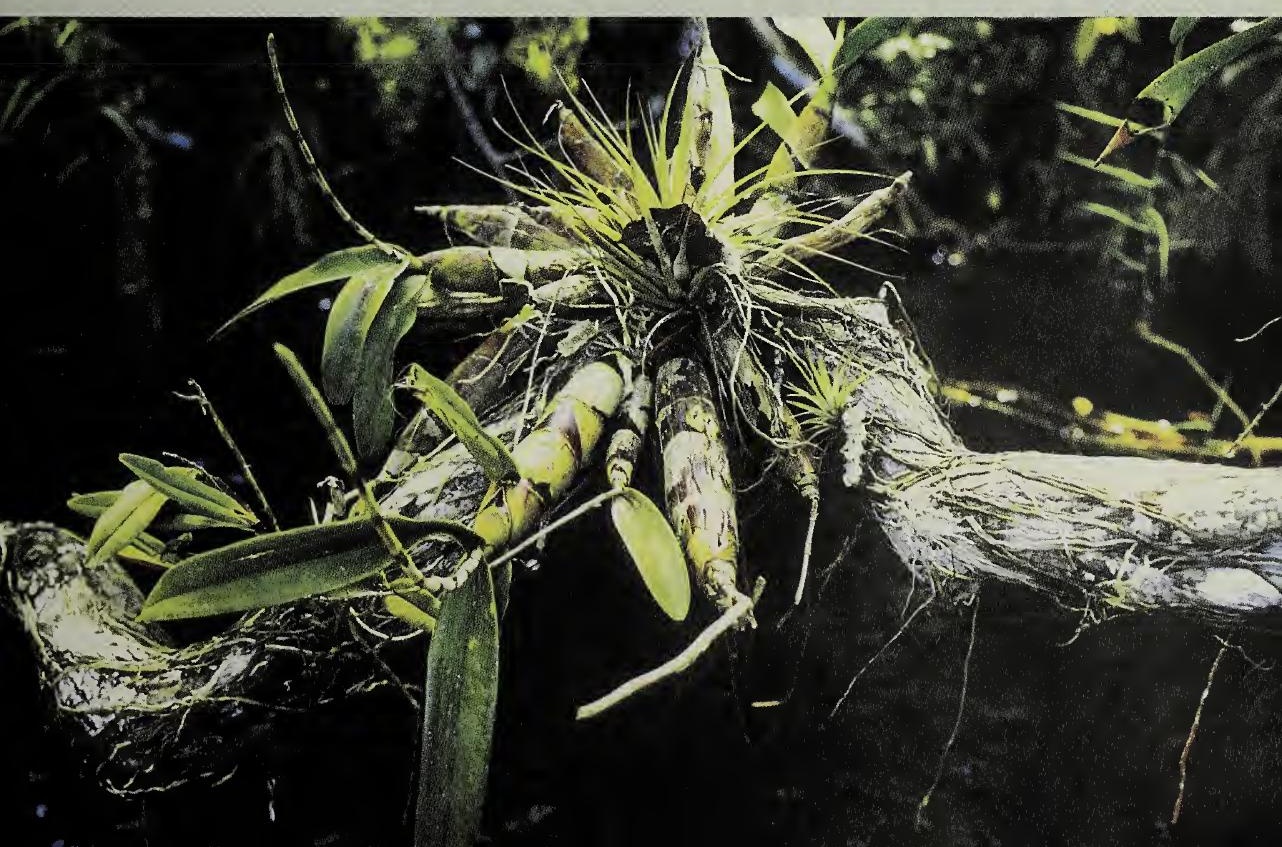


Las epífitas pertenecen a varias familias de plantas; entre las principales están las orquídeas, las bromeliáceas y los helechos. Las bromeliáceas son nativas de América $\mathrm{y}$ habitan en muchos bosques, e incluso en desiertos. Otra característica particular de las bromeliáceas epífitas es que carecen de raíces y absorben el agua y las sales minerales únicamente por sus hojas, mediante estructuras especializadas.

\section{La búsqueda de luz}

En los bosques tropicales los árboles deben crecer altos para alcanzar la luz solar, que les proporciona energía necesaria para efectuar la síntesis de los azúcares o fotosíntesis. En ellos abunda el agua (la mayor parte del año) y los minerales están siempre presentes en el suelo por la descomposición de la materia orgánica, es de cir, las hojas, ramas y troncos de los árboles. Sin embargo, en la parte baja del bosque, el sotobosque, donde la luz es escasa, pocas plantas pueden vivir. Siendo la luz uno de los recursos más limitados allí, la única manera en que las plantas pueden alcanzarla es utilizando a los árboles mayores como soporte.

Otro tipo de plantas que también emplean a los árboles grandes para este propósito son los bejucos, ya sean enredaderas o trepadoras y las lianas, que son enredaderas leñosas. Ellas tienen sus raíces en el suelo, pero sus hojas alcanzan las partes altas del bosque, al igual que las epífitas, obteniendo así luz abundante para crecer.

Gracias a sus raíces, los árboles y plantas trepadoras obtienen minerales y agua del suelo; las epífitas deben hacerlo por medio del agua que se escurre por las ramas y troncos de los árboles, enfrentando escasez.

\section{Para sobrevivir en lo alto del bosque}

Casi todas las epífitas asemejan a las plantas del desierto, es decir, tienen características que les ayudan a conservar el agua y tolerar la sequía. En algunas encontra-

Una bromelia del género Tillandsia en un bosque de Florida muestra la acumulación de materia orgánica, la cual se puede llegar a descomponer dentro de su tanque, proporcionándole minerales para su crecimiento.

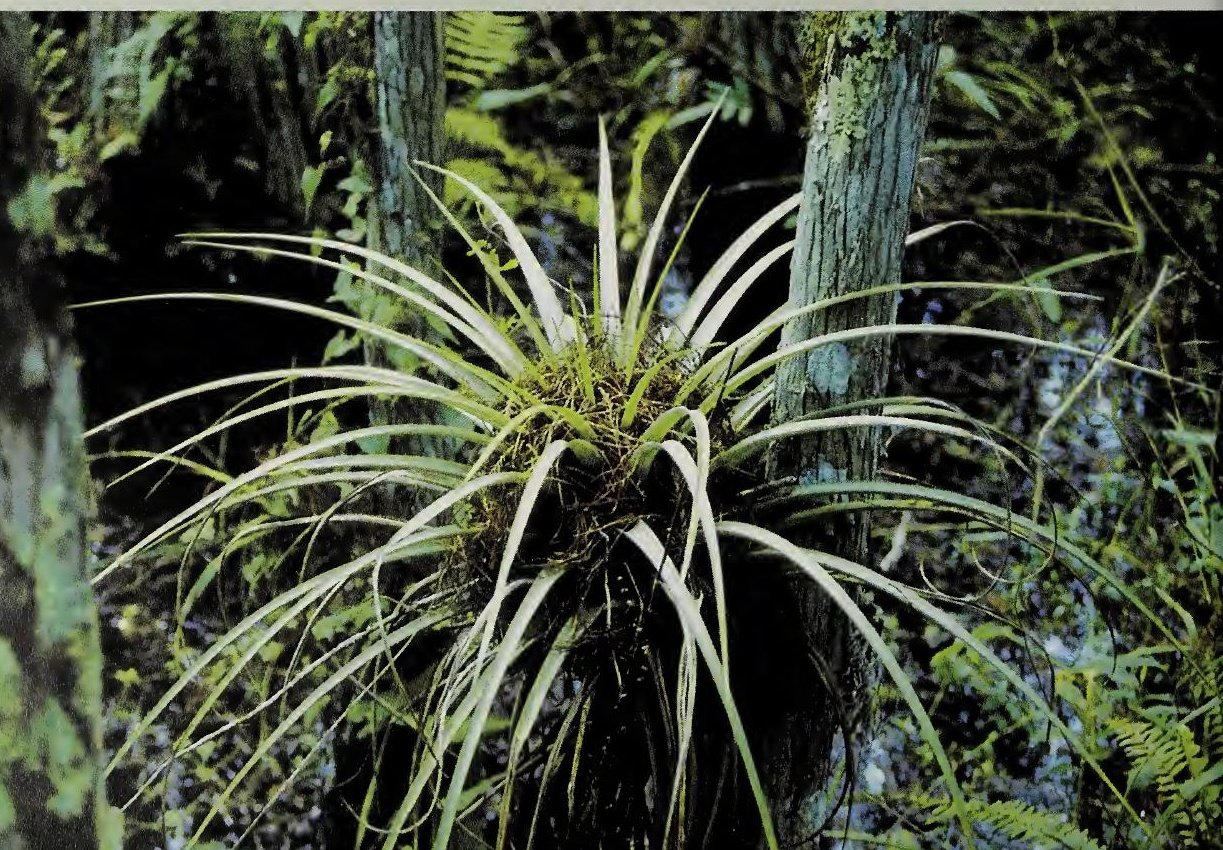




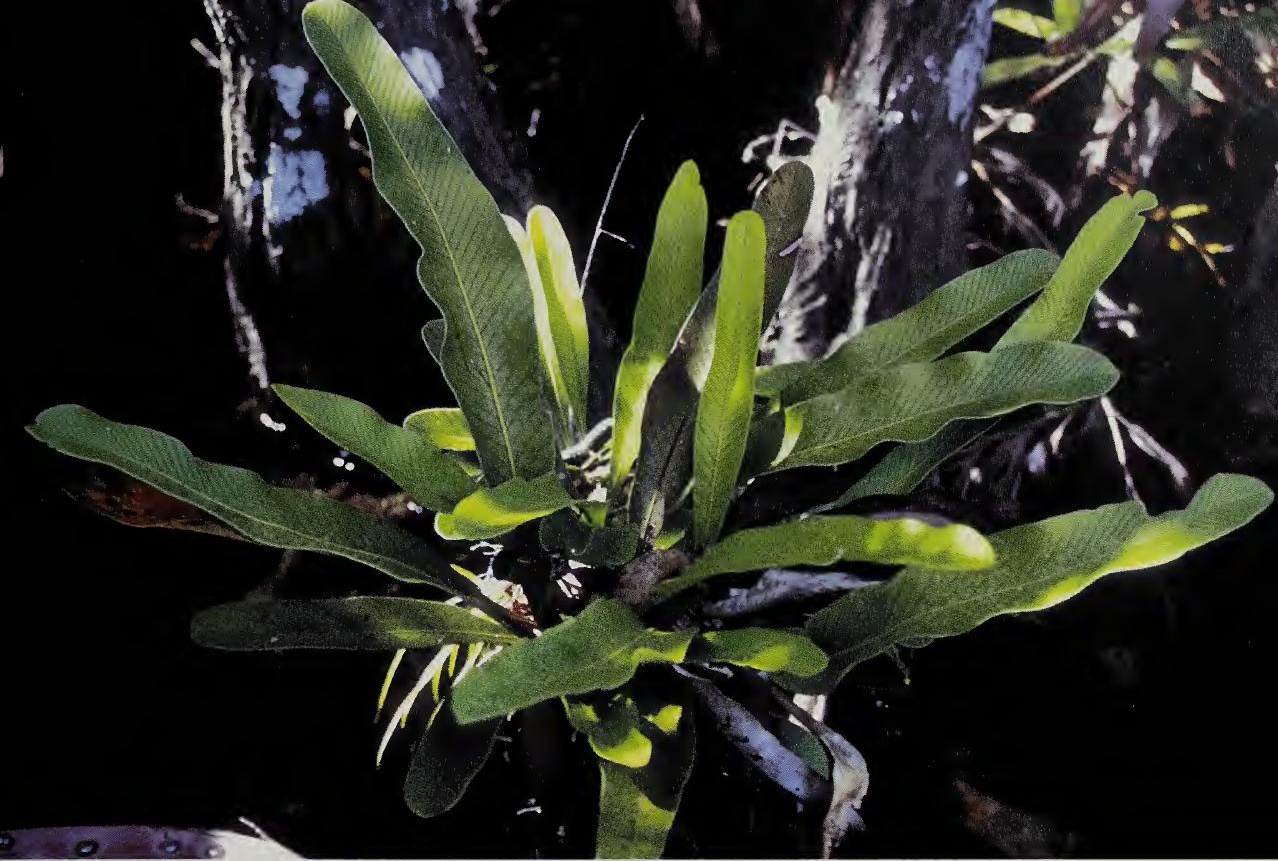

Arriba: Un helecho epífito llamado Polypodium crassifolium, creciendo sobre un árbol en un bosque lluvioso de Costa Rica. Se observa que sus raíces forman una especie de nido, donde se acumula materia orgánica. En estas plantas la biomasa de las raíces puede ser el doble de la biomasa aérea.

mos tallos y hojas suculentas para almacenar agua; también una cutícula gruesa, es decir, una capa cerosa en la epidermis que impide la pérdida de agua. Sus tejidos resisten la desecación y tienen un metabolismo especial, llamado metabolismo ácido de las crasuláceas. Un comportamiento en el cual los estomas (las estructuras de las hojas que se abren para obtener el bióxido de carbono de la atmósfera para realizar la fotosíntesis) se abren por la noche (en todas las demás plantas los estomas se abren de día) y así reducen la pérdida de agua. Este tipo de metabolismo nocturno es muy común de las epífitas y muchas plantas del desierto como los cactus.

A través de nuestros estudios, hemos descubierto que las plantas que se adaptan mejor a la sequía viven en los lugares más expuestos del dosel, o la copa de los árboles. Así, las plantas que son más susceptibles a la pérdida de agua sobreviven mejor en los sitios más sombreados. Este comportamiento se acentúa en las plantas jóvenes, pues en algunos casos, las plantitas de algunas epífitas pueden perder más del $50 \%$ del agua de sus tejidos en un día sin lluvia.

\section{Las relaciones entre las plantas y los insectos}

Los ecosistemas tropicales son muy complejos, ejemplo de ello son las estrechas asociaciones que existen entre diversas especies de plantas y animales, sin las cuales no podrían subsistir por sí mismas. Las epífitas se asocian con varios tipos de animales para obtener minerales en abundancia. Entre las principales asociaciones que hacen están las hormigas; muchas epífitas tienen orificios y órganos huecos en sus hojas y tallos, donde los insectos construyen sus nidos: se cree que al mismo tiempo las raíces de las epífitas ayudan a mantener la estructura del nido. Otro ejemplo son los llamados jardines de hor- 
migas, que ocurren cuando estos insectos colectan semillas y las llevan a sus nidos, donde germinan y crecen formando jardines. De esta forma, gracias a las actividades de las hormigas, mucha materia orgánica se acumula dentro de estas plantas o en sus raíces.

\section{Conservación de las epífitas}

Por último, debemos hablar acerca de la importancia de conservar este recurso. Debido a que la mayoría de las epífitas crece lentamente, su recolección por parte del hombre afecta a las poblaciones de estas diminutas plantas, y a su vez, a las de las especies asociadas a ellas. Desde hace muchos años, las epífitas se han recolectado por sus formas raras y sus hermosas flores, especialmente donde son abundantes, como en los bosques nubosos de altura. Debido al exceso de recolección, muchas especies raras han desaparecido. De nosotros depende legar este maravilloso recurso a nuestros hijos, evitando recolectar epífitas en los bosques y comprándolas más bien en los viveros que las producen.

Asimismo podemos protegerlas evitando talar las selvas, pues un solo árbol puede contener cientos de pequeñas plantas que crecen sobre sus ramas y tronco.

Las epífitas son muy diversas, en el bosque tropical de Panamá podemos encontrar un elevado número de especies, las cuales pueden pertenecer a diversas familias como las: Bromeliaceae, Orchidaceae, Cactaceae, Araceae, entre otras. Un considerable número de ellas son helechos (Pterydophytas). Aquí se observa un bosque nuboso en el cual la especie conocida como "Musgo español" Tillandsia usneoides L. de la familia Bromeliaceae, es la epífita mas abundante.

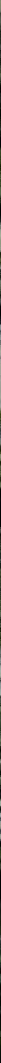




\section{Las briofitas 0 musgos de los bosques nubosos}

\section{Noris Salazar-Allen}

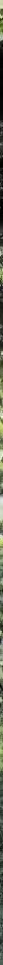

Vegetación típica del bosque nuboso.

Obsérvese las briofitas colgantes. Cerro

Campana, Panamá. Foto: N. Salazar Allen. 
$\mathrm{E}$ $\mathrm{n}$ los trópicos, los bosques nubosos de altura tienen un aspecto casi mágico. Los troncos y ramas de los árboles, las rocas y el suelo están cubiertos por una capa vegetal de plantas que se conocen comúnmente como musgos, y cuyo nombre científico es briofitas (del griego bryon = musgo y phyton $=$ planta).

Estas plantas, que en la escala evolutiva ocupan un sitio entre las algas y los helechos, desempeñan funciones vitales dentro del bosque. Ellas retienen grandes cantidades de agua de las lluvias y de la neblina, evitan la erosión del suelo y son muy sensibles a cambios en la humedad; fácilmente absorben contaminantes del agua y del aire, actuando como buenas indicadoras de la salud del ambiente. También capturan minerales del aire, que liberan con la lluvia, y que son utilizados por otras plantas como nutrientes. Estos mantos de musgos sirven para que otras plantas crezcan y también para dar alojamiento a muchísimas especies de insectos y organismos microscópicos.

Las briofitas están entre las plantas más antiguas del planeta. Surgieron hace unos 400 millones de años, en el período Devónico, mucho antes de los dinosaurios. La fragilidad de sus cuerpos vegetales dificulta encontrar sus restos fósiles. Entre las primeras evidencias de estas plantas están algunas que crecieron en Rusia, durante el período Pérmico, hace 280 millones de años. A pesar de su antigüedad, poco o nada sabe-

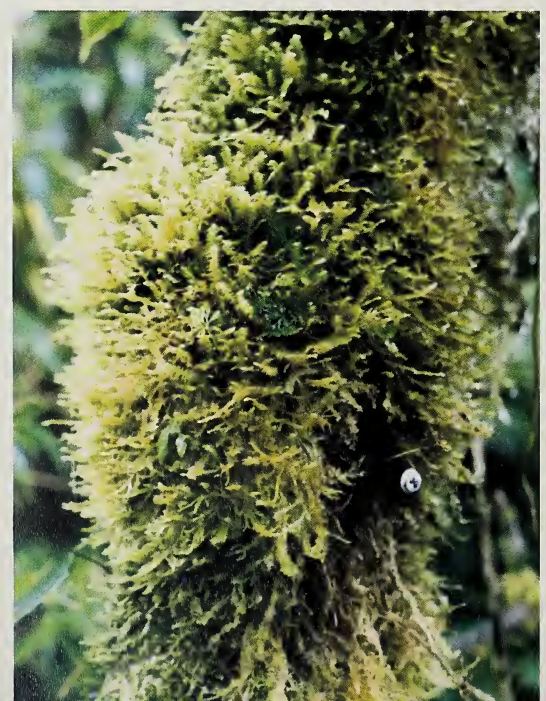

mos sobre cuáles aparecieron en Panamá, aunque hay evidencias que indican que vinieron de Sur y Norteamérica. Tampoco sabemos acerca de su tasa de crecimiento, ni a qué velocidad colonizan los bosques.

Generalmente las briofitas son plantas pequeñas, aunque en el hemisferio sur, en Nueva Zelandia y Australia, algunas especies alcanzan casi un metro de alto, asemejando arbolitos navideños. Usualmente son plantas tropicales que prefieren los bosques nubosos de altura, arriba de los 500 metros. Aunque pueden vivir en las condiciones extremas de los polos y los desiertos, no crecen en el mar, quizás por no tolerar la salinidad.

\section{Briofitas y angiospermas}

Existen en el planeta unas 200,000 especies de plantas, en su abrumadora mayoría angiospermas, las plantas con flores. El número total de briofitas apenas alcanza las 15,000 especies y cerca de 4,000 de ellas se presentan en la América tropical. En América Central, que tiene una extensión de $522,000 \mathrm{~km}^{2}$, encontramos cerca de mil especies de musgos. Panamá, con una extensión territorial de $77,000 \mathrm{~km}^{2}$ (que equivale al $15 \%$ del total de Centroamérica) tiene más de 500 especies. Ello refleja la importancia de nuestro país en cuanto a la diversidad de plantas.

Varias características importantes distinguen a las briofitas de las plantas con flores. Las briofitas carecen de flores, semillas y raíces para sostenerse. Para absorber el agua y los nutrientes usan sus hojas y tallos, un tipo de conducción de agua llamado ectohídrico (del griego, ek=externo, e hydro=agua). Contrariamente, gracias a sus raíces, las angiospermas trasladan el agua y las sales del suelo por su sistema de conducción interno conocido como endohídrico (del griego, endon =interno e hydro =agua).

Crecimiento de briofitas que cubre los troncos de los árboles a 3,440 metros de altura en el Parque Internacional La Amistad, Provincia de Chiriquí. (El punto blanco que apenas sobresale de la mata de briofitas es un marcador que mide 13.5 centímetros de largo).

Foto: N. Salazar Allen. 
El agua es vital para la fertilización de las briofitas. Para que sus células sexuales masculinas, llamadas espermatozoides, puedan llegar a las células sexuales femeninas, deben desplazarse por el agua moviendo dos flagelos o látigos que tienen en su parte frontal. Las células femeninas pueden estar en la misma planta que las masculinas, o en otra diferente. Curiosamente, las briofitas pueden reverdecer luego de permanecer secas por años en un herbario o biblioteca de plantas.

También se diferencian las briofitas de las angiospermas en la forma o morfología de sus cuerpos. Las briofitas tienen dos tipos de cuerpos: el taloso en el cual la planta asemeja una cinta, una lámina aplanada, compuesta por células verdes, debido a su contenido de clorofila. Ellas se fijan al suelo con unas estructuras que asemejan pelos, llamadas rizoides. Las de cuerpo folioso tienen varias hileras de hojas a lo largo de su tallo, que puede ser erecto o rastrero.

\section{Los tres grupos de briofitas}

Tomando en cuenta sus relaciones de parentesco, las briofitas se dividen en tres grupos: las hepáticas (División Hepatophyta), los musgos propiamente dichos (División Bryophyta) y los antocerotes (División Anthocerotophyta) que es el grupo que cuenta con el menor número de especies. Hay 1350 especies de hepáticas, 2600 de musgos y cerca de 30 de antocerotes en la América tropical. (Gradstein, 2001; Churchill \& Salazar Allen, 2001).

Las hepáticas son el tipo más antiguo. Actualmente conocemos 285 especies en Panamá, pero ese número seguramente se duplicaría de contarse con más especialistas que estudiaran otras regiones. Algunas de las hepáticas tienen sus cuerpos acintados y otras tienen hojas y tallos, siendo estas últimas las más numerosas.

Octoblepharum aibidum, un musgo con su esporofita (Es) que contiene las esporas. La gametofita o planta sexual está representada por las estructuras semejantes a hojas. (Ca) es el símbolo de caliptra, una cubierta que protege a la esporofita en su desarrollo. Foto: N. Salazar Allen.
La mayoría de las hepáticas tienen dentro de las células depósitos aceitosos, que contienen sustancias aromáticas disueltas que las protegen de sus enemigos, de la sequía y del ataque de microorganismos. Algunos de estos compuestos son volátiles y al evaporarse rápidamente, dan a la planta su olor característico, dulce en algunos casos, semejante a la zanahoria, y agrios o picantes en otros. Algunas de estas sustancias retardan el crecimiento de tumores malignos, otras irritan la piel al contacto frecuente con ellas. En pequeñas cantidades, algunas de estas sustancias pueden ser tóxicas para animales como los peces.

En los bordes de los caminos y cerca de las quebradas, en las selvas altas de Chiriquí, pueden apreciarse unas hepáticas acintadas (talosas) muy comunes, que tienen sus órganos sexuales en ramas que asemejan paraguas. Algunas hepáticas tienen un lóbulo o pequeño doblez en la parte inferior de las hojas donde retienen agua y se alojan animalitos microscópicos. A diferencia de los musgos, estas hepáticas foliosas tienen sus hojas dispuestas en 2 o 3 hileras y llevan sus órganos reproductores en la punta de sus ramas.

La mayoría de las briofitas pertenecen al grupo de los musgos. Panamá cuenta con más de 500 especies de musgos. Los musgos son foliosos, es decir, que tienen varias hileras de hojas alrededor del tallo. Estas hojitas pueden tener una o dos nervaduras,

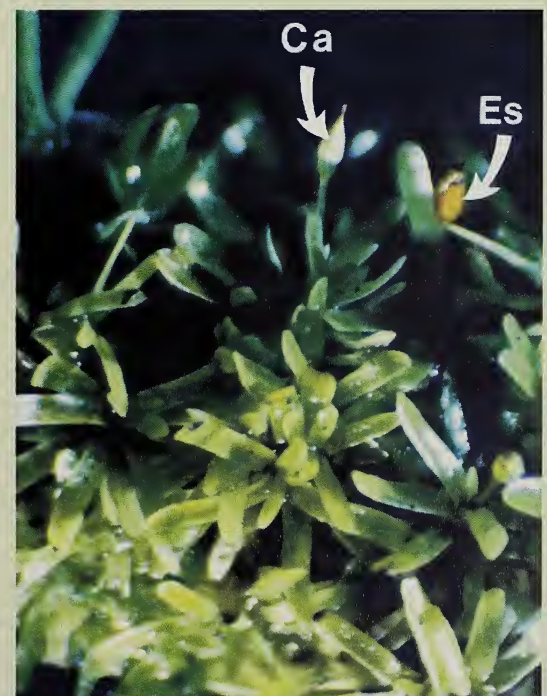


aunque algunas carecen de ellas. No cuentan con cuerpos aceitosos complejos y sus rizoides están compuestos por varias células. Sus órganos sexuales están en las ramas o en la punta de los tallos principales y usualmente están rodeados por hojas que los protegen.

Entre los bosques más investigados y por tanto con mayor número de especies conocidas están: La Fortuna en Chiriquí (225 especies), el Parque Nacional Altos de Campana (175), la isla Barro Colorado (88), e isla Coiba (56). Un estudio reciente y preliminar detectó 69 especies en el Parque Nacional Cerro Hoya, en la Península de Azuero.

El tercer grupo, los antocerotes, apenas cuenta con cerca de 100 especies en todo el mundo; para la América tropical se conocen 30 y tan sólo 5 especies para Panamá. Este grupo ha recibido escasa atención de los investigadores. Estas plantas no resisten sequías prolongadas y mueren al secarse el sustrato.
Algunos antocerotes asemejan cintas rastreras, pero otros crecen como rosetas. Son principalmente terrestres, y crecen en áreas descumbradas de laderas húmedas, en piedras de ríos y quebradas. Sin embargo, en las selvas y montañas lluviosas encontramos un género que es epífito, el Dendroceros, que crece sobre otras plantas. El Notothylas, un antocerote muy común en nuestros patios durante la época lluviosa, forma pequeñas rosetas verdes en sitios húmedos.

\section{Usos antiguos y actuales}

Desde tiempos remotos, los musgos han sido muy útiles para el hombre. En Europa, los estudios arqueológicos sugieren que sirvieron como alfombra, vendaje y yesca, para los romanos que vivieron en el norte de Inglaterra (Seaward, 1976; Watling \& Seaward, 1976). Los vikingos los empleaban para rellenar sus sandalias. Muchos se han empleado como plantas medicinales, sobre todo en las zonas templadas de América del Norte, Europa y China. En esta última, en el siglo

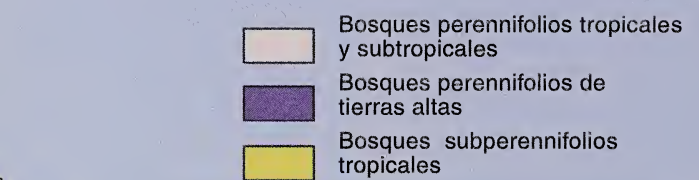

$\square$ Bosques y tierras inundables

5

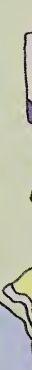

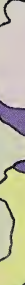

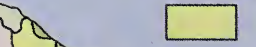

Areas de cultivos, sabanas y vegetación secundaria pionera 
XVI, se describieron especies de los musgos Fissidens con propiedades diuréticas, que estimulan la orina. También se creía que las cenizas del musgo Polytrichum estimulaban el crecimiento del cabello (Asakawa, 1990). Además, se utilizaron para elaborar tapetes, rellenar las grietas de las casas y para acolchar las botas de piel de foca usadas por los esquimales (Richardson, 1981).

La mayoría de las especies de musgos de uso medicinal se han aplicado como emplastes. Se muele la planta, mezclándola con aceites para hacer una pasta usada para curar heridas y quemaduras. Los antiguos indígenas y esquimales de Norteamérica utilizaron el Sphagnum para pañales y rellenar almohadas. Esta especie sirvió como vendajes durante la guerra Ruso-Japonesa (1904-1905) y en la Primera Guerra Mundial, por sus propiedades antisépticas y absorbentes. El Sphagnum también se utilizaba para rellenar almohadas que se colocaban debajo de las heridas y miembros dislocados. Cuando seco, las hojas de este musgo retienen el aire y actúan como un soporte suave y esponjoso. Su tejido absorbe de 16 a 20 veces más de su peso en seco, es decir de 3 a 5 veces más que el algodón (Richardson, 1981). Estas propiedades obedecen a la anatomía de la planta, cuyas hojas están compuestas por células muertas con poros. Además, el arreglo compacto de sus hojas y ramas a lo largo del tallo forman una red de espacios capilares que favorecen la absorción. Al final de la Primera Guerra Mundial, en 1918, se habían establecido fábricas en Inglaterra, Estados Unidos y Canadá, para la elaboración de vendajes utilizando el Sphagnum (Richardson, 1981).

Este musgo de las turberas (peat moss) que crece en áreas húmedas e inundadas de las zonas templadas, es el musgo comercialmente más importante. Las turberas, compuestas en su mayoría por Sphagnum, son uno de los mayores depósitos de carbón en el mundo. En Europa se ha usado para generar electricidad. Actualmente, este musgo se utiliza como relleno para la producción del material de construcción llamado peatcrete o peatwood (Ruel et al., 1977), con este musgo también se protege las raíces de las plantas que son trasladadas de los semilleros a los sitios de venta y para adornos florales $(R i$ - chardson, 1981). El peat moss que se vende en los departamentos de jardinería de los comercios locales para acondicionar los suelos, es Sphagnum triturado, que proviene generalmente de Norteamérica.

En Panamá este musgo se encuentra en el suelo o sobre los árboles en bosques de altura como cerro Jefe, cerro Colorado, cerro Tute y en las tierras altas del Darién.

Otros musgos se utilizan para decorar los afamados jardines japoneses y los paisajes en miniatura llamados bonkei, bankei o sakei. El jardín de musgos más famoso se encuentra en Saihoji, en las faldas del Monte Koizan en la provincia de Kyoto, Japón (Richardson, 1981).

\section{El futuro de los musgos}

Existen amenazas que se ciernen sobre estas pequeñas pero importantes plantitas. La más grave es la continua destrucción de los bosques nubosos de altura en los trópicos. En Panamá, los bosques nubosos más amenazados son los de tierras altas de Chiriquí, el de la región de Santa Fé en Veraguas, ce-

Taxilejeunea sulphurea (Lehm. \& Lindb.) Schiffn., hepática foliosa mostrando sus dos hileras de hojas laterales. Parque Nacional Altos de Campana.

Foto: N. Salazar Allen.

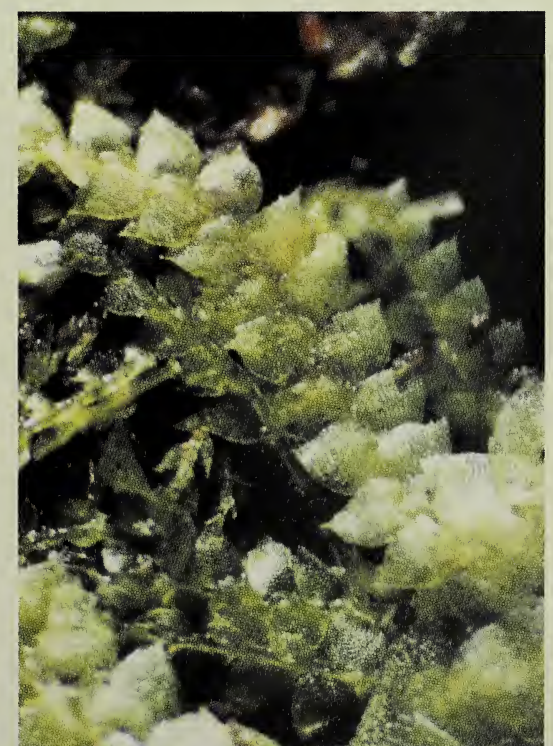


rro Hoya en la Península de Azuero y los del Darién. Otra amenaza es la creciente extracción de los musgos para uso en los nacimien. tos o belenes que adornan las casas e igle. sias en épocas de Navidad. Finalmente, otra práctica nociva es el uso indiscriminado de herbicidas e insecticidas en la agricultura, cuyos compuestos se acumulan en los frágiles cuerpos de las briofitas. Esta contaminación no sólo deteriora a las plantas sino también a los numerosos animales que comen o dependen de ellas para su ciclo de vida. Este preocupante tema está por estudiarse.

Hemos visto la importancia de estas pequeñas plantas para el bosque nuboso y para nuestras vidas. La desaparición de los bosques pone en peligro el equilibrio biológico y la biodiversidad, no sólo de estas especies de plantas, sino también de los muchos organismos asociados a ellas.

Protejamos nuestros bosques y su excepcional diversidad, utilizando racionalmente los valiosos recursos a nuestra disposición. Aunque Panamá es un país riquísimo en briofitas, son escasos los recursos invertidos para estudiar estas singulares plantas y su relación con otras especies. No se puede evadir la responsabilidad que nos compete a todos en la preservación de este valioso componente de nuestro patrimonio natural.

Bibliografia citada

Asakawa, Y. 1990. Terpenoids and aromatic compounds with pharmacological activity from bryophytes. Págs. 369-410. En H.D. Zinsmeister \& R. Mues (eds.). Bryophytes, their Chemistry and Chemical Taxonomy. Oxford Science Publications. Oxford. England.

Churchill, S.P. \& N. Salazar Allen. 2001. A Guide to the Bryophytes of Tropical America. Mosses. Memoirs of the New York Botanical Garden 86: 240-571.

Gradstein, S. R. 2001. A Guide to the Bryophytes of Tropical America. Liverworts and Hornworts: Keys and Descriptions. Memoirs of the New York Botanical Garden 86: 70-239.

Richardson, D.H.S. 1981. The Biology of Mosses. John Wiley \& Sons Inc. New York. USA.

Ruel, M., Chornet, S., Coupal, B., Aitcin, P. y Cossette, M. 1977. Industrial utilization of peat moss. Págs. 221-246. En N.W. Radforth y C.O. Brawner (eds.), Muskeg and the Northern Environment in Canada. Toronto. Canada.

Seaward, M.R.D. 1976. The Vindolanda Environment. Barcombe Publications, Halt-whistle.

Watling, R. y Seaward, M.R.D. 1976. Some observations on puff-balls from British archeological sites. J. Archeol. Sci. 3: 165-172.

Dumortiera hirsuta, una hepática talosa. Las ramas erectas muestran las esporofitas dispersando las esporas que aparecen como manchas rojas. Foto de Paraguay, E. Reiner-Drehwald.

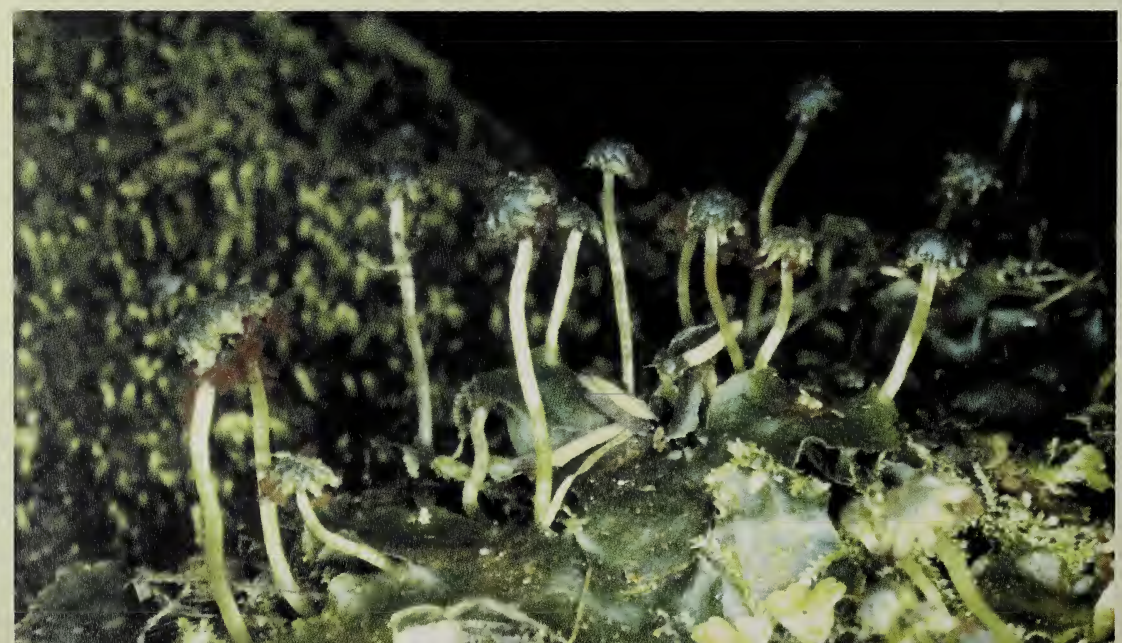




\section{El consumo de agua en los árboles del Parque Natural Metropolitano}

\section{José Luis Andrade}

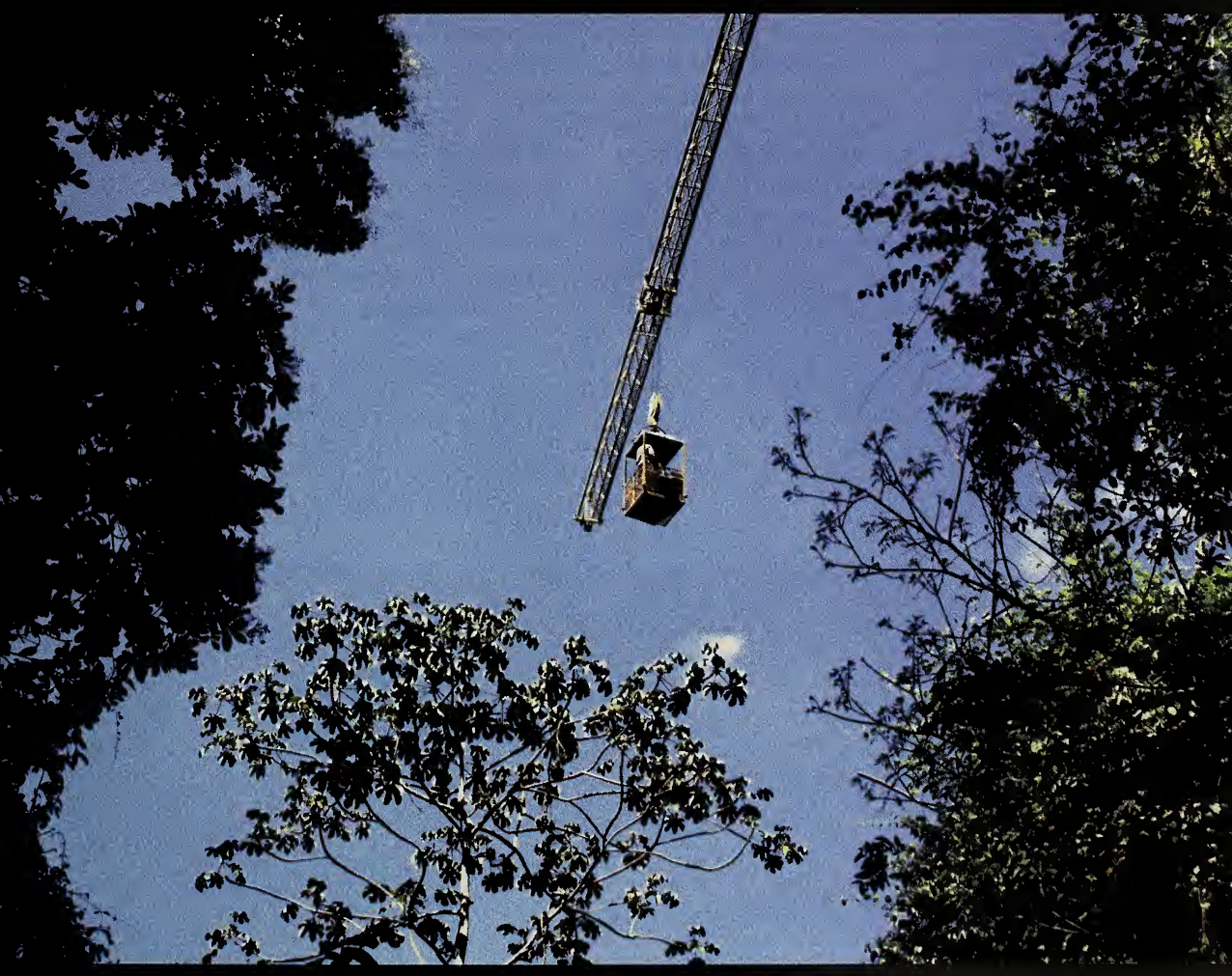

Góndola de la grúa para alcanzar el dosel del bosque, la cual puede alojar de 1 a 6 investigadores a la vez. Esta grúa funciona en el Parque Natural Metropolitano de ciudad de Panamá desde 1990 bajo el auspicio de STRI y el Programa de las Naciones Unidas para el Ambiente. Actualmente existe otra grúa para estudiar el bosque húmedo de Sherman, cerca a la ciudad de Colón en la costa caribe. El dosel del bosque se estudia con la ayuda de grúas en Australia, Estados Unidos, Japón y Venezuela. 
$\mathrm{H}$ ace varios años, dos fisiólogos vegetales, los doctores Guillermo Goldstein y Frederick Meinzer, presentaron una propuesta para estudiar cómo transportan el agua los árboles de algunos bosques de Panamá.

Uno de los sitios escogidos para el estudio fue el Parque Natural Metropolitano, bosque tropical seco del Pacífico, de 230 hectáreas, que forma parte de un corredor ecológico. Este corredor está constituido por varias áreas naturales protegidas, que se extienden desde el Pacífico hasta el Atlántico, a orillas del Canal. El Parque Metro. politano, establecido en bosques de la antigua Zona del Canal, está ubicado en el corazón de la ciudad de Panamá, y a 10 minutos de distancia de los laboratorios del Instituto Smithsonian. En este bosque está instalada una grúa de construcción utilizada por los investigadores para estudiar la selva a diferentes niveles, unos 35 metros de altura dentro del bosque en un radio de 40 metros; el trabajo con la grúa permite abarcar unos 180,000 metros cúbicos de bosque. Estas razones hacen de este par- que un sitio único para los interesados en la ciencia de los bosques tropicales.

La "National Science Foundation", organismo de los Estados Unidos para el apoyo de la ciencia, aceptó financiar este proyecto por tres años. Fui elegido para supervisarlo en dos de sus partes principales: una realizada en la isla Barro Colorado y la otra en el Parque Metropolitano, que se detalla a continuación. El proyecto comenzó en diciembre de 1995, concluyendo el trabajo de campo en diciembre de 1998. Durante estos tres años colaboraron en este estudio otros tres investigadores de otras tantas universidades, además de 14 estudiantes universitarios, principalmente de Brasil, Argentina y Panamá. Los estudiantes apoyaron la investigación durante estadías de uno a dos meses.

Instrumentos para medir el movimiento del agua en base a la temperatura

Para transportar el agua desde el suelo hasta sus copas, los árboles del bosque tropical deben elevarla más de 30 metros de al-

J. L. Andrade verifica el registrador de datos que se encuentra dentro de una caja aislante para protegerlo de la lluvia. En esta caja también se encuentra un módulo de almacenaje, que contiene el programa para las mediciones y en el que se acumulan los datos. A la derecha, dentro de una canasta se observa la batería de un carro que suministra electricidad para calentar los sensores superiores. Dependiendo del número de sensores, la batería puede durar entre dos días y dos semanas.

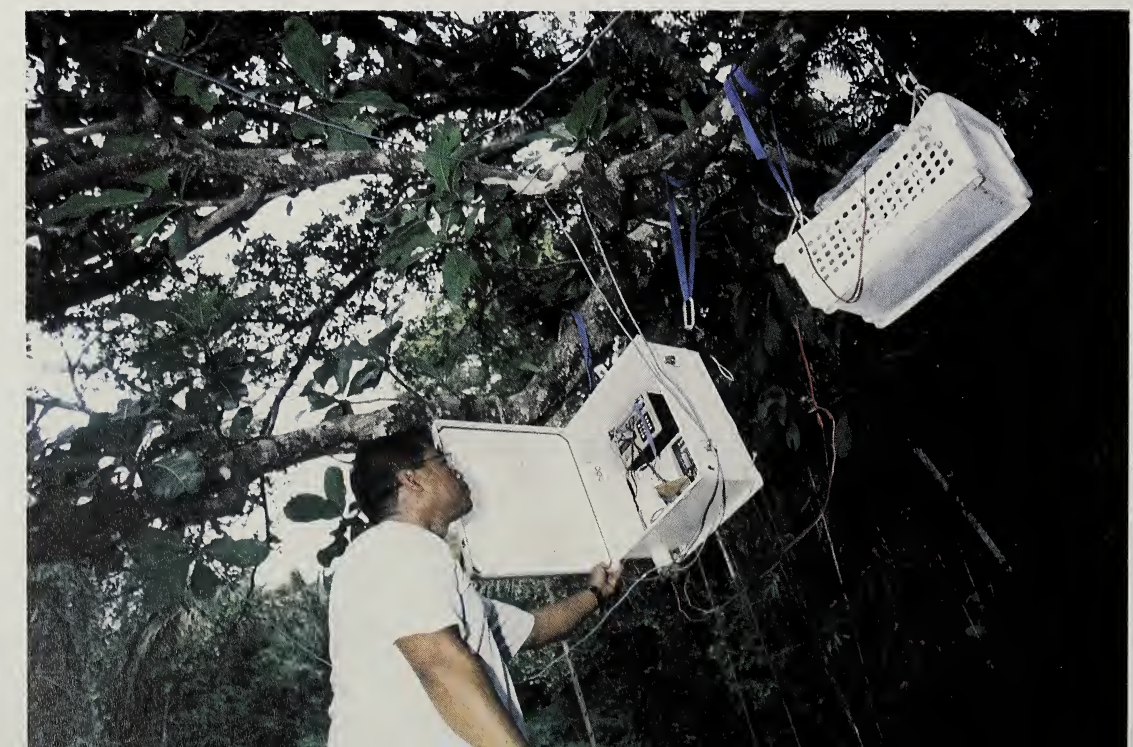


tura. $\mathrm{Si}$ a ello sumamos la extensión de las raíces, vemos que dentro de un solo árbol el agua debe moverse 100 metros o más. Entre las preguntas que nos planteamos estuvieron: ¿Cómo logra subir el agua desde el suelo hasta las hojas? ¿Cuánta agua consume un árbol y cuánta almacena dentro de su tronco? ¿Cómo se regula el transporte del agua en los árboles? Para responder a estas interrogantes utilizamos diversos instrumentos. El movimiento del agua dentro de los árboles se midió usando la llamada sonda de disipación de calor o de calor constante, la cual describiré. Inicialmente el método de disipación de calor fue propuesto por el investigador francés Granier. Consiste en dos sensores de $2 \mathrm{~mm}$ de diámetro y $20 \mathrm{~mm}$ de largo, que registran la temperatura; ambos se insertan dentro del tronco del árbol. El sensor superior se calienta constantemente mediante una batería o panel solar; el sensor inferior mide la temperatura del tronco. Al moverse el agua hacia arriba dentro del árbol, ella enfría el sensor superior. A mayor velocidad del agua más rápido enfriará el sensor. Como la sonda mide la diferencia de temperaturas entre los dos sensores, cuando esta diferencia entre ambos es mínima, mayor es la velocidad del agua dentro del árbol. A mayor la desigualdad de temperatura entre los sensores, el flujo del agua dentro del árbol es cero, es decir que el agua no se mueve, tal como ocurre durante la noche. Estas disparidades en las temperaturas de los sensores permiten calcular la velocidad del agua en el interior del árbol a diferentes horas del día.

Como es necesario medir a lo largo de todo el día las diferencias de temperatura, para ello también utilizamos otros instrumentos. Uno es el registrador de datos, el cual almacena un programa para medir los sensores, envía la señal para que se calienten los sensores superiores y en ciertos intervalos envía los datos a otro equipo, donde se almacenan. La energía necesaria para que se active el programa y para calentar los sensores, debe proporcionarla una fuente de energía. En nuestro caso, utilizamos una batería de automóvil, la cual se usa por varios días antes de recargarse.

Posteriormente los datos de los sensores colocados en los árboles se vacían en una computadora, y mediante cálculos sencillos, se obtienen la velocidad del flujo del agua y el volumen que se mueve dentro del árbol hacia la atmósfera.

En un día soleado, un árbol de 30 metros de altura en el Parque Metropolitano puede consumir más de 25 litros de agua por hora, es decir, más de 150 litros diarios. Al mismo tiempo su tronco puede almacenar hasta unos 25 litros de agua al día. El espavé (Anacardium excelsum), uno de los árboles más grandes en este bosque, puede consumir unos 400 litros de agua por día en la es-
Una sonda Granier en la base de un árbol del Parque Natural Metropolitano. Para colocar la sonda, se hacen pequeños orificios con un taladro, después de remover la corteza. Luego se introducen pequeños tubos de aluminio y se instalan los sensores. Este sistema se cubre luego para evitar interferencias con el ambiente.

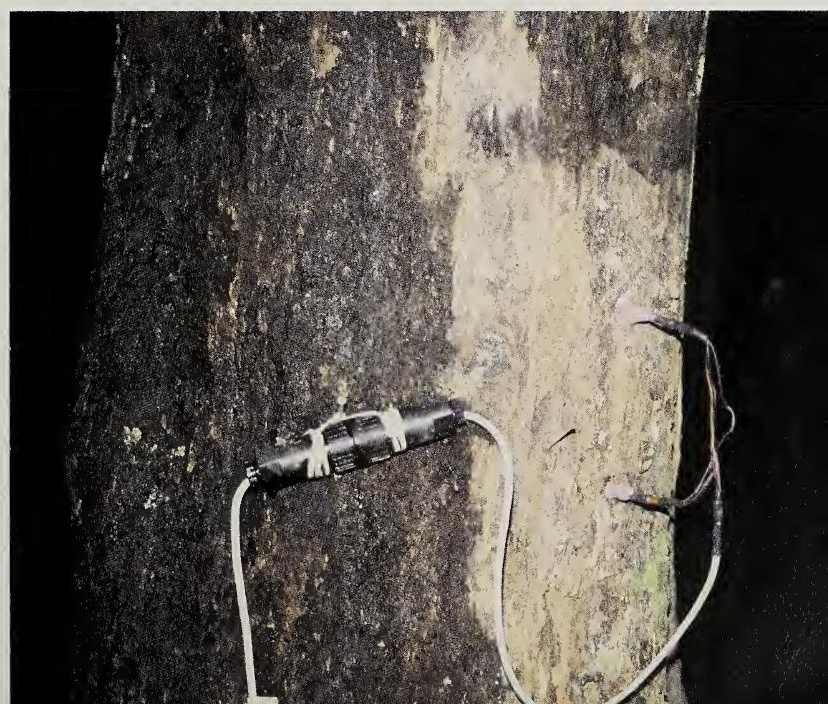


tación seca, mientras que un guarumo (Cecropia longipes) apenas utiliza unos $50 \mathrm{li}$ tros.

Del mismo modo, pudimos calcular la cantidad de agua que se almacena diariamente en los troncos de los árboles y que las ramas utilizan en las primeras horas del día. Este volumen va desde 4 litros diarios para un guarumo, hasta unos 54 litros para un espavé. En base a estas cifras podríamos calcular cuánta agua se mueve dentro del bosque hacia la atmósfera en forma de vapor e imaginar qué sucedería si este bosque se deforestara. Sin embargo, para estimar tal cantidad debemos medir el flujo del agua en las diferentes especies de árboles, que en un bosque tropical pueden ser cientos, y bajo diferentes condiciones ambientales. Una primera aproximación la realizamos en las selvas de la isla Barro Colorado, cuyos resultados se darán a conocer próximamente.

Los resultados de nuestros estudios en el Parque Natural Metropolitano han sido publicados como artículos en diversas revistas científicas internacionales. Agradezco la ayuda indispensable del Instituto Smithsonian y del Parque Natural Metropolitano.

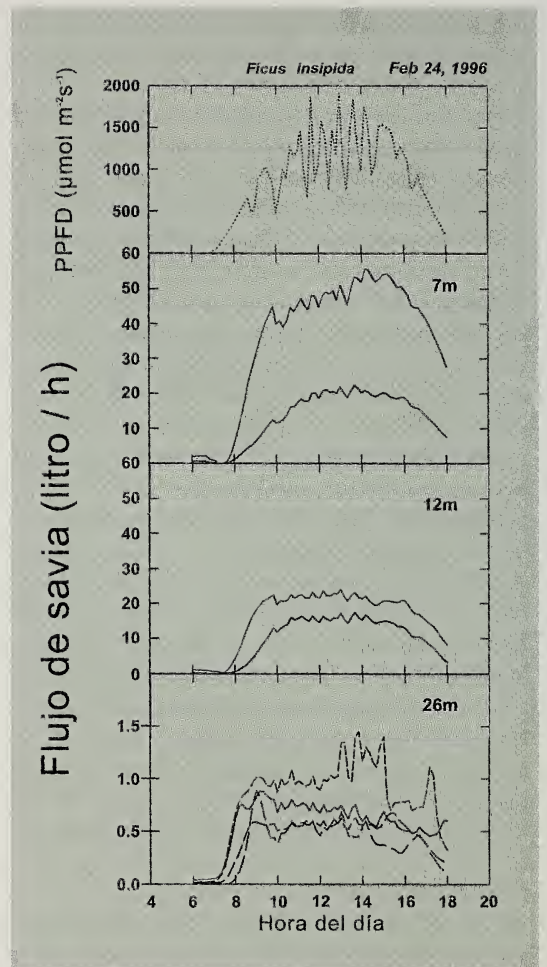

La rama de un higuerón con el sistema de sensores cubierto con una capa aislante, una de material reflejante y la otra de plástico impermeable. Esta rama está a 30 metros del suelo.

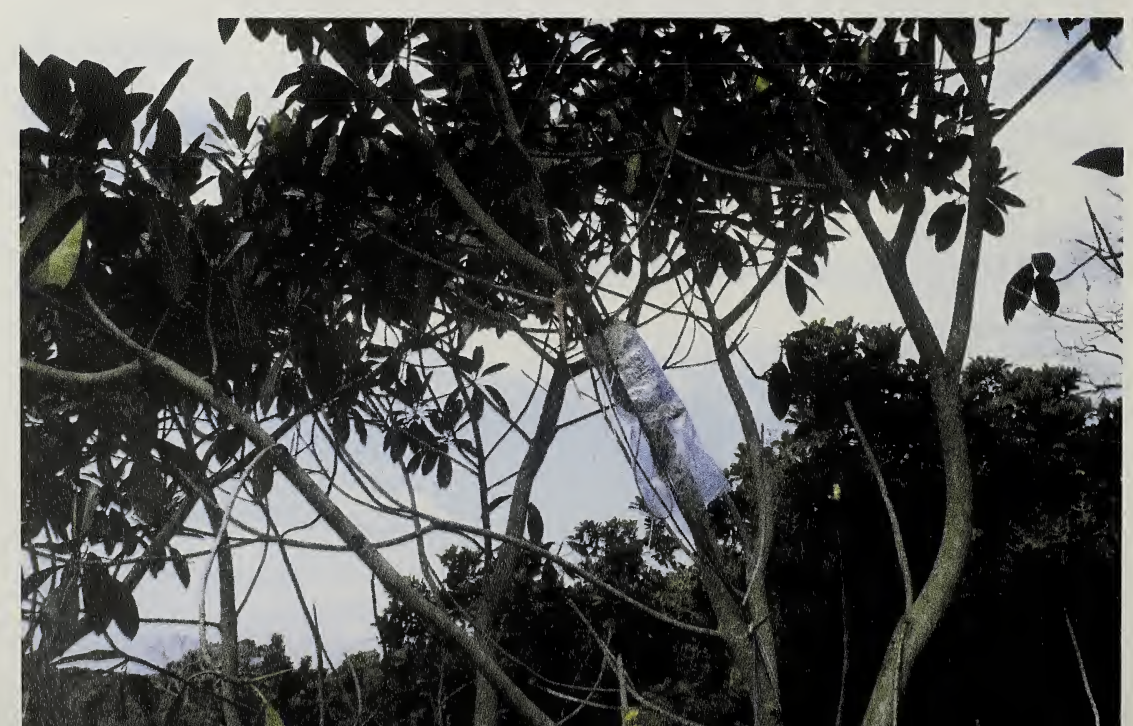




\section{Bosques de la cuenca del Canal de Panamá}

Salomón Aguilar

4.

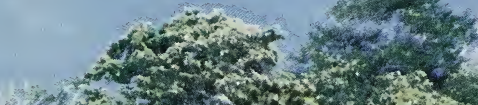

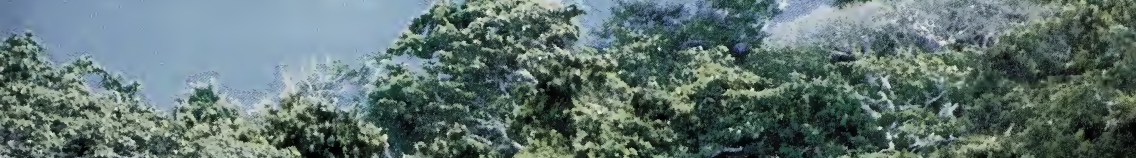

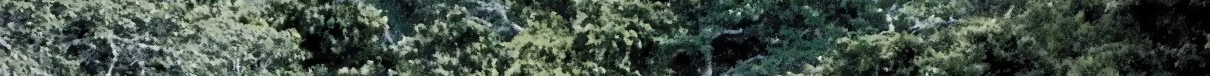
H. 1.

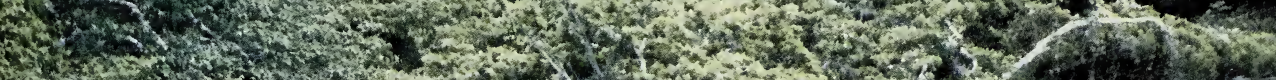

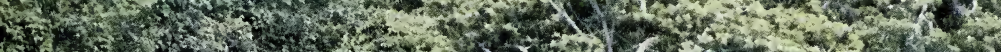

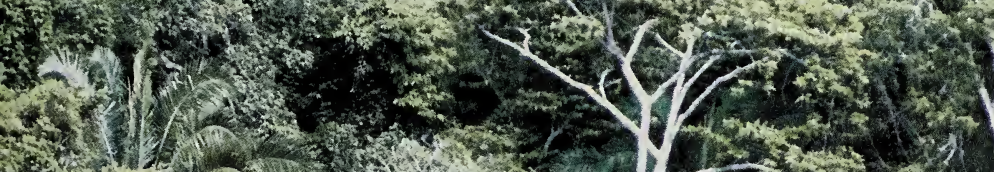

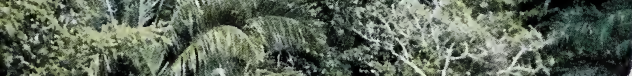

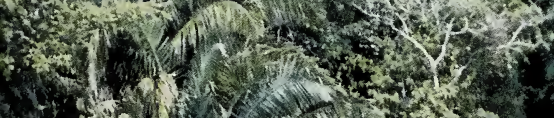

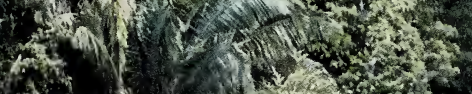

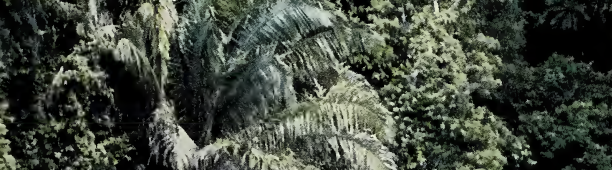
Y. tin

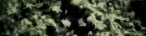
1

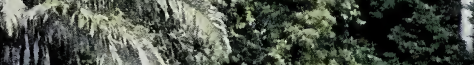

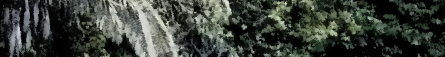
1. Wheto

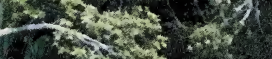

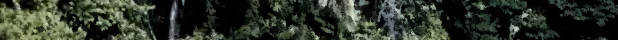

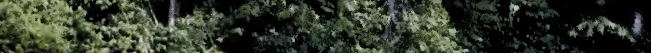

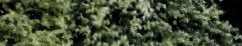

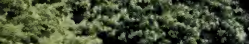

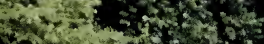
at. 310

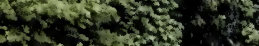
Dexter:

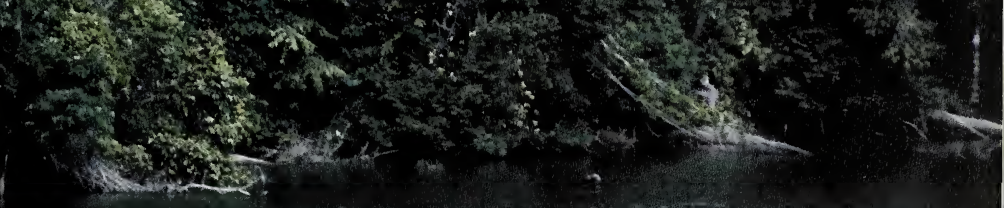
6.t.

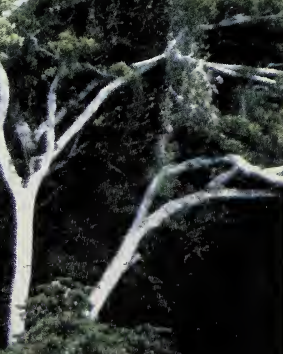

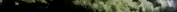


$\mathrm{U}$ bicados en la parte central y más angosta del Istmo, los bosques de la Cuenca del Canal contribuyen gracias a su ciclo de vida a producir agua para la vía interoceánica y para las plantas potabilizadoras que abastecen de agua a las poblaciones de las ciudades de Panamá y Colón.

Topográficamente la cuenca del Canal o del río Chagres, con unos 3,300 kilómetros cuadrados, se divide en dos: la parte baja, que incluye el lago Gatún y los ríos Cirí Grande y Trinidad, que ha sido casi totalmente deforestada, y la parte superior, que comprende el lago Alhajuela y sus principales afluentes: Chagres, Pequení y Boquerón. En esta parte está la mayoría de los bosques existentes, aunque también ha sufrido el impacto de la mano del hombre en el siglo $\mathrm{XX}$, con la llegada de colonos ganaderos de las provincias centrales en la vertiente pacífica del país y, en menor escala, por indígenas emberá del Darién.

Distintos botánicos han estudiado la flora del Chagres desde el siglo XIX, aunque es a partir de la construcción del Canal que sobre ella se intensifica el interés científico. Entre estos estudios sobresalen los del suizo Dr. Henry Pittier, miembro del equipo de reconocimiento biológico hecho por el Instituto Smithsonian entre 1910 y 1912, en las selvas a orillas del Canal y en las zonas montañosas más elevadas de Panamá: Darién, en la frontera con Colombia y Chiriquí, en el límite con Costa Rica. A pesar de que la Cuenca ha sido objeto de diversas investigaciones, aún tiene sitios poco explorados donde en el futuro probablemente se encontrarán nuevas especies de plantas.

El estudio más reciente y completo sobre estos bosques lo realizó el Proyecto de Monitoreo de la Cuenca del Canal (PMCC), entre 1996 y 1999, coordinado por el Instituto Smithsonian de Investigaciones Tropicales. El PMCC investigó cuatro aspectos: la cobertura boscosa, las aguas y suelos, los vertebrados y las poblaciones humanas. El equipo o componente de cobertura boscosa buscaba determinar la superficie de los bosques y establecer sus condiciones, conocer mejor la diversidad de plantas y su distribución, así como los usos actuales del suelo.

\section{Usos actuales del suelo}

Para determinar la cobertura boscosa se utilizaron imágenes del satélite Landsat de abril de 1998, un período de poca nubosidad, al igual que de otras fechas, así como fotos aéreas infrarrojas a color. La verificación de campo se hizo con GPS o sistemas de posicionamiento geográfico. Estas tecnologías modernas facilitaron obtener una visión precisa de la extensión de los bosques y otros usos del suelo, así como confeccionar el mapa más actualizado de la región.

Se establecieron siete categorías de usos del suelo: a)cobertura boscosa, áreas con árboles de $\mathbf{1 0}$ metros de alto o más y diámetros superiores a 10 centímetros; b) rastrojos y matorrales, aquéllas cubiertas con vegetación joven, menor a 5 metros de altura, donde prevalecen arbustos, plantas herbáceas y bejucos, cuya estructura densa y enmarañada dificultan caminar; c) potreros, herbazales, áreas cultivadas y plantaciones forestales, categoría que incluyó a la "paja blanca" o "paja canalera", maleza exótica originaria de Asia cuyo nombre científico es Saccharum spontaneum; d) poblaciones humanas, categoría que incluyó las ciudades y áreas semi urbanas de la Cuenca, cuyas dimensiones permitían identificarlas mediante imágenes de satélite; e) suelos desnudos, aquellos sin vegetación al momento del estudio; f) las aguas, básicamente los lagos Gatún y Alhajuela y algunas pequeñas lagunas, y finalmente; g) áreas que no pudieron clasificarse debido a que la nubosidad impedía a los satélites obtener imágenes claras.

La superficie total de la Cuenca es de 331,309 hectáreas. El 47\%, unas 156,991 hectáreas, están cubiertas por bosques. El $53 \%$ restante está bajo otros usos.

No fue posible distinguir la superficie de bosques maduros de la de bosques secundarios más jóvenes con la tecnología de la que disponíamos. Sin embargo, estimamos que un $60 \%$ de los bosques de la Cuenca son maduros, concentrándose dentro del Parque Nacional Chagres, hacia las cabeceras de los ríos Chagres, Pequení y Boquerón. También existen parches en la mitad sur de la isla Barro Colorado, en la Península Gigante, en el camino al Oleoducto y al norte del pueblo 
ra sus cultivos de subsistencia. Las parcelas para estos cultivos son conocidas por los campesinos como "montes".

En el período de 1997-1998, se extendieron 199 permisos de roza y quema en la Cuenca. Estas talas se inician en el mes de marzo, y las quemas se hacen en abril y mayo. El tamaño de las áreas taladas o rozas oscila entre una y dos hectáreas, por tanto se estima que se talan entre 199 y 398 hectáreas de rastrojos al año. Los lugares con más solicitudes para talas son el sector Salamanca, Santa Librada y otras comunidades campesinas al oeste y al norte del lago Alhajuela; los sitios con menos solicitudes son los sectores del corregimiento de cerro Cama y la Arenosa, al suroeste del lago Gatún.
Los campesinos usan estos "montes" por un año, abandonándolos seguidamente por su baja fertilidad. Luego estas parcelas abandonadas son invadidas por una hierba exótica muy agresiva llamada "paja blanca" (Saccharum spontaneum), introducida originalmente en Panamá para controlar la erosión a orillas del Canal. Esta maleza dificulta la regeneración del bosque. Cuando los campesinos queman sus "montes", frecuentemente se incendian accidentalmente estos pajonales, destruyendo el borde de los bosques cercanos. Así la paja blanca avanza hacia el bosque cada vez más. ¿Cúanto bosque destruyen las quemas anuales de estos pajonales? Sólo lo sabremos de continuarse monitoreando la vegetación y la paja blanca.

Distribución de los bosques maduros y secundarios, 1999. Los maduros tienen más de cien años y contienen mas especies de plantas. Se localizan principalmente en los sitios más remotos, precipitados y lluviosos, como las cabeceras del Chagres.

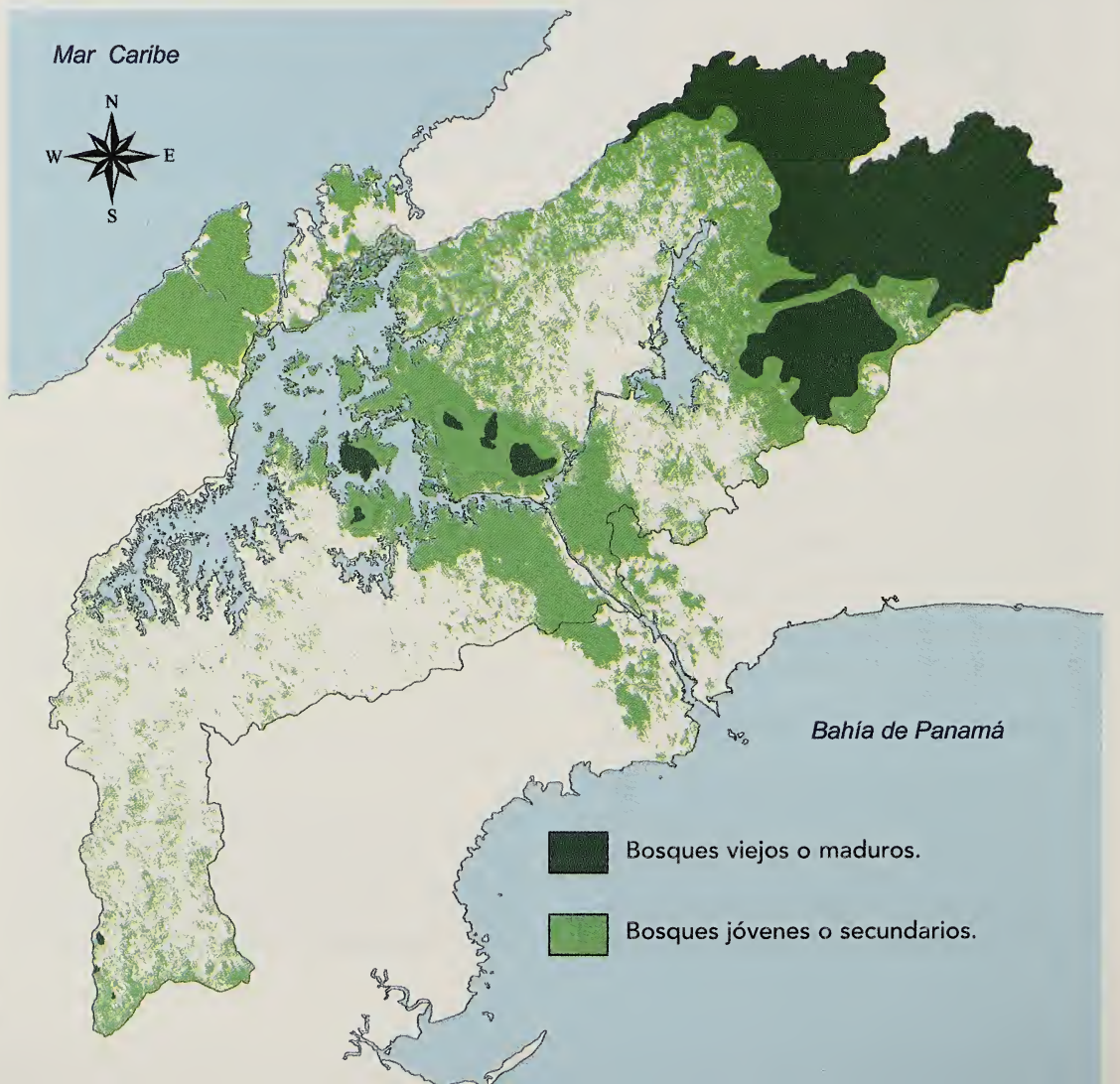


no sólo se conocía para Costa Rica; Lecointea sp, conocida para Brasil, Perú y Venezuela; Ficus brevibracteata, un tipo de higuerón que ha sido reportado para Centro y Sur América; Pouteria foviolata, tan sólo conocida para Costa Rica y Nicaragua; y finalmente Pentagonia parvifolia, la cual se encontró en cerro Bruja, en las cabeceras del río Chagres y que se ha reportado en Colombia, Ecuador y Perú.

\section{Distribución de las especies}

Muestran los datos de la investigación una alta correlación entre la humedad y la edad del bosque con el número de especies. Dicho de otra forma, a más viejo y lluvioso el bosque, mayor será el número de especies. La mayor cantidad de especies con distribucio-

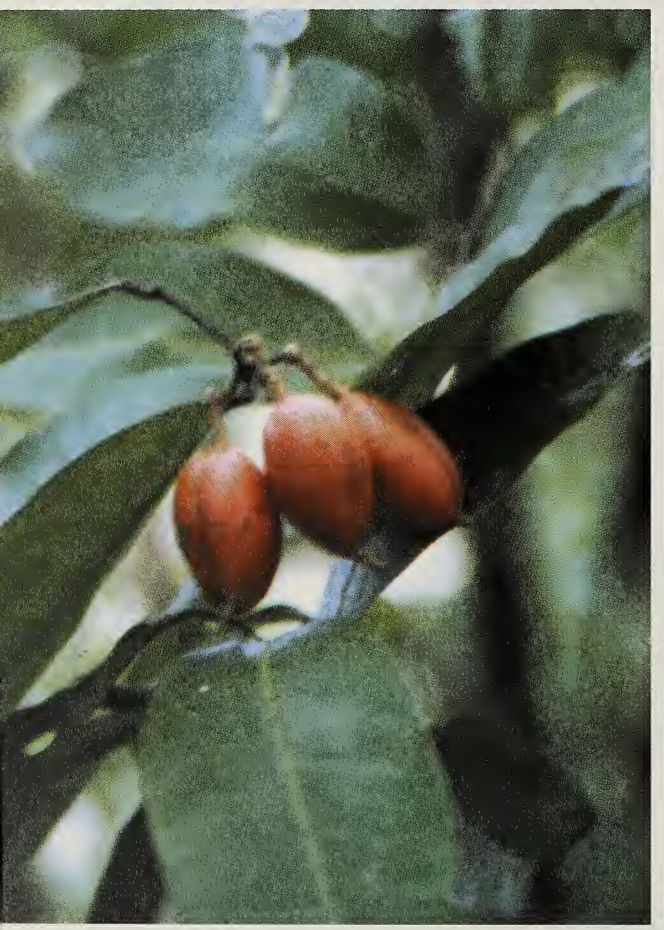

El naranjillo (Swartzia simplex) es la planta con la distribución mas amplia en toda la cuenca. Se encuentra en tierras bajas y altas y en bosques secos y lluviosos. Foto: Nefertari Daguerre. nes restringidas está al norte y suroeste de la Cuenca, en sitios con bosques muy húmedos, lo que concuerda con los resultados del Dr. Richard Condit, quien ha señalado que muchas especies de plantas tienen una distribución limitada por ser intolerantes a las sequías.

La mayoría de las 1,125 especies registradas para la Cuenca se encontraron en bosques maduros. El contraste en el número de especies, según el número de vegetación, se encontró a lo largo del Canal, donde en 90 hectáreas de bosques secundarios se reportaron 523 especies. Por el contrario, en 2.5 hectáreas de bosques maduros del Parque Nacional Chagres se reportaron 438 especies. Asimismo, en media hectárea de bosque viejo en cerro Negro, se identificaron 164 especies.

Tanto las cabeceras del río Chagres como cerro Negro cuentan con un alto nivel de endemismo de plantas, es decir, que la mayoría de las especies encontradas en estos sitios no aparecen en otros lugares de la Cuenca. El $62 \%$ de las especies reportadas para cerro Negro y el $\mathbf{5 5 \%}$ de las especies del Parque Nacional Chagres son únicas a estos sectores; ambos tienen floras exclusivas, diferentes a las de los bosques adyacentes a la vía interoceánica, en sitios como Cocolí, Barro Colorado, el Parque Nacional Soberanía y Sherman.

En conclusión puede decirse que en la Cuenca del Canal existen tres floras diferentes: en las cabeceras del río Chagres, que comprende el filo de Santa Rita y el Parque Nacional Chagres; la de cerro Negro, en las montañas del distrito de Capira, y finalmente la ubicada a ambas orillas del Canal.

Ante el elevado endemismo de plantas encontradas por este estudio, cabe recomendar que en el futuro se establezcan parcelas adicionales de investigación en áreas remotas de la Cuenca, hasta ahora poco conocidas. Estas investigaciones bien podrían determinar la existencia de otros sectores de alto endemismo, con floras exclusivas.

Finalmente, cabe señalar que hay áreas con muy alto endemismo de plantas que actual mente no reciben protección. Tal es el caso 
de las cabeceras de los ríos Trinidad y Cirí Gigante y el filo de Santa Rita. Por su importancia ecológica, estos sitios ameritan ser incorporados a los sistemas de áreas protegidas, sean estatales o privadas.

Descubierta recientemente en las cabeceras del Chagres, Lecointea sp. es una especie nueva para la flora panameña. A pesar de que la cuenca del canal ha sido objeto de muchos estudios botánicos con frecuencia se encuentran nuevas especies.

Foto: Nefertari Daguerre.

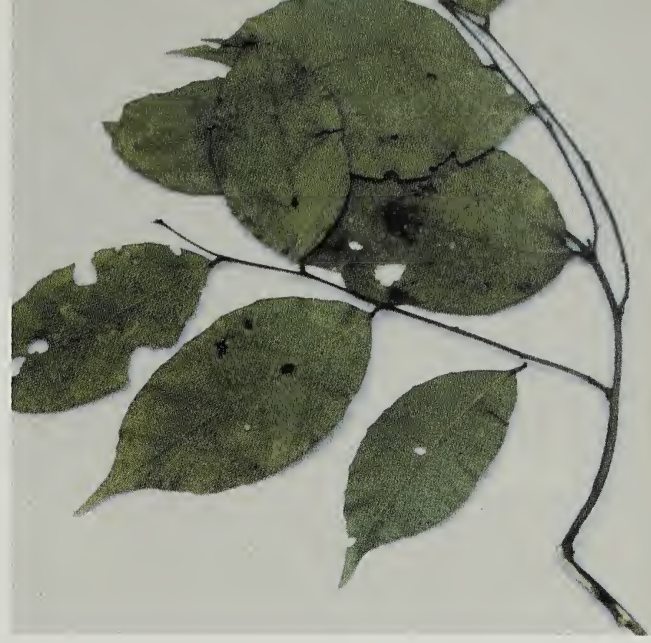

El membrillo (Gustavia superba) es el árbol más común de los bosques secos del lado pacífico.

Su fruto es muy apetecido por los animales silvestres. Foto: Nefertari Daguerre.

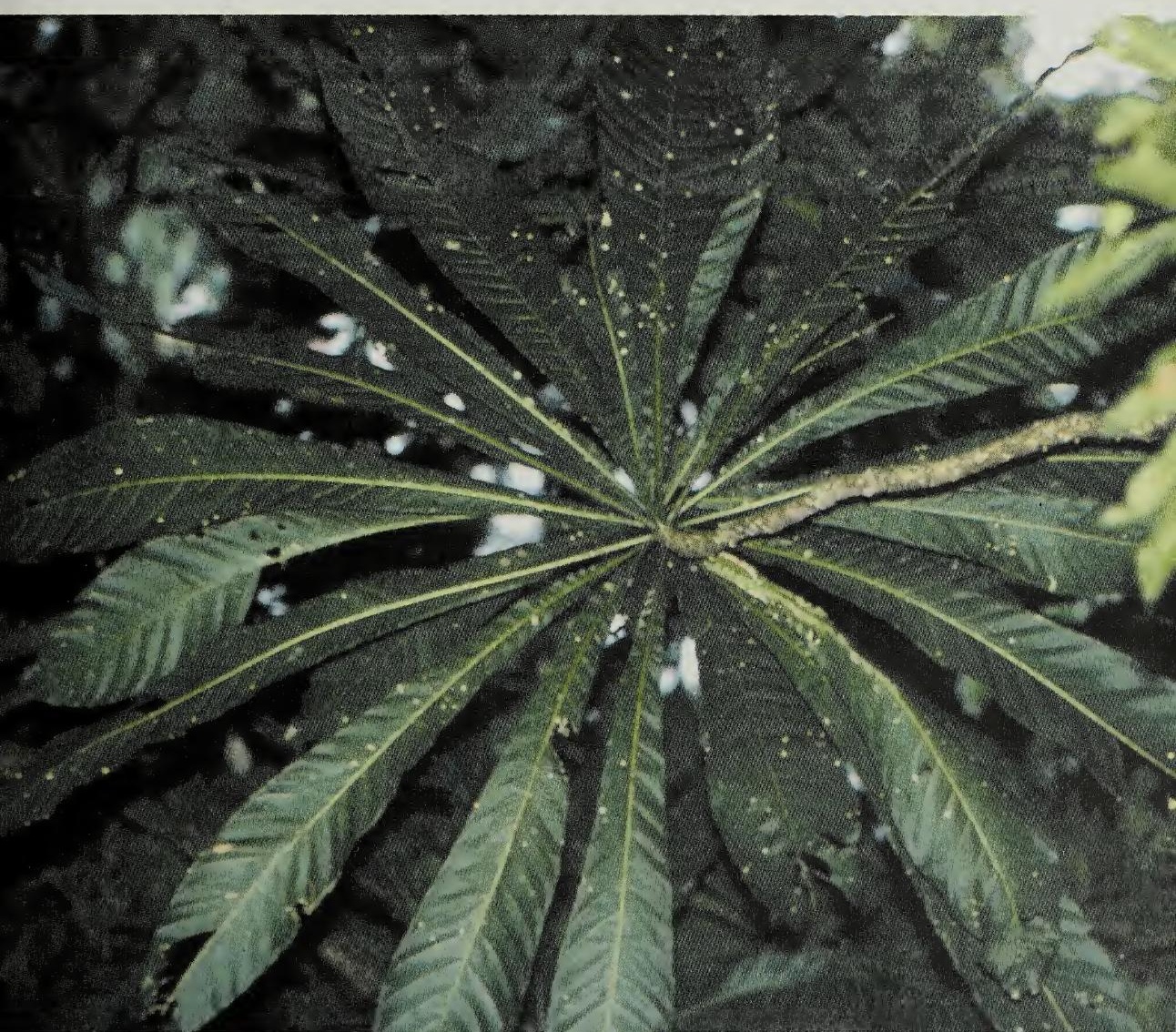


$\mathrm{L}$ a mayoría de las plantas terrestres son organismos inmóviles, que se sujetan con sus raíces al sustrato para estabilizarse. Asimismo las raíces les permiten obtener los nutrientes del suelo y del aire para crecer, reproducirse y existir. Pero, si las plantas no pueden moverse para escapar del peligro, como por ejemplo, buir de un animal, ¿cómo pueden ellas defenderse? Antes de responder a esta pregunta, debemos hablar sobre las amenazas que las acechan.

\section{Los enemigos de las plantas}

De sus enemigos, los insectos son los más numerosos. Según E.O. Wilson, en su obra Biodiversidad (1992), se han identificado más de un millón de insectos, de los cuales tres cuartas partes afectan las plantas, de una forma u otra, atacando sus hojas, semillas, flores, troncos y raíces. Sin embargo, no todos son dañinos, pues algunos son necesarios para la polinización e indispensables para la reproducción y supervivencia de las plantas.

Otro grupo de enemigos son los microorganismos patógenos, es decir, bacterias, virus y hongos que les provocan enfermedades. Algunos patógenos se introducen en la planta a través de la saliva de los animales, cuando éstos se las comen. No obstante, existen algunos microorganismos esenciales para el bienestar de las plantas co- mo la bacteria Rhizobium que se adhiere a las raíces, contribuyendo a fijar el nitrógeno y estimular el crecimiento de la planta. Por su lado, los hongos micorriza facilitan la absorción de nutrientes a través de las raíces.

Finalmente, el grupo más pequeño de enemigos lo componen los mamíferos que comen las hojas y frutos de las plantas, aunque algunos son importantísimos para dispersar semillas, tales como murciélagos, saínos, conejos y ñeques.

\section{Defensas físicas}

Para defenderse de sus enemigos las plantas terrestres utilizan estrategias físicas y químicas. Su primera línea de defensa es la física, que puede observarse en la superficie de las hojas, ramas, troncos, corteza y raíces. Las hojas pueden estar cubiertas por vellosidades y escamas. Tomando en cuenta la escala de tamaños, imagine a un insecto aterrizando sobre una hoja y enfrentando una jungla de pelos, algunos de los cuales contienen compuestos químicos. Otras hojas tienen superficies muy lisas, pues están cubiertas de una cutícula o cubierta cerosa. La biotecnología moderna produce variedades de repollo cuyas hojas están tan saturadas de estas ceras que hasta brillan; los insectos que se alimentan de estos repollos toman más tiempo en palparlas y desisten de comerlas.
La superficie de una hoja puede ser un terreno muy borrascoso para un insecto, pues algunas plantas tienen hojas cubiertas de vellosidades, algunas de ellas conteniendo sustancias tóxicas, como los tricomas redondos en Cordia curassavica (Boraginaceae). Foto: Imagen de microscopio electrónico de barrido.

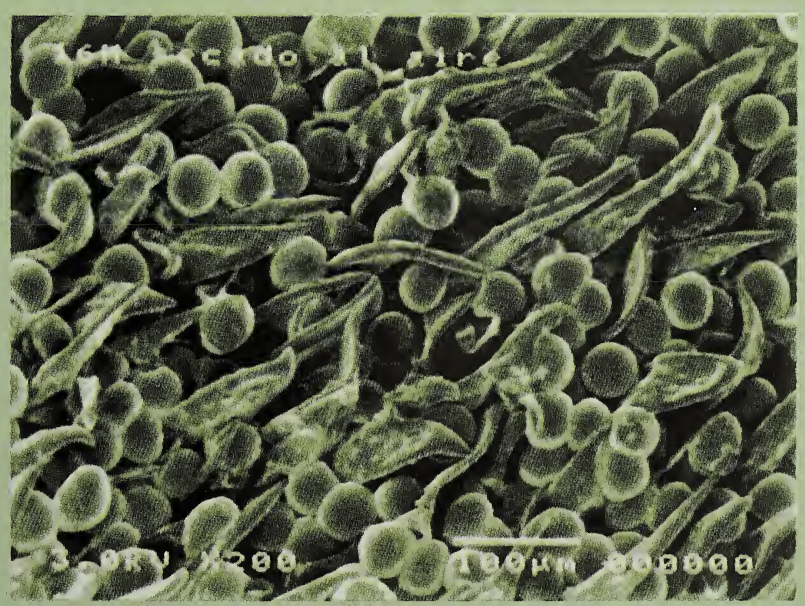


También podemos observar que las ramas, troncos y raíces tienen una cubierta protectora, la corteza, que en algunos casos puede tener espinas, como es el caso de la palma de chunga y la de Pacora, cuyos troncos están repletos de espinas.

Para defender sus órganos reproductivos femeninos, las plantas los colocan dentro de las flores, a salvo de muchas plagas.

En ocasiones, la defensa física y la química están íntimamente ligadas. Por ejemplo, la superficie de las hojas del tomate silvestre está cubierta por varios tipos de pelos, que liberan dos sustancias diferentes al morderlas los insectos. Al mezclarse ambas sustancias forman una especie de pegamento, quedando las mandíbulas del insecto prácticamente pegadas a la superficie, siéndole imposible comer.

\section{Defensas químicas}

La defensa química de las plantas es sofisticada y fascinante; ellas han desarrollado mecanismos sumamente complejos para producir sustancias que las protegen de distintas amenazas. Uno de los aspectos interesantes es que cada especie tiene su propia artillería química. Al mismo tiempo, plantas individuales de la misma especie pueden producir componentes defensivos similares, en diferentes cantidades y combinaciones. Tomando en cuenta que existen más de 200,000 especies de plantas identificadas en el planeta y que cada una produce una batería particular de compuestos defensivos, puede afirmarse que la riqueza biológica va acompañada de una riqueza química aún mayor.

Otro tipo de defensa quimica es la inducida, que se produce cuando un insecto o un patógeno ataca la planta, momento en que se libera una sustancia que lleva la señal del ataque a la membrana de las células que producen las sustancias químicas defensivas. Al llegar la señal a la membrana, se transforma en un mensaje que activa la célula. El resultado es que dentro de la célula se produce un ácido graso que sufre una serie de cambios en su estructura química. El último compuesto de esta cadena, llamado jasmonato, entra al núcleo, donde activa la información genética, que codifica la producción de las sustancias defensivas. Todo este complicadísimo proceso toma apenas segundos.

Uno de los avances más extraordinarios de la ciencia y la tecnología del siglo XX ha sido entender estos procesos. Entre sus muchos impactos positivos es que nos permite evaluar las mejores condiciones para "inmunizar" las plantas que cultivamos, aumentando sus defensas antes de que sean atacadas, reduciendo así el uso de los agroquímicos. Aún más, un número creciente de estudios sugiere que las plantas, al ser atacadas, liberan olores que estimulan las defensas químicas en otras plantas de la misma especie que crecen cerca.

Otras investigaciones muestran que las sustancias liberadas por las plantas sirven para atraer a enemigos naturales de los insectos que las atacan. El depredador del insecto atacante se lo come o deposita sus huevos dentro de él. Otra variante de la defensa química inducida se observa

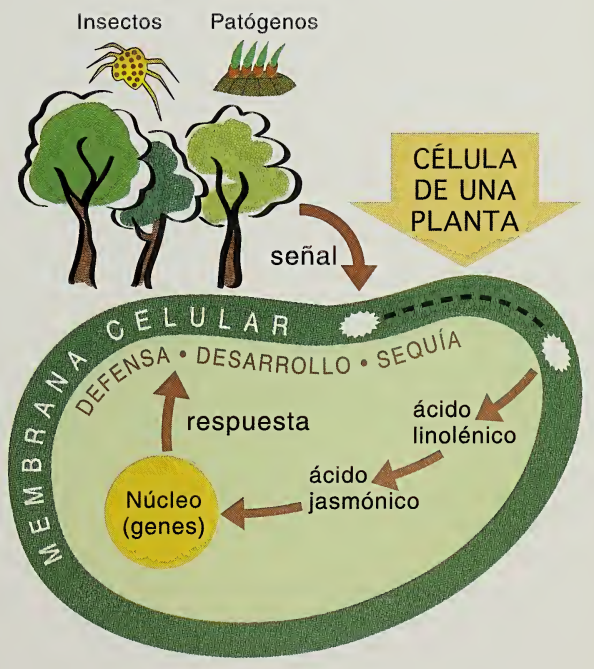

Dibujo simplificado de la cadena del ácido octanoico, uno de los mecanismos de defensa inducida que han desarrollado las plantas para defenderse de sus enemigos. 
cuando la planta, al ser atacada por patógenos, destruye el tejido infectado. Puede decirse que la propia planta "mata" el tejido enfermo, para que sus hojas continúen sanas. Las manchas negras que a veces vemos sobre las hojas son el resultado de este proceso de autodestrucción de partes específicas para salvar el resto del cuerpo.

Algunos investigadores especulan que estos sistemas defensivos químicos pueden ser generados por hongos endófitos, es decir, que viven dentro del tejido de las hojas, sin provocarle enfermedades a la planta.

Algunos insectos se han adaptado a estas defensas de las plantas, utilizándolas para su propio beneficio. Así, la mariposa monarca se alimenta de plantas que tienen compuestos llamados alcaloides, que son muy tóxicos para otros animales, incluyendo a los seres humanos. El macho de esta especie transforma estos alcaloides dentro de su cuerpo, convirtiéndolos en feromonas, sustancias que sirven para atraer a la hembra durante el ciclo reproductivo. Al aparearse o durante el vuelo nupcial, espolvorean sobre la hembra los alcaloides que han transformado. La hembra a su vez prefiere al macho que tiene la mejor y mayor combinación de alcaloides.

A pesar de la inmensa variación de las defensas químicas y barreras físicas de las plantas, los insectos son capaces de reconocer las hojas de sus plantas huéspedes. Para ello utilizan sus colores, olores, texturas y sabores. Estos insectos han desarrollado diversas y sofisticadas formas para explotar las plantas como alimento y guarida, contrarrestando sus mecanismos de protección.

¿Qué pasa cuando el entorno se vuelve hostil?

La sequía, las heladas, las inundaciones, la contaminación y la radiación ultraviole. ta del sol son factores que pueden provocar la muerte de las plantas. Afortunadamente ellas tienen mecanismos para enfrentarse a tales eventos. Por ejemplo, algunas plantas tienen hojas gruesas y enceradas para evitar la pérdida de agua; otras contienen una especie de anticongelante en su sistema de transporte de fluidos que evita que la savia se congele; algunas producen bloqueadores de radiación ultravioleta en sus hojas para evitar el daño a sus células; otras plantas tienen raíces aéreas para enfrentar las inundaciones, tal como la palma gira o el mangle rojo. De hecho, hay árboles que crecen muy bien en pantanos, como es el caso del cativo. Sin embargo, la exposición contínua a estos elementos ambientales negativos puede provocar daños irreversibles y por lo tanto, la muerte de estos maravillosos seres vivos.

\section{Aplicaciones}

Las plantas tienen mecanismos bioquímicos complicados para protegerse, defen-

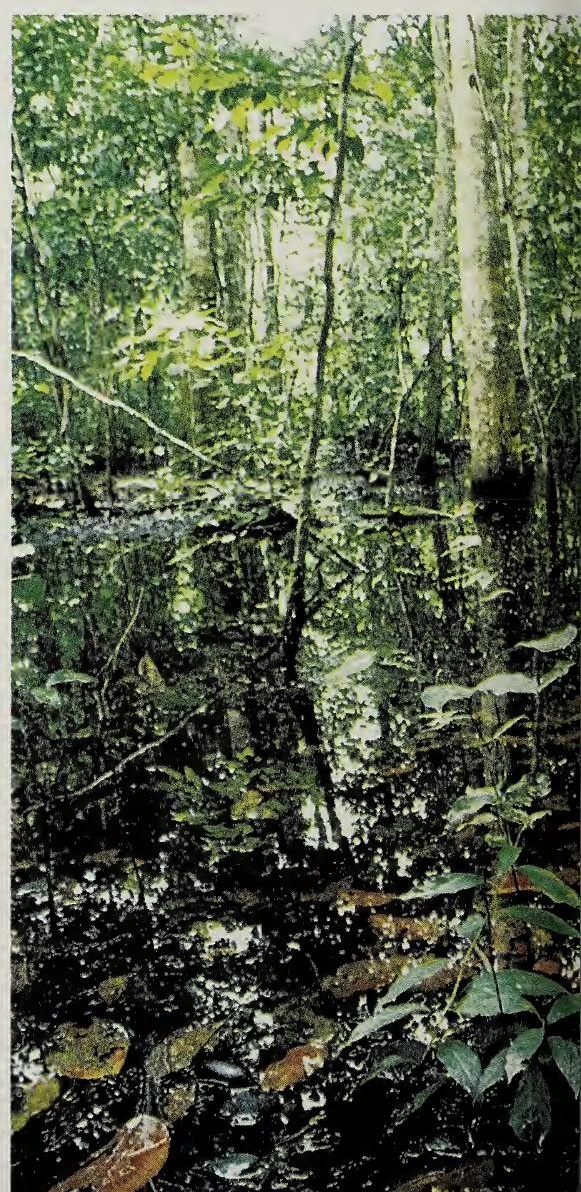


derse, curarse e inmunizarse frente a los ataques del entorno. El entender estos mecanismos, a través de las investigaciones en ciencia básica, ha llevado a los agrobiotecnólogos y ecólogos a generar métodos para mitigar las plagas en la agricultura. Entre estos esfuerzos está el intento de "inmunizar" a las plantas cultivadas, producir plantas genéticamente mejoradas, trampas con feromonas para atrapar insectos machos y liberar sustancias olorosas para atraer a los enemigos de las plagas.

Así mismo, los compuestos que las plantas usan para defenderse pueden ser evaluados para detectar sustancias promisorias para la medicina, lo cual se hace mediante la prospección biológica o bioprospección. El contexto ecológico, es decir, el estudio de las interrelaciones entre las plantas y su hábitat, nos permite contar con criterios más poderosos y así seleccionar plantas potencialmente útiles. De hecho, un gran porcentaje de los medicamentos actuales contiene alguna sustancia extraída de las plantas y que ellas utilizan como defensa. Por ejemplo, para tratar desórdenes cardíacos se usan ampliamente medicamentos en base a los glicósidos cardíacos, que están presentes en especies de la planta Digitalis y que la protegen exitosamente contra los insectos herbívoros.

En conclusión, las plantas son seres vivos extraordinarios que han tenido que desarrollar maneras de lidiar y de sobreponerse a su ambiente agresivo. Ellas merecen nuestro respeto. Después de todo, nuestra existencia depende totalmente de la suya.

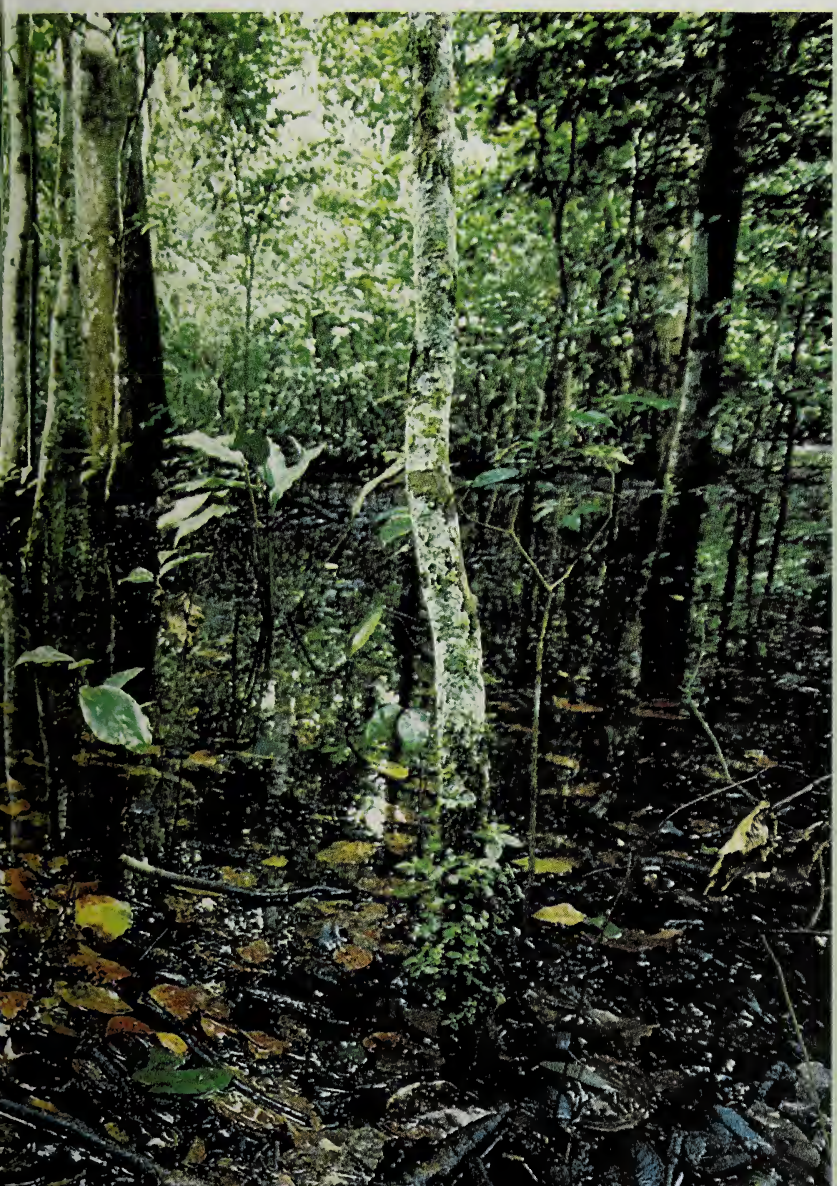

El cativo, Prioria copaifera (Caesalpinioideae), crece en áreas pantanosas. En Darién hay grandes áreas inundables donde predomina esta especie. Es todavía un misterio el mecanismo que esta planta utiliza para poder permanecer sometida a estas condiciones por meses. Foto: Instituto Smithsonian. 


\title{
Las plantas tropicales y el aumento de ditóxido de carhono en la atmósfera
}

\author{
Klaus Winter
}
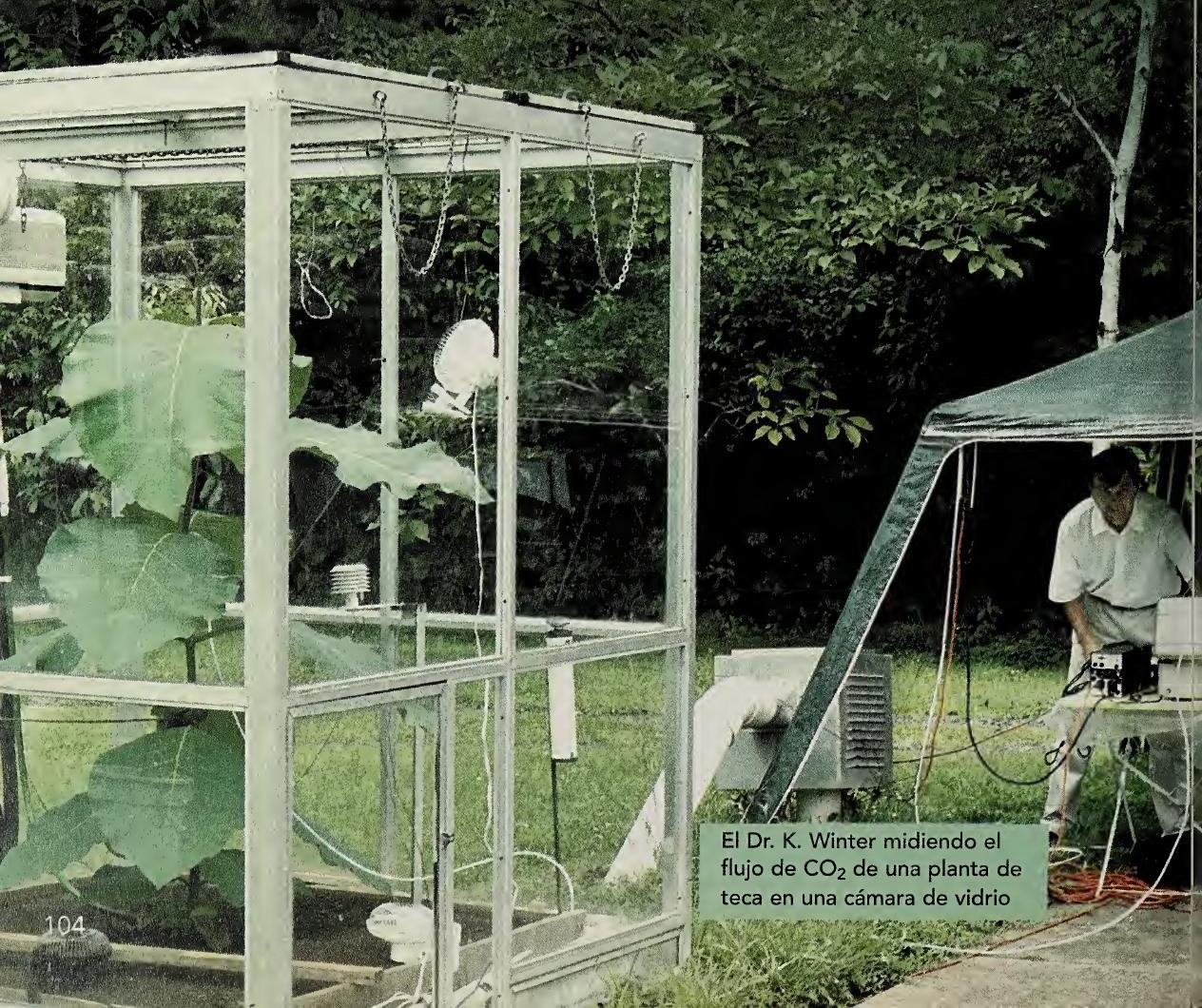
$\mathrm{D}$ esde mediados del siglo XIX, los cambios producidos por la Revolución Industrial trajeron un aumento en las concentraciones de dióxido de carbono $\left(\mathrm{CO}_{2}\right)$ en la atmósfera. El creciente consumo de combustibles fósiles, como el carbón y el petróleo, y una mayor deforestación, han incrementado la presencia del dióxido de carbono de 290 partes por millón (ppm) en el siglo XIX a unas 360 ppm actualmente (360 ppm equivale a 0.00036 litros o 360 microlitros de $\mathrm{CO}_{2}$ puro en 1 litro de aire). Sólo en los últimos cuarenta años, las concentraciones globales de $\mathrm{CO}_{2}$ han aumentado en unos 45 ppm. De continuar esta tendencia es posible que para finales del siglo XXI el $\mathrm{CO}_{2}$ sobrepase las 550 partes por millón.

\section{¿Por qué es importante el $\mathrm{CO}_{2}$ para las plantas?}

A los seres humanos no nos afecta directamente que aumente el $\mathrm{CO}_{2}$, pero sí nos preocupa el denominado calentamiento global, que es el resultado de mayores concentraciones de $\mathrm{CO}_{2}$ en la atmósfera. Contrariamente, a las plantas sí les afecta directamente una mayor presencia de $\mathrm{CO}_{2}$.

Utilizando energía solar, las plantas verdes tienen la capacidad de tomar el dióxido de carbono de la atmósfera, convirtién- dolo en materia orgánica, como carbohidratos y celulosa. Este proceso, denominado fotosíntesis, es el que permite a las plantas crecer. El catalizador bioquímico o sustancia clave, que les permite fijar $\mathrm{CO}_{2}$, es una proteína con un nombre complicadísimo: Ribulosa Bifosfato Carboxilasa Oxigenasa, RUBISCO, en breve. Esta proteína tiene dos propiedades claves que nos ayudan a comprender cómo responden las plantas a incrementos en el $\mathrm{CO}_{2}$. Primero, RUBISCO es un catalizador "perezoso", es decir, en el lenguaje de los bioquímicos, que tiene una baja actividad específica. Debido a su ineficiencia, las plantas necesitan mucho RUBISCO para realizar su fotosíntesis. Por tanto, no es sorprendente que este catalizador sea la proteína más abundante en la tierra: ¡hay más de 10 kilogramos de ella por cada persona en el planeta! Segundo, RUBISCO es un catalizador "promiscuo", que utiliza tanto al dióxido de carbono como al oxígeno (ver figura abajo). El $\mathrm{CO}_{2}$ y el oxígeno compiten, desencadenando dos ciclos bioquímicos distintos aunque relacionados. En la figura, abajo, vemos a la izquierda el ciclo de carboxilación, que promueve el incremento del carbono y el crecimiento de las plantas. A la derecha está el ciclo de oxigenación, que causa la pérdida de algo de dióxido de carbono, disminuyendo la productividad de la planta. Cualquier cambio

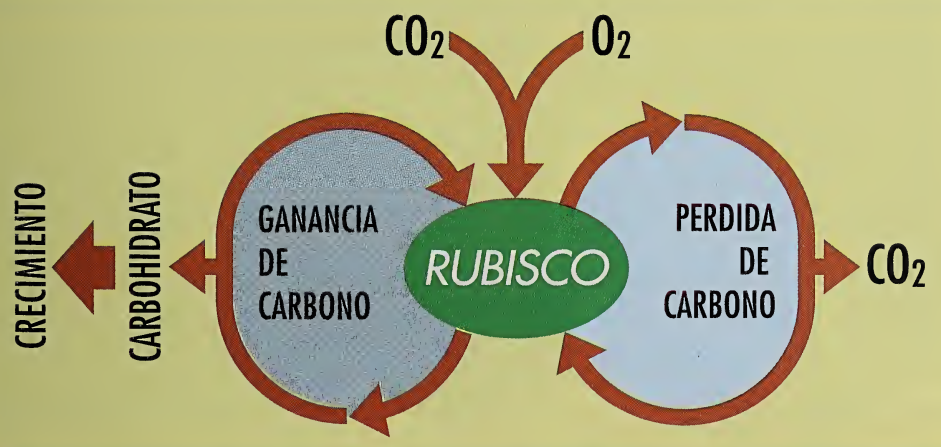

La fijación de $\mathrm{CO}_{2}$ y del oxígeno como dos reacciones competitivas catalizadas por la enzima RUBISCO en las hojas de las plantas. La fijación de $\mathrm{CO}_{2}$ resulta en el ciclo fotosintético de reducción del carbono (a la izquierda) que permite a las plantas crecer. La fijación de oxígeno resulta en el ciclo de oxidación del carbono (a la derecha), lo que se traduce en la pérdida de dióxido de carbono y disminución de la tasa de crecimiento. Aumentos en la concentración de $\mathrm{CO}_{2}$ atmosférico favorecen el ciclo de la izquierda. 
en la proporción de dióxido de carbono y de oxígeno en la atmósfera afecta la frecuencia de ambos ciclos. De aumentar el nivel de dióxido de carbono en la atmósfe. ra, este favorecerá el ciclo de carboxilación, estimulando el crecimiento de las plantas.

\section{Las tres vías de la fotosíntesis}

Las consideraciones hechas arriba se refieren a plantas que según los fisiólogos poseen la vía fotosintética del C3, es decir, la forma en que la mayoría de las especies, incluyendo todos los árboles tropicales (con excepción de ciertas especies de $\mathrm{Clu}$ sia, como el árbol de Copé), adquieren el $\mathrm{CO}_{2}$. No incluye a plantas con las otras dos vías fotosintéticas alternas, las cuales son: la fotosíntesis C4 usada por las gramíneas tropicales, y el metabolismo de ácido crasuláceo (CAM) empleado por los cactus, muchas orquídeas y bromelias tropicales. La fotosíntesis C4 y CAM aumentan la concentración del $\mathrm{CO}_{2}$ dentro de las hojas y alrededor de la proteína RUBISCO, suprimiendo el ciclo de oxigenación. Como consecuencia, las plantas con fotosíntesis
C4 y CAM responden menos a incrementos en el $\mathrm{CO}_{2}$ atmosférico que las plantas C3.

\section{Aumentos del $\mathrm{CO}_{2}$ y los bosques tropicales. Algunas preguntas claves}

Cientos de estudios científicos se han enfocado en investigar las respuestas de las plantas de zonas templadas del norte a mayores niveles de $\mathrm{CO}_{2}$ y es común que los horticultores comerciales de países templados estimulen el desarrollo de las plantas en los invernaderos, aumentando artificialmente las concentraciones de $\mathrm{CO}_{2} \mathrm{CO}-$ mo también dotándolas de cantidades óp. timas de agua y nutrientes. Sin embargo, poco sabemos acerca de cómo reacciona rán las plantas silvestres a cambios en el $\mathrm{CO}_{2}$ en su ambiente natural, donde la disponibilidad de agua y nutrientes también son factores importantes en su crecimiento.

Es limitado nuestro conocimiento sobre cómo el incremento de $\mathrm{CO}_{2}$ afecta a los bosques tropicales, que representan casi $60 \%$ de la vegetación boscosa del mundo.

Cámaras en forma de túnel con filme plástico transparente para estudiar el crecimiento de plantas en el sotobosque de isla Barro Colorado en concentraciones de $\mathrm{CO}_{2}$ actuales y elevadas.

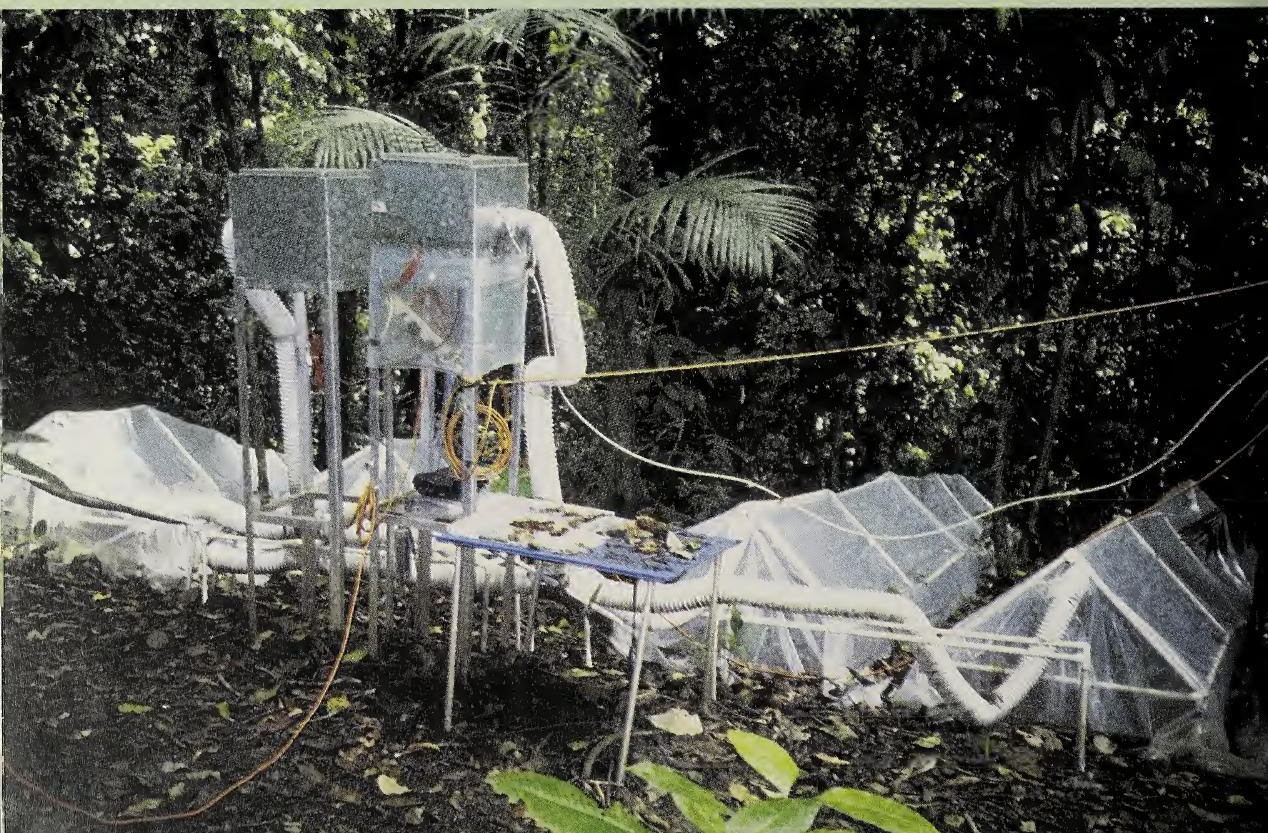




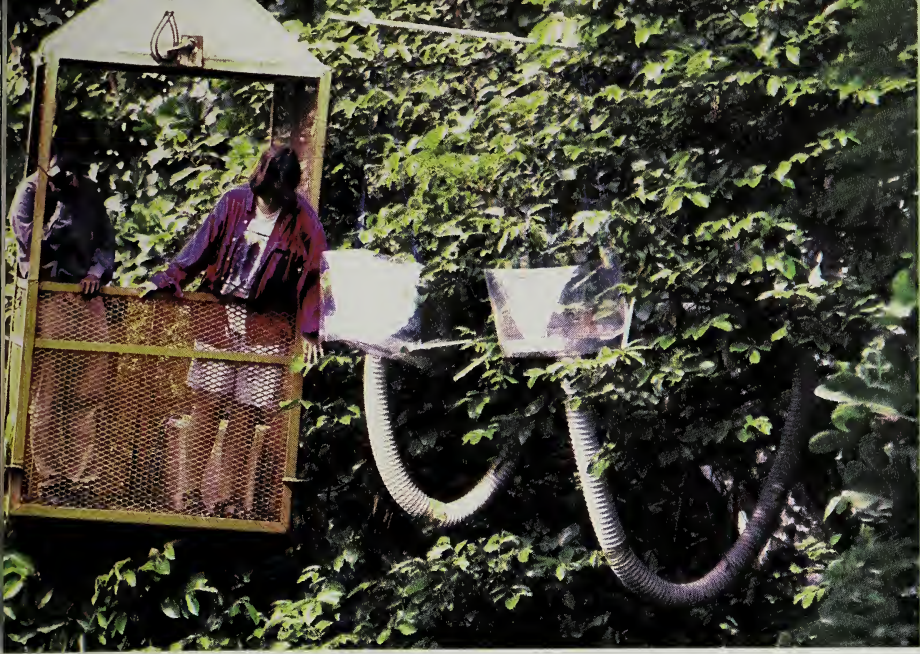

Los Dres. Virgo y Lovelock en la góndola de la grúa del Parque Natural Metropolitano. Al lado de la góndola están dos cámaras, una con $\mathrm{CO}_{2}$ elevado y la otra con $\mathrm{CO}_{2}$ bajo condiciones corrientes.

Entre las preguntas que nos hacemos están: ¿Aumentarán en el futuro los bosques tropicales su biomasa, aérea y subterránea, por unidad de área? ¿Madurarán más rápido los árboles tropicales? ¿Serán más altos? ¿Será posible que al incrementar los árboles su asimilación mitigue el alza en el $\mathrm{CO}_{2}$ atmosférico? ¿Responderán algunas especies mejor que otras? ¿Habrá ganadores y perdedores entre ellas? ¿Cambiará la composición de las especies de plantas del bosque tropical?

\section{Métodos para aumentar el $\mathrm{CO}_{2}$}

Para responder a estas interrogantes debemos aumentar experimentalmente la concentración de $\mathrm{CO}_{2}$ en torno a las plantas. Una manera de hacerlo a gran escala es mediante los llamados sistemas FACE. En inglés, FACE son las siglas de Free Air $\mathrm{CO}_{2}$ Enrichment, que traducido al español sería Enriquecimiento del $\mathrm{CO}_{2}$ en el Aire Libre. Fstos sistemas consisten típicamente de terrenos de 30 metros de diámetro, que se rodean con tubos verticales de hasta 15 metros de alto, a través de los cuales se libera el dióxido de carbono que el viento distribuye sobre la parcela experimental. Una computadora controla la tasa de liberación del $\mathrm{CO}_{2}$, considerando la velocidad y dirección del viento. Una instalación completa del sistema FACE consiste de varios anillos. Por ejemplo: tres de ellos elevan el dióxido de carbono y otros tres, de control, lo liberan en concentraciones actuales. En el presente no hay estu- dios con estos sistemas en el trópico. El STRI conjuntamente con la Universidad de McGill, Canadá, el Laboratorio Nacional de Brookhaven, y la participación de universidades de Estados Unidos y Panamá, están tratando de instalar un sistema de anillos FACE en Sardinilla, Panamá. Pero debemos aguardar un tiempo hasta que este sistema esté listo y se inicien las investigaciones.

A continuación explicaré brevemente algunos resultados de experimentos utilizando sistemas experimentales a menor escala para cultivar plantas bajo condiciones altas de dióxido de carbono. En uno de estos estudios en Barro Colorado hemos utilizado cámaras plásticas alargadas, como si fueran un túnel, para investigar las respuestas al $\mathrm{CO}_{2}$ elevado de las plantas del sotobosque que crecen bajo condiciones de poca luz. En otro proyecto utilizamos una de las dos grúas del STRI para estudiar cómo responden las ramas de los árboles de gran tamaño a condiciones altas de $\mathrm{CO}_{2}$, usando cámaras plásticas en forma de anillo con su techo abierto.

La mayoría de los estudios se hicieron en ocho cámaras de techo abierto (open topped chambers) en un claro del bosque del Parque Natural Metropolitano. Estas cámaras consisten de marcos de aluminio cubiertos de un plástico transparente con techo descubierto. Las cámaras eran ventiladas continuamente. En cuatro de las ocho cámaras, la concentración de $\mathrm{CO}_{2}$ se elevó 


\section{Biomasa y fotosíntesis}

La Tabla 1 contiene los resultados de tres experimentos consecutivos mostrando la acumulación de biomasa en las plantas bajo condiciones de $\mathrm{CO}_{2}$ actuales y elevadas. En el experimento (I) las plantas se cultivaron en el suelo del sitio, pobre en nutrientes, compactado y mal drenado. El aumento en el dióxido de carbono no afectó el crecimiento de las plantas. En un segundo experimento (II), con mejor suelo, observamos un poco más de biomasa con niveles altos de dióxido de carbono, aumento que no fue estadísticamente significativo. Finalmente, en un tercer experimento (III), el suelo fue fertilizado con nitrógeno, fósforo y otros elementos. Bajo estas condiciones, al elevarse el $\mathrm{CO}_{2}$ la biomasa se incrementó en un $50 \%$. Estos tres experimentos señalan que el $\mathrm{CO}_{2}$ es apenas uno de varios factores que afectan el crecimiento de las plantas y que evidentemente el aumento de dióxido de carbono sólo estimula marcadamente el desarrollo de las plantas cuando otros factores, como la calidad del suelo y la disponibilidad de agua también son óptimos.

Sugieren los resultados que el crecimiento del bosque tropical puede estar limitado principalmente por factores distintos al $\mathrm{CO}_{2}$ en la atmósfera. Necesitamos recordar que nuestros experimentos fueron realizados con plantas jóvenes en un período de hasta siete meses. La fase juvenil es crítica para las plantas. Sin embargo, siete meses constituyen sólo una pequeña fracción en la vida de un árbol y es posible que cambios minúsculos en la biomasa acumulada a corto plazo, como en el segundo experimento (II, Tabla 1), pueden resultar, a largo plazo, en un aumento significativo en la tasa de maduración de los árboles.

Cabe mencionar un segundo punto. En el primer y segundo experimento (I y II, Tabla 1), el $\mathrm{CO}_{2}$ elevado no hizo que las plantas crecieran más rápido pero las medidas de fotosíntesis muestran que las hojas desarrolladas bajo $\mathrm{CO}_{2}$ elevado absorben más $\mathrm{CO}_{2}$ que las que crecen en aire normal. ¿Por qué en estos dos experimentos el incremento en las tasas de fotosíntesis por unidad de área foliar, es decir, por superficie de la hoja, no resultaron en mayor
Tabla 1. Aumento de la biomasa de comunidades de árboles jóvenes, expuestas a concentraciones de $\mathrm{CO}_{2}$ actuales y elevadas. El experimento I fue realizado con una combinación de diez especies (Lovelock et al. 1998). Mientras, los experimentos II y III fueron conducidos con una mezcla de plantas de Ficus insipida y Virola surinamensis (Winter et al. 2000, 2001).

\begin{tabular}{|c|c|c|c|}
\hline \multirow{2}{*}{ EXPERIMENTO } & \multirow{2}{*}{$\begin{array}{l}\text { DURACION } \\
\text { (SEMANAS) }\end{array}$} & \multicolumn{2}{|c|}{$\begin{array}{l}\text { BIOMASA DE LA } \\
\text { COMUNIDAD (kg) }\end{array}$} \\
\hline & & $\begin{array}{l}\mathrm{CO}_{2} \\
\text { ACTUAL }\end{array}$ & $\begin{array}{l}\mathrm{CO}_{2} \\
\text { ELEVADO }\end{array}$ \\
\hline $\begin{array}{c}\text { I } \\
\text { SUELO POBRE, } \\
\text { MUY COMPACTADO }\end{array}$ & 26 & $1.5 \pm 0.2$ & $1.4 \pm 0.2$ \\
\hline $\begin{array}{c}\| \\
\text { SUELO NO } \\
\text { COMPACTADO }\end{array}$ & 30 & $2.3 \pm 0.4$ & $2.7 \pm 0.5$ \\
\hline $\begin{array}{c}\text { III } \\
\text { SUELO NO } \\
\text { COMPACTADO } \\
\text { Y FERTILIZADO }\end{array}$ & 16 & $3.0 \pm 0.1$ & $4.5 \pm 0.4$ \\
\hline
\end{tabular}

crecimiento? Una explicación es que bajo condiciones de $\mathrm{CO}_{2}$ elevado las plantas disminuyen la producción de su superficie en relación a su biomasa total, es decir, que reducen su "proporción de área foliar" (leaf area ratio, LAR) bajo condiciones de dióxido de carbono elevado. Esta "proporción de área foliar" se define como el área foliar total de una planta en relación a su biomasa total (su peso en seco). Otra explicación es que parte del carbono extra fijado bajo condiciones altas de $\mathrm{CO}_{2}$ es liberado al suelo a través de las raíces. Este y otros estudios indican que las interacciones entre la raíz y el suelo y la captura del carbono por los suelos tropicales en condiciones elevadas de $\mathrm{CO}_{2}$ son áreas importantes para investigaciones futuras.

La calidad de la hoja es otro aspecto afectado por un elevado $\mathrm{CO}_{2}$, particularmente en plantas que crecen en suelos pobres, donde la biomasa total cambia poco en respuesta al $\mathrm{CO}_{2}$. Aquellas hojas que crecen bajo $\mathrm{CO}_{2}$ elevado tienen más almidón $\mathrm{y}$, por tanto, más materia seca por unidad de área que las hojas de la misma especie que crecen en el aire normal (Tabla 2). 
Tabla 2. Propiedades de las hojas de Ficus insipida que crecieron en condiciones de $\mathrm{CO}_{2}$ actuales y elevadas en cámaras de techo abierto. El experimento se realizó sin fertilizante (Winter et al. 2000).

\begin{tabular}{c|c|c|} 
PARÁMETRO & $\begin{array}{c}\mathrm{CO}_{2} \\
\text { ACTULAL }\end{array}$ & $\begin{array}{c}\mathrm{CO}_{2} \\
\text { ELEVADO }\end{array}$ \\
$\begin{array}{c}\text { MASA FOLLAR : ÁREA FOLLAR } \\
\text { (MLLLGRAMO : }\left(\mathrm{CM}^{2}\right)\end{array}$ & $5.7 \pm 0.1$ & $7.9 \pm 0.3$ \\
$C: N$ & $16 \pm 2$ & $24 \pm 2$ \\
\hline
\end{tabular}

También disminuye el contenido de nitrógeno de las hojas comparado con el carbono, esto es, aumenta la proporción de carbono en relación al nitrógeno (Tabla 2). Tanto el almidón como las proteínas, que contienen el nitrógeno, son alimento para los animales herbívoros. Por tanto, cambios en la calidad de las hojas pueden tener consecuencias ecológicas importantes, pudiendo influir en las relaciones entre las plantas, insectos y otros herbívoros.

\section{Biomasa y agua}

Al hablar de fotosíntesis y crecimiento de las plantas, no debe olvidarse que estos procesos están muy ligados a las relaciones de las plantas con el agua. Durante la fotosíntesis el $\mathrm{CO}_{2}$ entra a las hojas a través de pequeños poros microscópicos, llamados estomas. Las plantas regulan el ta-

Tabla 3. Efecto del $\mathrm{CO}_{2}$ elevado en el incremento de la biomasa y cantidad de agua transpirada, por unidad de biomasa producida, en Ficus insipida. (K. Winter y colegas, datos no publicados).

\begin{tabular}{c|c|c|}
\hline TRATAMIENTO & $\begin{array}{c}\text { BIOMASA } \\
\text { (gramo) }\end{array}$ & $\begin{array}{c}\text { REQUERIMIENTO DE AGUA } \\
\text { (gramo agua : gramo biomasa) }\end{array}$ \\
\hline $\begin{array}{c}\text { SIN FERTILIZANTE } \\
\mathrm{CO} \mathrm{O}_{2} \text { ACTUAL }\end{array}$ & $8 \pm 1$ & $329 \pm 24$ \\
$\mathrm{CO} \mathrm{O}_{2}$ ELEVADO & $10 \pm 2$ & $213 \pm 19$ \\
\hline $\begin{array}{c}\mathrm{CON} \text { FERTILIZANTE } \\
\mathrm{CO}_{2} \text { ACTUAL }\end{array}$ & $23 \pm 5$ & $262 \pm 11$ \\
$\mathrm{CO}_{2}$ ELEVADO & $42 \pm 4$ & $176 \pm 3$ \\
\end{tabular}

maño de la apertura de estos estomas, por que cada vez que se abren para dejar entrar el $\mathrm{CO}_{2}$, grandes cantidades de agua en forma de vapor escapan de la hoja hacia la atmósfera. Este paso del agua, desde la hoja hacia la atmósfera, se llama transpiración. El agua que la planta pierde por transpiración debe reemplazarla absorbiendo agua del suelo a través de sus raí ces, transportándola rápidamente por su tallo hasta las hojas.

En una serie de experimentos, cultivamos las plantas en grandes potes para determinar los efectos de los altos niveles de $\mathrm{CO}_{2}$ en el crecimiento y la transpiración, es decir, para medir la cantidad de agua que las plantas consumen al crecer. La pérdida de agua de las plantas hacia la atmósfera reduce el peso de los potes, lo que se determinó con una balanza. Tomamos estas medidas dos veces por semana, y siempre se agregó agua al suelo para igualar, exactamente, el agua perdida por transpiración.

El $\mathrm{CO}_{2}$ elevado afecta enormemente el uso de agua de las plantas (Tabla 3). Las plantas de Ficus insipida, pertenecientes al grupo de árboles tropicales pioneros, fueron cultivadas en suelos normales y fertilizados y expuestos a niveles de $\mathrm{CO}_{2}$ actuales y elevados. En dos de los cuatro experimentos en potes, el crecimiento no fue significativamente mayor con dióxido de carbono elevado en las plantas no fertilizadas, pero siempre fue mayor en plantas abonadas y bajo un $\mathrm{CO}_{2}$ alto. La Tabla 3 muestra un ejemplo en que la biomasa no aumentó con un $\mathrm{CO}_{2}$ elevado en plantas no abonadas. Bajo ambos regímenes nutricionales, un $\mathrm{CO}_{2}$ elevado redujo fuertemente la pérdida de agua por transpiración; las plantas fertilizadas en un aire normal utilizaron 262 gramos de agua para producir un gramo de biomasa seca. Mientras, en condiciones de $\mathrm{CO}_{2}$ elevado, el requerimiento de agua fue $33 \%$ menor. Sorprendentemente, en las plantas no fertilizadas, bajo un $\mathrm{CO}_{2}$ elevado, también se redujo en un $35 \%$ la transpiración de agua: de 329 a 213 gramos de agua, por gramo de materia seca. Estos resultados demuestran que si en el futuro los cambios en el $\mathrm{CO}_{2}$ atmosférico no llegasen a ocasionar cambios mayores en la biomasa de los bosques tropicales, sí podrían disminuir significativa- 


\section{El fenómeno \\ de El Niño y los \\ bosques de isla \\ Barro Colorado}

\section{Joseph Wright}

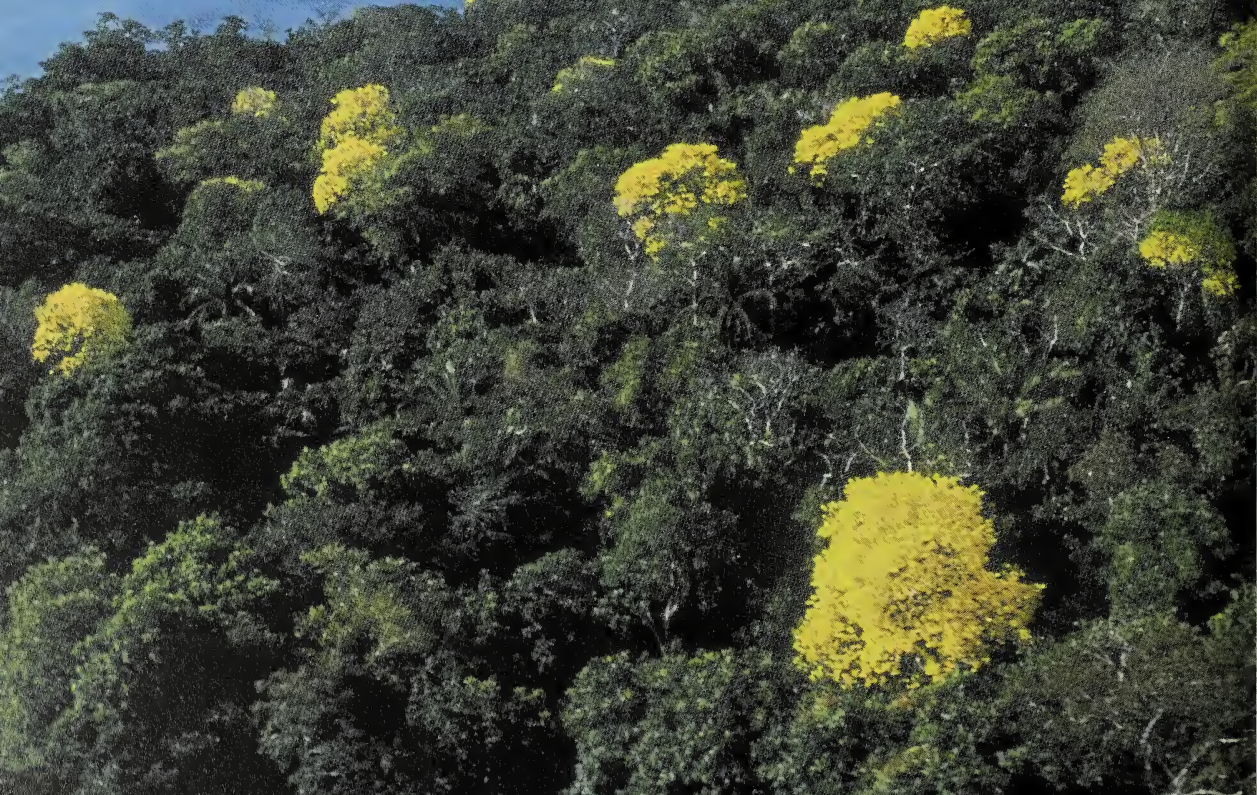


$\mathrm{E}$ n la isla Barro Colorado la producción de frutos del bosque varía de un año a otro. Con frecuencia, a un año de alta productividad le sigue otro en el que la producción natural decae seriamente, limitando la alimentación para los animales que comen frutas (frugivoros) y para los que dependen de semillas (granívoros). Se piensa que tales altibajos en la cantidad de frutos silvestres del bosque tropical guardan relación con el fenómeno climatológico llamado El Niño.

Durante 49 años se ha estudiado a los mamíferos de esta isla que dependen de fru. tas y semillas silvestres. Esto permite comprobar la hipótesis que sostiene que cuando El Niño reduce la producción de frutos, disminuye el número de animales que se alimentan de ellos. Cuando la producción de los árboles es alta, los animales se reproducen, crecen rápidamente, acumulan grasa y guardan semillas. Cuando es baja, hay hambruna entre los animales, con con- secuencia de pérdida de peso en unos, mientras otros mueren y algunos emigran.

\section{La Corriente de El Niño y el clima mundial}

Uno de los eventos climatológicos más extraordinarios del planeta es la Corriente de El Niño, fenómeno cuyas causas son poco conocidas. Desde que Barro Colorado se convirtió en una estación biológica, estos eventos han ocurrido 16 veces, la última en 1997.

El Niño eleva considerablemente la temperatura de la superficie del Pacífico, asemejando una lengua gigantesca de agua caliente que parte desde la costa oeste de América del Sur y avanza hasta la línea internacional de cambio de fecha, en el centro del Pacífico. Durante el evento en el este del Pacífico, la presión atmosférica es inusualmente baja y el manto de agua caliente impide que afloren los nutrientes de las aguas más frías y profundas. Esto

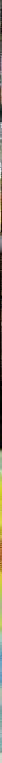

Irregularidades en la temperatura de la superficie del Oceáno Pacífico, el 30 de noviembre de 1997, durante el apogeo de El Niño de 1997-1998. En el mapa, el color rojo representa las aguas más calientes y el color azul, las más frías. Esta ilustración se basa en imágenes de satélites que registran las temperaturas de la superficie de los mares. 
provoca gran mortalidad entre las especies marinas. Las poblaciones de aves y mamíferos como focas y lobos de mar se reducen drásticamente.

Para Centroamérica, el norte de Sudamérica, el Amazonas, Malasia, Nueva Guinea, el norte de Australia, India y partes del Africa Ecuatorial Occidental, el Niño trae sequías, aumentos en las temperaturas y en el número de días soleados. Contrariamente, en regiones normalmente secas, como la costa pacífica de Sur América, California y partes de Africa, se producen fuertes lluvias e inundaciones.

A la corriente de El Niño, que a veces se extiende hasta por 24 meses, le puede seguir un período climatológico opuesto, $\mathrm{La}$ Niña. Esta se caracteriza en América Central por días más lluviosos, nubosos y temperaturas más bajas. En Barro Colorado la precipitación promedio anual es de 2,670 milímetros, pero durante El Niño de 1997 se registró la sequía más fuerte en la historia de la estación; apenas cayeron 1,650 milímetros. Contrariamente, en 1999, año de la Niña, se registró el segundo año más lluvioso en la historia de la isla con 3,500 milímetros de precipitación lluviosa.
Se piensa que en los bosques tropicales de Barro Colorado El Niño estimula la producción de frutos y que La Niña la reduce. Con El Niño vienen veranos fuertísimos e inviernos débiles, lo que expone las plantas a mayores cantidades de luz solar, aumentando la producción de frutos. Al llegar La Niña las plantas obtienen menos luz solar y producen menos frutos.

\section{Lluvias, sequías y frutos silvestres}

Normalmente en Barro Colorado la estación seca se extiende de mediados de diciembre a fines de abril. No obstante, dependiendo de la precipitación y duración de la temporada, el verano puede ser suave o severo. En una estación severa, como la de 1998, las lluvias dejaron de caer desde fines de noviembre y no volvió a llover significativamente hasta fines de abril. Cuando ello ocurre, la tierra se seca, se resquebraja y las plantas del bosque se marchitan y aumenta la mortalidad hasta entre los árboles maduros.

A diferencia de la agricultura, las plantas de los bosques tropicales húmedos requieren un nivel mínimo de sequía para florecer con éxito. La combinación de meses se.

Reducciones de las poblaciones de coaties y saínos observadas en la isla Barro Colorado entre agosto de 1993 y marzo de 1994. La reducción ocurrió después del evento de El Niño de 1992, caracterizado por una alta producción de frutos, a la que siguió una temporada seca corta en 1993, con una extraordinariamente baja producción de frutos entre julio de 1993 y marzo de 1994. Ambas especies se alimentan de frutos y semillas.
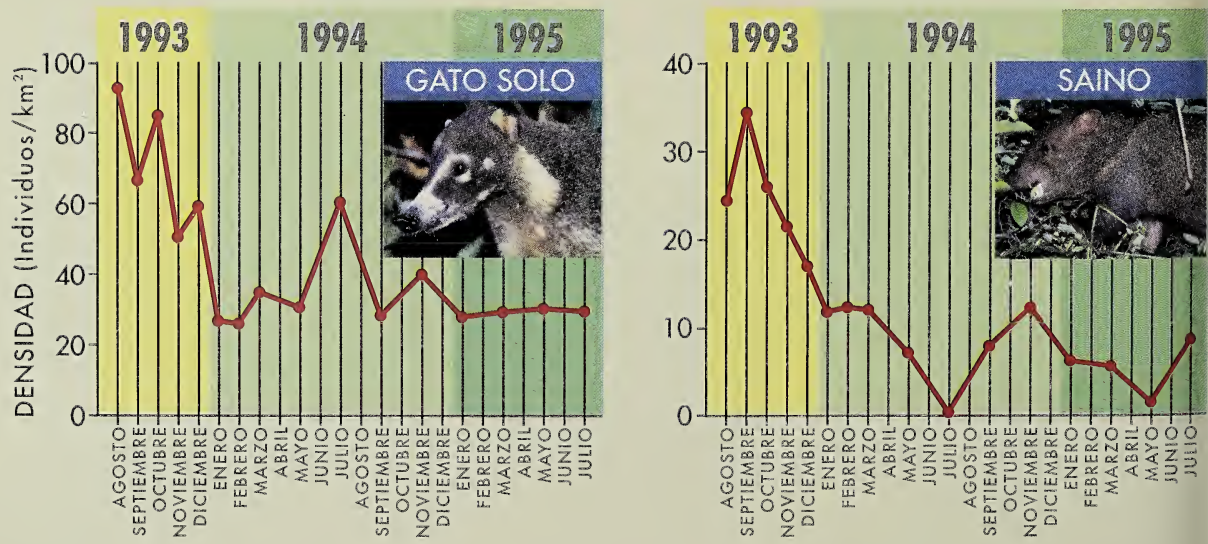
cos y sol fuerte favorecen la producción de frutos. Como la estación seca sincroniza el florecimiento de la mayoría de las plantas del bosque, ellas alcanzan su mayor producción de frutas entre enero y agosto.

En el registro de 49 años de los bosques de Barro Colorado ha podido observarse en dos ocasiones, un ciclo compuesto por un año de alta producción de frutos, seguido de otro cuando esta decae considerablemente. Esto ocasiona una fuerte hambruna entre los mamíferos que dependen de las frutas y semillas silvestres. Es nuestra hipótesis que este aumento en la producción de frutos que es estimulado por El Niño, exige a los árboles un mayor esfuerzo que consume sus reservas de nutrientes y reduce su productividad al año siguiente. Al mismo tiempo, si El Niño es seguido por La Niña, una estación seca suave y con lluvias, la producción de frutos decae dramáticamente.

Esta incapacidad de dar frutos, luego de una estación seca suave, cae en desproporción sobre las especies de plantas que florecen en mayo, junio y julio. Estas son las especies que requieren niveles mínimos de sequía para iniciar su floración.

\section{Las hambrunas de mamíferos}

Uno de los registros ecológicos más importantes del mundo sobre los bosques tropicales concierne a las hambrunas y mortandades de los mamíferos en Barro Colorado. Las hubo en los años 1931-1932, 19581959, 1970-1971 y en 1993-1994. Todas ocurrieron entre septiembre y enero. Durante la hambruna de 1931-1932, se encontraron coatíes (Nasua narica), saínos y venados (Mazama americana) gravemente enflaquecidos, mientras que los saínos y puercos de monte (Tayassu tajacu y T. Pecari) buscaban comida cerca de los edificios de la estación biológica. Nuevamente en 1958 -1959, se observaron saínos y venados severamente extenuados, pereciendo más de la mitad de la población de coatíes. En el peor punto de las hambrunas de 1970-1971 y 1993-1994, muchos animales frugívoros aparecían muertos a lo largo de los senderos de la isla, siendo los meses más crudos entre septiembre y diciembre, cuando po- cas especies de plantas maduran sus frutos.

\section{La variabilidad del clima y la producción} de frutos

Queremos plantear la hipótesis siguiente. Primero, el fenómeno de El Niño conlleva condiciones ambientales que estimulan la producción de frutas; segundo, una alta producción de frutas consume los recursos energéticos guardados por las plantas; tercero, una estación seca suave reduce la producción de frutas.

Cada especie de planta puede responder a cualquier combinación de los tres componentes de esta hipótesis. Los niveles más bajos de producción de frutos en un bosque húmedo como Barro Colorado son más probables cuando una estación seca suave le sigue a un año de El Niño. Durante los 49 años de observaciones en Barro Colorado estas condiciones fueron invariablemente asociadas con hambrunas entre los mamíferos que comen frutas, sustentando nuestra hipótesis.

Bonifacio De León examina los restos de un zaíno que pereció en la hambruna de 19931994, en la isla Barro Colorado.

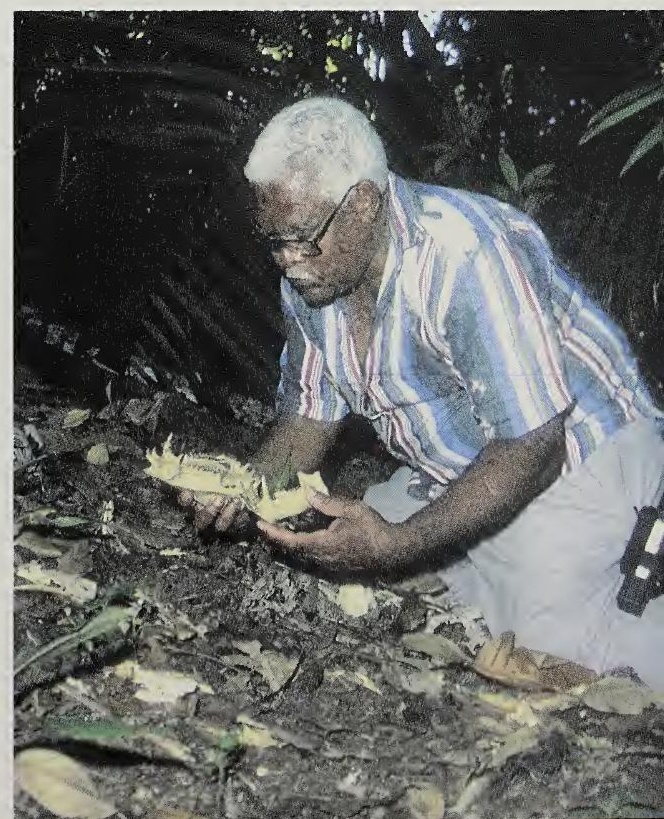


Indica el registro a largo plazo que una estación seca severa, aunque importante, no es suficiente de por sí para iniciar este ciclo de dos años de producción de frutos que termina en una hambruna. Así, no hubo hambrunas en tres ocasiones cuando a una estación seca severa le siguió una estación seca suave, pero sin coincidir con El Niño.

Así como el ciclo de sequía y lluvia puede tener un papel importante en los niveles de producción de frutos silvestres, también puede jugarlo la radiación solar. Durante El Niño hay menos nubes, lo que aumenta la cantidad de luz sobre grandes áreas del trópico. Los niveles de luz limitan a muchas especies de plantas del bosque tropical, hasta las del dosel. Una mayor radiación solar al promedio podría estimular la producción de frutos. Pero a El Niño, con sus períodos soleados intensos, le sigue frecuentemente un año más nuboso, con menores niveles de radiación solar y niveles de producción de frutos reducidos.

En conclusión, El Niño ha ocurrido 21 veces en el siglo XX y ha traido baja precipitación, altos índices de radiación solar y temperaturas elevadas a la mayoría de las regiones boscosas del trópico. Los modelos usados para predecir los cambios climáticos globales, por ejemplo, los que estudian el efecto del invernadero o calentamiento global, y los modelos dirigidos para la deforestación, predicen que en el futuro en los trópicos lloverá menos, las temperaturas aumentarán y las estaciones lluviosas y secas serán más intensas. El estudio de los eventos de El Niño puede permitirnos una ventana al futuro del cambio climático de nuestro planeta.

El nivel de las aguas del Lago Gatún bajó drásticamente durante la severa sequía asociada al evento de El Niño de 1997-1998. Nunca antes las aguas del lago habían llegado a niveles tan bajos como estos. Foto: M. Guerra.

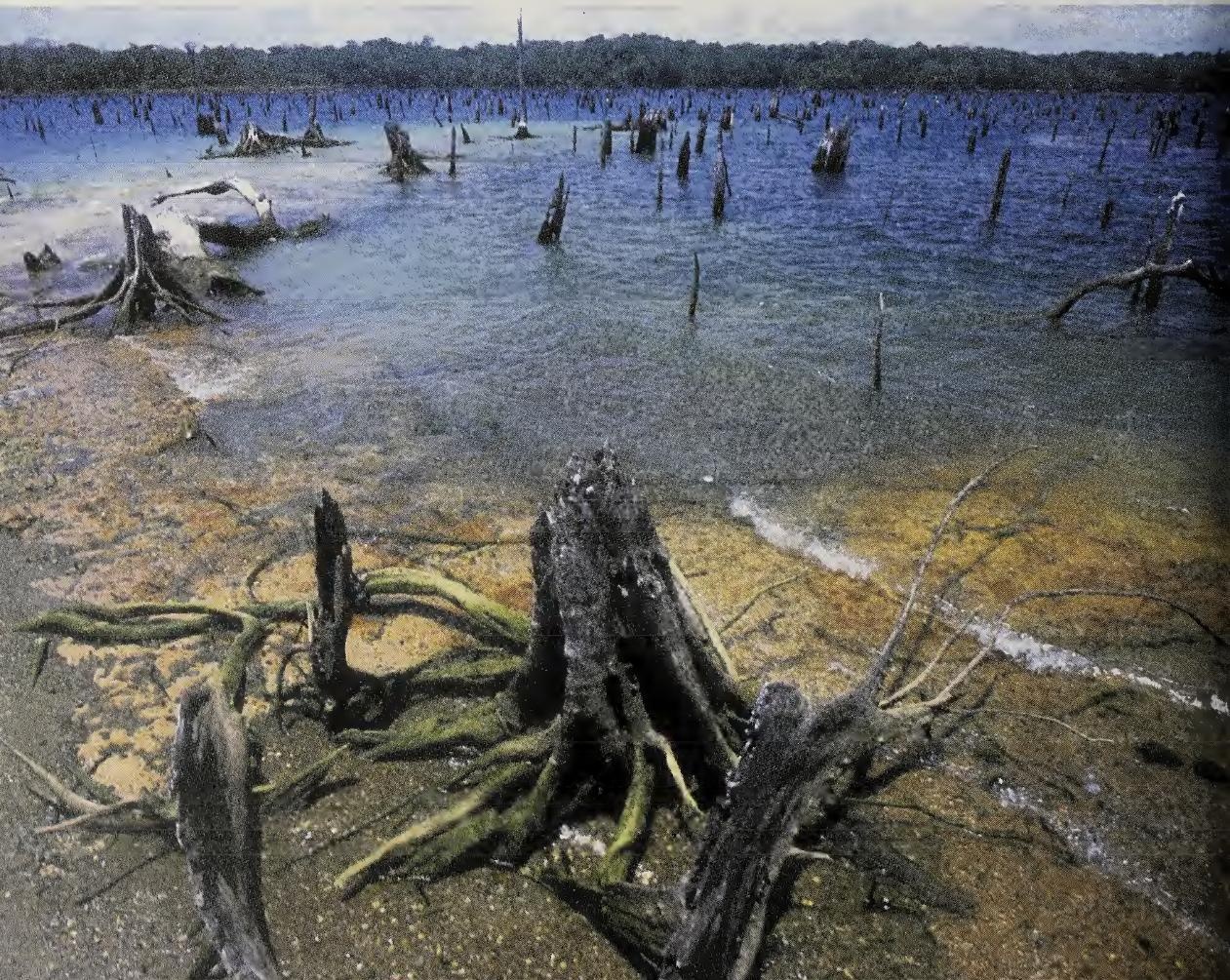




\section{CAPITULO 3}

\section{EL PEQUEÑO GRAN MUNDO DE LOS INSECTOS}
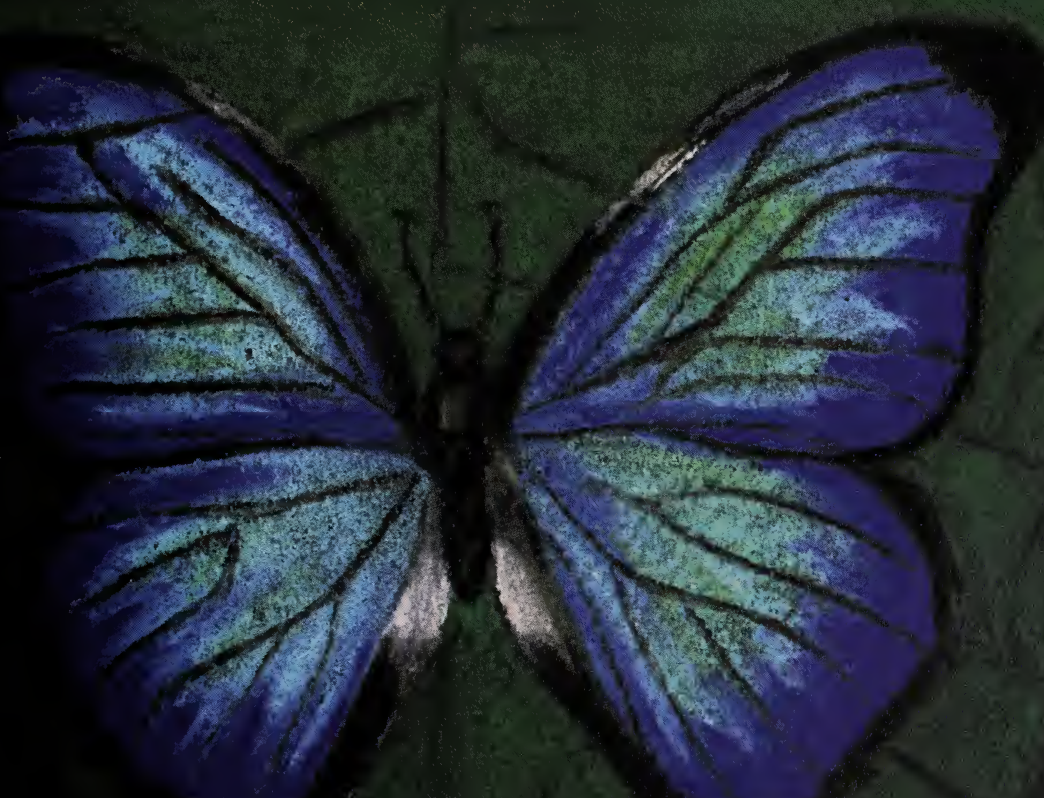
$\mathrm{L}$ as mariposas son uno de los grupos de insectos más numerosos del trópico. Existen al menos ciento sesenta y cinco mil especies de mariposas en el mundo, y más de dieciséis mil de ellas habitan en Panamá. ¿Sabía usted que cada mariposa pasa la mayor parte de su vida como larva, es decir oruga, comiendo plantas? Estas orugas (Fig. 1) pueden ser tan bellas e interesantes como las mariposas mismas (Fig. 2).

Científicamente, las mariposas son conocidas como Lepidoptera, palabra griega que significa "alas con escamas"; usualmente los colores brillantes de sus alas son producidos por tintes contenidos en las escamas. Las mariposas se dividen aproximadamente en cien familias, y la mayoría de ellas son nocturnas. Las diurnas representan solamente el $10 \%$ de las especies conocidas y sólo siete de las cien familias. Sin embargo, sabemos mucho más sobre las diurnas y sus orugas que sobre las nocturnas. Ello obedece a que es más fácil estudiar las diurnas y a que sus colores son más llamativos y atraen más nuestra atención. Es una lástima que sea tan poco lo que conocemos sobre las mariposas de noche, pues son más diversas y, de cierta forma, hasta más interesantes que las del día.

\section{Las formas de vida de las orugas}

Las orugas carecen de alas y escamas; sus variadísimos colores son producidos por tintes que poseen en la piel. Hay orugas transparentes que parecen de color verde, pues podemos ver dentro de sus estómagos las hojas que han comido (Fig. 3). En verdad, nuestro conocimiento sobre la vida de las orugas es limitado, especialmente de las especies tropicales.

Las orugas tienen diversos estilos de vida. Entre las más primitivas están las "minadoras de hojas" (Fig. 4), las que viven dentro de las hojas y que al comerse el tejido verde van dejando un túnel. Otras prefieren habitar dentro de los tallos de las plantas.

Aunque la mayoría de las orugas construye viviendas de varios tipos, con distintos
Figura 2. La mariposa adulta Gonora sp. de alas transparentes. Pertenece a las mariposas nocturnas pero vuela de día. Foto: L. González.
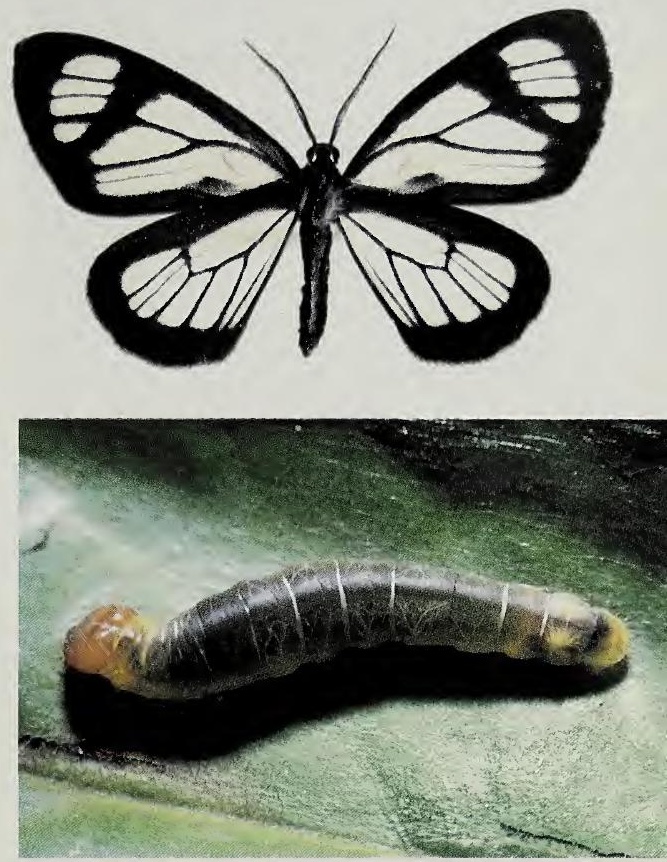

Figura 3. La oruga de Pythonides limaea, una mariposa diurna (familia Hesperiidae). Dentro de su estómago se pueden ver las hojas que ha comido. Foto: A. Aiello.

Figura 4. Este dibujo muestra la "mina" o túnel hecho dentro de una hoja por la oruga de una pequeña mariposa o microlepidóptera.

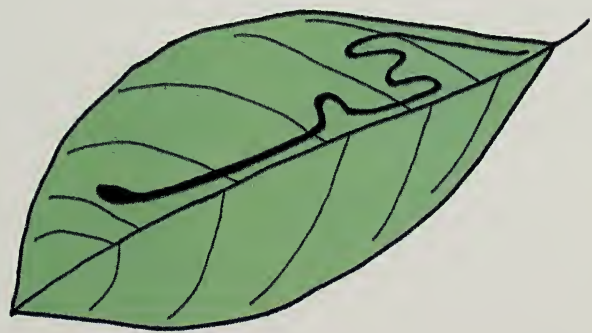


especie, pudiendo ser flores, semillas, frutas, tallos o maderas podridas, pero en la mayoría de las especies, la oruga come hojas de plantas específicas. Ciertamente, la oruga es una máquina hecha para comer y su cuerpo se expande al hacerlo, hasta quedar muy hinchado. Puede decirse que este insecto es más que nada un gran estómago.

Ahora, para seguir creciendo, la oruga necesita comer rápido, pero enfrenta un problema: su cabeza y mandíbulas son muy pequeñas para realizar esta tarea con eficiencia. Necesita, pues, obtener una cabeza más grande y para ello debe mudar de piel, o sea que debe despojarse completamente de su viejo esqueleto exterior o exoesqueleto. Durante el proceso de muda, la oruga deja de comer y permanece tranquila mientras su nueva cabeza y cuerpo se forman (Fig. 12).

Cuando ya está lista, la piel vieja se rompe detrás de la cabeza y emerge la nueva oruga. Como su cuerpo aún está suave y pálido, la oruga toma aire para expandirlo,

De arriba hacia abajo:

Figura 9. La oruga de la mariposa nocturna Tarchon felderi (familia Apatelodidae) advierte a sus enemigos que tiene tóxicos en su piel, anunciándolo con sus brillantes colores. Foto: A. Aiello.

Figura 10a. Los ojos falsos del abdomen le sirven a la oruga de la mariposa nocturna Eudocima materna (familia Noctuidae) para asustar a posibles enemigos, especialmente aves. Foto: A. Aiello.

Figura 10b. La oruga de la mariposa Hemeroplanes triptolemus (Sphingidae). intimida a sus depredadores imitando a una serpiente. Para ello expande el tórax, exponiendo dos manchas que parecen ojos y se coloca con el vientre hacia arriba, como se observa en la foto en recuadro. Foto: Nick Smythe.

Figura 11. La formidable oruga de la mariposa nocturna Acharia sp. (familia Limacodidae) está cubierta por pelos irritantes. Foto: A. Aiello.
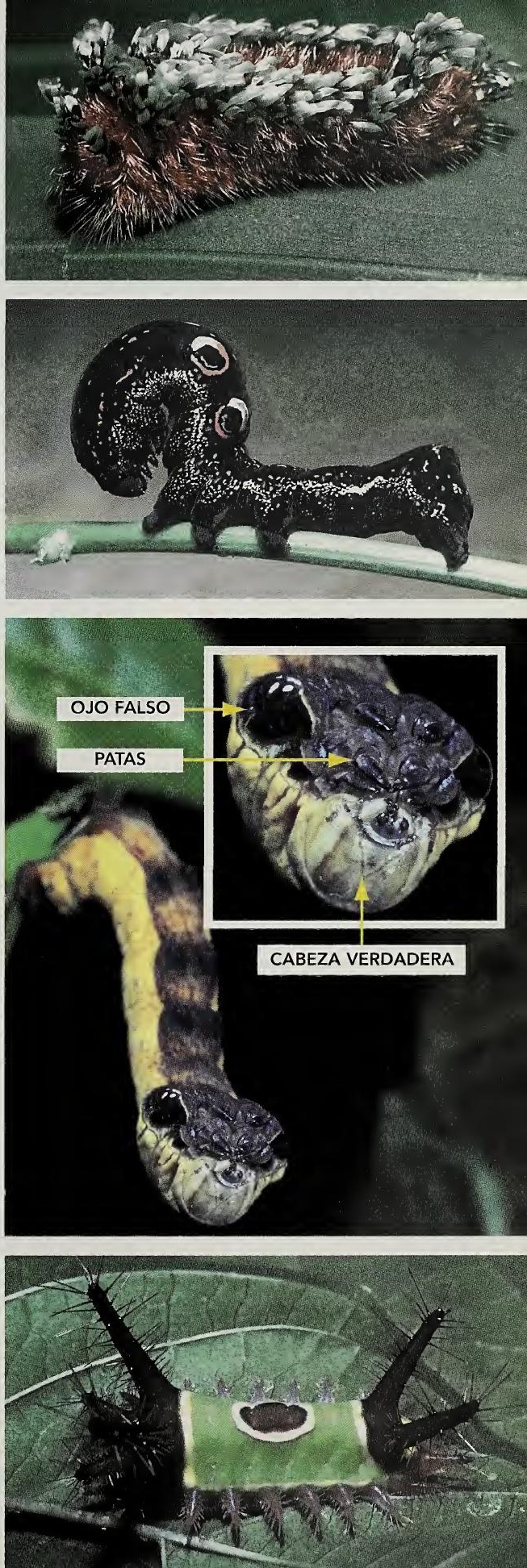
En esta página, de arriba hacia abajo:

Figura 12. La oruga de la mariposa crepuscular Bungalotus quadratum (familia Hesperiidae) lista para mudar. La nueva cabeza puede verse formándose dentro del tórax. Foto: A. Aiello.

Figura 13. La inofensiva oruga de la mariposa nocturna Eucereon (familia Arctiidae) en su penúltimo estadio. Foto: A. Aiello.

Figura 14. La oruga de la mariposa nocturna Eucereon en su último estadio $\mathrm{y}$ antes de convertirse en una muy aburrida pupa color chocolate, de la cual saldrá una mariposa que se asemeja a un avispa. Foto: A. Aiello.

Figura 15. La elegante pupa de la mariposa nocturna Aleuron sp. (familia Sphingidae), mostrando el bosquejo de sus futuras alas, antenas y patas dobladas. Foto: A. Aiello.

En la página opuesta, de arriba hacia abajo:

Figura 16. Anartia fatima (Nymphalidae) es la mariposa diurna más común en Mesoamerica y Panamá. Foto: C. Hansen.

Figura 17. La oruga de la mariposa Anartia fatima sólo come una especie de planta, Blechum pyramidale

(Acanthaceae) una yerba común en áreas alteradas.

Foto: R. Silberglied.
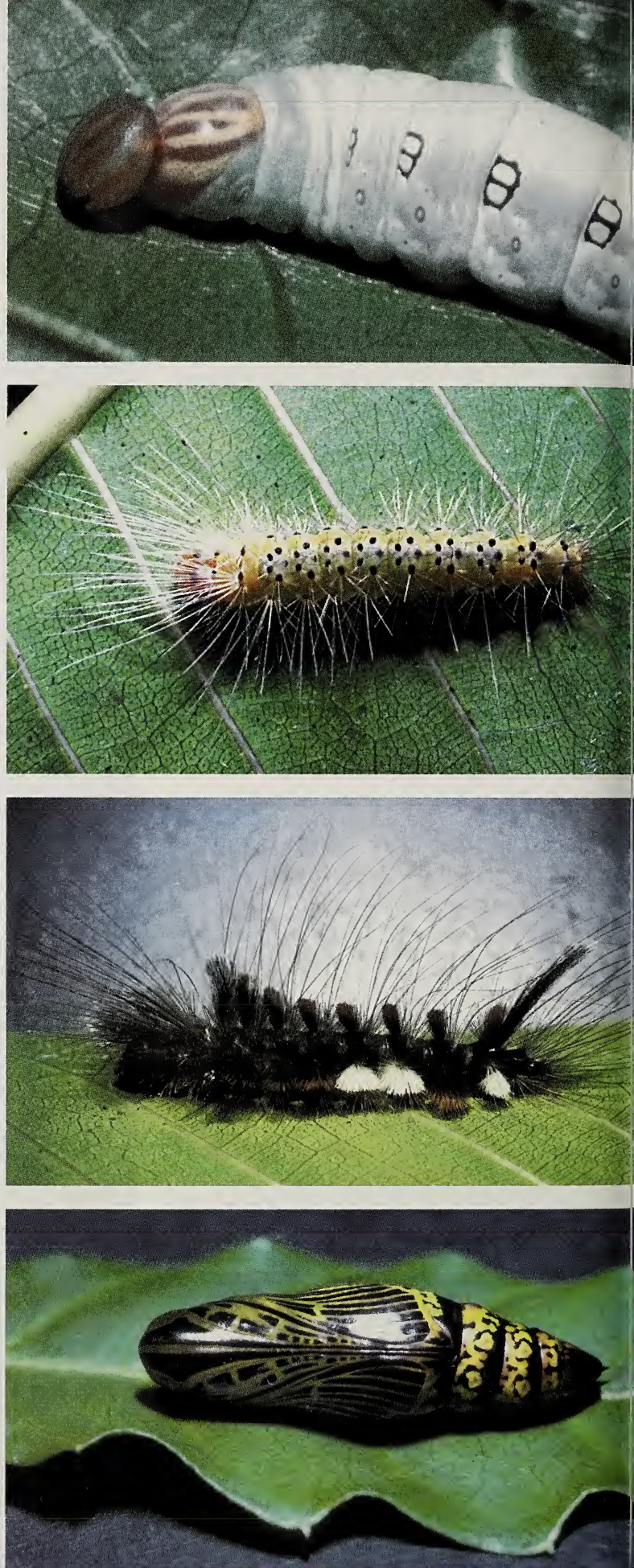
comer de noche. Las orugas ya bien alimentadas se separan y salen del árbol en busca de un soporte en donde transformarse en crisálidas, es decir, pupas sin capullos. Con frecuencia, las crisálidas las encontramos pegadas debajo de los techos o en los marcos de las ventanas. La mariposa adulta vuela al atardecer y en la madrugada.

Las orugas de Melanchroia chephise (Geometridae) atacan a los arbolitos de la fruta de la grosella Phyllanthus acidus, (familia Euphorbiaceae) y a veces son tan numerosas que no dejan hoja alguna. Esta delgada oruga es amarilla con bandas negras y la cabeza anaranjada. Sus poblaciones pueden aumentar tanto que sus pupas prácticamente cubren el suelo; se pueden ver muchas mariposas adultas volando alrededor del arbolito en busca de hojas donde poner sus huevos. La mariposa adulta tiene las alas negras y el tórax anaranjado (Fig. 21).

La lepidóptera más común es una mariposita gris que vive en nuestras casas, pero que la mayoría de nosotros no notamos. Su oruga construye un capullo de seda y arena (Figs. 22 y 23). Podemos verla de noche cuando se activa: la oruga, dentro de su capullo, se arrastra en busca de alimento, tales como insectos muertos y cabellos humanos.

Esta es una breve descripción de la complejidad de los tipos de vida y el comportamiento de las orugas.

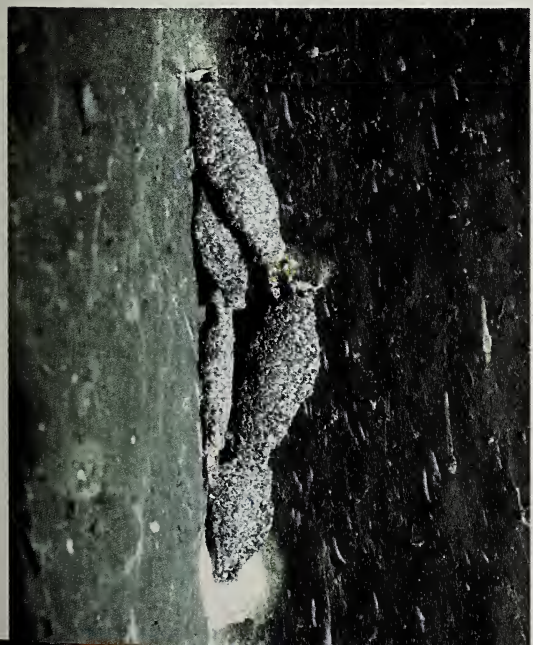

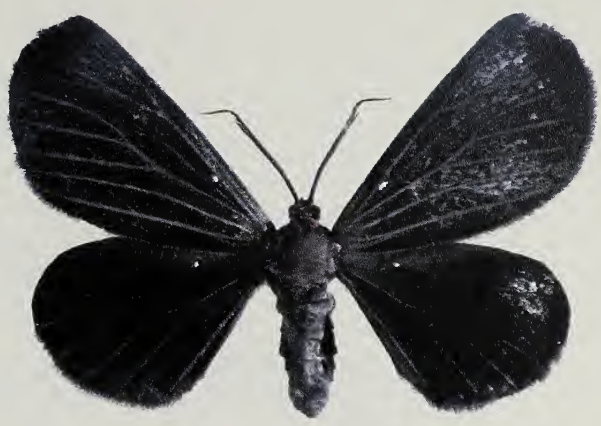

Figura 21. La mariposa Melanchroia chephise (familia Geometridae) tiene alas negras con puntas blancas. En las ciudades se concentran en grandes nubes alrededor de las plantas de grosella sobre las cuales depositan sus huevos. Foto: L. González.

Abajo, izquierda:

Figura 22. En las paredes de las viviendas es común encontrar las casas portátiles de la larva de la mariposa Phereoeca allutella (familia Tineidae). Foto: A. Aiello.

Derecha:

Figura 23. La oruga de Phereoeca allutella en busca de alimento, insectos secos y pelo humanos, arrastra su casa portátil. Foto: A. Aiello.

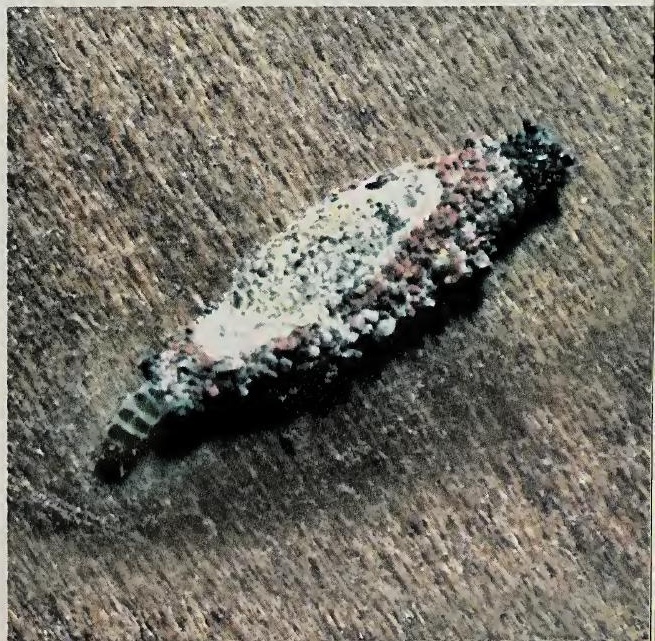




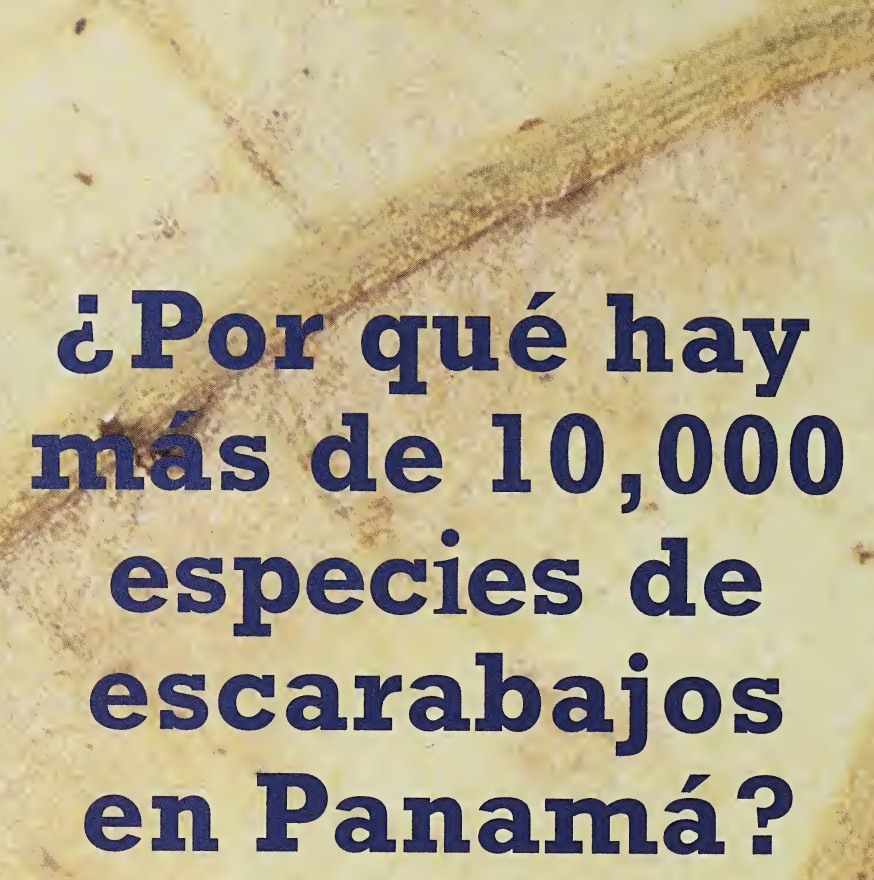

\section{Donald Windsor}

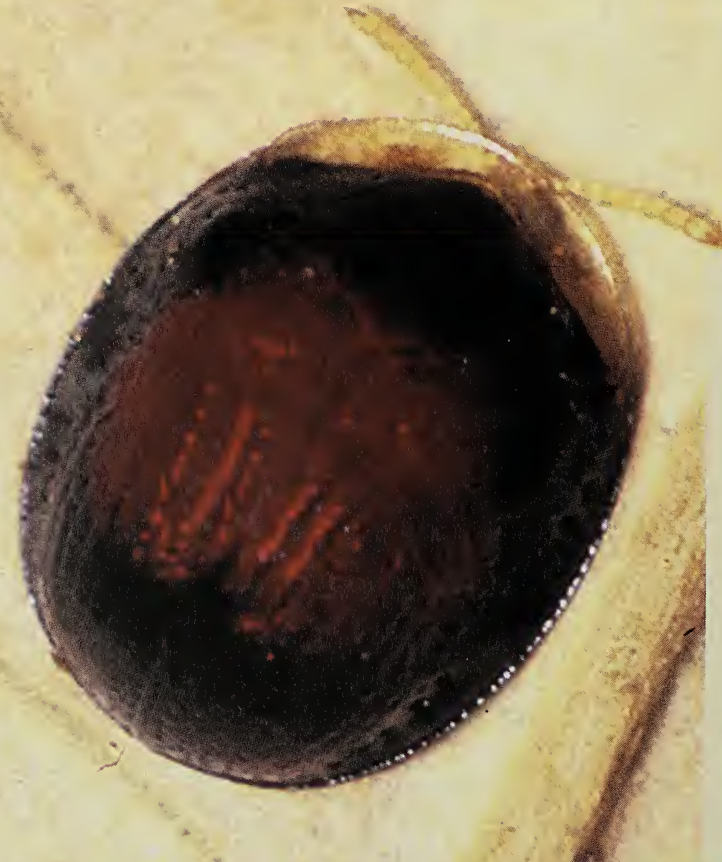

Joyas del trópico, los escarabajos "tortuga" demuestran la diversidad y belleza de los escarabajos de Panamá (fam. Chrysomelidae, subfam.

Cassidinae). Los colores metálicos que se observan en los élitros -o alas duras externas- de estos escarabajos se producen cuando los rayos de luz, tanto incidentes como reflejados, pasan a través de las finas capas de humedad atrapadas entre la cutícula, interactuando entre ellos. El Charidotis erythrostigma Ch. se encuentra sólo en Cerro Campana, donde grandes números de adultos se alimentan de las hojas de Allenanthus erythrocarpus y la Rondeletia buddleoides, dos especies de la familia de cafetos conocida como Rubiaceae. 
L os seres humanos admiramos y estudiamos todos los aspectos del mundo natural, quizás, como ha sugerido E.O. Wilson, porque tenemos una disposición intuitiva hacia la naturaleza, nacida milenios antes de que nos congregáramos en ciudades. Esta tendencia innata, (llamada "biofilia") adquirida a través de nuestra evolución, nos ha ayudado a sobrevivir.

Los escarabajos son conocidos por su diversidad y por la enorme cantidad de especies que viven juntas. Su diversidad llevó al biólogo británico J. B. S. Haldane a concluir en una famosa cita, que esta característica revelaba "un cariño desmesurado por - los escarabajos" por parte del Creador.

Hasta la fecha han sido descritas unas trescientas mil especies, provenientes de todos los rincones del planeta; son más especies que ningún otro grupo comparable de animales o plantas. Por otro lado, su estudio se dificulta por la pérdida de bosques debido a la deforestación.

\section{Primeros estudios sobre los escarabajos panameños}

El primer inventario de las especies de escarabajos de Panamá fue conducido por el entomólogo británico George Champion, quien entre abril de 1881 y mayo de 1883 hizo extensas colectas en el Istmo. Sus descripciones e ilustraciones fueron publicadas en Londres en la monumental obra Biologia Centrali-Americana, constituida por sesenta y tres volúmenes; este trabajo requirió de treinta y seis años de preparación y presentó más de treinta y ocho mil insectos, la mitad de los cuales fueron nuevos para la ciencia.

De los treinta y siete tomos dedicados a los insectos, los escarabajos ocuparon dieciocho. Guatemala y Panamá, en especial la provincia de Chiriquí, fueron las principales áreas de recolección de Champion. Hoy día, la Biologia, nombre bajo el cual se conoce esta obra, es la mejor referencia para quien estudie la fauna insectívora panameña, o simplemente, para quien desee conocer el nombre científico de un escarabajo.

Durante las primeras décadas del siglo XX la investigación entomológica en Panamá se concentró en la biología de los mosquitos portadores de la temible fiebre amarilla y la malaria, enfermedades que amenazaban la salud de los trabajadores de la construcción del Canal. Después de la apertura de la vía, arribó una oleada de naturalistas interesados en la taxonomía y el comportamiento de los insectos, quienes se congregaron rápidamente en isla Barro Colorado, en el lago Gatún y en el Instituto Gorgas de Medicina Tropical, en Ciudad de Panamá. Entre ellos están James Zetek, William Morton Wheeler y Charles Mitchener. Ellos se ocuparon de investigar la historia natural de otros insectos como las avispas, las hormigas, y las polillas o comején.

Después, a mediados de la década de 1970, se realiza un nuevo inventario de la diversidad total de insectos de un sector de
El escarabajo Charidotis aurofasciata Er. se encuentra en Centro y Sur América. En Panamá, estas especies se alimentan de las hojas de la Paragonia pyramidata (Bignoniaceae), un bejuco leñoso que se eleva hasta la parte alta de los bosques.
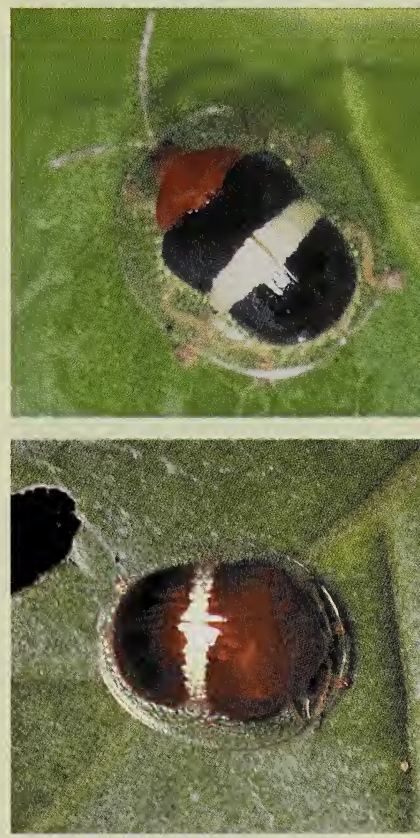

El Charidotis sp. ha sido raramente observado o capturado, y se alimenta de Anemopaegma sp. así como posiblemente de algunos otros bejucos leñosos de la familia de las Bignoniaceae. 


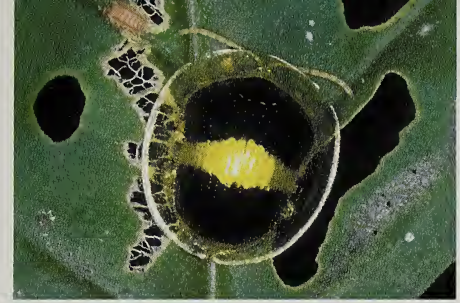

los insectos más fácilmente de lo que se logra. Con el método de trampas, que requiere un trabajo exhaustivo.

Los entomólogos han notado que los escarabajos que se alimentan de plantas tienen mayor diversidad de especies que aquellos con otros hábitos alimentarios.

Entre las órdenes que comen plantas hay cuatro: Coleóptera, Lepidóptera, Hemíptera y Homóptera, las cuales suman la mitad de todas las especies de insectos conocidas.

La mayoría de los escarabajos son herbívoros, pertenecientes a tres superfamilias: Curculionoidea, Chrysomeloidea y Cerambycidoidea. La pregunta que nos hacemos es por qué ciertas familias de plantas atraen más insectos que otras; como dirían los panameños, "esto no es chance".

Si tuviésemos una visión más clara de la distribución de los insectos y las plantas que ellos prefieren en las distintas regiones geográficas de Panamá, esta información podría ser útil a la conservación, ya que se le daría prioridad a ciertas áreas sobre otras.

\section{La antigua relación entre plantas y escarabajos}

El registro geológico nos atestigua que el número de especies de escarabajos ha ido en aumento, al mismo tiempo que se incrementan las especies de plantas con flores a las cuales ellos están asociados.

Entre las primeras plantas con semilla que existieron en la 'Tierra, estuvieron las cycads (Cycadaceae), que asemejan una palmera. Existen pocas muestras de escarabajos fosilizados asociados a estas plantas; esta escasez podría reflejar la falta de diversidad de plantas en tiempos primitivos, y por tanto la falta de oportunidades de los escarabajos para diversificarse. La mayoría de estas palmas se extinguieron, pero aquellas que sobreviven quizás tengan algo que enseñarnos.

En Panamá crecen al menos doce especies de cycad (Zamia sp.) y en las cercanías de la ciudad de Panamá crece abundantemente la Zamia fairchildiana. Estas plantas mudan sus hojas simultáneamente a inicios de mayo, después de los primeros aguaceros fuertes de la estación lluviosa. Dos grupos de especies errantes de escarabajos herbívoros, Aulacoscelis appendiculata y Nomotus sp., se alimentan de plantas jóvenes. Nuestras observaciones de la Aulacoscelis alimentándose de las cycads brinda-
Izquierda: El Charidotis incincta Boh. se encuentra ampliamente difundido $y$ habita las partes bajas de los bosques, alimentándose aparentemente de retoños de Amphilophium paniculatum (Bignoniaceae). Junto a las especies $C$. pustulata y $C$. auroguttata, este escarabajo está entre los más pequeños del género, midiendo apenas unos $4 \mathrm{~mm}$ de largo.

\section{Centro: El Charidotis}

leprieuri Boh. se encuentra extensamente difundido por Centro y Sur América, en donde se alimenta también de Citharexylum sp. La forma de alimentación de sus larvas es única entre los escarabajos "tortuga", y consiste en cortar una trinchera circular en la epidermis superior de la hoja, presumiblemente para prevenir que la planta envíe sustancias químicas defensivas al sitio en donde se está alimentando la larva.

Derecha: El escarabajo Charidotis circumducta $\mathrm{Ch}$. fue descrito por George Champion en 1883, a partir de especímenes recolectados en las laderas del Volcán de Chiriquí. En individuos recientemente recolectados cerca del poblado de Volcán, se observó que se alimentan de Citharexylum sp. (Verbenaceae). Es el más grande entre las especies de Charidotis que se han encontrado hasta ahora en Panamá, y mide entre 8 y $9 \mathrm{~mm}$. de largo. 


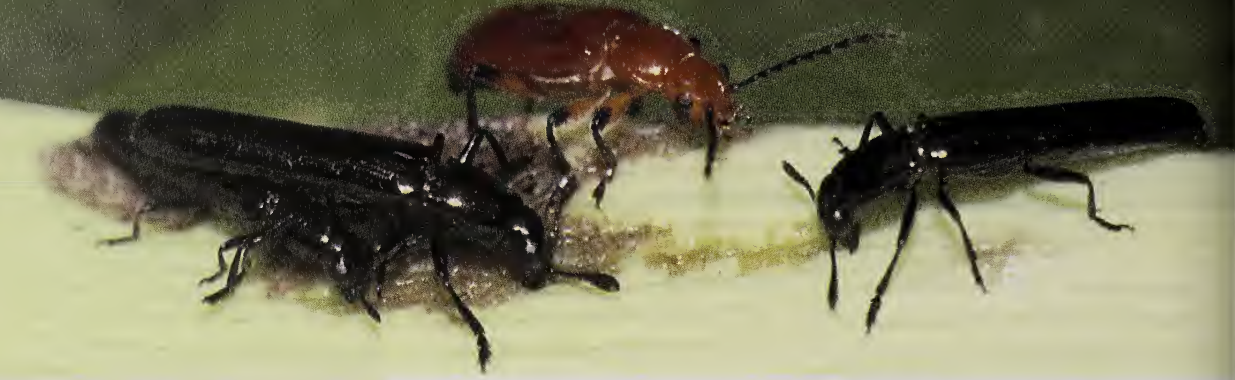

Los escarabajos Nomotus sp. (Languriidae), de color oscuro, y Aulacoscelis appendiculata (Aulacoscelidinae), de color rojizo, se alimentan de la savia de las hojas de los vegetales fósiles vivos llamados Cycads (Zamia spp.), en Panamá. Se desconoce como estos escarabajos toleran los componentes altamente venenosos de los jugos de las hojas de estas plantas.

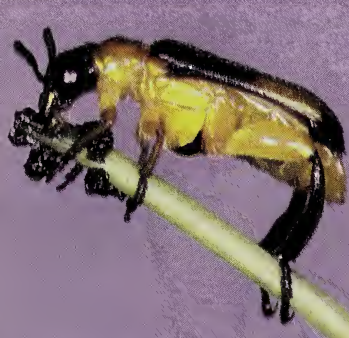

Los adultos del escarabajo Megalopus sp. (Megalopodinae), extraen los jugos de los tallos tiernos de las plantas de las familias Convolvulaceae y Solanaceae. Las larvas del Megalopus barrenan los tallos. Aunque son muy pequeños, tienen grandes ojos y están siempre prestos para volar. El estudio de su comportamiento requiere paciencia y buenos ojos. ron la primera evidencia directa de su asociación con estas plantas primitivas que aún existen.

Los hábitos de los escarabajos lagartija (Languriidae) son muy enigmáticos. Lo poco que sabemos de su biología nos indica que cuando son larvas viven en los tallos de las plantas y que al llegar a adultos recogen los escombros de las superficies de las hojas. Hemos observado a escarabajos adultos atacando y destruyendo casi completamente las hojas nuevas de la Zamia, raspando la epidermis y alimentándose de sus jugos.

Finalmente, cabe mencionar a los Megalopodinae, una antigua subfamilia de escarabajos que comen hojas; sus larvas se hospedan en los tallos, mientras que los adultos se alimentan de la savia de la planta huésped.

Los hábitos de estos escarabajos herbívoros nos pueden sugerir de qué manera se alimentaban los escarabajos del Mesozoico.

Todos estos ejemplos muestran que los escarabajos panameños pueden contribuir a entender el gran cariño que sentía el Creador hacia estas abundantísimas criaturas del planeta.

\section{REFERENCIAS:}

I) Información general para la recolección e identificación de insectos:

D.J. Borrer and C.A. Triplehorn and N.F. Johnson, 1989. An Introduction to the Study of Insects (6th Edition). Saunders College Publishing, Philadelphia, 875 pp.

2) Información para la recolección e identificación de escarabajos:

R.E. White. 1983. A Field Guide to the Beetles. Houghton Mifflin Company, Boston, 368 pp.

3) Información acerca de la biología de la Cassidinae panameña:

Windsor, D.M., E.G. Riley and H.P. Stockwell. 1992. An introduction to the biology and systematics of Panamanian tortoise beetles (Coleoptera: Chrysomelidae;Cassidinae), pp. 372-39, in Insects of Panama and Mesoamerica; Selected Studies. D. Quintero and A. Aiello (eds.), Oxford University Press, 692 pp. 


\section{Las abejas}

\section{africanas y ol}

\section{oafó en Panamá}

\section{David Roubik}

Cerezos verdes de café después de seis meses de desarrollo. La cinta anaranajada identifica a un grupo de flores cubiertas con bolsas de tela, para evitar visitas de cualquier polinizador de las flores del café. Los números indican la cantidad de flores que abrieron, comparado con la cantidad de frutos o cerezos de café, lo que indica el éxito de la producción cafetera. Foto: D. Roubik. 
$\mathrm{E}$ n las tierras altas del occidente de Panamá, al pie de la cadena de montañas de Talamanca o Serranía del Tabasará, como se le llama en Chiriquí, estudiamos la historia natural de la polinización de las plantas del café Coffea arabica. Este arbusto, originario de Africa oriental, en lo que hoy es Etiopía, es el cultivo económicamente más importante para los países tropicales.

Aunque la polinización del café se había estudiado por décadas, ninguna investigación se había realizado fuera de los cafetales o plantaciones donde no hay áreas "naturales". No existía consenso sobre el papel de los animales como polinizadores, comparado con la autofecundación de las flores por el propio árbol de café. Aunque el cafeto puede autofecundar sus flores, no se sabía en cuánto podía aumentar la producción del grano, gracias a la ayuda de animales silvestres, en especial las abejas.

Estos estudios previos sobre polinizadores se habían hecho usando colmenas transportadas a los cafetales y se estudiaba su comportamiento al florecer el café. Había, sin embargo, buenos indicios de que la abeja de miel del Viejo Mundo, Apis melli- fera (europea) podía ser una de las principales polinizadoras. Pero no se sabía qué pasaba en un cafetal donde no había colmenares manejados por el hombre.

\section{De Africa a Brasil y Chiriquí}

En la década de 1950 fue llevada al Brasil la abeja africana, para un programa orien. tado a mejorar genéticamente a la abeja europea, la cual no se adapta bien al trópico. Pronto las abejas africanas escaparon, formando poblaciones silvestres que se multiplicaron. En la década de 1970 existían grandes cantidades de abejas africanas naturalizadas o silvestres, que desde Brasil comenzaron a expandirse en todas direcciones. A Darién llegaron en 1982, y a la zona cafetalera de Chiriquí, en 1984.

Entre los datos que documentan esta inmigración, están los del Cuerpo de Bomberos de David, Chiriquí, que registra el arribo de cientos de enjambres y nidos de abejas africanas silvestres. Entre 1957 y 1985 solo se había detectado un enjambre silvestre que era de Apis mellifera europea.

Cuando las abejas africanas migran, pueden volar en forma de enjambre hasta 27

Las tierras altas de Chiriquí viendo al norte, hacia los bosques nubosos de la división continental de aguas entre el Caribe y el Pacifico. En primer plano, potreros y cafetales. Los bosques nubosos cubrian anteriormente casi toda esta cordillera. Foto: D. Roubik.

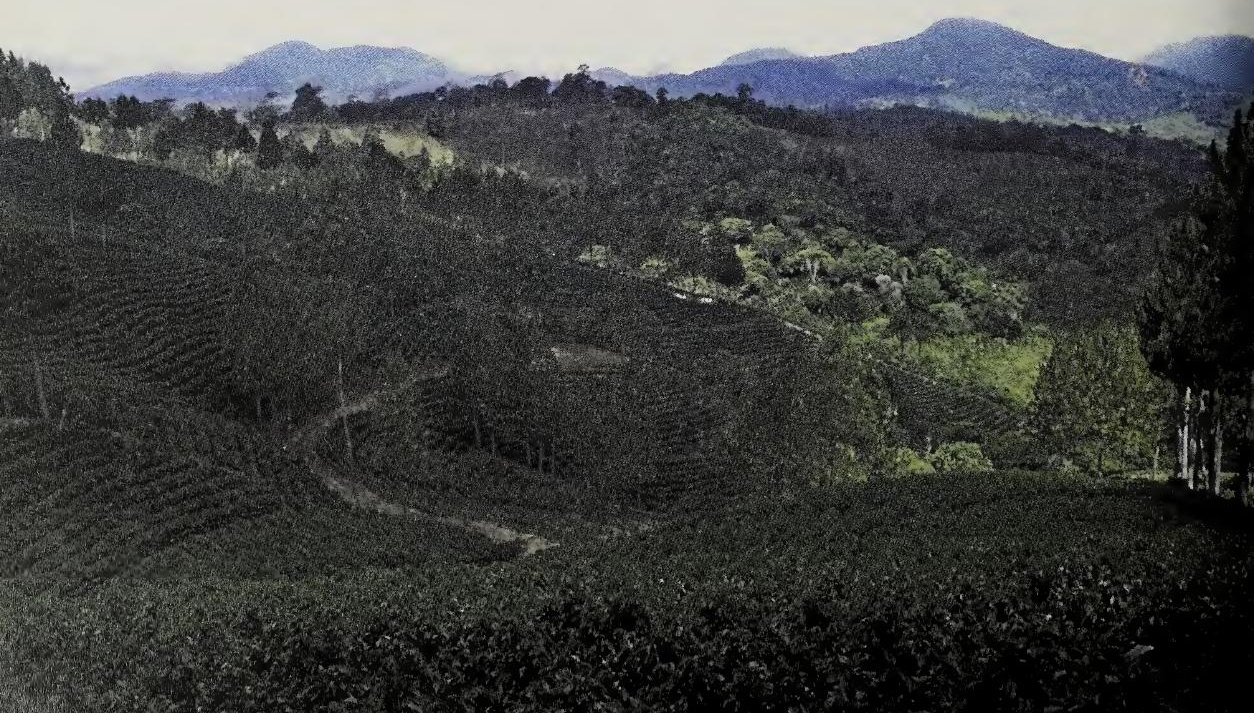


kilómetros todas a la vez, sobre mar o tierra. A veces recorren hasta 200 kilómetros en línea recta antes de establecer un nuevo nido. Cuando buscan alimentos desde su nido, pueden volar un máximo de 7 a 8 kilómetros, con un promedio de vuelo menor a 2 kilómetros. Una sola colonia de abejas puede cubrir una superficie de 200 kilómetros cuadrados en busca de alimento y dispersando polen entre las flores.

\section{Algunas preguntas}

Estaba convencido de que esta abeja en su estado silvestre iba a ser ecológicamente importante para la producción del café, cultivo que, por su gran papel económico, permitía estudiar a gran escala miles de plantas y animales y sus interacciones. $\mathrm{Me}$ preguntaba, además, qué pasaría con la po- linización de las otras plantas nativas al bosque tropical, con la llegada de las abejas africanas.

Este estudio de la ecología de la polinización del café en el occidente de Panamá nos permitió abrir simultáneamente tres nuevos campos de investigación. Primero, qué importancia tienen en la reproducción de las plantas tropicales, cultivadas o no, las abejas africanas invasoras. Segundo, cuán importantes son los polinizadores silvestres nativos a la región cafetalera, fueran estos aves, insectos $u$ otros animales. Tercero, qué pasa si perdemos los bosques habitados por estos polinizadores nativos y finalmente, qué papel tienen los dos principales métodos de cultivo del café: el sistema tradicional, que usa el árbol de café arábigo bajo árboles de altura, y el método
Un hermoso árbol de sombra en un cafetal. Sus ramas más bajas han sido podadas por el método llamado "sombra manejada". En el cultivo tradicional del café se dejan muchos árboles de sombra, que benefician a la naturaleza al ofrecer un buen habitat para plantas y animales silvestres. Recientemente se ha comprobado que el café cultivado así resulta de mejor sabor.
Para aumentar la producción, los cafetales tradicionales son sustituídos por métodos más intensivos, que requieren plantar más cafetos por hectárea. Para lograrlo se eliminan los árboles de sombra, se usan más agroquímicos y se renuevan todos los cafetos en pocos años. Este nuevo tipo de plantación es muy susceptible a enfermedades producidas por hongos.

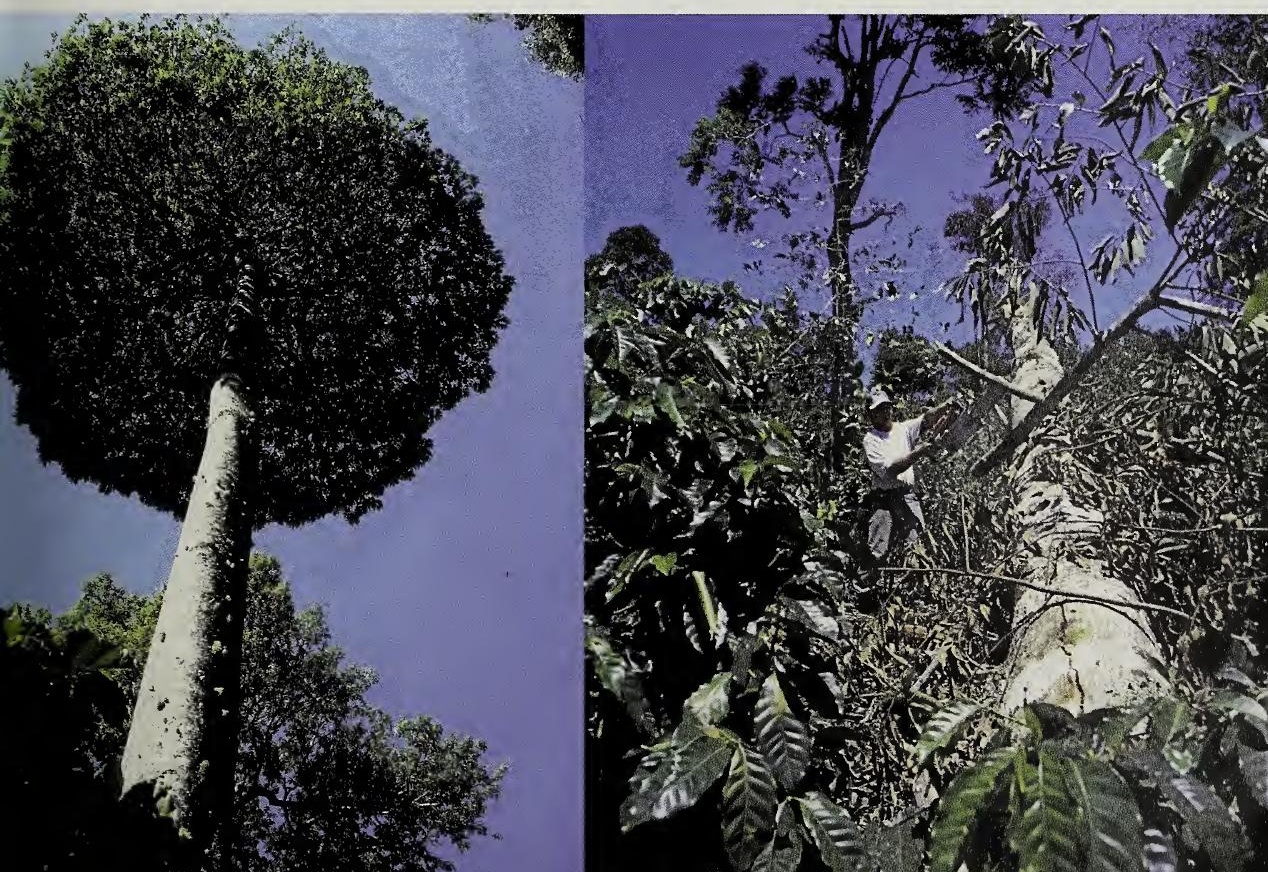


de moda, ecológicamente menos amistoso, consistente en derribar los árboles de sombra y sembrar altas densidades de híbridos de café, derivados recientemente y que en pocos años rinden cosechas.

\section{El plan de estudio y técnicas principales}

El café comienza a florecer durante la estación seca, usualmente una semana después que cae la primera lluvia copiosa. Los cafetos florecen simultáneamente y luego de tres días la floración cesa por unas semanas, hasta que otra lluvia la propicia nuevamente. Normalmente la planta pierde muchos de sus frutos antes de que maduren y puedan cosecharse.

El área estudiada floreció un promedio de cuatro veces por año, entre 1993 y 1997. Durante 1997 hubo dos grandes floraciones y pudimos observar las flores abiertas del café, las abejas y los demás polinizadores visitantes. Cada uno fue identificado hasta el nivel de especie. Estas observacio-

Hileras de cafetos arábiga con sus árboles de sombra. En cada hilera se colocaron bolsas sobre las flores (en recuadro) a razón de un árbol por cada diez.

Foto: D. Roubik. nes se hacían durante el día, cuando los vi. sitantes llegaban a las flores, entre las 7:30 a.m. y las 4:30 p.m.

Los cafetales estudiados están a 30 kilómetros de la frontera con Costa Rica, en un área colindante con los bosques del Parque Internacional La Amistad (PILA), entre las comunidades de Santa Clara y Río Sereno, en la cuenca del río Chiriquí Viejo. Es un área de unos 13 kilómetros de largo, muy rica en tumbas precolombinas, pues a menudo se encuentran en los cafetales restos de tiestos o vasijas de esa época.

Estudiamos dos variedades de cafeto: $\mathrm{Ca}$ turra, que se cultiva en todos los trópicos bajo el sistema llamado de sombra manejada y Catimor, que crece a pleno sol y es el resultado de un híbrido de las especies C. arabica y C. canephora, proveniente de Costa Rica.

Los cafetos de Caturra estaban junto a las selvas del PILA o en áreas hasta dos kilómetros de distancia. La variedad Cati. mor estaba en una gran plantación alejada del bosque y rodeada por otros cultivos. Había, eso sí, unas colmenas de abejas africanas manejadas para producir miel.

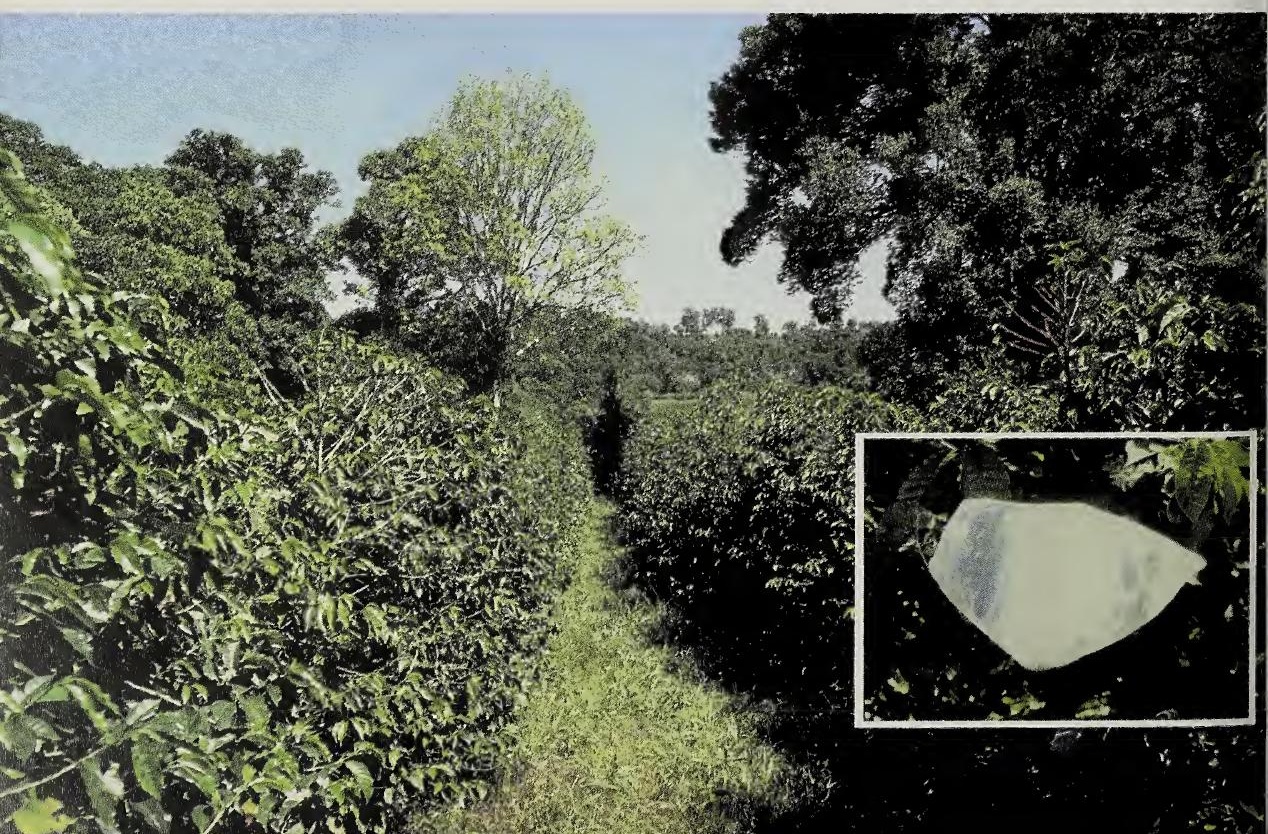


Los dueños de estos cafetales no usaban insecticidas ni herbicidas, pero sí aplicaban funguicidas después de la floración en abril. A las plantas de Catimor se les aplicaba abonos artificiales y a las de Ca-turra abonos orgánicos.

En 1997 se iniciaron los estudios de campo, monitoreándose 558 arbustos de ambos tipos de café, situados entre los 1300 y 1600 metros de altura sobre el nivel del mar. Estos árboles estaban distribuídos en once transectos de 100 metros de largo.

Para mostrar el impacto de los polinizadores silvestres en un mismo árbol, a algunas de las ramas se les cubrieron sus botones (flores sin abrir) con bolsas de tela de malla fina, para excluir toda clase de "visitantes" y así llevar un control de la cantidad de los frutos de café producidos por la autofecundación de cada planta, es decir, sin intervención de polinizadores visitantes. Esto se hizo para comparar la producción de granos de las ramas que no habían sido cubiertas y a las cuales podían llegar los polinizadores sin obstáculos.

Un mes después de terminado el florecimiento, se removieron las bolsas. Luego se contaron cuántas flores había. Se dice que hay un $100 \%$ de éxito cuando cada flor pro. duce un fruto que llega a madurar y cada cerezo tiene dos granos.

En ocho meses regresamos a Chiriquí cua tro veces, para observar el crecimiento de los miles de frutos del café, y realizar la tarea de contar en el campo, bajo todo tipo de condiciones climáticas y de terreno, cerca de trescientos mil cerezos en desarrollo.

Además se monitorearon ciento sesenta y cuatro plantas para estudiar el peso final de cada cerezo y comparar el rendimiento bajo circunstancias de autofecundación y la fecundación promovida por animales.

\section{La dinámica de los polinizadores}

Apis mellifera scutellata, la abeja invasora africana, realizó más del $95 \%$ de todas las visitas a los cafetos estudiados e hizo casi todas las polinizaciones. Otros polinizadores fueron colonias de abejas sin aguijón, de las cuales hay unas sesenta especies en Panamá y a las cuales la gente conoce comúnmente como mosca de miel; también tres clases de abejorros y abejas solitarias de varias especies. Entre las aves el único visitante fue una especie de colibrí endémico y varias especies de mariposas.

Es notable cómo la abeja africana rápidamente copó los parches de vegetación ricos en recursos, como los cafetales en flor.

Las visitas de las abejas africanas a cualquiera de las flores, en cualquiera de las

Tolda de malla fina de nylon, usada para impedir que los insectos o animales visitasen las flores de los árboles de café.

Foto: D. Roubik.
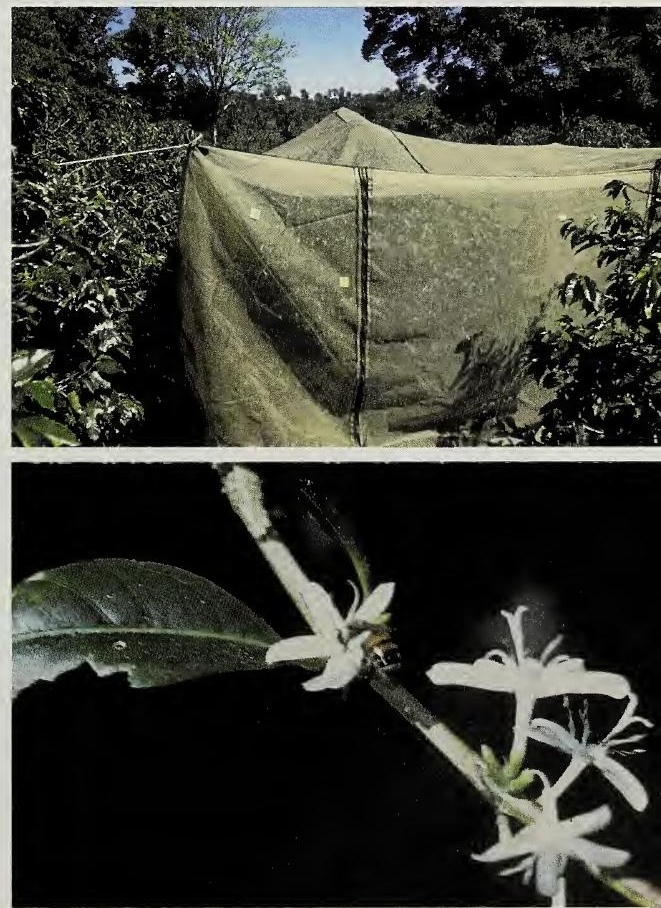

Abeja africana visitando las flores del café para recolectar néctar y polen. Estas abejas llegaron a Chiriquí alrededor de 1983, habiendo iniciado su migración desde Brasil en 1956. Foto: Sheryl Soucy. 


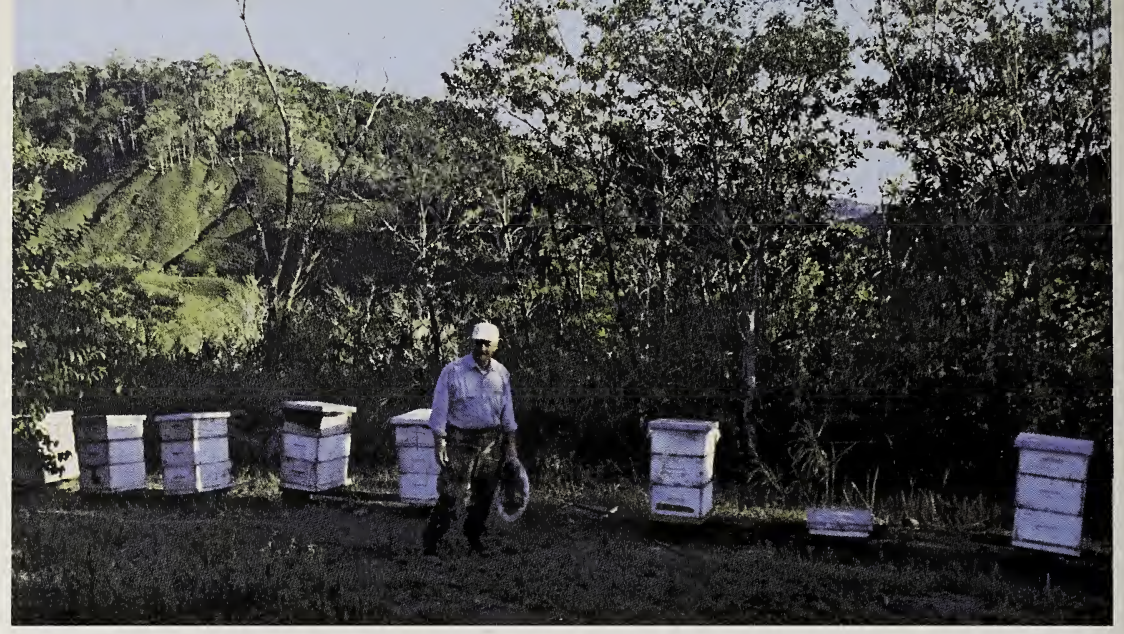

Panamá tiene unas 1000 especies de abejas silvestres. Estos insectos son los principales polinizadores de las más de 10,000 especies de plantas con flores de la flora panameña. Aquí, colmenas de abejas africanas en una finca chiricana usadas para producir miel. Foto: D. Roubik.

parcelas estudiadas, sumaron cuarenta visitas por flor cada día. Todas las parcelas fueron saturadas por las abejas africanas, ya sea que estuviesen cerca de un bosque natural, en un cafetal tradicional cerca o lejos de bosques, o en una plantación de alta densidad de Catimor, con colmenas de abejas africanas.

A pesar de que pareciese que la abeja africana ha desplazado a los polinizadores nativos que encontró en esta zona cafetalera, ha sido mayor el impacto ambiental causado por la presencia del hombre en los tró- picos, ya sea porque deforesta, extrae madera o introduce prácticas de cultivo que aumentan sus rendimientos, pero que son hostiles al medio ambiente.

\section{El impacto de las abejas en la producción}

Al comparar la cantidad y calidad de los granos de café entre plantas con flores cubiertas y con flores abiertas, se encontró que las variedades de Caturra y Catimor mostraron un aumento de más del $25 \%$ en la cantidad de cerezos que maduraron. Los cerezos y granos de Caturra pesaron $25 \%$
En el mundo hay más de 30,000 especies de abejas, 600 de las cuales producen miel. Sus parientes más cercanos son las avispas, y tanto abejas como avispas están emparentadas con las hormigas.

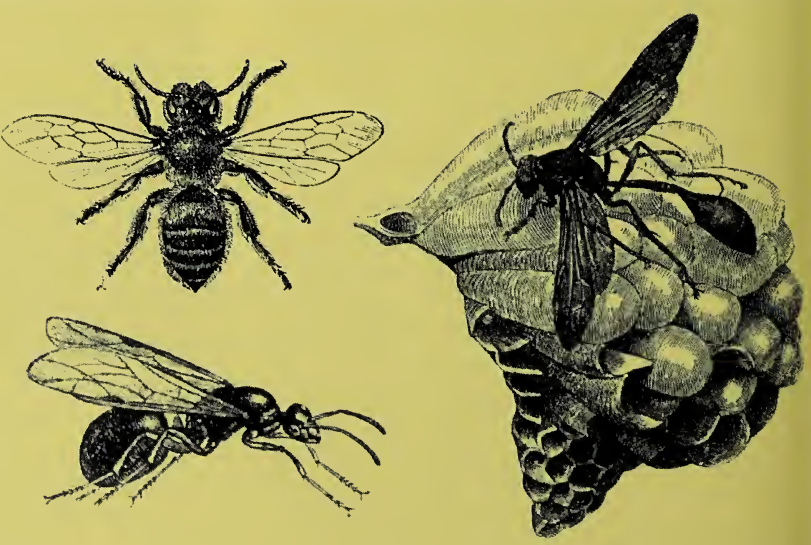


más y se desarrollaron más rápido, gracias a la polinización abierta, realizada casi exclusivamente por las abejas africanas. El rendimiento total por planta o parcela aumentó en un 56\%. En cambio, los cafetos Catimor no produjeron granos más pesados al ser polinizados por abejas.

Es posible que la llegada de abejas africanas pueda haber aumentando la polinización de otros cultivos y aún de plantas silvestres. Pero para comprobarlo habrá que hacer otros estudios.

En América, la abeja africana ha contribuido a mejorar el proceso de polinización de una planta africana, un cultivo de enor- me importancia económica. Antes de la llegada de estas abejas inmigrantes, había diversos polinizadores nativos más abundantes, puesto que los cafetales se encontraban más cerca de los bosques naturales. Por tanto, si usted quiere aumentar la producción de su cafetal sin costo adicional, siémbrelo cerca del bosque, que es el área de origen del café.

En las zonas cafetaleras de Chiriquí los indigenas ngobe o guaymíes son la fuente principal de mano de obra, como esta trabajadora ngobe que vacía los granos cosechados desde su canasta hacia una jaba. Foto: D. Roubik.

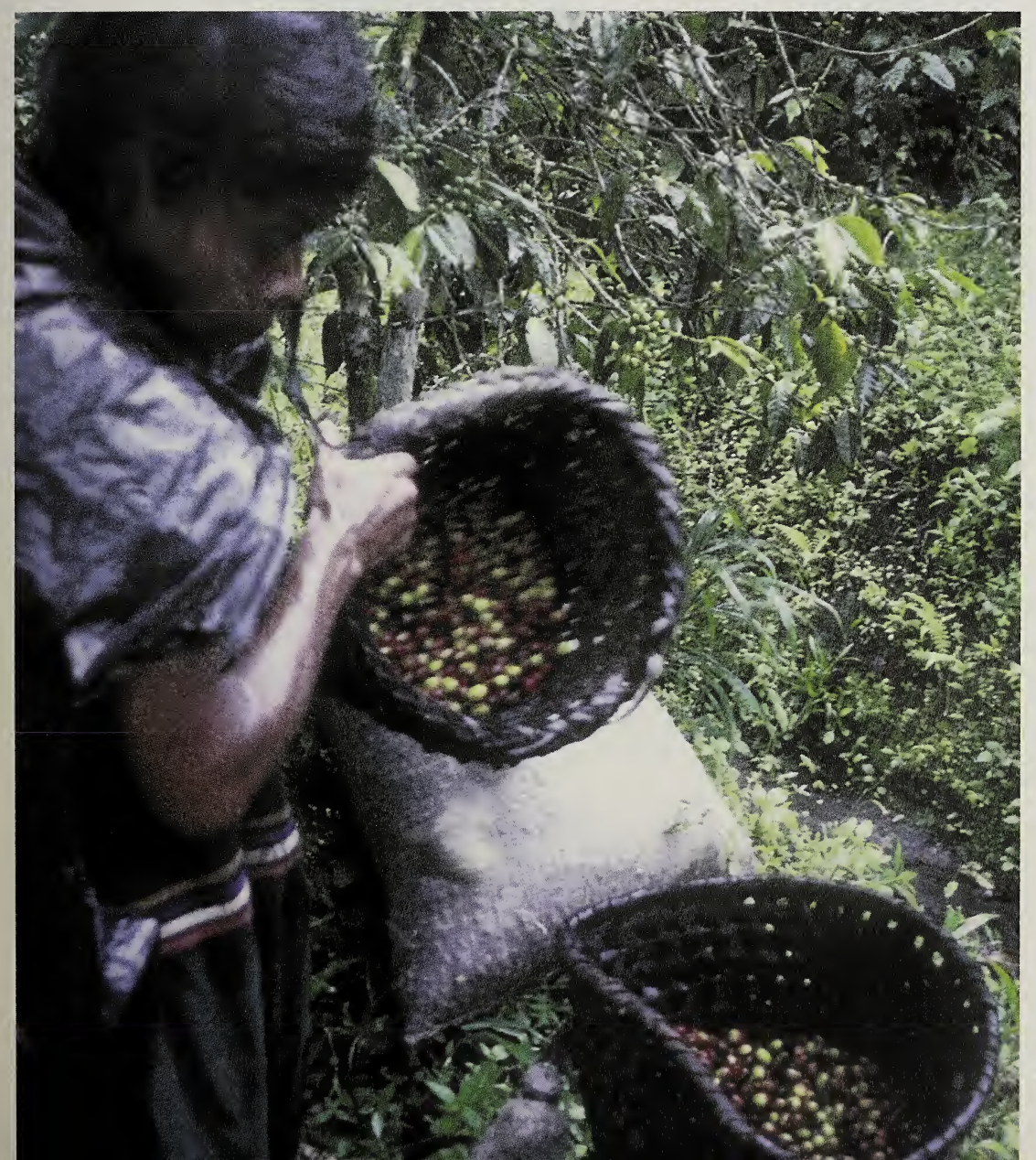




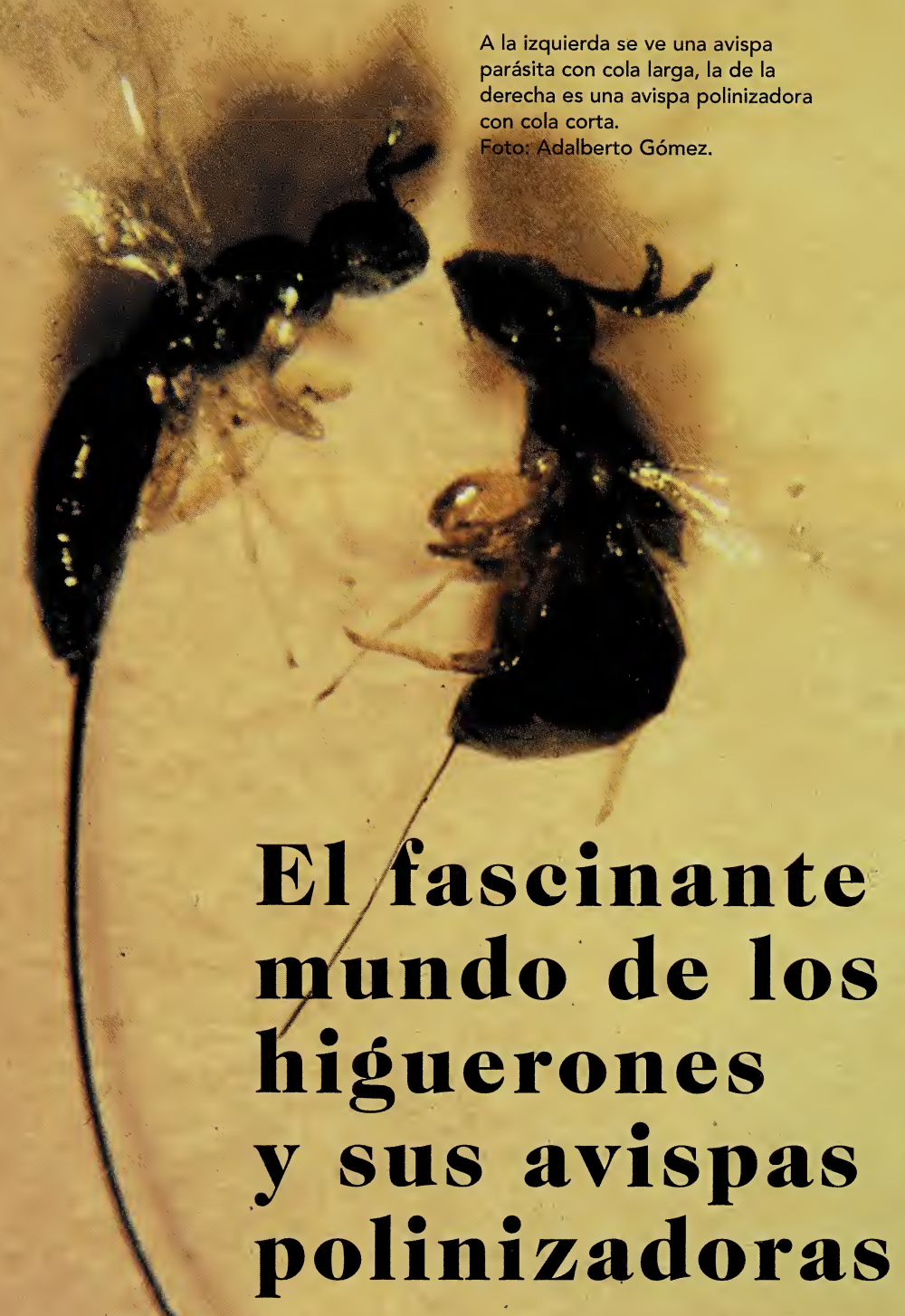

Allen Herre 
$\mathrm{U}$ no de lo árboles mas fascinantes del bosque tropical son los higuerones, por la extraordinaria relación que tienen con muchos otros organismos.

Los higos, las abundantes frutas de los higuerones (Ficus), son vitales en la alimentación de muchos frugívoros, animales que comen frutas, tales como aves, murciélagos y monos. Existen en los trópicos más de 700 especies de higuerones, casi la cuarta parte en los bosques del Nuevo Mundo y se piensa que son originarios a Suramérica.

En Panamá encontramos mas de 40 especies de higuerones en diferentes tipos de bosques, pero la mayoría prefiere los bosques más húmedos. Los higuerones son diversos en sus características, sea en la forma y altura de los árboles, en sus hojas y en los colores de sus frutos maduros. Estas diferencias tienen importantes consecuencias ecológicas. Por ejemplo, estudios recientes en Panamá muestran que las aves que comen frutas, prefieren los higos que cuando maduran son rojos. Por su parte los murciélagos prefieren a los que son de tonos verdes. A pesar de estas diferencias entre los higuerones, la polinización que posibilita su gran producción de higos, depende de unas minúsculas avispitas. A la relación entre estos grandes árboles y las pequeñas avispas se le conoce como mutualismo.

\section{La polinización de los higuerones}

Todas las especies de avispas que polinizan higuerones pertenecen a la familia Agaonidae y sus ciclos de vida son bastante similares. Generalmente, cada especie de avispa sólo poliniza a una especie de higuerón.

Veamos los fascinantes detalles de cómo estos pequeños insectos polinizan a estos árboles. El proceso comienza con la llamada "avispa fundadora" hembra, que vuela transportando polen en las cavidades externas de su tórax hasta que encuentra un árbol en estado receptivo. Cuando el higuerón está en estado receptivo, produce gran número de unas estructuras redondas, casi cerradas, llamadas por los científicos synconium que están compuestas por muchas florecillas. Estas estructuras especializadas son la característica que define el género Ficus, y que eventualmente se convertirán en la fruta del higuerón.

Cuando la avispa fundadora entra a una de estas estructuras especializadas, deposita el polen que trae consigo sobre las florecillas que bordean el interior de esta inflorescensia. $\mathrm{Al}$ mismo tiempo coloca sus hue-

Rama de un árbol de higerón con sus higos o frutos que son muy apetecidos por aves y otros animales. Foto: A. Herre.

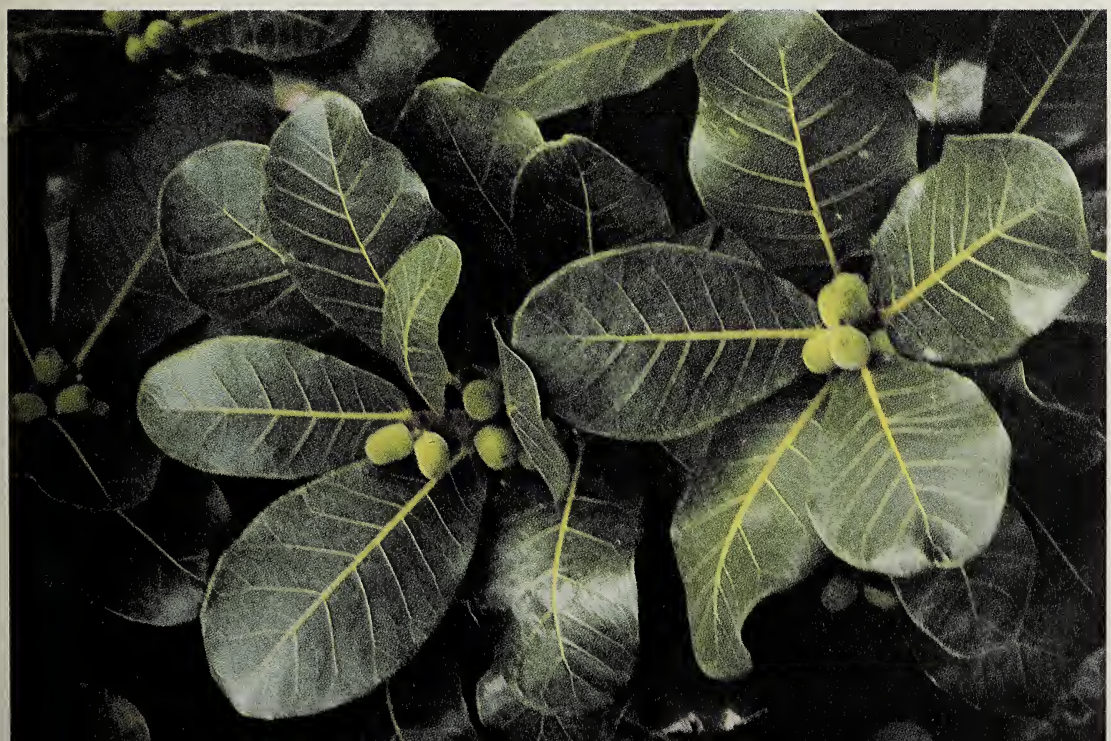


vos en algunas de estas flores. Luego, la fundadora muere dentro del único higo que ha polinizado. Al nacer las avispitas, salen de sus huevos y cada una se alimenta del contenido de una sola semilla. No obstante muchas semillas quedan intactas.

$\mathrm{Al}$ acercarse la etapa final de la maduración del higo, las avispas machos -que carecen de alas- salen de las semillas que les han servido de alimento y se arrastran hacia el interior del syconium, abren las semillas donde están las avispas hembras y se aparean con ellas. Luego las hembras, como tienen alas, emergen de las semillas, recolectan el polen en su tórax y salen del higo donde nacieron para volar y dispersar el polen y comenzar nuevamente su ciclo de vida. Como la esperanza de vida de las avispas es corta, de 2 a 4 días, la hembras, tan pronto salen del higo maduro deben encontrar un higuerón de la misma especie en estado receptivo.

Despues que las avispas abandonan el higuerón que les vió nacer, las frutas maduran y sirven de alimento a muchos animales que dispersan sus semillas. Sin la ayuda de las avispas polinizadoras, los higuerones no podrían producir las frutas de las cuales dependen tantas especies de animales. Por ello, en relación a su minúsculo tamaño estas avispas ejercen una influencia desproporcionadamente grande sobre las poblaciones de vertebrados en los bosques tropicales.

\section{Compartiendo la polinización y la reproducción}

Tanto la polinización de los higos, como la maduración de sus frutas y el ciclo de vida de las avispas, están estrechamente sincronizados. Este ciclo de fructificación de los higos y la generación de las avispas, desde que son huevecillos hasta que mueren, apenas dura un mes.

En su estado natural, la mayoría de las especies de higos existe en bajas densidades en el bosque, a razón de un árbol o menos por hectárea. Asimismo sólo una pequeña porción de ellos pueden estar receptivos en cualquier momento. Esto, en combinación con la cortísima vida de la avispa, impone una enorme carga de responsabilidad en las avispas polinizadoras. Ellas deben encontrar en poco tiempo el synconium de la especie de higuerón con la cual es compatible para reproducirse. Afortunadamente ellas son buenas voladoras, pudiendo viajar distancias hasta de 40 kilómetros o más.

Para volar aprovechan las corrientes de viento. $\mathrm{Al}$ chocar el aire contra los árboles, el flujo del viento se altera y la turbulencia resultante hace descender a las avis-
Esta fruta de higuerón partida en dos está en su estado receptivo, lista para recibir el polen de una avispa polinizadora.

Foto: P. Becker.

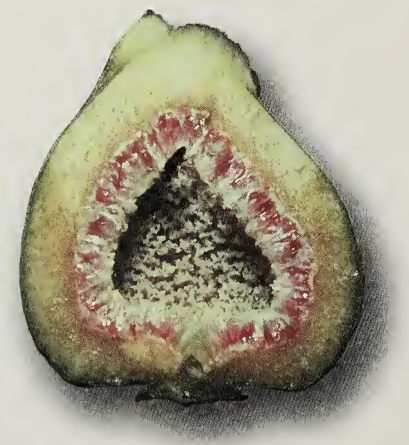

Vista de un fruto que ha sido polinizado. Las semillas negras sirvieron de alimento a las avispas polinizadoras; las de color dorado estan sanas y servirán para reproducir el árbol. Foto: P. Becker.

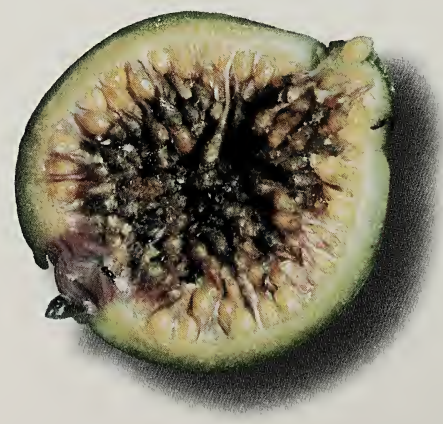




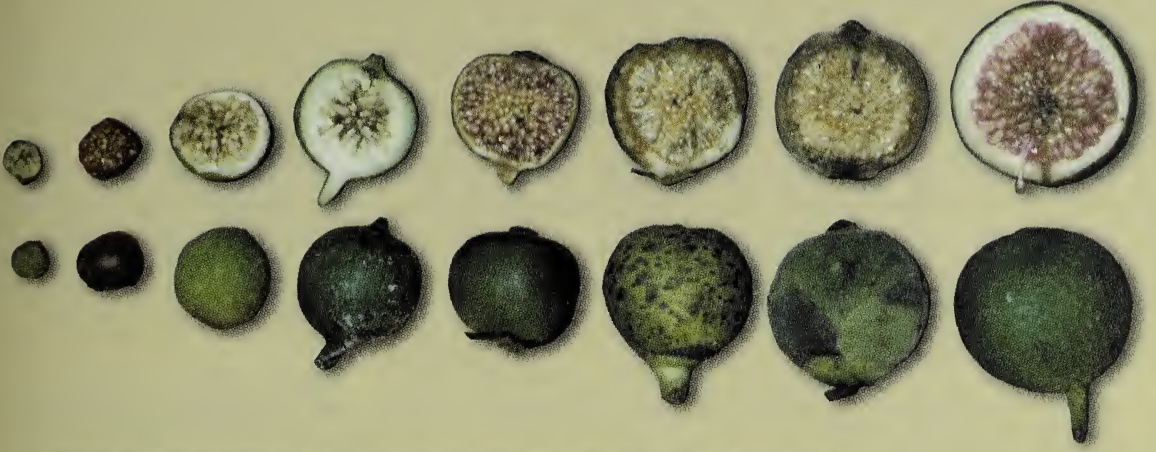

Diversidad de tamaños y colores de algunas de las especies de higerones de un bosque tropical. Foto: A. Herre.

pas, que son conducidas a lo largo de las ramas de los árboles, las hojas y finalmente hasta las frutas. Si el higuerón es de la especie compatible y está receptivo, las avispas salen de la corriente de aire y vuelan hacia el árbol donde se encuentra el synconium receptivo. Seguramente la avispa detecta el higo gracias a químicos aromáticos que este produce cuando está receptivo.

Estudios recientes en el STRI muestran que este intrincado sistema de polinización entre el higuerón y la avispa, es asombrosamente eficiente. Alrededor del $85 \%$ de los higos son visitados por las polinizadoras. Aunque las avispas hembras apenas viven un par de días como adultas, es común que polinicen higuerones que distan de 5 a 7 kilómetros de su higo natal. Como consecuencia de la baja densidad de los higuerones en el bosque, los árboles adultos con potencial para intercambiar polen están dispersos en áreas que exceden los 100 kilómetros cuadrados. Esto significa que la producción de frutos en cualquier higuerón es catalizada por avispas procedentes de docenas de árboles dispersos en vastos sectores del bosque tropical.

Con igual eficiencia, los murciélagos y otros animales frugívoros viajan cada noche distancias de más de 1 a 2 kilómetros para consumir más del $80 \%$ de las frutas maduras producidas por los higuerones. Recogida la fruta, la llevan a otros sitios para comérsela, dispersando las semillas.
El exitoso mutualismo entre estos árboles y sus avispas polinizadoras es antiquísima. Se ha identificado frutas fósiles de higuerones que vivieron hace 50 millones de años en el Nuevo y Viejo Mundo. En República Dominicana se ha encontrado avispas polinizadoras preservadas en ámbar, que vivieron hace más de 20 millones de años.

\section{Sombras en el mutualismo: las avispas parásitas}

Hemos visto la parte positiva de la relación entre las avispas polinizadoras y los higuerones receptivos. Pero hay otro grupo de avispas que aunque podrían considerarse "primas" de las polinizadoras, son parásitas y amenazan el mutualismo. En contraste con las polinizadoras, las hembras de las avispas parásitas generalmente no entran al higo a depositar sus huevos ni a polinizar, sino que depositan sus huevos desde el exterior del syconium. Estas especies son similares en tamaño a las polinizadoras, y en el caso del género del Nuevo Mundo Idarnes, parecen desarrollarse a costa de las avispas polinizadoras.

Los ciclos de vida de estas avispas parásitas son más complejos, pero menos estudiados y por tanto, menos entendidos. Así, en algunas de estas especies parásitas los machos carecen de alas, pero en otras especies todos los machos tienen alas. Una posible explicación es que debido a las bajísimas densidades de las poblaciones de estas avispas, existe una alta probabilidad 
que una avispa macho se desarrolle en un fruto de higuerón carente de hembras. Por tanto, podría ser ventajoso para un macho tener alas para salir a buscar hembras a otros sitios. Inversamente, cuando las densidades de avispas son altas, los machos casi siempre se desarrollarán en un higuerón que contiene varias hembras de su especie. En este caso, lo más probable es que tenga más oportunidades de aparearse con hembras dentro del fruto donde ha nacido.
Entre los machos de las avispas parásitas hay un amplio rango de agresividad mutua. Dicho de otra forma, los machos de las especies parásitas son más agresivos y a menudo sostienen combates mortales. Mientras entre los machos de las especies polinizadoras los niveles de agresión son menores. Estas son apenas algunas de las muchas historias fascinantes que tienen lugar dentro, y alrededor de los frutos y el árbol del higuerón.

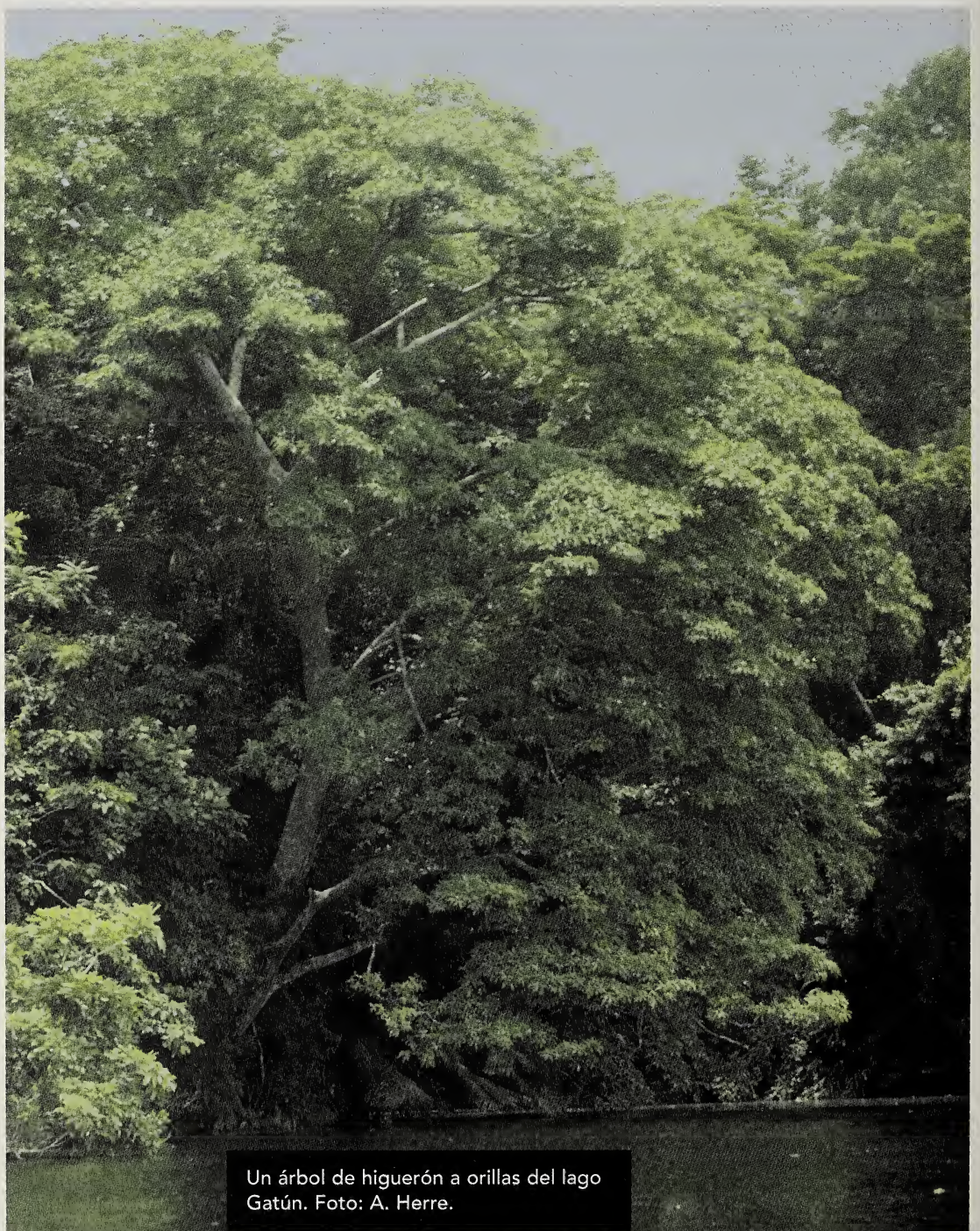




\section{El gusano barrenador en Panamá}

\section{John Welch y Danel Haile}

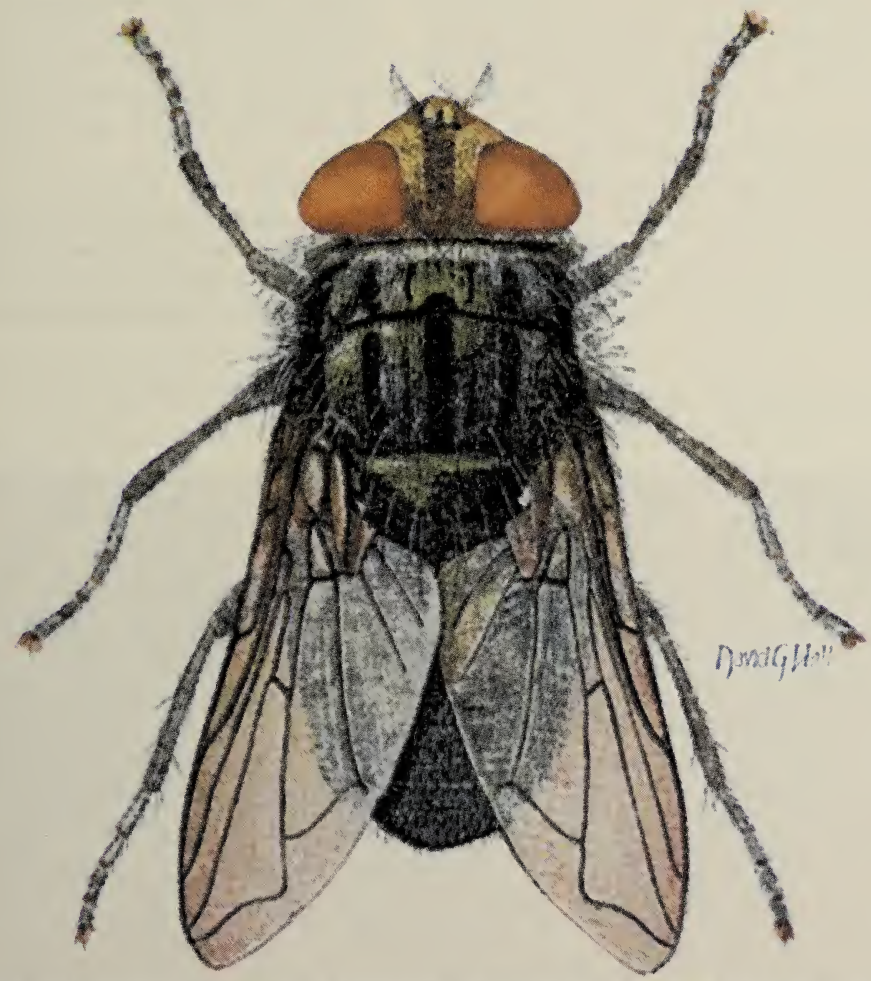

Mosca hembra del gusano barrenador, Cochliomya hominivorax (Coquerel) (antes Cochliomya americana). El nombre de la especie, hominivorax, significa "devorador de hombres". Este insecto ataca a todos los animales de sangre caliente, incluyendo al hombre y puede causar la muerte en pocos días, si no se aplica tratamiento. 
$\mathrm{E}$ 1 gusano barrenador del Nuevo Mundo, Cochliomya hominivorax (Coquerel), es un parásito de los animales de sangre caliente que pasa parte de su vida en un animal vivo, incluyendo el hombre.

El nombre de la especie, hominivorax, quiere decir "devorador de hombres". Así la nombró el médico francés Dr. Charles Coquerel, quien la descubrió en 1858 y la identificó como responsable por la muerte de cientos de prisioneros en la colonia penal de la Isla del Diablo, en la Guyana Francesa, pues una vez que una persona o un animal es infectado por el gusano barrenador, su muerte es casi inevitable, salvo que la herida sea curada.

En las regiones tropicales y subtropicales del continente americano, este insecto causa gravísimos daños a las crías de animales como el ganado vacuno, caballos, cerdos y ovejas. También ataca animales silvestres. Su distribución es muy amplia y está limitada básicamente por el frío, ya sea por las bajas temperaturas del invierno en el hemisferio norte y en el sur de las Américas, o por altitudes mayores a los 2,400 metros sobre el nivel del mar.
A inicios de la década de 1950, el Departamento de Agricultura de los Estados Unidos (USDA) inició un programa para erradicar este gusano empleando el método de liberar moscas estériles. Este método impide que las hembras silvestres se reproduzcan al aparearse con machos estériles, erradicando gradualmente la población de la mosca.

Para impedir que las moscas migraran a Estados Unidos, el programa se extendió a México en la década del 70. En los años de 1980, el programa incorporó a Centroamérica y Panamá.

Por su estratégica ubicación geográfica y angostura, se planea establecer en Panamá una barrera permanente que impida la entrada de la mosca desde Sur América, liberando continuamente moscas estériles. Esta barrera se ubicará en la región oriental, principalmente en la provincia del Darién, colindante con Colombia.

El USDA y el Ministerio de Desarrollo Agropecuario de Panamá (MIDA) han formado la Comisión Panamá - Estados Unidos para la Erradicación y Prevención del Gusano Barrenador del Ganado (COPEG),

Larvas del gusano barrenador, alimentándose en el medio artificial en donde son criados, en la planta para la producción de moscas estériles. Foto: P. Greb

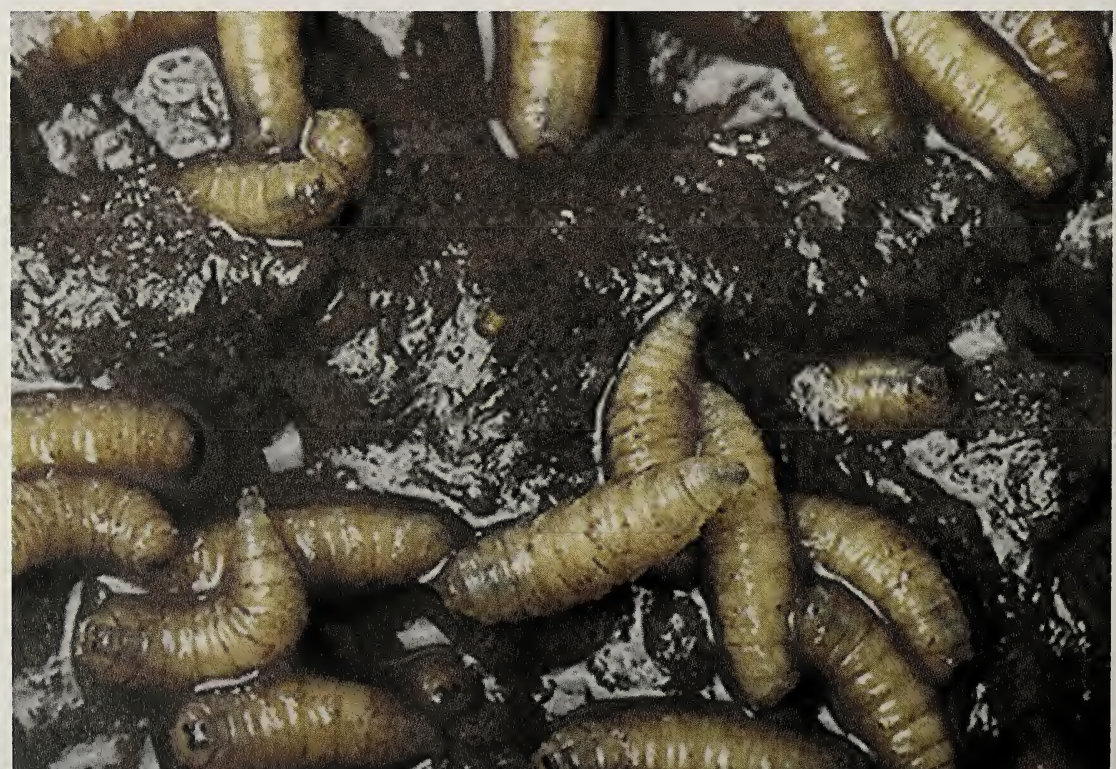


comisión encargada de erradicar el gusano en Panamá y que cuenta con un gran número de técnicos a lo largo del país.

Nuestro proyecto, parte del servicio de investigación del USDA, apoya el programa de erradicación de campo. Su sede es el Instituto Smithsonian de Investigaciones Tropicales, que cuenta con excelentes instalaciones y laboratorios. Componen nuestro equipo humano tres científicos, siete técnicos y un perro.

\section{El ciclo de vida del gusano barrenador}

El ciclo de vida de este gusano comienza cuando la mosca hembra deposita, dentro o alrededor de la herida de un animal vivo, una masa de doscientos a trescientos huevecillos, los cuales son blancos y mínimos, apenas de un milímetro de largo cada uno. Su gestación dura de diez a doce horas, cuando las larvas o gusanos salen de sus huevos y comienzan a comerse la carne del animal.

Mientras crecen se alimentan incesantemente utilizando un par de ganchos afilados que tienen en la boca. Por cinco días las larvas comen de la herida, pasando por dos etapas adicionales antes de arrastrarse fuera de ella para luego caer al suelo.

En esta etapa las larvas miden de 6 a 17 milímetros de largo. Una vez en el suelo, ellas se entierran a una profundidad de 1 a 2 pulgadas, donde desarrollan su etapa de crisálida o pupa. Después de siete días, las moscas ya adultas salen de la pupa a la superficie de la tierra, expanden y secan sus alas y emprenden el vuelo. Tres días después, machos y hembras se aparean y las hembras depositan sus huevos en animales vivos heridos. Las hembras, que pueden vivir entre 15 y 30 días, depositan cada tres días una masa de huevecillos. Durante su corta vida, una de estas moscas puede poner hasta $10 \mathrm{u} 11$ veces.

Una vez que las larvas del gusano barrenador infectan una herida, esta se torna más atractiva a las moscas hembras, que depositarán allí más y más huevecillos. De esta manera, una herida puede infectarse rápidamente con cientos y miles de larvas que

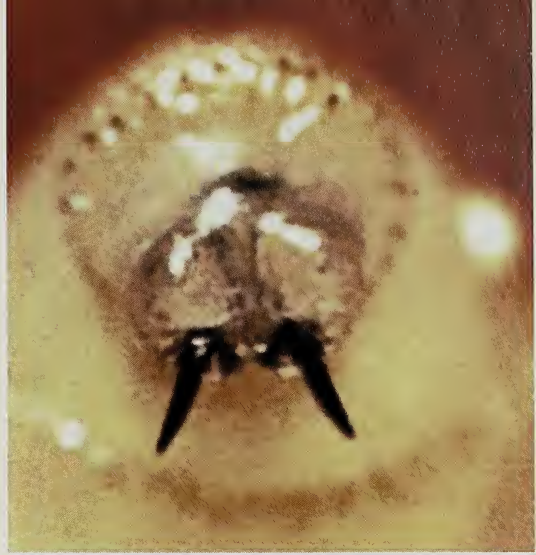

Aparato bucal de la larva del gusano barrenador. Observe las mandíbulas con las que devora la carne de sus huéspedes.

ocasionan la muerte del animal, si no es curado. Como ejemplo, una vaca infectada puede morir en diez días.

La mosca del gusano barrenador es más grande que la mosca doméstica y se diferencia de otras por su color, que varía desde el azul oscuro metálico, un verde azuloso metálico hasta el verde metálico. En su espalda, en medio de ambas alas, tiene tres franjas oscuras longitudinales, de las cuales la del medio es más corta. Los machos, que miden entre 10 a $12 \mathrm{~mm}$ de largo, son un poco más grandes que las hembras, que miden de 8 a $10 \mathrm{~mm}$.

\section{Investigaciones sobre el gusano barrenador}

Debido al terrible impacto económico causado por este insecto, el USDA comenzó a estudiar diferentes métodos para controlarlo y desarrolló la técnica conocida como "macho estéril", que consiste en criar moscas masivamente en una planta de laboratorio, esterilizándolas con radiación para luego liberarlas desde avionetas.

Las constantes investigaciones han mejorado estos métodos, así como nuestros conocimientos sobre la biología y la ecología de tan dañino insecto. Sugieren estos estudios que la mosca prefiere el bosque para vivir y que deposita más huevos en los animales silvestres que en los domestica- 
dos; que se colectan más moscas en los bosques secundarios (los cuales tienen entre quince y veinte años) que en los bosques primarios, y que su sitio preferido son los bordes de los bosques, en el área de transición entre la selva y las áreas abiertas o deforestadas; y finalmente, que es en la estación lluviosa cuando la mosca prolifera más y que se encuentra con mayor frecuencia en sitios húmedos que en los secos.

La misión de los científicos de la USDAARS es realizar investigaciones prácticas y aplicadas para erradicar al gusano de Centroamérica y el Caribe, y con ello prevenir la reinfestación de la región. Entre los objetivos del programa están: mejorar el conocimiento biológico y ecológico del gusano; evaluar el potencial de la tecnología de sensores remotos para predecir su distribución; mejorar los equipos y estrategias para liberar machos estériles, sobre todo en la barrera al este de Panamá y en áreas reinfectadas. Asimismo, perfeccionar las técnicas para reproducir el gusano en gran escala en cautiverio y transferir esta información al programa de erradicación de campo. Finalmente, detectar cambios genéticos en las cepas de las moscas usadas en la producción del gusano en la planta ubicada en México.

\section{Investigaciones en Panamá}

El trabajo de campo en Panamá se inició en 1995 en la Cuenca del Canal, y se estudió la dinámica de la población de moscas, es decir, sus densidades durante las dos estaciones del año y su comportamiento.

Los sitios donde se colectaron muestras fueron las selvas muy accesibles del Parque Nacional Soberanía y la isla Barro Colorado. Para establecer los hábitats preferidos por las moscas, se estudia la temperatura y los tipos de vegetación. Los Sistemas de Información Geográfica (SIG) producen imágenes de satélites muy útiles para clasificar la vegetación y desarrollar métodos para predecir los niveles de población de la mosca.

Pamela Phillips, especialista en sensores remotos, analiza estos datos empleando imágenes LANDSAT TM, SPOT e imágenes de RadarSAt para determinar el me-

Una mosca del gusano barrenador marcada con un disco de plástico numerado, adherido con goma. Luego se libera la mosca, y es recapturada con el fin de estudiar sus patrones de dispersión y supervivencia. Foto: P. Greb.

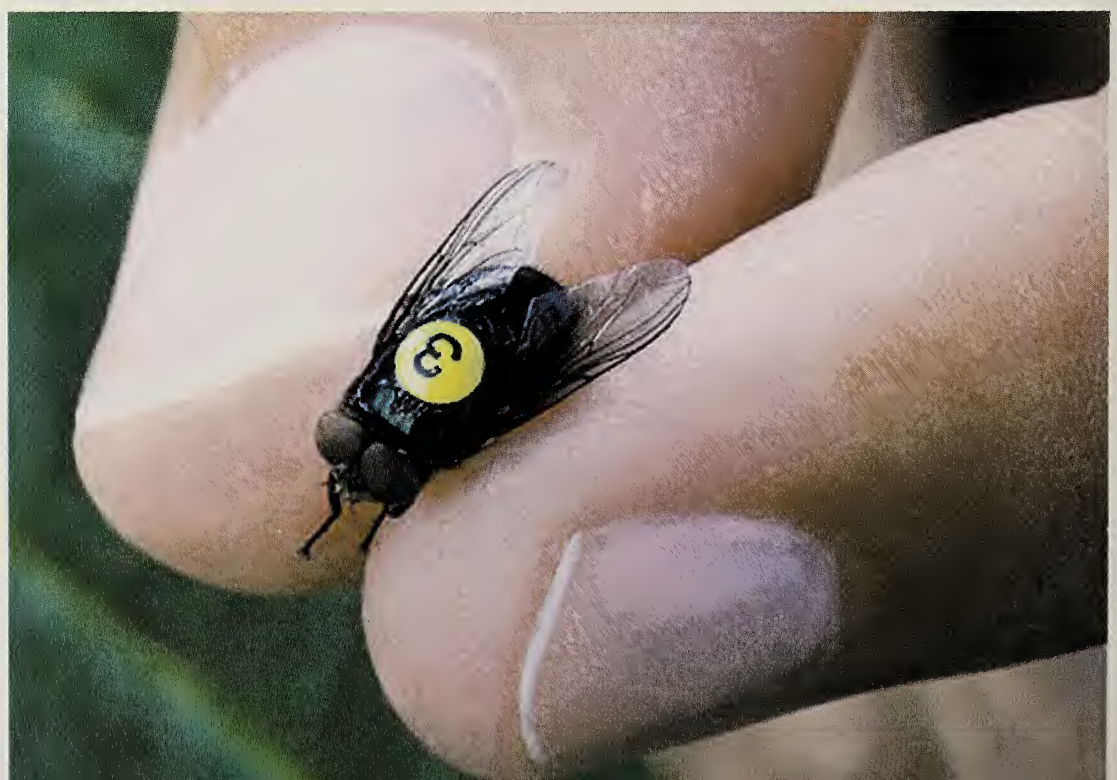


jor método y el más económico para identificar áreas donde el personal de erradicación tendría más probabilidades de obtener moscas del gusano.

Además de las investigaciones en Panamá, también se realizan trabajos en otros laboratorios del USDA-ARS en Estados Unidos y México, en especial sobre la genética de la especie.

Algunos estudios buscan desarrollar nuevas cepas genéticas para usar en la planta laboratorio de moscas estériles en Chiapas de Corzo, México.

Desde septiembre de 1996 se inició en el Parque Nacional Soberanía un estudio de dinámica de población empleando la técnica de marcación-lanzamiento-recaptura, que consiste en capturar moscas con red, marcarlas con pequeñísimas etiquetas y luego liberarlas. Cuando las moscas marcadas son recapturadas, se obtienen datos sobre la densidad y supervivencia de las poblaciones de la mosca durante las distintas temporadas del año. Estos datos que nunca antes habían estado disponibles, proporcionarán ahora un mejor entendimiento del gusano, su comportamiento y ecología.

Estos datos de población se correlacionan con información sobre clasificaciones de vegetación para producir mapas que identifiquen los hábitats preferidos por el gusano barrenador. Estos datos también permiten calibrar y verificar modelos de computadora que simulan las dinámicas de la población del gusano barrenador.

Otra parte de nuestros estudios en Panamá trata el impacto del gusano barrenador sobre los monos aulladores en la isla Barro Colorado, estudio que se hace conjuntamente con la Universidad de Berkeley, California. Este es un proyecto pionero para determinar el efecto del gusano en la mortalidad de estos animales silvestres.

\section{Perros para detectar gusanos}

El programa de erradicación de la mosca requiere que el ganado transportado por carretera sea inspeccionado en los pues-

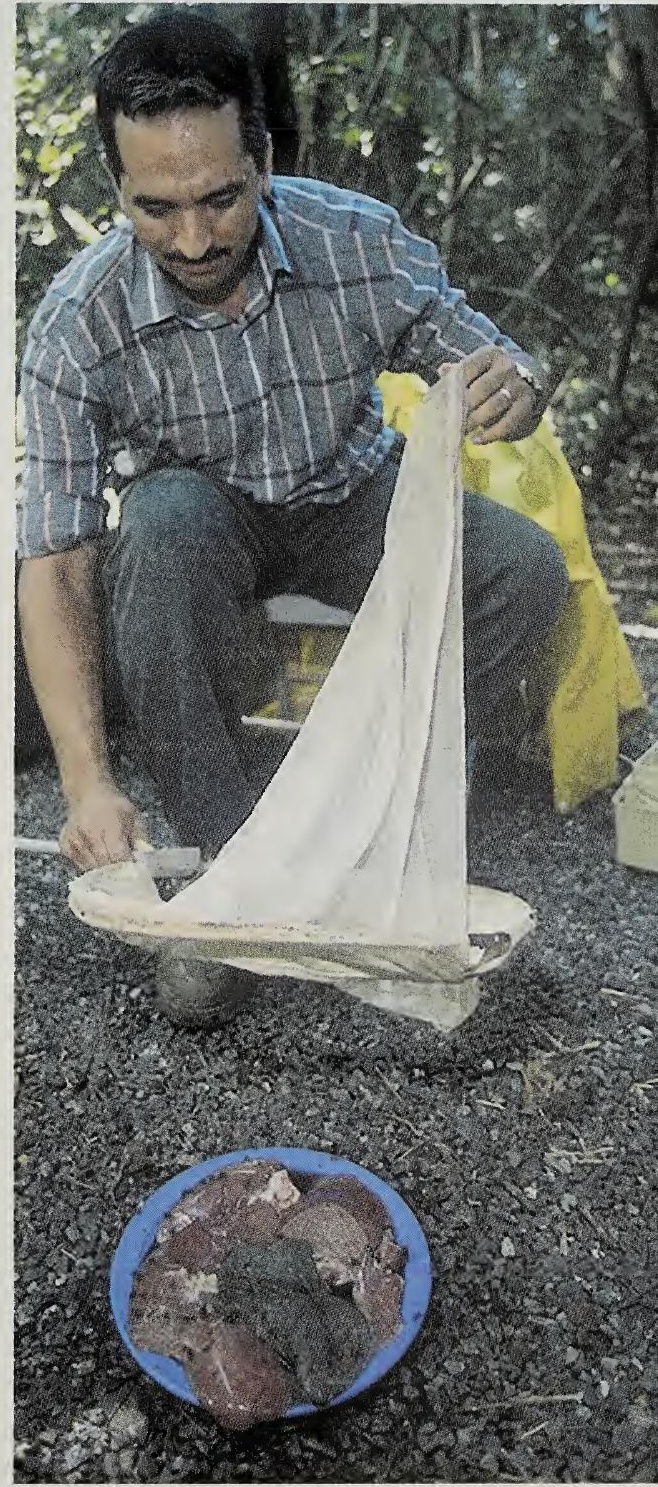

Un técnico biólogo del proyecto del gusano barrenador, atrapa moscas que se posan sobre un plato con trozos de hígado. Estas moscas serán luego marcadas con pequeñísimos discos plásticos numerados, para luego liberarlas en el bosque del Parque Nacional Soberanía. Foto: P. Greb. 
tos de cuarentena, para impedir que la mosca reinfeste áreas previamente desinfectadas.

Dado que los perros tienen un olfato más agudo que el hombre, son mejores inspectores que este. Por tanto, otro aspecto de nuestra investigación es establecer procedimientos para entrenar perros que detecten la presencia del gusano en animales con heridas infectadas, aumentando así la eficiencia de los inspectores humanos al alertarles de la presencia de gusanos.

El primer perro utilizado en este esfuerzo se llama "Severn Runs Cazador", mejor conocido como "Caz", un pointer alemán entrenado para buscar gusanos en animales con heridas, así como la pupa del gusano en la tierra. Después de cinco meses de entrenamiento, Cazador era capaz de detectar el gusano en las heridas. En tres meses adicionales podía encontrar las pupas en el suelo. Su tasa de éxito es de $100 \%$ con señuelos y $95 \%$ con animales vivos.

\section{La simulación del ciclo de vida en computadoras}

El Modelo de Simulación de la Mosca del Gusano Barrenador (SWFSIM) introduce a una computadora datos del ciclo de vida de la mosca y de factores climáticos que inciden sobre la mosca, como temperatura, humedad y lluvia. Este modelo, desarrollado por un equipo científico liderado por Danel G. Haile, permite simular diferentes estrategias de control en distintas áreas geográficas.

Aspiramos a que en el futuro podamos desarrollar mediante computadoras, un modelo más complejo que integre el modelo SWFSIM con el Sistema de Información Geográfica (SIG) y datos de sensores remotos. Este proporcionaría una mejor herramienta al personal de erradicación a fin de desarrollar estrategias para combatir epidemias en áreas reinfestadas y para mantener una barrera entre las áreas erradicadas y las infestadas.

Podemos señalar con satisfacción que como resultado de esta cooperación técnica y científica entre Panamá y Estados Unidos, la erradicación del gusano barrenador avanza firmemente. Actualmente el gusano ha sido eliminado casi por completo de toda la región al oeste del Canal, hasta la frontera con Costa Rica, país donde ya ha sido eliminado. Posteriormente, el programa de liberación de moscas estériles se concentrará en la región oriental, en Darién, estableciendo la barrera permanente que protegerá a toda Centro y Norteamérica de la migración de las moscas del gusano barrenador suramericanas.

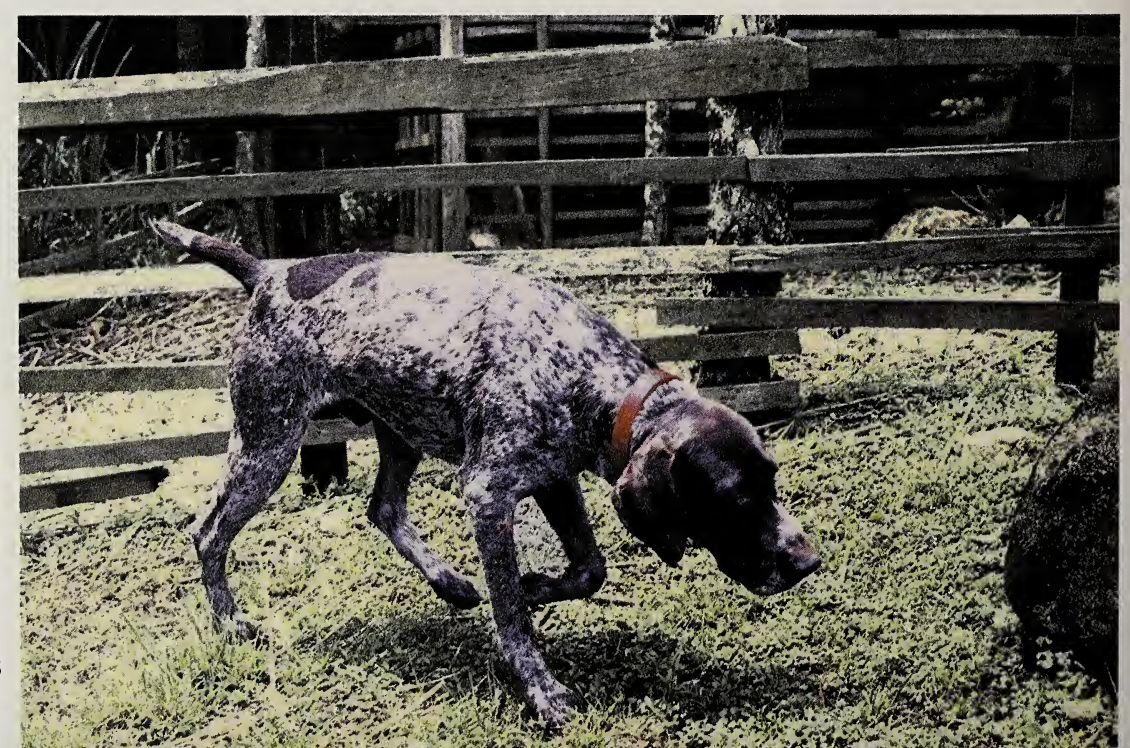




\section{CAPITULO 4}

\section{EL MUNDO DE}

LOS ANIMALES TERRESTRES

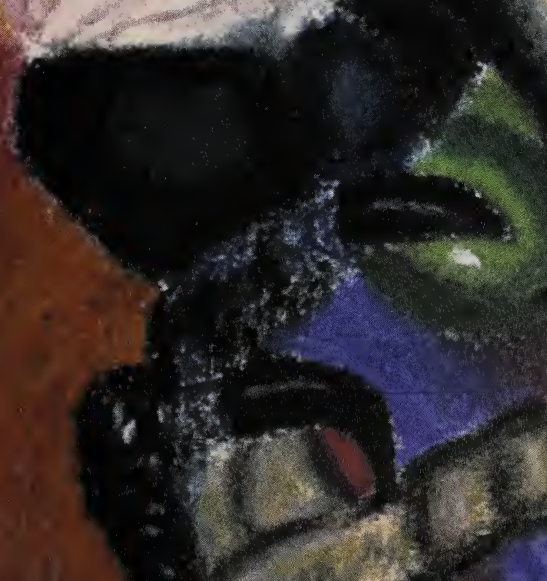




\section{Roberto Ibáñez D.}

\section{Los anfibios del área central de Panamá}

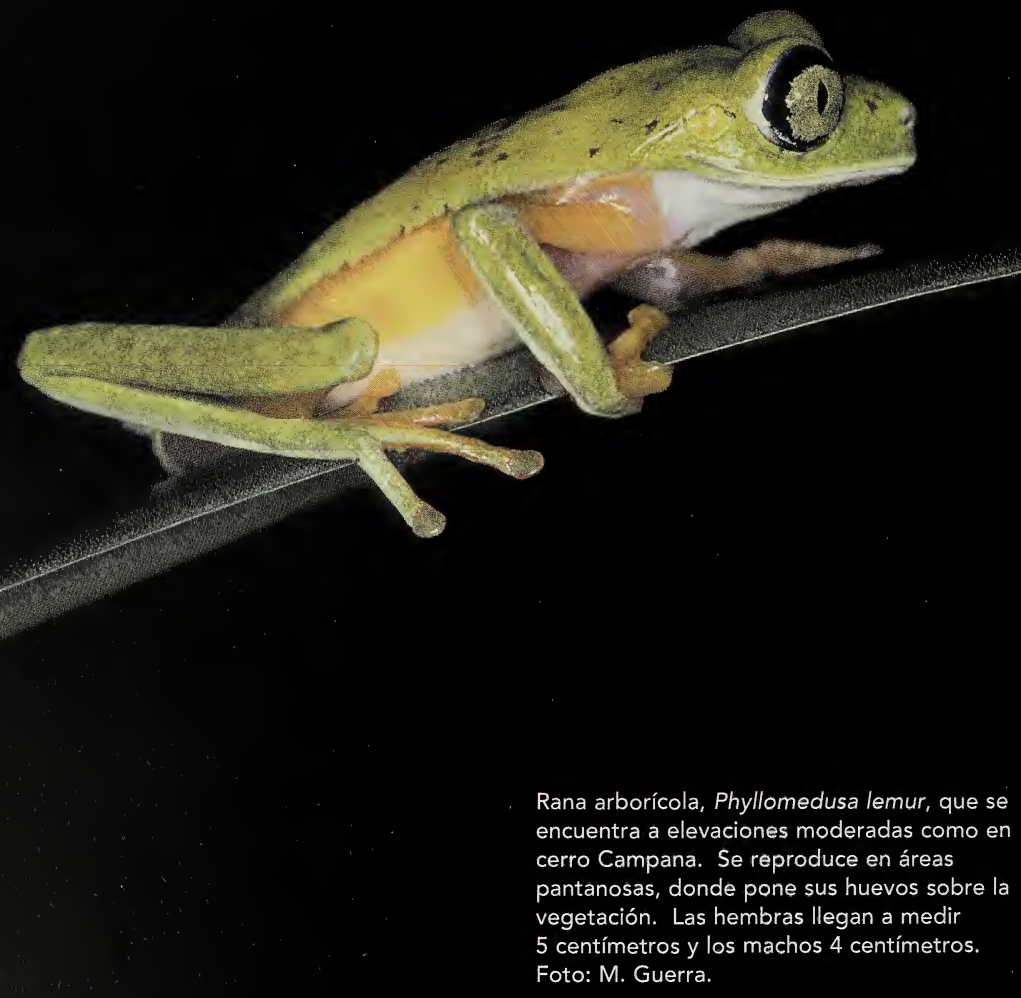


$\mathrm{L}$ os anfibios son animales con vértebras, de piel lisa y húmeda, que usualmente ponen sus huevos en el agua o en sitios húmedos. Los más conocidos son las ranas y salamandras.

Originalmente se les llama anfibios, de las palabras griegas amphi: ambos y bios: vida, pues pasan parte de su vida en el agua y otra en tierra. Se consideraba que su ciclo de vida clásico consistía en poner sus huevos en el agua, de los cuales salen renacuajos que se desarrollan en ese medio, seguido luego por la metamorfosis, y por último el abandono del agua para convertirse en animales terrestres. La mayoría de los anfibios se reproducen durante la estación lluviosa. Sin embargo, en los trópicos existen muchas especies que no necesitan reproducirse ni vivir en el agua.

\section{La diversidad de anfibios de Panamá}

Se conocen para todo el mundo más de 4600 especies. Panamá posee una alta diversidad de anfibios: 175 especies aproximadamente, más o menos el $4 \%$ de los anfibios del mundo. Esta cifra es alta, en relación a nuestro pequeño territorio. Los anfibios se pueden encontrar por todo el país, desde las tierras bajas cerca al mar hasta los puntos más elevados, como el volcán Barú a 3450 metros sobre el nivel del mar. Las tierras altas a ambos extremos del país, en Darién, Bocas del Toro y Chiriquí, son quizás las más ricas en cuanto a diversidad y número de especies únicas. Aún existen regiones poco exploradas, que seguramente guardan especies por descubrir.

Nuestra riqueza en anfibios va mas allá del simple número de especies. Esta diversidad es enriquecida por la variedad de sus formas, modos de vida, comportamientos y relaciones entre los anfibios y otros animales.

Para el público panameño los anfibios son animales casi desconocidos, salvo por las especies que usualmente se encuentran en las áreas pobladas. Muestra de este desconocimiento es que la gran mayoría de éstos, ni siquiera tienen nombres comunes. La actitud de la gente hacia ellos varía, desde la repugnancia a los sapos, hasta la fascinación por la rana dorada. Las ranas aparecen en piezas de cerámica y de oro precolombinos. En excavaciones arqueológicas se han encontrado evidencias de que el sapo común era parte de la dieta de los istmeños de cientos de años atrás.

Un ejemplar juvenil de la cecilia Dermophis parviceps encontrado en cerro Jefe. Esta especie se le observa en raras ocasiones, ya que son especies que viven enterradas en la hojarasca y el suelo. Los adultos pueden medir unos 30 centímetros.

Foto: M. Guerra. 


\section{Los anfibios y el canal}

Este artículo se limitará a los anfibios de la región central de Panamá, que incluye la Cuenca del Canal, aunque muchas de sus especies representativas también se hallan en otras áreas del país. Los anfibios de la región central son los mejor conocidos, ya que históricamente se han concentrado aquí las exploraciones y estudios sobre la fauna panameña. Las expediciones para conocer sus especies se iniciaron en la segunda mitad del siglo XIX, por estudiosos como John Bransford, un cirujano asistente de la expedición que buscaba establecer la ruta del canal interocéanico y que en sus tiempos libres recolectaba anfibios a lo largo del ferrocarril. Muchos otros investigadores han explorado la región central de manera intermitente hasta años recientes, con los inventarios biológicos del Canal de Panamá (1992-1993) y el Proyecto de Monitoreo de la Cuenca del Canal (1996-2000). Algunos de los anfibios más comunes en esta región han sido estudiados detalladamente, conociéndose aspectos de su fisiología, su comportamiento, ecología y biología evolutiva; tal es el caso del sapito túngara Physalaemus pustulosus, cuya comunicación vocal o cantos han sido estudiados por Stanley A. Rand y Michael J. Ryan.

En las tierras bajas de la región central, que incluye al Monumento Natural Barro Colorado, la ribera sudoeste del Canal, los parques nacionales Soberanía y Camino de
Cruces, el Parque Natural Metropolitano, la ciudad de Panamá, la isla Taboga y áreas adyacentes, se encuentran 62 especies de anfibios. Un número similar existe hacia el este, a mayores elevaciones, en la menos explorada serranía Piedras de Pacora en las cabeceras del río Chagres. En esta serranía hay especies que no encontramos en las tierras bajas de la Cuenca del Canal.

\section{Los tres grandes grupos}

Se dividen los anfibios en tres órdenes 0 grandes grupos, que pueden definirse por las formas de sus cuerpos. El orden Gymnophiona incluye a las cecilias, que parecen lombrices pues carecen de patas. Como viven la mayor parte del tiempo enterradas en el suelo o la hojarasca, es raro verlas. Poco se sabe de su biología, pero se conocen varias de sus formas de reproducirse. Algunas especies se desarrollan directamente en huevos de los cuales salen pequeñas cecilias. Otras paren a sus crias vivas.

El orden Caudata comprende a las salamandras, anfibios con cuatro patas y cola. Estas especies se observan con más frecuencia en las tierras altas del área central. Las salamandras del trópico americano tienen un desarrollo directo, es decir, carecen de estadio larvario, y como no tienen pulmones respiran únicamente por la piel. Una representante del área central es Oedipina parvives, de cuerpo y cola alargada con patas delgadas y cortas.

Bolitoglossa schizodactyla, salamandra que puede encontrarse sobre la vegetación, durante las noches húmedas, en lugares como los cerros Campana y Jefe. Los adultos tienen una longitud total aproximada de 6 centímetros. Foto: A. S. Rand. 
El orden Anura incluye ranas y sapos. Tienen cuatro patas, con las de atrás desarrolladas para saltar y carecen de cola. Es el grupo más conocido por la gente, pues en su época reproductiva, durante las noches, desde charcas, arroyos y el bosque, los machos cantan para atraer a las hembras. Los anuros son los anfibios más diversos de $\mathrm{Pa}$ namá y se dividen en ocho familias: Bufonidae, Centrolenidae, Dendrobatidae, Hylidae, Leptodactylidae, Microhylidae, Pipidae y Ranidae. La familia Pipidae es la única ausente en la región central de Panamá.

\section{La familia Bufonidae}

Esta familia incluye a los comúnmente conocidos como sapos. Las especies existentes en Panamá, se reproducen en charcas o arroyos y tienen estadio larvario. Ponen sus huevos en tiras dentro del agua, de los cuales salen larvas o renacuajos y luego, después de una metamorfosis, abandonan el agua con la forma corporal de un adulto. El sapo común, Bufo marinus, es una especie que aún se observa, durante la noche, debajo de las luminarias de los suburbios de la ciudad de Panamá. Otras especies sólo viven en áreas boscosas, como el Bufo typhonius, cuyos colores los confunde con las hojas secas: se le ve frecuentemente saltando en el suelo y sobre la hojarasca. A esta familia pertenece la famosa rana dorada de Pana- má, Atelopus zeteki; sin embargo, otras especies del género viven en la región central. Atelopus limosus, es una especie endémica menos llamativa, de color verde limoso, que sólo se conoce en un área muy pequeña del mundo: la sierra Llorona, provincia de Colón, y alrededores. Habita en esta sierra lluviosa, desde los cerros más elevados, como Bruja con 950 metros de altitud, hasta las tierras bajas.

\section{La familia Centrolenidae}

Comprende esta familia a las llamadas ranas de cristal, ya que algunas especies tienen la piel del vientre transparente y se puede ver sus huesos y órganos internos. Estas ranas pasan por una etapa larvaria, reproduciéndose a orillas de las quebradas en la estación lluviosa; ponen sus huevos en la vegetación, fuera del agua, en las márgenes de los arroyos. Los machos de algunas especies cuidan de los huevos. Cuando los renacuajos salen de los huevos caen al agua y se entierran en el fondo y en las orillas de los arroyos. Al final de la metamorfosis salen del agua con forma adulta. Hylinobatrachium fleischmanni es una ranita de cristal común a la región, siendo una de las especies cuyos machos cuidan los huevos. En contraste, Cochranella granulosa pone masas de huevos con gelatina abundante que luego abandona a su suerte.
Un individuo de una población de una rana dorada en cerro Azul. Al parecer pertenecen a la especie Atelopus zeteki, aunque los individuos de esta población difieren en medidas corporales de las poblaciones de esta especie en cerro Campana.

Desafortunamente, la zona restringida donde existe esta única población está siendo modificada por el hombre, ya que se encuentra fuera de los parques nacionales. Los machos adultos miden unos 3.5 centímetros.

Foto: M. Guerra.

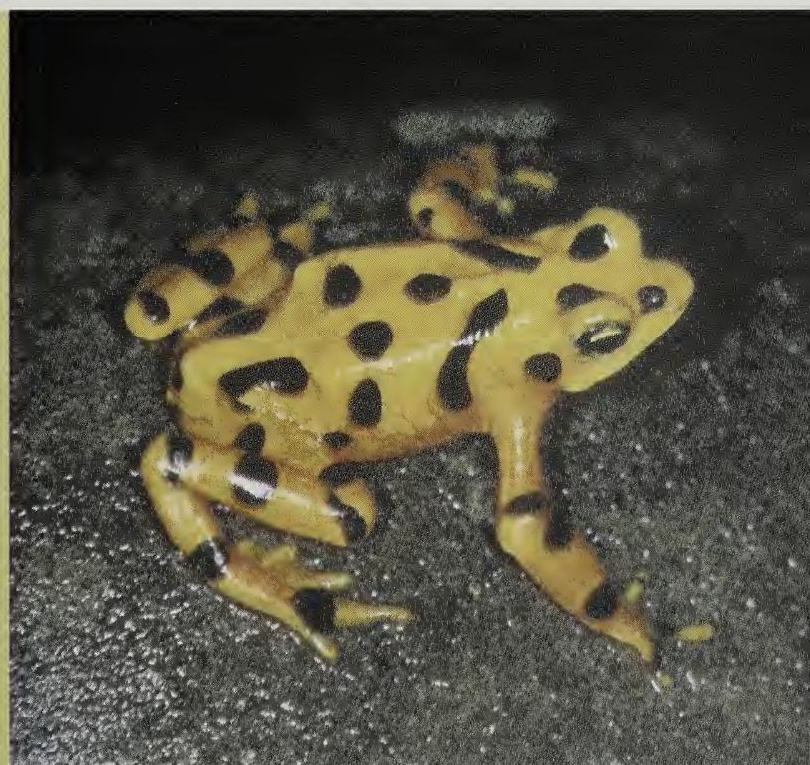




\section{La familia Dendrobatidae}

Incluye especies de ranas venenosas de $\mathrm{Su}$ damérica, cuya piel segrega toxinas que han sido usadas por los indígenas para envenenar las puntas de los dardos de sus cerbatanas. Son especies que habitan en los bosques y están activas solamente durante el día, moviéndose en saltos cortos. Ponen sus huevos entre la hojarasca o en cavidades en el terreno. Los padres cuidan sus huevos y en algunas especies solamente cuida la hembra y en otras el macho. El padre o la madre cargan en sus espaldas a los renacuajos hasta el agua, donde se desarrollan y se transforman para vivir en tierra. La piel de la mayoría de las especies del género $\mathrm{Co}_{0}$ lostethus no produce venenos. Estas ranas son de colores oscuros, negro y marrón. Dejan sus renacuajos en las quebradas del bosque. Colostethus flotator es una de las especies más abundantes; es una ranita pequeña (los adultos apenas llegan a los $18 \mathrm{~mm}$ ) que vive en el suelo y la hojarasca de los bosques del área central. En algunos sitios muy húmedos, como en el Fuerte Sherman en la costa atlántica, Colostethus talamancae es más común. Las especies del género Den-

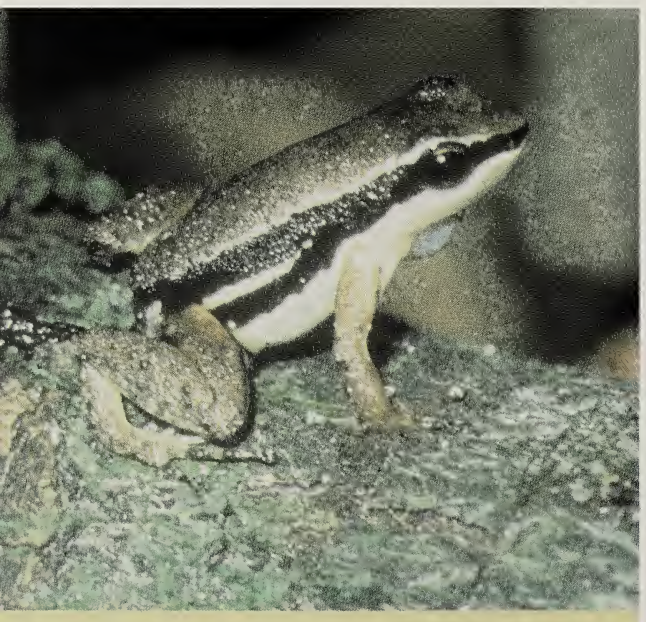

Colostethus pratti es una ranita abundante en el suelo del bosque, a elevaciones moderadas, cuyos machos cantan durante el día. Las hembras y los machos miden unos 2.5 centímetros. Foto: K. D. Wells. drobates usualmente tienen colores llamativos y sustancias venenosas en la piel, pero menos potentes que las de las ranas sudamericanas de esta familia. Estas especies depositan sus renacuajos en los charquitos de agua que se depositan entre las hojas de las bromelias, en los huecos de los troncos, o las pencas caídas de las palmas. La rana verde y negra Dendrobates auratus es muy común en cerro Ancón e isla Taboga, aunque la tabogana es verde y marrón.

\section{La familia Hylidae}

Comprende a las ranas comúnmente llamadas arborícolas, que viven en los árboles y que pueden treparlos gracias a discos adhesivos que tienen en la punta de sus dedos. Algunas especies viven en herbazales, pero la mayoría prefiere los bosques. Son especies nocturnas, que se reproducen en la estación lluviosa; muchas ponen sus huevos en la vegetación o dentro del agua de las charcas y quebradas donde se crían los renacuajos.

Algunas hacen nidos en las orillas de los arroyos; unas pocas ponen los huevos en huecos o en troncos con agua, donde los renacuajos se desarrollan. Otras llevan sus huevos en el dorso, los cuales tienen un desarrollo directo sin estadio larvario.

La llamativa rana arborícola de ojos rojos Agalychnis callidryas, es una especie muy común que en la estación lluviosa se congrega en la vegetación alrededor de las charcas y lagunas dentro o cerca del bosque. Los machos emiten cantos cortos, como chasquidos. Las parejas suelen poner sus huevos sobre la vegetación, en donde los abandonan. No obstante, los renacuajos cuentan con un recurso que pueden utilizar si algún peligro mortal acecha: pueden salir rápidamente de los huevos, antes del tiempo requerido, para escapar -por ejemplo- al ataque de una serpiente. Por unos cuantos días al inicio de la estación húmeda, se escuchan grandes coros de Phrynohyas venulosa; son los machos que llaman a las hembras desde charcas y desde la vegetación adyacente. Los adultos son grandes y su piel secreta una sustancia pegajosa que irrita las mucosas de los seres humanos. 
Hemiphractus fasciatus, una especie de aspecto algo diabólico, se encuentra principalmente en los bosques nubosos de las tierras moderadamente altas de la región central, como en cerro Bruja. A diferencia de la mayoría de las ranas arborícolas, ésta tiene hábitos terrestres y parece una hoja seca, encontrándosele en la hojarasca o sobre la vegetación baja. Se alimenta de otras ranas, lagartijas e insectos. Las hembras llevan sus huevos en su espalda.

\section{La familia Leptodactylidae}

Consiste de las denominadas ranas del trópico de América. Son especies con formas y hábitos variados; aunque la mayoría son de piel lisa, algunas la tienen rugosa, parecidas a sapos, algunas especies son terrestres y otras arborícolas. En la región central encontramos cuatro géneros: Eleutherodactylus, Leptodactylus, Physalaemus y Pleurodema.

Las especies nativas de Eleutherodactylus viven en los bosques, se reproducen durante la época de lluvias, se desarrollan directamente sin pasar por la etapa de larvas. Algunas se encuentran en el suelo como en la vegetación baja, varias son completamente arborícolas y a unas pocas sólo se les encuentra en las quebradas. En los jardines de la ciudad de Panamá, encontramos especies exóticas de Eleutherodactylus, originarias de las Antillas, introducidas al país en plantas ornamentales. Las especies de Leptodactylus, Physalaemus y Pleurodema viven en áreas con herbazales, arbustos y árboles dispersos; se reproducen en la estación lluviosa, poniendo sus huevos en un nido de espuma; los renacuajos se desarrollan en las charcas. Algunas habitan el bosque, como Leptodactylus pentadactylus, una especie grande que se alimenta de insectos y de otras ranas.

Physalaemus pustulosus es muy común en áreas modificadas por el hombre, aunque también habita en el bosque. Se le conoce popularmente como sapito túngara, por su peculiar canto.

La mayoría de las especies de la familia Leptodatylidae no cuidan sus huevos: una vez puestos, éstos son abandonados. Sin embargo, existen especies como las hembras de

Hemiphractus fasciatus es una rana arborícola con hábitos que tienden a ser más terrestres. Estas ranas se alimentan, además de insectos, de otras ranas y lagartijas. Las hembras y los machos adultos pueden medir hasta 6 centímetros. Foto: C. C. Hansen. 


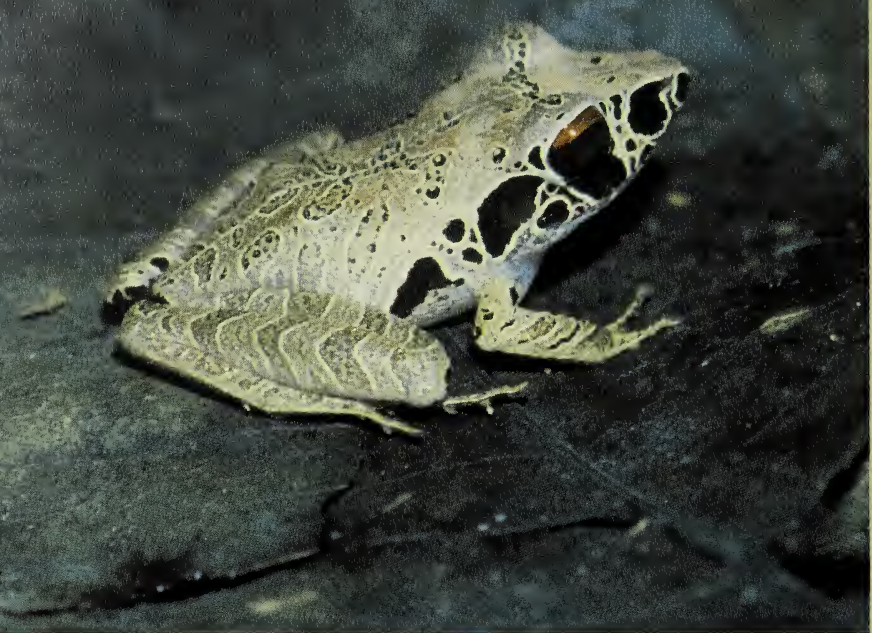

Individuo joven de

Eleutherodactylus gollmeri, una especie que se encuentra en la hojarasca del suelo del bosque, y que es común en sitios a una elevación moderada, como los cerros Azul y Campana. Las hembras adultas pueden medir hasta 5 centímetros y los machos hasta 4 centímetros.

Foto: M. Guerra.

Eleutherodactylus caryophyllaceous que ponen sus huevos en la vegetación y los protegen; las madres de Leptodactylus insularum también cuidan a sus cardúmenes de renacuajos.

\section{La familia Microhylidae}

Incluye a los llamados sapos de boca angosta, con cuerpo rechoncho y hocico puntiagudo. Son especies que se entierran en el suelo, a veces se les encuentra debajo de troncos o tablones en el suelo. Se reproducen en los meses de lluvias y ponen sus huevos en el agua, donde se desarrollan los renacuajos. Es un grupo poco diverso en Panamá: solamente hay tres especies en la región central, dos de las cuales habitan las áreas con hierbas, arbustos y árboles dispersos, y la otra vive en el bosque. Los machos de Chiasmocleis panamensis se reconocen por su llamado, un silbido trinado y agudo que emiten en las noches, desde las charcas, usualmente después de una fuerte lluvia.

\section{La familia Ranidae}

Comprende a las ranas verdaderas, nombre que primero recibieron en Europa. Tienen la piel lisa y membranas bien desarrolladas entre los dedos de sus patas traseras. Estas especies tienen lo que antes se consideraba el ciclo de vida clásico de las ranas y sapos. También es un grupo poco diverso en Panamá, en el área central sólo hay tres especies. Una especie de charcas grandes o lagunas de áreas abiertas, pertenece al complejo de especies de las ranas leopardo (Rana pipiens complex). La Rana vaillanti habita en pantanos del bosque o de áreas abiertas. Una especie que vive a lo largo de los arroyos del bosque es la Rana warszewitschii, nombrada en honor a su colector, el naturalista polaco Josef Warszewicz, quien visitó el istmo a fines de la década de 1840 , cruzando la cordillera desde Chiriquí hasta Bocas del Toro.

\section{El fenómeno de la disminución de las poblaciones}

Existe entre los científicos una creciente preocupación sobre el futuro de los anfibios, debido a que se han reportado grandes desapariciones y disminuciones en sus poblaciones alrededor del mundo. En América Central se registraron declinaciones de anfibios primeramente en la Reserva del Bosque Nuboso de Monteverde, en las tierras altas de Costa Rica, sitio donde ha desaparecido el sapo dorado, Bufo periglenes, y donde las poblaciones de otras especies de ranas se mantienen muy reducidas. Luego en las Tablas, otro sitio en las tierras altas de Costa Rica, cerca a la frontera panameña, se 
observaron ranas muertas de algunas especies y una reducción repentina en su abundancia. Estas drásticas disminuciones en las poblaciones de anfibios también se suscitó en Panamá. En 1996 y 1997, hubo una gran mortandad de ranas en la Reserva Forestal de Fortuna, en las tierras altas de Chiriquí, que diezmó las poblaciones de varias especies, especialmente las que viven en las quebradas. Esta disminución ocurrida en Fortuna, que en el pasado era un excelente sitio para observar ranas, se ha mantenido hasta años recientes. En Panamá la mortalidad está asociada a un hongo chitridiomiceto que afecta la piel de las ranas, causando su muerte.
Contrariamente a lo sucedido en las tierras altas de Costa Rica y Chiriquí, en las tierras bajas de la región central de Panamá no se ha detectado una mortandad de los anfibios. Basándonos en estudios realizados en esta región entre 1991 y 1998, podemos afirmar que las poblaciones de ranas y sapos se mantienen estables, es decir que se encuentran en un estado saludable. No obstante, se requiere de un monitoreo continuo a largo plazo para entender la dinámica de las poblaciones de anfibios tropicales y para detectar cambios que indiquen algún problema con estas especies, como los que puede causar la aparición del hongo patógeno en la región.

El sapo Bufo coniferus tiene una coloración verde a chocolate y una hilera de tubérculos puntiagudos en el costado, es más común en las áreas más húmedas y a elevaciones moderadas dentro de la cuenca. Las hembras adultas alcanzan los 9 centímetros y los machos 7 centímetros. Foto: M. Guerra.

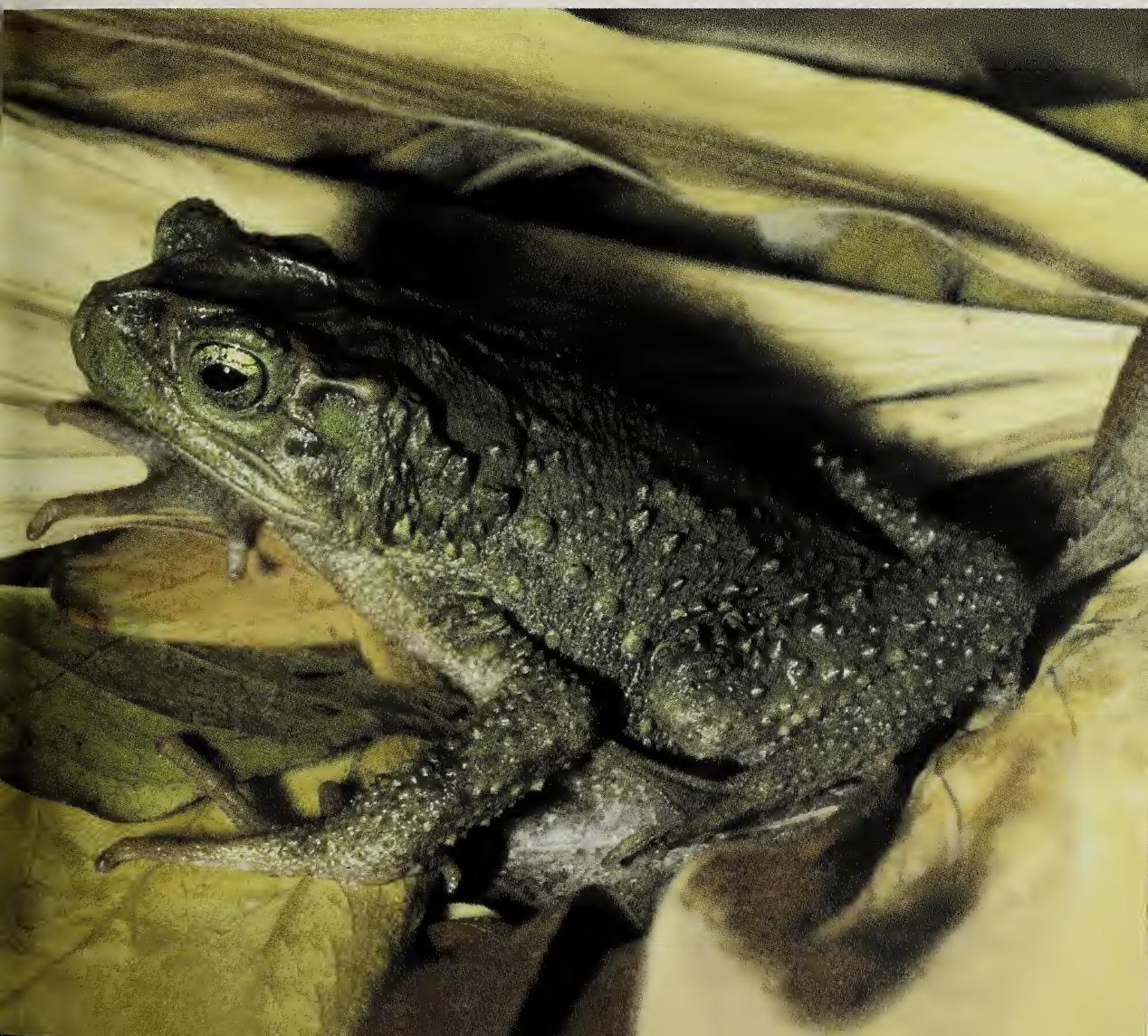




\section{Frank A. Solis $y$ César A. Jaramillo}

Las

serpientes de Panamá

Algunas serpientes pueden tener coloraciones muy vistosas, como la Siphlophis cervinus. Esta serpiente de la familia Colubridae es totalmente inofensiva parà el hombre. Foto: Alejandro Caballero. STRI.

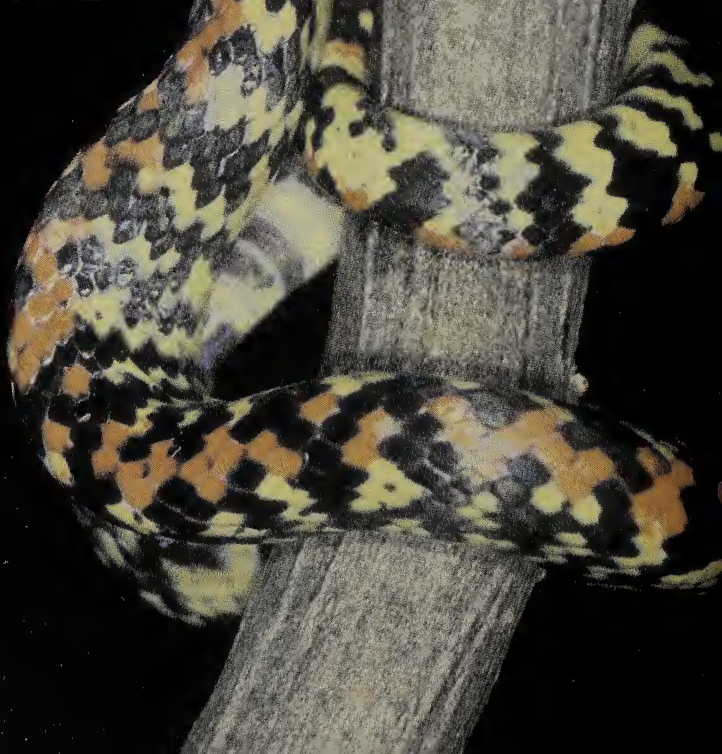


$\mathrm{L}$ as serpientes son los animales más rechazados por el hombre, quizás debido a la creencia errada de que todas son venenosas y, por ende, peligrosas. Tradicionalmente, la reputación de este reptil ha sido asociada con el mal, lo feo, repugnante, peligroso y despreciable.

Esta fama alcanza, incluso, a algunos relatos de índole religiosa que influyen en la conducta de algunas personas hacia estos animales; así vemos que la Biblia culpa a la serpiente de que el hombre fuera expulsado del paraíso terrenal. Frecuentemente se escuchan en nuestro país frases como la de "culebra vista, culebra muerta"; contraer una deuda se conoce popularmente como "tener una culebra"; y decir que una persona "es una culebra" es atribuirle los peores adjetivos. Sin embargo, para bien o para mal, las serpientes siempre han llamado la atención, fascinando a los naturalistas y han sido objeto de muchas investigaciones científicas.

Existen más de dos mil seiscientas especies de serpientes en el planeta, de las cuales menos del $10 \%$ son potencialmente venenosas para el ser humano. Ellas habitan casi todos los climas de la Tierra, salvo los polos y las altitudes mayores de 4,600 metros; y abundan especialmente en las zonas tropicales.

El conocimiento que tenemos actualmente de las serpientes de Panamá es el resultado de un gran número de contribuciones que se iniciaron a mediados del siglo dieciocho con las obras del gran naturalista sueco Linnaeus (1707-1778). Hoy día conocemos para Panamá ciento veintiséis especies de serpientes, agrupadas en cincuenta y ocho géneros y ocho familias; doce especies son endémicas.

\section{Serpientes no venenosas}

Las ciento seis especies de serpientes no venenosas de Panamá están agrupadas en seis familias: La familia Anomalepididae, con tres especies, reune a serpientès pequeñas conocidas como "culebras ciegas", que viven prácticamente enterradas bajo el suelo. La especie Liotyphlops albirostris es muy común en los jardines de la ciudad de Panamá, pero sólo se hace visible después de fuertes lluvias, cuando salen a la superficie; ellas pasan inadvertidas al ser confundidas con lombrices de tierra.

En la familia Boidae, con cuatro especies, encontramos la serpiente más popular y conocida en nuestro país: "la boa común", Boa constrictor, que vive en el suelo y los árboles de nuestros bosques y puede alcanzar un tamaño de más de 3 metros.

La mayoría de las serpientes de Panamá están agrupadas en la familia Colubridae, con noventa y cinco especies, donde podemos encontrar especies pequeñas y grandes, diurnas y nocturnas, nadadoras, terrestres, arborícolas y algunas que viven
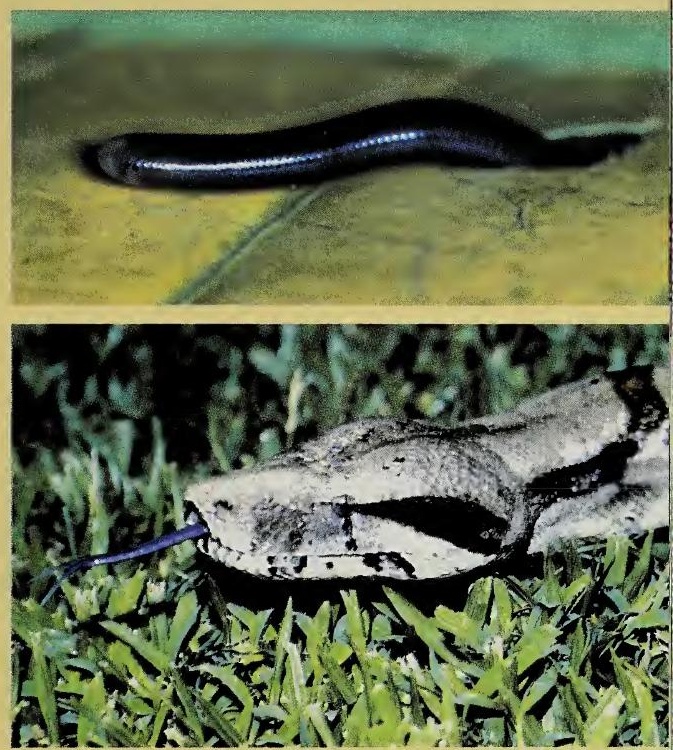

Arriba: A la culebrita Liotyphlops albirostris, usualmente se le confunde con una lombriz de tierra. Vive enterrada y puede alcanzar un tamaño de $20 \mathrm{~cm}$. Foto: M. Guerra.

Abajo: La Boa constrictor es la culebra más conocida en Panamá. Alcanza longitudes mayores a los 3 metros y se alimenta de animales de sangre caliente, como aves y mamíferos. Foto: M. Guerra. 
anillos de dos colores, negro y rojo. La culebra marina, Pelamis platurus, que se encuentra en las aguas del Pacífico, también pertenece a la familia de las "corales".

La familia Viperidae, la de las víboras, cuenta con once especies. Son serpientes con cabeza grande y triangular, que poseen una cavidad entre el ojo y el orificio nasal, la cual les sirve para detectar el calor que emite el cuerpo de sus presas (foseta loreal). Las víboras son las culebras venenosas más peligrosas de nuestros bosques, porque al morder inyectan su veneno como una aguja hipodérmica, ya que tienen un par de grandes colmillos móviles y huecos, ubicados en la parte anterior de la mandíbula superior. El veneno de las víboras produce daño o degradación de los tejidos musculares afectados (necrosis) y dolores intensos en el área de la mordida. La especie Bothrops asper, conocida generalmente como "equis" o "terciopelo" es la más común, agresiva y peligrosa de las víboras panameñas y puede alcanzar un tamaño de dos metros; esta es la víbora que causa el mayor número de mordeduras en Centroamérica.

La víbora más grande de América, que puede llegar a medir más de dos metros y medio, también pertenece a la familia viperidae y se conoce como la "verrugosa", "cascabel muda" o "bushmaster". En Panamá se encuentra la verrugosa Lachesis stenophrys, habitando en el bosque húmedo de las tierras bajas de la vertiente atlántica, aunque se encuentra también en la vertiente pacífica de la región central del istmo, hasta Darién. También tenemos serpientes venenosas que viven en los árboles y la más común en nuestros bosques es la Botriechis schlegelii, conocida como "víbora de pestañas" porque tiene sobre sus ojos unas escamas alargadas que dan la impresión de ser pestañas; es muy peligrosa porque generalmente muerde en la parte superior del cuerpo, la cara, brazos y manos, provocando accidentes de cuidado.
Importancia económica y ecológica de las serpientes

Algunos pobladores del país consumen ocasionalmente serpientes grandes como las boas, cuya carne es considerada como un delicioso manjar; su piel puede ser utilizada para confeccionar correas, carteras, zapatos o recordatorios turísticos. Pero la mayor importancia que tienen las serpientes está dentro de los ecosistemas, todas las especies son depredadoras y por lo
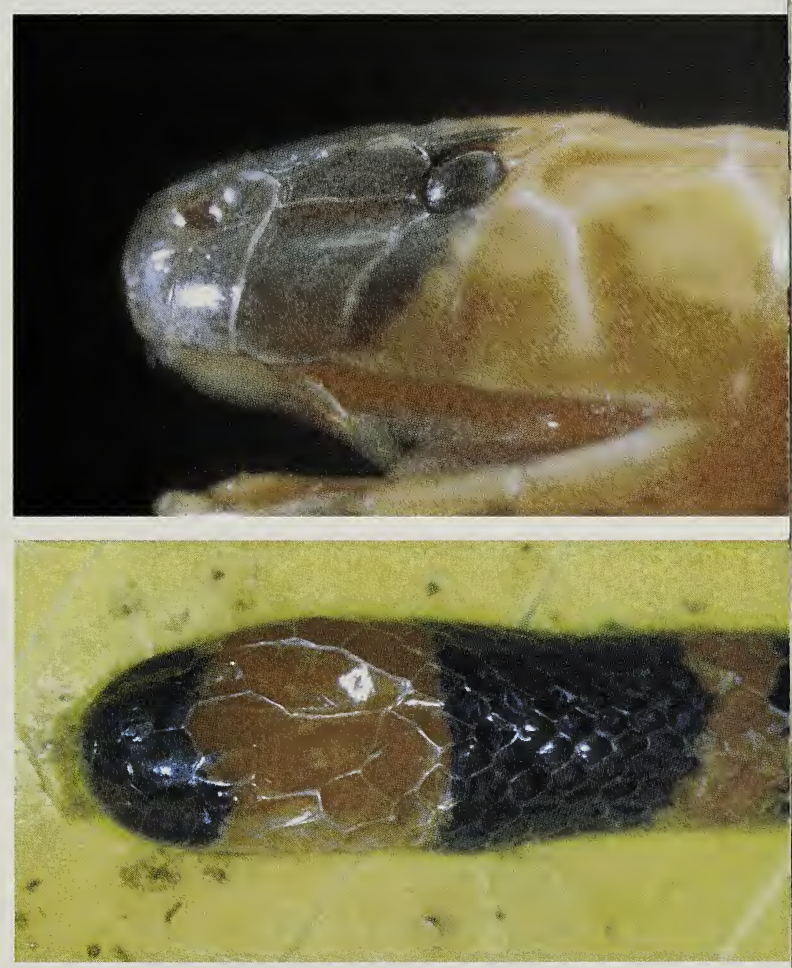

Arriba: Vista lateral de la cabeza de las "corales" o Micrurus. Observese el pequeño colmillo fijo en la parte anterior de la mandíbula superior. Foto: M. Guerra.

Abajo: Vista dorsal de la cabeza de la "coral" - Micrurus. No hay una diferencia clara entre la cabeza y el cuello. La punta de la cabeza de las "corales" es redondeada y sus ojos son muy pequeños. Foto: M. Guerra. 


\section{Jessica Eberhard}

\section{Biología y \\ conservación de \\ Ios loros, pericos \\ y guacamayos \\ de Panamá}


D ebido a su àtractivo plumaje, su carismática habilidad para imitar la voz humana y su innata sociabilidad, los loros han llamado la atención del hombre durante siglos. Desde la Antigua Grecia, el hombre los ha tenido como mascotas, y Cristóbal Colón regresó a Europa de su primer viaje al Nuevo Mundo con loros cubanos. En América, los indígenas cazaban loros para comerlos, utilizaban sus plumas para elaborar trajes ceremoniales y en ocasiones los mantenían como mascotas. No obstante, sabemos muy poco sobre la historia natural de estas aves.

\section{Diversidad y distribución}

Todas las aves conocidas comúnmente como loros, pericos, cacatúas, cotorras, guacamayas, etc., pertenecen a la familia Psittacidae (orden Psittaciformes); parece ser un grupo muy antiguo, que probablemente ya existía como un grupo diferente de las otras aves en la época de los dinosaurios. Existen unas trescientas cuarenta especies en el mundo, y la mayoría prefiere vivir en los bosques tropicales. Algunas habitan las zonas de sabanas y áreas abiertas, y también se les encuentra en tierras altas, donde a veces cae nieve.

La familia de los loros puede dividirse en tres grupos: los loros de Australia y el Pacífico sur, los de Africa y Asia y los loros de América. En esta última región encontramos aproximadamente ciento cuarenta especies y veintidós de estas se pueden observar en Panamá.

Los bosques, manglares y potreros de Panamá albergan 22 especies de loros. Algunas como el Perico Barbinaranja (Brotogeris jugularis) y el Loro Cabeciazul (Pionus menstruus) son muy comunes y se pueden observar hasta en zonas urbanas. Otras especies, como la Guacamaya Roja (Ara macao), son más difíciles de observar. Se cree que esta especie estaba ampliamente distribuida por el país, pero ahora se encuentra solamente en la isla Coiba y en el remoto suroeste de la Península de Azuero. Los bosques húmedos del Darién sirven de hogar a varias guacamayas, mientras que el Perico Barreteado (Bolborhynchus lineola) y el Perico Aliamarillo
Página anterior: La casanga (Pionus menstruus) habita los bosques primarios y secundarios de las tierras bajas, desde Costa Rica hasta Brasil. Es uno de los pistacidos más comunes a Panamá. Foto: Jerry Bauer.

En las mañanas y en las tardes, es común ver bandadas de Amazona autumnalis que van y vienen de sus dormideros comunales. Dentro de los grupos, los loros vuelan de dos en dos, los miembros de la pareja "conversando" casi constantemente. Foto: Jerry Bauer.

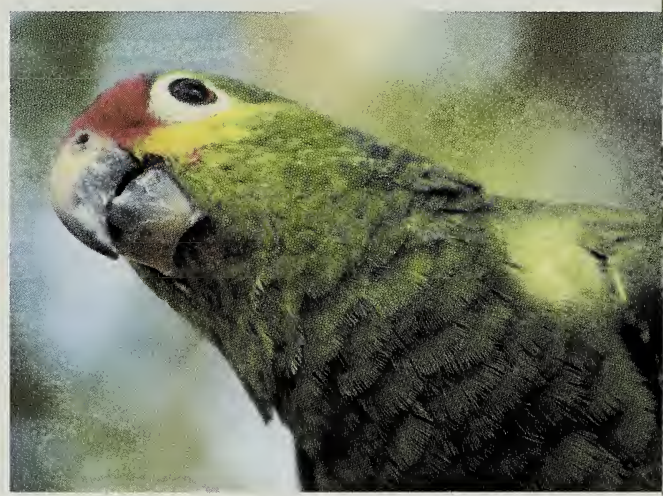

(Pyrrhura hoffmanni) se encuentran solamente en las tierras altas de Chiriquí y Bocas del Toro. El Amazona Coroniamarillo (Amazona ochrocephala) es una de las especies más cotizadas en el tráfico de mascotas, y sus poblaciones se ven severamente amenazadas por los cazadores que saquean sus nidos.

\section{Características y hábitat}

Los loros son fácilmente reconocibles por varias características distintivas. Tal vez la más obvia es su pico relativamente grande y robusto. La mandíbula superior es encorvada y cubre la inferior; adentro se encuentra una lengua muy hábil que parece un pequeño dedo, que les permite manipular delicadamente objetos que recogen con el pico. Comparados con otras aves, los loros tienen cuellos cortos y cabezas relativamente grandes y anchas. Sus patas tie- 


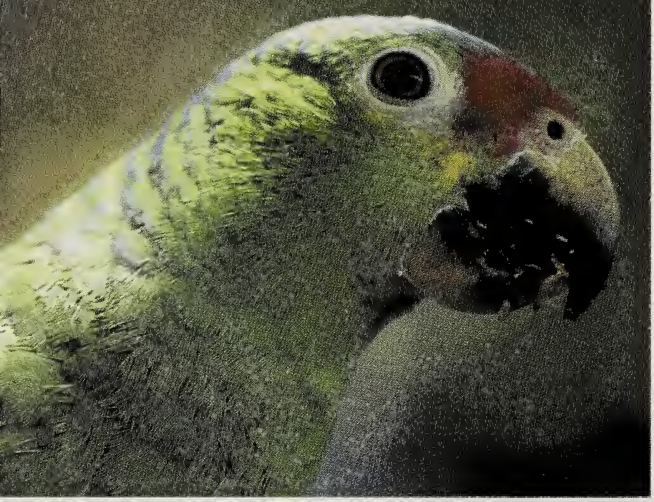

El loro flor roja (Amazona autumnalis) es relativamente común y ampliamente distribuído en las tierras bajas de Panamá. Foto: Jerry Bauer. acuerdos nacionales e internacionales para limitar este comercio, y en 1977 Panamá se adhirió a CITES (la Convención Internacional sobre el Tráfico de Especies en Peligro de Extinción), la cual regula el movimiento internacional de especies amenazadas.

En 1986, la ley panameña prohibió la caza, compra y venta y cualquier actividad comercial que involucrara la fauna silvestre (viva o muerta) del territorio nacional. Recientemente, la ANAM ha comenzado a implementar la regulación de programas de cría en cautiverio con fines comerciales, y los loros se encuentran entre las especies criadas de esta forma. Un objetivo de estos programas es el de suplir el mercado de mascotas sin tener que saquear nidos ni reducir las poblaciones silvestres de especies amenazadas.

La mejor opción para una persona interesada en tener un loro como mascota es comprar uno que haya sido criado en cautiverio.

Cualquier persona que haya tenido la oportunidad de observar loros en su hábitat natural, en el zoológico, o incluso que los haya conocido en cautiverio, se habrá dado cuenta que son animales excepcionalmente inteligentes, sociables y hermosos. Apenas estamos comenzando a estudiar y conocer su comportamiento, su vida social y sus interacciones con las plantas y animales de su medio. Merecen una vida en libertad bajo nuestra protección, y espero que nosotros, y nuestros hijos también, podamos seguir admirándolos en su medio natural.

Junto a la destrucción de su habitat, el tráfico de mascotas es la mayor amenaza a la superviviencia de los loros. Una de las especies más perseguidas para el mercado de animales silvestres en Panamá es el loro flor amarilla (Amazona ochrocephala). La extracción de pichones de sus nidos reduce la cantidad de juveniles que logra formar parte de las poblaciones silvestres, y puede resultar en poblaciones sin una generación joven. 


\section{EL AGUILA HARPIA Y SU CONSERVACIÓN EN PANAMÁ}

\section{Karla Aparicio}

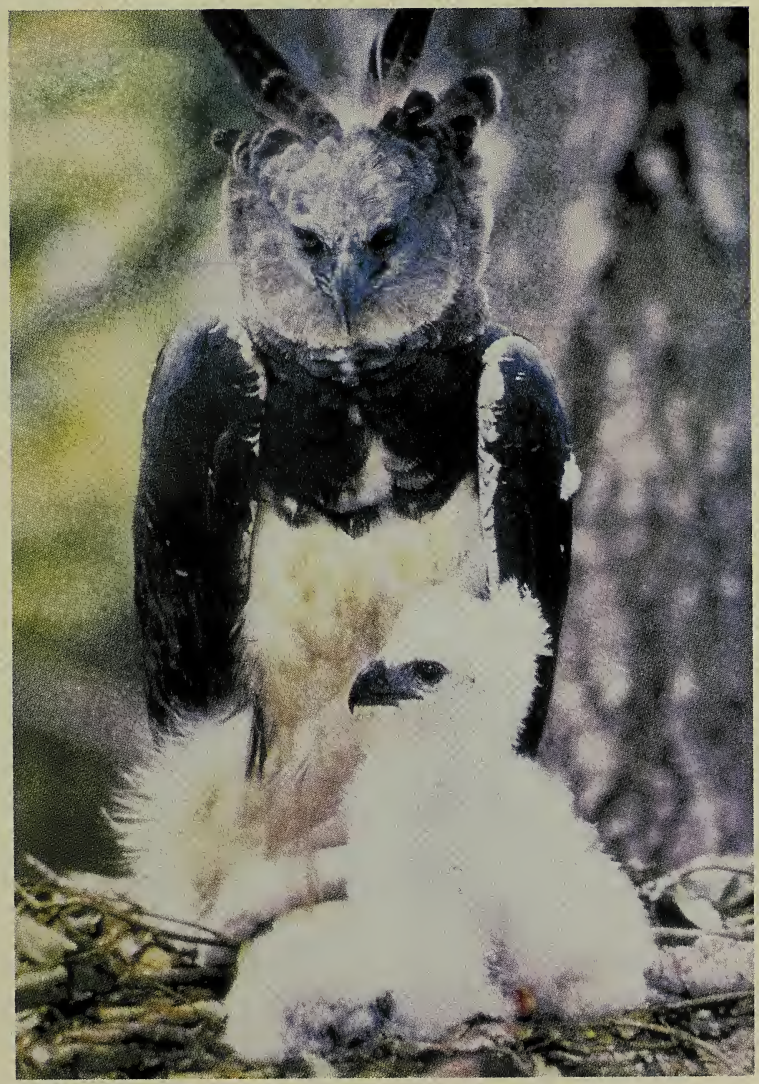

Aguila Harpía hembra cuidando a su pichón en el nido.

Foto: Neil Rettig. 
$\mathrm{E}$ 1 águila harpía (Harpia harpyja) es considerada una de las águilas más grandes del planeta. Habita los bosques del Nuevo Mundo desde el sur de México, Centroamérica y el Amazonas, hasta el norte de Argentina.

A pesar de ser considerada el ave nacional de Panamá, es poco lo que sabemos de esta magnífica especie.

Existen datos que confirman su existencia en el Pacífico y a lo largo del Caribe desde 1863 ; sin embargo, debido a la intensa deforestación, la especie ha desaparecido de la región pacífica, donde hoy casi no existen bosques. Actualmente, en Panamá sólo sabemos de su presencia en el Parque Nacional Chagres, ubicado en la parte central del país, en la Comarca Kuna Yala y en el Parque Nacional Darién, en el extremo este que colinda con Colombia. Se estima que también podría encontrarse en las extensas selvas húmedas de las tierras bajas y en estribaciones, entre 500 y 1200 metros sobre el nivel del mar, a lo largo de la vertiente del Caribe.

Según la Unión Internacional para la Conservación de la Naturaleza (UICN) esta especie está catalogada como de menor riesgo, es decir casi amenazada.

Pichón de pocos dás de nacido. Su cuerpo está cubierto por un suave plumón blanquecino. Foto: Kike Arnal.

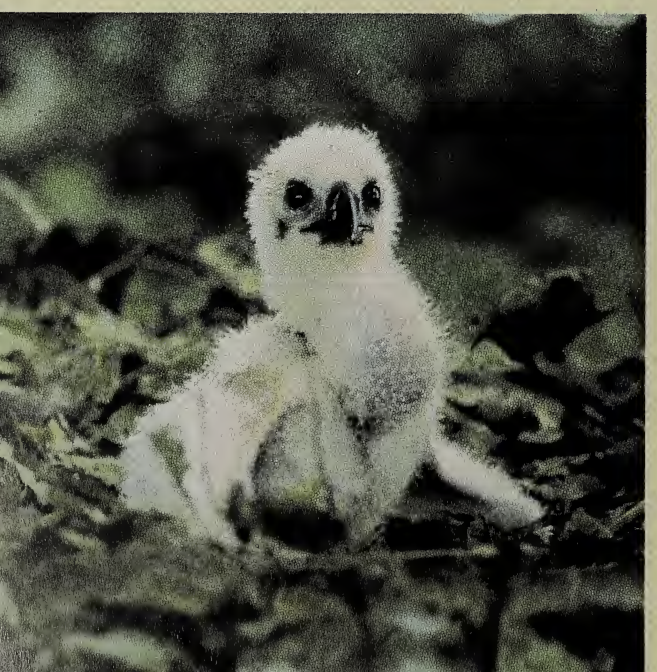

Por su parte, el Convenio sobre comercio internacional de especies amenazadas de fauna y flora silvestre (CITES) la incluye en el Apéndice I, identificándola como especie en peligro de extinción, debido al comercio. En Panamá también se le considera una especie en peligro de extinción.

\section{Características físicas}

Los polluelos recién nacidos son completamente blancos, y a medida que crecen las alas se tornan grises veteadas con negro; la cresta, cabeza, cuello y pecho continúan de color blanco. La cola tiene diez franjas blancas delgadas e irregulares. Un pichón deberá esperar hasta cuatro años para adquirir el plumaje adulto.

Los adultos se caracterizan por su cresta negra terminada en dos puntas, cabeza y cuello grises, pecho negro, abdomen blanco, muslos con franjas negras. Viéndola desde la parte posterior, las alas y la cola también son negras, mientras que la cola, vista desde el frente, presenta tres franjas blancas intercaladas con tres franjas negras. Al volar, sus alas son anchas y redondeadas, con plumas que terminan a manera de dedos.

Como todas las aves rapaces, las hembras del águila harpía son más grandes que los machos. Una hembra adulta puede medir más de un metro de longitud de la cabeza a la cola y pesar 18 libras $(9.0 \mathrm{~kg})$, mientras que un macho adulto puede medir cerca de un metro y pesar 11 libras $(5.0 \mathrm{~kg})$. Este es el caso de "Chagres", un macho adulto que estudiamos en el río San Juan de Pequení, que desagua en el lago Alhajuela. La envergadura de estas aves, es decir la extensión de las alas de punta a punta, oscila entre 1.83 y $2.24 \mathrm{~m}$.

Los adultos del águila harpía son difíciles de confundir con cualquier otra ave, pero sus juveniles tienden a parecerse al águila crestada (Morphus guianensis). Sin embargo esta última es de menor tamaño (entre 0.79 a $0.89 \mathrm{~m}$ de longitud), posee una silueta delgada, pico menos fuerte, patas más delgadas y largas, además de que la cresta que adorna su cabeza termina en una sola punta y no en dos, como la de la harpía. 


\section{Alimentación}

El águila harpía se alimenta principalmente de mamíferos arbóreos, es decir que viven en los árboles, así como de otros animales y aves que atrapan. Podemos estimar la variedad de su dieta examinando los huesos de los residuos que encontramos en el nido y en la base o pata del árbol donde está el nido. Estos restos reciben el nombre de egagrópilas, unas bolitas formadas por pelos, uñas, dientes y huesos como cráneos, mandíbulas y costillas, es decir, las partes de las presas que las águilas no pueden digerir y que tiran al suelo.

El estudio de estos residuos nos permite establecer que la dieta de estas águilas se divide en las siguientes proporciones: poco más del $33 \%$ la constituyen perezosos de dos y tres dedos, un 33\% la forman diferentes especies de monos. Un $5 \%$ son aves y menos del $5 \%$ de su alimentación la constituyen las zarigueyas o zorras, puercoespines, ñeques y un mono nocturno llamado cusumbí.

\section{Reproducción}

Para construir el nido, la pareja busca árboles grandes que tienen una forma especial; en nuestras selvas prefieren el Cuipo (Cavanillesia platanifolia) y la Ceiba (Ceiba pentandra) o Bonga, ya que su tronco se abre en forma de $\mathrm{T}$ en enormes ramas hori-

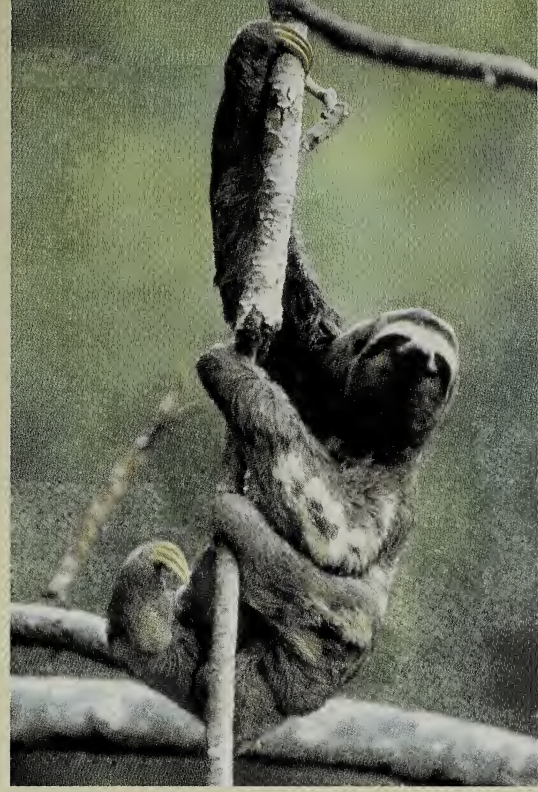

El perezoso de tres dedos es uno de los alimentos preferidos por las águilas harpías. Foto: Kike Arnal.

Al comer, las harpías arrojan los huesos fuera del nido. Aquí, huesos de diversos animales recogidos en la pata del tronco de un árbol que sirve de nido a una pareja de águilas y su pichón en el Parque Nacional Chagres. Las dos hileras superiores están compuestas de bolitas de pelos regurgitadas por las aves. Foto: Karla Aparicio.

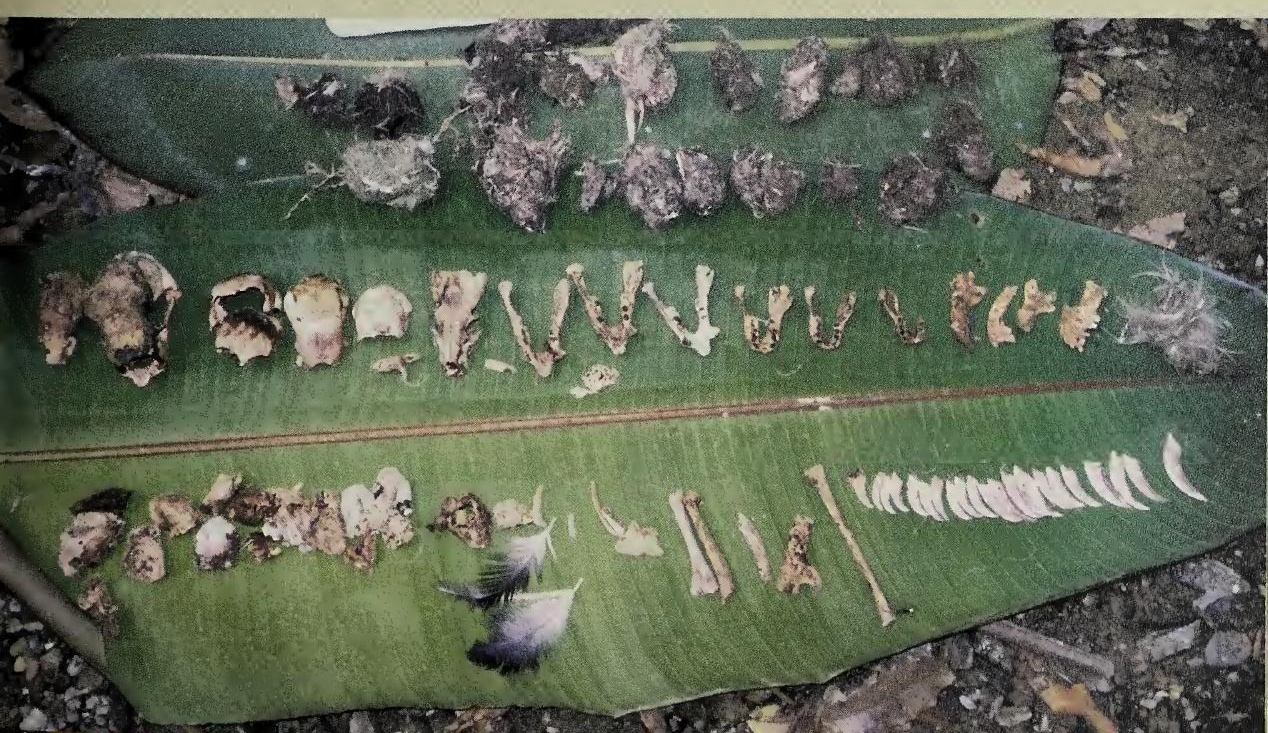


zontales, justo arriba de la copa, proporcionando así una excelente base para soportar el nido, además de permitirle al juvenil moverse, ejercitar sus alas y eventualmente practicar el vuelo.

Ambos adultos ayudan a construir el nido, que sitúan entre los 16 y 50 metros de altura. El nido mide generalmente un metro de ancho. En Panamá, un nido que fue utilizado en dos ocasiones por una misma pareja de águilas midió 1.70 por 1.90 metros.

El Aguila Harpía tiene uno de los ciclos reproductivos más largos para un ave. Pone de uno a dos huevos, aunque la mayor parte de las veces sólo uno sobrevive; el otro se rompe, se descompone y pasa a ser material del nido. El período de incubación dura alrededor de 55 días, durante los cuales el macho provee de alimento a la hembra. Luego de nacer el pichón, pasarán casi tres años para que la misma pareja pueda tener otra cría. Las harpías son aves de costumbres monógamas. Cuando se unen, una pareja de águilas adulta necesita de 10 a 63 kilómetros cuadrados de selva para desplazarse y encontrar su alimento.

Después de seis meses de nacidos, los juveniles estarán listos para volar. Primero vuelan distancias cortas, de una rama a otra del árbol nido, luego vuelan a los árboles más alejados, hasta 500 metros del

El árbol de Cuipo es el preferido por las águilas harpías para hacer sus nidos.

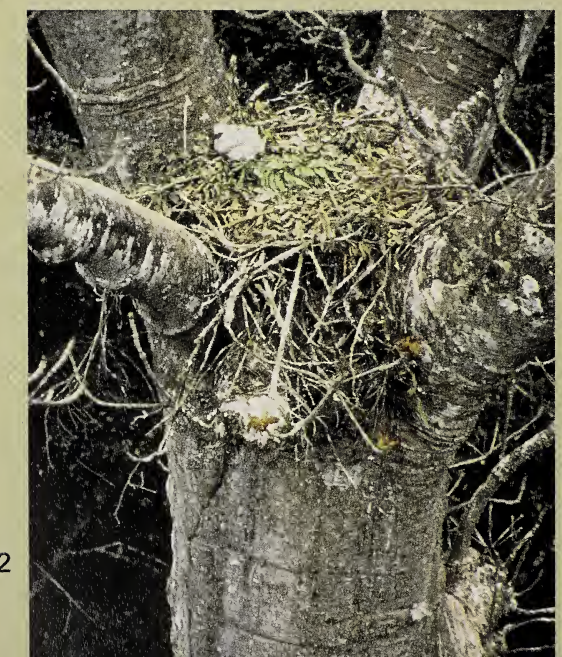

nido. Estos desplazamientos son siempre alrededor del nido, en espera a las atenciones de los padres. A los treinta meses de edad el águila joven obtiene su independencia.

\section{Participación comunitaria en el Parque Nacional Chagres}

En 1997, al inicio del Proyecto de Monitoreo de la Cuenca del Canal, confirmamos la existencia de dos nidos con pichones, uno en una quebrada del río Pequení, y otro en río Chico, afluente del Chagres, ambos dentro del Parque Nacional Chagres. Este parque de 135,000 hectáreas se caracteriza por su gran cantidad de bosques tropicales húmedos, un hábitat ideal para el águila harpía.

Desde el descubrimiento de los nidos, hemos trabajado arduamente en su protección y estudio, tratando de involucrar a las comunidades campesinas e indígenas vecinas con el objeto de educarles en la importancia de conservar la especie, darles a conocer su biología y convertirlos en asistentes de campo.

Desde junio de 1999, estas actividades se reforzaron a través del estudio Caracterización del hábitat de anidación del águila harpia en el Parque Nacional Chagres y distribución actual e histórica en Panamá.

Una hembra juvenil en su árbol nido, en el Parque Nacional Chagres. Foto: Karla Aparicio.

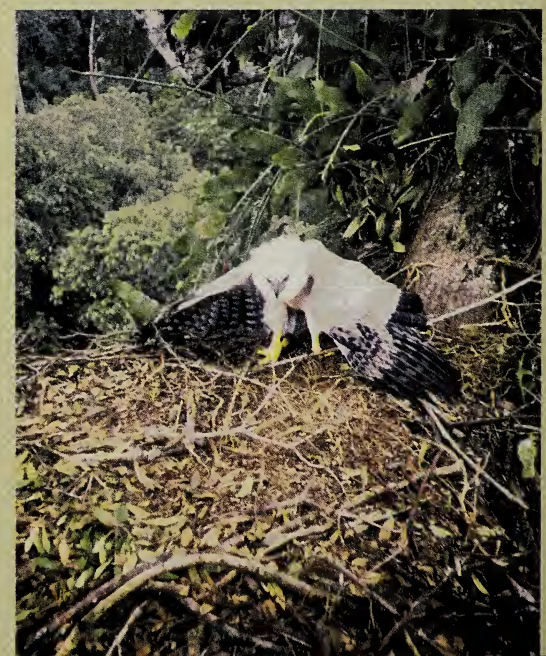


Este trabajo de maestría busca caracterizar el bosque en donde están los nidos y proporcionar recomendaciones para mejorar el manejo y la conservación de la especie.

El estudio incluyó una recopilación de los registros históricos del águila harpía en Panamá para todo el siglo XX, a fin de establecer su distribución. Para ello se utilizó el Sistema de Información Geográfica (SIG).

Esta fase de la investigación fue el punto de partida para determinar las áreas prioritarias y potenciales para la conservación e investigación de la especie.

La investigación social incluyó entrevistas a profundidad, encuestas y talleres participativos con las comunidades. Los talleres tuvieron dos objetivos: capacitar a personas del área como informantes claves y adquirir información sobre el conocimiento popular, la distribución actual e histórica y las amenazas que enfrenta la especie.

Luego el proyecto, apoyado por la Sociedad Audubon de Panamá incorporó a las comunidades del Parque Nacional Chagres como piezas fundamentales en la obtención de información biológica y cultural, involucrándolas como actores principales de la protección y conservación de la especie en esta zona.

Aspiramos a que el buen manejo de toda esta información sirva para sustentar un turismo naturalista que beneficie a estas comunidades pobres y estimule la investigación científica para asegurar la supervivencia de esta majestuosa ave.

\section{Esfuerzos de conservación de la especie en Panamá}

En 1992 se inició el Programa de Conservación del Aguila Harpía, con la participación activa del personal del Parque Nacional Darién y las comunidades campesinas e indígenas.

La fase educativa incluyó la publicación de un afiche, charlas y entrevistas con personas en la zona de amortiguamiento, en- contrándose ocho nidos con pichones en 1995.

La fase de investigación, apoyada por el Fondo Peregrino, consistió en colocar pequeños radiotransmisores en las aves, cuyas señales son captadas por satélite para determinar la localización del ave. Para detectar a las águilas en el bosque, los biólogos les colocaron pequeños radios convencionales del tipo VHF, que envían señales a un receptor.

En 1994 se instalaron estos radios convencionales a dos águilas juveniles en el Darién, y se demostró que ellas adquieren su independencia lentamente. Para el año 2000 se habían colocado radiotransmisores a otros dos juveniles y un adulto en el Parque Nacional Chagres.

A partir de 1997, el Fondo Peregrino y la Autoridad Nacional del Ambiente (ANAM) iniciaron la reintroducción en las selvas de Panamá de juveniles de águilas harpías criados en cautiverio, los cuales fueron liberados en el Parque Nacional Soberanía, a orillas del Canal y en el Monumento Natural Isla Barro Colorado.

Las patas de la harpía son fuertes. Un anillo metálico de identificación facilita su estudio en la selva. Foto: Kike Arnal.

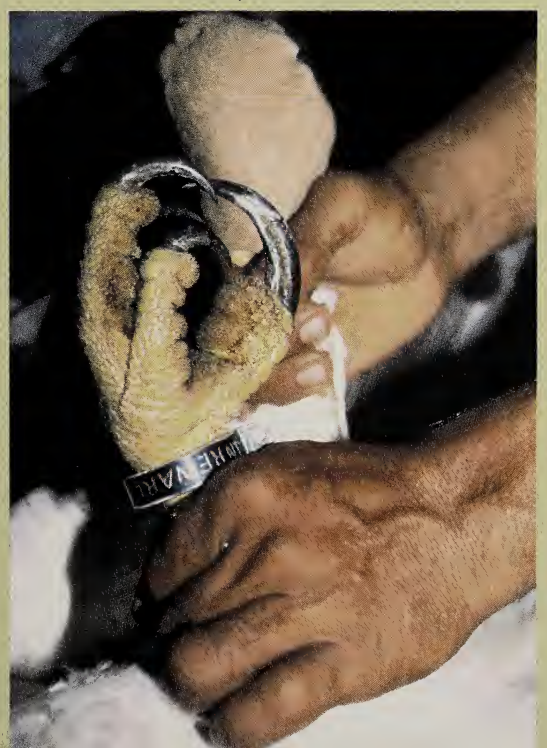




\section{Mito y \\ realidad \\ asombrosa \\ de los \\ murciélagos}

\section{Wibke Thies}

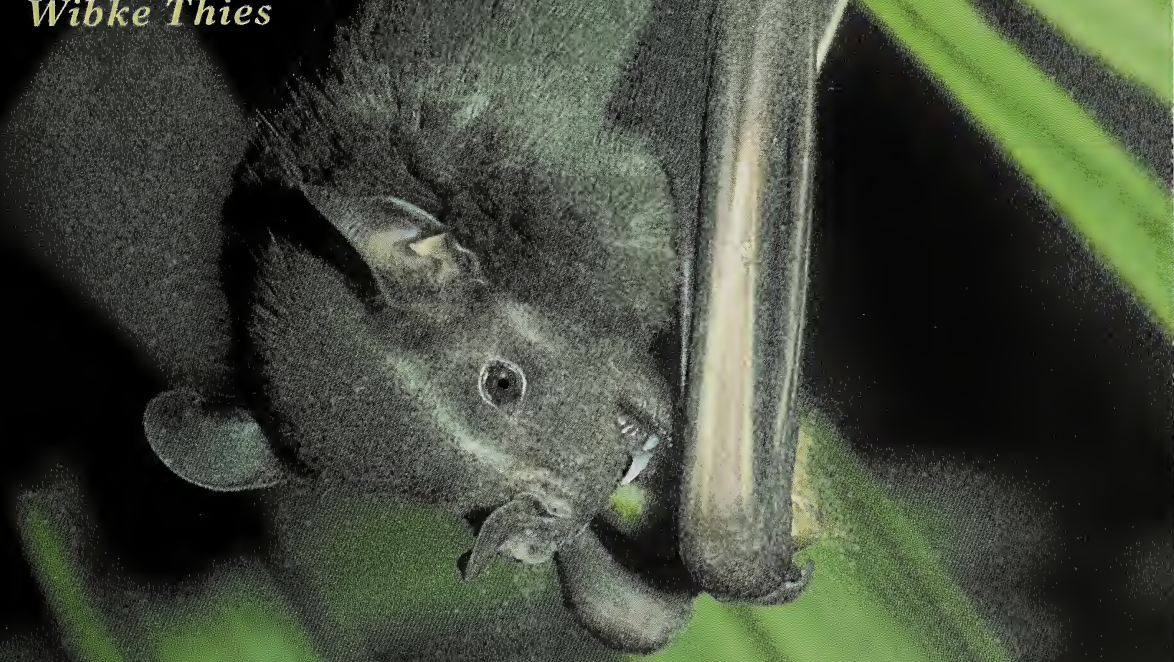

El murciélago frugívoro común (Artibeus jamaicensis) comiendo un higo guindado de la rama de una palma. Observe las rodillas orientadas hacia la espalda. El murciélago asegura el fruto con sus pulgares mientras lo muerde. Después de algún tiempo, las semillas que el murciélago tragó junto con la pulpa son depositadas y dispersas junto con los excrementos. 
L a mayoría de la gente considera al murciélago el animal' más asqueroso del mundo. Muchas veces se le asocia con la muerte, con criaturas diabólicas y malévolas, por ser un animal nocturno, que se mueve sin esfuerzo en la oscuridad; esto crea un sentimiento de miedo y desconfianza.

El murciélago también despierta curiosidad en el ser humano, una característica que ha desarrollado nuestra capacidad de comprensión y acción en el desarrollo de nuestra vida, por lo que quiero demostrar que los murciélagos son beneficiosos, que poseen una gran diversidad y un comportamiento extraordinario.

\section{Mitología}

La asociación más común que se hace de los murciélagos es con Drácula, personaje basado en un príncipe rumano que existió hace quinientos años, conocido por sus crueldades, tales como beber la sangre de sus enemigos para mostrar su poder. El murciélago vampiro se añadió a la leyenda cuando los españoles, al regresar del Nue-

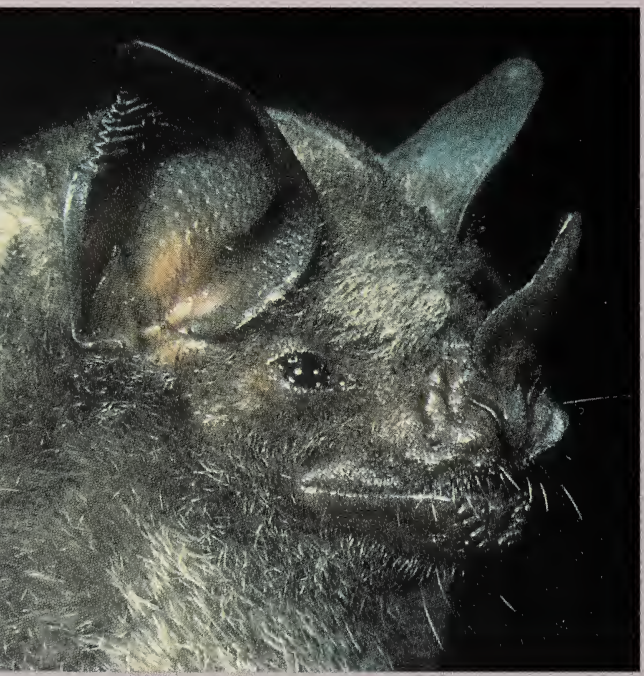

El murciélago frugívoro Carollia perspicillata, un representante de la familia de los filostomídeos (murciélagos con nariz en forma de hoja). vo Mundo, contaban historias sobre murcielagos que se alimentaban de la sangre de animales. Los Mayas vinculaban a los murciélagos con la oscuridad; Camazotz, representado por la figura de este animal, era su dios del mundo de la muerte. En la mitología griega eran animales sagrados para Persephone, la hija de Zeus y esposa de Hades, soberano del mundo de los muertos. Sin embargo, para otras culturas no son bichos malos. En la mitología china y para los gitanos de Europa son portadores de buena suerte y larga vida.

\section{Desarrollo y características}

El origen y la evolución de los murciélagos no están definidos con claridad, y se encuentran escasamente representados en muestras fósiles. Los fósiles más antiguos, pertenecientes a la época del Eoceno (60 millones de años atrás), fueron encontrados en los Estados Unidos y en el sur de Alemania; estos muestran murciélagos completamente evolucionados, pero no nos explican de dónde surgen sus antepasados. Se supone que los murciélagos provienen de pequeños animales que se alimentaban de insectos que habitaban en las copas de los árboles, lo que explicaría cómo llegaron a las alturas; estos animales trepaban, pero no podían volar. Tal vez poseían algo similar a una membrana con la cual podían planear para controlar el descenso. Dejándose caer de las ramas, extendían los brazos con membranas para aminorar la velocidad, lo cual es distinto a volar, para lo que se necesita agitar las alas.

Hoy día los murciélagos vuelan activamente, es decir, que pueden mantenerse en el aire volando, ya que poseen alas. Supuestamente la transición de vuelo planeado a vuelo activo ocurrió de setenta a cien millones de años atrás.

Los animales vertebrados han desarrollado alas en tres estadios de evolución: en los extintos Pterosauros de la época jurásica, en las aves y en los murciélagos. Estos últimos son los únicos mamíferos que han desarrollado el vuelo activo. A diferencia de las aves, estos tienen los dedos de las manos alargados y entre ellos se extiende una membrana muy flexible. 
Otra característica es su forma de descansar con la cabeza hacia abajo. Una consecuencia de la adaptación a la vida en vuelo fue que sus piernas perdieron la capacidad locomotora. Esto no significa que los murciélagos no pueden moverse en el suelo, sino que las piernas no pueden cargar su peso, lo que les impide descansar boca arriba como las aves; éstas aguantan el pe. so del cuerpo cuando están sentadas en las ramas. Las rodillas de los murciélagos están orientadas hacia atrás, y los huesos de sus piernas son largos y finos, comparados al tamaño del cuerpo. Sin embargo, sus huesos son muy útiles para aguantar la tensión de un peso colgado.

Las hembras tienen mamas y alimentan a los bebés las primeras semanas con su leche. Las crías no tienen pelo y desarrollan las alas con el tiempo, de modo que no pueden volar al principio y la madre tiene que cargar al pequeño cuando sale a buscar alimento.

\section{Mil especies de murciélagos}

Existen casi mil especies diferentes de murciélagos en el mundo, divididas en dieciocho familias. De estas, cinco son endémicas para América Latina, es decir, que solamente existen en este continente. En esta región, los murciélagos constituyen el mayor grupo de mamíferos. En Panamá se han encontrado unas ciento veinte especies diferentes de murciélagos; la familia de los filostomídeos, los murciélagos con nariz en forma de hoja, forman el grupo más grande. En la pequeña isla Barro Colorado, de 16 kilómetros cuadrados, hay setenta especies conocidas. En toda Europa tan solo se dan treinta especies diferentes de murciélagos; esta discrepancia es enorme, una particularidad más que hace a los bosques tropicales tan especiales y preciosos.

\section{¿Dónde viven?}

La gran variedad de murciélagos del neotrópico o del Nuevo Mundo vive en hábitats muy distintos. Sus lugares de descanso son muy diversos: los conocemos como vecinos de nuestras casas, donde viven bajo el techo o acomodados en las paredes, pero para ellos este es sólo un sitio donde pasar el día.

Muchos murciélagos del bosque viven en los huecos de los árboles, donde forman pequeñas colonias. Muchas veces se pueden encontrar diferentes especies en el mismo árbol. La especie Tonatia silvicola piensa que los huecos en los nidos del comején son buenas casas. Nuevos estudios muestran que son los mismos murciélagos los que hacen los huecos en los nidos vivos, conviviendo tranquilamente con los comejenes sin que uno moleste al otro. Sin embargo, cuando estos desocupan los nidos, los comejenes cierran rápidamente el hueco hecho por los murciélagos.

Los individuos de las especies Artibeus watsoni, Vampyressa pusilla, Ectophylla alba o Uroderma bilobatum, de la familia de los filostomídeos, construyen sus propias casas. Aprendieron a cortar las venas de las hojas de las palmas y de los tallos de guineo como protección contra la lluvia y los predadores. Allí viven grupos pequeños por algunas semanas hasta que las hojas se sequen y necesiten hacer una casa nueva.

La casa refugio del murciélago insectívoro Tonatia silvicola es un hueco hecho en nidos de comején. En esta foto hecha desde abajo, se pueden contar alrededor de ocho individuos (cuente las orejas).

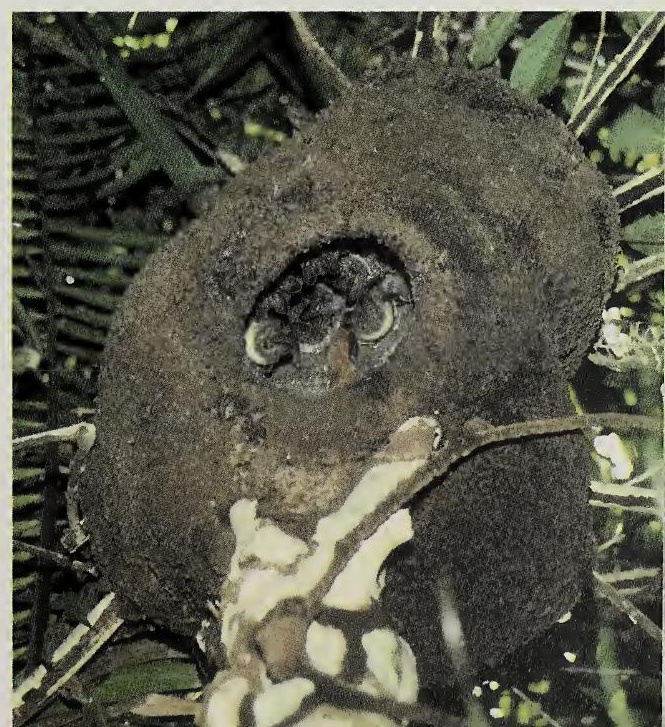


mente en América Latina. Entre estas tres especies, solamente una, Desmodus rotundus o vampiro común, se alimenta de la sangre de mamíferos. Esto quiere decir que entre las ciento veinte especies que viven en Panamá y que se alimentan de insectos, néctar y frutos, existe sólo una por la cual todas las otras especies son odiadas, perseguidas y asesinadas.

Puede ser que la idea de que existe un animal que se alimenta de sangre sea repugnante (no es el único, si tomamos en cuenta a los mosquitos, los chinches y hasta un pájaro en las islas Galápagos), pero en realidad el murciélago vampiro es un animal interesante. Su comportamiento social es casi único entre los animales, incluyendo al hombre. Si un vampiro no consigue encontrar comida en la noche y corre el riesgo de morirse de hambre, sus compañeros lo alimentan regurgitando algo de la sangre que ellos bebieron antes. Ellos son de los pocos animales que adoptan huérfanos y cuidan individuos viejos y enfermos que no son parientes. ¿Se puede decir algo tan "humano" de nosotros?

Los vampiros no atacan brutalmente a sus víctimas, sino que se acercan cuidadosamente a los individuos dormidos caminando en el suelo. Antes de hacer un pequeño corte de 1 a 3 milímetros en la piel, lamen el área por mucho tiempo. Su saliva tiene un narcótico, de manera que la presa no siente el corte. El vampiro no chupa la sangre, sino que la lame con su lengua. Para que la herida no se cierre de una vez, la saliva del vampiro tiene un anticoagulante.

¿Cuánta sangre toma un vampiro de noche? La cantidad que necesita para sobrevivir hasta tres días cabe en dos cucharas, de 20 a 30 mililitros, una porción pequeña. Por tanto, el problema no es que el vampiro se alimenta de sangre, sino que puede transmitir enfermedades, especialmente la rabia, una enfermedad peligrosa, que casi siempre causa la muerte.

Esta figura muestra cómo los científicos se imaginan la evolución del ala de los murciélagos:

(A) La evolución comenzó con un pequeño mamífero insectívoro arbóreo, que tenía una incipiente membrana de piel para planear durante las caídas; en esta etapa la membrana se extiende entre los dedos cortos y el cuerpo, y es aún peluda como el resto de la piel. (B-D) El desarrollo gradual de dedos prolongados aumenta la superficie de la membrana, lo que hace posible el vuelo activo, y mantenerse en el aire por su propia fuerza.

(E) El ala, tal como se le encuentra en un murciélago actual, una membrana fina, sin pelos y con dedos muy largos, del mismo tamaño del cuerpo.
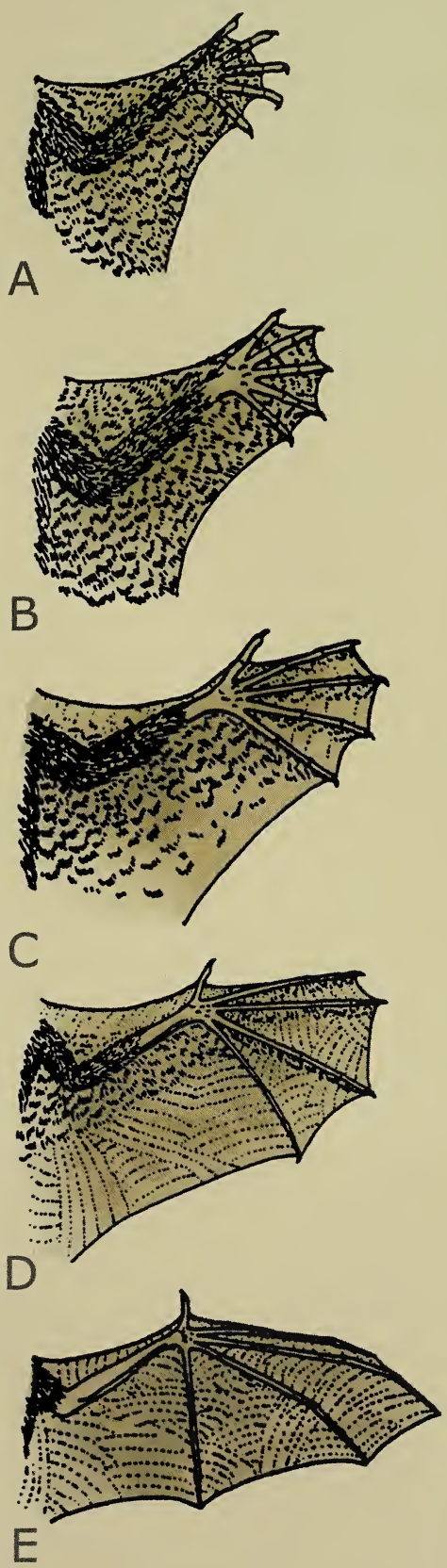


\section{CAPITULO 5}

\section{LA BÚSQUEDA DE ALTERNATIVAS}

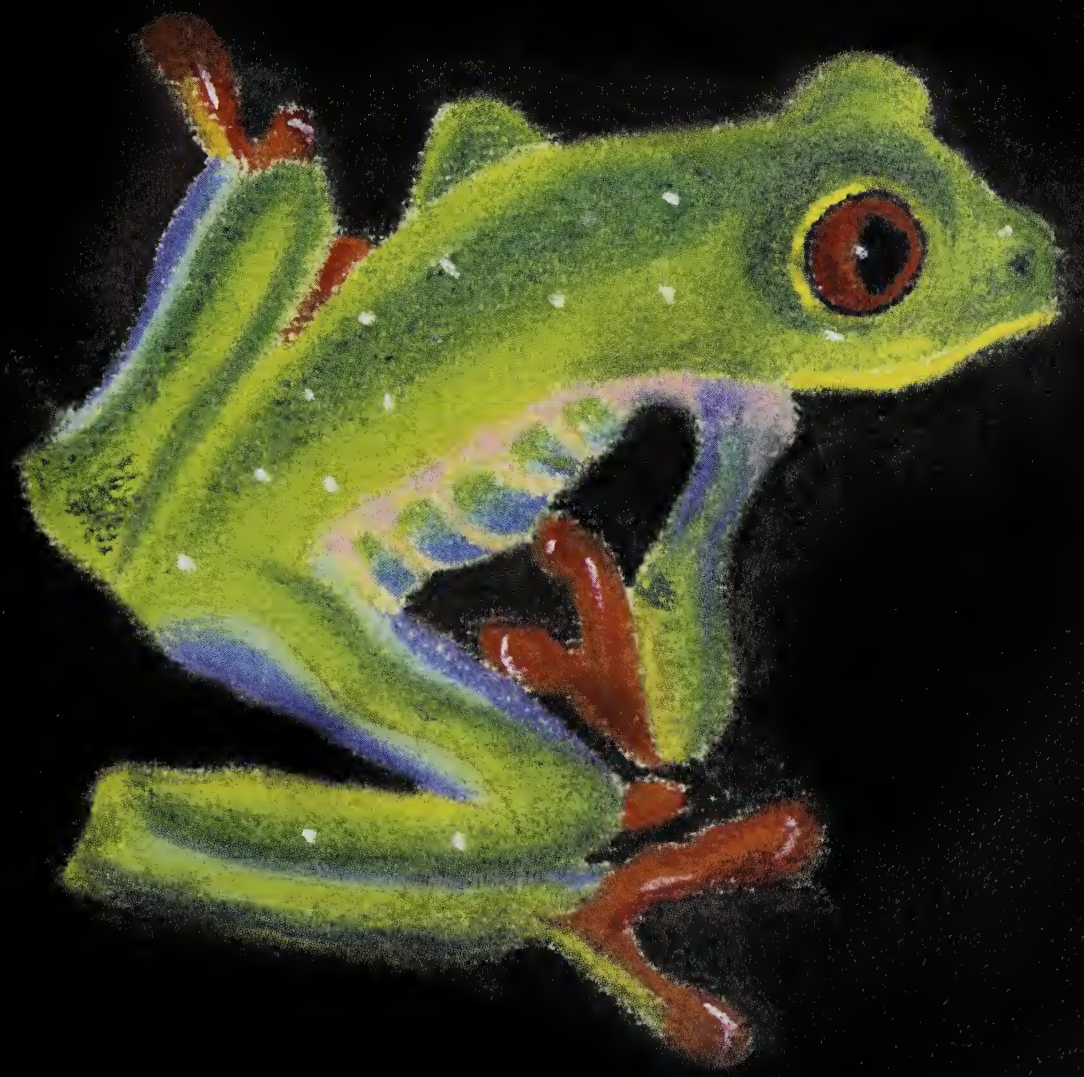

Ilustración: Melva Olmos 


\section{La búsqueda de medioamentos on el bosque Iropical panameño}

\section{Todd Capson}

Phyllobates

terribilis, una ranita endémica a Colombia, es la más venenosa en el mundo. Probablemente su brillante color sirve como señal de advertencia a sus enemigos. 
$\mathrm{U}$ na de las tareas más fascinantes para los científicos de hoy es la búsqueda de medicamentos nuevos en las selvas tropicales. En este artículo hablaremos de la importancia de la biodiversidad como fuente de medicamentos para la humanidad, así como de la necesidad de establecer incentivos para proteger la gran riqueza biológica de Panamá.

Hoy en día, la mayoría de los medicamentos se derivan de sustancias extraídas de plantas, hongos, animales, bacterias y organismos marinos.

De los ciento cincuenta productos farmacéuticos más prescritos en los Estados Unidos en 1993, el $57 \%$ contenía al menos un compuesto derivado, directa o indirectamente, de fuentes biológicas.

Dos ejemplos de medicamentos utilizados para tratar el cáncer son el Vincristine y el Vinblastine, extraídos ambos de la planta Catharanthus roseus, usados frecuentemente desde los años sesenta. Otro ejemplo es el Taxol, proveniente del árbol Taxus brevifolius; actualmente es el remedio más efectivo contra el cáncer de los senos y ovarios. Antes de descubrirse sus propiedades, este árbol se descartaba como inútil en la extracción de madera de los bosques norteamericanos.

Tales medicamentos son muestras representativas de la diversidad y complejidad química de las plantas, cuyas estructuras moleculares son muy difíciles de reproducir artificialmente.

Otra razón de peso para promover el estudio de medicamentos provenientes de los bosques tropicales es la urgente necesidad de establecer incentivos novedosos para salvar los bosques. Actualmente, la acelerada deforestación significa la pérdida irremplazable de medicamentos para el futuro. Para el año 2050, de continuar la destrucción de los bosques con la misma intensidad de hoy, habremos perdido la mayoría de los bosques tropicales.

Como puente entre la flora de norte y Suramérica y por sus muy variadas regiones, la flora de Panamá es una de las más diversås del mundo. Su enorme riqueza tiene gran potencial como fuente de medicamentos nuevos. Más del $42 \%$ de su territorio está cubierto de bosques, muchos de ellos se encuentran amenazados.

\section{El sistema tradicional de buscar medicamentos en el trópico}

Por muchos años los países tropicales exportaron plantas como materia prima a las universidades o a las industrias farmacéuticas de los países industrializados, donde se llevaban a cabo las investigaciones necesarias para desarrollar medicamentos nuevos. Este sistema era poco justo, pues el país exportador casi no recibía beneficios económicos, ni tampoco incentivaba la protección de la biodiversidad, fuente de la materia prima.

Afortunadamente, hoy están surgiendo modelos más justos en la relación entre los países ricos e industrializados (pero más pobres en biodiversidad) y los países en vías de desarrollo, pero biológicamente ricos.

\section{Un nuevo modelo en la búsqueda de medicamentos}

Hoy se reconocen internacionalmente los derechos soberanos de los Estados sobre sus propios recursos biológicos, concepto incorporado en la Convención de las Naciones Unidas sobre la Diversidad Biológica, el 5 de junio de 1992 y ratificado por Panamá en enero de 1995.

La nueva relación busca una colaboración más estrecha entre las instituciones científicas de los países tropicales anfitriones y los industrializados, con beneficios y ventajas para ambos participantes. De esta forma el país anfitrión tendría la oportunidad de recibir tecnología nueva, capacitar estudiantes y desarrollar su infraestructura científica, creando una base sólida para este tipo de investigación y para la ciencia básica en general.

\section{Los estudios ecológicos como guías} en la búsqueda de medicamentos

Para obtener éxito en un proyecto de esta naturaleza, es necesario contar con una estrategia que indique hacia dónde debe diri- 
girse la búsqueda de material biológico.

Las investigaciones básicas realizadas por el Instituto Smithsonian de Investigaciones Tropicales (STRI) sobre la ecología tropical han sido claves para nuestros propósitos. El STRI ha funcionado en Panamá por más de 75 años como un centro de categoría mundial de estudios sobre la ecología y biología tropical; la información brindada por STRI nos ha permitido seleccionar plantas con mayor potencial para medicamentos. Los doctores Phyllis Coley y Thomas Kursar han estudiado por más de 20 años la defensa de las plantas contra los animales e insectos que se las comen. Sus estudios han revelado que las hojas jóvenes, con mayor concentración de nutrientes y usualmente más tiernas, y por tanto más apetecidas por sus depredadores, han desarrollado defensas de todo tipo; entre ellas defensas químicas que

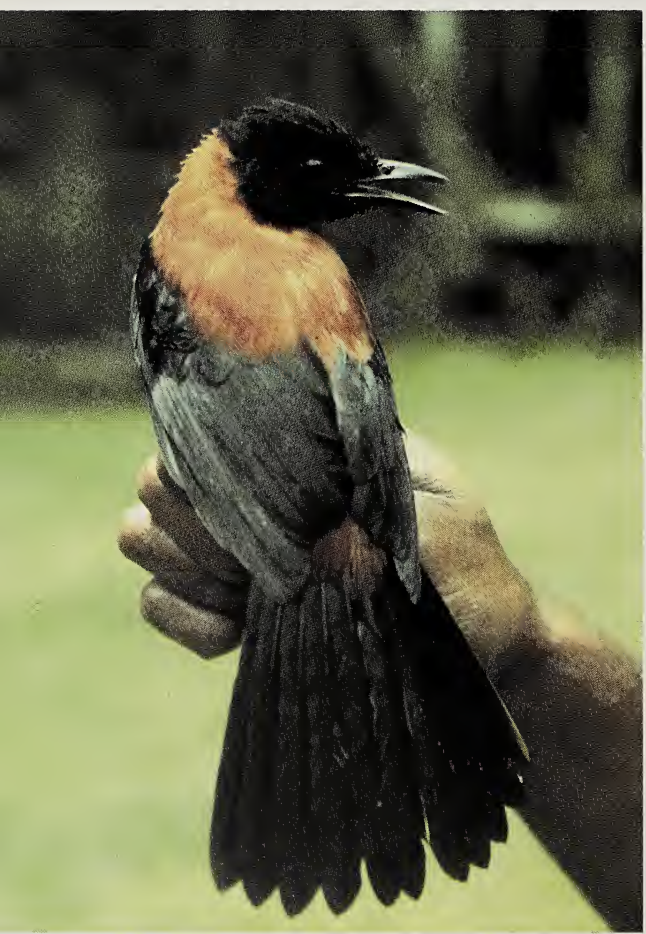

El Pitohui, especie endemica a la Nueva Guinea y cuyo veneno es igual a la ranita Phyllobates terribilis. pueden tener efecto contra las enfermedades humanas.

Animales, insectos, plantas y medicinas nuevas

Existen numerosos ejemplos de estudios ecológicos que señalan la presencia de compuestos con propiedades útiles para la humanidad. Un caso clásico lo encontramos en el veneno homobatrachotoxin, que se halla en las plumas de un pájaro de Nueva Guinea llamado Pitohui y en la piel de una rana colombiana, la especie Phyllobates terribilis. Se presume que este veneno sirve para disuadir a sus depredadores y su efecto es muy potente y de alto valor científico para los estudios bioquímicos.

Varias observaciones indican que este veneno proviene de la dieta de ambos animales, cuya fuente original es una planta.

Es interesante señalar que cuando una hembra y un macho de esta venenosa rana Phyllobates, son trasladados fuera de su hábitat natural para ser reproducidos en cautiverio, sus crías ya no portan el veneno, posiblemente porque ya no tienen acceso a la fuente del tóxico.

Probablemente el veneno se transmite a través de un vector, un insecto, que ha comido la planta que contiene el veneno homobatrachotoxin. Así, la cadena empieza con una planta venenosa, luego sigue un insecto que se come la planta y este sirve posteriormente de alimento a los pájaros y las ranas. Este caso demuestra la necesidad de conservar los ecosistemas, pues en ellos se sucitan estas interacciones entre las especies, produciéndose así compuestos beneficiosos para la humanidad.

Un programa novedoso que une la búsqueda de medicamentos en el bosque tropical y la conservación de la biodiversidad

Hace unos cuatro años empezamos a armar un programa para esta búsqueda vinculando a instituciones del gobierno panameño, la comunidad universitaria, institutos de investigación científica y organizaciones ambientales no gubernamentales. Esta investi- 
gación es un esfuerzo conjunto entre el Instituto Smithsonian de Investigaciones Tropicales, la Universidad de Panamá y el Instituto Conmemorativo Gorgas de Estudios de la Salud, ANAM y la Fundación Natura.

Naturalmente, un proyecto tan ambicioso y novedoso requiere de fondos. Afortunadamente, existe un programa del Instituto $\mathrm{Na}$ cional de Salud de los Estados Unidos (NIH por sus siglas en inglés) que apoya la búsqueda de medicamentos nuevos y simultáneamente conserva la biodiversidad y promueve el desarrollo sostenible.

Esta organización patrocina nuestro programa local, conocido como Grupos Internacionales Cooperativos de la Biodiversidad (por sus siglas en inglés, ICBG). En el programa ICBG participan treinta y tres científicos y estudiantes panameños de la Universidad de Panamá, el Instituto Gorgas y el Instituto Smithsonian, y cada institución tiene un papel distinto e importante en el proyecto.

\section{STRI}

El STRI provee una masa crítica de investigadores así como una incomparable información científica sobre la ecología y biología del bosque tropical, obtenida gradualmente durante las últimas ocho décadas. Esta fuente de datos básicos sobre las plantas del bosque es un instrumento fundamental para guiar nuestro estudio. Ejemplo de ello es el caso ya citado de los estudios de los doctores Kursar y Coley que muestran que las hojas jóvenes de las plantas tienen más sustancias químicas con potencial medicinal que las hojas viejas.

STRI aporta también su avanzada infraestructura de investigación con sus modernos laboratorios y su biblioteca especializada.

El proceso empieza en el bosque cuando los botánicos del STRI colectan y clasifican plantas. Una vez colectadas, se hacen extractos alcohólicos de las hojas que se suministran a las instituciones panameñas colaboradoras. Todos los botánicos de campo que trabajan en el ICBG son egresados de la Universidad de Panamá, donde estudiaron con la profesora Mireya Correa, Investigado- ra Permanente de STRI y Directora del Herbario Nacional.

\section{Universidad de Panamá}

Las facultades de Farmacia, Medicina, Ciencias Naturales y Exactas, y Tecnología de la Universidad de Panamá, participan en el proyecto.

En la Facultad de Farmacia, bajo la dirección del Dr. Mahabir P. Gupta, se llevan a cabo bioensayos que detectan actividad contra el cáncer de los senos, del pulmón y del sistema nervioso central. Debido a que los extractos de las plantas son una mezcla de muchos compuestos químicos, a veces hasta de docenas, no es fácil purificar el compuesto que puede ser efectivo contra una enferme-

Rafael Aizpurúa y Blanca Araúz recolectando hojas tiernas de plantas en Barro Colorado.

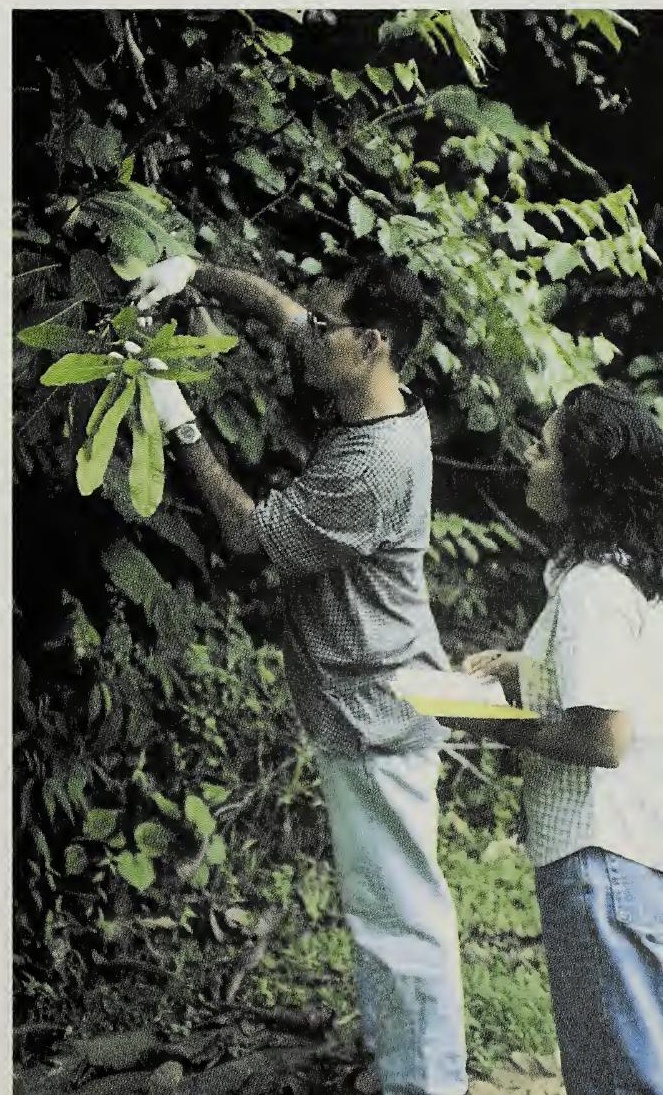


dad. Esta purificación de compuestos se realiza en el laboratorio del Dr. Gupta; en esta etapa participa también el Dr. Luis Cubilla de la Escuela de Química.

En la Facultad de Medicina, en el Departamento de Microbiología bajo la dirección del profesor Basilio Gómez, se prueban extractos de plantas que puedan ser activas contra el SIDA. El virus VIH utilizado en este ensayo es una cepa especial, no infecciosa, desarrollada para aplicaciones como la nuestra. Las células y otros componentes del virus utilizados para el ensayo fueron donados por el Instituto Nacional del Cáncer de los Estados Unidos, el cual envió expertos a Panamá para preparar a los científicos panameños sobre el manejo de estos componentes.

\section{Instituto Conmemorativo Gorgas de Estudios de la Salud}

El Instituto Gorgas busca medicamentos contra tres enfermedades tropicales predominantes mundialmente: la malaria, el mal de Chagas y la leishmaniasis.

Este programa está dirigido por el Dr. Eduardo Ortega-Barría, apoyado por la Dra. Luz Romero, médica parasitóloga, experta en la leishmaniasis.

Inicialmente, el ensayo para descubrir actividad contra la malaria se manejó a través de colaboraciones entre el Instituto Gorgas, el Walter Reed Army Institute of Research y la Universidad de California en San Fran. cisco. Estas dos últimas instituciones de los Estados Unidos cuentan con programas dedicados a descubrir medicamentos nuevos contra la malaria. Gracias a estas relaciones, científicos del Gorgas se han capacitado en las técnicas del ensayo y cultivo del parásito de la malaria. Actualmente, los equipos para realizar estos bioensayos se están estableciendo en el Instituto Gorgas.

\section{ANAM y Fundación Natura}

Una meta fundamental del ICBG es vincular todo este programa de investigación científica con la conservación de la biodiversidad; para ello es vital la colaboración de la Autoridad Nacional del Ambiente (ANAM), entidad gubernamental que administra los recursos naturales del país.

Desde un principio se ha trabajado estrechamente con la ANAM en el diseño e implementación del programa ICBG. Los términos de esta colaboración se formalizaron en un acuerdo firmado por la ANAM y STRI en abril de 1999. De llegarse a descubrir a través del ICBG un medicamento que genere ingresos, una porción de ellos se invertirá en promover la conservación de la biodiversidad. Para ello, STRI y la Fundación Natura han desarrollado un fideicomiso ambiental especial que recibirá una porción de todos los ingresos. Natura será la administradora del fideicomiso para ser utilizado en proyectos que promuevan la conservación de la biodiversidad.

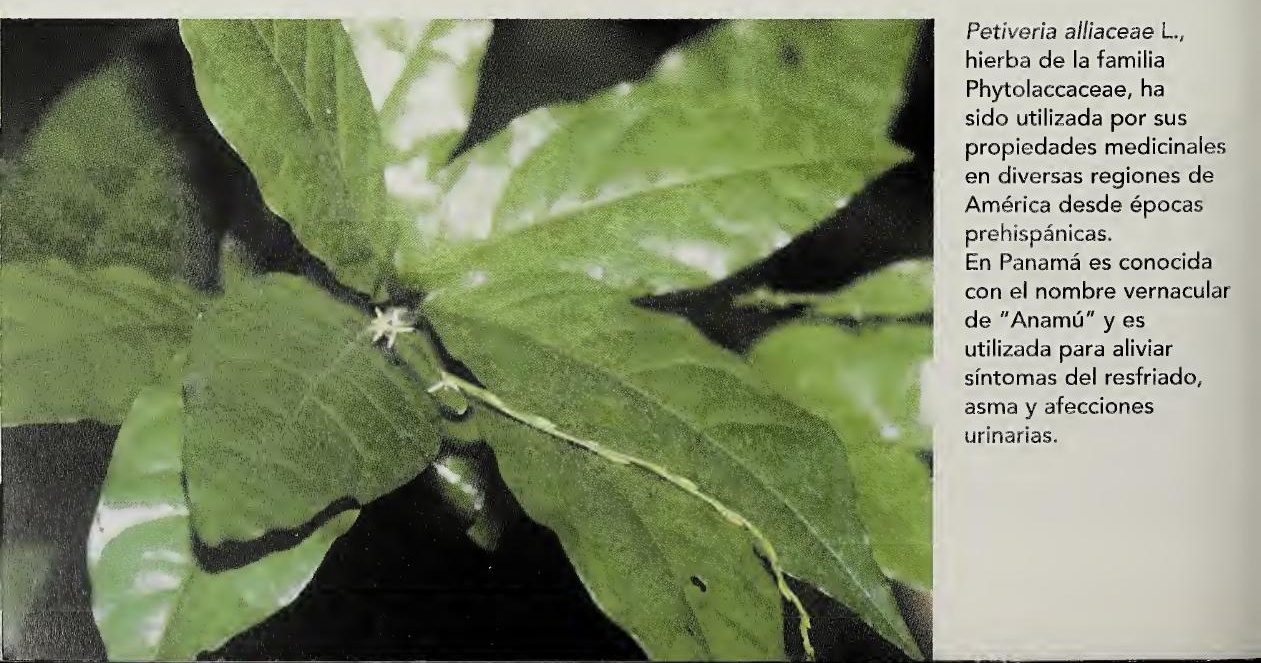




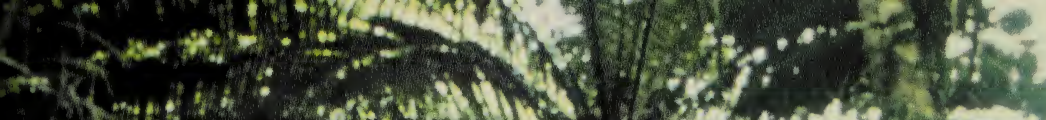
牙然 s. Sempit

\section{Julia Velásquez-Runk \\ y James Dalling}

- matre

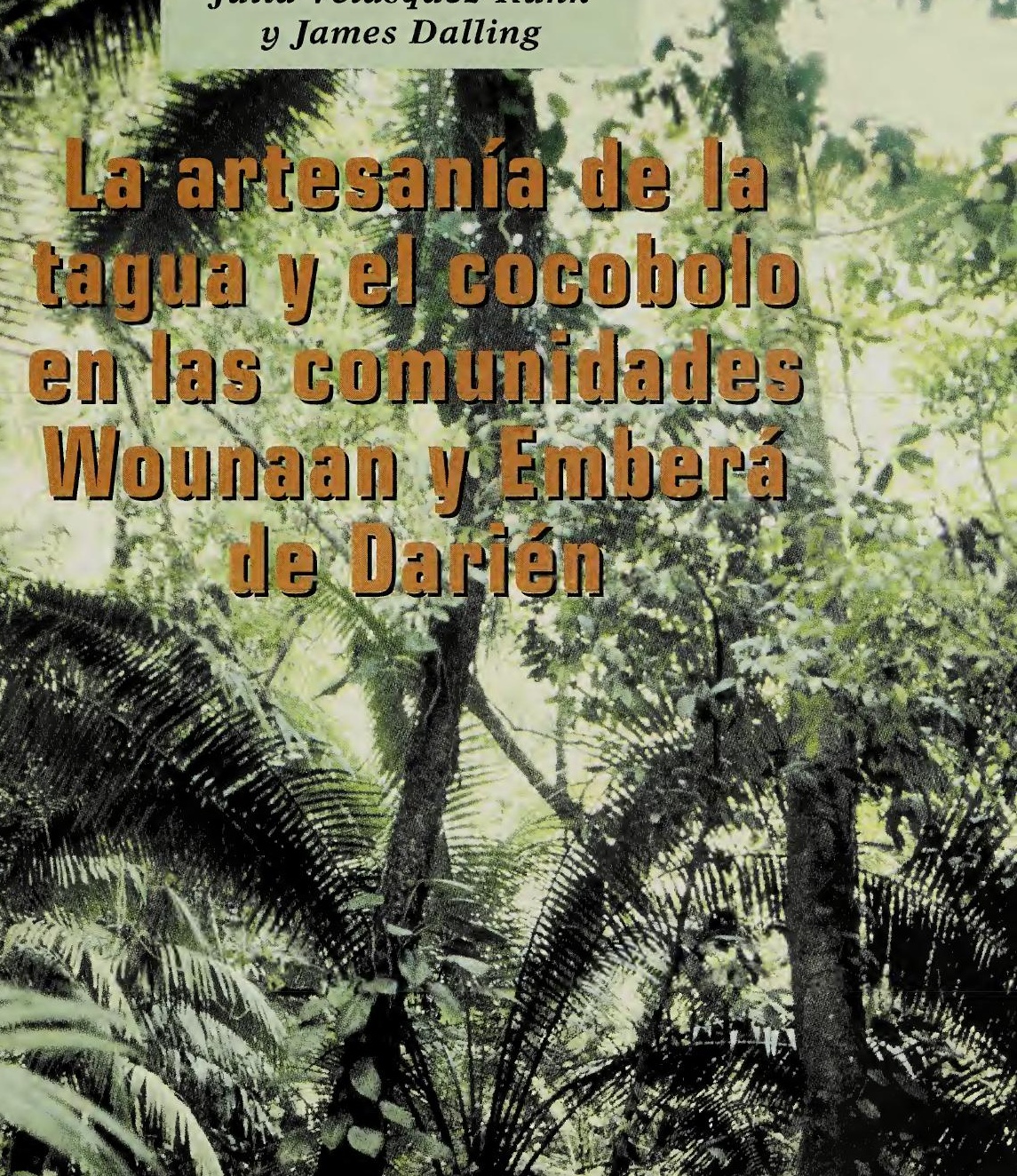

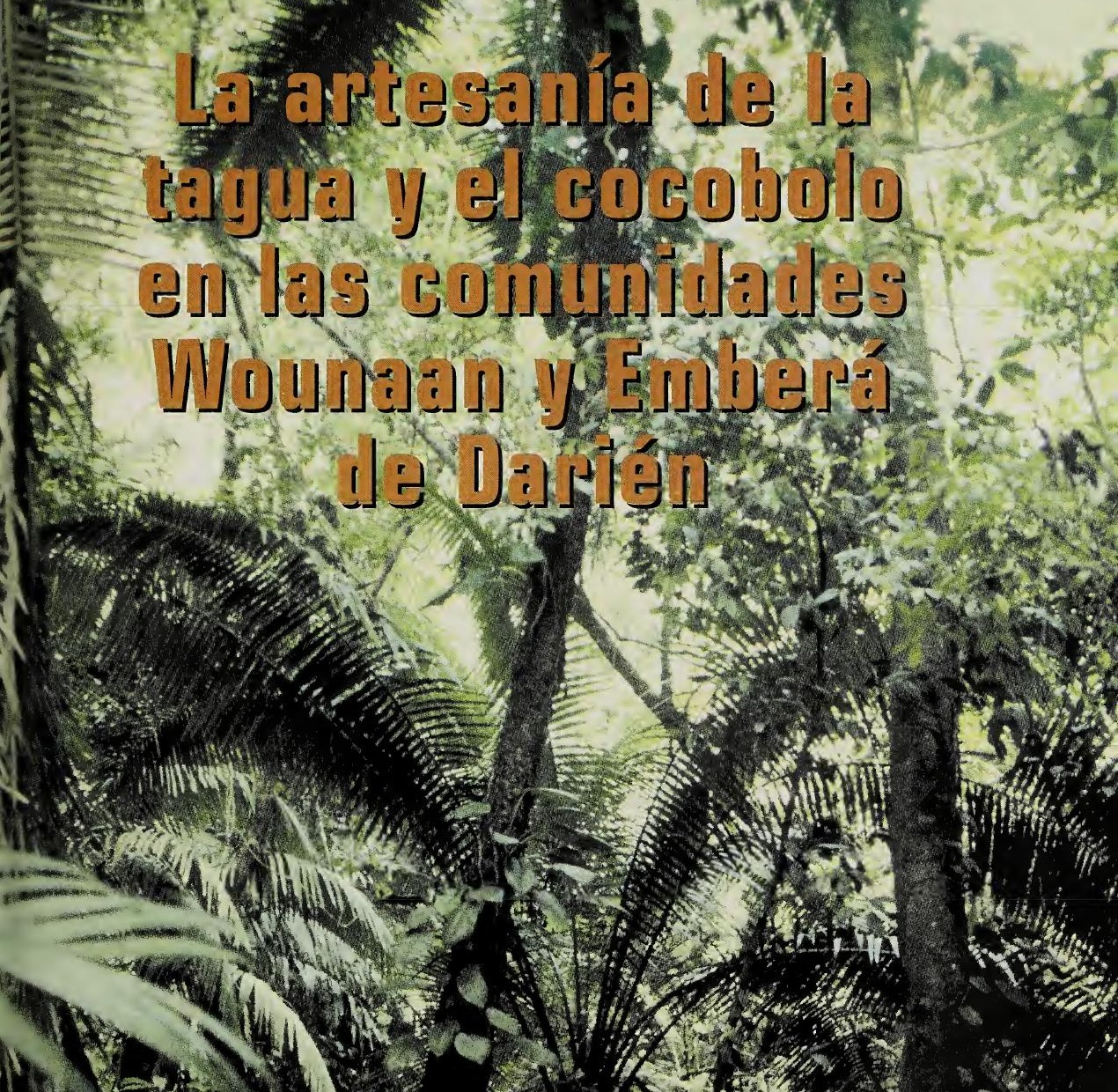

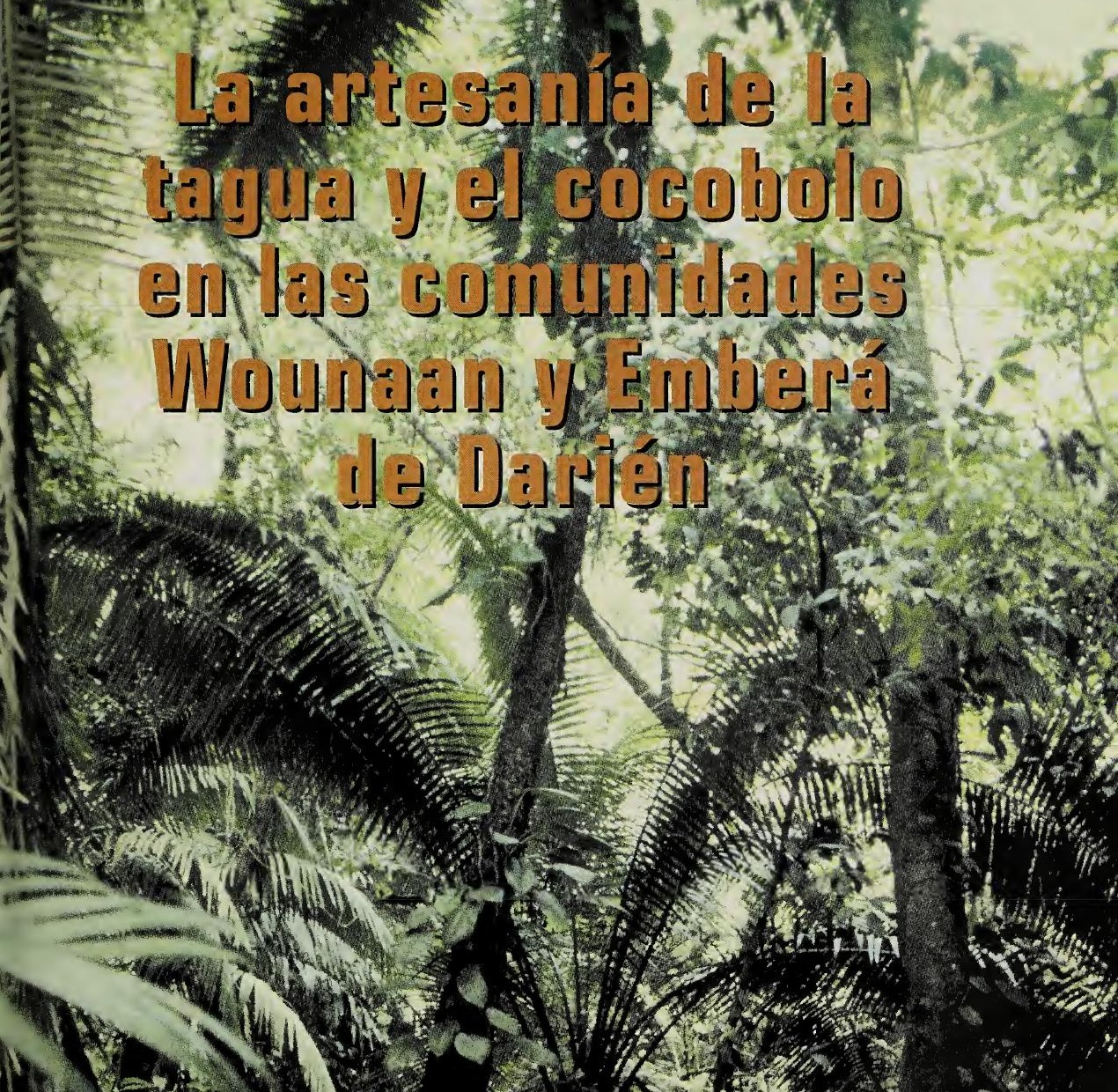

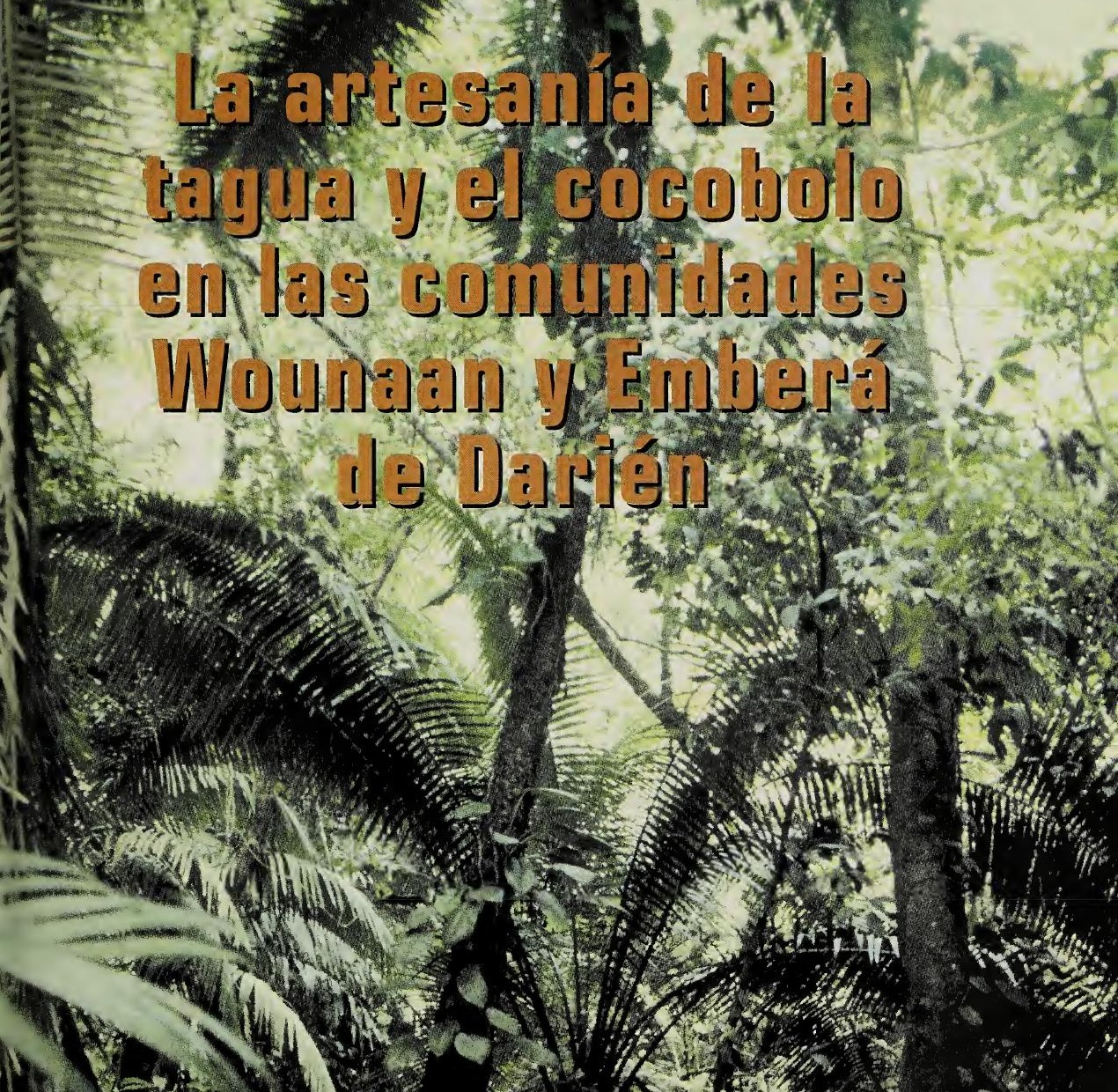

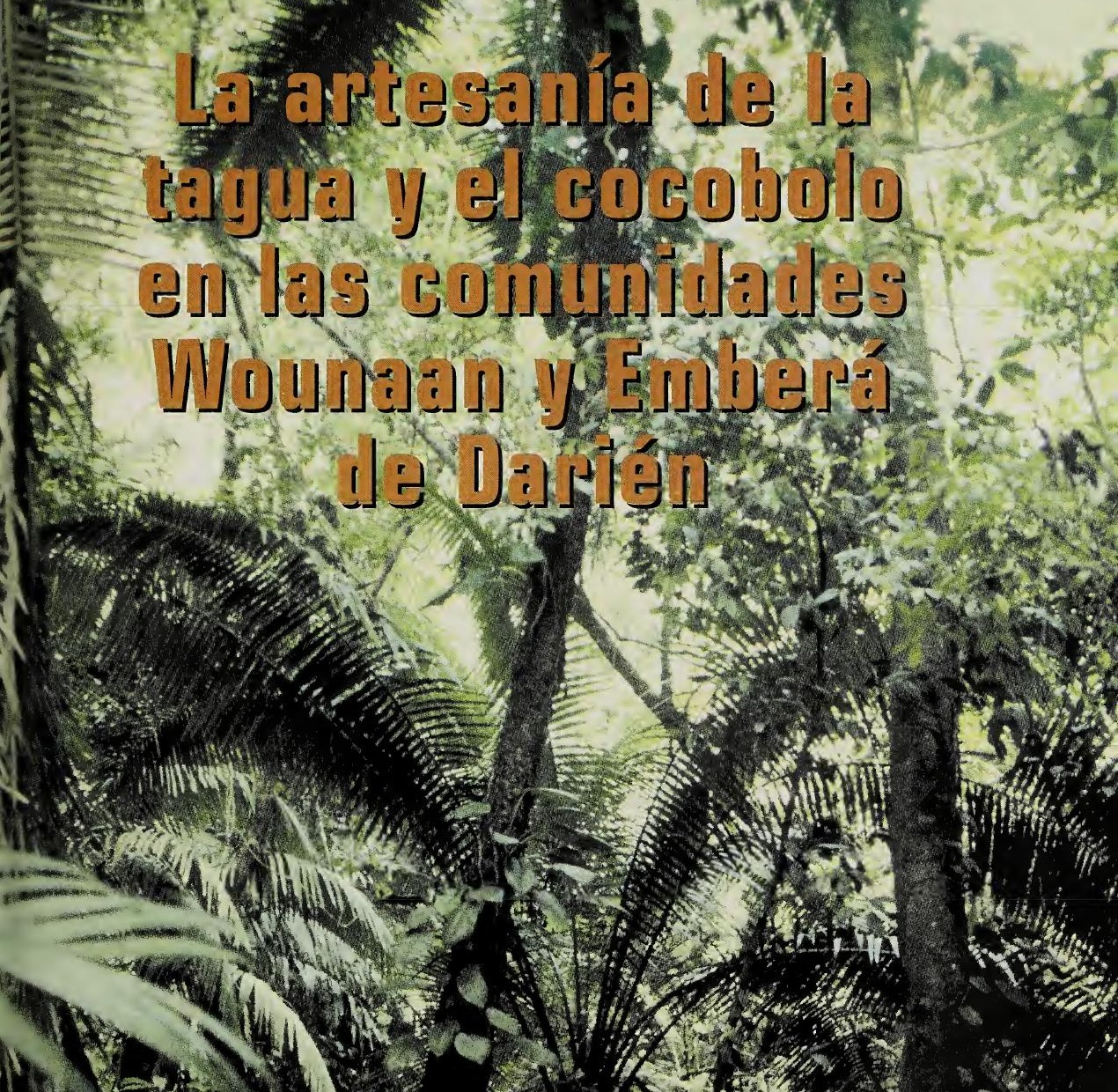

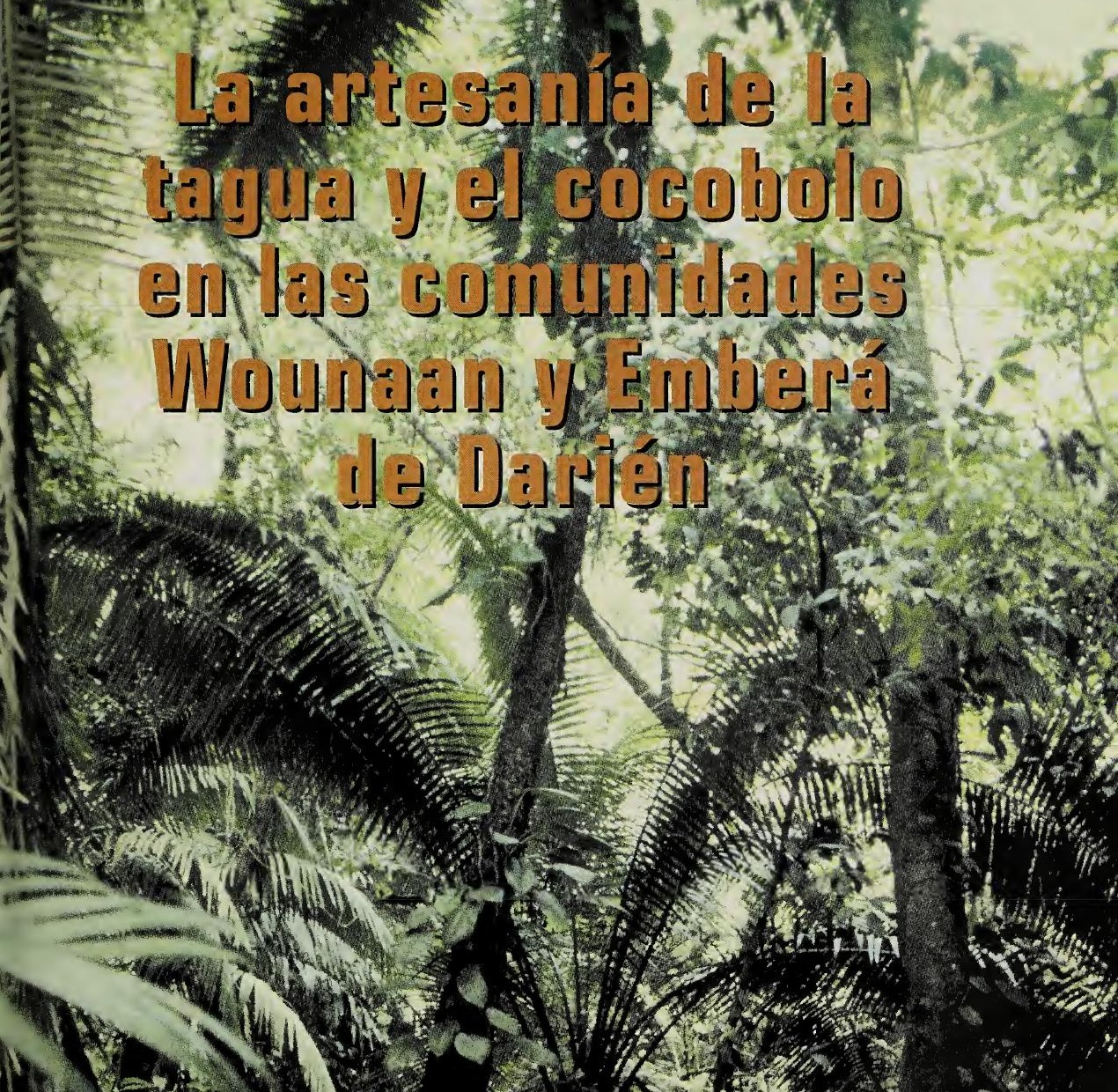

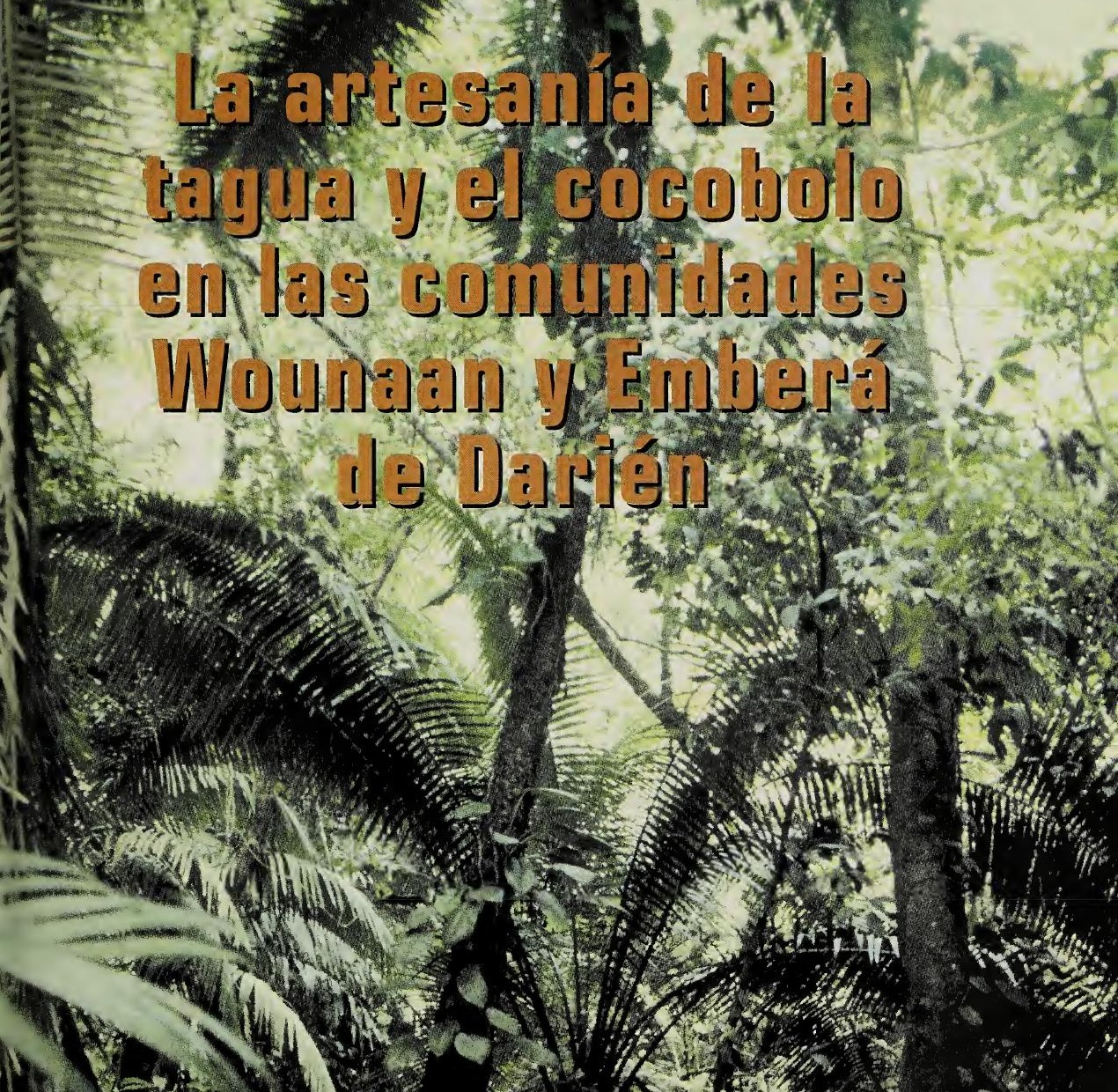

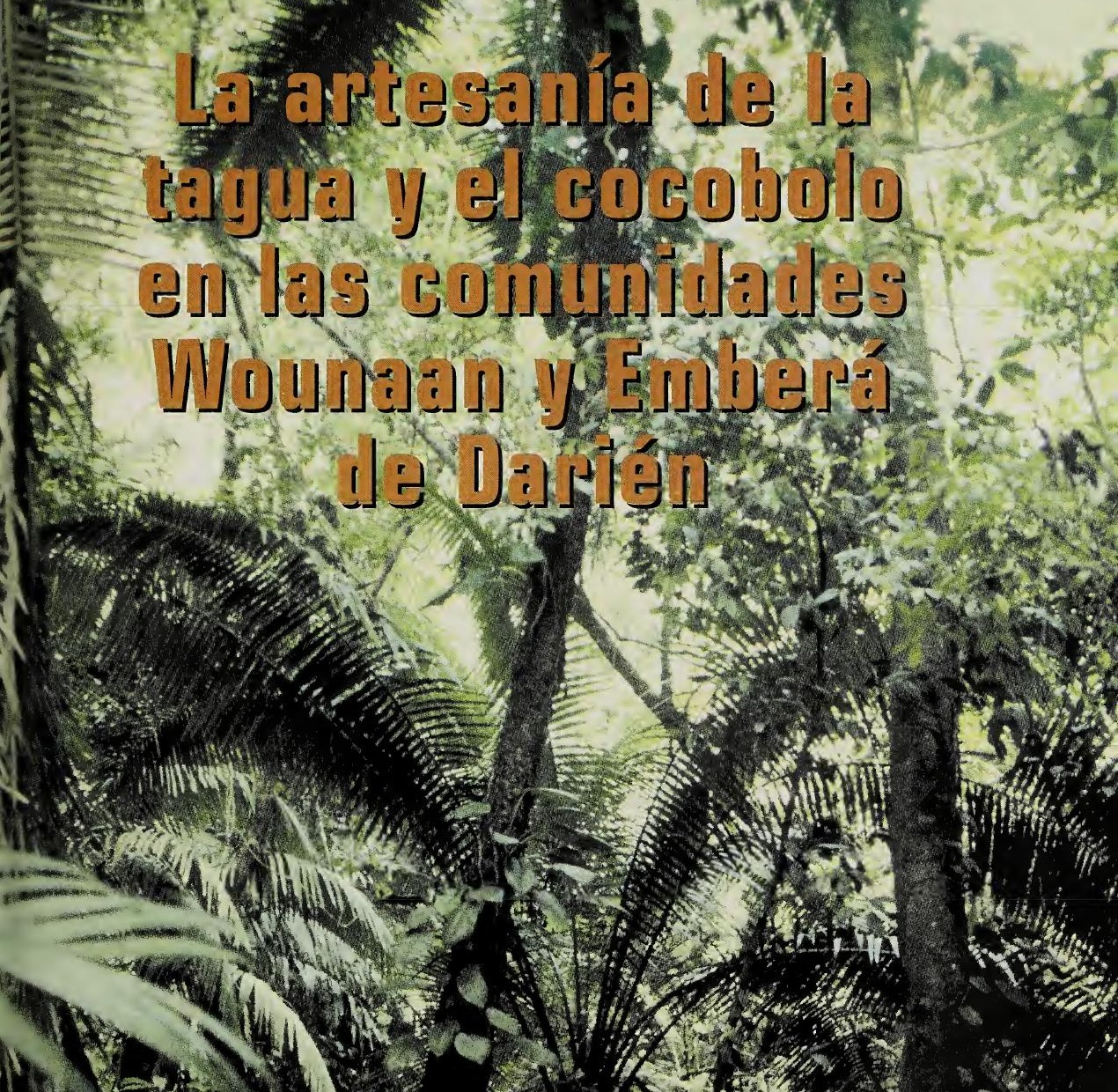

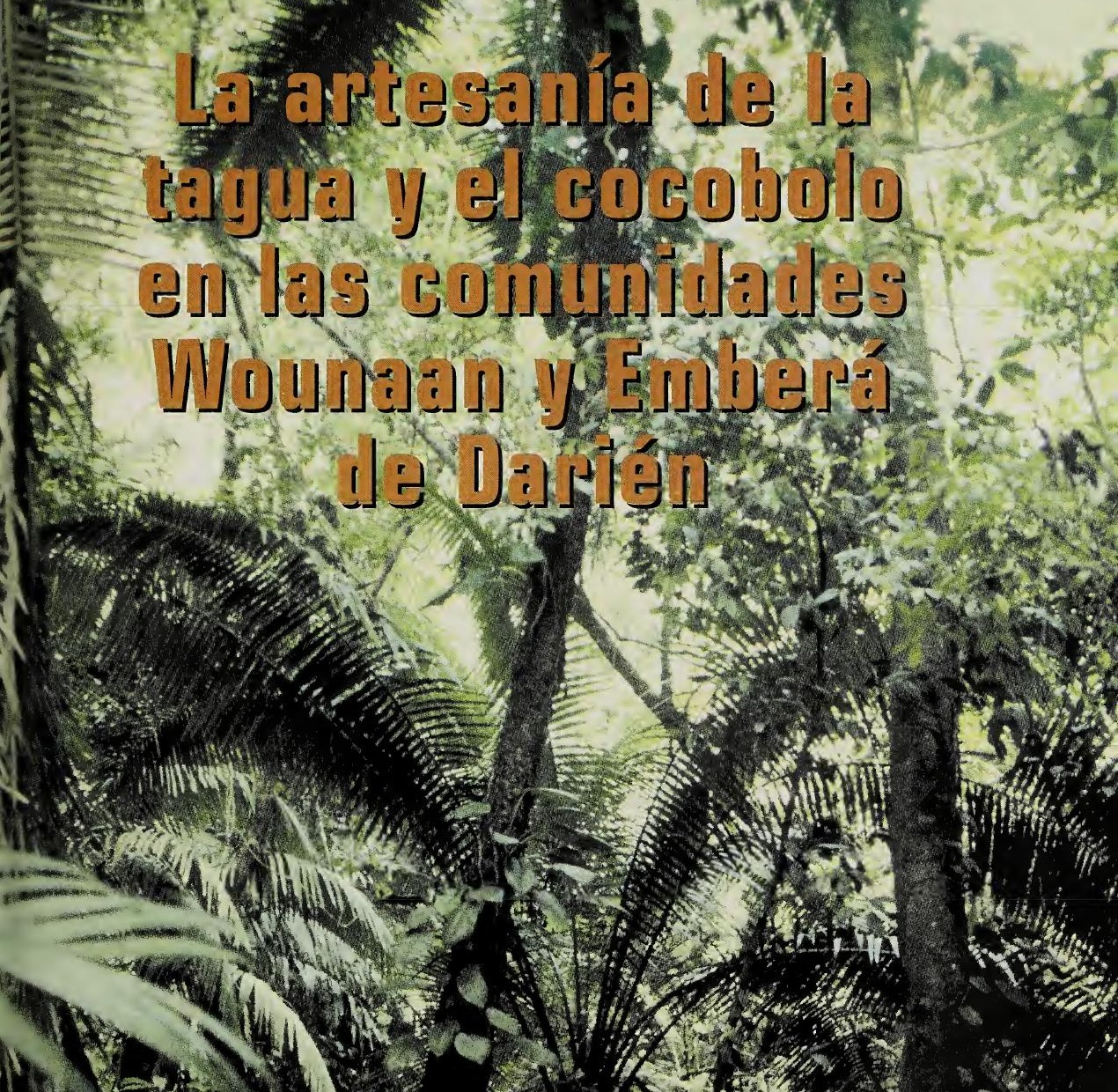

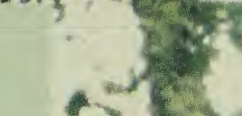

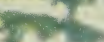

8

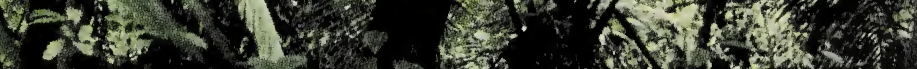

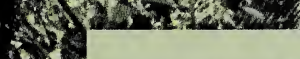

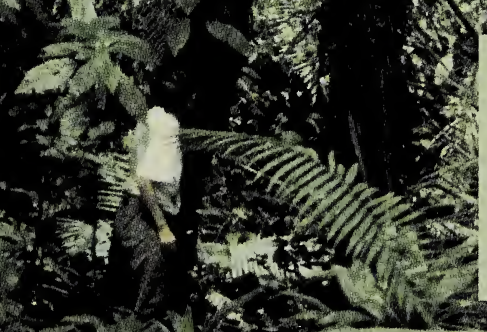

Julia Velásquez-Runk al lado de una palma de tagua o marfil vegetal, que puede ser una nueva subespecie. Río Membrillo, afluente del Chucunaque, 1997.

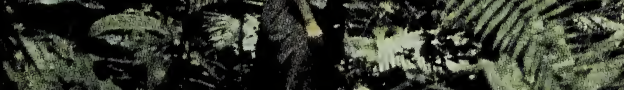
Foto: J. Dalling.

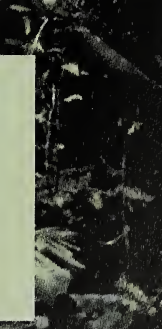




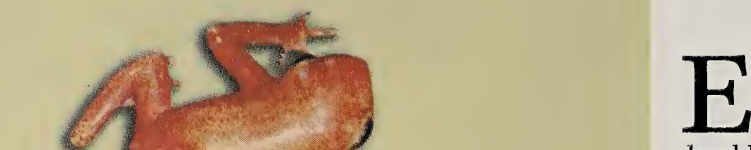

T $\mathrm{n}$ las últimas dos décadas, en Panamá ha aumentado la venta de objetos de arte elaborados con productos no maderables de los bosques de Darién y otras provincias. Entre las artesanías más cotizadas están las tallas hechas por los artesanos de las etnias indígenas Wounaan y Emberá, usando nueces de la palma de tagua (Phytelephas seemannii) y de la preciosa madera llamada cocobolo (Dalbergia retusa).

Aunque ambas comunidades obtienen significativos ingresos gracias a estos productos selváticos, conocen muy poco sobre la ecología básica de ambas especies de plantas. Existe el peligro real de que al aumentar la demanda de estas tallas en el mercado, de no dárseles un manejo adecuado a los bosques, pueda suscitarse una sobreextracción de la tagua y el cocobolo.

En 1997, el Instituto Smithsonian de Investigaciones Tropicales, junto con la Autoridad Nacional del Ambiente y fondos de la Organización Internacional de Maderas Tropicales (OIMT), iniciaron un proyecto de cuatro años (el Proyecto Manejo de Cativales y Productos No Maderables con Comunidades Campesinas e Indígenas en Darién). Ello para mejorar la conservación y administración de los principales productos maderables y no maderables de los bosques de Darién.

Con 16,800 kilómetros cuadrados y 60,000 habitantes, ubicada en la frontera con $\mathrm{Co}$ lombia, Darién es la provincia más grande y menos poblada de Panamá. Asimismo, es la que cuenta con más bosques, siendo muy reconocida por su rica mezcla de flora y fauna de Norte y Sur América

Ecología de la tagua o "marfil vegetal"

La palma tagua, Phytelephas seemannii, nombrada en honor del naturalista alemán Berthold Seeman, es muy conocida en Panamá y Colombia como la fuente de nueces y semillas utilizada para tallas. Desde mediados del siglo XIX las especies de tagua panameñas y suramericanas se han utilizado para confeccionar botones, juguetes, piezas de ajedrez y joyería.

Figurillas de tagua hechas por los artesanos Wounaan Alfredo Membache y Selerino Cheucarama. Foto: J. Velásquez Runk
La especie de tagua panameña, $P$. seemannii, se encuentra distribuida a lo largo de las tie- 
rras altas de Darién, en bosques espesos. Generalmente se encuentran entre 270 y 400 palmas maduras por hectárea, con mayores números en las laderas bajas de las montañas. También se le halla a orillas de ríos y quebradas, probablemente dispersada por las frecuentes inundaciones. Quizás en el pasado la tagua también abundaba en las tierras bajas, tales como el Chocó colombiano. Sin embargo, las tierras bajas del Darién se han talado extensamente para la agricultura y la ganadería desde principios del siglo XX, sobre todo luego de la construcción de la carretera panamericana en la década de 1980.

Las palmas de tagua son pequeñas pues sólo alcanzan de uno a dos metros de altura, con troncos que pueden ser rastreros o poco inclinados. Unas son masculinas y otras femeninas, por lo cual popularmente se les llama "palma macho" y "palma hembra". Ambas se distinguen por sus grupos de flores o "inflorescencias", que producen mayor cantidad de flores en la estación seca. Durante estos meses las palmas macho producen una inflorescencia larga, que asemeja una lengua, con miles de florecitas que contienen polen. Esta inflorescencia sale de la base de la corona de la palma, y en pocas horas crece hasta alcanzar su tamaño máximo, entre uno y dos metros de largo. Su fuerte olor dulzón atrae a muchas abejas y escarabajos. En Colombia, los estudiosos Bernal y Ervik descubrieron recientemente que la tagua es polinizada por pequeños escarabajos que depositan sus huevos en la base de la palma macho, para luego transportar su polen hacia las flores de las palmas hembras.

La palma hembra produce inflorescencias más pequeñas, que una vez polinizadas se transforman en infructescencias, "racimos", especie de grandes gajos de una curiosa fruta leñosa semiredonda, que asemeja una pelota de fútbol con protuberancias. Estas frutas se desarrollan lentamente y maduran en varios años. Al principio de su maduración, las semillas son tiernas y suaves, y su centro líquido puede beberse como el agua de coco. Una vez maduras, las semillas se tornan durísimas como una piedra, convirtiéndose entonces en el llamado marfil vegetal que es la semilla que se comercializa. La semilla de tagua es en realidad una sustancia, un car-

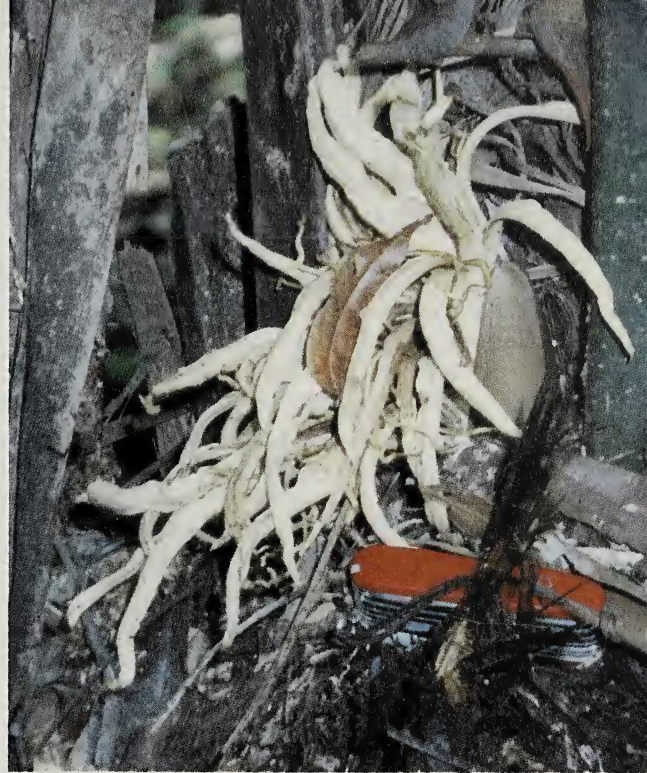

La flor hembra de la tagua se abre por unos pocos días, para ser polinizada principalmente por pequeños escarabajos.

bohidrato, del cual las palmas jóvenes se alimentan durante su crecimiento inicial. Una palma hembra puede tener un promedio de cuatro frutos simultáneamente, y cada uno puede contar con un promedio de 30 semillas. En sitios donde no se colectan las semillas, la regeneración de la tagua es sumamente abundante, encontrándose por hectárea hasta 3,400 palmas juveniles y más de 4,500 semillas sanas.

Los recolectores de tagua cosechan las semillas que salen tan pronto se abre el racimo leñoso. Existe una estrecha relación entre la tagua y los animales silvestres del bosque como los ñeques y los saínos, que gustan comer la cubierta carnosa anaranjada de las semillas y así ayudan a dispersarlas. Las semillas demoran más de dos años para germinar, siendo escasas las probabilidades de éxito; muchas palmitas mueren poco después de germinar.

\section{Los artesanos Wounaan y Emberá}

La talla de objetos de tagua para artesanías comerciales se ha desarrollado en los últimos quince años, como una ocupación ex- 
clusivamente masculina. Al mismo tiempo, esta actividad se ha basado en la antigua tradición cultural de los Wounaan y Emberá de tallar objetos domésticos e instrumentos religiosos usados por los curanderos.

Curiosamente, la mayor parte de las semillas utilizadas por los indígenas del Darién provienen de Kuna Yala o San Blas, el territorio de los Kunas en la costa Caribe de $\mathrm{Pa}$ namá, aunque algunas vienen de los pies de la Serranía del Darién, al norte de la provincia. Los Kunas venden la semilla a precios que oscilan entre cincuenta centésimos y un dólar cada una. Los artesanos de los grupos indígenas Wounaan y Emberá prefieren las semillas del Caribe por ser más grandes que las del Pacífico, probablemente porque son de una especie o subespecie diferente de palma.

Desde finales de la década de 1980, el arte de tagua ha evolucionado de tal manera que se ha convertido en una industria doméstica, para abastecer en gran parte a los turistas extranjeros. Los mejores artesanos de la tagua son de Darién y en su mayoría pertenecen al grupo Wounaan, aunque ahora muchos viven en Ciudad de Panamá, para estar más cerca del mercado turístico. Tallar, pulir y pintar una figura toma típicamente de 2 a 3 días. Frecuentemente los talladores usan

Pieza de artesanía hecha de una semilla de tagua y pintada con tinta china, por el artesano Domitilo Chichiliano.

Foto: J. Velásquez-Runk.

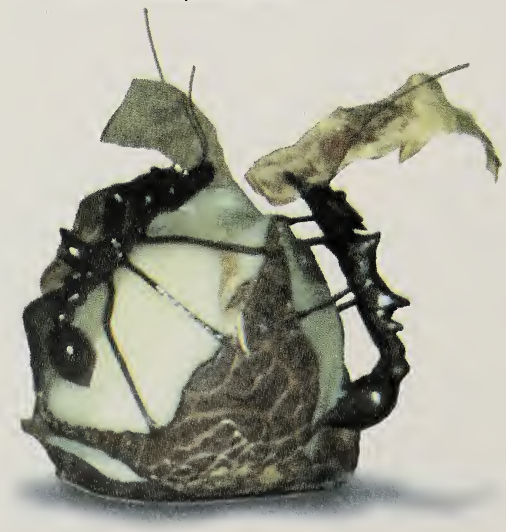

máquinas eléctricas para el trabajo inicial, luego elaboran los detalles con cuchillos. En una quincena pueden llegar a ganar hasta 800 dólares. Sin embargo, los artesanos que residen en Darién, sólo esperan ganar de 20 a 30 dólares en una quincena. Tal diferencia en ingresos obedece a que Darién carece de un mercado local y a que los artesanos sólo usan herramientas manuales, pero también porque buena parte del tiempo que podrían dedicar a tallar, deben invertirlo en mantener sus cultivos agrícolas para alimentar a sus familias. En los pequeños caseríos del Darién, el ingreso de dinero gracias a la tagua es significativo, porque el trabajo asalariado es casi inexistente. Los vendedores de tagua en la ciudad de Panamá creen que siempre existirá un mercado para este producto del bosque, ya que puede adaptarse a un gran número de objetos, desde joyas y cajas hasta figuras de animales.

\section{Ecología del cocobolo}

Se conoce como cocobolo (Dalbergia retusa) al hermoso palo rosado que crece desde Méjico hasta Panamá. La explotación de este árbol se ha mantenido desde hace al menos un siglo; existe un registro de la exportación panameña de 2,600 toneladas métricas de cocobolo en 1917. Dada su fuerza y durabilidad, esta madera se ha utilizado sobre todo para hacer mangos de cuchillos. En Panamá se utiliza actualmente para tallas y puede encontrarse piezas pequeñas en el mercado de artesanías internacional en forma de bolígrafos, partes de instrumentos musicales y muebles. Recientemente una compañía local de productos madereros nos informó que consideraba su uso para pisos.

Los árboles de cocobolo se distribuyen esparcidamente en Panamá a lo largo de la vertiente más seca del Pacífico. Crecen lentamente; los árboles maduros llegan a medir 20 metros de altura y usualmente se identifican por su corteza escamosa y su madera extremadamente dura. A pesar de ello, hemos comprobado que mucha gente de las zonas rurales del Darién no puede identificar el fruto del cocobolo ni las plantas jóvenes. Este árbol florece en la estación seca y produce una o varias semillas dentro de una pequeña vaina. Según nuestras observaciones y las del investigador Carlos Gómez, la semi- 
lla germina rápidamente en un vivero, aunque al crecer tiende a ramificarse: es una especie prometedora para la silvicultura comercial.

\section{La artesanía del cocobolo}

Los artesanos reconocen que la madera del cocobolo tiene varios colores que van desde el rojizo, el marrón profundo sonrosado, hasta el negro, encontrándose este último en partes de las raíces. La madera en sí es muy dura y resistente a la putrefacción, ya que contiene un fungicida natural; según los artesanos un árbol talado puede tomar décadas para pudrirse en el suelo. El cocobolo es bien conocido en la literatura médica por producir dermatosis o una alergia respiratoria entre algunas personas que lo cortan, lo pulen, o quienes lo usan en una pieza como joya. El aserrín que queda de la talla se hierve y se usa solo o mezclado con tumeric, ceniza, o tierra para teñir las canastas hechas de las fibras de palma chunga Astrocaryum standleyanum. Así obtienen de diversas formas tintes del cocobolo, de color marrón, amarillo mostaza, chocolate, o negro.

$\mathrm{Al}$ igual que en el caso de la tagua, la talla de cocobolo es una ocupación de hombres casi por completo. Tradicionalmente, los Wounaan y los Emberá han tallado cocobolo y otras maderas duras para hacer los bastones de curar que usan los curanderos y confeccionar objetos domésticos; sólo en los últimos 20-25 años se ha abierto un mercado para las tallas finas. Históricamente, los artesanos han usado solamente las raíces y las ramas de los árboles caídos para tallar, aunque ahora han comenzado a cortar árboles. Aunque muchos de los talladores usan tanto la tagua como el cocobolo, hay menos artesanos de cocobolo y son pocos los que se han mudado a la ciudad de Panamá desde el Darién o el oeste de la provincia de Panamá. Ello posiblemente obedece a que el peso de la madera limita su transporte. Un maestro artesano que trabaja a tiempo completo puede terminar una pieza grande y compleja en una semana y venderla por 100 dólares. Sin embargo, las tallas voluminosas pueden ser difíciles de vender, por lo tanto muchos artesanos prefieren hacer figuras pequeñas, como de animales de la selva y piraguas, con un valor de 20 a 50 dólares.
El futuro de los productos no maderables del bosque

Los objetos de arte creados con productos no maderables de los bosques de Darién representan fuentes de ingreso nuevas e importantes para las comunidades indígenas Emberá y Wounaan, que tradicionalmente han dependido de pequeños excedentes en la agricultura de maíz, arroz y plátano, o del trabajo como "jornaleros", como fuentes de dinero en efectivo. Sin embargo, el éxito de la industria artesanal a largo plazo dependerá no sólo de su capacidad para generar ingresos, sino también de mantener la ecología de las plantas que utilicen.

La industria de la tagua parece sostenible en Darién, ya que nuestras observaciones de campo sugieren que quedan cientos de hectáreas de tagua sin cosechar en los bosques de la provincia, y muy posiblemente, en la frontera con Kuna Yala. Es más difícil evaluar si en el futuro la industria del cocobolo será sostenible, debido a la escasez general de este noble árbol, carestía que ya hace

Figura de murciélago tallada en madera de cocobolo, por el artesano Enoc.

Foto: J. Velásquez-Runk, 1998. 
problemática su investigación. Aunque las figuras de cocobolo están perdiendo mercado, dada la popularidad creciente de las tallas de tagua y las canastas tejidas con fibras de la palma de chunga, estas continúan vendiéndose en el mercado artesanal del turismo doméstico. Para algunas comunidades, como las de Majé y Chepo en la provincia de Panamá, los ingresos del cocobolo siguen siendo importantes.

La amenaza principal para estos extraordinarios recursos forestales en Darién no es la cosecha excesiva, sino la creciente deforestación muchas veces por parte de los colonos interioranos que migran de otras provincias y quienes siguen los caminos hechos

Bastones de cocobolo, aproximadamente de los años 1970-1990. Artesanos desconocidos. (Colección de Bill y Susan Harp).

Foto: J. Velásquez-Runk.

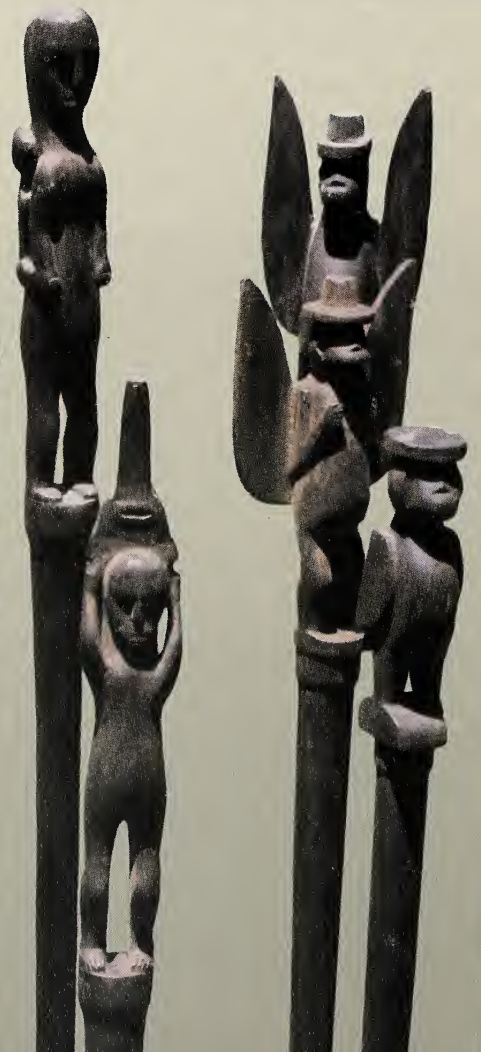

por las compañías madereras. En el Darién, durante la estación seca de 1998 que se extendió y agravó por el fenómeno de El Niño, los incendios causados por el hombre destruyeron más de 8,000 hectáreas de bosques.

Quizás el paso más importante para asegurar la oferta a largo plazo de los productos no maderables de los bosques del Darién, será la legalización de los derechos sobre la tierra por las comunidades que tradicionalmente han sido usuarias de las selvas. Esta necesidad ha sido reconocida por el Banco Interamericano de Desarrollo y ha sido incorporada en su paquete de préstamos para el mejoramiento de la carretera interamericana desde Chepo hasta Yaviza.

De igual forma, tradicionalmente las áreas protegidas de Panamá, que han seguido un formato administrativo originado en las distintas condiciones de Europa y Norte América y basadas en la conservación total de la biodiversidad, no resuelven las necesidades de las comunidades locales, cuyo bienestar depende de los productos del bosque. La ANAM está considerando desarrollar un sistema adicional de reservas de usos múltiples o de concesiones comunitarias en tierras aptas para la extracción de productos no maderables del bosque. Nuestro proyecto de investigación de productos no maderables puede aportar la asistencia técnica requerida por la ANAM para manejar la extracción de estos productos y desarrollar una estrategia a largo plazo que incorpore a las comunidades locales a la planificación para la conservación.

Bibliografía:

Bernal y Ervik 1996; Record y Garratt 1923; Bultman y Southwell 1976. 
Thomas Kursar

y William Grauel

\section{Manejo sostenible de los cativales del Darién}

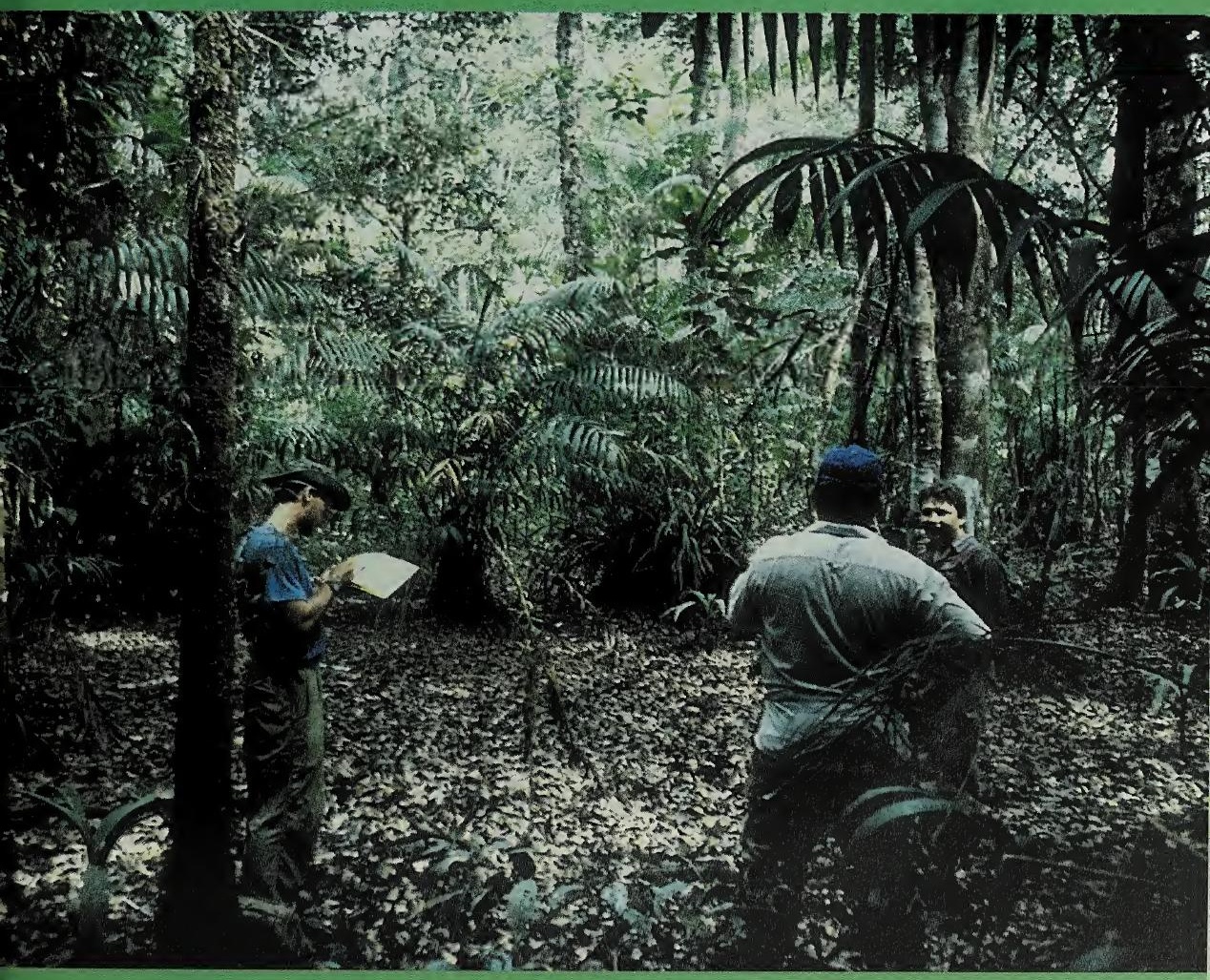

Investigadores forestales en los cativales de Río Juanacatí, El Real, Darién, 1997. Bill Grauel

(STRI) tomando notas, Manuel Rodes (ANAM) de espaldas y Milcíades Samaniego. 
$\mathrm{P}$ anamá tiene trece tipos distintos de ecosistemas boscosos, cada uno con una sorprendente diversidad biológica. Las diferencias entre las plantas y animales del Caribe húmedo y el Pacífico seco son marcadas, al igual que los contrastes entre la región este, aledaña a Suramérica y la oeste colindante con América Central.

Dentro de esta alta biodiversidad están los cativales -bosques formados por el árbol de cativo- originarios del Darién.

Los cativales se encuentran en tierras bajas desde Nicaragua hasta Colombia, aunque las mayores superficies están a lo largo de ríos como el Atrato, que desagua al Golfo de Urabá, y en los ríos Tuira y Chucunaque, en Darién. Generalmente los cativales crecen en áreas anegadas por las aguas de lluvias y mareas.

\section{Importancia económica de los cativales}

El cativo (Prioria copaifera) es un árbol de la familia de las legumbres, especie que tiene un papel clave en la economía panameña. Ella provee el $90 \%$ de la materia prima utilizada en la producción de madera contrachapada o "plywood" del país. La tala y venta del cativo se ha convertido en una de las fuentes más importantes de dinero para las comunidades de gente negra llamadas darienitas y para los indígenas Emberá y Wounaan, sobre todo a partir de la década del 80 , después que la enfermedad llamada sigatoka negra destruyera sus cultivos de plátanos.

Estas comunidades venden el cativo a intermediarios que suplen a las fábricas ubicadas en la provincia de Panamá. La mayoría de los cativales que sobreviven en Darién están dentro de las comarcas o territorios de las comunidades Wounaan y Emberá, quienes tienen derechos colectivos sobre su uso. Los cativales en tierras nacionales han sido sobreexplotados por los madereros y muchas veces convertidos a usos agrícolas y ganaderos.

\section{Ecología de un bosque ribereño}

Los cativales, al igual que otros bosques que ocupan las orillas de los ríos, tienen una función ecológica importante. Ellos se encuentran en áreas de alta productividad biológica; durante las inundaciones de la estación

Acarreo de una tuca de cativo hacia río Marea, afluente del Balsa, donde será transportada por mar hasta la ciudad de Panamá. Foto: T. Kursar.

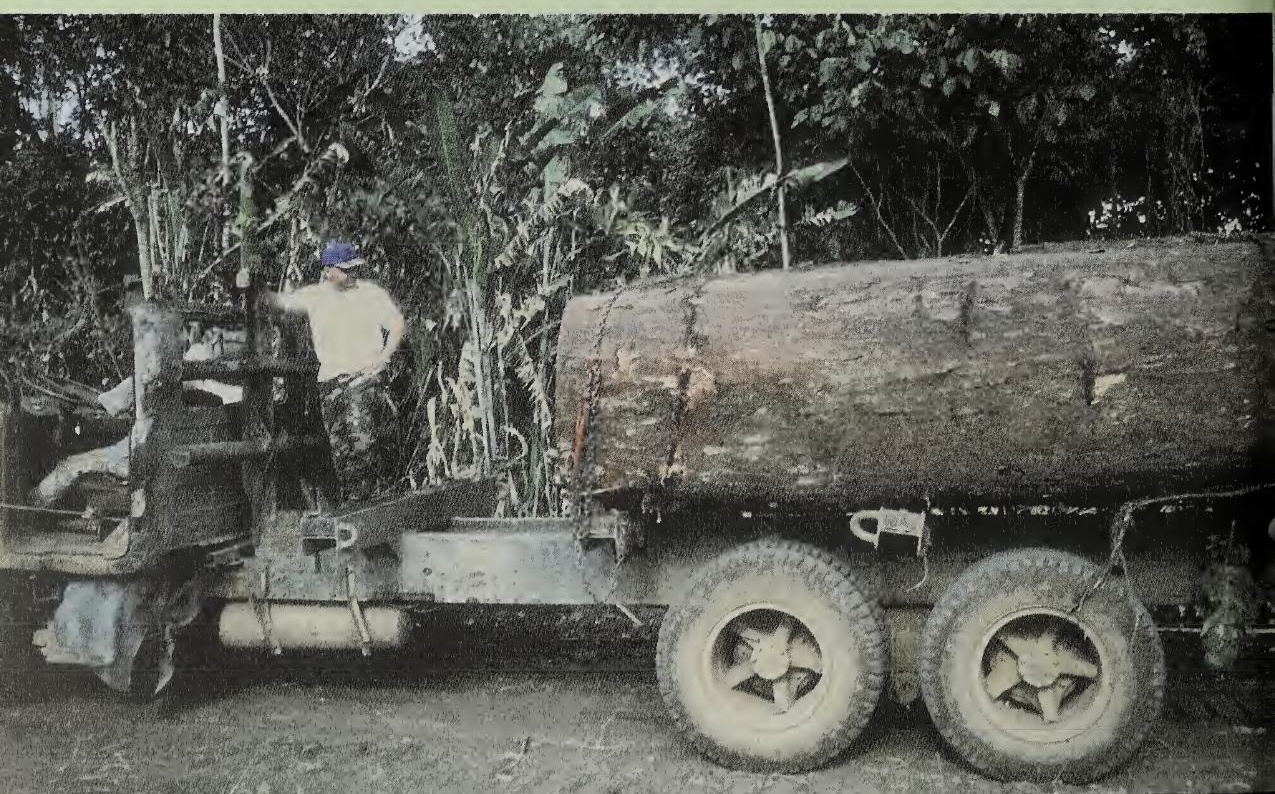


lluviosa reducen la erosión de los suelos en las márgenes de los ríos y absorben muchísima agua que luego es usada por el bosque en la estación seca. También ejercen un papel notable al mantener la calidad de las aguas que salen de los ríos al mar, ya que estos bosques remueven y reciclan los nutrientes. Para el Darién, la calidad de las aguas que salen del río Tuira al Golfo de San Miguel es de importancia crítica: este golfo es una de las áreas más productivas para la pesca comercial del camarón en Panamá. Muchos organismos marinos, ade-

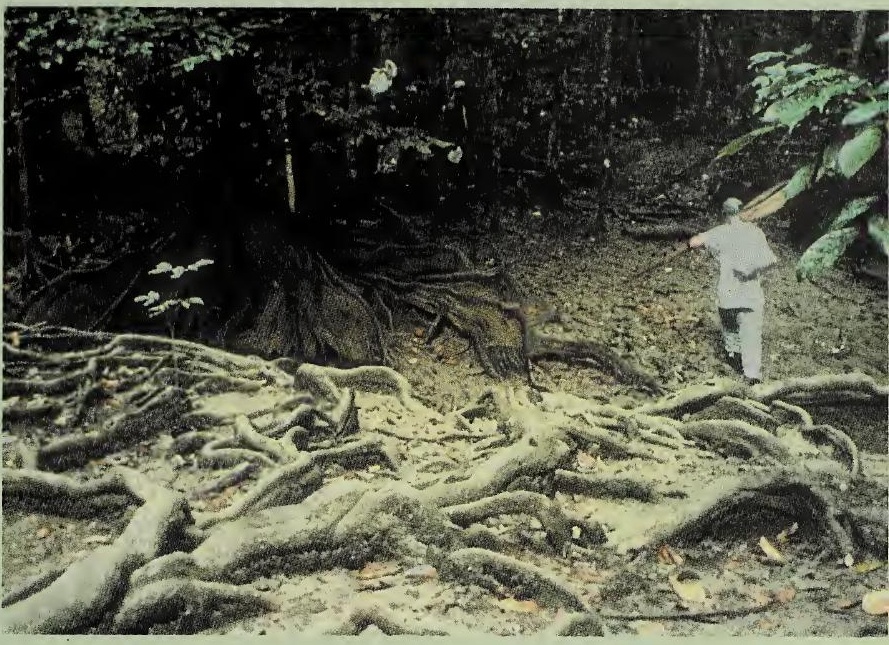
más de los camarones, se reproducen y maduran en los esteros. Actualmente contamos con poca información acerca de las funciones ambientales que desempeñan los bosques de las riberas de los ríos Tuira, Chucunaque y Balsas; al igual que sobre los drenajes de estas cuencas hidrográficas y los sistemas marinos adyacentes.

Más del 95\% de los árboles que encontramos en este tipo de bosque pueden ser cativo, pero también crecen otras especies, como el sangre de gallo (Pterocarpus officinalis), el espavé (Anacardium excelsum), el alcornoque (Mora oleifera), tangaré (Carapa guianensis) y el coco (Lecythis tuyrana).

Muchos mamíferos y pájaros recorren los cativales buscando frutas y cangrejos. Estos incluyen halcones, monos de cara blanca y titís, coatíes y ñeques.

En el pasado, los tapires también eran vistos frecuentando estos bosques durante la estación seca, aunque hoy es raro verlos, dado el exceso de cacería.

Aunque los cativales se han explotado intensamente desde la década del 60 , nuestra información con respecto a estos bosques es muy pobre. Desconocemos cuál es la superficie que ocupan en Panamá, cuál la salud o el estado de degradación de los bosques supervivientes, su capacidad de regeneración,

Catival intacto del área del río Chunga, afluente del Sambú. Las grandes raíces, en primer plano son de la especie "sangre de gallo" (Pterocarpus Officinalis).

Foto: W. Grauel.

ni cuál será su productividad en el futuro, bajo las actuales prácticas rudimentarias de explotación.

Para ampliar nuestros conocimientos sobre esta especie forestal y mejorar los métodos empleados en su extracción, en 1996 la Organización Internacional de las Maderas Tropicales (OIMT), otorgó fondos al entonces Instituto Nacional de Recursos Naturales Renovables de Panamá -actualmente Autoridad Nacional del Ambiente (ANAM)para que en colaboración con el STRI estudiase los cativales del Darién. El proyecto se inició en enero de 1997, con sede en La Palma, cabecera de la provincia y situada a orillas del río Tuira.

\section{La metodología para estudiar los cativales}

Para desarrollar un plan de manejo forestal es necesario obtener dos tipos de información básica. Primero, las características ecológicas del cativo, como su tasa de crecimiento, mortalidad y capacidad de regeneración. La obtención de estos datos ecológicos fue responsabilidad del STRI. 
Segundo, es necesario conocer la distribución y superficie cubierta por los cativales y el estudio de las prácticas actuales de extracción. La investigación de estos datos estuvo a cargo de la ANAM.

Así, combinando los nuevos conocimientos sobre la especie, con las técnicas mejoradas de tala y extracción, será posible elaborar planes en el futuro para el manejo forestal sostenible a largo plazo y que puedan transferirse a las empresas madereras, a los pequeños taladores darienitas y a los indígenas.

El equipo de campo de la ANAM lo conforman Ricardo Pineda, Manuel Rodes y José Solís. Aquí describiremos la organización del equipo de investigación de STRI, los métodos utilizados para estudiar el cativo y cómo la información obtenida puede utilizarse para establecer un plan de manejo forestal.

William Grauel ha colectado y analizado los datos sobre el crecimiento y la mortalidad del cativo, en tanto que los científicos Thomas Kursar y Richard Condit, han asesorado en el análisis de los datos de campo.

\section{Campamentos y sitios de estudio}

El equipo estableció cuatro sitios permanentes de estudio, donde se mide el crecimiento y la mortalidad del cativo. En otros seis lugares sólo se mide el crecimiento. El trabajo de campo se hace bajo condiciones muy difíciles, pues por estar bajo el agua buena parte del año, estos sitios se encuentran llenos de lodo y repletos de mosquitos. Por tanto, la mayoría de los estudios debe realizarse en la estación seca, de enero a abril.

Como esta región es pantanosa y desprovista de caminos, se viaja en cayucos con motores fuera de borda y, debido a que en los cursos bajos de los ríos Balsas, Sambú y Tuira las mareas fluctúan muchísimo, el desplazarse a través de ellos depende de las mareas.

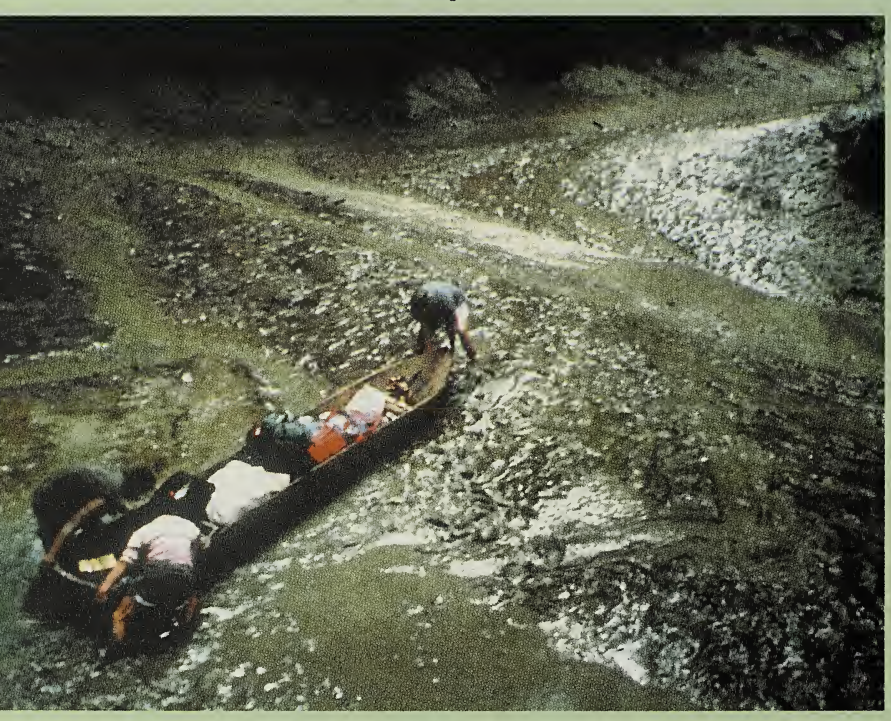

Los campamentos principales del proyecto están en Casarete, un aserradero sobre el río Balsas, 18 kilómetros arriba de su confluencia con el Tuira. El Balsas tiene unos 150 kilómetros de largo, uno de los más caudalosos del Darién. Los poblados más grandes son Camogantí y Tucutí, habitados mayormente por darienitas, y Manané, un poblado Emberá. Hay otro campamento en un bosque de la quebrada de Naranzatí, 5 kilómetros al oeste de $\mathrm{Ca}$ mogantí. El tercero está en La Chunga, una comunidad Emberá a orillas de un afluente del río Sambú, cerca del mar.

En las zonas de cativales la movilización se hace en botes, aprovechando la marea alta. Aquí el equipo de investigadores del proyecto de cativales hala el bote con la marea seca en río Chunga, afluente del Sambú. Foto: W. Grauel.
Finalmente, hay uno en Juanacatí, en un campamento maderero sobre el Tuira, $11 \mathrm{ki}$ lómetros abajo del poblado de El Real, uno de los pueblos más viejos e importantes de la provincia. 


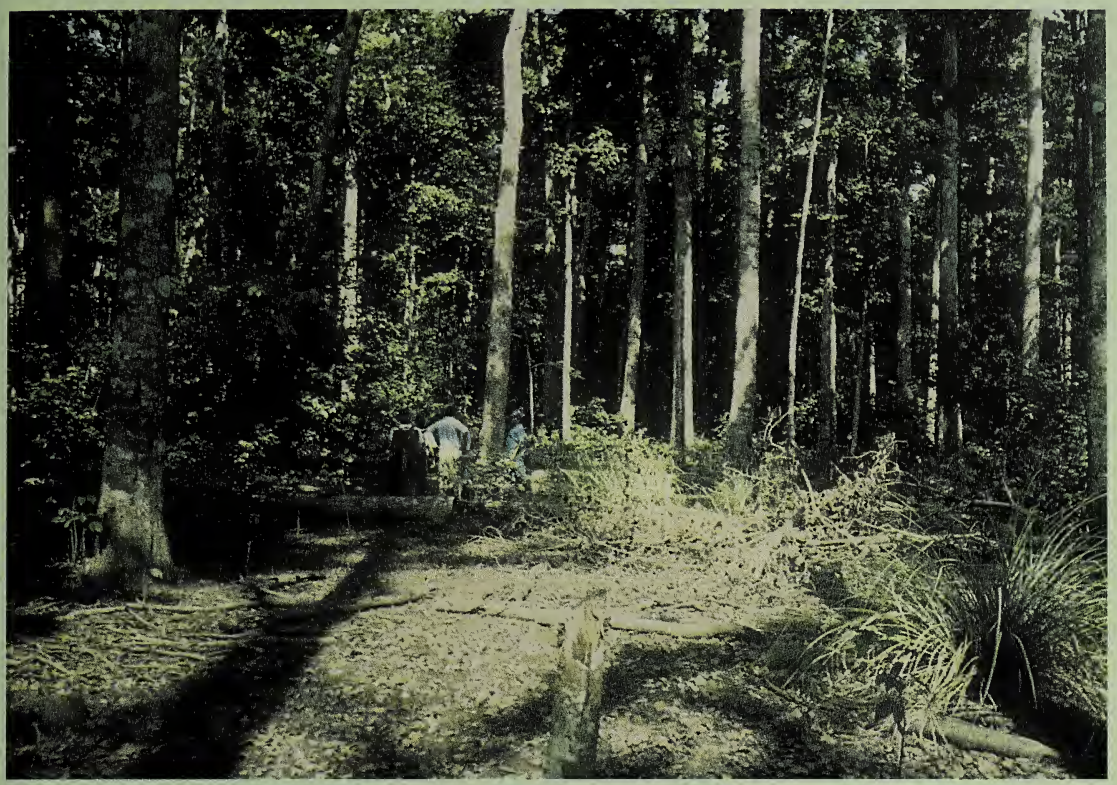

Catival del río Sambú, después del aprovechamiento forestal en Darién, 1998.

Requiere el trabajo de campo que el investigador obtenga apoyo de las comunidades, pues ellas tienen muchos conocimientos sobre los bosques locales; también debe tener capacidad para trabajar con las distintas comunidades, darienitas e indígenas.

\section{La alta productividad de un catival}

Aunque los bosques tropicales están dotados de una alta diversidad de árboles, pocas son las especies con valor comercial, por tanto el volumen de madera que se les puede extraer es menor.

Lo anterior contrasta con un catival, donde casi todos los árboles grandes son aprovechables, pues se supone que un catival intacto puede llegar a producir hasta 120 metros cúbicos de madera por hectárea. Tal volumen de madera tiene un alto precio: los madereros tienden a extraer todos los árboles grandes, causando gravísimos daños al bosque que tomará décadas en repararse.

Nuestros estudios muestran que en los cativales talados por los madereros quedan muy pocos árboles mayores de 60 centímetros de diámetro, el tamaño mínimo especificado por la ANAM para la extracción de madera. Al no quedar árboles de dimensiones aprovechables, la próxima tala deberá esperar hasta que los cativos alcancen un diámetro mayor de 60 centímetros y, obviamente, el tiempo de espera dependerá de las condiciones de los sitios. Nuestros análisis preliminares de los índices de crecimiento sugieren que hay áreas inundadas donde los cativos crecen lentamente, mientras que en otras crecen con mayor rapidez. Estas diferencias pueden atribuirse a factores diversos, como puede ser el tiempo que permanece inundado un sitio; lo cual trae como consecuencia que a mayor tiempo bajo el agua, el crecimiento del cativo es menor.

El desarrollo del cativo también puede retrasarse debido a la sal, que se introduce en la tierra durante los aguajes o mareas altas.

Curiosamente encontramos que durante un año de sequía severa, el crecimiento de la especie fue mayor que en un año con estación seca normal. El hecho de que los ár- 
boles de cativo tuviesen mayor crecimiento durante una sequía intensa, se podría explicar partiendo del hecho de que hay menos inundaciones de los ríos y mayor disponibilidad de luz solar.

\section{Resultados y beneficios}

¿Qué implican los índices actuales de crecimiento del cativo para las cosechas del futuro? Basándonos en estos indicadores, estimamos que los árboles que ahora miden 40 centímetros de diámetro sólo alcanzarán un tamaño apto para talarse ( 60 centímetros de diámetro) en unos cuarenta o cincuenta años. Para cortar los árboles que actualmente tienen 20 centímetros, habrá que esperar de ochenta a ciento veinte años.

La ausencia casi total de árboles cosechables en la mayoría de los cativales explotados por los madereros y los extensos intervalos que requerirán para volver a crecer, muestran la urgente necesidad de establecer un plan de manejo sostenible a largo plazo.

William Grauel realizó pruebas de campo para saber si es posible reforestar con cativo en áreas inundadas, desprovistas de árboles, tal como pantanos, así como la factibilidad de reforestar cativales degradados, transplantando plantas jóvenes de un catival sano.

Los resultados de los dos primeros años del estudio parecen sugerir que ambos proyectos son factibles, esto es, que es posible reforestar áreas pantanosas y cativales degradados.

En los lugares donde los cativales han sido sobretalados, la gran cantidad de luz que entra al bosque favorece el crecimiento profuso de una liana llamada localmente "mostrenco", un pariente cercano del árbol del cocobolo.
William Grauel estudia el efecto del mostrenco en el crecimiento del cativo y los resultados de sus dos primeros años de investigación muestran que tal liana retarda el crecimiento del cativo. Asimismo, es posible duplicar el incremento de los árboles grandes cortándole estas lianas. Por tanto, la tala en los cativales debe manejarse de modo que se evite la sobreextracción y la formación de áreas abiertas donde el mostrenco pueda establecerse.

Como parte de la investigación de doctorado realizada por Omar López para la Uni-

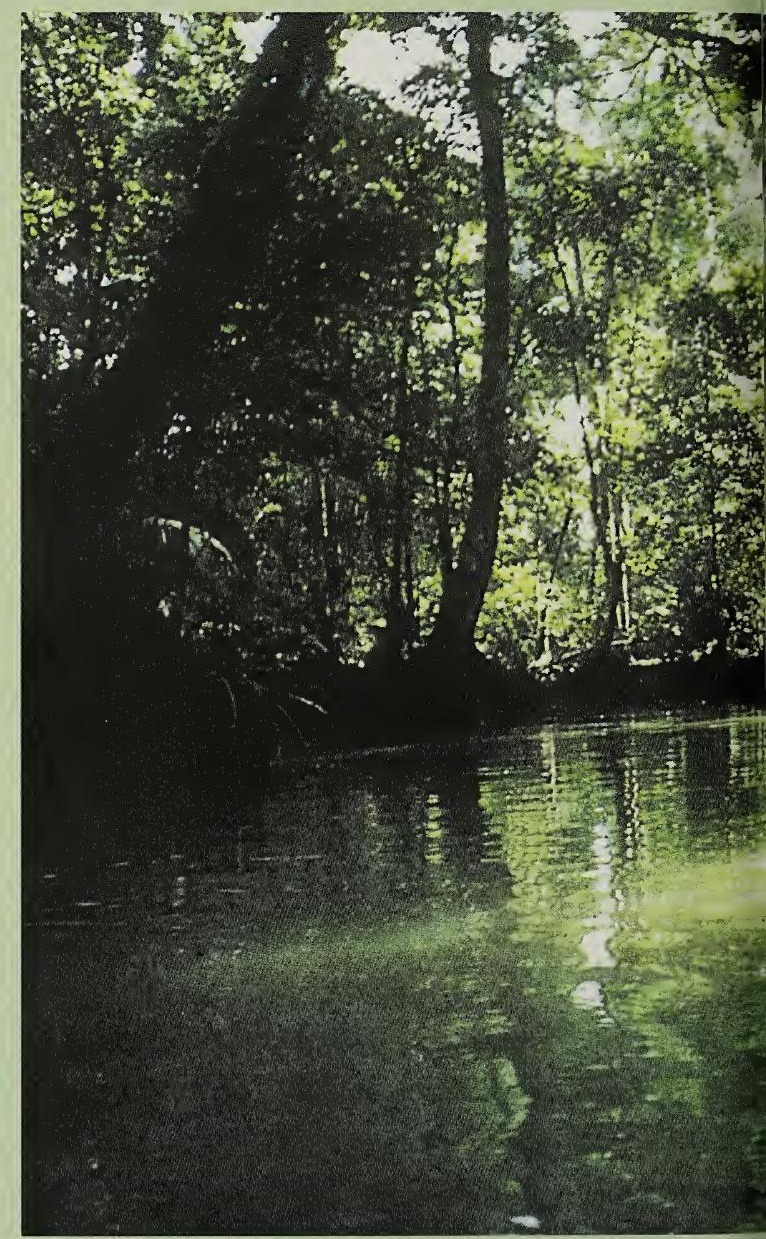




\section{La pesca y el} deterioro de

los arrecifes.

en el Caribe

y Panamá

Gabriel Jácome

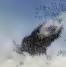$$
\text { (a) }
$$

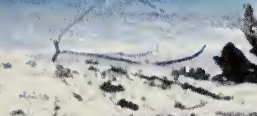

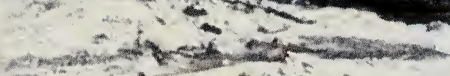

4

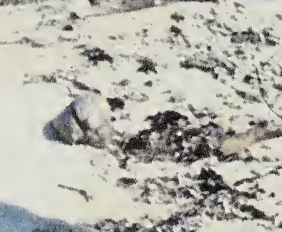

$-2 e^{2}-2$

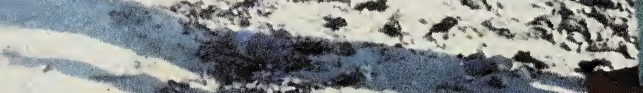

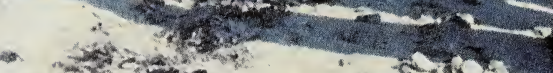

(2)

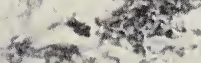

Q

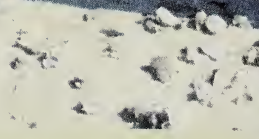

El uso de atarrallas hechas con tela

C. de mosquitero, que son utilizadas con frecuencia en el Caribe para la a. -5. captura de sardinas y otros peces de carnada, es causa de deterioro de los arrecifes. Foto: G. Jácome.
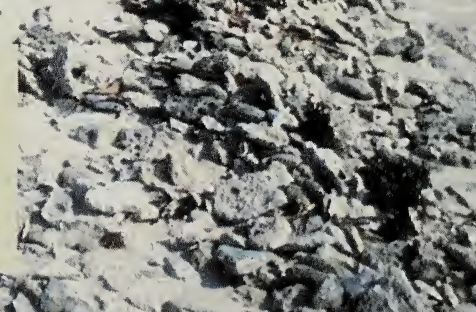

$-1+20$.

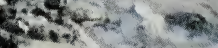


$\mathrm{L}$ os océanos cubren tres cuartas partes de la superficie de nuestro planeta. Se estima que los arrecifes de coral cubren apenas 617,000 kilómetros cuadrados. A pesar de que estos ecosistemas sólo representan el $0.2 \%$ de la superficie de los océanos, contienen una altísima biodiversidad, gracias a sus muy diferentes tipos de corales, centenares de especies de peces y miles de tipos de plantas y animales marinos. Alrededor del $25 \%$ de los peces marinos pasan sus vidas parcial o totalmente en los arrecifes. Toda esta compleja y prolífera vida submarina juega un papel en el balance natural de los arrecifes.

El futuro de los mares tropicales, así como el bienestar de millones de seres humanos en noventa países, depende de la salud de los arrecifes. No obstante, en las últimas décadas se ha acelerado el deterioro de los corales. A nivel mundial se considera que el $10 \%$ de los arrecifes están degradados y que para el año 2020 habremos perdido el $30 \%$ de ellos.
Este artículo señala los factores que están destruyendo estos frágiles ecosistemas marinos, particularmente en el Caribe, y revisa el efecto que pueden tener algunos métodos de pesca muy comunes.

\section{Distribución y tipos de arrecifes}

Los arrecifes de coral se encuentran en los mares tropicales, desde la superficie hasta los 50 metros de profundidad, donde la luz puede penetrar con intensidad y las temperaturas cálidas de las aguas favorecen su crecimiento.

El 15\% de los arrecifes de todo el mundo se encuentran en el Caribe. En las costas de Panamá hay unas 400 hectáreas entre ambos mares. Los de la costa caribeña se concentran en los archipiélagos de San Blas, Colón y Bocas del Toro, en ambos extremos del Istmo, mientras que en la costa del Pacífico se encuentran principalmente en el archipiélago de Las Perlas, y en las islas de Coiba e Iguana.

\section{Tipos de Arrecifes}

Hay tres tipos de arrecifes: los de borde o franja, que crecen a lo largo de las costas; los de barrera, que se forman cerca de las costas, dando lugar a amplias lagunas interiores; y finalmente, los de atolón, más comunes en el Pacífico, que surgen cuando los corales crecen sobre promontorios submarinos. En Bocas del Toro, Colón y San Blas existen los de franja, que bordean las costas de las islas y de la tierra firme.
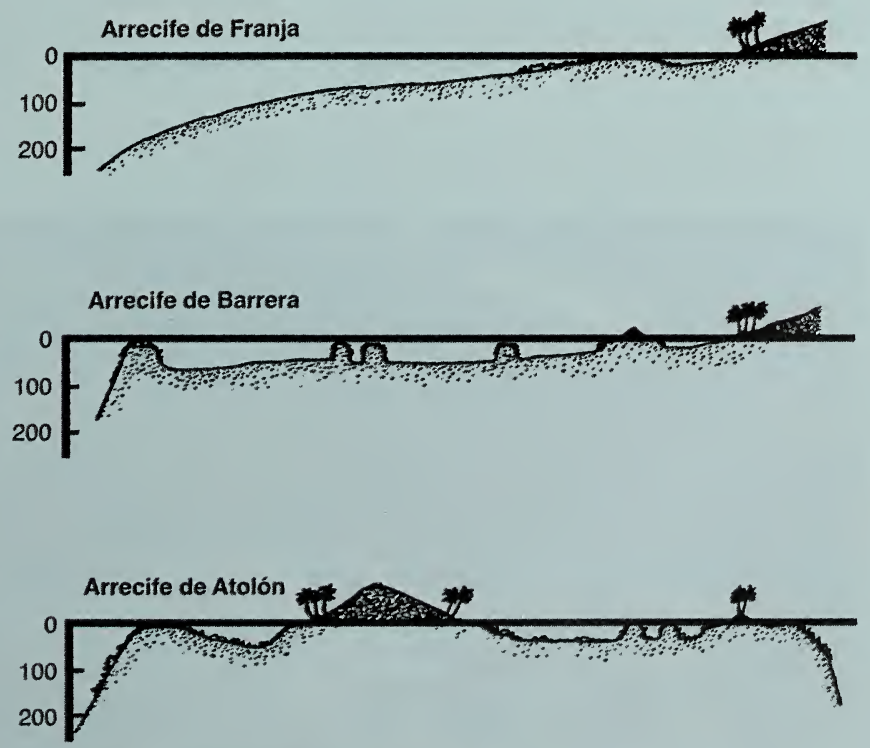


\section{Funciones}

Variadas e importantes son las funciones de los arrecifes. Ellos dan santuario a una cuarta parte de todos los organismos marinos, incluídos peces, tortugas, caracoles, langostas, pulpos, erizos y muchas plantas marinas como las algas. En el Caribe, unas trescientas sesenta especies de peces pasan su vida, parcial o completamente, en los arrecifes.

Otra de sus funciones es proteger las costas de la erosión ocasionada por el embate de las olas. Al servir como una barrera natural, los arrecifes facilitan el desarrollo de otros ecosistemas como los manglares y pastos marinos.

Para noventa países del mundo, los arrecifes son de suma importancia económica, porque proveen alimentos y recreación a millones de personas. En el Caribe, en base a los arrecifes y playas coralinas, se ha desarrollado una pujante industria del turismo que genera millones de dólares en divisas y muchísimos empleos.

\section{El deterioro de los arrecifes}

A lo largo del siglo XX y en especial en los últimos cincuenta años, los arrecifes se han convertido en receptores de volúmenes cre- cientes de aguas servidas, agroquímicos y derrames de hidrocarburos de refinerías y naves. En Panamá, en 1986, se produjo en el Caribe (Bahía de las Minas) un derrame de petróleo que cubrió 60 kilómetros de costa, y causó la mortandad de arrecifes, manglares y pastos marinos. En 1968 ya había ocurrido en este sector un derrame menor, al encallar un tanquero con combustible búnker.

Otro factor de deterioro es la extracción creciente de corales y arena para la construcción y para rellenar las costas.

Actualmente, en torno a la ciudad de Colón e isla Margarita, en la entrada atlántica del Canal, se realizan varios proyectos de rellenos. En la década de 1970 se propuso la construcción de una planta de cemento cerca de esta ciudad, cuya materia prima sería extraída de los arrecifes costaneros, pero afortunadamente el proyecto fracasó.

La multiplicación e intensificación de los impactos negativos sobre los arrecifes obedece al aumento de la población y de algunas industrias en las islas y las costas de los continentes que rodean el Caribe. A ello se suman ciertas políticas económicas estatales, cuyo estilo de desarrollo destruye los recursos naturales, como es el caso de los créditos y subsidios que se otorgan para ex-

Heridas causadas al coral por peces coralívoros, cuya proliferación obedece a la ausencia de sus depredadores, como consecuencia de la sobrepesca.

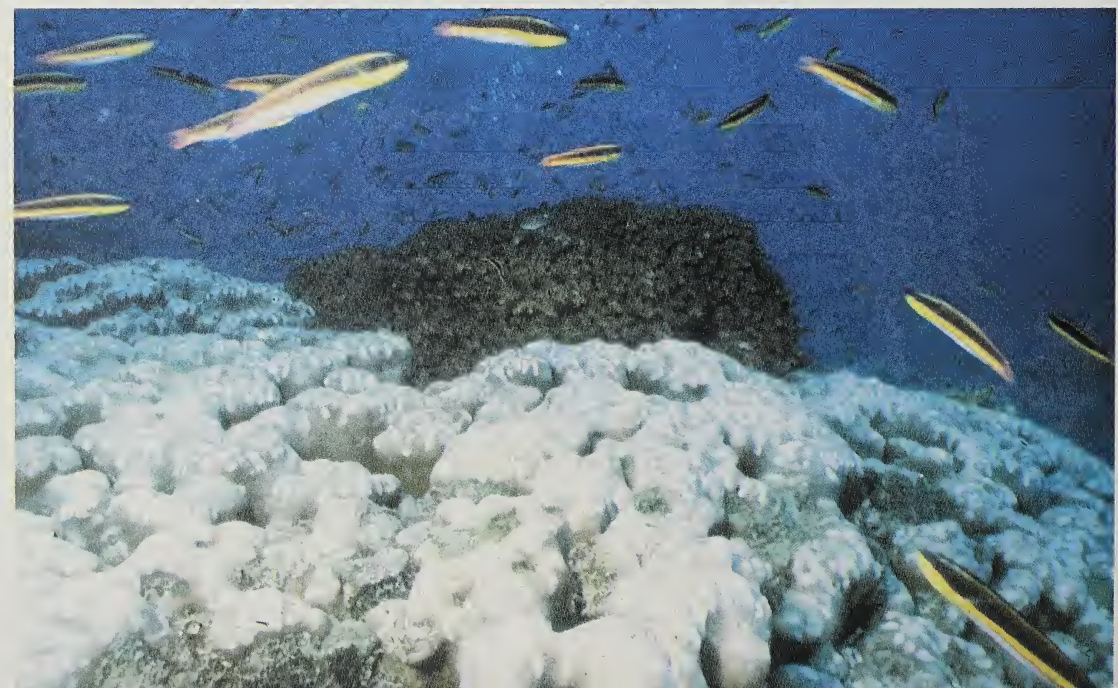


pandir la ganadería y la construcción de carreteras hacia las selvas.

La carretera costanera Colón-PortobeloNombre de Dios trajo una extensa deforestación a lo largo de la serranía que corre paralela a la costa arriba de Colón, en tanto que la expansión ganadera produjo acaparamiento de tierras por parte de ganaderos de la vertiente pacífica, con consecuencias de creciente pérdida de los suelos.

Durante las frecuentes crecientes de la estación lluviosa, los numerosos ríos y quebradas descargan miles de toneladas de sedimentos que salen al mar y forman una espesa capa de lodo que gradualmente cubre los corales y les produce una muerte progresiva.

A los procesos de deterioro ocasionados por el hombre, se añaden las causas de origen natural. Entre ellas, el calentamiento global suscitado por el efecto invernadero, como producto del aumento del dióxido de carbono $\left(\mathrm{CO}_{2}\right)$ en la atmósfera, dado el uso creciente de combustibles fósiles y la destrucción de los bosques. Este proceso altera las temperaturas de la atmósfera y del agua.

Otro factor natural que afecta a los arrecifes es el fenómeno de El Niño, una masa de agua caliente procedente de Australia e Indonesia que llega hasta las costas de Panamá y Suramérica, elevando la temperatura del mar, lo cual produce una gran mortandad de corales. Durante la Corriente de El Niño de 1983 y 1991, ocurrió la muerte masiva de corales en ambas costas del Istmo. El blanqueamiento del coral es el síntoma característico de su muerte.

\section{Métodos de pesca destructivos}

Los científicos consideran que la pesca es una de las actividades más dañinas para la salud de los arrecifes.

En el Caribe, la captura de peces está dividida, mitad y mitad, entre la pesca industrial y la artesanal. La sobrepesca disminuye las poblaciones de peces y de otras especies como caracoles, pulpos y langostas. En algunos casos, la disminución de especies puede tener consecuencias irreversibles, como de hecho está ocurriendo con el bacalao, atún, tiburón, langosta y caracol.

Parte importante del problema son los métodos usados por los pescadores. Uno muy común es el uso de anzuelos de tamaños inadecuados en las cuerdas de pescar a mano $\mathrm{y}$ en los llamados palangres. Este último método consiste en un largo cordel amarrado a boyas, al cual se ata gran cantidad de cuerdas con muchos anzuelos. Estos palangres son anclados usualmente cerca de los arrecifes y sus anzuelos atrapan indiscriminadamente peces de todos los tamaños, incluyendo muchos juveniles y especies de poca importancia comercial.

Otro método destructivo es el trasmallo de "ojo" o luz de malla pequeños, redes que se anclan o se dejan a la deriva de las corrientes, cerca de las costas.

Los trasmallos, además de atrapar peces, capturan tortugas, delfines e invertebrados como cangrejos. Frecuentemente se colocan cerca de los arrecifes y se enredan a los corales, asfixiando y causando la muerte a los organismos que los habitan.

Panamá llegó a contar con casi trescientos barcos camaroneros en ambos mares, sobre todo en el Pacífico. La exportación del camarón ha sido una de las fuentes de divisas más importantes del país. Sin embargo, la sobrepesca ha traído un colapso de la industria. La flota camaronera ha sufrido una drástica reducción y ha sido necesario aumentar considerablemente la temporada de veda.

Aunque a estas embarcaciones se les llama camaroneros, en realidad sus redes atrapan toda clase de especies marinas, conocidas como revoltura, mismas que, luego de separados los langostinos, son arrojadas al mar. Es más, el volumen de revoltura que se bota por la borda de los barcos, es mayor que el de los mismos camarones atrapados.

En cuanto a los corales, son dos los problemas que ocasionan estas naves pesqueras. Primero, con mucha frecuencia lanzan sus anclas sobre los arrecifes; segundo, sus redes arrancan muchas veces los corales del 
lecho marino, además de que el arrastre levanta gran cantidad de sedimentos que luego cubren los arrecifes. En teoría, la legislación panameña exige que este tipo de pesca se efectúe a 3 kilómetros de la costa y se prohíbe en áreas de arrecifes coralinos. En la práctica esto no se cumple y resulta un problema particularmente grave en las islas de Iguana y Coiba.

Otras modalidades de pesca que pueden resultar destructivas son las trampas para peces y las nasas para atrapar cangrejos y langostas, herramientas construídas con alambres o madera.

En los numerosos esteros del país, en cuyas aguas salobres se mezclan las especies marinas con las de agua dulce, es común encontrar los llamados "encierros" o "atajos" que aprovechan las subidas y bajadas de las mareas para capturar peces grandes y pequeños, y otros sin valor comercial.

También es un problema la captura de carnada por los pescadores artesanales, que valiéndose de atarrayas, venenos y hasta dinamita, colectan grandes cantidades de peces para cebar sus cuerdas.

Panamá cuenta con varios miles de pescadores artesanales en ambas costas, mas no ha sido cuantificado el volumen de carnada obtenido por cada uno. En un estudio realizado recientemente en los Cayos Cochinos, Honduras, se estimó que alrededor de cin-

\section{Artes de Pesca más comunes en Panamá}

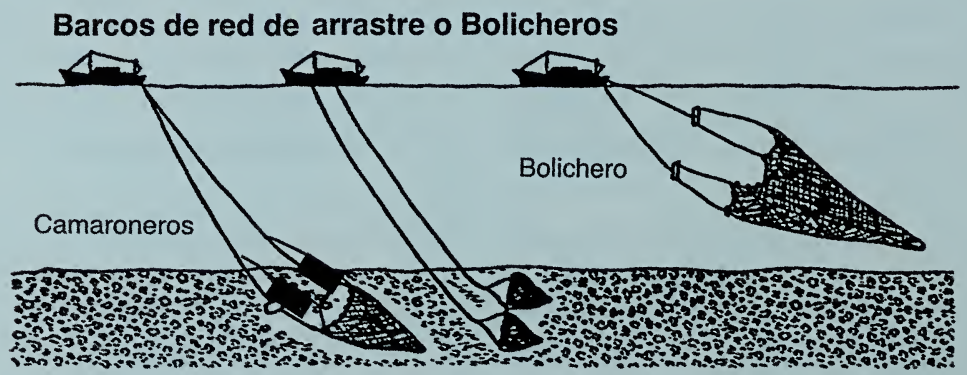

Mallas Agalleras o Trasmallos
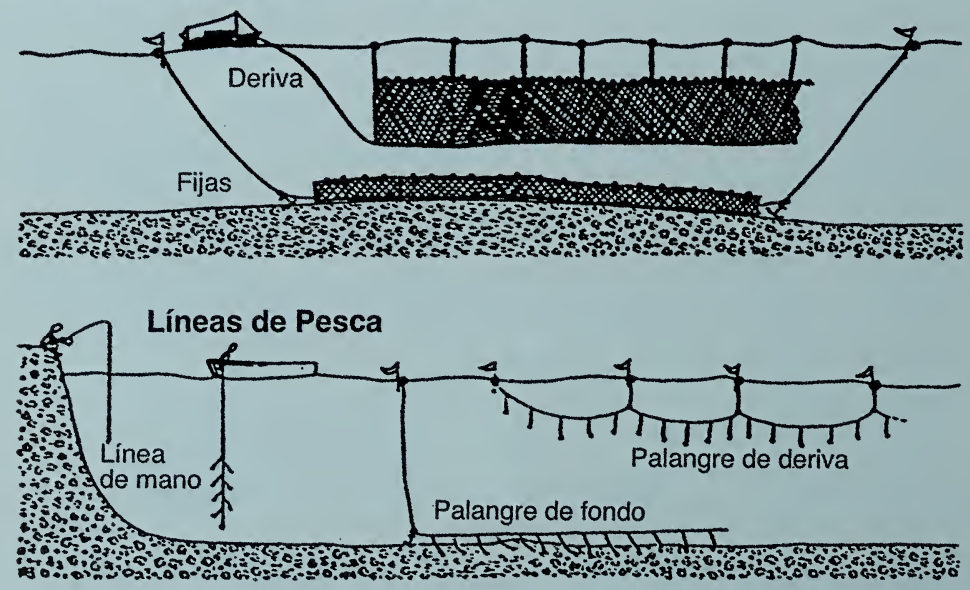
cuenta pescadores atrapaban aproximadamente veinticuatro toneladas métricas de carnada por año, concentrándose en diver. sas especies de sardinas y peces juveniles de arrecifes.

En Panamá están de moda los acuarios decorativos en casas, oficinas y restaurantes. Como muchos de los peces que habitan los arrecifes de coral son los de mayor colorido y formas atractivas, se ha desarrollado una industria de coleccionistas y comerciantes de estas especies, para los acuarios. Este tipo de pesca se centra en peces juveniles, sobre todo de especies pertenecientes a los géneros Gramma, Chromis, Hypoplectrus, Halichoeres, Serranus (mero), Scarus (loros), y Stegastes (damiselas). La actividad se realiza principalmente en Portobelo y Bocas del Toro. En el Pacífico, se lleva a cabo en las islas de Las Perlas y Taboga.

\section{La sobrepesca de la langosta y el caracol}

Dos de las especies más apetecidas y amenazadas por la sobrepesca son el caracol o cambute (Strombus gigas) y la langosta espinosa (Panulirus argus).

La pesca de la langosta y del caracol es motivo de constantes enfrentamientos entre las fuerzas armadas de Honduras, Nicaragua, Belice, Jamaica y Guatemala, debido a las violaciones de sus mares territoriales por parte de las embarcaciones de pesca. En algunos países caribeños, cuando desaparecen estas especies de sus costas, los pescadores se dan a la tarea de actuar ilegalmente, invadiendo fronteras ajenas a sus países y entrando a reservas o parques naturales protegidos.

La captura de estas especies implica grandes gastos en equipos de buceo autónomo, embarcaciones, motores y herramientas.

Por su parte, los pescadores que usan tanques de buceo o sólo máscaras, hacen uso de arpones, ganchos, barras, mazos, venenos y químicos. Estos métodos traen como consecuencia la merma de las poblaciones de langostas y caracoles y la destrucción de los corales donde usualmente habitan.

En Panamá las áreas langosteras son: $\mathrm{Ku}$ na Yala (San Blas) y Bocas del Toro en el Caribe y el archipiélago de Las Perlas en el Pacífico.

En Kuna Yala a diario salen avionetas cargadas con langostas para suplir el mercado nacional e internacional, donde los precios

El buceo autónomo o scuba en el Caribe se usa en la pesca del caracol y la langosta, sin control de la talla o madurez de los ejemplares. Foto: G. Jácome.

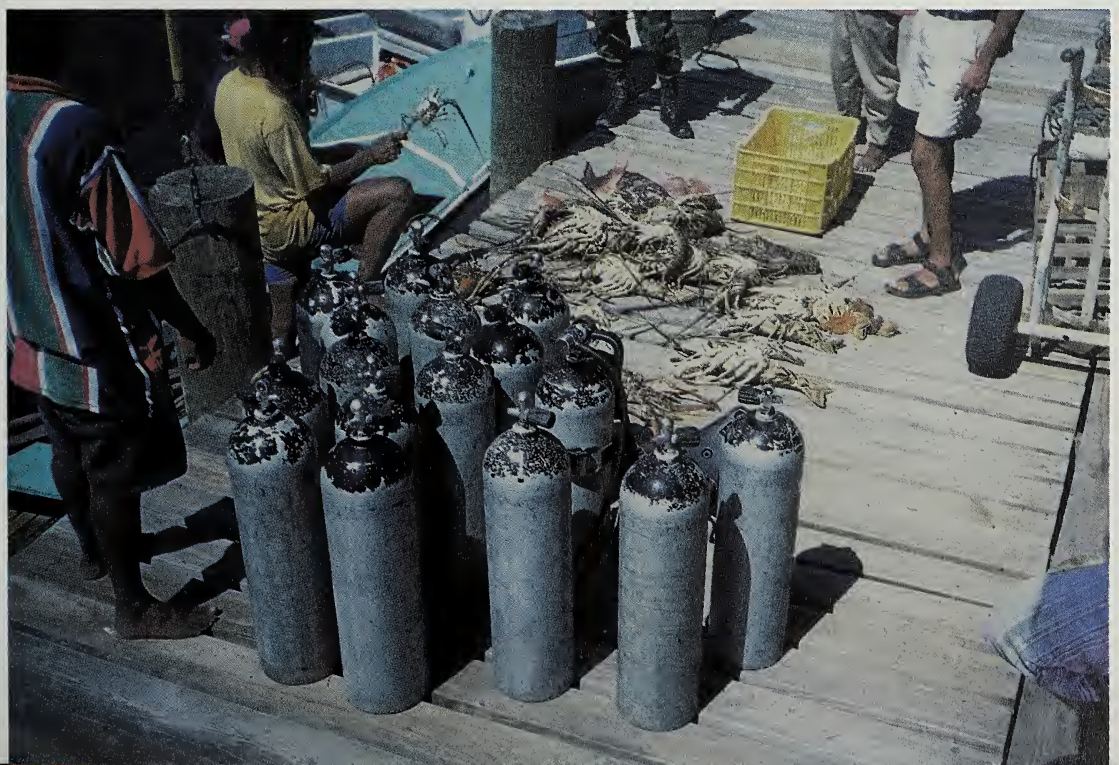


están en alza continuamente. Lamentablemente, carecemos de estadísticas confiables que permitan siquiera un acercamiento a la magnitud del volumen de las capturas. Frecuentemente se observa que muchas de las langostas capturadas no alcanzan las tallas comerciales mínimas, de 3 a 4 pulgadas de tórax, que son las que corresponden a un especimen adulto. Esta información es fundamental cuando se establecen programas de manejo de la langosta.

En países como Belice y Bermudas, y en la Florida, existen regulaciones de veda y leyes que regulan la talla y métodos de captura. En Panamá no hay veda, y aunque existe una ley que regula la talla, esta no se aplica.

En el caso del caracol, además de ser el ingrediente principal de famosos platillos caribeños, también se ecuentra su concha en los estantes de ventas como "souvenirs" para turistas. Otras veces se usa su concha para hacer rellenos para viviendas, como en las islas de San Blas. Al igual que las langostas, no existen estadísticas de la pesca del caracol y como consecuencia de la sobrepesca, las poblaciones han disminuido o han desaparecido de algunas regiones.

Algunos investigadores han recomendado en foros internacionales que se establezca que la talla mínima permitida para su captura sea de 24 centímetros de largo, que se considera el tamaño de un individuo maduro, y salvaguardar así las poblaciones o agregaciones de adultos en reproducción. Un ejemplo exitoso de programas de manejo del caracol es el de Jamaica, donde se han establecido regiones y períodos de captura.

\section{La pesca y los dilemas de la conservación}

Ante la creciente amenaza de la sobrepesca para la supervivencia de las especies marinas, se ha establecido una serie de pactos y convenios internacionales que hacen recomendaciones y sugieren medidas de presión. Entre las especies decretadas como prioritarias a nivel internacional, por considerarse en vías de extinción, están las tortugas, delfines, atún, tiburones y caracoles. Lamentablemente, a pesar de que tales acuerdos existen, muchos países no los cumplen. En Panamá es patente la caza de tortugas en vías de desaparición como la caguama y la verde.

Las leyes que regulan la pesca en Panamá están desfasadas, basadas en datos obsoletos, obtenidos a través de estudios que no cumplen con el rigor del método científico.

Durante las últimas dos décadas se ha establecido una serie de áreas marinas protegidas por ley. Sin embargo, la pesca ilegal en estos parques es común. Las autoridades estatales argumentan que la poca protección es debido a la falta de recursos económicos. No obstante, un problema general a la región es la corrupción de funcionarios, quienes permiten que muchas de estas prácticas ilegales de pesca se den bajo su tutela.

Dentro de la economía pesquera es usual escuchar a las entidades estatales invitando a explotar, o realizando convenios de explotación pesquera con países o empresas foráneas, que en sus países no han sabido proteger sus propios recursos.

Las comunidades pesqueras son parte clave del problema y también de la solución a la degradación de los arrecifes de coral y las especies que los habitan. Generalmente, estas comunidades, en su gran mayoría pobres, no han sido consideradas prioritarias dentro de las viejas y nuevas estrategias económicas.

Aunque no será fácil regular los efectos negativos de la pesca, sí se puede minimizar su impacto, estableciendo programas adecuados de explotación, sistemas de vigilancia para reducir la pesca ilegal, y realizando registros diarios de capturas, claros y amplios. Es imperativo establecer programas de educación ambiental marina dirigidos a pescadores y sus comunidades, así como fortalecer la capacidad de investigación científica para entender mejor el ecosistema marino de los arrecifes y las especies que lo conforman. 


\section{Cantidad y calidad de agua en la Cuenca del Canal de Panamá}

\section{Martín Mitre}

El enriquecimiento del agua por nutrientes provoca la eutroficación. La manifestación más tangible de este fenómeno en la Cuenca del Canal es la proliferación de malezas acuáticas, las cuales afectan la navegación, la estética y afectan los procesos de potabilización. Foto: M. Mitre.

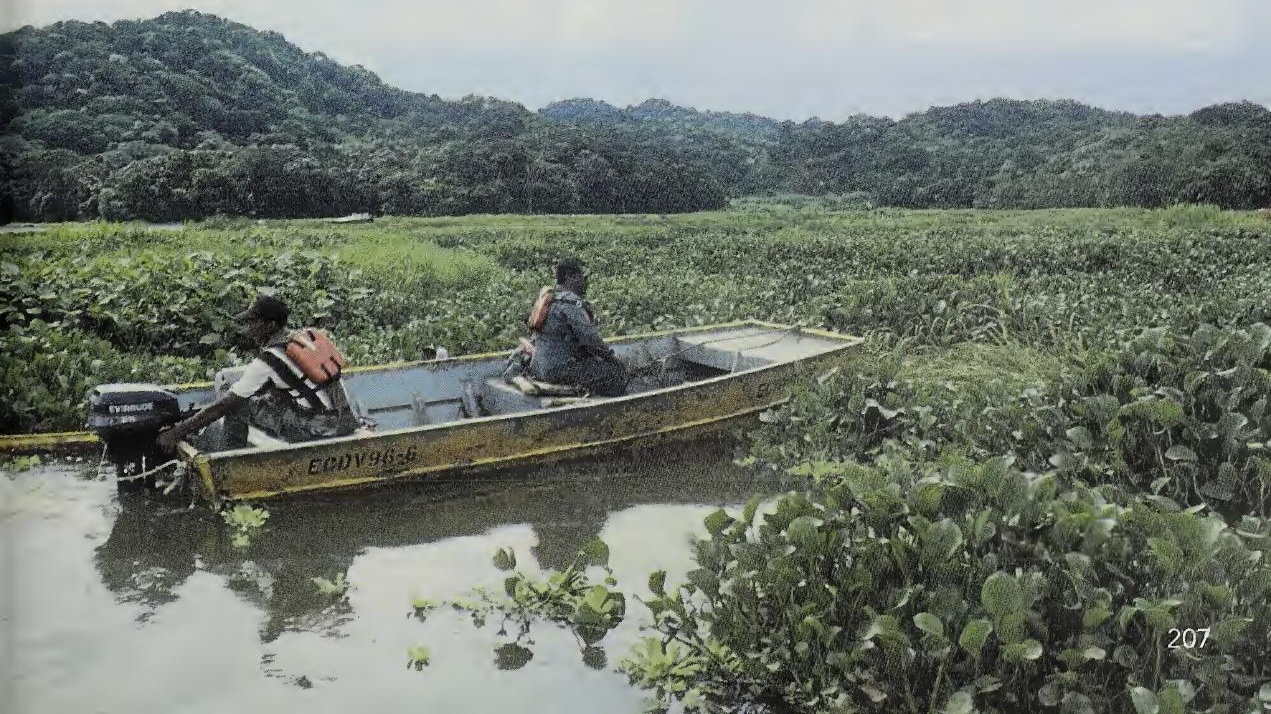


$\mathrm{L}$ a Cuenca Hidrográfica del Canal de Panamá se encuentra ubicada entre las provincias de Panamá y Colón, con una superficie de 3300 kilómetros cuadrados, y una capacidad de producción de 4390 millones de metros cúbicos de agua dulce por año. La Cuenca del Canal aporta el agua necesaria para el funcionamiento del Canal Interoceánico, donde cada barco requiere unos 52 millones de galones de agua por travesía. En ella también se encuentran las plantas potabilizadoras que suministran agua a las ciudades de Panamá y Colón, las cuales concentran la mayor cantidad de población e industrias del país.

La Cuenca del Canal se subdivide en dos sistemas hidrográficos bien definidos: el lago Gatún y el lago Alhajuela. El sistema del lago Alhajuela es de importancia crítica, ya que aunque ocupa menos de un tercio de la superficie total de la Cuenca, aporta alrededor del $46 \%$ del total de agua de la misma. Los principales ríos que drenan al Alhajuela son: el Chagres, el Boquerón y el Pequení. El Pequení tiene los mayores caudales (en litros por segundo por kilómetro cuadrado), sin embargo el Chagres, al tener un área superior de capta- ción, aporta mayor cantidad de agua. De hecho, el Chagres por sí solo aporta el $40 \%$ del agua total que se genera en la Cuenca.

Algo que ha contribuído mucho al mantenimiento de estas altas tasas de suministro de agua al lago Alhajuela, es que los bosques de las montañas donde nacen los tres ríos fueron protegidos con la creación, en 1985, del Parque Nacional Chagres.

Hasta hace poco, la mayor preocupación para los organismos administradores del Canal era la cantidad de agua disponible; sin embargo, no se conocía mucho acerca de la calidad. En los últimos años los esfuerzos también se han dirigido hacia la conservación de su calidad y los factores que la afectan.

\section{Estudiando la calidad del agua}

Como parte de estos estudios, desde 1996 hasta diciembre de 1999, se desarrolló el Proyecto de Monitoreo de la Cuenca del Canal (PMCC), esfuerzo conjunto entre el Instituto Smithsonian de Investigaciones Tropicales (STRI), la Autoridad Nacional del Ambiente (ANAM), y la Agencia Esta-

Remoción de tierra durante la construcción de una barriada comercial en el sector de Alcalde Díaz. La escorrentía arrastra el suelo y lo lleva hacia los ríos y lagos agravando los problemas de sedimentación. Foto: A. Sanjur.

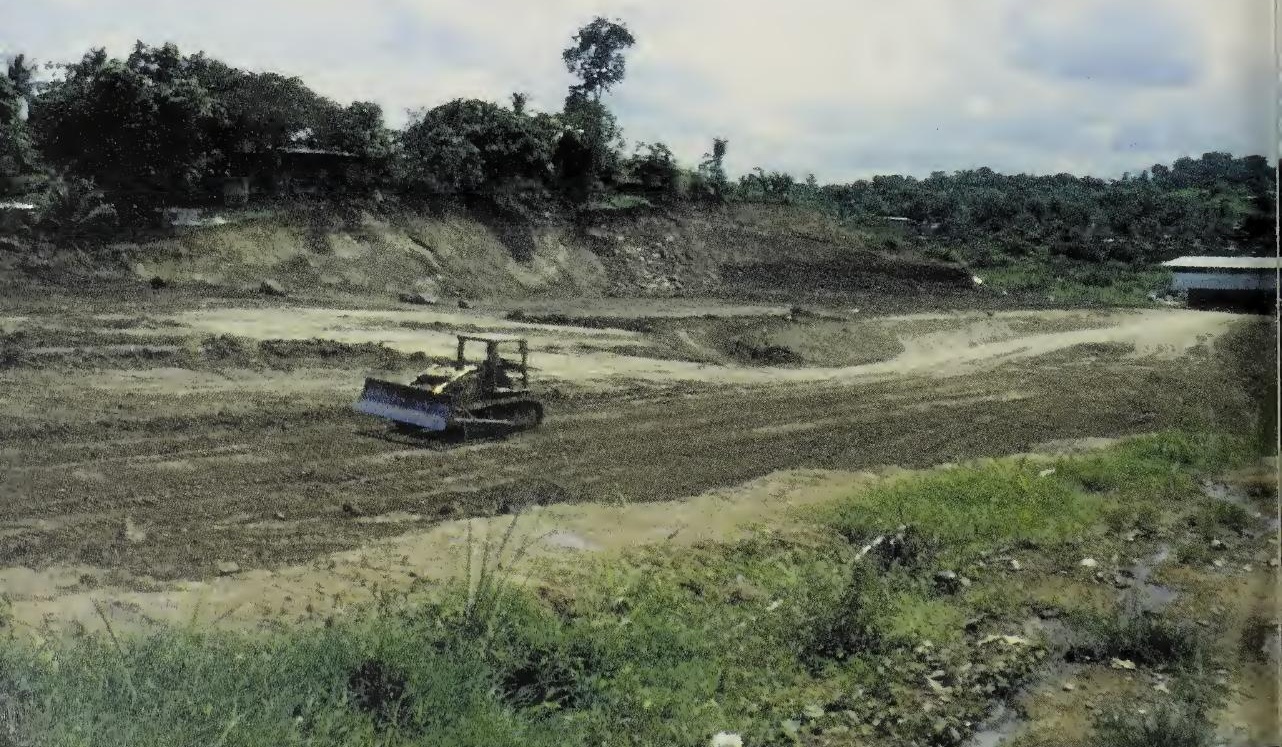


dounidense para el Desarrollo Internacional (USAID). Uno de sus componentes, el de Aguas y Suelos, se encargó del estudio de la disponibilidad y el grado de calidad de las aguas en la Cuenca.

Para el estudio de calidad, el PMCC estableció 15 estaciones permanentes de monitoreo, que aumentaron a 52 durante la estación seca de 1998, con el propósito de cubrir la mayoría de los ríos y quebradas de la Cuenca.

Parte de los estudios se realizaron directamente en el campo, donde se midieron características del agua como su turbiedad, la acidez $(\mathrm{pH})$, la cantidad de oxígeno disuelto en ella, su temperatura, conductividad eléctrica y salinidad. Además se recogieron muestras de agua para analizar el sedimento en suspensión, los niveles de nutrientes (cantidad de fosfatos y nitratos), y la presencia de sustancias químicas disueltas. También fue de suma importancia medir la contaminación por bacterias coliformes totales o fecales (presentes en las heces humanas y de animales).

También se estudió la composición y las características físicas de los suelos y sedimentos, información muy útil al momento de evaluar los efectos de los procesos de deforestación y otros cambios en el uso de los suelos.

A fin de complementar los estudios del PMCC, se recopiló y analizó información de otras investigaciones realizadas previamente en la Cuenca por instituciones como el IDAAN (Instituto de Acueductos y Alcantarillados Nacionales) y el IRHE (Instituto de Recursos Hidráulicos y Electrificación). Además se estudiaron los datos de caudales y sedimentación generados por la ACP (Autoridad del Canal de Panamá).

\section{Deforestación y erosión de los suelos}

El análisis de los resultados de estudios anteriores nos permite afirmar que tanto la erosión como la sedimentación de ríos y lagos han tendido a disminuir, pero la pérdida de calidad en el agua va en aumento. Entre 1981 y 1996 la tasa de erosión dis- minuyó sostenidamente, debido en gran medida a la creación de áreas protegidas que han contribuido a la protección de los bosques, que a su vez han ayudado a preservar el régimen de lluvias y a proteger los suelos. En 1996, un año muy lluvioso, se dio un aumento significativo en la producción de sedimentos; sin embargo, sus niveles no alcanzaron los observados los años anteriores, lo que nos indica la capacidad amortiguadora de la vegetación sobre la erosión.

La erosión es un proceso natural que contribuye a modelar el relieve, y a lo largo del tiempo controla la formación de los suelos por la degradación progresiva de las rocas. Sin embargo, si este proceso se acelera por actividades humanas, tiene consecuencias negativas. Las principales causas del aumento de la erosión y posterior sedimentación son la deforestación, la construcción de barriadas comerciales y caminos de pe-

Lecho seco del río Palenque durante el verano de 1997, debido a la deforestación. Este mismo fenómeno se presentó en otros ríos como Los Hules, Tinajones y Gatuncillo, afectando a la disponibilidad de agua para el paso de los barcos por el Canal.

Foto: M. Mitre.

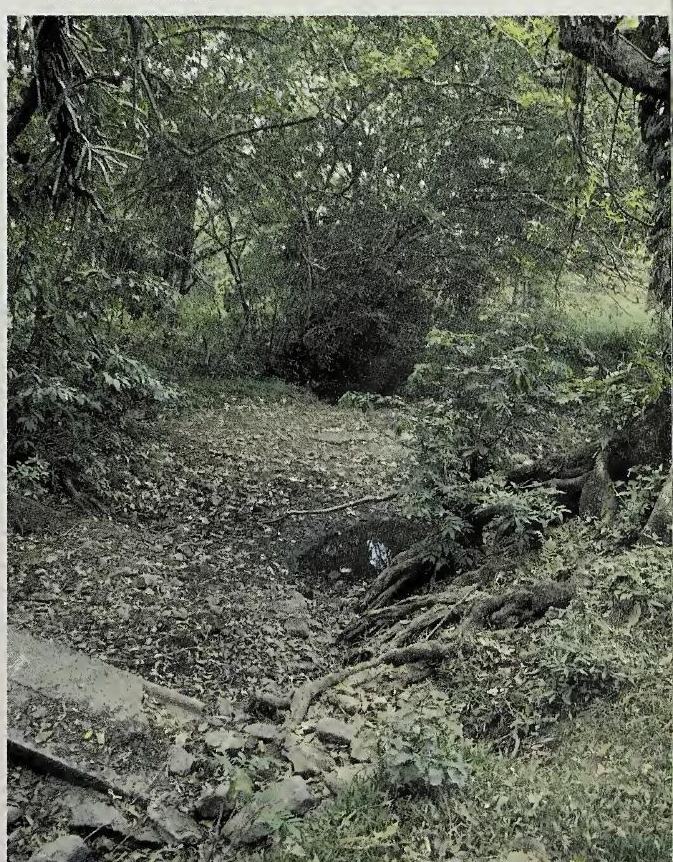


netración, el sobrepastoreo y las técnicas rudimentarias usadas en la agricultura.

Los efectos más palpables del deterioro de los suelos en la Cuenca son: la disminución de la fertilidad, la formación de cárcavas por escorrentía, la reducción de la capacidad de almacenamiento de los lagos por acumulación de sedimentos en el fondo, la reducción del caudal de los ríos, la alteración de la ecología acuática y el aumento de la turbiedad del agua.

En el sector oeste de la Cuenca es donde se presenta mayor deterioro de los suelos, sobre todo en las partes medias de los ríos Cirí Grande y Trinidad, así como cerca de las comunidades de Tinajones, Los Hules, Cerro Cama y Las Pavas. Aquí los bosques han sido talados hasta la orilla de los ríos para establecer potreros y la agricultura de roza y quema, produciendo suelos muy frágiles y zonas propensas a deslizamientos.

Un ejemplo preocupante de la alteración de los niveles de agua disponible para la Cuenca se presentó en los ríos ríos Tinajones y Los Hules. Hace 30 años estos ríos eran muy caudalosos, pero en el verano de 1997 los niveles de ambos bajaron hasta secarse en gran parte de su recorrido, quedando expuestos grandes bancos de sedimento y extensos playones. Según los pobladores del área, esto fue algo que jamás había ocurrido antes.

Los ríos que producen las mayores tasas de sedimento en la Cuenca son los ríos Boquerón y Pequení, que desembocan en el lago Alhajuela. Esto se debe a que ellos recorren zonas montañosas con mucha pendiente y con un intenso régimen de lluvias; además los suelos se derivan de rocas sedimentarias, siendo más propensos a erosionarse. Además, aunque corren dentro del Parque Chagres, hay zonas con desarrollo agropecuario no intensivo. Cuando se creó el Parque Nacional se disminuyó significativamente la explotación agrícola que se daba en la región en la década de los ochentas. De no haber sido así, actualmente esta región estaría sometida a un desarrollo agropecuario y forestal intenso, y seguramente hoy estaríamos ante la pérdida de la mayor parte de la capacidad de almacenamiento del lago Alhajuela.

Deforestación de bosques secundarios para ser reemplazados por monocultivos de teca en el área de Santa Rita, Colón. Esta práctica requiere del uso de fertilizantes los cuales deterioran la calidad del agua, afectan la biodiversidad y hacen los suelos frágiles. Foto: M. Mitre.

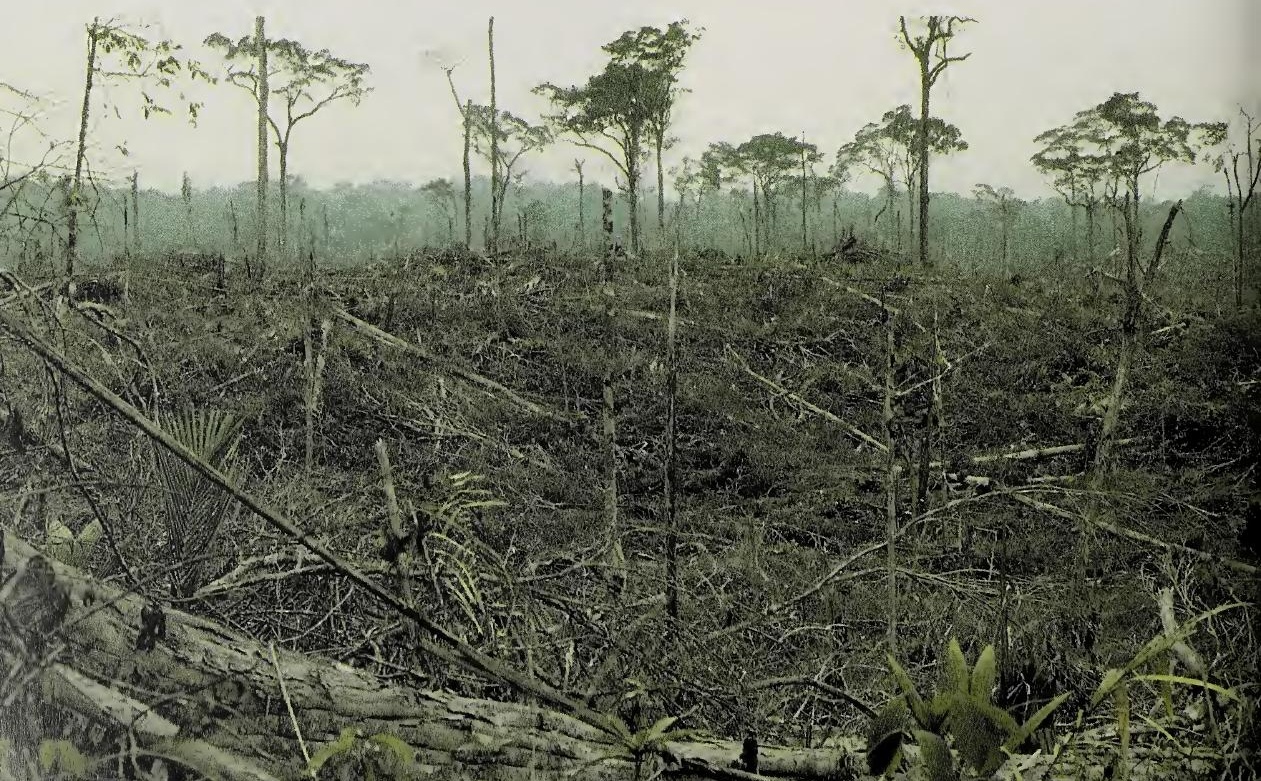


En la actualidad la frontera agrícola se ha desplazado al noroeste, hacia la sierra de Santa Rita, en la cuenca alta del río Gatún. Con la aparición de nuevas fincas se está dando una disminución acelerada de la cobertura boscosa, y se ha llegado a extremos como talar bosques y matorrales naturales para reemplazarlos por plantaciones principalmente de Teca. El manejo de este monocultivo produce suelos más frágiles y afecta en gran medida la biodiversidad del sector.

\section{Aguas servidas, basura y contaminación}

El análisis de los resultados del PMCC indican que en algunos sectores de la Cuenca, sobre todo a ambos lados de la carretera Transístmica, se está dando un aumento progresivo de la contaminación del agua. Esto se debe al vertido no controlado de desechos sólidos (basura, chatarra, etc.) a los cuerpos de agua, así como a las aguas servidas domésticas e industriales y a fertilizantes provenientes de la agricultura.

Los ríos más afectados por estas prácticas son el Chilibre y el Chilibrillo, los cuales drenan la zona más densamente poblada e industrializada de la Cuenca. Para determinar la situación en ambos ríos se ubicaron varios puntos de muestreo desde sus nacimientos hasta sus desembocaduras en el Chagres. Uno de los indicadores de buena calidad de agua es la cantidad de oxígeno disuelto en ella, los niveles altos indican una buena condición. En el Chilibre, los niveles de oxígeno disuelto fueron muy bajos en los puntos poblados y de mayor industria, presentando también niveles altísimos de contaminación bacterial. En el Chilibrillo la zona más contaminada es la quebrada La Cabima (su principal afluente), en la que los niveles de contaminación fecal son preocupantes.

\section{El problema de la eutroficación}

La mala disposición de los desechos provoca un enriquecimiento de las aguas por nutrientes (principalmente fosfatos y nitratos), dándose una degradación progresiva en su calidad, lo cual provoca el fenómeno llamado eutroficación. Este es un fenómeno que ocurre en forma natural al descomponerse la materia orgánica.

\section{Depósito de chatarras cerca del cauce del río Chagres. El óxido y los restos de aceite van a}

parar al río, contaminando sus aguas. Foto: M. Mitre.

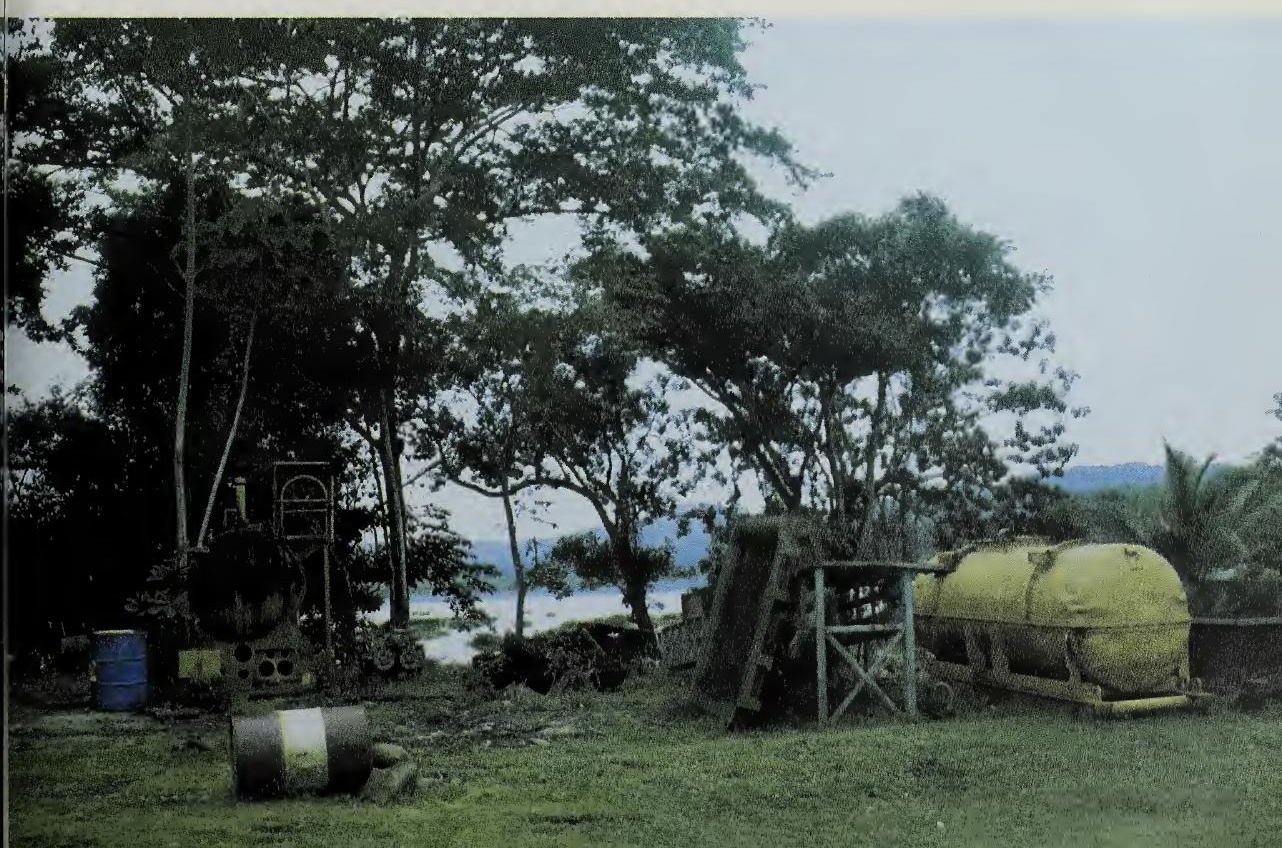


Bajo condiciones normales, la eutroficación espontánea, aun a largo plazo, no produce grandes problemas. Sin embargo, si a este proceso natural se le suma un incremento rápido de nutrientes -producto de actividades humanas- el fenómeno se acelera y el deterioro se percibe rápidamente. Sus manifestaciones más claras son el crecimiento acelerado de algas y vegetación acuática, la coloración verde-grisácea del agua, la producción de mal olor y la disminución en las concentraciones de oxígeno disuelto.

A nivel mundial, la eutroficación constituye actualmente uno de los problemas que más afectan la calidad del agua, y la Cuenca del Canal sufre también de este problema. El crecimiento excesivo de las plantas acuáticas (flotantes, sumergidas y enraizadas), acelera la degradación de las aguas y ocasiona problemas como la alteración del color y sabor, lo que aumenta considerablemente los costos de potabilización. En los embalses estas plantas obstruyen las turbinas y corroen el equipo hidroeléctri- co, afectando la producción de energía. En los lagos, afectan la navegación al provocar el atascamiento de motores y obstruir algunos canales de calado bajo. Además dañan la estética de los cuerpos de agua, incidiendo negativamente en el turismo.

Todos estos problemas de contaminación se presentan en la Cuenca del Canal, siendo desde moderados hasta altamente preocupantes en algunas zonas, causando gastos extras para el IDAAN en el suministro de agua potable y para la Autoridad del Canal en el control de la maleza acuática.

Para conocer el estado de eutroficación en la Cuenca se desarrolló un estudio de la proliferación de la maleza acuática en 12

Fondo seco del Lago Alhajuela durante el fenómeno de El Niño de 1997. La gran cantidad de sedimento acumulado en el fondo del lago es un indicativo de la pérdida progresiva de su capacidad de almacenamiento de agua. Foto: M. Mitre.

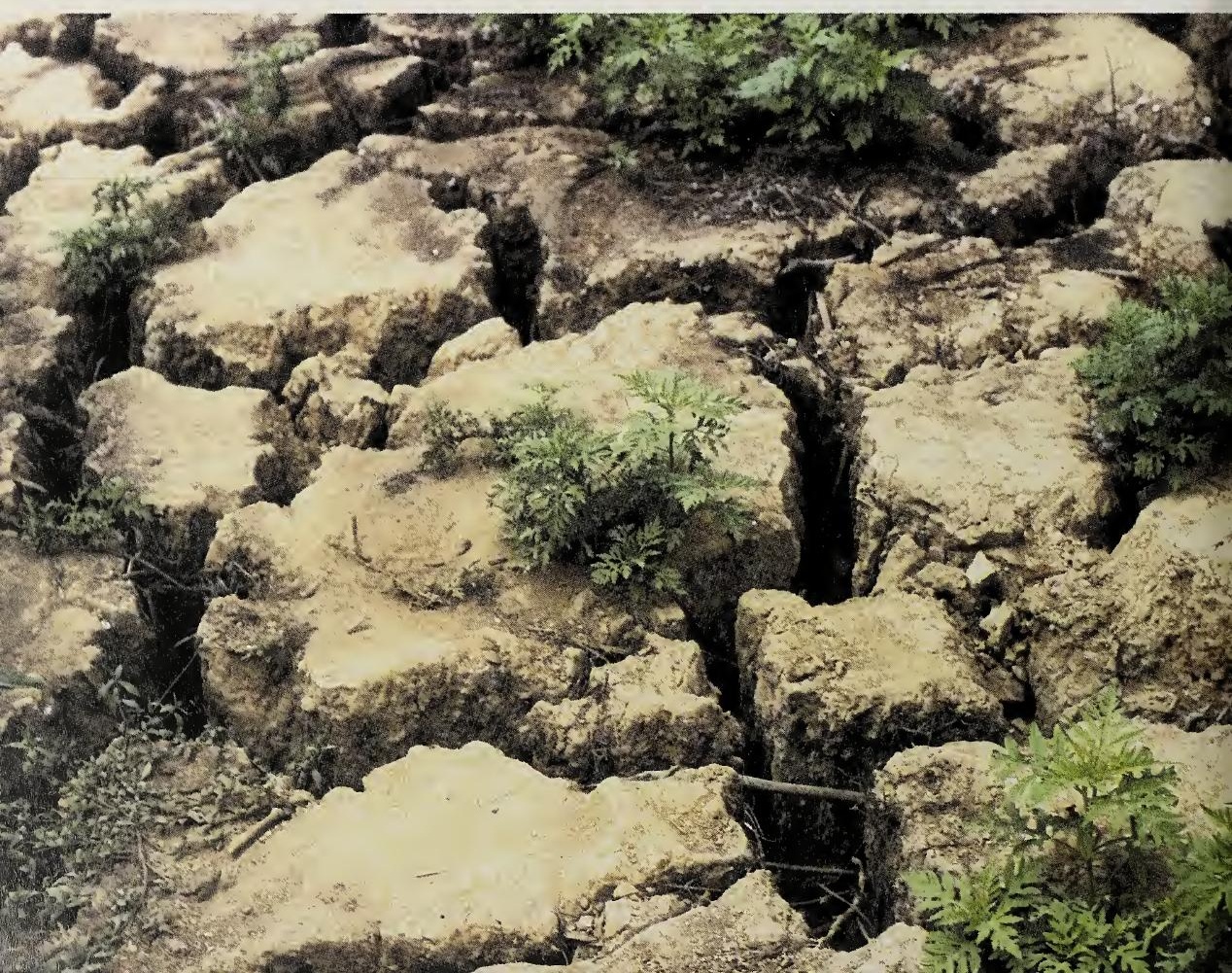


puntos, 9 en el lago Gatún y 3 en el lago Alhajuela. En cada punto se observó la presencia y densidad de la vegetación acuática, se tomaron fotografías y se colectaron especímenes para su identificación. Además, se registró la existencia de vertederos de basura en los márgenes, salida de desagües industriales y domésticos, y se entrevistó a los pobladores de los lugares afectados sobre la frecuencia con que la vegetación acuática se presenta y los problemas que les acarrea en sus actividades.

Se determinó que las zonas más afectadas por la proliferación de maleza acuática son la salida del río Chagres en Gamboa y las desembocaduras de los ríos Paja y Cirí Grande al lago Gatún. En Gamboa hay una alta influencia de los ríos Chilibre, Palenque, Gatuncillo y Limón que desembocan al curso medio del Chagres y arrastran con- taminantes del corredor Transístmico. En el río Paja, los mayores problemas vienen de fincas ganaderas, de plantaciones forestales y de poblados rurales que usan el río como letrina y como vertedero de basura.

\section{Observaciones finales}

En términos generales, la situación de la calidad del agua en la Cuenca del Canal se ha deteriorado en los últimos años, pero todavía no llega a niveles alarmantes. Sin embargo, si continúa el aumento de la población a orillas de los ríos y lagos, se continúan las malas prácticas de desecho, se construyen letrinas de forma no adecuada y se vierten aguas servidas en los ríos, poco a poco se alcanzarán mayores niveles de contaminación, que podrían quedar fuera de control. Aún estamos a tiempo de revertir el proceso.

Gran cárcava en el sector de Cerro Cama. La sobreexplotación ganadera produce suelos empobrecidos y frágiles, los cuales son fácilmente erosionables por las lluvias. Foto: M. Mitre.

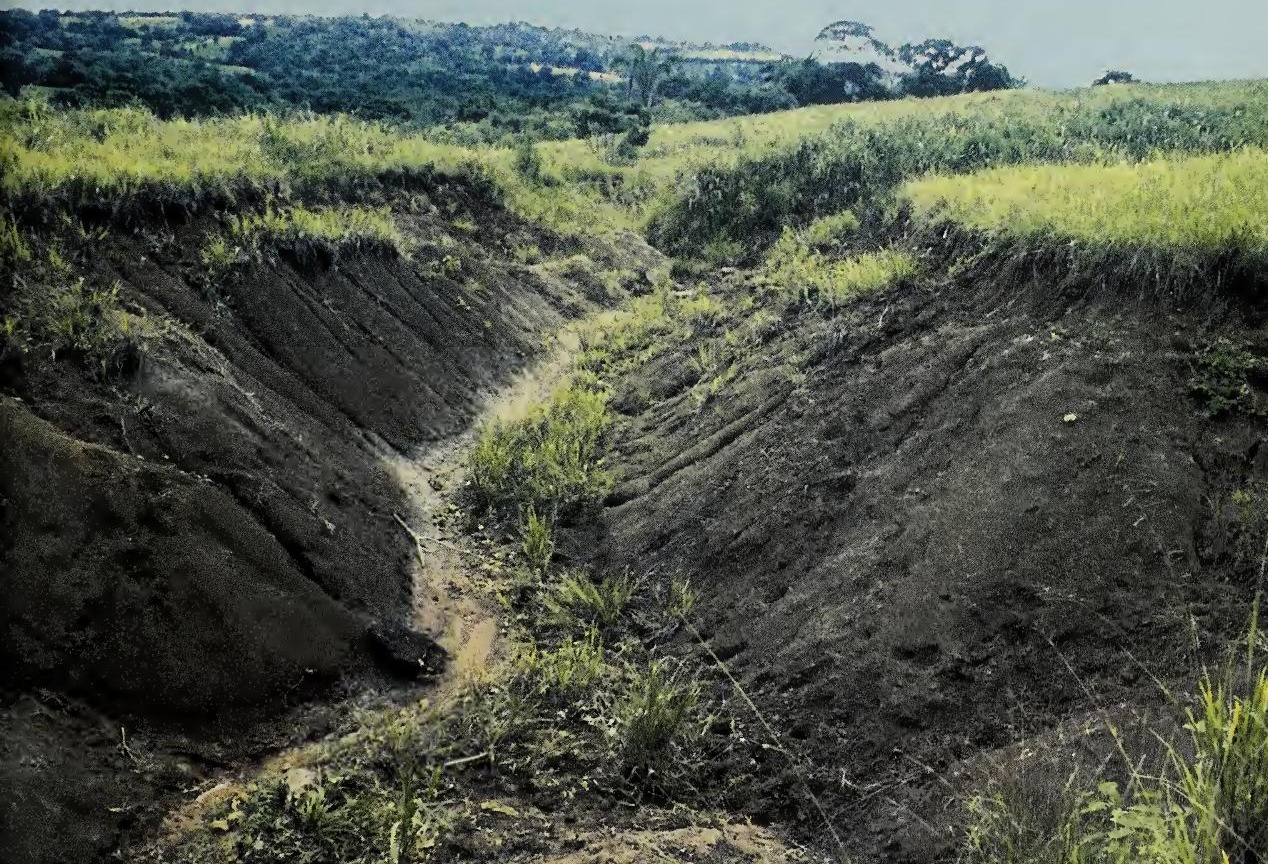




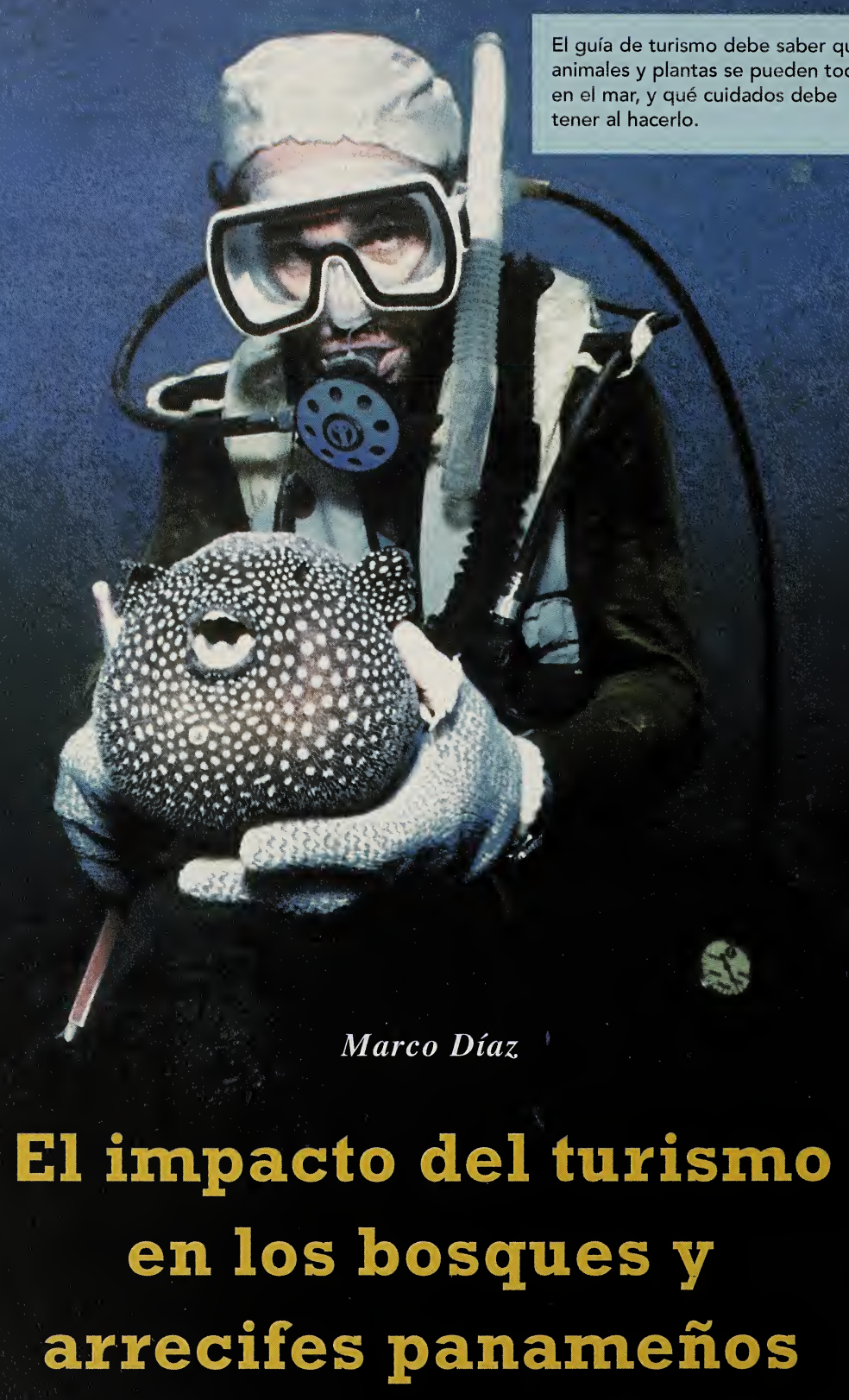


L os estudios sobre los atractivos turísticos de Panamá indican que existen 1,400 sitios de interés, de los cuales 1,005 , es decir el $72 \%$, son sitios naturales. El ecoturismo, la industria sin chimeneas, se considera como una de las actividades con mayor futuro en el país.

Ecoturismo se define como "la afición de viajar a un área natural o ecológica para admirar, interpretar es decir explicar, estudiar e interactuar con los paisajes naturales, las plantas y los animales silvestres y las manifestaciones culturales existentes en dichas áreas.”

Veamos ocho conceptos básicos que deben caracterizar al ecoturismo. Asimismo, identificaremos algunos impactos ambientales negativos que a lo largo del país ocasiona el hombre a dos de los ecosistemas con mayor potencial turístico: los bosques tropicales y los arrecifes de coral.

Finalmente, indicaremos algunas medidas para mitigar estos impactos deletéreos, incluyendo la conducta que los visitantes deben guardar al visitar las áreas silvestres.

\section{Ocho preceptos fundamentales}

Existen ocho conceptos básicos que una actividad debe cumplir para clasificarse como ecoturística:

\section{Los ecosistemas deben estar en buen es-} tado y completos. Teóricamente los encontramos en las áreas protegidas. Sin embargo, en Panamá no todas estas áreas cumplen con esta regla, en buena medida por la conducta inapropiada de un gran número de visitantes, en su mayoría nacionales, que al no saber como comportase, degradan el ecosistema, por ejemplo con ruido o basura.

2. Educación ambiental. Las giras a zonas silvestres deben ser ante todo educativas. El ecoturista busca conocimientos de calidad sobre el área que visita, sobre su flora y fauna, historia, cultura y costumbres. El guía juega en esto un papel fundamental, pues debe poseer toda una gama de conocimientos así como habilidad para transmitirlos de manera clara, sencilla y veraz.
3. La investigación científica es fundamental para garantizar la calidad del turismo naturalista. La participación de los científicos es vital, pues sus estudios generan la información que luego será transmitida a los visitantes. Corresponde asimismo a los científicos realizar los monitoreos ambientales de las áreas turísticas, para evaluar la salud de los ecosistemas y el impacto de las actividades ecoturísticas. Ejemplo de esta relación entre la ciencia y el turismo es el Monumento Natural Barro Colorado, que debido a los miles de estudios sobre plantas y animales realizado durante más de 75 años, permiten brindar al visitante una cantidad y calidad de información excepcional sobre los bosques tropicales.

4. Seguridad y atención. El turista desea sentirse seguro, bien atendido y respetado. Los alimentos que se le brinden deben ser sanos, bien presentados. El país entero, incluyendo el guía, la operación y el que trata con los visitantes, debe reflejar tal sentimiento de seguridad y hospitalidad. Panamá, país con vocación de servicios, se ha caracterizado por la escasa vocación de su gente a servir bien al visitante, aunque sea con una sonrisa.

5. Participación de las comunidades. Las comunidades locales del país deben beneficiarse del turismo naturalista, a través de ingresos. Ello les garantizará un mejor nivel de vida y asegurará que los recursos naturales no se usen destructivamente, por ejemplo, por la caza descontrolada y la sobrepesca.

6. Fondo de conservación. Todo visitante debe, en una forma $u$ otra, ayudar a compensar el área natural visitada, contribuyendo a generar fondos para mantener la infraestructura, equipamiento del personal, actividades de monitoreo ambiental y la investigación científica. La manera más común de lograrlo es cobrando al visitante un "fondo de conservación". Sin embargo, este cobro no aportaría nada si constantemente se hacen excepciones y descuentos a ciertos visitantes, o si estos dineros no se invierten en el área protegida donde se generaron. Las empresas de ecoturismo deben colaborar con el área protegida, por medio de donaciones en efectivo o en espe- 
cies, e informando a la administración del área sobre irregularidades observadas.

\section{Bebidas alcohólicas. El consumo excesi-} vo de alcohol durante una gira de campo a un área protegida, pone en peligro la seguridad del grupo, lo que es responsabilidad del operador. El guía podría perder el control del grupo y un accidente puede costarle una demanda legal. Además, la persona ebria pierde la conciencia de sus actos y puede ocasionar serios impactos al ecosistema.

8. Toda presencia humana en un área natural tiene un impacto. Por ello, debe controlarse el tamaño de los grupos y su conducta. En un sendero en el bosque, los grupos no deben de exceder las 15 personas por guía: más de 10 personas dificultan su labor. Según aumenta la cantidad de personas, disminuye la atención personalizada, y por tanto, la cantidad y calidad de la información transmitida. Ejemplo de los impactos negativos sobre el bosque sería la presencia de un grupo de 15 visitantes en la estacion seca: sus pisadas sobre la hojarasca producirían tanto ruido que asustaría a los animales ahuyentándolos, degradando así la calidad de la gira.

En síntesis, toda actividad que no cumpla con estos ocho conceptos no puede considerarse "ecoturismo".

\section{El ecoturismo y el turismo}

Son varias las diferencias entre ambas actividades. Primero, el ecoturista busca adquirir experiencias educativas bajo la guía de expertos. Esta actividad depende íntimamente de la investigación científica que genera los conocimientos necesarios para satisfacer el apetito de información del visitante. El turista regular se inclina hacia el aspecto recreativo y solicita menos información sobre el país y sus costumbres. Por tanto, los guías turísticos tradicionales requieren un menor nivel de preparación ecológica que el guía ecoturístico.

Segundo, el ecoturismo se desarrolla principalmente en áreas silvestres, por lo cual los grupos de visitantes deben ser pequeños para disminuir el impacto sobre la naturaleza y poder ofrecer más información y de mayor calidad. Contrariamente el turismo regular es masivo y se le ofrece a grupos grandes de personas. Un turista regular puede convertirse en ecoturista en algún momento del viaje, al participar en una gira guiada por un experto a un área natural y con un grupo pequeño.

Una gira ecoturística cuesta más que la de turismo regular, debido al menor tamaño de los grupos, la mejor capacidad del personal técnico, la necesidad de aportar fondos a la conservación de las áreas silves-

Una playa en Isla Iguana en grave estado de contaminación, después de un aguaje. La basura fue arrastrada por las corrientes desde la ciudad de Panamá, a 150 kilómetros. Foto: M. Díaz.

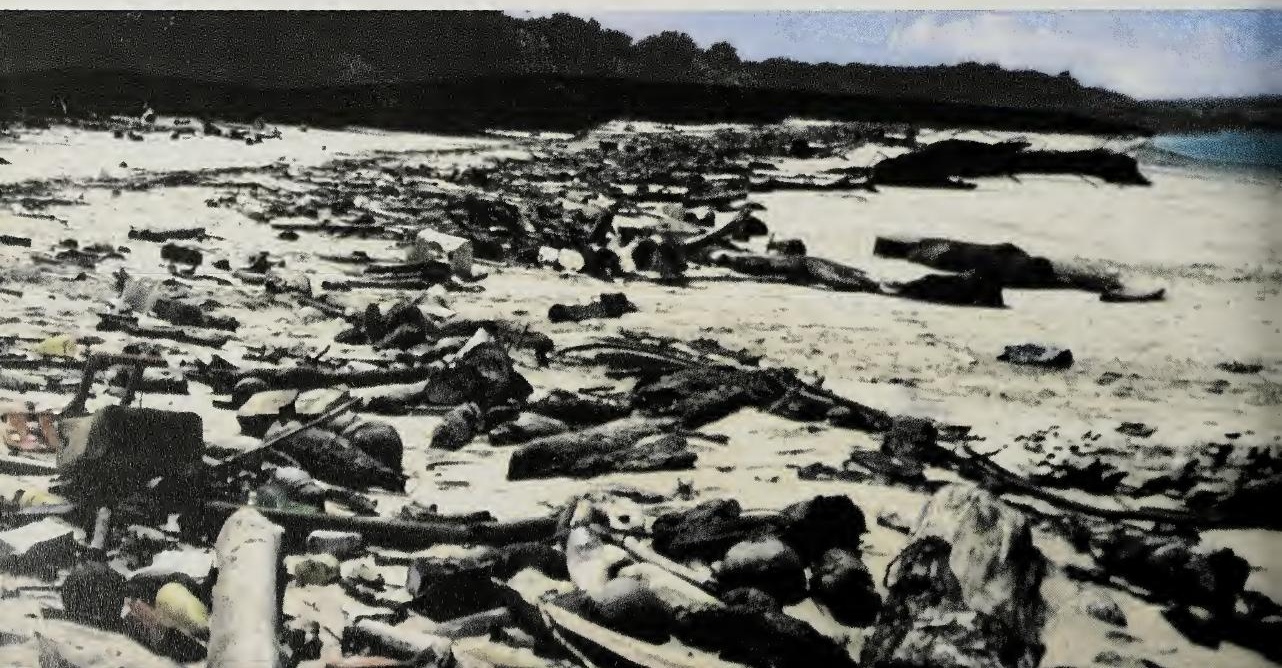


tres y el material que debe generarse y transmitirse, sea este escrito o en video.

Durante casi un siglo, Panamá ha contado con la presencia de entidades de investigación de fama internacional, como el Instituto Smithsonian de Investigaciones Tropicales, institución de conocimientos avanzados sobre los trópicos, que ha generado una enorme cantidad de información, de la cual carecen otras naciones de Centro y Sur América. Este acerbo debería aumentar nuestras ventajas de mercadeo y generación de giras naturalistas con mayor calidad y diversidad de información.

Impactos del turismo sobre los ecosistemas.Veamos algunos costos del turismo en las áreas silvestres.

La tala de bosques para la construcción de infraestructura, como caminos, hoteles, cabañas, centros de visitantes y estaciones de guardaparques deterioran el medio. Antes de edificarse, deben realizarse estudios ambientales de campo que garanticen la selección del sitio indicado y que estas estructuras encajen arquitectónicamente en el medio natural. Las medidas de mitigación de daños deben observarse para mantener la calidad del medio.

El frecuente recorrido de senderos, ya sea a pie, a caballo, bicicletas o vehículos mo- torizados, degrada los senderos, sobretodo en áreas quebradas y lluviosas como en Panamá. La velocidad de degradación de un sendero dependerá de la topografía y cantidad de visitantes. Un buen método de mitigación es utilizar bloques de cemento para construir los senderos, que además facilitan al visitante caminar sobre una superficie fija. Tal deterioro por la falta de control sobre el número de visitantes se observa en el sendero El Charco, en el Parque Nacional Soberanía. Al visitar un bosque, debe mantenerse a los visitantes dentro del sendero para evitar erosionar las áreas adyacentes a éste.

Casi siempre, quienes visitan las áreas naturales desean llevarse un recuerdo. Este impacto es común y es más dañino en las áreas marinas y sitios arqueológicos. Debemos recordar que todo componente físico y biológico de un área es importante, incluyendo rocas, conchas, arena o esqueletos de cangrejo, y por tanto deben permanecer en el sitio. Si cada visitante del Refugio de Vida Silvestre Isla Iguana decide llevarse una colonia de coral, el arrecife y las blancas arenas que tanto atraen a sus visitantes desaparecerían en menos de 30 años. Llévese fotografías solamente.

La cacería es muy común en las áreas protegidas de Panamá, aunque la mayoría caza para subsistir. También debemos respe-

Las playas de Isla Iguana deben permanecer limpias, tal como es su estado natural, para conservar su carácter silvestre y su importancia turística. Foto: M. Guerra.

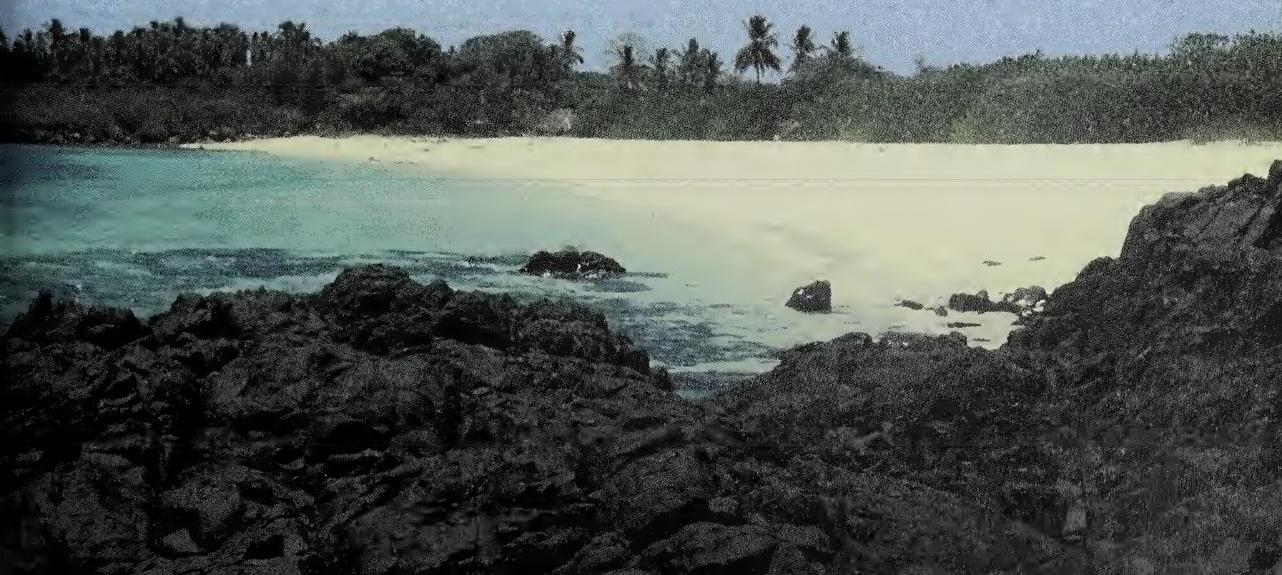


Heraclio López.

y Sarah Dalle

\section{El desarrollo sostenible en la reserva biológica y Comarca Kuna de Wargandi, Darién}

Bohíos de la comunidad de Nurna, con techos hechos de la palma de soska. Foto: Dobbo Yala.

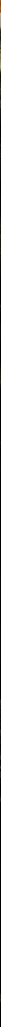


$\mathrm{U}$ no de los pueblos menos conocidos de Panamá es el de los kunas del alto río Chucunaque, en Darién. Esta región, entre la Cordillera de Kuna Yala, la Comarca de Madugandi, Distrito de Chepo, el Distrito de Chepigana y el río Sogubdi, es la última comarca creada por el estado panameño, mediante la Ley 34 del 25 de julio de 2000, y se conoce como Comarca Kuna de Wargandi que a su vez también es una reserva biológica. Su nombre posiblemente deriva de dos viejos vocablos kuna: war: tabaco y gandi: mucho. En español se leería "río de mucho tabaco".

La mayoría de sus 77,500 hectáreas están cubiertas por un espeso bosque húmedo tropical, caracterizado por una estación seca que va desde enero a abril y una lluviosa de mayo a diciembre. Las precipitaciones anuales fluctúan entre los 1,850 y $3,400 \mathrm{mi}$ límetros aunque la media anual es de 3,000 milímetros. Su temperatura media anual es de 26 grados centígrados, con una humedad relativa de $85 \%$.

La atraviesan dos grandes ríos: el Chucunaque, en cuyas orillas se encuentran las comunidades de Nurna, Wala y Morti, y el Sogubdi o Sucurtí, río relacionado con el florecimiento de la cultura kuna del siglo XVIII. El Sogubdi ha jugado un papel clave en la historia y expansión del kuna en la región oriental de Panamá. Los kunas se establecieron a sus orillas siglos atrás y a la llegada de los españoles la región estaba habitada por indígenas de la familia lingüística chibcha, a quienes ellos denominaron cuevas, ascendientes de los kunas de hoy. Desde los años de 1719 a 1726 muchos pueblos kunas emigraron al norte, hasta la costa caribe de Kuna Yala (San Blas) y hacia el valle del río Bayano, al oeste. Esta vigorosa expansión kuna obedeció en parte a la existencia de muchas enfermedades como la malaria y la fiebre amarilla que diezmaron a los kunas de Darién.

Hoy los 1,500 habitantes de Wargandi aún poseen un profundo sentido de identidad y gran conciencia del valor de su modo de vida; mantienen vivas sus tradiciones culturales, como el uso de su lengua y cantos, su religión y filosofía de vida, las cuales guardan una estrecha relación con el bosque. La cultura de los kunas del alto Chucunaque difiere poco de la de Kuna Yala, así como de los que habitan el río Bayano y las cabeceras del Tuira, donde están las comunidades de Pucuro y Paya, cerca de la frontera con Colombia.

\section{El impacto de la Panamericana en Darién}

Hasta la construcción de la carretera Panamericana hacia el Darién, en la década de 1970, una espesa carpeta selvática cubría el valle del Chucunaque. Con la carretera entraron los colonos, campesinos del interior, tanto agricultores como ganaderos, que hicieron caseríos y rápidamente cambiaron el paisaje. Las últimas migraciones, de mayor incidencia, ocurrieron a partir de 1978 con la apertura de la carretera desde río Bayano hasta Yaviza, a orillas del Chucunaque. Miles de hectáreas de selvas fueron derribadas, quemadas y convertidas en potreros.

La carretera desató una intensa actividad de extracción de madera de las selvas. Los kunas comienzan a participar en este ne-

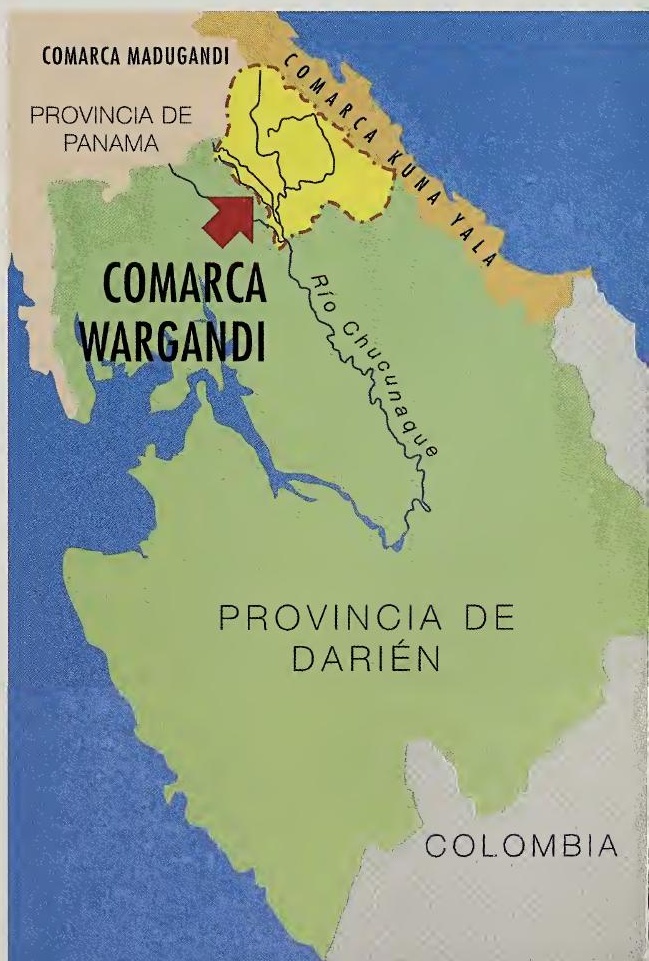


Las consecuencias de la colonización de los bosques y la extracción de la madera han resultado gravísimas para los kunas del Chucunaque. Con la deforestación ocurrió una notable disminución en el caudal del Chucunaque en la estación seca, un agotamiento de la materia del bosque para medicinas y viviendas, que cada día se encuentran más lejos de las comunidades. Asimismo, una mayor escasez de la caza y la pesca.

Además, muchos hombres abandonan la agricultura de subsistencia para convertirse en peones de las empresas madereras que operan especialmente en la estación seca, cuando se realiza la zafra maderera. Los jóvenes, más interesados en obtener dinero, quieren "modernizarse" y por tanto no prestan tanta atención a los sistemas agroforestales tradicionales y otros aspectos de la cultura, como la medicina, que se están abandonando.

\section{El proyecto de desarrollo sostenible}

El preocupante deterioro ambiental motivó a los dirigentes de Wargandi a buscar apoyo de la Fundación Dobbo Yala, organización no gubernamental sin fines de lucro formada por profesionales indígenas para impulsar el desarrollo de las comunidades kunas y conservar su patrimonio natural. Desde 1993 se emprendieron tareas conjuntas entre esta ONG y las comunidades del Chucunaque, para buscar alternativas de manejo sostenible de recursos naturales, sobre todo de los bosques. El resultado más sobresaliente ha sido la participación de las comunidades en el desarrollo sostenible de su región.

Dobbo Yala, conjuntamente con las comunidades de Nurna, Wala y Morti tratan de enfrentar la expansión de la frontera agrícola y evitar la conversión de sus tierras vírgenes en potreros para la ganadería por parte de los colonos interioranos mestizos. Con este objetivo, gracias al "Proyecto de Desarrollo Sostenible de Wargandi", financiado por la Agencia Internacional de Desarrollo de Dinamarca (DANIDA), a través de NEPENTHES, una ONG danesa, se han organizado tres tipos de actividades: la legalización del territorio kuna, la educación ambiental y la búsqueda de alternativas económicas.

\section{Los programas del proyecto}

La legalización del territorio promueve la autogestión y busca establecer nuevas relaciones administrativas y de respeto mutuo entre los kunas de Wargandi y el Estado Panameño. Entre los logros significativos está la sanción de la Ley 34 del 25 de julio de 2000, que crea la Comarca Kuna de Wargandi. Reconoce esta ley la propiedad colectiva de las tierras indígenas; prohíbe la apropiación privada de estas tierras; reconoce al Congreso General como autoridad máxima tradicional de la Comarca, cuya función medular es fortalecer, desarrollar, conservar y proteger la cultura, a fin de promover su desarrollo económico y social. También es intención de esta ley la protección, conservación y uso sostenible de los recursos naturales. Se prohíbe la explotación forestal intensiva y otras actividades que atenten contra la biodiversidad y los recursos naturales del área. Para la

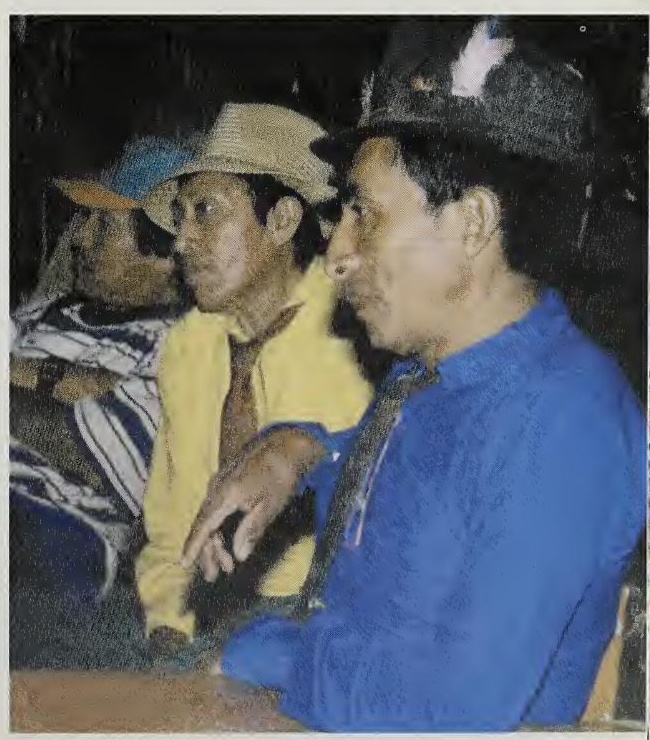

Arriba: Los líderes/dirigentes de la comunidad Kuna de Wargandi se reúnen para discutir asuntos comunitarios. Foto: Dobbo Yala. 
Comarca de Wargandi la próxima tarea es elaborar un plan de manejo y desarrollo de la región según su cultura y tradiciones, garantizando también la biodiversidad.

Paralelamente a la búsqueda de apoyo legal para delimitar las tierras, se ha capacitado a los dirigentes kunas del alto Chucunaque en temas como los derechos indígenas en las constituciones políticas, en la legislación panameña, en las leyes ambientales; en el derecho internacional, recursos naturales y pueblos indígenas, y cómo preparar documentos sobre estos temas, es decir, la redacción de cartas y resoluciones. Gracias a esta capacitación los líderes indígenas conocen mejor sus derechos básicos.

El propósito del programa de educación ambiental es lograr en el área una comunidad sana, en base a una combinación entre los conocimientos tradicionales y las prácticas modernas para minimizar la degradación del bosque y el ambiente. Desde el inicio Dobbo Yala comprendió que esta educación ambiental debía enraizarse en la cultura kuna, partiendo de la visión indígena de la naturaleza. Se trabajó con tres hombres y dos mujeres kunas, conocedores de la gran tradición oral kuna. Se entrevistaron y se grabaron en cintas magnetofónicas sus conocimientos sobre la ecología y el ambiente; especialmente estudiando y sistematizando los conocimientos y pensamientos sobre la vida y el lenguaje de las plantas y sus relaciones con el hombre; sobre el origen del hombre y el comportamiento de las aves según Wagibler (ornitólogo kuna); acerca de la creación y evolución de la madre tierra; y sobre la redondez de la tierra y el equilibrio cósmico. Esta investigación está sintetizada en una cartilla titulada "We napanega ibi nuedi, anmar nue sabgumala" (Esta es nuestra madre tierra, cuidémosla). Todo ello nos llevó a concluir que los kunas poseen un rico y vasto conocimiento sobre la conservación y el manejo del bosque que fueron la base para elaborar los materiales didácticos.

El programa de alternativas económicas y de producción agrícola promueve la autonomía económica de los kunas de Wargandi y el uso sostenible de los recursos naturales. Se han programado actividades durante los tres años del proyecto. Algunos logros son: la capacitación en la producción de café a personas que lo cultivan en la región; el establecimiento de una comisión de venta por comunidad, con conocimientos básicos en administración y comercialización; capacitación para el transporte y la

Comunidad de Nurna, situada en las riberas del Río

Chucunaque, tal como lucía en 1999. Foto: Dobbo Yala. 
ubicación de mercados. Nuestro agrónomo ha cultivado con los kunas de Wargandi dos parcelas: una de 5 hectáreas, con $5,000 \mathrm{ca}$ fetos de la variedad caturra, y dos de 10 hectáreas con 10,000 plantones de la misma variedad.

\section{Estudio de conservación de plantas útiles}

Un aspecto importante para el desarrollo sostenible de Wargandi es conservar las plantas útiles. Para los kunas el bosque es a la vez un supermercado, farmacia y ferretería. De él obtienen toda clase de materiales para construir sus viviendas, cayucos, fibras para tejidos, utensilios domésticos como pilones, batidores y cucharones para la cocina. También materiales para la confección de flautas, chichas, y pepitas pa- ra sus ceremonias religiosas, así como una extensa lista de plantas medicinales.

Por el papel fundamental de las plantas para la supervivencia de la cultura kuna, es crítico conservar la flora, especialmente las plantas útiles y los conocimientos asociados a ellas. Debido a presiones externas que han reducido su territorio, como por cambios suscitados por el crecimiento de la población y a cambios culturales entre los mismos kunas de esta región, es vital estudiar los problemas en el manejo de las plantas de uso tradicional y encontrar estrategias para conservarlas.

Esta inquietud motivó a Dobbo Yala, en colaboración con la Universidad McGill de Canadá, a iniciar un proyecto de investiga-

\section{PLANTAS CON ALTO VALOR CULTURAL EN LA COMUNIDAD DE NURNA}

\begin{tabular}{|c|c|c|c|}
\hline VOCABLO KUNA & ESPAÑOL & NOMBRE CIENTIFICO & USOS \\
\hline Alar-uar & - & Bactris Colorodonis & Utensilios de casa \\
\hline Baila & Bálsamo & Myroxylon balsamum & Postes de casas, ornamento \\
\hline Buarsip & - & - & Postes de casas \\
\hline Bunur sapi & - & - & Batidos \\
\hline Dubsip & Cortezo & Apeiba tibourbou & Soga \\
\hline Dupu & Membrillo & Gustavia superba & Comestible \\
\hline Ila & Jira & Socratea exorrhiza & Paredes de casas \\
\hline Ipup & Nazareno & Peltogyne purpurea & Leña \\
\hline Kaoban & Caoba & Swietenia macrophylla & $\begin{array}{l}\text { Construcción, madera comercial, } \\
\text { piraguas }\end{array}$ \\
\hline Koibir & Cocobolo & Dalbergia retusa & $\begin{array}{l}\text { Construcción, postes de casas, } \\
\text { utensilios de casa, artesanías }\end{array}$ \\
\hline Mageb & - & Arrabidaea chica & Tinta \\
\hline Mutu & Cerillo & Symphonia globulifera & Herramientas para coser \\
\hline Naba-uar & Chunga & Astrocaryum standleyanum & Paredes de casas, comestible \\
\hline Nai-uar & - & Carludovica palmata & Cestería \\
\hline $0 \mathrm{a}$ & Pita & Aechmea magdalenae & Comestible, ritos \\
\hline Sabdur & Jagua & Genipa americana & Tinta \\
\hline Sargi & Bejuco real & Heteropsis oblongifolia & Amarres de techo \\
\hline Sianele & - & Theobroma sp. & Ritos, comestible \\
\hline Siler & Maquengué & Oenocarpus mapora & Paredes de casas, cestería \\
\hline Soska (Soso) & Guágara & Sabal mauritiiformis & Techos de casas, ornamentos \\
\hline Ugar-uar & Laurel & Cordia alliodora & Leña \\
\hline Ukur-uar & Balsa & Ochroma lagopus & Ritos, escaleras, muñecos \\
\hline Uichur-sichit & - & Oxandra sp. & Postes de casas \\
\hline
\end{tabular}


ción aplicada en junio de 1998. Este estudio ha sido realizado gracias a una donación del Centro Internacional de Investigaciones para el Desarrollo (CIID) con sede en Ottawa, Canadá, coordinado por la Dra. Catherine Potvin (U. McGill).

Este proyecto intenta identificar las plantas útiles -en peligro de extinción- en el área de Wargandi y estudiar su ecología básica. Asimismo, conocer más acerca de las prácticas tradicionales y de las técnicas de manejo y cosecha que estas plantas reciben. La investigación se inició en la comunidad de Nurna y se concentró en 23 especies, escogidas en colaboración con la comunidad, por su importancia cultural en cinco categorías de uso: en construcción, utensilios, fibras, plantas comestibles y leña para cocinar.

\section{Metodología}

Para recopilar información sobre el uso y manejo de estas 23 especies de plantas, se entrevistó a hombres y mujeres de la comunidad de Nurna. También se obtuvieron sus opiniones sobre cambios ocurridos en la abundancia de estas plantas en diferentes períodos, según observaciones hechas por estos informantes durante sus vidas. Estos datos se complementaron con un estudio sobre la ecología básica de las 23 especies. Consistió en un inventario ecológico sobre un territorio de 3,500 hectáreas alrededor de la comunidad de Nurna. Dos jóvenes de la comunidad, capacitados previamente en técnicas de investigación botánica de campo, trabajaron con la bióloga Sarah Dalle para establecer más de 300 parcelas en distintos puntos de este territorio. En cada parcela se documentó la abundancia de plantas, las condiciones del bosque y las actividades humanas. Para establecer las coordenadas geográficas de cada parcela, para mapear la ubicación precisa de los caminos usados por la gente y los límites del territorio, el equipo utilizó la nueva tecnología conocida como SPG (Sistema de Posición Geográfica).

\section{La palma de Soska y sus usos}

Aunque todavía falta completar el análisis para todas las especies estudiadas, pode- mos ilustrar la utilidad de la información recogida tomando como ejemplo la palma Soso, cuya penca llamada soska es muy importante en la construcción de viviendas. La palma tiene el nombre científico de $S a$ bal mauritiiformis y se conoce como guágara en otras regiones de Panamá. Es una palma típica de los bosques primarios y áreas perturbadas, como rastrojos y orillas de caminos. El adulto llega a crecer hasta más de 15 metros de altura y sus pencas son grandes y resistentes, sirviendo para entechar las casas tradicionales kunas. Es la única especie de palma que se emplea en Wargandi para construir los techos.

Los hombres cortan las hojas de las palmas jóvenes, cuando aún estas crecen del tronco, porque así son fáciles de alcanzar. Se necesitan más de 1,000 hojas para entechar una casa de familia y 15,000 hojas para el techo de la Casa del Congreso (Onmaked Nega, en lengua kuna), lugar donde se reúne toda la comunidad para realizar debates sobre la cultura, identidad y problemas sociales, y organizar las actividades del pueblo. Estos congresos son presididos por el "saila", quien es la máxima autoridad de cada comunidad kuna. Según la gente entrevistada, la abundancia de la palma de Soska ha disminuído en los últimos 10 a 15 años y se teme que se extinga en las áreas cercanas a los poblados.

Los datos recogidos del inventario sobre la Soska permiten elaborar mapas de la distribución de esta palma sobre el territorio, determinar las condiciones de luz, agua y el suelo en que crece mejor y evaluar el impacto de las extracciones que hace el hombre sobre la abundancia de la especie. Hasta la fecha los resultados indican que aunque la Soska se da en ambientes muy diversos, parece restringirse a suelos derivados de sedimentos calizos. Esta palma se da en la misma 
área donde crece la caoba, precisamente donde se tala más madera; todavía se desconoce el impacto de la tala mecanizada en esta especie y en otros recursos silvestres.

Para conocer el impacto causado por los kunas sobre estas palmas, se comparó la abundancia de individuos de la especie en diferentes edades, tanto en áreas cosechadas como no cosechadas, y se encontró que son más escasas en las primeras. Las palmas juveniles se cosechan frecuentemente, y su importancia en la vida cotidiana hace poco probable que su explotación se reduzca, aunque la producción de la palma en sistemas agroforestales es promisoria. En la tradición kuna ya existe este tipo de manejo con algunas otras especies, por ejemplo, con plantas medicinales importantes.

Los estudios sobre el hábitat y la regeneración de las especies de plantas más importantes, pueden ayudar en la selección de sitios para iniciativas de este tipo.

Una madre kuna y su hija desgranan el maíz, como parte de las tareas domésticas que tradicionalmente se asignan a las mujeres de esta etnia indígena, en el poblado de Nurna. Foto: Dobbo Yala.

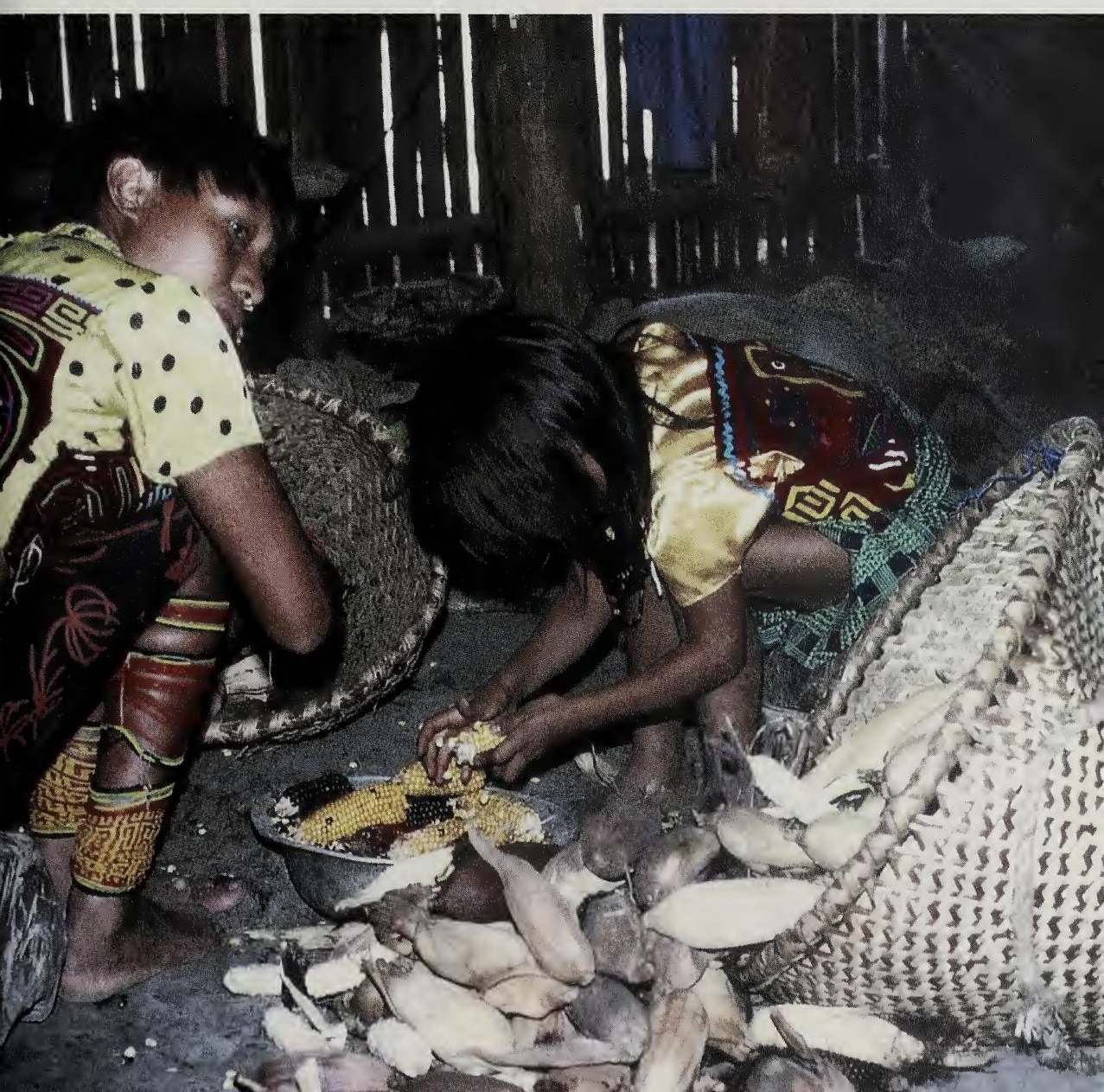




\section{Jorge Ventocilla \\ y Valerio Núñez}

\section{Experiencias de educación ambiental en Kuna Yala}

Dibujo ganador del primer concurso de dibujo infantil promovido por el STRI y el Ministrio de Educación de Panamá. La ilustración refleja el típico paisaje de los linderos de Kuna Yala entre el Caribe y la Serranía de San Blas.

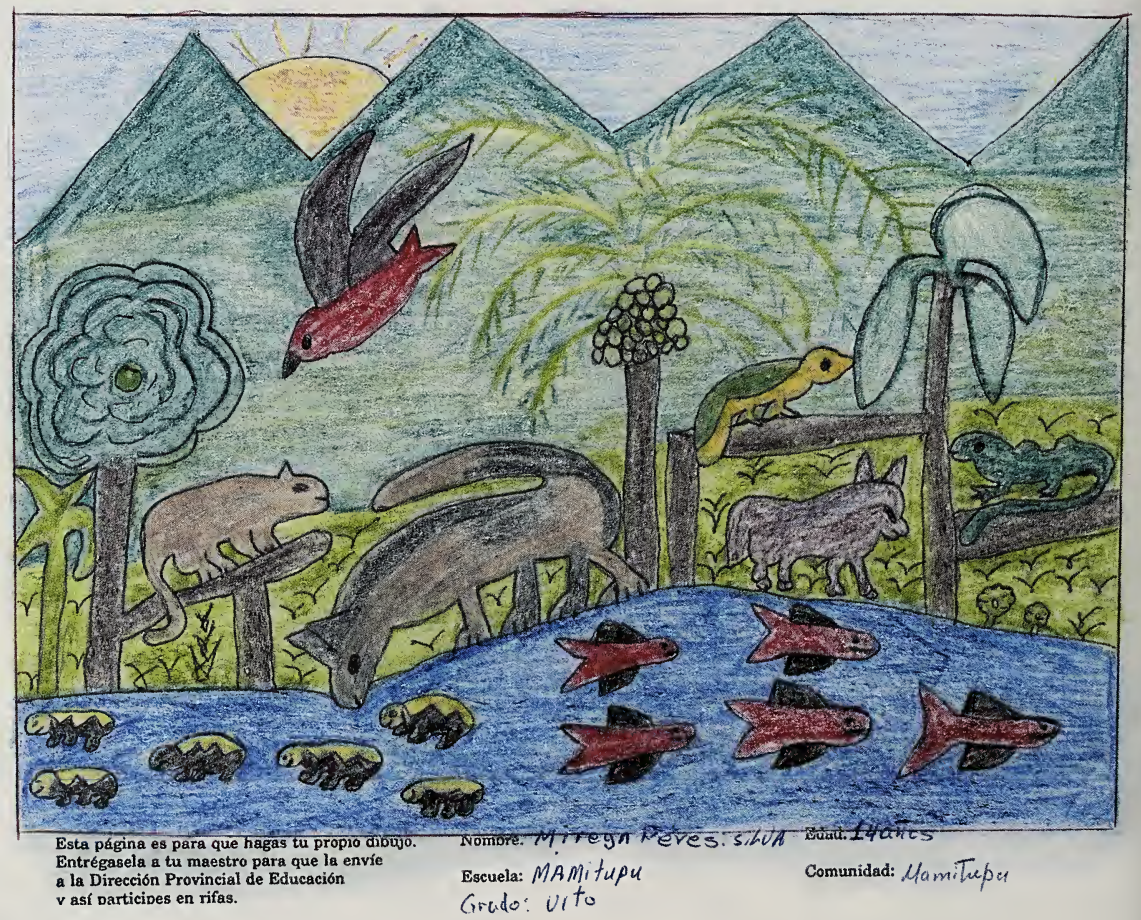


$\mathrm{E}$ 1 Instituto Smithsonian de Investigaciones Tropicales mantuvo una estación de campo en la Comarca Kuna Yala, región de la costa caribeña de Panamá también conocida como San Blas, desde principios de la década de 1970 hasta finales de los 1990. Durante ese tiempo se estableció una relación de colaboración con el pueblo kuna, la cual incluía su participación en programas de educación ambiental.

Los indígenas kunas poseen en forma colectiva un territorio de 3,200 kilómetros cuadrados que se extiende más de 220 kilómetros, desde la Punta de San Blas hasta Puerto Obaldía, cerca al límite con Colombia. Su territorio incluye un archipiélago con más de 300 islas. Por ley nacional, la demarcación física de la Comarca es el divorcio de aguas entre el atlántico y el pacífico en la cumbre de la Cordillera de San Blas.

En 1983, los kunas organizaron un proyecto de conservación que abarcó 60,000 hectáreas al oeste de su Comarca, conocido como PEMASKY (Proyecto de Estudios para el Manejo de las Areas Silvestres de Kuna Yala). STRI brindó apoyo mediante los inventarios de flora y fauna en el área del proyecto y en la formulación del Plan de Manejo y su sub-programa de educación ambiental. Además, el Instituto brindó el uso sin costo de sus instalaciones del Centro Tupper, de su biblioteca y otros servicios. En este artículo relataremos las experiencias adquiridas en educación ambiental en territorio kuna, desde 1983 hasta 1995.

\section{Los años del PEMASKY}

Las primeras actividades de educación ambiental en la Comarca Kuna empiezan con PEMASKY. El equipo técnico del proyecto viajó por la Comarca, concentrándose en el área de Cartí, participando en los Congresos Generales que se organizaban cada seis meses. Expusimos ideas sobre el cuidado del ambiente y la urgente necesidad de frenar el avance de los colonos campesinos de la vertiente pacífica que destruían los recursos, quienes habían traspasado la Cordillera de San Blas. Antes del proyecto, las comunidades no habían reparado en la importan-
El maestro kuna Isidro Morales y el biólogo J. Ventocilla explicando a los niños de Cangandi la flora y fauna de los alrededores de su comunidad (1989). Foto: Rutilio Paredes.

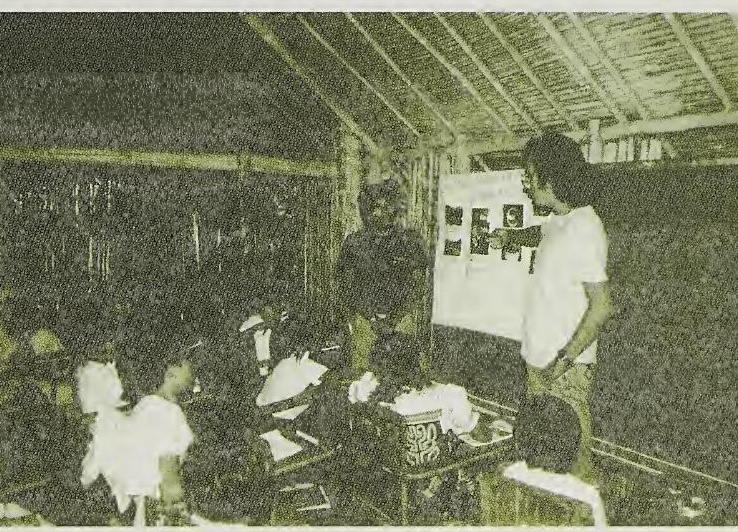

cia de marcar sus límites; a través del PEMASKY se sensibilizó a la población que adoptó el alinderamiento como algo propio: se formaron grupos de voluntarios de distintas comunidades, que abrieron trochas $\mathrm{y}$ marcaron hitos, estableciendo así las fronteras de la región.

En los primeros años se produjo material educativo como la revista "Sapi garda", que abordaba la problemática de la conservación, los derechos indígenas y la flora y fauna de Kuna Yala; se imprimió una serie de afiches y se hizo la película "El Espíritu de Kuna Yala”, dirigida por Andy Young. Esta película, con versiones en español e inglés y en formato de video, fue utilizada profusamente en las campañas de promoción a favor de los objetivos del proyecto PEMASKY, a nivel nacional e internacional.

El Plan de Manejo y Desarrollo del proyecto de conservación incluía elaborar un plan de educación ambiental e interpretación, diseñado en función de la estación de Nusagandi, ubicada en el límite de la comarca con la Provincia de Panamá, sobre la carretera entre El Llano y Cartí. Nusagandi se percibía en esos años como el siguiente centro neurálgico del proyecto PEMASKY, donde irían los estudiantes de la Comarca a recibir educación ambiental. Por esta razón se establecieron varios senderos en los alrede- 
dores. El sendero más importante fue el Sendero Inaigar ("sendero de las plantas medicinales"). Desde las islas se trajo a tierra firme un botánico, quien por varias semanas identificó plantas y árboles, anotando su utilidad en la medicina tradicional. Años más tarde, en 1998, la imprenta de la Universidad de Panamá publicaría la guía escrita del Sendero Inaigar.

Vale anotar que desde el comienzo del proyecto en PEMASKY se hablaba de hacer educación ambiental en forma tal que el proceso incluyera "recuperar" la información tradicional para "devolverla" a las comunidades. Se sabía que los viejos kunas eran instruidos en el respeto al medio ambiente y en prácticas de agricultura y de vida

En la costa caribe de Panamá se encuentra Kuna Yala (San Blas), territorio del pueblo kuna. De sus 32,000 habitantes la mayoría son niños y niñas como esta jovencita de la comunidad de Cartí Suidup.

Foto: J. Ventocilla.

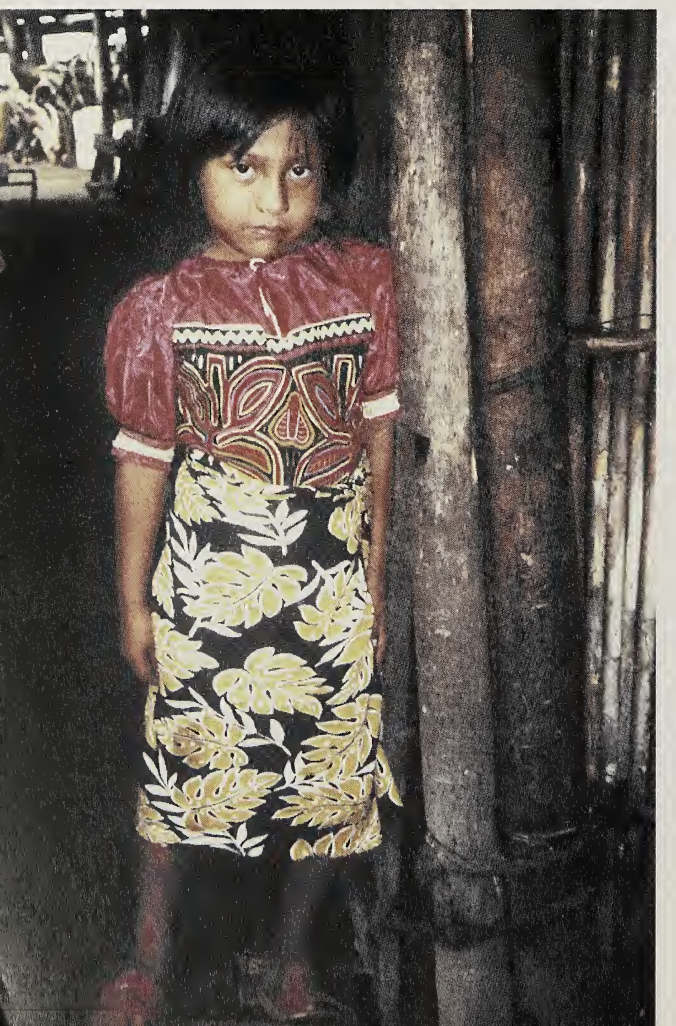

más benévolas para la tierra; los técnicos del proyecto deseábamos obtener esta instrucción. Además, el reglamento que regía las investigaciones científicas en el área establecía la obligación de que el estudioso "devolviera la información", producto de sus investigaciones, a las comunidades. Con el paso del tiempo vemos que esta idea noble no siempre encontró un cauce fácil para ponerla en práctica. ¿Cómo recuperar y luego transmitir la información? ¿Cómo juntar y entrelazar la información tradicional indígena y la ciencia occidental? A nuevos actores les tocará cumplir con este reto.

\section{La época de Cangandí}

Desde junio de 1989 hasta febrero de 1990, Ventocilla y Rutilio Paredes (técnico forestal del PEMASKY) estudiaron la cacería de subsistencia entre los kunas de Cangandi. Esta es una comunidad ubicada en tierra firme, sobre la margen del Cangandi y a hora y media caminando desde la bahía de Moliyá, en el golfo de Cartí. Esta investigación sería el trabajo de Ventocilla y serviría para conocer los requisitos de carne de monte de una comunidad dentro del área de influencia del proyecto. Su objetivo fue, en resumen, aprender más sobre qué animales cazan los kunas, cómo, dónde, y cuánto, entrelazando esta actividad con sus otras labores de subsistencia. El estudio fue algo así como una mirada a la cultura kuna a través del lente de la cacería.

Al iniciar la investigación acordamos en la Casa del Congreso del pueblo de Cangandi "devolver" lo aprendido en la investigación. Luego se incorporó Valerio Núñez a las labores de educación ambiental que iniciamos en la escuelita local. Los maestros eran Arcadio Bonilla e Isidro Morales, ambos kunas. Utilizábamos las fotografías que tomábamos para nuestra investigación y los conocimientos que adquirimos de los comuneros sobre la flora y fauna local, para luego transmitirlos a los niños y niñas de la escuelita.

Finalizada la investigación de campo, cumplimos con devolver la información a través de un libro de colorear; algo así como la versión infantil del estudio. Incluye 15 especies de la fauna silvestre de Kuna Yala, explicando por qué estos animales son necesarios para la vida física y cultural del pueblo 
preste más atención a los niños, a sus circunstancias de vida y a su potencial.

Fomentar en los niños el conocimiento de los valores culturales propios, entendiendo como cultura desde las expresiones artesanales hasta los principios de solidaridad humana.

Inculcar en ellos el saber que les permita apreciar mejor su medio ecológico, para que eventualmente reclamen y participen con su sociedad en un uso justo de la naturaleza.

Desde entonces un joven promotor kuna ha estado trabajando con niños y niñas en cada taller, enseñándoles y compartiendo con ellos el dibujo, la pintura mural, poesía, teatro, danza, canto y demás. La red ha celebrado el festival anual de arte infantil kuna desde 1995, realizándolos de forma ininterrumpida hasta el año de 1999. Esta alquimia de niños, arte, cultura y educación ambiental ha probado ser fructífera y necesaria. A través de nuestros errores y aciertos, quisié-

Afiche del IV festival de arte infantil celebrado en la isla de Dadnakue-Dupbir (San Ignacio de Tupile).

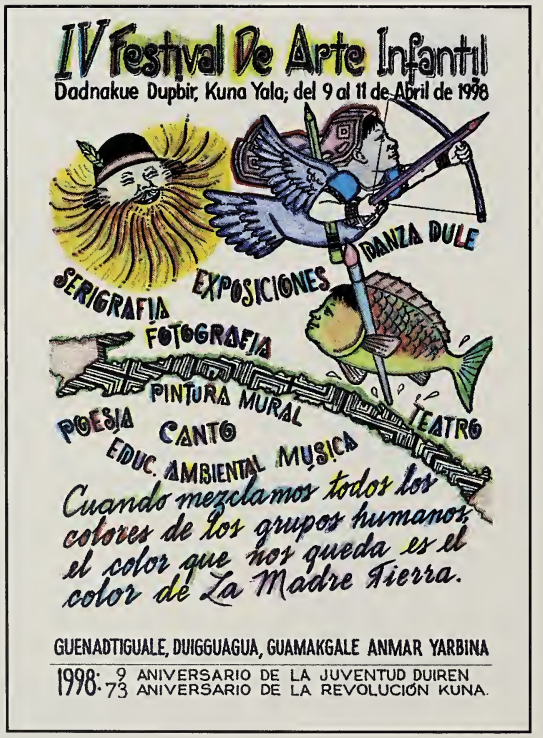

ramos creer que con la red de talleres hemos sembrado una buena semilla, que quizás sirva de ejemplo para otras comunidades del país.

\section{El Espíritu de la Tierra}

En 1991-1992 (año del V Centenario del descubrimiento de América/Encuentro de Culturas) y en forma paralela al trabajo de los talleres, trabajábamos en un texto sobre ecología dirigido a estudiantes kunas. Decidimos incluir en el libro comentarios de 20 kunas, hombres y mujeres, sobre esta conmemoración, sobre la relación de los kunas con su tierra, y las visiones que tenían de cara al futuro de Kuna Yala.

El libro, pensado inicialmente para estudiantes kunas de secundaria, "voló con sus propias alas" hasta concluir en El Espíritu de la Tierra: plantas y animales en la vida del pueblo kuna (Editorial Icaria, 1997; Editorial Abya Yala, 1999), y una versión en inglés titulada Plants and animals in the life of the Kuna (Texas University Press, 1995). En él logramos juntar información técnica producida sobre Kuna Yala con el conocimiento tradicional y popular. Incluye cuatro testimonios de gran valor hechos por tres hombres y una mujer kuna, junto con abundantes ilustraciones de animales silvestres y plantas medicinales. El libro es un aporte útil para el conocimiento y la comprensión del pueblo kuna; ha sido leído en las comunidades de Kuna Yala, al igual que utilizado como referencia en universidades del extranjero.

A lo largo de la producción del libro tuvimos experiencias muy especiales. Como nuestro objetivo era que el libro fuera leído principalmente por los kunas (siguiendo la idea de la "devolución de información"), gracias a la Fundación Tierra llegamos a un acuerdo satisfactorio con la Editorial Icaria de Barcelona, España; la edición constaría de 1,500 ejemplares, de los cuales 1,000 quedarían en España para la venta y 500 serían enviados al Congreso General Kuna para su distribución sin costos en Panamá.

Podemos decir con satisfacción que cuando iniciamos la educación ambiental mediante la divulgación -viajando entre las islas de 
Kuna Yala, hablando sobre la necesidad de demarcar y proteger la Comarca- hasta el presente, en el que contamos ya con varias publicaciones realizadas para devolver la in- formación a los locales, vemos lo vivido como un largo trabajo, pero grato y muy creativo, conscientes de tener el honor de hacerlo para un pueblo y la Madre Tierra.

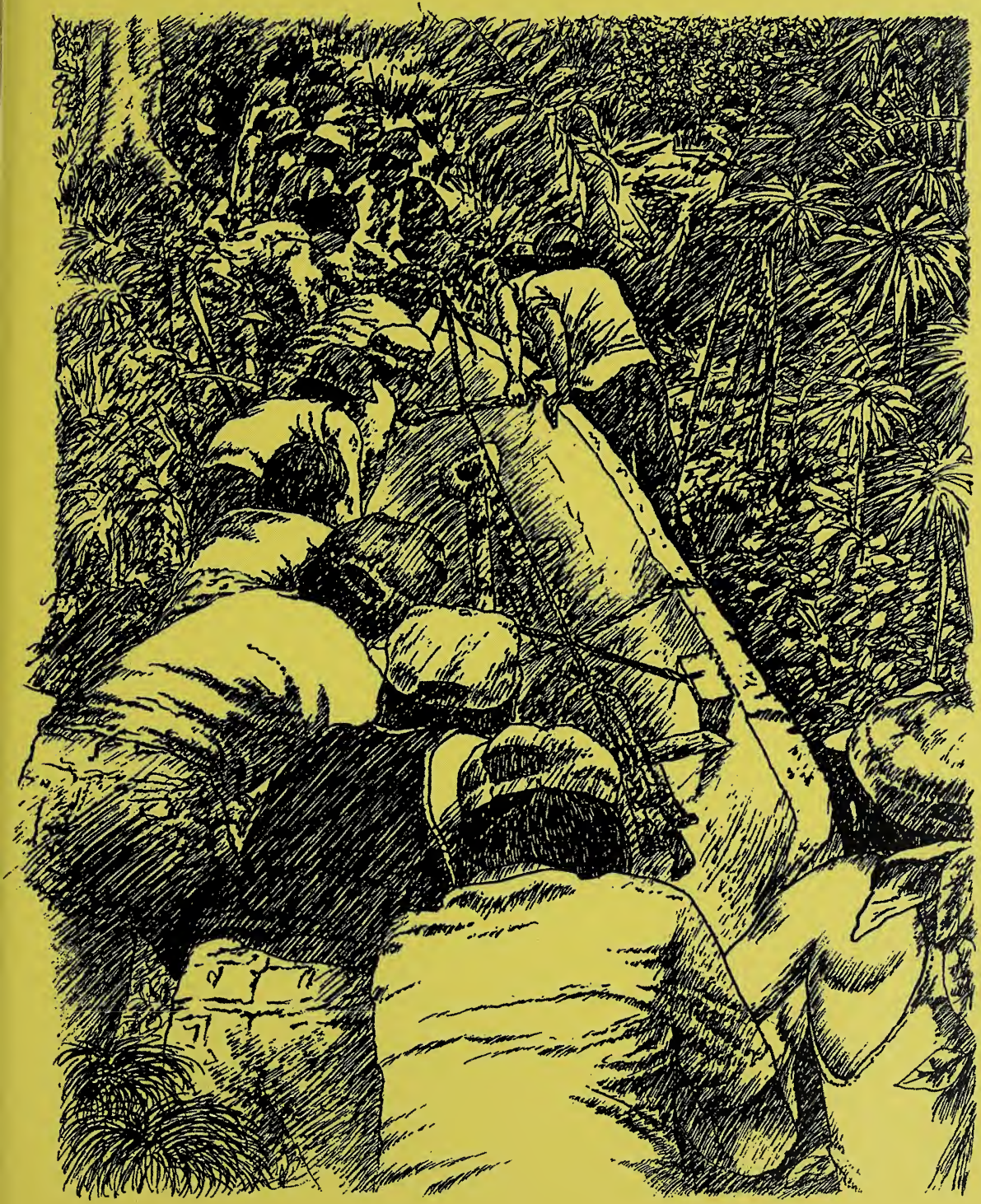

Dibujo a plumilla de Ologuagdi, que representa hombres kuna de Cangandi arrastrando un cayuco recién labrado, desde la selva hacia el río. 



Stanley Heckadon-Moreno nació en la zona bananera de Chiriquí, Panamá, en una familia de agricultores y maestros rurales. La Universidad de Los Andes, Bogotá, le otorgó la licenciatura en antropología (1970). En la Universidad de Essex, Inglaterra, obtuvo la maestría (1973) y doctorado (1983) en sociología.

En las décadas de 1970 y 1980 trabajó con comunidades indígenas y campesinas de Panamá y Centro América en programas de desarrollo comunitario y tenencia de la tierra. Fue de los pioneros del movimiento ambiental en la región. De 1987 a 1990 trabaja como científico social principal del Centro Agronómico Tropical de Investigación y Enseñanza (CATIE), Costa Rica, con proyectos forestales para América Central y el Caribe. Fue director general del Instituto Nacional de Recursos Naturales Renovables (INRENARE) de Panama de 1990-1991. Es miembro fundador de la Asociación Panameña de Antropología y de la junta directiva del Center for International Forestry Research (CIFOR), Bogor, Indonesia.

Se vincula al Instituto Smithsonian de Investigaciones Tropicales (STRI) en 1983 como investigador asociado. Actualmente es asesor del director para temas de transferencia tecnológica y política ambiental. EI STRI ha publicado cuatro de sus libros: "Cuando se Acaban Los Montes" (1983); "Agonía de la Naturaleza" (1985) coeditado con Jaime Espinoza González; Agenda ecológica y social para Bocas del Toro (1993) y "La cuenca del canal de Panamá: deforestación, urbanización y contaminación" (2000) co-editado con Roberto lbañez y Richard Condit.

\section{5}

Otras de sus obras son "Memorias de un criollo bocatoreño" (1980); "Colonización y Destrucción de bosques en Panamá" (1982) coeditado con Alberto Mckay; "La cuenca del canal de Panama" (1986); "Por una centroamérica verde"(Costa Rica, 1990); "Madera y leña de las Milpas" (Costa Rica, 1990); y "Panamá en sus usos y costumbres".

Stanley esta casado con Sonia Martinelli Tono y tiene dos hijos, Diego y Mónica.

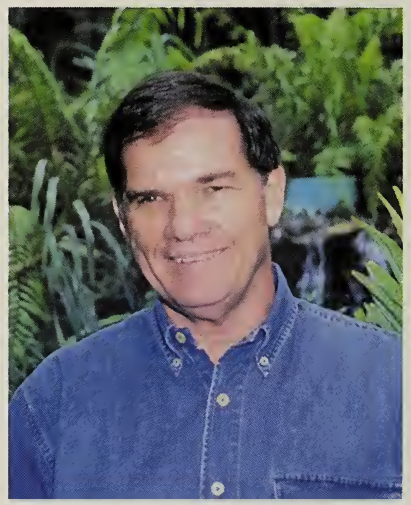

